\title{
Een besef van eigen kracht : Limburgse provinciale politiek in de periode 1962 - 2007
}

Citation for published version (APA):

van Elmpt, H. J. P. G. (2011). Een besef van eigen kracht : Limburgse provinciale politiek in de periode 1962 - 2007. [Doctoral Thesis, Maastricht University]. Provincie Limburg.

https://doi.org/10.26481/dis.20110629he

Document status and date:

Published: 01/01/2011

DOI:

10.26481/dis.20110629he

Document Version:

Publisher's PDF, also known as Version of record

\section{Please check the document version of this publication:}

- A submitted manuscript is the version of the article upon submission and before peer-review. There can be important differences between the submitted version and the official published version of record.

People interested in the research are advised to contact the author for the final version of the publication, or visit the DOI to the publisher's website.

- The final author version and the galley proof are versions of the publication after peer review.

- The final published version features the final layout of the paper including the volume, issue and page numbers.

Link to publication

\footnotetext{
General rights rights.

- You may freely distribute the URL identifying the publication in the public portal. please follow below link for the End User Agreement:

www.umlib.nl/taverne-license

Take down policy

If you believe that this document breaches copyright please contact us at:

repository@maastrichtuniversity.nl

providing details and we will investigate your claim.
}

Copyright and moral rights for the publications made accessible in the public portal are retained by the authors and/or other copyright owners and it is a condition of accessing publications that users recognise and abide by the legal requirements associated with these

- Users may download and print one copy of any publication from the public portal for the purpose of private study or research.

- You may not further distribute the material or use it for any profit-making activity or commercial gain

If the publication is distributed under the terms of Article $25 \mathrm{fa}$ of the Dutch Copyright Act, indicated by the "Taverne" license above, 

in de periode 1962 - 2007

Hendrik Jan van Elmpt 


\section{Een besef van eigen kracht}

Limburgse provinciale politiek in de periode 1962 - 2007 
() Copyright Hendrik Jan van Elmpt, Sittard/Maastricht 2011

ISBN 978-90-77540-04-6

Uitgegeven door de Provincie Limburg

Opmaak en druk: Grafisch Centrum Provincie Limburg

Omslagontwerp en foto voorzijde: Hendrik Jan van Elmpt

Foto achterzijde: Frits Widdershoven

Dit proefschrift is geschreven in opdracht van de Directie van de Provincie Limburg.

De uitgever heeft ernaar gestreefd de rechten van de illustraties volgens de wettelijke bepalingen te regelen. Degenen die desondanks menen rechten te kunnen doen gelden, kunnen zich alsnog tot de uitgever richten.

\section{provincie limburg}




\title{
Een besef van eigen kracht
}

Limburgse provinciale politiek in de periode 1962 - 2007

\author{
Proefschrift
}

ter verkrijging van de graad van doctor aan de Universiteit Maastricht op gezag van Rector Magnificus prof. mr. G.P.M.F. Mols

volgens het besluit van het College van Decanen

in het openbaar te verdedigen

op woensdag 29 juni 2011 om 16:00 uur

door

Henricus Johannes Peter Gertrudis van Elmpt 


\section{Promotores}

Prof. dr. T. Blom

Dr. J.A. Hoogenboezem

\section{Beoordelingscommissie}

Prof. dr. A. Knotter (voorzitter)

Dr. N.A.A. Baakman

Dr. P. Caljé

Prof. dr. W.B.H.J. van de Donk (Universiteit van Tilburg)

Prof. dr. P. Schnabel (Universiteit Utrecht) 



\section{Gehanteerde afkortingen}

$\begin{array}{ll}\text { ARP } & \text { Antirevolutionaire Partij } \\ \text { AW } & \text { Aanvullende Werkgelegenheid (subsidieregeling) } \\ \text { AWT } & \text { Adviesraad voor het Wetenschaps- en Technologiebeleid } \\ \text { BRW } & \text { Bijzondere Regionale Welzijnsbeleid } \\ \text { CBS } & \text { Centraal Bureau voor de Statistiek } \\ \text { CDA } & \text { Christen Democratisch Appèl } \\ \text { CdK } & \text { Commissaris der Koningin } \\ \text { CPB } & \text { Centraal Planbureau } \\ \text { CRM } & \text { ministerie van Cultuur, Recreatie en Maatschappelijk Werk } \\ \text { D66 } & \text { Democraten '66 } \\ \text { DACW } & \text { Dienst Aanvullende Cultuurtechnische Werken } \\ \text { EFRO } & \text { Europees Fonds voor Regionale Ontwikkeling } \\ \text { EGKS } & \text { Europese Gemeenschap voor Kolen en Staal } \\ \text { EIM } & \text { Economisch Instituut voor het Midden- en kleinbedrijf } \\ \text { EOI } & \text { statencommissie Economie, Onderwijs en Internationalisering } \\ \text { Erac } & \text { European regional affairs consultants } \\ \text { Etil } & \text { Economisch technologisch instituut ter bevordering van de industriële } \\ & \text { belangen in de provincie Limburg } \\ \text { EZ } & \text { ministerie van Economische Zaken } \\ \text { FAZ } & \text { statencommissie Financiën en Algemene Zaken } \\ \text { FES } & \text { Fonds Economische Structuurversterking } \\ \text { GS } & \text { College van Gedeputeerde Staten } \\ \text { IKOL } & \text { Instituut voor Kategoriaal Overleg Limburg } \\ \text { IPO } & \text { Interprovinciaal Overleg } \\ \text { IPR } & \text { Investeringspremieregeling } \\ \text { KSW } & \text { Kaderwet Specifiek Welzijn } \\ \text { KVK } & \text { Kamer van Koophandel } \\ \text { KVP } & \text { Katholieke Volkspartij } \\ \text { LEI } & \text { Landbouw Economisch Instituut } \\ \text { LIOF } & \text { N.V. Industriebank LIOF, Limburgs Instituut voor Ontwikkeling en } \\ \text { LLTB } & \text { Financiering } \\ \text { LNV/L+V } & \text { Limburgse Land- en Tuinbouwbond } \\ \text { LOZO } & \text { Limburgse Organisatie voor Zelfstandige Ondernemers } \\ \text { LWV } & \text { Limburgse Werkgeversvereniging } \\ \text { Merit } & \text { Maastricht Economic Research Institute on Innovation and Technology } \\ & \text { Midden- en kleinbedrijf } \\ & \end{array}$




$\begin{array}{ll}\text { NAVO } & \text { Noord-Atlantische Verdragsorganisatie } \\ \text { NUBL } & \text { Nadere Uitwerking Brabant-Limburg } \\ \text { PBW } & \text { Provinciaal Bureau Welzijnsplanning } \\ \text { PNL } & \text { Perspectievennota Zuid-Limburg } \\ \text { POL } & \text { Provinciaal Omgevingsplan Limburg of Provinciaal Opbouworgaan } \\ & \text { Limburg } \\ \text { POWL } & \text { Provinciaal Orgaan Welzijnsbevordering Limburg } \\ \text { PPC } & \text { Provinciale Planologische Commissie } \\ \text { PPD } & \text { Provinciale Planologische Dienst } \\ \text { PPR } & \text { Politieke Partij Radicalen } \\ \text { PS } & \text { Provinciale Staten } \\ \text { PV } & \text { Permanente Vertegenwoordiging } \\ \text { PvdA } & \text { Partij van de Arbeid } \\ \text { REP } & \text { directoraat-generaal Regionaal Economische Politiek } \\ \text { RfV } & \text { Raad voor de financiële verhoudingen } \\ \text { RKSP } & \text { Roomsch-Katholieke Staatspartij } \\ \text { Rob } & \text { Raad voor het openbaar bestuur } \\ \text { ROM } & \text { Ruimtelijke Ordening en Milieu } \\ \text { ROV } & \text { hoofdgroep Ruimtelijke Ordening en Volkshuisvesting } \\ \text { RPD } & \text { Rijksplanologische Dienst } \\ \text { RSV } & \text { Rijn-Schelde-Verolme concern } \\ \text { RTP } & \text { Regionaal Technologieplan Limburg } \\ \text { SEOL } & \text { Stichting Economische Ontwikkeling Limburg } \\ \text { SER } & \text { Sociaal-economische Raad } \\ \text { SIR } & \text { wet Selectieve Investeringsrekening } \\ \text { STIKOL } & \text { Stichting Stimulering en Koördinering Economische Activiteiten Limburg } \\ \text { STRIDE } & \text { Science and Technology for Regional Innovation and Development } \\ \text { TTR } & \text { Technologische topregio } \\ \text { tUL } & \text { transnationale Universiteit Limburg } \\ \text { VenW } & \text { ministerie van Verkeer en Waterstaat } \\ \text { VNG } & \text { Vereniging van Nederlandse Gemeenten } \\ \text { VORm } & \text { Verhandelbare Ontwikkelingsrechten methode } \\ \text { VRO(M) } & \text { ministerie van Volkshuisvesting, Ruimtelijke Ordening (en Milieubeheer) } \\ \text { VVD } & \text { Volkspartij voor Vrijheid en Democratie } \\ \text { VWS } & \text { ministerie van Volksgezondheid, Welzijn en Sport } \\ \text { WRR } & \text { Wetenschappelijke Raad voor het Regeringsbeleid } \\ \text { WVC } & \text { ministerie van Welzijn, Volksgezondheid en Cultuur } \\ \text { WVG } & \text { Wet Voorzieningen Gezondheidszorg } \\ & \end{array}$




\section{Inhoudsopgave}

$\begin{array}{lc}\text { Gehanteerde afkortingen } & 6\end{array}$

Voorwoord 11

1. Inleiding: een besef van eigen kracht 15

1.1 Het debat over provincies: naar een nieuwe vraagstelling 16

$\begin{array}{ll}1.2 \text { Provincie als politiek systeem } & 23\end{array}$

1.3 Een conceptueel kader voor provinciale besluitvorming 28

1.3.1 Het gebruik van bevoegdheden en instrumenten $\quad 29$

$\begin{array}{ll}\text { 1.3.2 Analyse van invloed en macht } & 31\end{array}$

1.3.3 Het gebruik van geografische indelingen $\quad 33$

1.3.4 Inzicht in de politiek-ambtelijke verhoudingen 35

1.3.5 Momenten van nieuwe agendavorming $\quad 36$

1.4 Methodologie 41

1.4.1 Afbakeningen en selecties binnen het onderzoek 41

1.4.2 Gehanteerde bronnen $\quad 43$

1.5 Opbouw van het boek 45

$\begin{array}{lll}\text { 2. Provincie Limburg en de ruimtelijke ordening 1962-2007 } & 47\end{array}$

2.1 Ontwikkelingen in het nationale ruimtelijk ordeningsbeleid 48

2.2 Limburgse ruimtelijke ordening voor 1962

Eerste omslagmoment: een nieuwe wet, nieuwe afweging van belangen (1962-1965) 55

2.3 De hoogtijdagen van het streekplan (periode 1965-1979) 57

Tweede omslagmoment: einde van de macht van de Planologische Commissie (1978-1979) 63

2.4 Ruimtelijke ordening in dienst van de economie (periode 1979-1990) 64

Derde omslagmoment: nieuwe wetgeving en ambtelijke macht (1990) 67

2.5 Op zoek naar een integraal ruimtelijk beleid (periode 1990-2004) 68

Vierde omslagmoment: flexibiliteit in de ruimtelijke ordening (2003-2004) 78

2.6 Van ordenen naar ontwikkelen (periode 2004-2007 en verder) 79

2.7 Hoofdlijnen en voorlopige conclusies $\quad 84$

3. Provincie Limburg en het economisch beleid 1962-2007 87

3.1 Ontwikkelingen in het nationale regionaal economisch beleid 88

3.2 Limburgs economisch beleid voor $1962 \quad 91$ Eerste omslagmoment: provinciale belangenbehartiging (1962-1965) 93

3.3 Economische herstructurering: een rijksverantwoordelijkheid (periode 1965-1978) 96 Tweede omslagmoment: een nieuw politiek moment (1978) 104

3.4 Politieke onderhandelingskracht: drie periodes PNL-beleid (periode 1978-1992) 106 Derde omslagmoment: Limburg op eigen kracht (1990-1992) 115

3.5 Europese proefregio: een provinciaal technologiebeleid (periode 1992-2004) 117

Vierde omslagmoment: de ambitie van technologische topregio (2003-2004) 122

3.6 Het ontstaan van de Versnellingsagenda (periode 2004-2007 en verder) 124

$\begin{array}{ll}3.7 \text { Hoofdlijnen en voorlopige conclusies } & 130\end{array}$ 
4.1 Ontwikkelingen in het nationale welzijnsbeleid 134

$\begin{array}{ll}4.2 & \text { Limburgs welzijnsbeleid voor } 1962 \\ \end{array}$ Eerste omslagmoment: inhoudelijke bemoeienis (1962-1965) 140

4.3 Een voorzieningenbeleid (periode 1965-1979) 142

Tweede omslagmoment: de macht van het particulier initiatief doorbroken (1979) 146

4.4 Herstructurering en decentralisatie (periode 1979-1992) 147

Derde omslagmoment: 'Carte blanche' voor een provinciaal welzijnsbeleid (1990-1992) 154

4.5 Het einde van het welzijnsbeleid (periode 1992-2003) 155 Vierde omslagmoment: de Provincie in de wijk! (2003) 160

4.6 Einde van welzijn, leve de leefbaarheid (periode 2003-2007 en verder) 161

4.7 Hoofdlijnen en voorlopige conclusies 166

5. Een overzicht van 45 jaar Limburgse provinciale politiek 169

5.1 Het gebruik van bevoegdheden en instrumenten 169

5.2 Een analyse van invloed en macht $\quad 171$

5.3 Het gebruik van geografische indelingen 174

5.4 Inzicht in de politiek-ambtelijke verhoudingen 176

$\begin{array}{lr}\text { 6. Conclusie } & 179\end{array}$

$\begin{array}{ll}\text { 6.1 De praktijk van besluitvorming } & 180\end{array}$

6.2 Patronen in besluitvorming: vier periodes, vier strategieën 181

6.3 Nieuwe agendavorming: vier omslagmomenten 183

6.4 Een reflectie op de bevindingen: opnieuw het debat over provincies $\quad 184$ $\begin{array}{lr}\text { Tot besluit } & 189\end{array}$

$\begin{array}{ll}\text { Eindnoten } & 190\end{array}$

Geraadpleegde archieven $\quad 245$

Literatuur $\quad 246$

Overzicht geïnterviewde personen $\quad 259$

$\begin{array}{ll}\text { Summary } & 261\end{array}$

$\begin{array}{ll}\text { Over de auteur } & 266\end{array}$

Appendices: $\quad 267$

Appendix I Ontwikkeling formatie ambtelijk apparaat in de periode 1962-2007

Appendix II Financiële ontwikkeling provinciale begrotingen in de periode 1962-2007 Appendix III Uitslagen provinciale verkiezingen in de periode 1919-2007 Appendix IV Samenstelling Colleges van Gedeputeerde Staten in de periode 1962-2007 
Voor Henk van Elmpt

Van wie ik heb geleerd dat er niets is besloten,

totdat het op papier staat.

$\mathrm{Pa}$, het staat er. 


\section{Voorwoord}

De Provincie Limburg en de Universiteit Maastricht hebben in meerdere opzichten een nauwe verbintenis. Zo bestaat er een fysieke verbintenis in die zin dat de huidige locatie van de Maastrichtse Rechtenfaculteit tot 1986 huisvesting bood voor bijna 350 ambtenaren, 63 statenleden, 7 gedeputeerden en 1 gouverneur. Ook in de ontstaansgeschiedenis van de universiteit zijn er nauwe relaties geweest met de provinciale politiek ${ }^{1}$. De founding father van de universiteit, J.G.H. Tans, was al in zijn periode als PvdA-statenlid (19581966) pleitbezorger geweest van de komst van een universiteit in Limburg. In 1965 werd op initiatief van toenmalig gouverneur Van Rooy de Stichting Wetenschappelijk Onderwijs Limburg (SWOL) opgericht. In de periode na de officiële opening (1976) was de 'uitbouw' van de universiteit een belangrijke steunmaatregel van het provinciale Perspectievennotabeleid. Een directe vorm van samenwerking tussen universiteit en Provincie ontstond in 2003 toen er gezamenlijk plannen werden gemaakt voor realisatie van een grootschalige campus op het grondgebied van die andere belangrijke speler in de Limburgse sociaal-economische ontwikkeling: DSM.

Vanuit een microperspectief is het voorliggende boek natuurlijk ook een resultaat van een meerjarige samenwerking tussen de Provincie en universiteit. Het werken als 'buitenpromovendus' zorgt voor zowel distantie als betrokkenheid naar beide organisaties. Betrokkenheid omdat deze universiteit - en in het bijzonder de Faculteit der Cultuurwetenschappen zoals zij in mijn studieperiode (1997-2001) nog heette - voor mij de intellectuele basis heeft gelegd voor het schrijven van dit boek. De interdisciplinaire benadering was daarbij eerder een natuurlijk gegeven dan een beredeneerd vereiste. Toch was er eveneens sprake van distantie omdat je zowel letterlijk als figuurlijk op enige afstand van de academische omgeving opereert. Je werkt in deeltijd aan je onderzoek, voornamelijk thuis en je hebt geen onderwijsverplichtingen als buitenpromovendus. Betrokkenheid was er natuurlijk ook naar de Provincie Limburg, waar ik als beginnend onderzoeker in 2001 mijn opgedane universitaire vergezichten moest zien te vertalen in meetbare kwantitatieve en kwalitatieve indicatoren voor het meten van de effecten van beleid. Al snel bleek dat de Provincie ook een organisatie is waar mensen de ruimte krijgen om kennis op het snijvlak van wetenschap en praktijk op te doen. De vorm van een promotie-traject schiep de nodige distantie om de vele meters aan provinciale nota's, rapportages, memo's en jaarverslagen op waarde te schatten en in de historische, maatschappelijke context te plaatsen.

In de vele interviews die ik heb gevoerd voor dit boek, werd voortdurend het belang van de universiteit benadrukt als het ging om de sociaal-economische en culturele ontwikkeling van Limburg. In de recent uitgebrachte bundel Maastricht kennisstad. 850 jaar onderwijs en wetenschap (2011) was ik verrast te lezen dat de universiteit in feite een vergelijkbare ontwikkeling heeft doorgemaakt als de Provincie. In zijn bijdrage beschrijft Pieter Caljé de ontwikkeling van de universiteit als volgt: 
"In 1990 was de achtergestelde positie van Limburg voorbij. Dat betekende dat de nationale kaders, waarbinnen het argument van hulpbehoevendheid naar voren was gebracht, hun belang als oriëntatiepunt begonnen te verliezen. Het zelfbewuste Limburg zocht nu op basis van eigen kenmerken en eigen kracht naar mogelijkheden zich te ontwikkelen. Dat gold ook voor de universiteit. Tot het midden van de jaren tachtig was het ook voor de universiteit nog hoogst onzeker of het experiment Rijksuniversiteit Limburg zou slagen. Toen de studenten in die periode begonnen toe te nemen kreeg men vertrouwen dat het goed zou komen. Toch bleef de universiteit tot het begin van de jaren negentig sterk in zichzelf gekeerd en vooral op zoek naar erkenning binnen de kaders van de nationale universitaire structuur. Vanaf die periode toonde zij een nieuw zelfbewustzijn om zich op eigen kracht vanuit haar positie in de regio en het internationaal 'gebrande' Maastricht verder te ontwikkelen" (Caljé, 2011: 250-251).

Een zoektocht naar erkenning werd ingeruild voor een zelfbewuste opstelling, een groeiend besef van eigen kracht, van zowel de universiteit als de provinciale overheid.

Een proefschrift daarentegen schrijf je nooit volledig op eigen kracht. Ik bedank alle geïnterviewden voor hun openhartige medewerking en de verstrekte inzichten. De gesprekken werkten als een Tom-Tom door het omvangrijke provinciale archiefmateriaal. Dat ambtenaren te veel en te dikke nota's maken kan ik volmondig bevestigen. Een woord van dank aan de medewerkers van zowel de provinciale bibliotheek, het provinciale archief, als het Rijksarchief Limburg voor alle hulp bij het opvragen van de vele dossiers. Dank ook aan de collega's Jan Maatjens, Henk Groen, Frank van Lissum en Ben van Essen die hun persoonlijke archieven beschikbaar stelden. Verschillende mensen hebben op gezette momenten delen van de tekst gelezen en voorzien van commentaar. Elly, Jan, Gé, Ben en Raymond, het waren lappen tekst, maar hopelijk was de inhoud interessant genoeg om de aandacht erbij te houden. Andere collega's hebben zonder dat zij zich daarvan direct bewust waren een bijdrage geleverd wanneer ik hen even snel benaderde met een vraag over een bepaalde situatie in het verleden en de motieven, verklaringen of achtergronden van het beleid en de provinciale politiek. Een speciaal woord van dank voor Janine en Theo die het manuscript in de laatste fase gezuiverd hebben van de persoonlijke stijlbloempjes, ambtelijk jargon en de Limburgse voorkeur voor germanismen. Jelka, dank voor je lezing als niet-Limburger. Ma, dank voor je lezing als Limburger.

Ik ben er trots op dat zowel de opmaak, druk als uitgave van dit proefschrift - hoe kan het ook anders - is verzorgd door mijn directe collega's van het Grafisch Team van de Provincie. Lea en Huub, dank voor het meedenken over de vormgeving en het mogelijk maken van de uitgave van het boek. Ook dank aan Marijke en de dames van het secretariaat die gezorgd hebben voor het gereedmaken van de verzending van het boek.

Ik ben de toenmalige Directie van de Provincie (Wim, Jan en in het bijzonder Fred) dankbaar voor hun besluit om eind 2005 in te stemmen met dit promotietraject. Ik weet dat het geen vanzelfsprekendheid was om opdracht te verlenen voor een project waarvan de definitieve resultaten en inzichten pas over vijf jaar echt duidelijk zouden worden. Ik hoop jullie tussentijds met voldoende scherpte en uit het verleden opgedane inzichten te hebben geprikkeld en de meerwaarde van een promotietraject duidelijk te hebben gemaakt. Dank ook aan de huidige Directie en in het bijzonder Ad voor het gecontinueerde vertrouwen. 
Maar ook ere wie ere toekomt: Paul, zonder jou was dit proefschrift er nooit gekomen. Je enthousiasmerend leiderschap, je scherpe inhoudelijk en politiek analyserend vermogen en je blijvende steun heb ik bijzonder gewaardeerd.

Tannelie en Jaap, ik had soms het gevoel dat ik een van de kandidaten in de serie Topchef was, waarbij de beoordeling van de verschillende tussengerechten kritisch, constructief, maar vooral - en daar leer je het meeste van! - ongezouten was. Dat het geen Hell's Kitchen is geworden ligt vooral in het feit dat we uiteindelijk altijd - om in de metafoor te blijven - de gewenste kruidenmix wisten te vinden in een aangename mise en place waarin we eigenlijk nooit van mening hebben verschild over de basisingrediënten.

In een bepaald opzicht zijn de laatste negen maanden van een proefschrift te vergelijken met een zwangerschapsperiode. Geleidelijk raakt je hoofd er helemaal vol van, wordt je belevingswereld aanzienlijk kleiner en is de uiteindelijke geboorte zeker geen sinecure. Een proefschrift afronden én vader worden in dezelfde periode was dan ook een hele bevalling. Maar het is gelukt. Fleur, we hebben een pracht van een dochter, die nu eindelijk ook op papa's studeerkamer de boel onveilig mag maken. Je steun is op elke pagina wel op de een of andere manier voor mij terug te vinden.

Dit boek is opgedragen aan Henk van Elmpt die 33 jaar bij de Provincie Limburg heeft gewerkt. Pa, allebei hebben we vanuit een 'staffunctie' de provinciale organisatie leren kennen en die organisatie uitvoerig met elkaar besproken en geanalyseerd. Je organisatiekennis en vooral je mensenkennis waren zowel impliciet als expliciet van onschatbare betekenis voor de totstandkoming van dit boek.

Sittard / Maastricht, april 2011. 



\title{
1 \\ Inleiding: een besef van eigen kracht
}

"[H]et ... blijkt reeds, dat bestaande staatsrechtelijke normen slechts in beperkte mate het provinciale leven in bepaalde banen hebben geleid. Men zal niet kunnen volhouden, dat het wettelijk keurslijf een ruimere ademhaling der provinciën ernstig heeft belemmerd. Ontbreekt het het provinciaal bestuur aan besef van eigen kracht, mist het de activiteit nieuwe taken ter hand te nemen, zo zal, ondanks de fraaiste wettelijke constructie, het staatsrechtelijk gebouw niet aan zijn bestemming beantwoorden." ${ }^{2}$

Ontwerp Provinciewet, Memorie van Toelichting, 13 maart 1959

(cursivering HvE)

\begin{abstract}
"Het geheel overziende mogen wij met voldoening constateren, dat de nieuwe wet niet alleen een erkenning inhoudt van de belangrijke positie, welke de provinciale besturen in de loop der jaren zijn gaan innemen in de bestuurlijke praktijk van ons land, doch dat deze ook een gunstig klimaat heeft geschapen voor een sterke bewustwording van de provinciale activiteiten, welke in decentralisatie haar verankering dienen te verkrijgen." ${ }^{3}$
\end{abstract}

Gouverneur 4 in de Provincie Limburg F.J.M.A.H. Houben, 6 juni 1962 (cursivering $\mathrm{HvE}$ )

De Provinciewet, die in 1962 de oude Provinciale Wet van 1850 verving, kende geen nieuwe taken of bevoegdheden toe aan de Nederlandse provincies. Noch veranderde er echt fundamenteel iets aan de sinds de jaren '30 gegroeide provinciale taken en activiteiten. Wat de Provinciewet bekrachtigde, was echter een besef en bewustwording van iets wat in de Grondwet (1848) formeel al verankerd was, maar nooit eerder zo krachtig was uitgesproken: een bevestiging van het besef van eigen kracht. De opstellers van de wet bevestigden en benadrukten dat de rol van provincies niet als een uitvoeringsorganisatie van de rijksoverheid moest worden gezien, noch dat de Commissaris der Koningin een soort toezichthouder van Den Haag in de provincie was, maar dat provincies op moesten komen voor de belangen van hun inwoners (Burger, 1964: 52). Aan 'belemmeringen' vanuit de rijksoverheid zou het niet liggen. Een laatste mogelijke belemmering, de goed- of afkeuring van provinciale verordeningen door de rijksoverheid verviel met de Provinciewet ${ }^{5}$. De wet zorgde voor een impuls aan provinciebesturen om sterker dan voorheen eigen initiatief en nieuwe activiteiten te ontwikkelen, zoals het tweede citaat van gouverneur F.J.M.A.H. Houben (KVP) verwoordt. Zonder te overdrijven kan gesteld worden dat de politiek-psychologische uitwerking van de wet vele malen groter was dan de staatsrechtelijke consequenties.

Dit boek gaat over de ontwikkeling van dit besef van eigen kracht van een provincie, de Provincie Limburg ${ }^{6}$. In zowel de Provinciale Wet als deze nieuwe Provinciewet werden geen inhoudelijke taken of verantwoordelijkheden benoemd, maar uitsluitend de spelregels en procedures voor provinciale politieke besluitvorming ${ }^{7}$. Er wordt dan ook gesproken van een 'open huishouding's van provincies, waarmee wordt bedoeld dat de 
keuze voor inhoudelijke taken, projecten of activiteiten, een verantwoordelijkheid van de provincie zelf is. De functie van een politiek systeem is niet meer en niet minder dan het nemen van collectief bindende besluiten. Over welke onderwerpen de besluitvorming gaat, is niet vastgelegd, vandaar een open huishouding.

In de Provinciewet zijn dan wel geen inhoudelijke taken of bevoegdheden vastgelegd, in diverse andere wetten worden er door de regering wel inhoudelijke activiteiten aan provincies opgedragen. Vanaf eind jaren ' 60 hebben provincies een groei doorgemaakt in het aantal uit te voeren wettelijke taken. Provincies kregen o.a. taken op het gebied van het milieu, de ruimtelijke ordening, het verdelen van subsidies aan culturele instellingen, woningbouw of zorginstellingen. Dit worden ook wel medebewindstaken genoemd. Daarnaast zijn er ook werkzaamheden waaraan geen wet ten grondslag ligt, bijvoorbeeld het provinciaal economisch beleid of het sportbeleid. In de aanpak van deze autonome taken hebben provincies een grote mate van vrijheid (De Monchy, 1976: 195-196).

Een open huishouding met een verscheidenheid aan besluitvorming over diverse onderwerpen, wel of niet voorzien van een wettelijke grondslag, zegt nog niets over de daadwerkelijke uitoefening hiervan door een provincie. Voor provincies is het hierboven geciteerde 'besef van eigen kracht' veel belangrijker, dan de formele bevoegdheden en taakverdeling van een 'wettelijk keurslijf'.

\subsection{Het debat over provincies: naar een nieuwe vraagstelling}

Over het bestaansrecht van provincies wordt al decennialang een maatschappelijk en politiek debat gevoerd ${ }^{9}$. Aanleiding voor deze discussies zijn vaak op handen zijnde provinciale Statenverkiezingen of het aantreden van een nieuw kabinet. De bestuurlijke organisatie van Nederland ('Huis van Thorbecke') en de positie van provincies daarbinnen, is dan een terugkerend onderwerp.

De bijdragen van diverse auteurs in het debat over de Nederlandse provincies liegen er niet om. Er worden sterke gevoelens en overwegend negatieve opvattingen naar voren gebracht over het bestaan van deze bestuurslaag. In de meer voorzichtige formuleringen wordt de provincie gekenschetst als een 'terughoudende en risicomijdende instelling' (De Graaff-Nauta, 1990), een 'roestige scharnier' (Tjeenk Willink, 1984) of 'de bleekneus onder de drie bestuurslagen' (Nieuwenhuijsen, 1999). Andere auteurs zijn meer expliciet als zij spreken van 'een geatrofieerd overblijfsel uit vroegere tijden' (Van Schendelen, 1990), 'het opgeblazen bestuur' (Peters, 2007) of 'een poppenkast voor tweederangs politici' (De Vries, 2011). Tegelijkertijd constateert Peters dat het debat zich voortdurend op dezelfde problemen en oplossingen richt (Peters, 2007: 15), waarbij de oplossingen zoals die de afgelopen decennia zijn voorsteld, weinig hebben opgeleverd (Hendriks, 2002: 90; Berkhout, 2002: 13; Boogers \& Hendriks, 2005: 19; Peters, 2007: 15). Voor een analyse van een provincie waarin vooral gekeken wordt naar wat een provincie doet en hoe besluitvorming tot stand komt, zijn de voorlopige uitkomsten van dit debat onbevredigend. In dit boek wordt een ander perspectief op de provincie voorgesteld.

Alvorens over te gaan op dit nieuwe perspectief zal eerst worden ingegaan op de verschillende posities in het debat. Vervolgens worden de kenmerken van het debat en 
de gebruikte typeringen geanalyseerd. Ten slotte zal de balans worden opgemaakt en een eigen positie worden ingenomen. Daarmee wordt tevens de onderzoeksvraag ingeleid.

\section{Onderwerpen binnen het debat}

Er zijn verschillende argumenten en scheidslijnen te onderscheiden die voortdurend terug komen in het debat over provincies. Hier zullen de drie belangrijkste onderwerpen aan de orde komen ${ }^{10}$.

Een eerste onderwerp betreft het takenpakket en de rol van de provincie. Volgens Van Schendelen (1987) en De Vries (2003) is dat takenpakket en die rol in de loop van de tijd meer en meer uitgehold (Van Schendelen, 1987: 256; De Vries, 2003: 115). Diverse provinciale taken worden in hun ogen meer en meer door gemeentelijke overheden, zelfstandige bestuursorganen, agentschappen of maatschappelijke organisaties uitgevoerd. De Raad voor het Openbaar Bestuur (Rob) en De Vries wijzen er bovendien op dat de financiële armslag van provincies beperkt is en dat slechts 2 tot $3 \%$ van de publieke uitgaven in Nederland door provincies worden gedaan (Rob, 1999: 14; De Vries, 2003: 121; De Vries, 2011). Herwijer wijst daarentegen op het belang van de provincie als het gaat over het omgevingsbeleid of wat Van Kemenade de taken op het gebied van de 'grondgebonden materie' noemt (Herweijer, 1999: 22; Van Kemenade in Hendriks, 2002: 81). Berkhout en Herweijer benadrukken inderdaad het feit dat het takenpakket van de provincie 'weinig echte doetaken' of 'beleidsuitvoerende en burgerbindende taken' kent, maar wijzen er op dat het takenpakket juist is afgestemd op de provincie als bemiddelend, coördinerend en toezichthoudend middenbestuur (Berkhout, 1999: 77; Herweijer, 1996: 68). Provincies zelf, in de vorm van het Interprovinciaal Overleg (IPO), benadrukken ook dikwijls het belang van specifieke taken. Het in 2008 verschenen rapport van de Gemengde Commissie Decentralisatievoorstellen Provincies (ook wel de 'Commissie Lodders' genoemd) benadrukte dat provincies zich vooral zouden moeten toeleggen op de taakvelden ruimte, economie en cultuur ${ }^{11}$.

In tegenstelling tot het belang dat hierboven genoemde auteurs hechten aan het takenpakket van provincies, benadrukt Schaap dat de betekenis van de provincie niet zozeer ligt in de taken die zij doet, maar veel meer in haar rol (Schaap in Hendriks, 2002: 81; zie ook Schaap et.al., 2000). Geelhoed volgt deze lijn wanneer hij stelt dat provincies vooral 'bestuurlijke arbiters en makelaars' zijn (Geelhoed, 1990: 22). Als het gaat om de coördinatie van regionale initiatieven of onsamenhangend rijksbeleid zou dat een belangrijke functie van provincies zijn (Ten Berge, 1988: 13; Derksen, 1999). De Raad voor het Openbaar Bestuur, Modderkolk en Van den Heuvel noemen vooral de 'integrerende rol' van provincies bij het oplossen van problemen in de regio (Rob, 1999: 5; Modderkolk, 1990: 2-3; Van den Heuvel, 2000: 13). De hierboven genoemde 'Commissie Lodders' introduceerde de term van 'gebiedsregisseur' naast de gebruikte termen als 'kadersteller, toezichthouder en partner' (Commissie Lodders, 2008). Berkhout en Derksen vinden dat de provinciale rol zich bij uitstek leent om 'bestuurlijk partner' te zijn voor andere overheden, instellingen of bedrijfsleven (Berkhout, 1999: 66; Derksen, 1999).

$\mathrm{Al}$ deze benamingen maken het debat over de provincies er niet overzichtelijker op. 
Zo constateert Peters terecht dat de vele benamingen voor de provinciale rol en met name de benaming 'regisseur' (wel of niet achter de schermen) vaak niet worden verduidelijkt (Peters, 2007: 47; zie ook Bekkers \& Lips, 1998: 166). Bovendien heeft een provincie meerdere rollen die soms ook strijdig met elkaar kunnen zijn. Ten Berge wijst erop dat de provincie soms als toezichthouder, maar dan weer als bemiddelaar, regisseur of partner optreedt (Ten Berge, 1988: 15). De Vries is het meest kritisch over deze rolvermenging en stelt dat deze dubbele pet in sommige grootschalige provinciale projecten zelfs leidt tot fiasco's (De Vries, 2003: 123).

Een tweede onderwerp dat in het verlengde van het vorige ligt betreft de positie van de provincie binnen het binnenlands bestuur en specifiek de positie tussen rijksoverheid en gemeentelijke overheid. De provincie vervult in het binnenlands bestuur volgens de Raad voor het Openbaar Bestuur (Rob) en de Raad voor de Financiële Verhoudingen (Rfv) een 'scharnierfunctie' (Rob/Rfv, 2007: 9). In feite vinden beide Raden dat provincies nodig zijn om de twee andere bestuurslagen - rijk en gemeenten - goed te kunnen laten functioneren. De provincie kan optreden als belangenbehartiger voor gemeenten in de lobby naar de rijksoverheid, maar kan ook taken oppakken waartoe een individuele gemeente niet in staat is (Versteden, 1990: 15). Zijderveld heeft het over het 'dunne, toch onmisbare kraakbeen in de ruggengraat' (Zijderveld in Hendriks, 2002: 79) en ook de Raad voor het Openbaar Bestuur gaf een rapport over de provincies de titel Het bestuurlijke kraakbeen (Rob, 1999). De Vries wijst er fijntjes op dat als het gaat om de kraakbeenfunctie ook gezegd moet worden dat ditzelfde kraakbeen - om in de metafoor te blijven - met het ouder worden steeds dunner wordt (De Vries, 2003: 114). En Tjeenk-Willink constateert dat voor zover de scharnier-metafoor opgaat, het hier toch vooral een 'roestig scharnier' betreft (Tjeenk-Willink, 1984: 43).

Enerzijds zijn gemeenten groter geworden door herindelingen en hebben ze van de rijksoverheid meer taken en bevoegdheden gekregen, anderzijds heeft de rijksoverheid steeds meer regionaal verzorgende functies verzelfstandigd of geprivatiseerd (zoals de ziekenhuiszorg of de woningcorporaties). Van Schendelen en De Vries vinden dat in het interbestuurlijk samenspel de rijksoverheid de provincies steeds meer passeert ten faveure van de gemeenten of zelfstandige bestuursorganen (Van Schendelen, 1990: 26; De Vries, 2003: 122). Voor de zaken waar de provincie verantwoordelijk voor is, is zij bovendien sterk afhankelijk van de opstelling van de rijksoverheid en de medewerking van gemeenten (Herweijer, 1996: 69). Vanuit het perspectief van de gemeenten is de veranderende opstelling van bijvoorbeeld de Vereniging van Nederlandse Gemeenten (VNG) naar provincies relevant. Werd er in 1982 nog gesproken van een ontwikkeling 'van verre vriend naar goede buur' (VNG, 1982), in 2006 pleitte de VNG voor een 'gesloten huishouding' voor de provincie terwijl zij tevens constateerde dat veel provincies zich inkopen bij gemeenten om lokale projecten op te zetten (VNG, 2006). Figee vindt daarentegen dat de relatie tussen provincie en gemeenten zich eerder kenmerkt door 'bestuurlijk partnerschap' (Figee, 2003: 269). Niet langer staan provincies en gemeenten tegenover elkaar, maar veel meer naast elkaar. Daar tekent Kleinfeld wel bij aan dat er sprake is van een tweedeling binnen de Nederlandse gemeenten, waarbij hij doelt op het 
verschil tussen de grote stedelijke gemeenten en de kleine gemeenten en hun relaties met zowel provincie als rijk (Kleinfeld, 1999: 137).

Staatsen hanteert nog een ander argument om provincies niet af te schaffen. Op de eerste plaats is het geen aanlokkelijk perspectief voor de rijksoverheid om de provincielaag eruit te halen vanwege het feit dat zij dan met een groot aantal gemeenten rechtstreeks zaken moet doen (Staatsen, 1984: 183). Ten tweede stelt hij dat zonder de provinciale overheid het rijksbeleid op een aantal terreinen 'een aanzienlijk centralistischer karakter' zou hebben gehad (idem.183). Kleinfeld brengt bovendien naar voren dat het proces van gemeentelijke herindeling zonder provincies nooit in deze mate zou zijn gerealiseerd (Kleinfeld, 1999: 143).

Het derde onderwerp dat in het debat over provincies voortdurend terugkomt is de discussie over de regionale schaal. Hierboven werd er al door Van Schendelen en De Vries op gewezen dat door de opschaling van de gemeenten veel publieke zaken door de lokale overheid kunnen worden uitgevoerd. De Vries benadrukt dat grote steden dikwijls grotere ambtelijke apparaten hebben dan de gemiddelde provincie, over uitgebreide expertise beschikken en vaak een regionale functie voor de omliggende gemeenten verzorgen (De Vries, 2011). Van Schendelen wijst daarnaast op de mogelijkheden voor regionale samenwerking tussen gemeenten (o.a. via de Wet Gemeenschappelijke Regelingen) en op de specifieke bevoegdheden van de grote gemeenten (o.a. stedelijke vernieuwing of openbaar vervoersconssessies) die ervoor hebben gezorgd dat gemeenten veel zelf kunnen en de provincie daarvoor niet nodig hebben (Van Schendelen, 1987: 258). Van den Heuvel constateert dat deze nieuwe samenwerkingsvormen de betekenis van 'territoir' hebben verkleind: "De schaal als leidend beginsel voor de inrichting van het binnenlands bestuur is daarmee gerelativeerd" (Van den Heuvel, 2000: 12). Toonen constateert daarentegen dat intergemeentelijke samenwerking zijn grenzen kent en dat er op diverse terreinen sprake is van een 'regionaal gat' waar de verantwoordelijkheden onduidelijk of in ieder geval verdeeld zijn tussen bestuurlijke organisaties (Toonen, 2005: 9; zie ook IPO/Commissie Regionaal Bestuur in Nederland ${ }^{12}$, 2002: 15). Provincies zouden de meest aangewezen bestuurslaag zijn die op regionale schaal een coördinerende rol zouden kunnen vervullen (Versteden, 1990: 15; Van den Heuvel, 2000: 13-14; Toonen 2005: 16).

Een variant die in deze context vaak opduikt, is de stelling dat het Europese politieke systeem zich nadrukkelijker is gaan richten op regio's in Europa in plaats van op de nationale lidstaten. Van Schendelen sprak begin jaren '90 van een 'regionalisering van de beleidsoriëntatie' in het Europese beleid ten koste van de nationale overheden (Van Schendelen, 1990: 29). Europese regiovorming wordt door de Europese Commissie gestimuleerd, blijkens het toenemende belang van Europese regionale subsidies en de (nog beperkte) rol van het Comité van de Regio's (Van Schendelen, 1990: 28; Hendriks, 2002: 83; Figee, 2003: 271). Meijer stelt bovendien dat de belangenbehartiging van regio's op Europees niveau lang niet altijd door de nationale overheid kan worden gedaan vanwege de verschillen tussen regio's (Meijer, 1990: 27).

Het argument dat het belang van provincies versterkt wordt door de regionalisering van het Europese beleid is niet erg overtuigend. Berkhout wijst op het feit dat de regio's van 
Europa niet altijd overeenkomen met het Nederlandse provinciale schaalniveau en dat hier meer in landsdelen gedacht moet worden, vergelijkbaar met de Duitse Länder of zelfs de 'regio Nederland' (Berkhout, 2002: 16; zie ook Meijer, 1990: 31). Ook de constatering dat het grootste deel van het Europese beleid nog gewoon door de nationale lidstaten wordt bepaald en dat Europese regelgeving nationaal vertaald moeten worden laat zien dat de nationale politieke systemen nog steeds een belangrijkere rol spelen dan de provincies of gemeenten. Het Comité van de Regio's heeft slechts beperkte invloed op de Europese besluitvorming, constateert Peters (Peters, 2007: 69).

\section{Typering van het debat}

Het debat over provincies lijkt vooral te gaan over 'wat de provincie niet doet, niet is, niet kan', constateert Berkhout (Berkhout, 2002: 13). De Raad voor het Openbaar Bestuur stelt vast dat er 'weinig eenduidigheid' is in het debat over het middenbestuur (Rob, 1999: 4) en Hendriks spreekt van de 'bekende plaat van de structuurdiscussie, met alle bekende thema's en refreinen' (Hendriks, 2002: 91).

Het debat kenmerkt zich in de eerste plaats door een nog formalistische, staatsrechtelijke benadering. Zowel als het gaat om de taken of rollen van de provincie, als om de schaal van handelen en de interbestuurlijke relaties zijn de argumenten vooral formeel en juridisch van aard. Een analyse van de toegewezen taken of de formele rollen van een provincie zegt echter weinig over de bestuurlijke slagkracht of werkwijze van een provincie. Bovendien veranderen taken en bijbehorende rollen voortdurend. Geelhoed stelt terecht: "[E]en theoretisch bevredigende toedeling van competenties en taken over de verschillende bestuurslagen ... als het al te vinden is, bestaat hoogstens per beleidsterrein en dan nog voor een korte periode" (Geelhoed, 1990: 22).

In de tweede plaats wordt er voortdurend gesproken over de provincie als bestuurslaag. In haar boek Het opgeblazen bestuur gaat Peters in op de vraag of er wel gesproken kan worden van de provincie of dat er toch onderscheid tussen provincies moet worden gemaakt. Zij concludeert: "De overeenkomsten zijn echter groter dan de verschillen" (Peters, 2007: 16), verwijzend naar het feit dat provincies deel uitmaken van het bestuurlijk bestel, de vergelijkbare organisatiestructuur en het overeenkomende takenpakket. De verschillen tussen provincies zijn slechts 'accentverschillen' (idem.16) en Van Schendelen heeft het over 'marginale en voorbijgaande nuances' (Van Schendelen, 1987: 257). Als dat het uitgangspunt van het debat is, kan er een discussie over de provincie worden gevoerd. Dit weerspiegelt zich ook in het feit dat in het debat veel bijdragen eindigen met voorstellen om de structuur van het binnenlands bestuur te wijzigen. Provincies zouden samengevoegd moeten worden of juist opgeknipt moeten worden in kleinere eenheden. De Vries en Van Schendelen hebben zelfs gepleit voor afschaffing van de provincies. Dat deze voorstellen de afgelopen decennia weinig concrete resultaten hebben opgeleverd wordt door velen in een adem bevestigd. Peters stelt dat er sprake is van 'een soort rituele dans' (Peters, 2007: 15; zie ook Hendriks, 2002; Berkhout, 2002; Boogers \& Hendriks, 2005).

De vraag is echter of er wel sprake is van het middenbestuur of $d e$ provinciale politiek? Veel van de hierboven aangehaalde auteurs concluderen immers dat de verschillen tussen 
provincies groter zijn dan de overeenkomsten (zie Staatsen, 1984: 177; Ten Berge, 1988: 16; Versteden, 1990: 16; Kleinfeld, 1999: 138; Van den Heuvel, 2000: 13; Toonen, 2005: 23). Zelfs Van Schendelen geeft toe dat de discussie over provincies in de Randstad een andere discussie is dan die bijvoorbeeld in provincies als Friesland, Zeeland en Limburg (Van Schendelen, 1987: 257; 1990: 28, 31). De Duitse onderzoeker Kleinfeld vindt de discussie over de provincie dan ook gesimplicifeerd: "Modelauto's zijn mooi om mee te spelen, maar ze deugen niet om je van de ene plaats naar de andere te brengen" (Kleinfeld, 1999: 138). En: "Wat is er verkeerd aan, dat in Friesland provincie en gemeenten tot een andere oplossing bij de verdeling van hun taken komen als dat bijvoorbeeld in Limburg het geval is" (idem.138)? Van den Heuvel zit op eenzelfde lijn als hij stelt: "De provincie is een veld van regionale knooppunten en regionale functionele verdichtingen. Vandaar dat per regio de functie van de provincie moet worden gespecificeerd naar de problemen die zich daar voordoen en naar het bestuurlijk potentieel en de beleidscapaciteit van de gemeenten in de regio ..." (Van den Heuvel, 2000: 13). Overigens kiest ook de rijksoverheid voor differentiatie als het gaat om taken voor gemeenten of provincies. Zo kunnen een aantal grote steden taken uitvoeren die op andere plaatsen in het land door provincies worden uitgevoerd (openbaar vervoer, jeugdzorg, beheer budget stedelijke vernieuwing). In het verleden gold dit voor de uitvoering van de wet op de Bejaardenoorden en het grotestedenbeleid (Bordewijk, 1999: 115).

Als er vanuit wordt gegaan dat de verschillen tussen provincies groter zijn dan de overeenkomsten heeft dit ook consequenties voor de gepresenteerde onderwerpen in het debat. Natuurlijk zijn bevoegdheden, taken en rollen van belang als het gaat om de mogelijkheden van een provincie. Maar om uitspraken te kunnen doen over de provinciale rol en de manier waarop de provincie taken uitoefent en bevoegdheden inzet, zal ook gekeken moeten worden naar de aard en schaal van de regionale problematiek of opgave. Daarnaast is de positie van de provincie en haar toegevoegde waarde gerelateerd aan de sterkte van diverse spelers op regionale of lokale schaal. In het interbestuurlijke krachtenveld tussen rijksoverheid en gemeenten is het 'tegenspelvermogen' van provincies - om met Van Schendelen te spreken - cruciaal. De kwaliteit en het vermogen om tegenspel te bieden aan andere overheden, maar zeker ook bedrijfsleven en maatschappelijke instellingen, verschilt per thema, per regio en per provinciaal bestuur.

De bestaande bestuurskundige, politicologische en staatsrechtelijke literatuur ontbeert een helder conceptueel kader voor de analyse van de provincie maar schiet vooral tekort in haar empirische onderbouwing van de vaak generaliserende uitspraken over provincies. Zo heeft Peters onderzoek gedaan naar meerdere provincies waarbij echter niet zo zeer het functioneren van provincies centraal stond, maar de 'prestaties' (doeltreffendheid) van de provinciale overheid (Peters, 2007: 17). Empirisch onderzoek over een langere periode naar het functioneren van een provincie ontbreekt. Het is veelzeggend dat de enige belangrijke studie die over de Nederlandse provincies is verschenen en specifiek ingaat op de rolopvatting en het functioneren van provincies, geschreven is door twee Duitse onderzoekers in opdracht van het Duitse Bundesland Nordrhein-Westfalen (zie Hesse \& Kleinfeld, 1990). 


\section{Naar een nieuwe vraagstelling}

Zowel de interbestuurlijke politieke context als de nationale en regionale maatschappelijke ontwikkelingen zijn van invloed op het provinciale functioneren. Een empirische onderbouwing is zowel nodig als het gaat om de toegevoegde waarde en effectiviteit van overheidsingrijpen vast te stellen, evenals om - zoals in dit boek wordt gedaan - een analyse te geven van de manier waarop besluitvorming tot stand komt. Deze regionale dynamiek met een variëteit aan thema's, partners en schaalniveaus vraagt niet om een discussie over de structuur van het binnenlands bestuur en de provincie daarin, maar veel meer om wat Berkhout 'bestuurlijke responsiviteit' noemt (Berkhout, 1999: 57). Provincies opereren in de een dynamische omgeving, waarin voortdurend belangen veranderen, actoren nieuwe posities innemen en bestuurdersgremia wijzigen. Het debat over provincies zou veel meer moeten gaan over de manier van werken en het functioneren van provincies, dan over wat zij idealiter zouden moeten zijn. Daarbij gaat het veel meer om een 'procesdenken' dan een 'structuurdenken' (Schaap et.al., 2000: 166).

Door naar het daadwerkelijk functioneren van een provincie te kijken wordt inzichtelijk hoe de interactie tussen het provinciale politieke systeem en haar omgeving in de praktijk gestalte krijgt. Drie zaken vallen dan op die in het huidige debat over provincies vaak buiten beschouwing blijven. In de eerste plaats is de interactie van een provincie met niet-politieke organisaties intensiever en omvangrijker dan het debat doet vermoeden. De contacten tussen provincie en bedrijfsleven, maatschappelijke instellingen, intermediaire organisaties, kennisinstellingen en het zogeheten 'particulier initiatief' hebben substantieel invloed op het functioneren van provincies. In de tweede plaats krijgt het zogeheten 'autonome' beleid weinig aandacht in het huidige debat. Vooral de verhouding tussen autonoom beleid en beleid in medebewind blijft tot nu toe onderbelicht. In dit boek zal juist worden aangetoond dat in combinatie met de wettelijke taken van een provincie, de autonome ruimte belangrijk is om in te kunnen spelen op veranderende regionale omstandigheden en nieuwe maatschappelijke opgaven. Ten slotte biedt de in dit boek gevolgde benadering inzicht in een onderwerp dat vaak aan de aandacht ontsnapt in het debat, namelijk de manier waarop de provincie omgaat met geografische indelingen. Wederom kan worden geconstateerd dat dé regionale schaal niet bestaat. Provincies wisselen voortdurend tussen een provinciale, regionale of zelfs lokale aanpak in hun beleid. Zij maken onderscheid tussen stedelijke gebieden of het platteland, experimenteren op kleine of grotere schaal en formuleren bijvoorbeeld beleid voor het noordelijk deel van de provincie dat onderscheidend is van het beleid voor het zuidelijke deel.

Deze drie elementen maken inzichtelijk dat de verhouding tussen de provincie en haar maatschappelijke omgeving een dynamisch karakter kent. De huidige te formalistische en te staatsrechtelijke beschrijving van provincies in het debat zorgt voor een te statische analyse van de provincies. Deze benadering heeft te weinig oog voor de voortdurend veranderende omstandigheden waarbinnen provincies opereren en de manier waarop provincies op hun omgeving inspelen. Daarom staat in dit boek de vraag centraal hoe een provincie functioneert. In deze analyse fungeert de Provincie 
Limburg als onderzoeksobject. Het is ondoenlijk om een grondig historisch-empirisch onderzoek uit te voeren over 45 jaar voor alle twaalf provincies. Alhoewel het hieronder geschetste conceptuele kader de mogelijkheid biedt voor vergelijkbare empirische analyses van andere provincies, gaat dit boek over de provinciale politiek in Limburg. Een interprovinciale vergelijking ontbreekt derhalve, evenals een antwoord op de vraag of de Provincie Limburg een unieke ontwikkeling doorgemaakt heeft. Deze analyse levert daarentegen wel een vernieuwende bijdrage aan het debat over provincies en biedt een onderzoekskader voor vervolgonderzoek bij andere provincies. De onderzoeksvraag luidt:

Op welke manier komt provinciale besluitvorming in de Provincie Limburg tot stand, welke meerjarige patronen zijn hierin te onderscheiden en onder welke omstandigheden veranderen deze patronen?

Om antwoord op deze vraag te geven is een politiek-sociologisch kader ontwikkeld. De provincie wordt in de eerste plaats gepositioneerd ten opzichte van haar politieke omgeving waar rijksoverheid en gemeenten invloed uitoefenen op provinciale besluitvorming. In de tweede plaats wordt de provincie beschreven vanuit een regionaal-maatschappelijke context waarin de provincie positie moet kiezen ten opzichte van de diverse personen, groepen of instellingen die ook invloed uitoefenen op provinciale besluitvorming. Ten slotte zal ook de besluitvorming binnen het provinciale politieke systeem geanalyseerd worden.

De provincie wordt in dit boek opgevat als een politiek systeem dat bindende besluiten neemt binnen haar territoriale grenzen, waarmee zij voortdurend inspeelt op de belangen, ontwikkelingen en prikkels vanuit haar omgeving. Deze politiek-sociologische benadering is voorzien van een historisch-empirische onderzoeksaanpak. Alleen zo kunnen grote veranderende patronen en posities van de provincie in kaart gebracht worden.

\subsection{Provincie als politiek systeem}

Dit boek gaat over de manier waarop provinciale besluitvorming tot stand komt. Implementatie van besluitvorming zal alleen aan de orde komen, als dit relevant is voor nieuwe besluitvorming. Onderzoek gericht op de implementatie of effectiviteit van besluitvorming vereist een aparte vraagstelling en een andere conceptuele en methodologische benadering. Over de effectiviteit van het provinciale beleid worden dan ook geen uitspraken gedaan. Wel kunnen de percepties van betrokken actoren (persoon, groep of institutie) over de effectiviteit van beleid een rol spelen, bijvoorbeeld in de voorbereiding van nieuwe besluitvorming. Vermeende knelpunten in de uitvoering van eerder vastgesteld beleid kunnen dan input zijn voor nieuwe besluitvorming of bijsturing. Alvorens uitgebreider in te gaan op het theoretisch kader, is het nodig om stil te staan bij de positie van provincie als politiek systeem.

\section{Een nieuwe positiebepaling voor provincies}

In de Provinciewet (1962), maar ook al in haar voorloper de Provinciale Wet (1850), en in 
de Grondwet (1848), heeft de regering bekrachtigd dat provincies een open huishouding kennen. De provinciale overheid is tegelijkertijd ook een onderdeel van de Nederlandse gedecentraliseerde eenheidsstaat. In Europees perspectief hebben de nationale lidstaten verenigd in de Europese Unie vanaf de jaren '90 invloed op de nationale, regionale en lokale besluitvorming met bindende Europese richtlijnen en verordeningen.

Provincies nemen dus besluiten in relatieve autonomie. Zij zijn vrij om eigen thema's te agenderen, maar zijn tegelijkertijd gebonden aan de medewerking en ruimte die de Europese Unie, de rijksoverheid, of gemeenten bieden voor provinciale besluitvorming. Deze autonomie in gebondenheid bakent in algemene zin de speelruimte van provincies af (De Monchy, 1976: 196).

Maar de provinciale speelruimte voor besluitvorming wordt niet alleen bepaald door de positie binnen het Nederlands-Europese politieke systeem. De invloed van nationale en regionale maatschappelijke ontwikkelingen speelt ook een rol. Zo kunnen economische conjunctuur (werkloosheid of krapte op de arbeidsmarkt) of lokale omstandigheden (denk aan overstromingen, fluctuerende grondprijzen, migratiestromen, de aanwezigheid van een universiteit) eveneens van invloed zijn op besluitvorming. Met andere woorden, een politiek systeem als de provincie kent in feite twee soorten omgevingen. De omgeving van de andere politieke systemen en de omgeving van maatschappelijke functiesystemen (economie, recht, media, gezondheidszorg, onderwijs, kunst etc.).

De fundamentele vraag die hierbij naar voren komt, is hoe de provincie reageert op de prikkels van deze beide omgevingen. Reageert de provinciale overheid vooral op signalen van de rijksoverheid, of zijn maatschappelijke ontwikkelingen meer bepalend voor de koers van een provincie? En als beide elementen een rol spelen, hoe ziet dit samenspel er dan uit? Hoe wordt deze informatie in de provinciale organisatie verwerkt tot politieke besluitvorming? Het is te simplistisch om te stellen dat een provincie enkel en alleen een doorgeefluik ${ }^{13}$ is van wetgeving uit Den Haag. Het is eveneens problematisch om te veronderstellen dat provincies een intermediaire rol vervullen tussen rijksoverheid en gemeenten. Tjeenk Willink (1984) twijfelt terecht aan deze intermediaire 'scharnierfunctie' van provincies, door sommigen ook wel de 'kraakbeenfunctie' genoemd ${ }^{14}$. Provincies hebben op sommige terreinen een toezichthoudende functie op gemeenten. Andere taken worden in opdracht van de rijksoverheid uitgevoerd (medebewind). Dit zijn eerder afspraken die uitdrukking geven aan een bepaalde taakverdeling tussen rijk, provincie en gemeenten, dan dat het hier gaat om een intermediaire of bemiddelende rolopvatting.

Ten slotte veranderen de taken en inhoudelijke activiteiten van een provincie voortdurend. Met name na 1945 heeft de overheid (rijksoverheid, provincies en gemeenten) activiteiten op zich genomen die daarvoor door particuliere organisatie en instanties werden uitgevoerd. De groei en ontwikkeling van de verzorgingsstaat heeft ook de provinciale taken en bijbehorende financiële en personele middelen vanaf de jaren '60 verbreed (zie appendices III en IV). In de jaren '60 en '70 kregen provincies nieuwe taken op het gebied van milieubescherming en de planning van de ziekenhuis- en bejaardenzorg. In de jaren ' 80 kregen de provincies de verantwoordelijkheid voor het welzijnsbeleid, de volkshuisvesting en stads- en dorpsvernieuwing, gevolgd door extra taken in de jaren '90 
op het gebied van verkeer en (openbaar) vervoer, natuur en landschap, water en jeugdzorg. Maar provinciale activiteiten verdwijnen ook. De Wet op de Bejaardenoorden werd in 1998 ingetrokken waarmee de totale omvang van de provinciale begroting ineens met bijna eenderde verminderde (zie appendix II). Het belang dat het Limburgse Provinciaal Bestuur hechtte in de jaren ' 90 aan het afvalbeleid, lijkt anno 2010 ondenkbaar. Taken veranderen, prioriteiten worden verlegd.

Om de positie van de provinciale overheid te beschrijven is een politiek-sociologisch kader nodig vanuit een historisch perspectief.

\section{Niklas Luhmanns politieke sociologie}

Hierboven is de provincie beschreven als een regionaal politiek systeem dat besluiten neemt binnen de context van de Nederlandse gedecentraliseerde eenheidsstaat en de prikkeling van andere maatschappelijke functiesystemen (economie, onderwijs, recht etc.). De politieke sociologie van de Niklas Luhmann (1927-1998) is een belangrijke bron van inspiratie voor het vormgeven van een conceptueel kader dat de beschrijving van de ontwikkelingen in provinciale besluitvorming mogelijk maakt.

De maatschappij is volgens Luhmann functioneel gedifferentieerd in een aantal functiesystemen zoals economie, recht, politiek, kunst, zorg, wetenschap, media (Luhmann, 1997: 743). Elk functiesysteem heeft binnen de maatschappij een eigen specifieke functie. Zo houdt de wetenschap zich bezig met vragen en problemen die gaan over het vaststellen van waarheid, het rechtssysteem richt zich op de vraag of iets rechtmatig is en het onderwijs stelt de intellectuele capaciteit van leerlingen vast. Zo ook het politieke systeem. De unieke functie van het politieke systeem is de capaciteit om collectief bindende besluiten te nemen op basis van macht (Luhmann, 1981: 82; 2000a: 84). Elk functiesysteem observeert en thematiseert de maatschappij op haar eigen wijze (Laermans, 1999: 257). Zo zal een olieramp door het economische systeem geïnterpreteerd worden in termen van financieel verlies, extra kostenpost en imagoschade van het betrokken bedrijf of zelfs de gehele olieindustrie. Het rechtssysteem moet vaststellen of er sprake is van aansprakelijkheid voor de ramp en of milieuwetgeving en veiligheidsmaatregelen zijn nageleefd. De wetenschap kan een rol spelen als het gaat om het vaststellen van de ecologische schade of in het ontwikkelen van toekomstige nieuwe (veilige) technologie. De politiek ten slotte, kan nieuwe wetgeving initiëren, beleid bijstellen, of vergunningen aanscherpen en handhavend optreden. Ook kan zij stimuleren dat het economisch of wetenschapssysteem geprikkeld wordt om andere vormen van meer duurzame energieproductie te ontwikkelen door bijvoorbeeld innovatiesubsidies. Met andere woorden, elk systeem communiceert op een eigen manier over dit maatschappelijke milieuprobleem (zie ook Luhmann, 2004).

Functiesystemen voorzien elkaar van 'ruis'. Deze ruis werkt als een prikkel voor andere (ontvangende) systemen. Het politieke systeem zorgt bijvoorbeeld door haar instrument van subsidieverstrekking voor prikkelingen in de markt (economisch systeem), maar schept ook randvoorwaarden voor de manier waarop het onderwijs of de zorg in Nederland haar taken uitvoert. De gevoeligheid van politici voor de publieke opinie, wordt overgebracht via het systeem van de (massa)media. En politieke besluitvorming zal 
altijd plaats moeten vinden binnen de grenzen van de wet (Brodocz, 2003: 85-86).

Alvorens in te gaan op de vraag hoe deze omgevingsprikkels binnen het provinciale politieke systeem verwerkt worden, is het nodig om te kijken hoe communicatie binnen het politieke systeem is vormgegeven. Het politieke systeem kent een bijzondere vorm van communicatie, namelijk het voortdurend nemen van bindende besluiten. Een bureaucratische organisatie neemt besluiten waarbij voortdurend selecties en keuzes gemaakt worden (Simon, 1997: 1-3). Lang niet alle informatie die bij het ambtelijk apparaat of individuele gedeputeerden binnenkomt, leidt tot besluitvorming. Anders gezegd, het gaat om een selectie van informatie die vervolgens actief gecommuniceerd wordt en een bijdrage levert aan alternatieven voor besluitvorming. Deze politieke communicatie kan geanalyseerd worden door het proces van besluitvorming inzichtelijk te maken. Het nemen van een besluit op basis van alternatieven wordt mogelijk gemaakt door het uitoefenen van macht. Macht maakt het mogelijk dat een politiek systeem zijn functie van collectief bindende besluitvorming ook daadwerkelijk kan uitvoeren (Blom, 1997: 241). Politieke macht is te definiëren als de bevoegdheid om uit een set van alternatieven een keuze te maken en deze keuze in een besluit vast te leggen. Dat besluit is dan tevens een gegeven (premisse) voor toekomstige besluiten.

Processen van besluitvorming zijn dus de kern van het politieke systeem. Op deze manier kan een politiek systeem ook de grenzen van zijn omgeving afbakenen. Hierboven is al aangegeven dat een provincie twee soorten 'omgevingen' heeft. De omgeving van andere politieke systemen (rijksoverheid, Europese Unie, gemeenten) en de omgeving van andere functiesystemen (economie, onderwijs, recht etc.). Een provincie - als regionaal politiek systeem - is in haar besluitvorming niet afhankelijk van andere functiesystemen, maar zal wel rekening moeten houden met consequenties en effecten van besluitvorming op haar omgeving. Omgekeerd oefenen personen, organisaties of bedrijven voortdurend invloed uit op de provinciale organisatie om besluitvorming te beïnvloeden. Deze interdependentie tussen functiesystemen kan ook in meer of mindere mate gestructureerd zijn, iets wat Luhmann 'structurele koppeling' noemt (Luhmann, 2000a: 373). Een politiek systeem kan op deze manier informatie uit de omgeving omvormen tot politieke besluitvorming, dat wil zeggen, informatie die ook een machtspolitieke vertaling kan krijgen.

Deze structurele koppeling kan op verschillende manieren vormgegeven worden. Zo kan een provinciale organisatie ingedeeld worden naar specifieke taakgerichte afdelingen. Organisatorische indelingen zoals een afdeling Economie, Zorg, Onderwijs of Juridische Zaken zijn voorbeelden van systeeminterne verwijzingen naar andere functiesystemen. Deze afdelingen hebben nog steeds de functie om bij te dragen aan provinciale bindende besluitvorming, maar kennen een specifieke sensitiviteit voor bepaalde andere functiesystemen. Het gaat hier dus niet om de trivialiteit dat politiek alleen maar politieke zaken belangrijk vindt of de wetenschap alleen wetenschappelijke kennis; informatie is alleen relevant voor een politiek systeem als zij te vertalen is in bindende besluiten. Daarmee realiseert het politiek systeem een 'extreme reductie van complexiteit' (Blom, 1997: 243244). Ook overlegstructuren met daarin vertegenwoordigers van externe politieke of nietpolitieke organisaties zijn een manier om informatie uit de omgeving politiek te vertalen. 
Instrumenten als subsidies, verordeningen of persberichten zijn communicatieve uitingen die andere functiesystemen weer tot hun eigen interne communicaties kunnen prikkelen. Het zijn manieren waarop een politiek systeem zich instelt op de prikkels van en naar haar omgeving (Luhmann, 1981: 62).

\section{Eisen aan het conceptueel kader}

Het conceptueel kader zal niet alleen rekening moeten houden met de manier waarop een provincie bindende besluiten neemt, tevens zal het proces van besluitvorming geanalyseerd moeten worden. Bij provinciale besluitvorming spelen vijf elementen een rol.

In de eerste plaats zegt een opsomming van de bevoegdheden en instrumenten op zichzelf genomen weinig over het functioneren en de positie van provincies. Veel meer gaat het om de manier waarop deze bevoegdheden worden ingezet. Om iets te kunnen zeggen over de positie van de provincies zal gekeken moeten worden naar de manier waarop de provincie deze bevoegdheden inzet.

Politieke besluitvorming gaat in de tweede plaats over het afwegen van belangen. Het naar voren brengen van deze (vaak strijdige) belangen gebeurt door een heel scala aan maatschappelijke organisaties, instellingen, bedrijven, overheden, individuen, belangengroepen, ambtenaren, politici, commissies en adviseurs. De formele macht om provinciale besluiten te nemen ligt bij het College van Gedeputeerde Staten $(\mathrm{GS})^{15}$ en Provinciale Staten (PS). Net zo relevant is echter de informele macht en de invloed die zowel buiten als binnen het provinciehuis wordt uitgeoefend in de voorbereiding van definitieve besluitvorming. Naast een analyse van de daadwerkelijke inzet van bevoegdheden, is er een analyse van invloed en macht nodig om te begrijpen hoe de provincie besluiten neemt.

Een derde element dat in provinciale besluitvorming een rol speelt, is de manier waarop een provincie gebruikt maakt van regionale indelingen. Zo is provinciale besluitvorming lang niet altijd van toepassing op het gehele gebied binnen de provinciegrenzen. Door middel van subsidieregelingen kan een provincie bijvoorbeeld eisen stellen aan de grootte van de gemeenten om hiervoor in aanmerking te komen. Een ander voorbeeld is het maken van een regionaal onderscheid tussen regio's met een hoog en regio's met een laag werkloosheidspercentage. Op basis hiervan kan de regio met een grote werkloosheid extra financiële ondersteuning ontvangen of in aanmerking komen voor speciale werkgelegenheidsprojecten. Regionale indelingen spelen dus een rol in de manier waarop besluitvorming tot stand komt.

Binnen het politieke systeem van de provincie moet een onderscheid gemaakt worden tussen de kaderstellende en controlerende rol van Provinciale Staten, de initiërende en uitvoerende rol van het College van Gedeputeerde Staten en de voorbereidende en ondersteunende rol van het ambtelijke apparaat. Daarbij is vooral het samenspel tussen het ambtelijke apparaat en het College van Gedeputeerde Staten van belang. Deze politiekambtelijke verhoudingen vormen een vierde element.

Een vijfde element dat van belang is zijn de momenten waarop de provincie haar strategische koers wijzigt. Momenten van nieuwe agendavorming veranderen de provinciale strategie en de manier waarop besluiten worden voorbereid en geïmplementeerd. Hoewel 
de provinciale rol op dossierniveau met enige regelmaat kan veranderen, zijn de echt fundamentele veranderingen processen van meerdere jaren, vaak decennia. Deze veranderingen over een grotere tijdspanne zullen geanalyseerd, geduid en verklaard moeten worden. De vraag is onder welke omstandigheden deze nieuwe provinciale koers tot stand komt.

Om het functioneren van een provincie en vooral de ontwikkeling van de hierboven genoemde elementen inzichtelijk te maken zullen deze elementen in een historischmaatschappelijke context worden geplaatst. De provinciale bevoegdheden en instrumenten wijzigen in de loop der jaren en nieuwe actoren nemen nieuwe machtsposities in. Bestaande geografische indelingen in het gevoerde beleid worden gewijzigd en politiekambtelijke verhoudingen wisselen waardoor de invloed van gedeputeerden of ambtenaren op de totstandkoming van beleid verandert. Omstandigheden en actoren beïnvloeden de manier waarop de provincie haar beleid gestalte geeft. Ook de momenten van nieuwe provinciale agendavorming waarbij sprake is van een nieuwe strategische koers, zullen in een historisch perspectief geplaatst moeten worden. De provinciale overheid nam in de jaren '60 een fundamenteel andere positie in binnen het binnenlands bestuur en de Limburgse samenleving, dan in de jaren ' 90.

\subsection{Een conceptueel kader voor provinciale besluitvorming}

Hierboven zijn vijf aspecten opgesomd die samen een conceptueel kader vormen voor de beantwoording van de onderzoeksvraag naar de manier waarop besluitvorming in de Provincie Limburg plaatsvindt, welke patronen hierin te ontdekken zijn en onder welke omstandigheden deze patronen veranderen. Deze vijf aspecten vormen de onderzoeksbril waarmee provinciale besluitvorming geanalyseerd wordt, of in termen van deelvragen:

1. Welke bevoegdheden en instrumenten heeft de Provincie Limburg voor het implementeren van provinciale besluitvorming en hoe worden deze ingezet? (\$1.3.1)

2. Welke actoren hebben invloed op provinciale besluitvorming en op welke wijze uit zich dat? (\$1.3.2)

3. Op welke manier worden geografische indelingen gebruikt in provinciale besluitvorming? (\$1.3.3)

4. Hoe zijn de politiek-ambtelijke verhoudingen te kenmerken en wat betekent dit voor de provinciale besluitvorming? (\$1.3.4)

5. Op welke momenten en onder welke omstandigheden is er sprake van nieuwe agendavorming in de Provincie? (\$1.3.5)

De eerste deelvraag biedt inzicht in de formele interbestuurlijke verhoudingen binnen het Nederlandse politieke systeem tussen rijksoverheid, provincies en gemeenten. De tweede deelvraag richt zich op de interactie tussen de provincie als organisatie en andere instellingen, organisaties, bedrijven of personen. De derde deelvraag analyseert de mogelijkheden voor regionale differentiatie en experimenten. De manier waarop informatie verwerkt wordt tot 
politieke besluitvorming binnen de provinciale organisatie is het onderwerp van de vierde deelvraag. Tenslotte wordt gekeken naar kenmerken van besluitvorming door de jaren heen en de belangrijkste wijzigingen in de patronen van besluitvorming.

\subsubsection{Het gebruik van bevoegdheden en instrumenten}

In algemene zin is de functie van een politiek systeem, waar een provincie een onderdeel van vormt, het nemen van collectief bindende beslissingen (Luhmann, 2000a: 84). De provincie heeft op basis van de Grondwet en de Provinciewet de bevoegdheid om beslissingen te nemen binnen de grenzen van haar provinciale gebied. Daarmee is niets gezegd over de specifieke inhoud van beslissingen, want belangen veranderen voortdurend, inhoudelijke onderwerpen komen en gaan, besluiten worden herzien, gecontinueerd of ongedaan gemaakt. Deze variëteit aan mogelijkheden is een belangrijk voordeel voor het politieke systeem, omdat op deze manier flexibiliteit ingebouwd wordt om in te spelen op diversiteit van maatschappelijke ontwikkelingen.

Een provincie is onderdeel van het Nederlandse politieke systeem. Nederland is een gedecentraliseerde eenheidsstaat, waarin de politieke macht verdeeld is over de rijksoverheid, 12 provincies en - per 1 januari 2010 - 431 gemeenten ${ }^{16}$. Het is een mix van centralistische en decentrale elementen (Toonen, 1987: 8). Centralistisch, omdat alleen de rijksoverheid bevoegd is om wetten uit te vaardigen. Decentraal, omdat binnen het kader van de wetgeving er een taakverdeling bestaat tussen rijk, provincies en gemeenten met een zekere mate van autonomie (Lutters, 1976: 41; Hendriks, 2001: 144). Voor alle drie overheidslagen geldt dat zij een bijdrage leveren aan de capaciteit tot het nemen van collectieve besluiten. De verdeling van de onderlinge bevoegdheden en de inzet van instrumenten zegt iets over de inhoud van besluitvorming (Mayntz \& Sharpf, 1975: 7). Een politieke bevoegdheid is het recht om over een bepaald thema collectief bindende besluiten te nemen. De provincie is 'bevoegd gezag' voor het verlenen van milieuvergunningen aan industriële bedrijven, het onderhoud van provinciale wegen en het toezicht op de gemeentelijke financiën. De rijksoverheid is als enige overheidslaag bevoegd om wetten uit te vaardigen. Provincies kunnen wel verordeningen opstellen of bijvoorbeeld tracébesluiten nemen voor de aanleg van een provinciale weg.

Bevoegdheden, oftewel het recht om ergens over te besluiten, is een van de vier instrumenten die een overheid ter beschikking heeft om besluiten uit te kunnen voeren (Hood, 1983: 4-5). Financiële middelen (subsidies, grondbezit, aandelen) zijn een tweede hulpbron voor het realiseren van besluitvorming. Organisatie en het inzetten van menskracht is een derde hulpbron. Tenslotte zijn provincies een knooppunt van informatie als het gaat om provinciale besluitvorming. Politieke besluitvorming vindt plaats op basis van een afweging van verschillende soorten informatie. Deze vier instrumenten kunnen afzonderlijk of in samenhang door een provincie worden ingezet om besluitvorming kracht bij te zetten. Terecht wijst Ringeling (1987) er op dat de inzet van beleidsinstrumenten lang niet altijd een vrije keuze is (Ringeling, 1987: 109). Het wel of niet inzetten van instrumenten wordt beïnvloed door eerder opgedane ervaringen of nieuwe wetgeving en het toekennen van bevoegdheden aan provincies door de 
rijksoverheid. Daarnaast spelen ook politieke overwegingen een rol bij de inzet van een instrument. Een provinciale overheid zal bijvoorbeeld slechts in het uiterste geval een gemeente een zogeheten aanwijzing geven, een bevoegdheid waarmee zij tegen de wil van de gemeente deze toch kan verplichten om aan een provinciaal besluit uitvoering te geven.

Het beschikken over en het daadwerkelijk inzetten van provinciale bevoegdheden en instrumenten is afhankelijk van de positie ten opzichte van de rijksoverheid en de gemeentelijke overheden. In de Nederlandse gedecentraliseerde eenheidsstaat is sprake van een voortdurend zoeken naar een balans tussen deze drie politieke deelsystemen. Door decentralisatie of (re)centralisatie van taken en bevoegdheden veranderen niet alleen de activiteiten waarover besluitvorming plaats vindt, maar ook de manier waarop deze worden uitgevoerd. Zo kunnen taken die een bevoegdheid zijn van de rijksoverheid ook decentraal worden uitgevoerd door provincies, gemeenten (territoriale decentralisatie) of niet-democratisch gecontroleerde instanties als agentschappen of zelfstandige bestuursorganen (functionele decentralisatie). Sterker nog, het is vaak zo dat besluiten voortdurend worden bijgesteld in de fase van uitvoering (Pressman \& Wildavsky, 1984: 227), niet alleen door lagere overheden, maar ook door lokale stakeholders. In die zin is er sprake van 'multi-level governance' waarbij verschillende overheden moeten samenwerken met belanghebbende organisaties (Marks \& Hooghe, 2005: 3). Dit is - in tegenstelling tot wat vaak wordt beweerd - geen nieuw fenomeen. De samenwerking van bijvoorbeeld de Provincie Limburg en de mijnindustrie, het bisdom en de particuliere welzijnsorganisaties vanaf de jaren '30 zijn voorbeelden van wat we nu 'netwerksamenleving' noemen.

In een aantal Europese landen zijn in de tweede helft van de 20e eeuw taken van de nationale overheden overgedragen naar regionale en lokale overheden (Marks \& Hooghe, 2005: 22-23). Ook in Nederland zijn vanaf de jaren '60 diverse taken overgedragen van rijksoverheid naar provincies en gemeenten. Pas in de jaren ' 80 werd er serieus werk gemaakt van decentralisatie door de verantwoordelijkheid voor een groot aantal taken op het gebied van de volkshuisvesting, bejaardenzorg, welzijnsbeleid en regionaal economisch beleid bij de provincies te leggen. Gemeenten zagen zich vooral in de jaren '90 geconfronteerd met een toename van de uitvoering van taken op het gebied van de bijzondere bijstand, sociale zekerheid en stedelijke herstructurering. Daarbij is het vooral interessant om te zien onder welke omstandigheden en voorwaarden taken bij provincies en gemeenten worden gelegd (Heij \& Schrijver, 1991: 56). Is er sprake van een bezuiniging bij de overdracht? Hoeveel beleidsvrijheid wordt er door de rijksoverheid verleend? Is er naast de taakoverdracht ook sprake van de overdracht van de bijbehorende financiële middelen? Welke rapportageverplichtingen zijn er?

In de volgende hoofdstukken zullen de provinciale bevoegdheden en instrumenten binnen de geselecteerde beleidsterreinen geanalyseerd worden. Daarbij zal niet alleen gekeken worden naar de beschikbaarheid, maar zal ook het gebruik en de inzet van bevoegdheden en instrumenten belicht worden. In de afwegingen bij provinciale besluitvorming zal een provincie inspelen op enerzijds reacties en prikkels van andere overheden (rijksoverheid en gemeenten), anderzijds op de positie van niet-gouvernementele organisaties. 


\subsubsection{Analyse van invloed en macht}

Elke week neemt het College van Gedeputeerde Staten een reeks van besluiten over zeer uiteenlopende zaken. Wanneer het gaat om belangrijke besluiten zullen Provinciale Staten een definitief besluit nemen. Het nemen van een besluit kan aangeduid worden als een uiting van formele macht. Waar het gaat om provinciale bindende besluitvorming is de provincie het centrum en concentratiepunt van besluitvormingsmacht. Macht is niet zozeer een pressiemiddel om besluitvorming door te kunnen voeren, maar veel meer de bevoegdheid om ergens over te besluiten. Je gaat erover of niet was de titel van het advies van Commissie Bestuurlijke Coördinatie waarin aanbevelingen aan de regering werden gedaan over het terugdringen van 'bestuurlijke drukte' in Nederland ${ }^{17}$.

Maar het spectrum van invloed en macht is breder. Formele besluitvorming kent een voorbereidingsfase, waarin alternatieven en varianten worden besproken en bediscussieerd, maar ook genegeerd worden of totaal niet aan bod komen. Een besluit kan ook betekenen dat er niks wordt gedaan (Peters, 2002: 72). Lang niet alle informatiestromen zijn politiek relevant en lang niet alle politiek relevante informatie leidt tot formele besluitvorming. Diverse actoren zijn betrokken in de voorbereiding van besluitvorming. Externe organisaties hebben opvattingen over het nodige beleid en proberen hun eigen belangen zo goed mogelijk over te brengen. Provinciale besluitvorming kan dus niet alleen maar geanalyseerd worden in haar interbestuurlijke context, ook de regionale maatschappelijke context, in de vorm van regionaal belanghebbenden, heeft invloed op besluitvorming. Een belangrijk verschil met besluitvorming op nationaal niveau is dat er op provinciaal niveau vrijwel geen sprake is van partijpolitieke afwegingen in de besluitvorming. Arbeidsmarktbeleid, cultuurbeleid of de financiële ondersteuning van het maatschappelijk middenveld, het zijn thema's die nauwelijks beïnvloed worden door partij-ideologie. Deze constatering is vergelijkbaar met de conclusie die Putnam (1993) trok in zijn analyse van een aantal Italiaanse regio's: "The most striking metamorphosis in regional politics to appear ... is a remarkable ideological depolarization, coupled with a strong trend toward a more pragmatic approach to public affairs" (Putnam, 1993: 28). Partijpolitieke motieven spelen op provinciaal niveau wel een rol bij politieke benoemingen en de samenstelling van een nieuw College van Gedeputeerde Staten.

Naast de formele macht van het nemen van een besluit, kan er een onderscheid gemaakt worden tussen invloed en informele macht (Blom, 2007: 16-17). Bij politieke invloed gaat het om de mogelijkheid om een bijdrage te leveren aan het menu van alternatieven waarover uiteindelijk besloten zal worden. Actoren hebben invloed als zij thema's en opvattingen kunnen agenderen voor politieke besluitvorming met het oog op het veiligstellen van de eigen deelbelangen. Het is op dat moment dat informatie onderdeel wordt van politieke communicatie. Er is sprake van informele macht als actoren binnen de provinciale organisatie (ambtenaren of politici) erin slagen om de omvang ('scope') van deze alternatieven substantieel te beperken ${ }^{18}$.

In de analyse van macht en invloed zullen echter ook de middelen ('resources') betrokken moeten worden waarmee deze invloed en macht uitgeoefend kunnen worden (Mokken \& Stokman, 1976: 42). Bevoegdheden en instrumenten zijn niet alleen voor 
een provincie van belang, ook actoren beschikken over hulpbronnen om besluitvorming te beïnvloeden. Financiële middelen, informatie en expertise of de mobilisatie van een achterban zijn voorbeelden van middelen die actoren kunnen benutten. Het is een eerste stap om te analyseren wanneer invloed omgevormd wordt tot informele macht. Maar de constatering dat de actoren beschikken over bevoegdheden en middelen zegt nog weinig over het gebruik ervan. Met andere woorden, onder welke omstandigheden kan informatie een bijdrage leveren aan het keuzemenu van alternatieven voor besluitvorming?

Een politiek systeem zal altijd selectief moeten zijn in wat het tot onderdeel van zijn politieke communicatie maakt, anders leidt dit tot 'ein unkoordinierbares Wirrwarr von Impulsen' (Luhmann, 2000a: 143). Om selectiviteit aan te brengen in de stroom van informatie beschikt een (politieke) organisatie over zogeheten beslispremissen (Simon, 1997: 23, Luhmann, 2000b: 222cf). Premissen zijn de uitgangspunten voor besluitvorming die niet ter discussie staan ('taken for granted'). Het zijn de 'facts \& values' die in de voorbereiding van besluitvorming in het politieke proces worden meegenomen (Simon, 1997: 24). Dit kunnen onderhandelingsresultaten zijn, een specifieke rolopvatting, relevant cijfermateriaal, duidelijkheid over wat er zeker niet besloten gaat worden, of de manier waarop alternatieven op tafel komen. Op het moment dat er een besluit wordt genomen, is dat besluit tevens een premisse voor toekomstige besluitvorming. Het uitoefenen van politieke invloed en macht gaat over het beïnvloeden van premissen van besluitvorming (zie ook Schaap, 1997: 98).

March \& Simon (1993) onderscheiden drie factoren die een structurerende werking hebben op de veelheid van informatie die een politiek systeem krijgt te verwerken: de 'taal' van de organisatie, functionele specialisatie en de mate van afhankelijkheid van informatie (March \& Simon, 1993: 186-187). De 'taal' van de organisatie is de routines, begrippen, gebruiken of classificaties die informatie stroomlijnen. Een brief van een vrijwilligersorganisatie met een subsidieverzoek aan de Provincie zal ingeboekt worden, intern verstuurd worden naar de behandelende afdeling en vervolgens afgedaan worden met een beschikking. De afweging: wel of geen subsidie kan op meerdere gronden genomen worden (subsidiepot is leeg, passend binnen criteria of op politieke gronden), maar het is voor iedereen duidelijk dat het hier om een proces van subsidieverlening gaat en dat dit een zekere volgorde vergt van handelingen waarover uiteindelijk besluitvorming zal plaatsvinden. Een ander voorbeeld zijn de administratieve handelingen die verricht moeten worden om een nota ter bespreking aan te bieden aan Provinciale Staten. Al deze interne procedures filteren en classificeren een veelvoud aan informatie.

Een tweede factor die informatie structureert en selecteert is de manier waarop een politiek systeem georganiseerd is. Informatie komt op verschillende plekken in een politieke organisatie binnen. Contacten tussen de provincie en haar externe omgeving zijn persoonsgebonden. Externe personen hebben contact met provinciale ambtenaren, gedeputeerden of statenleden en wisselen voortdurend informatie uit. Een provinciale organisatie kent een hiërarchische opbouw met een College van Gedeputeerde Staten, een directie, met daaronder vaak functioneel ingerichte eenheden voor ruimtelijke ordening, economie, welzijn, of infrastructuur. Zowel de functionele als de hiërarchische indelingen 
zijn structurerend voor de manier waarop een provincie informatie verwerkt.

Het uitwisselen van informatie is een wederkerig proces. Er komt niet alleen ongevraagde informatie binnen, ook wordt actoren in de omgeving vaak om specifieke informatie gevraagd. Onderzoeken worden in opdracht van overheden uitgevoerd, inspraakavonden zijn vaak mededelend van aard, maar geven een overheid tegelijkertijd informatie over de mate van draagvlak voor een toekomstige beslissing. Cijfermateriaal en statistiek wordt door ambtenaren geraadpleegd om besluitvorming te onderbouwen, uit te leggen of van extra informatie te voorzien in de hoop het College of partners te overtuigen. De mate van afhankelijkheid van informatie zegt iets over de invloed en informele macht van betrokken actoren.

In de volgende hoofdstukken zal gekeken worden welke actoren (personen, groepen en organisaties) invloed en macht uitoefenen in de voorbereiding van provinciale besluitvorming. Niet alleen zal bekeken worden welke actoren betrokken zijn, maar ook de manier waarop zij in het proces participeren. Welke rol spelen zij, welke hulpbronnen zetten zij in en vooral: op welke manier oefenen zij invloed en (informele) macht uit? Om deze invloed te beschrijven, zal gekeken worden naar de organisatie van formele en informele contacten. Deze kunnen zowel gestructureerd (via een commissie of overleg) als ongestructureerd en ad hoc plaatsvinden (lobby-activiteiten, incidenteel bestuurlijk overleg). Ten slotte zal de aandacht uitgaan naar de manier waarop het proces van besluitvorming plaats vindt. Een fasering van de stappen in het besluitvormingsproces maakt duidelijk op welke momenten actoren betrokken zijn, invloed uitoefenen en hoe hun suggesties uiteindelijk in besluitvorming wel of niet worden vervat.

\subsubsection{Het gebruik van geografische indelingen}

$\mathrm{Na}$ de Tweede Wereldoorlog hebben regionale overheden in Europa een sterke groei doorgemaakt. Niet alleen qua omvang van hun ambtelijke apparaten, maar ook zijn de bevoegdheden en middelen toegenomen. Daar zijn verschillende historische, ideologische, economische en politieke verklaringen voor te geven (Sharpe, 1993: 3-26). Maar de manier waarop deze regionale differentiatie van het nationale politieke systeem is vormgegeven, verschilt per land (Loughlin, 2001: 16). De manier waarop Bundesländer functioneren in de Duitse federatieve staat verschilt sterk van de manier waarop Italiaanse provincies een positie innemen ten opzichte van de nationale en gemeentelijke overheid. Nederland is een gedecentraliseerde eenheidsstaat waarin samenwerking niet alleen tussen politieke partijen, maar ook tussen rijksoverheid, provincies en gemeenten een gegeven is (Hendriks, 2001: 146). Elk politiek systeem hanteert geografische indelingen in de totstandkoming van besluitvorming.

Er zijn voor een overheid drie voordelen om geografische indelingen een rol te laten spelen in processen van besluitvorming. Een eerste voordeel voor een rijksoverheid is dat zij daarmee recht kan doen aan lokale en regionale variaties. Zelfs in een relatief klein land als Nederland zijn er provinciale, regionale en lokale verschillen, waarvoor regiospecifieke besluitvorming nodig kan zijn. Een rijksoverheid die als doelstelling heeft geformuleerd 
om het innovatiepotentieel in Nederland te stimuleren, kan beleid maken voor regio's of gebieden waar veel innovatieve bedrijvigheid plaatsvindt om zo economische 'spin off' te stimuleren. Een andere beleidsvariant zou kunnen zijn dat de rijksoverheid juist alleen die regio stimuleert waar het innovatiepotentieel is achtergebleven, om zo een extra impuls te geven aan de vernieuwing van de regionale economische structuur. Dit kan ook redistributieve consequenties hebben als het gaat om de inzet van financiële middelen. De keuze van de rijksoverheid om de prioriteit te leggen bij de Randstad in de Vierde Nota Ruimtelijke Ordening (1988), betekende voor niet-randstedelijke regio's dat zij op minder financiële middelen van de rijksoverheid konden rekenen. De subsidies voor bijvoorbeeld nieuw te bouwen woningen of de aanleg van nieuwe infrastructuur werden zo opnieuw herverdeeld over Nederland waarbij de Randstad op meer financiële ondersteuning kon rekenen dan andere regio's. Financiële verdeelmechanismen (wie krijgt wat, wanneer en waarom) zijn een uiting van regiospecifieke besluitvorming.

Een tweede voordeel ligt in het verlengde hiervan. De rijksoverheid kan door gebruik te maken van geografische indelingen ook experimenteren met nieuwe wetgeving of het toepassen van nieuwe beleidsinstrumenten. Zij kan regio's aanmerken als 'proefregio' of 'pilotregio' om bijvoorbeeld ervaringen op te doen met mogelijk nieuwe wetgeving of om te kijken hoe wijzigingen in het beleid in de praktijk uitpakken. Het bijkomend voordeel is dat wanneer het experiment mislukt, niet meteen het totale beleid ter discussie staat. Een recent voorbeeld is het rijksbeleid dat wordt ontwikkeld in regio's die kampen met dalende bevolkingsaantallen. Terwijl de randstedelijke provincies een sterke groei van de bevolking vertonen is er aan de randen van Nederland (Oost-Groningen, Parkstad Limburg, Zeeuws-Vlaanderen) sprake van een bevolkingskrimp. De provincies Groningen, Zeeland en Limburg fungeren in het nationale beleid als proefregio's voor nieuw overheidsbeleid ${ }^{19}$.

Een laatste voordeel voor een overheid is de mogelijkheid om vergelijkingen te maken tussen provincies, gemeenten of andere nationale overheden. Waarom is het Bijstandsbeleid in de ene gemeente succesvoller dan in de andere gemeente? Welke andere omstandigheden zijn er in de noordelijke provincies die er voor zorgen dat het economisch beleid anders uitpakt dan het beleid van de Provincie Limburg? Een rijksoverheid kan regio's vergelijken en in het beleid ook ervaringen opdoen met verschillen en variaties, evenals het uitspelen van die verschillen tussen regio's.

De drie voordelen zijn hierboven beschreven vanuit het perspectief van de rijksoverheid. Zij zijn echter ook van toepassing op het provinciale niveau. Ook provincies maken binnen hun provinciale territorium regionaal onderscheid. Zo kan in provinciaal beleid onderscheid worden gemaakt tussen stad en platteland of een onderscheid tussen het noordelijke en zuidelijke deel van de provincie. Een provincie kan daarnaast leren van het beleid dat andere provincies voeren. Inzicht in projecten of initiatieven van andere overheden kan voor een provincie bovendien nuttig zijn om zich te onderscheiden, bijvoorbeeld als het gaat om het onderscheid te benutten voor het binnenhalen van rijkssubsidies of de acquisitie van nieuwe bedrijven. Recht doen aan regionale verschillen, experimenteren in 
(deel)regio's en vergelijkingen tussen gemeenten, regio's of provincies, zijn mogelijkheden die een provinciaal politiek systeem kan benutten in haar besluitvorming.

\subsubsection{Inzicht in de politiek-ambtelijke verhoudingen}

De relatie tussen politici en ambtenaren is wederkerig in die zin dat beide partijen afhankelijk van elkaar zijn en moeten functioneren op basis van vertrouwen en loyaliteit (Nieuwenkamp, 2001:348). Het samenspel tussen bewindspersoon (minister, gedeputeerde of wethouder) en ambtelijke organisatie wordt slechts in beperkte mate gekenmerkt door hiërarchie of nadruk op formele macht. Discussies over het herstellen van het 'politieke primaat' gaan er impliciet van uit dat de ambtelijke organisatie niet aan politieke besluitvorming behoort te doen. Zoals hierboven is aangegeven, mag dat juist zijn als het gaat om het uitoefenen van formele macht, maar in de voorbereiding van besluitvorming hebben ambtenaren veel invloed op de manier waarop alternatieven, uitwerkingen en thema's in het besluitvormingsproces een rol spelen (Page \& Wright, 1999: 5). Het gaat dus om een effectieve machtsbalans tussen de politicus en de bureaucratie (Etzioni-Halevy, 1983: 157).

Ambtenaren behoren kennis te hebben van het krachtenveld in de samenleving rondom een bepaald thema, onderhouden relaties en participeren actief in netwerken. Zij maken een inschatting van de risico's van nieuw beleid, formuleren opvattingen over haalbaarheid en uitvoerbaarheid, volgen wetgeving en jurisprudentie. Met andere woorden: er is sprake van een informatie-asymmetrie. Een politicus kan nooit beschikken over de hoeveelheid informatie waarover een ambtelijke organisatie beschikt. Daarentegen kan een politicus over andersoortige informatie beschikken dan zijn ambtelijk apparaat, zoals informatie over draagvlak in het College of Provinciale Staten, externe kritiek op het functioneren van ambtenaren, of bestuurlijk vertrouwelijke informatie en - in toenemende mate - persoonsgerichte informatie per sms, gsm of e-mail. De relatie tussen politicus en ambtenaar is geen eenrichtingsverkeer, maar staat in voortdurende wisselwerking waarbij het uiteindelijk de politicus is die het genomen besluit moet verantwoorden (Visser, 2008: 214).

Binnen de politiek-ambtelijke verhoudingen van de Provincie Limburg zijn verschillende actoren en organisatiestructuren te onderscheiden. De provinciale 'politiek' bestaat uit het College van Gedeputeerde Staten, Provinciale Staten en diverse politieke partijen. Daarbinnen zijn er op individueel niveau gedeputeerden, gouverneurs, statenleden en partijleden te onderscheiden. De ambtelijke organisatie is onderverdeeld naar functioneel ingerichte eenheden met een hiërarchische rolverdeling. Zo is de algemeen-directeur (ook wel secretaris of voorheen griffier genaamd) de direct verantwoordelijke voor de ambtelijke organisatie. Deze organisatie kan weer ingedeeld zijn naar directies of hoofdgroepen, stafafdelingen, beleidsafdelingen, projectafdelingen en ondersteuningsafdelingen waarbinnen dan weer specifieke clusters te onderscheiden zijn.

Tot in de jaren ' 80 was in de meeste provincies sprake van het zogeheten griffiedienstenmodel. De provinciale organisatie was in het griffie-dienstenmodel opgeknipt in 
drie deelorganisaties die ook elk een eigen fysieke locatie hadden: de Provinciale Griffie (de 'beleidsafdelingen'), de Provinciale Planologische Dienst en de Provinciale Waterstaat. Deze laatste twee werden ook wel de 'technische diensten' genoemd. Deze 'diensten' werkten vooral op de beleidsterreinen ruimtelijke ordening en infrastructuur als het ging om de vakmatige, technische aspecten van de beleidsuitvoering. De beleidsinhoudelijke, politieke en juridische afwegingen met name in de fase van beleidsvoorbereiding was een taak van de 'griffie'. Deze taakverdeling was lang niet altijd even duidelijk en er werd vaak dubbel werk gedaan. Dit was een van de redenen dat verschillende provincies in de jaren ' 80 dit organisatiemodel inruilden voor een 'sectorenmodel'. In het sectorenmodel was er sprake van één provinciale organisatie met verschillende sectoren (directies of afdelingen) die zowel de beleidsvoorbereiding als de uitvoering van beleid coördineerden (Van Lier, 2007: 5, 4349). Veel provincies werken nog steeds volgens dit sectorenmodel (of varianten daarop).

De provinciale ambtelijke organisatie is vergeleken met een gemiddeld ministerie tamelijk overzichtelijk. Bij een provincie is ook in mindere mate sprake van departementalisering van organisatorische sectoren die relatief los van elkaar functioneren en waar weinig horizontale dwarsverbanden bestaan tussen de sectoren. Bij een provincie is de aansturing van de ambtelijke organisatie door het College van Gedeputeerde Staten alleen al door de geringe formatieomvang, makkelijker te realiseren dan bij een ministerie, laat staan de gehele rijksoverheid. Dat wil niet zeggen dat daardoor de contacten tussen ambtenaren en gedeputeerden frequenter en intensiever zijn dan op een ministerie. De contacten worden vooral bepaald door de organisatiecultuur en de persoonlijke opstelling van politici. De formele organisatiestructuur speelt in dat opzicht een minder belangrijke rol (Nieuwenkamp, 2001: 348).

In de volgende hoofdstukken zullen de politiek-ambtelijke verhoudingen tussen met name het College van Gedeputeerde Staten en de ambtelijke organisatie centraal staan. Daar waar relevant zal tevens worden ingegaan op de relatie tussen Provinciale Staten en Gedeputeerde Staten c.q. ambtelijk apparaat. Om te beginnen zal worden gekeken naar de manier waarop de Provincie vertegenwoordigd is in haar externe contacten. Is hier sprake van primair ambtelijke vertegenwoordiging of participeren direct of indirect ook politici? Ten tweede zal gekeken worden naar de persoonlijke contacten tussen het ambtelijk apparaat en het College of individuele leden van het College en hoe deze zijn vormgegeven. Zijn er bijvoorbeeld bestuurlijk-ambtelijke tandems te ontdekken of zijn er in de ambtelijke organisatie policy entrepeneurs (Kingdon, 2003: 179)? Een derde aspect heeft betrekking op de intensiteit en frequentie van de contacten tussen ambtenaren en politici. Ten slotte zal ook gekeken worden naar de specifieke expertise en competenties die in het samenspel tussen politiek en ambtelijke organisatie worden benut en ingezet.

\subsubsection{Momenten van nieuwe agendavorming}

Kingdon (2003) en Baumgartner \& Jones (1993) hebben zich beziggehouden met de vraag waarom een bepaald onderwerp op een gegeven moment op de politieke agenda komt en welke (meerjarige) effecten dit heeft voor de manier waarop beleid wordt vormgegeven 
en geïmplementeerd. Kingdon richt zich vooral op de totstandkoming van een politieke agenda, Baumgartner \& Jones onderzochten of dit proces van nieuwe agendavorming schoksgewijs of geleidelijk (incrementeel) verloopt. Beide elementen, het proces van agendavorming en de vraag of dit schoksgewijs of incrementeel verloopt, zijn belangrijk om de processen van agendavorming bij Provincie Limburg te analyseren. Kingdon alsook Baumgartner \& Jones vormen een belangrijke inspiratie voor het hieronder gepresenteerde conceptuele kader.

Een 'agenda' is in de ogen van Kingdon een lijst van onderwerpen of problemen waar personen binnen of nauw gerelateerd aan de overheid, aandacht aan schenken op een gegeven moment (Kingdon, 2003: 3). Hij onderscheidt deze algemene 'gouvernmental agenda' van een 'specialized agenda' en een 'decision agenda'. Een deelagenda ('specialized agenda') bestaat uit een specifiek onderwerp, bijvoorbeeld gezondheidszorg of infrastructuur. Met een besluitvormingsagenda ('decision agenda') geeft de overheid niet alleen prioriteit aan een bepaald onderwerp, maar is zij tevens bereid om hier beleidsvoorstellen en acties voor te ontwikkelen (idem.4). De besluitvormingsagenda is voor Kingdon het belangrijkst. De impact van deze agenda op het toekomstige beleid is vele malen groter dan de veranderingen die optreden bij de algemene gouvernementele agenda (zie ook Baumgartner \& Jones, 1993: 4). De vraag is echter waarom het ene onderwerp wel aandacht krijgt van beleidsmakers en politici en het andere onderwerp niet.

Kingdon onderscheidt drie verschillende elementen die een rol spelen in agendavorming: 'problems, politics, and visible participants' (Kingdon, 2003: 197). Problemen ofwel urgente situaties dwingen een overheid vaak tot een reactie. De toenemende werkloosheid, een oplopend financieringstekort, een ramp of kritiek op het gevoerde beleid, kan ervoor zorgen dat een onderwerp op de agenda komt. Een tweede verklaring wordt gezocht in het politieke klimaat. Een nieuwe regering kan andere prioriteiten stellen. Ook kan het politiek-maatschappelijke debat ('national mood') wijzigen ten faveure of ten nadele van een onderwerp. Een laatste verklaring ziet Kingdon in specifieke actoren die hun stempel weten te drukken op het beleid. Vaak zijn dit politici die uitgesproken voorkeuren naar voren brengen of met nieuwe voorstellen of initiatieven komen, maar dit kunnen ook - in mindere mate - ambtenaren of belangenbehartigers zijn die dicht op de politiek zitten.

Het feit dat een onderwerp of probleem op de politieke agenda komt wil echter nog niet zeggen dat hier ook actief iets mee wordt gedaan en dat dit leidt tot het nemen van (nieuwe) bindende besluiten. Evenmin betekent dit dat wanneer een bepaald probleem politieke aandacht krijgt, er lang niet altijd ook beleidsvoorstellen voor zijn ontwikkeld om het uit te voeren. Daarom besteedt Kingdon veel aandacht aan de manier waarop beleid en vooral de alternatieven voor beleid tot stand komen. Hij noemt het selectieproces van alternatieven voor beleid de policy stream (idem.200). De selectie en afweging van beleidsvoorstellen gebeurt niet willekeurig maar volgens een aantal criteria. Een belangrijk criterium is de haalbaarheid van een voorstel (ook in financiële zin), maar ook politieke ontvankelijkheid, draagvlak bij partners en het grote publiek zijn criteria die een rol spelen (idem.200). De 'policy stream' is voor Kingdon belangrijk omdat die naast 
'problems, politics and visible participants' een bijdrage levert aan de totstandkoming van een besluitvormingsagenda.

Wat Kingdon in feite ter discussie stelt is het rationele ontwerpproces van politieke besluitvorming. Thema's komen niet op de besluitvormingsagenda omdat er eerst een probleem is geïdentificeerd, dat vervolgens nader uitgediept wordt en waarvoor beleidsalternatieven worden voorgesteld die uiteindelijk tot een besluit leiden. Kingdon benadrukt daarentegen de simultaniteit van ontwikkelingen. Problemen, beleidsvoorstellen en politieke invloeden staan relatief los van elkaar. Agendavorming is een fluïde proces waarin actoren in en uit gaan, invloed uitoefenen en problemen uitvergroten, simplificeren of negeren. Het is een proces waar weinig ratio achter zit, maar voor een groot gedeelte op toeval berust. De uitkomst van het proces van agendavorming is niet te voorspellen, wat niet wil zeggen dat er over de patronen in agendavorming geen uitspraken zijn te doen.

Het garbage can model zoals dat in 1972 door Cohen, March \& Olsen werd ontwikkeld is voor Kingdon een belangrijke inspiratiebron. "In the garbage can model ... a decision is an outcome or interpretation of several relatively independent streams within an organization" (Cohen, March \& Olsen, 1972: 2-3). Cohen et.al. onderscheidden vier van zulke stromen: problemen, oplossingen, participanten en keuzemomenten (idem.3). Kingdon brengt dit in zijn analyse terug tot drie stromen die hij belangrijk acht voor de totstandkoming van een besluitvormingsagenda: problemen, beleidsvoorstellen (ofwel oplossingen) en politiek (Kingdon, 2003: 201). Juist op het moment dat deze drie afzonderlijke stromen samengaan ('coupling') is de kans groot dat een onderwerp op de besluitvormingsagenda komt. Dit is dus geen rationeel of voorspelbaar beleidsproces. Volgens Kingdon worden bovendien beleidsvoorstellen vaak om andere redenen geformuleerd dan het oplossen van een probleem. Bij betrokken actoren speelt veel meer het behoud van machtsposities, ideologische overwegingen of het veiligstellen van economische belangen (idem.228). Problemen worden met andere woorden gekoppeld aan de mate van politieke receptiviteit en de voor handen zijnde beleidsvoorstellen. Maar ook kan er voor politieke voorkeuren beleid worden ontwikkeld dat aansluit bij waargenomen problemen of urgente omstandigheden.

Kingdon benadrukt de rol van policy entrepeneurs in het samenbrengen van de drie stromen politiek, problemen en beleid (idem.204). Dit zijn personen die in staat zijn op het juiste moment beleidsvoorstellen te koppelen aan de actuele problematiek en de politieke prioriteiten. De momenten waarop dit mogelijk is zijn echter zeldzaam (idem.203). Baumgartner \& Jones verklaren dit door het 'dempende effect' van structuren (instituties) en wat zij 'beleidsmonopolies' noemen (Baumgartner \& Jones, 1993: 4). Onder beleidsmonopolies verstaan zij de dominante opvattingen over hoe beleid gestalte moet krijgen. Dit komt dicht in de buurt van wat eerder premissen voor besluitvorming is genoemd. De ervaringen uit het verleden zijn daarbij vaak leidend voor hoe problemen gepercipieerd en gedefinieerd worden en hoe besluitvorming tot stand komt.

Zowel Kingdon als Baumgartner \& Jones benadrukken dat een politiek systeem periodes van relatieve rust, stabiliteit en continuïteit kent. Veranderingen zijn dan vooral incrementeel van aard of zoals Lindblom het noemde: 'political change by small steps' 
(Lindblom, 1979: 517). Op gezette momenten is er echter sprake van dynamiek en komen nieuwe onderwerpen op de politieke agenda.

De theorie over agendavorming van Kingdon en Baumgartner \& Jones vormt een belangrijke inspiratiebron om de veranderingen in Limburgse provinciale besluitvorming te verklaren. Voor de analyse van nieuwe agendavorming in de Provincie Limburg is in dit boek een conceptueel kader ontwikkeld dat weliswaar voortbouwt op de inzichten van Kingdon en Baumgartner \& Jones, maar ook een aantal belangrijke verschillen kent.

Een eerste verschil betreft de reikwijdte van agendavorming. De genoemde auteurs analyseren issues, specifieke onderwerpen zoals beleid voor de gezondheidszorg, transport (Kingdon), kernenergie, pesticide, roken, stedelijke ontwikkeling, alcohol- \& drugsgebruik en kindermishandeling (Baumgartner \& Jones). Zij analyseren de mechanismen waardoor deze issues op een gegeven moment op de politieke agenda komen en besluitvorming plaatsvindt. De onderwerpen worden hier los van elkaar bekeken en vinden plaats in verschillende periodes. In de volgende hoofdstukken zal aangetoond worden dat het in het kader van provinciale agendavorming binnen de Provincie Limburg echter niet om enkelvoudige onderwerpen (issues) gaat, maar om een fundamentele verandering van strategie voor het totale provinciale beleid. Zowel in het ruimtelijke ordeningsbeleid, het welzijnsbeleid als het economische beleid is sprake van een gelijktijdige omslag. De manier waarop besluitvorming voorbereid en uitgeoefend wordt, verandert fundamenteel. Het 'beleidsmonopolie' oftewel de premissen van besluitvorming wijzigen in zeer korte tijd, waarmee de algemene provinciale strategie verandert. Dat vraagt om een verklaring die verder reikt dan uitsluitend verklaringen binnen een beleidsveld; het gaat hier om algemene principes die ten grondslag liggen aan meerjarige provinciale strategievorming. Strategie kan gedefinieerd worden als een patroon in een reeks van besluiten (Mintzberg \& Waters, 1985: 257). Provinciale agendavorming zorgt voor een nieuwe strategie voor toekomstige besluitvorming. Daarmee is agendavorming, zoals opgevat in dit boek, breder dan een debat over issues die wel of niet op de agenda staan. Agendavorming gaat hier over de strategische koers van het politieke systeem.

Een tweede nuancering betreft de rol die Kingdon toekent aan 'policy entrepeneurs'. Hoe verleidelijk het ook is om bepaalde personen binnen of zeer nabij de politieke organisatie een invloedrijke rol toe te kennen, dit leidt al snel tot een overschatting van de rol van individuen in het proces van agendavorming. Kingdon zelf is zich daar in de tweede editie van zijn boek ook van bewust als hij opmerkt dat een overconcentratie op individuen 'uncomfortably idiosyncratic' is en patronen van gebeurtenissen waarin deze personen opereren worden genegeerd (Kingdon, 2003: 224-225). In dit boek zal worden beargumenteerd dat agendavorming gaat om het samenspel tussen betrokken actoren.

Ten derde zal de inschatting van Baumgartner \& Jones dat de bevoegdheden en instrumenten die een politieke organisatie tot zijn beschikking heeft ('institutional venues'), een prominente rol vervullen in agendavorming (Baumgartner \& Jones, 1993: 31) worden omgedraaid. Zoals eerder is gesteld, zegt een bevoegdheid weinig over de daadwerkelijke inzet hiervan. In de volgende hoofdstukken zal worden aangetoond dat 
nieuwe bevoegdheden en instrumenten of veranderende organisatiestructuren veel meer een gevolg zijn van nieuwe provinciale agendavorming, dan dat zij nieuwe agendavorming veroorzaken.

Ten slotte zijn in de analyse van agendavorming in de Provincie Limburg de verklaringsgronden van Kingdon toegesneden op de provinciale praktijk. De voorbeelden waarmee Kingdon zijn driedeling problemen, beleidsvoorstellen en politieke afwegingen illustreert, suggereren een dusdanig breed palet aan verklaringen dat de indruk ontstaat dat hier alles relevant kan zijn voor nieuwe agendering. Daarvan is hij zich overigens wel bewust, maar veel verder dan de conclusie dat 'some couplings are more likely than others' komt hij niet (Kingdon, 2003: 207, 222). Baumgartner \& Jones benoemen op hun beurt maar liefst veertien aspecten die belangrijk zijn als het gaat om nieuwe agendavorming (Baumgartner \& Jones, 1993: 238-243).

Op basis van het onderzoek van het empirische materiaal blijken in het geval van de Provincie Limburg slechts drie aspecten van belang voor agendavorming: externe urgente omstandigheden, allianties tussen personen en de ruimte die de rijksoverheid geeft voor provinciale besluitvorming. Het gaat hier om drie afzonderlijke en onafhankelijk van elkaar werkende elementen, die op het moment dat zij samenkomen en verknoopt worden, zorgen voor een nieuwe provinciale strategie. In de volgende hoofdstukken zal op zo'n moment van nieuwe agendavorming gesproken worden van een omslagmoment. Personen, en scherper geformuleerd, allianties tussen personen (Kingdons 'policy entrepeneurs') vormen slechts één van de drie elementen in nieuwe agendavorming. Zij kunnen geen externe urgentie creëren, noch de ruimte afdwingen die de rijksoverheid biedt voor provinciale besluitvorming. Personen kunnen wel problemen herkennen of actief inspelen op de door de rijksoverheid geboden speelruimte. Omgekeerd kan een urgente omstandigheid een impuls geven aan nieuw rijksbeleid of ervoor zorgen dat personen nieuwe besluitvorming initiëren.

Als het gaat ompersonen gaat het vooral om de contacten of allianties tussen provinciale politici (gedeputeerden of een gouverneur) en personen van ofwel de rijksoverheid ofwel lokaal-regionale organisaties. Een gedeputeerde kan grote ambities hebben en deze ook formuleren, een samenwerkingspartner buiten de provinciale organisatie is cruciaal om deze ambities in concrete besluitvorming om te zetten. Op het moment dat er sprake is van diverse wisselingen op bestuurlijk niveau binnen de provincie, kan de ambtelijke organisatie als verzameling van personen externe allianties aangaan en zo provinciale agendavorming beïnvloeden. Het zal blijken dat de nieuwe allianties van personen vaak gevormd worden, niet lang na het aantreden van een nieuw College van Gedeputeerde Staten.

De voor een Provincie urgente omstandigheden zijn voornamelijk financieeleconomisch van aard (werkloosheid, bezuinigingen, verplaatsing of het stoppen van grote bedrijven) of zij kenmerken zich door een perceptie van ineffectiviteit van beleidsuitvoering. Beide aspecten, financieel-economische omstandigheden en ineffectieve uitvoeringsstructuren, spelen in de provinciale agendavorming een belangrijke rol. 
Voor een provincie is ten slotte de opstelling van de rijksoverheid belangrijk. Ook al zijn de huishoudboekjes van provincies en gemeenten 'open', men is gebonden aan de speelruimte die de rijksoverheid biedt in haar beleid. Provincies zijn afhankelijk van de rijksoverheid in financiële zin (bijvoorbeeld als het gaat om de criteria voor de verdeling van het Provinciefonds of Brede Doeluitkeringen), in staatsrechtelijke zin (alleen de Staten-Generaal stellen nationale wetgeving vast of stellen eisen aan de uitvoering van medebewindstaken) en in beleidsmatige zin (nieuw rijksbeleid kan provinciaal beleid initiëren). De opstelling, medewerking of toegankelijkheid van individuele ministers, ministeries of kabinetten is dus van grote invloed op provinciale besluitvorming.

In de volgende hoofdstukken zullen vier omslagmomenten van nieuwe provinciale agendavorming worden beschreven. Steeds opnieuw is daarbij sprake van het samengaan van extern urgente ontwikkelingen, allianties tussen personen en het benutten van de ruimte die door de rijksoverheid wordt geboden voor nieuwe provinciale besluitvorming. Of dit tevens een voorzet is voor een meer algemene analyse van provinciale agendavorming, zal vervolgonderzoek bij andere provincies moeten uitwijzen.

\subsection{Methodologie}

In dit boek wordt de Limburgse provinciale politiek geanalyseerd in de periode van 25 januari 1962 (publicatie Provinciewet in het Staatsblad) tot 7 maart 2007 (datum van de provinciale verkiezingen). Omdat dit een omvangrijke periode is, moeten er selecties, keuzes en afbakeningen gemaakt worden.

\subsubsection{Afbakeningen en selecties binnen het onderzoek}

Selectie van de Provincie Limburg als onderzoeksobject

De dataverzameling is beperkt tot informatie over de Provincie Limburg. Daarbij is vooral het provinciale archief als primaire bron gebruikt. Analyses van de totstandkoming van standpunten in andere organisaties (ministeries, Etil, KVK's, DSM, vakbeweging, of andere provincies) zijn niet onderzocht. Praktische overwegingen speelden hierbij een rol omdat het provinciale archief zeer omvangrijk is en voldoende informatie biedt over de standpunten en opvattingen van andere organisaties en niet-provinciale personen. Externe archief-informatie, andere bronnen of besluitvormingsprocessen in andere organisaties zijn pas voor de provincie relevant indien zij onderdeel worden van de provinciale politieke communicatie. Met andere woorden, externe informatie wordt pas relevant als zij terug te vinden is in de voorbereiding van de politieke besluitvorming en daarmee in de provinciale beleidsstukken. Vergelijkingen met bijvoorbeeld andere provincies zullen alleen een rol spelen als zij als referentie worden gebruikt voor eigen, Limburgse politieke besluitvorming en communicatie. Alhoewel er ongetwijfeld parallellen zijn te trekken met de ontwikkeling van andere provincies of regio's, is dat niet de insteek van dit boek. Hiervoor zou een meer vergelijkende studie uitkomst moeten bieden. Daarvoor is hier niet gekozen. 


\section{Selectie van de onderzochte beleidsterreinen}

In deze periode van 45 jaar zal met name worden gekeken naar de ontwikkeling van drie specifieke beleidsterreinen: het ruimtelijke ordeningsbeleid, het economisch beleid en het welzijnsbeleid. Deze aandachtsvelden zijn niet willekeurig gekozen, maar zijn, de provinciale activiteiten voor die periode overziend, de majeure beleidsthema's. Tegelijkertijd dienen zij als kapstok voor een redelijk breed en divers beeld van de provinciale activiteiten binnen die periode. Het uitgangspunt van deze studie is dus niet een inventarisatie van alle provinciale activiteiten of bevoegdheden, maar een analyse van de veranderende rol en positie van de provincie als politiek systeem. De drie geselecteerde beleidsterreinen bieden voor de beantwoording daarvan meer dan voldoende materiaal. Daarbij kunnen per beleidsterrein verschillende accenten worden gelegd. De decentralisatie I centralisatie-discussie tussen rijk en provincie werd met name in de welzijnssector in de jaren '80 gevoerd. De discussie ging tijdens de periode 2003-2007 juist op dat terrein weer sterk in op de relatie tussen provincie en gemeenten. Zo kunnen discussies over flexibele en rigide planvorming als telkens terugkomend thema in de ruimtelijke ordening worden teruggevonden. Het herstructureringsbeleid in de jaren '60 en '70 is een voorbeeld op het economisch terrein van een reactief reagerende provinciale overheid, terwijl het Perspectievennota-beleid en - meer recent - de economische Versnellingsagenda voorbeelden zijn van een besef van eigen kracht.

Deze drie inhoudelijke aandachtsgebieden worden in hun maatschappelijke, organisatorische en politieke context geplaatst. Op de eerste plaats is dat de maatschappelijke context waarbinnen deze beleidsterreinen zich ontwikkelden (conjuncturele ontwikkelingen, rampen en urgenties, (inter)nationale vertogen, mediaaandacht, of dominante denkbeelden). Verder is de organisatorische context van belang (beschikbaarheid van financiële middelen, inzet van juridische instrumenten, benoemingen, reorganisaties, competenties, expertise, organisatiestructuren, politieke prioritering). Tot slot zal ook de bestuurlijk-politieke context (verkiezingsuitslagen, coalitievorming, politiek-ambtelijk samenspel, allianties/relaties met het 'maatschappelijk middenveld' of bedrijfsleven, invloed nationale machtsverhoudingen) meegenomen worden.

\section{Selectie binnen beleidsterreinen}

Er zijn onderdelen binnen de drie beleidsterreinen die een hogere prioriteit hebben gekregen in dit boek. Binnen het ruimtelijke ordeningsbeleid is met name gekeken naar het streekplanwerk, met bijzondere aandacht voor: het Streekplan Oostelijke Mijnstreek (1958-1965), het Streekplan Noord- en Midden-Limburg (1973-1982), het Provinciaal Omgevingsplan I (1995-2001) en de herijking daarvan (2005-2006). Daarnaast wordt de reorganisatie van de Provinciale Planologische Dienst en Commissie (1979-1985), de decentralisatie van taken midden jaren '80, de gebiedsgerichte aanpak Nadere Uitwerking Brabant-Limburg (jaren '90) en tot slot het traject Heroriëntatie Ruimtelijke Ontwikkeling (2003-2007) belicht.

In de analyse van het economisch beleid is met name de besluitvorming rondom 
de Eerste Mijnnota (1965), het Herstructureringsbeleid en de voorbereiding van de Perspectievennota Zuid-Limburg (1966-1978), de drie periodes Perspectievennota-beleid (1978-1990), het Regionaal Technologieplan Limburg (1993-1999) en de totstandkoming van de Versnellingsagenda (2003-2007) geanalyseerd.

Binnen het welzijnsbeleid tenslotte heeft het Bijzondere Regionale Welzijnsbeleid (BRW-beleid 1963-1980), de commissies Sociale Begeleiding (1959-1983), de herstructurering van de diverse Raden en steunfuncties (1979-1989), het Bestuurlijk Experiment Kaderwet Specifiek Welzijn (1979-1989), de reorganisatie van de provinciale welzijnsstructuur tot de stichting Symbiose (1992-2003) en het thema Vitale Kernen en Buurten (2003-2007), bijzondere aandacht gekregen.

\section{Nadruk op besluitvorming, minder op uitvoering}

Zoals hierboven reeds gesteld, ligt het accent in deze studie met name op de beleidsvoorbereiding en politieke besluitvorming. Daarmee is niet gezegd dat uitvoering minder belangrijk is. Sterker nog, 'beleid' wordt voor een gedeelte ook nog gemaakt in de uitvoering (zie Pressman \& Wildavsky, 1984; Torenvlied, 1996; Mayntz, 1997; Hoogenboezem, 2003). Op het moment dat de uitvoering weer als input dient voor nieuwe besluitvorming, bijvoorbeeld naar aanleiding van een evaluatie, een stagnerende uitvoering of het niet nakomen van gemaakte afspraken, zal dit - indien geagendeerd worden meegenomen. Overigens zegt een nieuwe agendering van een item soms ook iets over de uitvoering van dat onderwerp (of een variatie daarop) in het verleden.

\subsubsection{Gehanteerde bronnen}

Voor dit onderzoek is gebruik gemaakt van archief- en dossieronderzoek, secundaire literatuur rondom de geselecteerde beleidsterreinen en algemene secundaire literatuur over regionale economie en politiek. Een derde bron wordt gevormd door 71 interviews, gehouden met diverse betrokkenen bij verschillende fases van de onderzoeksperiode. Op deze manier is de algemene argumentatielijn onderbouwd door een triangulatie van deze verschillende bronnen.

\section{Provinciaal archiefonderzoek}

Voor dit onderzoek is uitgebreid provinciaal archiefonderzoek verricht. Het provinciale archief is bijzonder rijk te noemen aan voorbereidingsnotities, memo's, nota's, verslagen van bijeenkomsten, notulen van vergaderingen van het College van Gedeputeerde Staten, handgeschreven opmerkingen en commentaar, conceptversies van voorstellen, ingekomen en verzonden brieven en reacties, faxen, en e-mailverkeer. In de meeste gevallen is deze informatie helder en overzichtelijk chronologisch geordend per dossier. Vanaf de tweede helft van de jaren ' 90 is het archief minder gestructureerd geordend en ontbreken stukken of zijn een aantal stukken zelfs al vernietigd door het verstrijken van ingegeven bewaartermijnen. Ook is de diversiteit binnen de dossiers aan beschikbaar materiaal beperkter. Het gaat steeds meer om de archivering van formele en definitieve eindstukken. Gelukkig bestond er de mogelijkheid om gebruik te maken van een aantal 
persoonlijke archieven van direct betrokken ambtenaren die de wat beperkte 'informele' informatie uit het officiële archief grotendeels compenseren.

Daarnaast is gebruik gemaakt van die bronnen uit het archief die een meer beschouwend karakter hebben zoals jaarverslagen, evaluaties, monitoringsrapportages, overzichtsnotities, krantenartikelen en overige publicaties. Tevens is gebruik gemaakt van meer algemene documenten zoals coalitieakkoorden, jaarlijkse begrotingen, jaarprogramma's van beleidsterreinen, verslagen van vergaderingen van Provinciale Staten en commissies, landelijke nota's en subsidieregelingen.

\section{Secundaire literatuur}

Om de regionale, nationale en internationale context van de provinciale beleidsontwikkeling in kaart te brengen is gebruik gemaakt van secundaire literatuur, overzichtswerken en meer beschouwende of kwantitatieve analyses over Limburg, politiek en bestuur in Nederland, regionale economische en demografische ontwikkelingen (o.a. analyses van het E'til, de PPD, ministerie van EZ, CBS). Verder is gebruik gemaakt van diverse publicaties van of over Limburgse organisaties, bedrijven, of personen en Limburgrelevante onderdelen uit nationale en internationale literatuur.

\section{Interviews}

Om de ambtelijk-bestuurlijke context van de provinciale ontwikkeling scherper in beeld te krijgen is een groot aantal interviews gevoerd met betrokkenen uit de periode 1962-2007. In totaal zijn er 71 interviews afgenomen. Daarbij zijn zowel ambtenaren, bestuurders alsook niet bij de Provincie werkende personen geïnterviewd. Er zijn gesprekken gevoerd met alle nog levende (en aanspreekbare) gedeputeerden en gouverneurs die in de periode 1962-2007 actief zijn geweest. In totaal gaat het dan om 27 bestuurders. Daarnaast zijn 33 provinciale ambtenaren geïnterviewd die vaak voor of na hun provinciale periode bij andere organisaties hebben gewerkt. Zo kon er een beeld worden verkregen van hoe de buitenwereld tegen de Provincie ankeek. Deze informatie werd geverifieerd met interviews van 11 personen die nooit bij de Provincie hebben gewerkt, maar wel in organisaties in de directe omgeving van de Provincie Limburg (gemeenten, ministeries, bedrijfsleven, intermediaire organisaties). De geïnterviewden is aan het einde van het gesprek gevraagd een suggestie te doen voor andere personen die zij van belang achten om te interviewen in het kader van dit onderzoek. Op deze manier (de zogeheten 'snowball methode') kon naast informatie uit het beschikbare archiefmateriaal een beeld worden verkregen van mogelijk relevante gesprekpartners. De uiteindelijke keuze voor de selectie van personen die geïnterviewd zijn ligt bij de auteur.

De interviews zijn in vier fases gehouden: de gesprekken met provinciale ambtenaren en externen zijn hoofdzakelijk gehouden in de periode mei - oktober 2007 en januari - juli 2008. De bestuurlijke gesprekken zijn in de periode januari 2009 - mei 2009 en maart - mei 2010 gehouden. De interviews waren semigestructureerd (geïnspireerd door het hierboven geschetste conceptuele kader) waarbij de gemiddelde gespreksduur dikwijls ruim boven de twee uur lag. De geïnterviewden kregen vooraf een korte synopsis van 
de aanpak van het onderzoek toegestuurd. De opbouw van de gesprekken kende een historisch-biografische opbouw, uitgaande van de werkzame carrière van de persoon zelf, waarbij werkzaamheden voor en na de directe provinciale betrokkenheid evenzo werden besproken.

De interviews hadden twee functies. Op de eerste plaats boden de gesprekken een globale leeswijzer voor het (zeer omvangrijke) primaire bronnenmateriaal. Gesprekpartners belichtten invalshoeken die richting gaven om de belangrijkste nota's, verslagen, argumentaties, overleggen etc. te ordenen en te interpreteren. Op de tweede plaats fungeerden de gesprekken als een verificatie en aanscherping van de globale analyse die op basis van een eerste raadpleging van het archiefmateriaal was gemaakt.

\subsection{Opbouw van het boek}

Dit boek is opgebouwd uit zes hoofdstukken. Na dit eerste inleidende hoofdstuk volgen drie historisch-empirische hoofdstukken. Hoofdstuk 2 behandelt de ontwikkeling van het provinciale ruimtelijke ordeningsbeleid. Daarbij wordt vooral ingegaan op de besluitvorming rondom de provinciale streekplannen. Het bieden van rechtszekerheid en het inspelen op veranderende omstandigheden, is de rode draad door het ruimtelijke beleid van de Provincie. De ontwikkeling van het economisch beleid door de Provincie Limburg staat centraal in hoofdstuk 3. De relatie tussen Provincie, ministerie van Economische Zaken en Limburgse bedrijfsleven, is het kernthema van dit hoofdstuk. In hoofdstuk 4 wordt het welzijnsbeleid beschreven waarin vooral de verschuivingen in bevoegdheden en taken tussen rijksoverheid, provincie en particulier initiatief aan de orde zullen komen.

De ontwikkelingen in deze drie empirische hoofdstukken zullen in hoofdstuk 5 samengebracht worden volgens het conceptuele kader van hoofdstuk 1. Op basis daarvan zal in hoofdstuk 6 de probleemstelling worden beantwoord. 



\title{
Provincie Limburg en de ruimtelijke ordening $1962-2007$
}

\begin{abstract}
"Ik wil hierbij niet verhelen dat op sommige plaatsen de werkelijke ontwikkeling zó snel is voortgeschreden, dat de in het streekplan neergelegde regeling daar reeds voorbij werd gestreefd. Het lijkt mij nuttig, even bij dit feit stil te staan omdat het ons confronteert met het steeds duidelijker wordende inzicht dat de ruimtelijke ordening geen statisch karakter draagt, maar zich telkens zal moeten aanpassen aan de dynamiek van het leven. Dat betekent dat de plannen zullen moeten worden aangepast aan veranderende omstandigheden waarbij de afweging van belangen opnieuw zal moeten plaats hebben." ${ }^{20}$
\end{abstract}

Gouverneur in de Provincie Limburg F.J.M.A.H. Houben (KVP), 26 oktober 1960

Het inrichten en ordenen van de openbare ruimte op basis van een afweging van verschillende belangen, is de kern van de ruimtelijke ordening. Belangen veranderen, soms in zeer korte tijd. De Commissaris der Koningin, die in Limburg ook wel gouverneur wordt genoemd, ging drie jaar later met pensioen. Hij kon niet hebben voorzien dat de 'dynamiek van het leven', Limburg in zo'n korte tijd zou veranderen.

Het Streekplan Oostelijke Mijnstreek waaraan hij refereerde, werd in 1962 door Provinciale Staten vastgesteld, maar bleek al snel achterhaald. Het streekplan was nog sterk beïnvloed door de mijnindustrie. De winning van kolen door de Staatsmijnen en de Oranje Nassau Mijnen was echter vanaf 1962 een verliesgevende activiteit. In Groningen was een paar jaar eerder een ondergrondse gasbel gevonden, waardoor de Limburgse mijnindustrie onder grote druk kwam te staan. De mijnen hadden sinds het begin van de 20e eeuw een grote invloed gehad op de inrichting en ordening van ZuidLimburg. Woningbouw, sociaal-culturele voorzieningen, parken en moestuinen, deze voorzieningen werden allemaal door de mijnen geregeld. Gouverneur F.J.M.A.H. Houben (KVP) nam in 1963 dan ook afscheid in 'een wolk van zorgen' (Mertens, 1963: 38).

Maar niet alleen de twee mijnstreken veranderden. De gehele Limburgse bevolking was sterk toegenomen, steden breidden zich uit, het autogebruik nam spectaculair toe en de mechanisatie in de landbouw zorgde voor een ongekende schaalvergroting. Voor de Provincie Limburg in haar algemeenheid, en de ruimtelijke ordening in het bijzonder, betekende dit een nieuwe afweging van belangen.

In dit hoofdstuk staat de ontwikkeling van het Limburgse ruimtelijke ordeningsbeleid in de periode 1962-2007 centraal. Het provinciale streekplan neemt in dit hoofdstuk een belangrijke plaats in. Een streekplan is een regionaal plan dat de gewenste ruimtelijke ontwikkeling schetst van een afgebakend gebied. Binnen dit gebied worden verschillende bestemmingen (woningbouw, industrie, natuur, landbouw) aangewezen. Het streekplan wordt in de wet beschreven als een 'richtsnoer' voor gemeenten bij het maken van bestemmingsplannen. De ruimtelijke wetgeving (nationale bevoegdheid), het opstellen 
van een streekplan (provinciale bevoegdheid) of bestemmingsplan (gemeentelijke bevoegdheid) is door de jaren heen altijd in meer of mindere mate met elkaar verbonden geweest. Deze interbestuurlijke verhoudingen worden tevens beïnvloed door maatschappelijke ontwikkelingen. Daarbij gaat het in het ruimtelijke ordeningsbeleid vooral om het scheppen van een balans tussen 'voorspelbaarheid en zekerheid enerzijds, en flexibiliteit anderzijds' (Van Assche, 2006: 17). Het tegelijkertijd bieden van rechtszekerheid én het inspelen op veranderende omstandigheden in de Provincie Limburg, is de rode draad in dit hoofdstuk.

Allereerst wordt de ontwikkeling van het nationale ruimtelijke ordeningsbeleid (\$2.1) geschetst voor zover deze van belang is geweest voor de Provincie Limburg. Vervolgens wordt stilgestaan bij de ontstaansgeschiedenis van de Limburgse ruimtelijke ordening vóór 1962 (\$2.2). Het jaar 1962 vormt hierna het startpunt van de analyse. In dat jaar stelden Provinciale Staten van Limburg het Streekplan Oostelijke Mijnstreek vast. De Eerste Kamer nam tevens de nieuwe Wet op de Ruimtelijke Ordening aan. Deze wet legde de juridische basis voor het ruimtelijke ordeningsbeleid van de navolgende decennia. De taakverdeling tussen rijksoverheid, provincies en gemeenten veranderde daarbij fundamenteel (Simonis \& Glasbergen, 1979: 18). Onderverdeeld in vier periodes wordt deze verandering vanuit het Limburgse perspectief beschreven $(\$ 2.3 \mathrm{t} / \mathrm{m} \$ 2.6)$. Daarbij zal antwoord worden gegeven op de in hoofdstuk 1 geformuleerde onderzoeksvragen over de provinciale bevoegdheden en instrumenten, de relevante en invloedrijke actoren (persoon, groep of organisatie), de manier waarop geografische indelingen een rol spelen, en de politiek-ambtelijke verhoudingen. Ten slotte zullen de hoofdlijnen worden samengevat en kunnen voorlopige conclusies getrokken worden (\$2.7).

\subsection{Ontwikkelingen in het nationale ruimtelijke ordeningsbeleid ${ }^{21}$}

Het tot stand brengen van de Woningwet in 1901 wordt vaak geduid als het startpunt voor het nationale ruimtelijke ordeningsbeleid (Pijnenburg, 1956: 8; Simonis \& Glasbergen, 1979: 16; Siraa, 1989: 59; De Ridder, 1990: 15; Van Damme \& Verdaas, 1996: 23; Van der Woud, 2004: 437; De Haas, 2006: 19). De wet moest zorgen voor een verbeterde woonsituatie in het industrialiserende Nederland van begin 20e eeuw. Er was een nauwe samenhang met de Gezondheidswet die in hetzelfde jaar werd aangenomen ${ }^{22}$. De sociale hygiëne in de zich uitbreidende arbeiderswijken werd steeds meer een maatschappelijk probleem.

Op de eerste plaats kregen gemeenten met de wet de bevoegdheid om vast te stellen of bewoning verantwoord was (Siraa, 1989: 60). De Woningwet vereiste bovendien dat elke gemeente een uitbreidingsplan moest opstellen. Dit plan moest goedgekeurd worden door de provinciale overheid. Nadat het opstellen van deze gemeentelijke uitbreidingsplannen op gang was gekomen, ontstond er in de jaren '20 en '30 een nieuw vraagstuk. Waren de plannen van buurgemeenten niet strijdig met elkaar? Moesten er voor aan elkaar grenzende gemeenten geen wettelijke afspraken komen (Pijnenburg, 1956: 10)? De regering wijzigde de Woningwet in 1931, waarmee de mogelijkheid ontstond voor gemeenten - die dat wenselijk achtten - een regionaal plan op te stellen, het zogeheten 
streekplan. In dit streekplan konden samenwerkende gemeenten een regionale verdeling van bestemmingen aangeven. Een 'streekplancommissie' bereidde dit plan voor waarna de provincie haar goedkeuring hierover moest uitspreken ${ }^{23}$. Veel provincies richtten in deze tijd eigen streekplannendiensten op om de streekplancommissies te ondersteunen (Pijnenburg, 1956: 32-37; De Ridder, 1990: 16-17). Daarmee was de ruimtelijke ordening een regionaal vraagstuk geworden (Van der Cammen \& De Klerk, 2006: 151).

De rijksoverheid hield zich niet bezig met uitbreidingsplannen of streekplannen. Zij was na 1918 vooral bezig met de uitbouw van de nationale infrastructuur en vanaf de crisisjaren '30 met de industriepolitiek van het land (De Rooy, 2005: 172; De Hen, 1980: 9). Ruimtelijke ordening werd overgelaten aan de decentrale overheden (Van der Cammen \& De Klerk, 2006: 157). Direct na de Tweede Wereldoorlog was de rijksoverheid vooral bezig met de wederopbouw en het aanpakken van de woningnood. 'Planning' en 'ordening' waren centrale begrippen die de wederopbouw in goede banen moesten leiden (idem: 165). Pragmatisch handelen ging boven wetgeving. Pas begin jaren '60 kwam de regering met een nationale visie op de ruimtelijke ordening. In de Nota inzake de Ruimtelijke Ordening (de 'Eerste Nota Ruimtelijke Ordening') van 1960 had het ministerie van Volkshuisvesting en Ruimtelijke Ordening een evenwicht proberen te vinden tussen de explosieve bevolkingsgroei, de toenemende verkeersproblemen in het westen van het land en de claims die hierdoor op de openbare ruimte werden gelegd (Bartels \& Van Duijn, 1981: 79). Twee jaar later, met de Wet op de Ruimtelijke Ordening (1962) werd het ruimtelijk beleid, wettelijk gezien, losgekoppeld van de volkshuisvesting.

Deze nieuwe wet was vooral een 'organisatiewet' die de taken en bevoegdheden tussen rijksoverheid, provincies en gemeenten veranderde (De Ridder, 1990: 26). Zo werd het bestemmingsplan (voorheen het uitbreidingsplan) het enige ruimtelijke plan met een directe juridische grondslag voor burgers. Het provinciale streekplan was niet langer een verplichtend kader waarmee gemeenten in het opstellen van de bestemmingsplannen rekening moesten houden. Het streekplan werd in de wet beschreven als een 'regionaal richtsnoer' voor gemeenten en provincies ${ }^{24}$. Provincies kregen daarbij de bevoegdheid om bestemmingsplannen inhoudelijk te toetsen. Het streekplan was daarvoor het inhoudelijke referentiekader. De rijksoverheid, ten slotte, stelde nationale plannen op waarin de grote ontwikkelingen geschetst werden. Een Inspectie Ruimtelijke Ordening ging wel per provincie toezien op de juiste toepassing van de nieuwe wet. De wet was een vertaling van het politiek belangrijke subsidiariteitsbeginsel, waarmee de belangrijkste bevoegdheden in het ruimtelijke ordeningsbeleid gelegd werden bij provincies en gemeenten (Van de Cammen \& De Klerk, 2006: 178). Deze nieuwe verdeling van taken tussen rijk, provincies en gemeenten zou tot 2007 van kracht blijven. De verhouding tussen provincie en gemeente was in principe gelijkwaardig (Simonis \& Glasbergen, 1979: 19).

In de periode na de invoering van de nieuwe wet in 1965 moesten veel gemeenten en provincies wennen aan deze nieuwe taakverdeling. Vanaf de jaren '70 stelde de rijksoverheid steeds meer eisen aan de ruimtelijke ordening. Nieuwe wetgeving op milieugebied ${ }^{25}$ stelde de rijksoverheid eisen aan de plannen van gemeenten en provincies. Ook de inspraak van de bevolking werd vastgelegd in procedures ${ }^{26}$. In de eerder verschenen 
Tweede Nota Ruimtelijke Ordening (1966) was een kaart van Nederland opgenomen met daarop aangegeven de gewenste hoeveelheid nieuw te bouwen woningen in Nederland. De kaart introduceerde een 'nationale kernenhiërarchie' die veel invloed heeft gehad op de provinciale streekplannen (Van der Cammen \& De Klerk, 2006: 216). Daarmee bleek dat het ruimtelijke ordeningsbeleid in de praktijk nog lang niet losgekoppeld was van de volkshuisvestingstraditie. Een ander aspect dat in het nationale beleid werd geïntroduceerd en dat veel navolging in het provinciale streekplan heeft gekregen, was het concept van 'facetplanning'27. Volgens dit concept ging ruimtelijke ordening niet alleen over volkshuisvesting, wegen en bedrijventerreinen, maar ook over de belangen van natuurwaarden, de landbouw, het grondwater en beekdalen. Deze verschillende belangen moesten tegen elkaar afgewogen worden. De belangen conflicteerden vooral op het platteland. Het kabinet Den Uyl (1973-1977) presenteerde in de jaren '70 drie grote nota's waarin de ruimtelijke relaties tussen stad en platteland werden verkend ${ }^{28}$. Dat was nieuw, want zeker het platteland was tot die tijd voor de overheid een 'terra incognita' (idem.282). Provincies en gemeenten verkregen zo nieuwe expertise in het opstellen van streekplannen en bestemmingsplannen.

In de jaren ' 80 stond het nationale ruimtelijke ordeningsbeleid in de schaduw van andere beleidsterreinen. Met name het financieel-economisch beleid kreeg prioriteit in de kabinetten Lubbers. Met de Herziene wet op de Ruimtelijke Ordening in 1985 kregen gemeenten grotere beleidsruimte, vooral door een versoepeling van de eisen die aan een bestemmingsplan werden gesteld (Van Damme \& Verdaas, 1996: 51). Het beleid voor stads- en dorpsvernieuwing werd, evenals de regionale volkshuisvesting in datzelfde jaar gedelegeerd naar provincies en gemeenten. Het was een eerste decentralisatieronde in de ruimtelijke ordening. De rijksoverheid, die zich langzaam terugtrok uit de regio, kwam echter eind jaren ' 80 weer via de achterdeur binnen. Het thema 'milieu' was - na jaren van economische hervormingen - hoog op de politieke agenda komen te staan.

Het streven naar een betere samenhang tussen de ruimtelijke ordening en het milieubeleid stond dan ook centraal in de Vierde Nota Ruimtelijke Ordening Extra (de 'Vinex-nota') van 1990, waarbij het beleid voor water, natuur en landinrichting belangrijk werd geacht ${ }^{29}$. Op regionaal niveau werden diverse 'nadere uitwerkingen' van deze nota verwacht. Gelijktijdig met de Vierde Nota werd door de regering een groot aantal wetten vastgesteld ter bescherming van natuur, water en milieu $^{30}$, dieverstrekkende invloed hadden op provinciale en gemeentelijke ruimtelijke plannen. Werd de verantwoordelijkheid voor de realisatie van de Vierde Nota primair gelegd bij gemeenten en projectontwikkelaars, met deze verschillende 'sectorwetten' trok de rijksoverheid toch de teugels weer aan. De nieuwe wetgeving vereiste een provinciale vertaling en aanvullende regelgeving.

Midden jaren ' 90 vond er een nieuwe decentralisatieronde ${ }^{31}$ plaats, de zogeheten Decentralisatie Impuls. Provincies kregen bevoegdheden inzake de landinrichting, de openluchtrecreatie, het landschaps- en bosbeleid en het beleid voor regionaal verkeer en vervoer ${ }^{32}$. Daarmee werd de positie van de provincie met name voor de ruimtelijke ordening van het platteland versterkt. Nieuwe regelgeving op provinciaal niveau was een van de gevolgen. Deze nieuwe regelgeving zorgde eind jaren '90 voor de heropleving van 
een oude nationale discussie, namelijk de mate van flexibiliteit in de ruimtelijke ordening. Vanuit de Tweede Kamer kwam er kritiek op de 'grote nota-ijver' van de ministeries (Van der Cammen \& De Klerk, 2006: 428). Ruimtelijke ordening was te reactief geworden. Economische ontwikkelingen werden geremd en het strakke ruimtelijke beleid belemmerde in de ogen van Kamerleden en gemeenten de noodzakelijke woningbouw in de steden en dorpen. Verschillende adviesraden vonden eveneens dat er een nieuwe 'ruimtelijke ontwikkelingspolitiek' nodig was ${ }^{33}$.

De kritiek had effect. De aanpassingen, die de kabinetten Balkenende I en II in het ontwerp van de Vijfde Nota maakten, verankerden het concept van een 'ruimtelijke ontwikkelingspolitiek'. Hiermee doelde men op de mogelijkheid om economische ontwikkelingen of nieuwe woningbouw toe te staan op plekken waar dit volgens het bestemmingsplan niet mocht. In ruil voor het toch toelaten hiervan, moest er een financiële compensatie geleverd worden. Om dit principe van 'voor wat, hoort wat' concreet gestalte te geven werden verschillende instrumenten ontwikkeld ${ }^{34}$. Met de nieuwe Nota Ruimte (2004) delegeerde de rijksoverheid veel verantwoordelijkheden aan provincies en gemeenten. Het motto was 'decentraal wat kan, centraal wat moet' ${ }^{\prime 3}$. Een nieuwe Grondexploitatiewet en een nieuwe Wet Ruimtelijke Ordening moesten dit juridisch mogelijk maken. Beide wetten versterkten de mogelijkheden voor een 'ontwikkelingsgericht' ruimtelijk beleid. Het was een omslag in het denken over ruimtelijke ordening en de relatie tussen rechtszekerheid en flexibiliteit.

In 2007 werden de nieuwe Wet Ruimtelijke Ordening en de Grondexploitatiewet door de Tweede en Eerste Kamer aangenomen. De nieuwe Wet Ruimtelijke Ordening had één belangrijke consequentie voor de provincies. De toetsingsbevoegdheid van provincies inzake de gemeentelijke bestemmingsplannen verviel. In de plaats daarvan kregen provincies de bevoegdheid om zelf een zogeheten 'inpassingsplan' te maken. Dit inpassingsplan kende dezelfde wettelijke status als het bestemmingsplan ${ }^{36}$.

Daarmee brak - na 45 jaar - een nieuwe fase aan in de verdeling van bevoegdheden tussen rijk, provincies en gemeenten. Ruimtelijke ordening was ruimtelijke ontwikkeling geworden. Provincies en gemeenten hebben in deze nationale ontwikkeling een belangrijke rol gespeeld. In Limburg werd aan het begin van de 21e eeuw zelfs een ruimtelijk ontwikkelingsbeleid gevoerd dat vooruit liep op het rijksbeleid. Dit beleid diende als voorbeeld voor een nieuwe ruimtelijke ontwikkelingspolitiek. Dat was niet altijd zo geweest.

\subsection{Limburgse ruimtelijke ordening voor 1962}

Het nadenken over ruimtelijke ordening in Limburg begon in 1918. Op initiatief van het Limburgse Tweede Kamerlid Ch.J.M. Ruys de Beerenbrouck ${ }^{37}$ (RKSP) werd er een 'Commissie tot onderzoek naar de sociaal-hygiënische toestanden in Zuid-Limburg' ingesteld. De architect J.Th.J. Cuypers uit Roermond kreeg de opdracht om een bebouwingsplan voor de regio op te stellen. De aanleiding voor het bebouwingsplan was de snel verslechterende woonsituatie van de Zuid-Limburgse arbeidersklasse. Het gevaar van sociale onrust lag op de loer ${ }^{38}$. Een jaar later lag er een bebouwingsplan voor Zuid- 
Limburg, volgens sommigen het eerste streekplan van Nederland (Pijnenburg, 1956: 24; De Ridder, 1990: 17). Het bebouwingsplan kon echter alleen betekenis hebben als de Limburgse gemeenten hun uitbreidingsplannen hierop afstemden. Hier kwam weinig van terecht. Gemeenten maakten geen haast met het opstellen van uitbreidingsplannen. Bovendien was het provinciale streekplan een weinig effectief instrument om de specifieke locaties voor woningbouw te reguleren. Het waren vooral de gemeenten en de mijnindustrie die via hun grondprijzen de ontwikkeling van de regionale woningbouw bepaalden. De commissie die de sociaal-hygiënische toestand in Zuid-Limburg moest onderzoeken, stierf een stille dood ${ }^{39}$. Toch had de commissie voor het eerst een regionaal perspectief geschetst op de Limburgse volkshuisvesting.

Aan de vooravond van de wijziging van de Woningwet (1931) deed zich een nieuwe kans voor. De Noord-Brabantse Commissaris der Koningin A.B.G.M. van Rijckevorsel deed in november 1929 zijn Limburgse ambtsgenoot een voorstel om een streekplan voor het Noord-Limburgse en Zuidoost-Brabantse Peelgebied op te stellen ${ }^{40}$. De ontginning van de Peel had het doel om nieuwe agrarische mogelijkheden te creëren (Pijnenburg, 1956: 26; Janssen, 2006: 89 e.v.). Het gewestelijke Peelplan lag er in 1930. De Nederlandse Heidemaatschappij had de opdracht gekregen voor de ontginning van de Peel. Het waren de eerste initiatieven op het gebied van de Limburgse ruimtelijke ordening die niet direct met volkshuisvesting van doen hadden.

Toen het streekplan in 1931 een wettelijke status kreeg, richtte het Provinciaal Bestuur van Limburg 'eene permanente streekplaninstantie' op ${ }^{41}$. Op 1 december 1934 werd de Limburgsche Streekplannendienst officieel opgericht onder leiding van J.H. Froger $^{42}$. Gemeenten droegen bij in de kosten. Tot in de jaren '50 zou de Dienst zich vooral bezighouden met het opstellen van gemeentelijke uitbreidingsplannen. Het streekplan had dan wel een formele status gekregen in de wetswijziging, maar het initiatief hiervoor lag nog steeds bij die gemeenten die samen wilden werken en niet bij de provincie. Initiatieven waren er wel, maar slechts op kleine schaal ${ }^{43}$.

Pas in de jaren ' 50 werd het opstellen van streekplannen door de Provincie Limburg serieus opgepakt ${ }^{44}$. Drie streekplannen werden in de jaren '50 door de Provinciale Planologische Dienst uitgewerkt. Deze streekplannen stonden in het teken van de Limburgse industrialisatie en dan vooral de ontwikkeling van de mijnindustrie. Het Streekplan Westelijke Mijnstreek (1954) was bovenal opgesteld om de uitbreiding van de Staatsmijn Maurits en de vernieuwde cokesfabriek Emma mogelijk te maken ${ }^{45}$. Het Streekplan Midden-Limburg ten oosten van de Maas (1956) bereidde de ontwikkeling van de nieuwe Staatsmijn Beatrix voor. Tegelijkertijd zorgde dit streekplan ervoor dat de stad Roermond zich kon uitbreiden (ten koste van de buurgemeente Maasniel), door deze gemeente alle ruimte te geven voor nieuwe arbeiderswoningen ${ }^{46}$. Volgens Beckers is dit het bewijs dat de provinciale planologen van die tijd vooral 'uitbreidingstechnici' waren (Beckers, 2006: 135). In 1959 werd Maasniel bij de gemeente Roermond gevoegd. Het was een van de eerste herindelingen in Limburg. Het toont aan dat ruimtelijke ordening en bestuurlijke ordening nooit ver uit elkaar hebben gelegen. De belangen van de mijnindustrie werden hier handig gekoppeld aan de belangen van de stad. De provinciale 
belangenafweging viel ongunstig uit voor de kleine agrarische buurgemeente.

Zowel het streekplan Westelijke Mijnstreek als het streekplan Midden-Limburg stonden nog sterk in het teken van gemeentelijke uitbreidingsplannen en lokale mijnontwikkelingen. Het derde streekplan uit die jaren, het Streekplan Oostelijke Mijnstreek (1958-1962), vormde de opmaat voor een nieuw type streekplan. Een regionale afweging van belangen stond daarin centraal.

In 1958, op het hoogtepunt van de ontwikkeling van de mijnindustrie, werkten in de Oostelijke Mijnstreek ongeveer 64.000 mensen in de mijnen. Reken daarbij nog eens de mensen die werkten bij de vele toeleveringsbedrijven en de verzorgende bedrijven zoals de middenstand, dan verschafte de mijnindustrie een directe en indirecte werkgelegenheid voor ruim 90.000 mensen. Wanneer de gezinssituatie meegerekend wordt, betekende dit dat 270.000 personen direct of indirect afhankelijk waren van de mijnindustrie. Dit was $70 \%$ van de totale bevolking van de Oostelijke en Westelijke Mijnstreek (Messing, 1988: 81-83). Naast de werkgelegenheid had de mijnindustrie tevens veel gronden in haar bezit en voorzag zij in de aanleg van wegen, riolering, woonblokken en de bouw van kerken. De gehele infrastructuur van de regio was gericht op de mijnindustrie. De kolencrisis van 1958 wierp zijn donkere schaduw vooruit. Gales ziet 1958 als het jaar waarin het denken over de toekomst van de mijnen fundamenteel veranderde (Gales, 2000: 51).

De Provinciale Planologische Dienst (voorheen de Streekplannendienst) zag de toekomst van de mijnindustrie somber in. De provinciale planologen stelden zich de vraag of het niet tijd werd om eens te kijken naar andere industrieën voor de regio. Bovendien hadden diverse gemeenten hun beklag gedaan bij de Provincie over het omvangrijke grondbezit van de mijnindustrie. Zij kregen weinig ruimte van de mijnindustrie om uitbreidingsplannen te realiseren voor woningen of nieuwe 'anders georiënteerde' industrie ${ }^{47}$. De belangen van de (grotere) gemeenten botsten hier met de belangen van de mijnindustrie. In de ontwikkeling van het streekplan Oostelijke Mijnstreek (1958-1962) kwamen deze belangentegenstellingen expliciet naar voren. De Planologische Dienst zag als belangrijkste oplossing hiervoor een regionale planning van bestaande en nieuwe industrieterreinen ${ }^{48}$. Een nieuw 'industrialisatieprogramma' voor de regio Heerlen, Kerkrade, Brunssum en Hoensbroek was nodig ${ }^{49}$. Ondanks het feit dat het streekplan de wettelijke mogelijkheid bood om deze nieuwe ruimtelijke verdeling af te dwingen ${ }^{50}$, was de Provincie zeer terughoudend om hiervan gebruik te maken. De subsidiariteit van gemeenten was voor de Provincie belangrijker dan het benutten van de wettelijke mogelijkheden. De constatering van Van der Cammen \& De Klerk dat het streekplan in de jaren '50 een 'zeer gedetailleerd ... bestemmingsplan voor bovengemeentelijke zaken' was (Van de Cammen \& De Klerk, 2006: 219), gold dan ook niet voor de Provincie Limburg. De autonomie van gemeenten op het gebied van de ruimtelijke ordening stond voorop. Overleg, diplomatie en wederzijds respect voerden de boventoon in de provinciaalgemeentelijke betrekkingen.

In deze contacten werd de Provincie vooral ambtelijk vertegenwoordigd en wel in de persoon van de directeur van de Planologische Dienst, J.C. van Poppel. In het 
overleg met de betrokken gemeenten benadrukte hij dat het streekplan niet gezien moest worden als een 'barrière' voor het gemeentelijke uitbreidingsplan of dat 'aan elk lijntje op het streekplan met alle gestrengheid de hand zal worden gehouden ${ }^{51}$. Dit bemoeilijkte natuurlijk een regionale planning, omdat elke gemeente opkwam voor het eigen lokale belang van een woonwijk of industrieterrein ${ }^{52}$. Maar niet alleen gemeenten speelden een belangrijke rol in het provinciale beleid, ook het Bisdom Roermond had veel invloed. De katholieke parochiestructuur was eveneens een ruimtelijke organisatiestructuur ${ }^{53}$. Nieuwe woonwijken betekenden nieuwe parochies (Beckers, 2006: 111). Een van de uitgangspunten voor het streekplan was dan ook het bieden van 'verantwoorde ontplooiingsmogelijkheden voor de parochiële eenheden ${ }^{\prime 54}$. Men moest dus rekening houden met de belangen van gemeenten en kerkelijke parochies. Ook in Brabant was een soortgelijke 'ordening op katholieke grondslag' een belangrijk thema deze periode (Janssen, 2006: 107 e.v.). Toch was in Limburg de mijnindustrie de meest invloedrijke speler in het Streekplan Oostelijke Mijnstreek. Zowel de Staatsmijnen als de particuliere mijnen hadden met omvangrijke grondposities feitelijk de macht in handen. De Provincie was daarnaast afhankelijk van de informatie die de mijnindustrie aanleverde ter onderbouwing van het streekplan. De prognoses voor de ontwikkeling van de werkgelegenheid en de behoefte aan nieuwe industrieterreinen kwamen rechtstreeks van de mijnen zelf. Zelfs het kaartmateriaal met daarop de grenzen van de consessiegebieden en risicoplekken voor mijnschade moest de Planologische Dienst bij de mijnbedrijven opvragen.

De banden tussen mijnindustrie en Provincie waren binnen de provinciale politiek nauw verweven. De directeur van de particuliere Oranje Nassau Mijnen, C.E.P.M. Raedts, was tevens fractievoorzitter van de Katholieke Volkspartij (KVP) in de Provinciale Staten. Het was gebruikelijk dat na de ambtelijke voorbereidingen van de Planologische Dienst er een Bijzondere Commissie uit Provinciale Staten werd samengesteld. Deze commissie moest ervoor zorgen dat het ambtelijke ontwerpstreekplan omgevormd werd tot een definitief streekplan dat aan Provinciale Staten werd aangeboden. De beantwoording van de inspraakreacties en de vertaling hiervan naar het definitieve plan, was een van de kerntaken van deze commissie. Zo kon het voorkomen - zoals in het Streekplan Oostelijke Mijnstreek gebeurde - dat de voorzitter van deze Bijzondere Commissie de fractievoorzitter van de KVP was. Raedts moest dus als voorzitter van de Commissie de ingediende bezwaarschriften van zijn bedrijf, de Oranje Nassau Mijnen beoordelen ${ }^{55}$. In haar eindadvies adviseerde de Commissie onder andere om 'complementaire bestuurlijke maatregelen' voor het gebied te nemen ${ }^{56}$. Men bedoelde een gemeentelijke herindeling. Het zou pas in 1969 tot een voorstel voor herindeling leiden. In de Commissie was naast een aantal Statenleden de gedeputeerde voor Ruimtelijke Ordening vertegenwoordigd. De rol van deze gedeputeerde beperkte zich tot het overbrengen van de bevindingen van de commissie naar het College van Gedeputeerde Staten. Van een sterke sturing vanuit het College was geen sprake en de inhoudelijke inbreng werd vooral geleverd door directeur Van Poppel van de Planologische Dienst ${ }^{57}$.

Het resultaat van deze eerste vingeroefening in bovengemeentelijke planning was een paar jaar later al achterhaald. De aankondiging van de mijnsluiting door minister 
Den Uyl betekende dat het streekplan niet langer actueel was. Immers, in het vastgestelde streekplan had de mijnindustrie de ruimte behouden die zij altijd al had via haar grondbezit. De gemeenten behielden de flexibiliteit om naar eigen inzicht uitbreidingsplannen te maken. Onderhandelingen met de mijnindustrie over de mogelijke overdracht van gronden naar gemeenten, beschouwde de Provincie niet als haar taak. De vestiging van nieuwe industrieën werd overgelaten aan het pas opgerichte Industrieschap Oostelijk Mijngebied waarin betrokken gemeenten samenwerkten. De (beperkte) resultaten van de Industrieschappen zullen in een ander hoofdstuk worden besproken. Het Streekplan Oostelijke Mijnstreek werd op 8 januari 1962 door Provinciale Staten goedgekeurd. Het was het jaar waarin de winning van kolen niet langer winstgevend was. Het was ook het jaar waarin de Eerste Kamer de Wet op de Ruimtelijke Ordening aannam. Het streekplan, zo moest ook de nieuwe directeur van de Planologische Dienst constateren, was bij vaststelling al ingehaald door de actualiteit ${ }^{58}$.

Concluderend kan gesteld worden dat de Limburgse ruimtelijke ordening tot 1962 sterk beïnvloed werd door de Limburgse lokale economische ontwikkelingen enerzijds en de macht van de mijnindustrie, kerk en - in mindere mate - gemeenten anderzijds. Het streekplan als bovengemeentelijk plan ontstond in het interbellum en kreeg een organisatorische vertaling in de jaren '30 met de oprichting van de Limburgse Streekplannendienst. Streekplannen werden tot de jaren '50 nog nauwelijks gemaakt. De streekplannen van de jaren '50 waren vooral een verzameling van cijfers, met globale prognoses en schetsen van gewenste ontwikkelingen op abstracte kaarten. Het streekplan werd opgesteld voor een klein afgebakend gebied, waarin op korte termijn ruimtelijke bestemmingen aangewezen moesten worden voor economische ontwikkelingen. In de streekplannen van de jaren '50 werd veel overgelaten aan het gemeentelijke uitbreidingsplan. Het belang van het subsidiariteitsbeginsel waarmee gemeenten, maar vooral de mijnindustrie, voldoende planologische ruimte kregen, ging boven het stellen van strenge ruimtelijke spelregels in een streekplan. Vanuit de Provincie was het vooral de directeur van de Planologische Dienst die de onderhandelingen met de mijnindustrie, het Bisdom en burgemeesters leidde. De rol van het College van Gedeputeerde Staten was beperkt. Maar het omgaan met de tegenstelling van belangen was nog nooit zo expliciet naar voren gekomen als in de totstandkoming van het Streekplan voor de Oostelijke Mijnstreek. Een voorteken van een nieuwe fase in de ruimtelijke ordening.

\section{Eerste omslagmoment: een nieuwe wet, een nieuwe afweging van belangen (1962-1965)}

De Wet op de Ruimtelijke Ordening was in 1962 door de Eerste Kamer aangenomen, maar werd pas op 1 augustus 1965 rechtsgeldig. Tot aan het begin van de jaren '70 bestond er nogal wat onduidelijkheid over de precieze bedoelingen van de wet. De streekplannen van voor 1965 moesten worden herzien en nieuwe streekplannen werden er nauwelijks gemaakt (Bröcking \& Van Geest, 1979: 149; Simonis, 1979: 116). Zo ook in Limburg. In het jaarverslag over de jaren '65-'66 meldde de Provinciale Planologische Dienst dat de nieuwe wet 'aanvankelijk leidde tot stagnatie, veroorzaakt door onwennigheid met de 
nieuwe voorschriften en het gemis aan jurisprudentie ${ }^{159}$. Het actualiseren van de oude streekplannen tot een 'streekplan-nieuwe-stijl'60 bleek geen gemakkelijke opgave voor de provinciale planologen. Voor de Planologische Dienst betekende de nieuwe wet een omslag in de manier waarop streekplannen werden opgesteld; met name de paragraaf 'beschrijving', die het programmatische karakter tot uitdrukking moest brengen en waarin formuleringen met een 'verordenende tendens' vermeden moesten worden, bleek lastig ${ }^{61}$. Niet langer was het streekplan, hiërarchisch gesproken, superieur aan het gemeentelijke bestemmingsplan. Hiervoor in de plaats kregen provincies wel de bevoegdheid om gemeentelijke bestemmingsplannen te toetsen en goed, respectievelijk, af te keuren of wijzigingen voor te stellen. Het was vooral deze nieuwe taak waar de nieuwe gouverneur en een nieuwe directeur van de Planologische Dienst zich vanaf begin jaren '60 sterk op gingen richten.

In 1961 was C.P.A. 't Hoen de nieuwe directeur geworden van de Provinciale Planologische Dienst. Drie jaar later, in 1964 volgde Ch.J.M.A. van Rooy (KVP) ${ }^{62}$ F.J.M.A.H. Houben (KVP) op als gouverneur. Gouverneur Van Rooy was daarvoor burgemeester van Heerlen geweest en had affiniteit met vooral de gemeentelijke ruimtelijke ordening. Samen met 't Hoen verlegde hij de in de jaren '50 gegroeide aandacht voor het streekplanwerk, naar de nieuwe provinciale taak, de toetsing van gemeentelijke bestemmingsplannen. Dat was niet geheel vreemd. Ook in Limburg waren in die tijd de bevolkingsprognoses van het Centraal Bureau voor de Statistiek doorgedrongen. In het jaar 2000 zou de Nederlandse bevolking gegroeid zijn tot 20 miljoen inwoners. Het Provinciaal Bestuur vertaalde deze cijfers naar een toename van bijna een half miljoen Limburgers tot $2000^{63}$. Ook in Limburg was begin jaren '60 nog steeds sprake van woningnood. De gemeentelijke bestemmingsplannen moesten deze groei mogelijk maken door nieuwe woonlocaties aan te wijzen. Gouverneur Van Rooy en directeur 't Hoen zorgden voor een verandering van koers in het tot dan toe gevoerde provinciale ruimtelijke ordeningsbeleid. Beiden hadden gezien dat het in 1962 vastgestelde streekplan Oostelijke Mijnstreek drie jaar na vaststelling eigenlijk al verouderd was en weinig richting gaf aan gemeentelijke bestemmingsplannen.

Naast de urgentie van het tekort aan woningen, werd in de periode 1962-1965 steeds duidelijker dat de Limburgse mijnindustrie structureel op verlies draaide. In de loop van 1965 groeide het inzicht bij de regering dat de mijnen niet langer rendabel waren. Minister J.M. Den Uyl (PvdA) kondigde een gefaseerde sluiting van alle Limburgse mijnen aan. Niet alleen was dit een enorme economische tegenslag voor heel Limburg, maar voor de beide mijnstreken zelf betekende dit tegelijkertijd een ruimtelijke opgave van formaat. De totale infrastructuur van de regio moest opnieuw vorm worden gegeven. Een transformatie die tientallen jaren zou gaan duren. Het net opgestelde streekplan was daarmee op slag verouderd. Een nieuw streekplan opstellen zou teveel tijd vergen, vandaar dat gouverneur Van Rooy en directeur Van Poppel hun aandacht primair gingen richten op de samenwerking met de gemeenten. De toets op bestemmingsplannen vervulde in hun ogen veel meer een aanjaagfunctie dan een check op de toepassing van richtlijnen uit het streekplan. Niet alleen de woningnood kon op deze manier het beste worden aangepakt, de nieuwe ruimtelijke transformatie van de mijnstreken evenzeer. 
Nieuwe wetgeving, nieuwe personen en nieuwe ruimtelijk-economische omstandigheden betekenden een omslag in het denken over de Limburgse ruimtelijke ordening in de eerste helft van de jaren '60.

\subsection{De hoogtijdagen van het streekplan (periode 1965-1979)}

In de jaren '60 stond het provinciale beleid in het teken van de mijnsluiting en de economische herstructurering van Zuid-Limburg ${ }^{64}$. De Planologische Dienst hield zich vooral bezig met de toetsing van gemeentelijke bestemmingsplannen, diverse verkennende studies ${ }^{65}$ en de actualisering van verouderde streekplannen. Met de aankondiging van de sluiting van de mijnen in december 1965 door minister J.M. den Uyl (PvdA) moest er snel werk gemaakt worden van het beschikbaar stellen van industrieterreinen voor nieuwe bedrijvigheid ${ }^{66}$. Bovendien moest de woningnood ook in Limburg worden aangepakt. In 1962 was dan wel door minister J. van Aartsen (ARP) de één miljoenste naoorlogse woning geopend, maar er was nog steeds een tekort (Siraa, 1989: 214). In Limburg was er tot 1970 sprake van een tekort aan woningen. In de toetsing van gemeentelijke bestemmingsplannen werden daarom de provinciale richtlijnen voor woningbouw - zoals die in de streekplannen stonden - door het Provinciaal Bestuur vaak bewust 'veronachtzaamd ${ }^{167}$. Juist vanwege deze woningnood kregen gemeenten veel ruimte om nieuwe woningbouwlocaties aan te wijzen. De provinciale planologie bestond in de jaren '60 uit het toetsen van bestemmingsplannen, maar ook spoorde de Provincie gemeenten aan om nieuwe gemeentelijke bestemmingsplannen te maken en verouderde bestemmingsplannen te actualiseren. Daarnaast hield de Planologische Dienst zich bezig met onderzoek, cijferverzameling en het opstellen van rapporten.

Begin jaren '70 kwam daar verandering in. De woningnood was over haar hoogtepunt heen, maar had voor nieuwe problemen gezorgd: een toenemende trek van stedelingen naar het platteland. De suburbanisatie werd gestimuleerd door de plattelandsgemeenten die op grote schaal gronden hadden aangekocht en die deze gronden voor een goedkope prijs beschikbaar stelden als nieuwe bouwkavels. Door het snel toenemend autogebruik en de toegenomen vrije tijd voor recreatie en ontspanning, was de druk op het Limburgse buitengebied sterk toegenomen. Zowel in het Zuid-Limburgse Heuvelland als in het Noord-Limburgse Peelgebied, werden recreatievoorzieningen, bungalowparken en 'tweede woningen' aangelegd. De afstand van het woon-werkverkeer nam toe. Deze ontwikkelingen vonden plaats op regionale schaal en zorgden voor een nieuwe tegenstelling van belangen. Diverse gemeenten werkten onderling samen in regionaal opererende Stadgewesten, Industrieschappen en Recreatieschappen. Het gemeentelijk schaalniveau was in de ogen van de provinciale planologen te klein om deze nieuwe maatschappelijke problemen aan te pakken ${ }^{68}$.

De regionale vraagstukken en gemeentelijke structuren van samenwerking gaven begin jaren '70 een nieuwe impuls aan het streekplanwerk. Provinciale Staten van Limburg hadden in 1969 nog het Streekplan Stadsgewest Sittard-Geleen vastgesteld ${ }^{69}$, maar hadden daarbij tevens de voorkeur uitgesproken voor één streekplan voor heel Zuid-Limburg ${ }^{70}$. Deze opdracht van Provinciale Staten en de toenemende tegenstrijdige 
belangen in het Limburgse buitengebied markeerden voor de Provinciale Planologische Dienst de start van twee grote streekplannen: het Streekplan Zuid-Limburg (1970-1977) en het Streekplan Noord-en Midden-Limburg (1973-1982). Hier zal alleen worden stilgestaan bij het Streekplan voor Noord- en Midden-Limburg.

Vergeleken met het streekplan voor Zuid-Limburg, dat nog sterk in de onderzoekstraditie van de jaren '50 en '60 stond, sloeg men met het Streekplan voor Noord- en MiddenLimburg een nieuwe weg in. Anders dan de aanpak van het Streekplan Zuid-Limburg werd er hier gekozen voor een aanpak via facetstudies ${ }^{71}$. Deze facetstudies waren thematische deelstudies ('facetten') naar o.a. de bevolkingsontwikkeling, economische aangelegenheden of natuurwaarden. De inzichten die deze studies opleverden, moesten uiteindelijk tot een geheel gesmeed worden in een nieuw streekplan. Een ander verschil met het Streekplan voor Zuid-Limburg was dat in het Streekplan Noord- en Midden-Limburg de bevolking in een vroegtijdig stadium betrokken werd. In het Streekplan Zuid-Limburg was een bijna kant en klaar streekplan ter inspraak voorgelegd. Daar had de Provincie veel kritiek op gekregen. In de totstandkoming van het Streekplan voor Noord- en MiddenLimburg wilde de Planologische Dienst een veel actievere rol van de bevolking in de betrokken gemeenten. Een derde en laatste verschil met het Zuid-Limburgse streekplan was dat de belangentegenstellingen veel explicieter naar voren zouden komen. Dit kwam door het detailniveau van de facetstudies ${ }^{72}$.

Het was niet de bedoeling van het College van Gedeputeerde Staten om in 1973 te beginnen met nóg een streekplan. De Provinciale Planologische Dienst was druk bezig met de voorbereidingen voor het Streekplan Zuid-Limburg (1970-1977). De directe aanleiding voor het opstellen van een nieuw streekplan voor het noorden en midden van Limburg waren vragen vanuit de Tweede Kamer. Op 20 februari 1973 had het Limburgse Tweede Kamerlid (en tevens Limburgs statenlid) H.J.G. Waltmans (PPR) schriftelijke vragen gesteld aan minister en staatssecretaris van Volkshuisvesting en Ruimtelijke Ordening over grootschalige recreatieplannen in Noord-Limburg ${ }^{73}$. Concreet ging het om het plan van de Noord-Limburgse gemeente Grubbenvorst om 300 vakantiebungalows te laten bouwen in een landschappelijk waardevol gebied. De Provincie Limburg had daar eerder in september 1970 goedkeuring aan verleend. In het antwoord erkende minister J.P.A. Gruijters (D66) de kritiek: "Hierdoor treedt inderdaad versnippering en aantasting op van ... waardevolle gebieden. Deze gang van zaken is onder andere het gevolg van het ontbreken van een streekplan voor geheel Noord-Limburg..." ${ }^{174}$. De minister had voor de beantwoording contact gezocht met het College van Gedeputeerde Staten dat had toegezegd snel te beginnen met de voorbereidingen voor een streekplan.

In de jaren '70 gingen gemeenten meer samenwerken. Deze samenwerking was eerder al staatsrechtelijk in de Wet Gemeenschappelijke Regeling verankerd. Steeds vaker verenigden gemeenten zich in wat werd genoemd het 'gewest'. Het gewest was een formeel samenwerkingsverband tussen gemeenten binnen een bepaalde regio dat ondersteund werd door een klein ambtelijk apparaat. In Limburg werden in de jaren '60 stadgewesten opgericht en in de jaren '70 ook regionale gewesten. Met name het regionale ruimtelijke 
ordeningsbeleid werd door gemeenten gedelegeerd aan het gewest. Het gemeentelijke bestemmingsplan bleef een kerntaak van de individuele gemeente. Maar het overleg met een provincie over de opzet van een nieuw streekplan evenals de organisatie van de inspraak, was dikwijls een taak voor de gewesten. Ook het opstellen van een zogeheten 'structuurplan' - een ruimtelijk plan dat tussen het schaalniveau van een streekplan en een bestemmingsplan in zat - was een taak van het gewest. Voor de Provincie waren de gewesten een eerste aanspreekpunt in de voorbereiding van het streekplan. Op deze manier hoefde het vooroverleg niet met iedere individuele gemeente gevoerd te worden, maar slechts met een vertegenwoordiging van het gewest dat namens de gemeenten kon spreken.

Het College van Gedeputeerde Staten had in 1973 al overleg gehad met de drie gewesten die in Noord-Limburg waren opgericht, over de afstemming tussen de gewestelijke structuurplannen en de provinciale streekplannen. Een stuurgroep met wethouders en burgemeesters werd ingesteld om deze afstemming te coördineren ${ }^{75}$. De echte voorbereidingen begonnen pas in februari 1974 toen de stuurgroep, onder voorzitterschap van gedeputeerde J. van der Woude (PvdA) voor het eerst bij elkaar $\mathrm{kwam}^{76}$. De Planologische Dienst had al een notitie opgesteld over hoe de inspraak van de bevolking op het streekplan georganiseerd moest worden. De Dienst had niet alleen gekeken naar ervaringen met de inspraak bij het Streekplan Zuid-Limburg, maar ook naar de ervaringen met inspraak van andere provincies ${ }^{77}$. Besloten werd tot het instellen van een 'streekcommissie' per gewest, een structuur die in andere provincies al was toegepast. De begeleiding van deze streekcommissies werd door de gewesten georganiseerd ${ }^{78}$. De kosten werden gelijk verdeeld tussen gewesten en Provincie ${ }^{79}$.

De voorbereiding van een streekplan kende een aantal vaste stappen. De Planologische Dienst maakte eerst een voorzet met daarin de grondgedachten en uitgangspunten voor het streekplan. Daarin werden de problematiek en ruimtelijke opgaven van het gebied geschetst en een voorstel voor de aanpak ervan. In het streekplan Noord- en MiddenLimburg was gekozen voor een facetaanpak. Dit hield in dat er zeven verkennende studies werden uitgevoerd rondom de thema's bevolking, recreatie, woonomgeving, verkeer, werkgelegenheid, milieu en land- en tuinbouw. Op basis van deze studies zou een integratie van belangen plaatsvinden in de zogeheten 'Integratieschets'. Deze Integratieschets werd vervolgens vertaald in een aantal stappen naar een definitief streekplan. De Provinciale Planologische Commissie, de commissie waarin alle belanghebbende Limburgse organisaties en nationale rijksinstanties waren vertegenwoordigd, werd op verschillende momenten in dit proces geraadpleegd voor advies. Het advies van deze Provinciale Planologische Commissie was niet bindend voor Gedeputeerde Staten, maar woog - zeker in de jaren '70 - zwaar mee in de uiteindelijke afweging van belangen.

In het voorjaar van 1974 had de Provinciale Planologische Dienst een tweetal notities afgerond: een 'Grondgedachten-nota' en een 'Uitgangspunten-notitie'. Beide nota's hadden een sterk ideologisch en beschouwend karakter waarbij de Planologische Dienst welvaart en welzijn recht tegenover elkaar werden geplaatst: "Het wordt steeds duidelijker dat de bevordering van welvaart niet de enige basis mag zijn voor het opstellen van ruimtelijke 
plannen doch dat die basis moet worden gevonden in het welzijn"80. 'De mens centraal stellen' paste in de tijdgeest ${ }^{81}$. De nadruk op het 'welzijn' als uitgangspunt voor het streekplan had een drietal praktische gevolgen. Op de eerste plaats werd de opdracht voor de zeven facetstudies daarmee dusdanig breed dat van te voren niet duidelijk was wat deze studies precies moesten gaan opleveren ${ }^{82}$. Ten tweede groeide het wantrouwen van het College van Gedeputeerde Staten en in bijzonder van verantwoordelijk gedeputeerde J. van der Woude (PvdA). Kon de Planologische Dienst het streekplan wel tijdig afronden? Gedeputeerde Van der Woude had zijn ambtelijk directeur bij de start van het streekplan er al voor gewaarschuwd dat het streekplan niet moest dienen 'als kapstok voor het uitdiepen van randfilosofieën'. Voorkomen moest worden dat er sprake zou zijn van 'een te lang tijdsverloop, een te perfectionistische opzet en een teveel aan vakjargon' ${ }^{183}$. Ook gouverneur Ch.J.M.A. van Rooy (KVP) had moeite met het in zijn ogen lage realiteitsgehalte van het streekplan. Hoe reëel was het om te pleiten voor minder aanleg van wegen of het afremmen van het autogebruik ${ }^{84}$ De discussie bracht de verschillende opvattingen tussen het College van Gedeputeerde Staten en Planologische Dienst scherp naar voren en verhevigde de toch al moeizame politiek-ambtelijke verhoudingen ${ }^{85}$. Een derde gevolg van de benadrukking van het welzijnsaspect was de keuze om de inspraak van burgers en belanghebbenden 'in het vroegste stadium' te laten plaatsvinden ${ }^{86}$. Dit betekende dat de in te stellen streekcommissies de taak kregen om niet alleen de Grondgedachten- en Uitgangspuntennotitie aan burgers voor inspraak beschikbaar te stellen, maar ook alle zeven facetstudies. Voor Gedeputeerde Staten daarentegen was niet zozeer het oordeel van de burger en de gewesten relevant, maar vooral het standpunt van de Provinciale Planologische Commissie.

Beide nota's werden in juni 1974 in de Commissie besproken ${ }^{87}$. De Kamer van Koophandel vond dat het welvaartsaspect neergezet werd als een 'vermaledijde zaak's8. Gedeputeerde G.A.A. Horsmans (KVP) - die sprak als voorzitter van de Agrarisch Planologische Subcommissie! - constateerde een 'eenzijdige, gekleurde benadering van de materie' door de Planologische Dienst. De (agrarische) buitenwacht had hierover toch echt wel een 'afwijkende visie' in de ogen van gedeputeerde Horsmans ${ }^{89}$. De Inspectie Ruimtelijke Ordening nam het voor de Planologische Dienst op, door te wijzen op het feit dat er nu wel 'houvast' geboden werd. Het ruimtelijke ordeningsbeleid verliep volgens de Inspectie tot nu toe 'teveel intuïtief ${ }^{190}$. De discussie schetste een mooi beeld van de machtsverhoudingen in de provinciale ruimtelijke ordening, waarbij met name de Inspectie Ruimtelijke Ordening het opnam voor de opstellers van het streekplan.

Een van de instrumenten waarmee de Provinciale Planologische Dienst in het streekplan experimenteerde was het principe van de 'kernenhiërarchie'. In de Tweede Nota Ruimtelijke Ordening (1966) was dit instrument door de rijksoverheid geïntroduceerd waarmee een onderscheid werd gemaakt tussen vier typen woonkernen ${ }^{91}$. De bevolkingsgroei van de gehele regio werd als uitgangspunt gehanteerd voor de verdeling van woningbouw over individuele steden en dorpen ${ }^{92}$. Dit had grote consequenties voor de woningbouwplannen van de Noord- en Midden-Limburgse gemeenten afzonderlijk. De regio kenmerkte zich 
door een omvangrijk platteland met slechts twee stedelijke kernen, Venlo en Roermond ${ }^{93}$. In de praktijk betekende dit dat vooral kleinere landelijke gemeenten beperkt werden in de ruimte voor nieuwe woningbouw. De Planologische Dienst wilde hiermee vooral de landschappelijke en natuurlijke kwaliteiten van het buitengebied beschermen door woningbouw, schaalvergrotingen in de landbouw en nieuwe recreatieve ontwikkelingen te weren ${ }^{94}$.

Regelgeving was één instrument. Een tweede instrument was kennis en expertise. Zoals in het streekplan voor de Oostelijke Mijnstreek van 1962 al was gebleken, was de Provincie Limburg in haar informatievoorziening vooral afhankelijk van externe partijen. Met de start van het streekplan voor Noord- en Midden-Limburg was dit nauwelijks veranderd. De kaarten voor bos en natuur kwamen nog steeds van Staatsbosbeheer en de Dienst Landinrichting. De woningbouwprognoses kwamen van de Inspectie Volkshuisvesting. Het Economisch-technologisch Instituut Limburg leverde nog steeds de prognoses voor de bevolkingsontwikkeling en de industrieterreinenbehoefte. Met de opdrachtverlening aan een aantal externe bureaus voor het opstellen van de zeven facetstudies werden inhoud en detailniveau van het streekplan verdiept. Indirect verrijkte de Planologische Dienst zich zo met nieuwe expertise en kennis. Deze kennis werd vooral opgedaan op het gebied van milieu, natuurwaarden, bodemgesteldheid en waterstromen. Het platteland was voor de Provincie Limburg nog steeds een 'terra incognita' (Van der Cammen \& De Klerk, 2006: 282). Na de voortvarende start in 1974 met de Stuurgroep kwamen de facetstudies Bevolking en Bevolkingsspreiding (1974), Openluchtrecreatie (1974) en Verkeer en Vervoer (1975) redelijk snel tot stand. De inzichten die deze studies brachten waren voor de Planologische Dienst nog grotendeels bekend terrein. De andere facetstudies, Natuurlijk milieu en milieuzorg en Land- en tuinbouw, konden niet anders dan nieuwe inzichten opleveren. Deze twee studies zouden het meest controversiële materiaal bevatten, maar vroegen daardoor meer voorbereidingstijd.

Degewesten hadden ondertussen inspraakavonden georganiseerd voor een bespreking van de eerste facetstudies met burgers en belanghebbenden. De gewesten hadden daarin de vrije hand gekregen van de Provincie. Het had geresulteerd in een onoverzichtelijke structuur van subregionale deelcommissies waarbij een heldere onderlinge communicatie ontbrak ${ }^{95}$. Bovendien hadden diverse Limburgse kranten de kritiek opgepikt uit de streekplancommissies, dat het Provinciaal Bestuur zich erg 'afzijdig' opstelde in het inspraakproces en de toelichtingen overliet aan haar ambtenaren. De betrokken burgers vroegen zich af of de inspraak 'geen schijnvertoning' was ${ }^{96}$. Het College van Gedeputeerde Staten had hierop gereageerd door de wethouder van de gemeente Roermond, J.P. Planje (KVP) in januari 1975 te vragen als inspraakcoördinator namens het College ${ }^{97}$. Verder wilde het College niet gaan. Politieke besluitvorming zou pas plaatsvinden nadat alle facetstudies samen kwamen in de Integratieschets en het voorontwerp-streekplan. Tot die tijd waren alle notities en studies 'ambtelijke stukken'98.

De benoeming van Planje als coördinator kon niet voorkomen dat de gehele voorbereiding van het streekplan vertraging opliep en uiteindelijk zelfs nog datzelfde jaar geheel vastliep. De stuurgroep zou pas twee jaar later weer bij elkaar komen. De 
belangrijkste reden voor de vertraging werd overigens veroorzaakt door de ontploffing die in november 1975 plaatsvond bij DSM in Geleen. Deze calamiteit, waarbij 14 mensen om het leven kwamen, vereiste een verscherping van veiligheidsnormen en zoneringen rondom het terrein zoals die in het voorontwerp Streekplan Zuid-Limburg waren gepresenteerd. Alle capaciteit van de Planologische Dienst werd vanaf dat moment daarop ingezet. Met de uiteindelijk afronding in 1977 van het streekplan Zuid-Limburg kon de draad weer opgepakt worden voor het Streekplan Noord- en Midden-Limburg. Maar niet alleen de ontploffing bij DSM had voor twee jaar vertraging gezorgd. Er was meer aan de hand.

Met ingang van 1 januari 1977 was A. Peters benoemd als nieuwe directeur van de Planologische Dienst ${ }^{99}$. Hij constateerde twee grote problemen. Op de eerste plaats een organisatie die op zeer grote afstand stond van het College van Gedeputeerde Staten. De politiek-ambtelijke verhoudingen waren de laatste jaren erg verslechterd ${ }^{100}$. Ook de samenwerking tussen zijn 'technische dienst' en andere provinciale afdelingen verliep stroef en gespannen ${ }^{101}$. Op de tweede plaats zag de nieuwe directeur zich geconfronteerd met een streekplanproces dat totaal was vastgelopen. De facetstudie Wonen (1976) was nog voor zijn aantreden afgerond, maar een tijdschema voor de nog komende facetstudies, laat staan de totale afronding van het streekplan, ontbrak. De inspraakcommissies waren doodgebloed ${ }^{102}$ en van afstemming tussen streekplan en structuurplannen was weinig terecht gekomen ${ }^{103}$. In de zomer van 1977 had directeur Peters een adviesbureau ingeschakeld om het proces vlot te trekken. Het rapport van het adviesbureau werd in december met de stuurgroep besproken ${ }^{104}$. Daarin zat ook een voorstel voor een tijdschema. De afronding zou niet meer plaatsvinden binnen de collegeperiode, maar waarschijnlijk ergens in de periode 1980-1982. De inspraak op de nog op te stellen Integratieschets bleef overeind maar kwam vanaf nu onder strakke regie van de Provincie ${ }^{105}$. De laatste twee facetstudies Natuur en Milieu en Land- en tuinbouw werden zo snel mogelijk afgerond. De rol van de stuurgroep werd beperkt tot een overlegstructuur, enkel bedoeld voor 'informatieuitwisseling'106.

Het was duidelijk, het College van Gedeputeerde Staten trok de teugels aan. De 'vrijblijvendheid en onduidelijkheid van de le fase' moesten eruit ${ }^{107}$. De tijd van politiek bedrijven via commissies, werkgroepen en stuurgroepen was ten einde. Er was nog slechts één commissie die veel macht had: de Provinciale Planologische Commissie.

In het najaar van 1977 en het voorjaar van 1978 werden de twee laatste facetstudies besproken in de Planologische Commissie. De bespreking van de facetstudie Natuurlijk milieu en milieuzorgzorgde voor een felle discussie over de confrontatie tussen de aantasting van het milieu door woningbouw enerzijds en landbouw anderzijds. De opstellers van de studie benadrukten sterk het belang van het beschermen van het milieu. De facetstudie Land-en Tuinbouw benadrukte juist de economische ontwikkelingsmogelijkheden van de agrarische sector. De besprekingen in de Provinciale Planologische Commissie - waarin de direct belanghebbenden vertegenwoordigd waren - verliepen moeizaam. De Planologische Dienst en de Inspectie Ruimtelijke Ordening stonden pal voor het milieubelang en de 
facetstudie Natuurlijk milieu. De Inspectie Landinrichting, de Limburgse Land- en Tuinbouworganisatie en de vertegenwoordiger van de Subcommissie Agrarische Belangen daarentegen stonden achter de facetstudie Land- en Tuinbouw. Gedeputeerde Van der Woude onthield zich vooralsnog van een politiek oordeel. Hij benadrukte dat het vooral zaak was om de Integratieschets, die alle facetstudies integreerde en belangen tegen elkaar afwoog, zo snel mogelijk op te stellen ${ }^{108}$. Wel liet hij doorschemeren dat de Planologische Dienst in haar kritische opstelling ten aanzien van de agrarische sector, 'gas moest terug nemen $^{\prime 109}$. De discussie leidde er toe dat de verschillende partijen zich dieper ingroeven in hun stellingen. Opnieuw trad er vertraging op. Deze keer was de vertraging echter maar van korte duur. Een nieuwe koerswijziging diende zich aan.

Tweede omslagmoment: einde van de macht van de Planologische Commissie (1978-1979) In 1978 participeerde het College van Gedeputeerde Staten in maar liefst 42 commissies $^{110}$. Provinciale politiek was in de jaren '60 en '70 vooral besturen via commissies. Zoals reeds is opgemerkt was een van de machtigste commissies de Provinciale Planologische Commissie.

In juni $1978 \mathrm{kwam}$ daar verandering in. Er werd een nieuw College van Gedeputeerde Staten geformeerd. Gedeputeerde J. van der Woude (PvdA) nam afscheid en E.M. Mastenbroek (KVP) werd de nieuwe portefeuillehouder voor Ruimtelijke Ordening. Ook de invloedrijke gedeputeerde G.A.A. Horsmans (KVP) nam afscheid, waarmee hij ook het voorzitterschap van de Subcommissie Agrarische Belangen neerlegde. Ten slotte nam ook gedeputeerde F.P.C. van de Voort (KVP) afscheid. Deze drie gedeputeerden hadden grote invloed gehad op het functioneren van de Provinciale Planologische Commissie. Van der Woude moest als voorzitter een onafhankelijke positie innemen, maar was tevens verantwoordelijk portefeuillehouder Ruimtelijke Ordening. Zijn collega-gedeputeerde Horsmans behartigde de belangen voor de agrarische sector via een subcommissie. En gedeputeerde Van de Voort was niet direct lid van de Commissie, maar was naast zijn deputéschap ook secretaris van de Kamer van Koophandel van Noord-Limburg. De Kamer van Koophandel had een zetel in de Commissie, die werd ingenomen door de voorzitter, R.J.C.M. Rijssenbeek. Als secretaris had Van de Voort dus indirect een relatie met de commissie. In 1978 namen deze drie gedeputeerden afscheid, waarmee ruimte ontstond voor een reorganisatie van deze commissie. Onder leiding van de driekwart jaar eerder aangetreden nieuwe gouverneur J. Kremers (CDA) werd de Provinciale Planologische Commissie gereorganiseerd. In de praktijk werd zo de invloedrijke rol van de Commissie teniet gedaan. De Kamer van Koophandel moest de zetel inleveren en vanaf nu was het College van Gedeputeerde Staten slechts met de voorzittersrol vertegenwoordigd in de Planologische Commissie. Het besturen via commissies was voorbij. De wisseling van personen had daarin een belangrijke rol gespeeld.

Zonder de steun van de Inspectie Ruimtelijke Ordening was deze verandering waarschijnlijk niet gelukt. Met name het beëindigen van het lidmaatschap van de Kamer van Koophandel werd actief ondersteund door de rijksinspectie. Voor de Inspectie zal hebben meegespeeld dat hiermee een belangrijke criticaster van de Limburgse 
streekplannen minder invloed kreeg. Wat de Inspectie echter niet verwachtte was dat het College van Gedeputeerde Staten niet langer meer zat te wachten op streekplannen. Gouverneur Kremers had maar één prioriteit en dat was het wegwerken van de Limburgse werkloosheid. Streekplannen vervulden daarin nauwelijks een rol. Om toch tegemoet te komen aan de kritiek van de Kamer van Koophandel dat er nu een gebrek aan economische expertise in de commissie optrad, vroeg het College het ministerie van Economische Zaken om in de commissie te participeren ${ }^{111}$. Het was de rijksinspectie die hier actief mee instemde. Hier werd via een alliantie met de rijksoverheid een nieuwe machtsbalans gecreëerd in de ruimtelijke ordening. De nieuwe werkwijze en samenstelling zou ingaan per 1 januari 1979 en zou na een jaar opnieuw bekeken worden. De nieuwe samenstelling bleef daarna van kracht.

Het afscheid van invloedrijke personen, de opstelling van de rijksoverheid via de Inspectie Ruimtelijke Ordening en de economische crisis in Limburg, zorgden ervoor dat de ruimtelijke ordening in een nieuw daglicht kwam te staan. Ruimtelijke ordening stond vanaf nu ten dienste van het provinciaal economisch beleid. Het streekplan Noord- en Midden-Limburg werd nog wel afgerond ${ }^{112}$, maar de prioriteiten lagen vanaf nu elders.

\subsection{Ruimtelijke ordening in dienst van de economie (periode 1979-1990)}

In de jaren ' 80 waren drie ontwikkelingen van belang voor het ruimtelijke ordeningsbeleid. Op de eerste plaats werd het ruimtelijke ordeningsbeleid ondergeschikt aan het economisch beleid. Gouverneur Kremers sprak in 1984 ter gelegenheid van het 50-jarig bestaan van de Provinciale Planologische Dienst duidelijke taal:

\footnotetext{
"Het zal niemand ontgaan zijn, dat bij de afstemming tussen het werkgelegenheidsbeleid en de overige beleidsvelden spanningen zijn opgetreden en nog optreden. Een verklaring hiervoor is niet zo moeilijk te geven. Als door de provincie een nieuw beleidsveld tot ontwikkeling wordt gebracht en bovendien wordt bepaald, dat aan dit beleid, een hoge zo niet de hoogste prioriteit zal worden toegekend, heeft dit vanzelfsprekend invloed op de andere beleidsterreinen. De overige beleidsvelden dienen zich in dat geval naar de nieuwe prioriteiten te richten." ${ }^{.13}$
}

Het was vloeken in de kerk. De ruimtelijke ordening ten dienste van de economie? Gouverneur Kremers pleitte voor een herijking van de positie van de ruimtelijke ordening ${ }^{114}$. In feite had de start van die herijking al in de periode 1978-1979 plaatsgevonden met het inperken van de macht van de Provinciale Planologische Commissie. Het ruimtelijke ordeningsbeleid werd in de jaren ' 80 door het Provinciaal Bestuur vooral ingezet voor het realiseren van economische projecten. Niet langer door het opstellen van nieuwe streekplannen, maar de regionale uitwerking van het streekplan stond centraal. Door een wijziging van de Wet op de Ruimtelijke Ordening in 1985 hadden deze 'uitwerkingen' ook een formele status gekregen als onderdeel van het streekplan. Hiermee kregen ruimtelijkeconomische projecten, zoals plannen voor nieuwe bedrijventerreinen, het opstellen van 'regionaal-economische ontwikkelingsplannen', de aanleg van infrastructuur of recreatieve plannen, prioriteit ${ }^{115}$.

Omdat de afspraken met de rijksoverheid in het kader van het economische 
Perspectievennotabeleid (zie hoofdstuk 3) zich uitsluitend richtten op Zuid-Limburg, bood het ruimtelijke ordeningsbeleid voor het Provinciaal Bestuur de kans om ook in NoordLimburg activiteiten te ontwikkelen. Hiervoor werden andere rijkssubsidies ingezet en werden ook eigen financiële middelen vrijgemaakt. Op deze manier probeerde het Provinciaal Bestuur tegemoet te komen aan de kritiek dat alle gelden naar Zuid-Limburg gingen. In dat opzicht werd het ruimtelijke ordeningsbeleid evenals het welzijnsbeleid (zie hoofdstuk 4), actief benut in de politiek van verdelende rechtvaardigheid tussen Limburgse deelregio's. De gedachte dat 'elke regio iets krijgt' heeft altijd een dominante rol gespeeld in de provinciale geschiedenis. In de ruimtelijke ordening vertaalde zich dat in aparte streekplanuitwerkingen en projecten voor de regio Venlo-Tegelen, de planologische inpassing van de Rijksweg 73 Noord, het Regionale Ontwikkelingsplan voor bedrijventerreinen in Noord-Limburg en het Kernenplan Stadgewest Roermond. Het zijn voorbeelden van ruimtelijk-economische projecten voor Noord- en Midden-Limburg in de jaren ' $80^{116}$.

Een tweede ontwikkeling in het ruimtelijke ordeningsbeleid van de jaren ' 80 betreft de decentralisatie. Diverse rijkstaken en bevoegdheden op het terrein van de ruimtelijke ordening en de volkshuisvesting werden overgeheveld naar provincies en gemeenten. Had het ruimtelijke ordeningsbeleid in de jaren '70 nog sterk in het teken gestaan van het zoeken naar nieuwe instrumenten, nu kwamen daar ook nieuwe bevoegdheden bij. De wijziging van de Wet op de Ruimtelijke Ordening (1985) was primair bedoeld om de positie van gemeenten te versterken. De provinciale toets van gemeentelijke bestemmingsplannen werd in de aangepaste wet minder streng en gemeenten kregen meer ruimte voor eigen afwegingen binnen hun plannen. In de praktijk ging het hier om een grotere vrijheid voor de individuele gemeente om bouwplannen - die (nog) niet voldeden aan het bestemmingsplan - toch door te laten gaan ${ }^{117}$. De Wet Voorkeursrecht Gemeenten (1985) versterkte eveneens de positie van de gemeenten, met name op het gebied van de stadsvernieuwing. Daarmee werd de autonomie en het zelfbewustzijn van de gemeenten versterkt (De Ridder, 1990: 36). In 1985 werd niet alleen de wet aangepast, maar werd ook het volkshuisvestingsbeleid overgeheveld van de rijksoverheid naar de provincies. Provincies kregen niet alleen de bevoegdheid om het aantal nieuw te bouwen woningen vast te stellen en te verdelen over de gemeenten, maar kregen daarnaast de bijbehorende financiële middelen ${ }^{118}$. Het Dorps- en Stadsvernieuwingsfonds werd overgedragen aan de provincies in datzelfde jaar. De post Ruimtelijke Ordening en Volkshuisvesting op de provinciale begroting groeide dat jaar van 8 miljoen naar bijna 23 miljoen gulden (zie appendix II $)^{119}$.

De wetswijziging en de decentralisatievoorstellen zorgden voor een nieuwe balans tussen de rijksoverheid, provincie en gemeenten. De rijksoverheid trok zich op meerdere terreinen terug uit de regio, waarbij de rijksinspecties een minder prominente rol in de provincies gingen vervullen. De relatie tussen de Provincie Limburg en de Limburgse gemeenten kwam daardoor in een nieuw daglicht te staan. Op het gebied van de ruimtelijke ordening werden de bevoegdheden van de gemeenten versterkt en werden provincies geacht om de bestemmingsplannen meer op hoofdlijnen te toetsen. Opnieuw werd de 
Provinciale Planologische Commissie gereorganiseerd. De termijnen voor het toetsen van bestemmingsplannen moesten worden gehalveerd; provinciale besluitvorming moest sneller plaatsvinden. Men besloot het aantal subcommissies in de Planologische Commissie terug te brengen naar twee: één voor zaken betreffende het landelijk gebied en één voor het stedelijk gebied. Deze twee subcommissies kregen daarbij een ruimer mandaat ${ }^{120}$.

Op het gebied van de volkshuisvesting werd de provinciale rol prominenter door de bevoegdheid voor planning en financiering van nieuw te bouwen woningen in Limburg. De nadruk op de toezichthoudende rol van provincies bij gemeentelijke bestemmingsplannen verdween hierdoor in de tweede helft van de jaren '80 langzaam naar de achtergrond. In plaats hiervan koos de Provincie voor een sterkere financieel verdelende rol als het ging om de volkshuisvesting en de bouwplannen van gemeenten. Deze veranderende rol van de Provincie ten opzichte van de Limburgse gemeenten verliep in de praktijk niet geheel zonder fricties ${ }^{121}$. Toch leidde de nieuwe rolverdeling tussen Provincie en gemeenten wel tot belangrijke gezamenlijke projecten, zoals de ontwikkeling van het Ceramiqueterrein in Maastricht, de realisatie van de Maasoever in Roermond en de aanleg van de Zuiderbrug in Venlo. Met name de Limburgse stadsbesturen groeiden daarbij in hun rol.

De derde ontwikkeling die van belang was voor de ruimtelijke ordening in de jaren ' 80 vond plaats binnen de provinciale organisatie. Gouverneur J. Kremers voerde begin jaren ' 80 een grootschalige reorganisatie door. Nadat eerst de Provinciale Waterstaat en de griffieafdelingen onderzocht waren, werd als laatste (periode 1983-1984) de Planologische Dienst onder de loep genomen. Hierin kwam met name de - door directeur A. Peters eerder al geconstateerde - moeizame relatie met de provinciale afdeling Juridische en Bestuurlijke Zaken (de $1^{\mathrm{e}}$ Afdeling) naar voren. In het organisatieonderzoek werden 'doublures' met deze afdeling in de werkzaamheden van de Planologische Dienst geconstateerd ${ }^{122}$. De reorganisatie van de provinciale organisatie leidde in 1985 tot de vorming van één nieuwe ambtelijke Hoofdgroep Ruimtelijke Ordening en Volkshuisvesting. Een jaar later werd ook de Provinciale Waterstaat geïntegreerd in de andere Hoofdgroep Verkeer, Water \& Milieu. Het zogeheten griffie/diensten-model waarin de Planologische Dienst en de Provinciale Waterstaat een eigen rechtspositie kenden, werd ingeruild voor een organisatiemodel met provinciale hoofdgroepen en afdelingen ${ }^{123}$.

In diezelfde periode had het Provinciaal Bestuur met eigen middelen een nieuw Provinciehuis laten bouwen in het Maastrichtse stadsdeel Randwyck. Koningin Beatrix opende het gebouw op 22 april 1986. Het organisatorische onderscheid tussen diensten en afdelingen, tussen 'techneuten' en 'ambtenaren' was daarmee ten einde. Het was een gevolg van de in de jaren '70 gegroeide spanningen tussen het ambtelijke apparaat en het College van Gedeputeerde Staten. De politiek-ambtelijke verhoudingen waren in de jaren '80 omgedraaid. Niet langer bepaalde de ambtelijke Planogische Dienst het ruimtelijke ordeningsbeleid, maar gold het politieke primaat van Gedeputeerde Staten. Het College van Gedeputeerde Staten, onder aanvoering van gouverneur J. Kremers en gedeputeerde K.W. Buck (CDA), stuurde scherp aan op het realiseren van met name economische beleidsdoelen. Men vond dat dit in een nieuwe ambtelijke organisatie vertaald moest 
worden. Voor de provinciale planologen betekende het een ander type werkzaamheden, met nieuwe bevoegdheden, een nieuwe centrale huisvesting en een werkwijze onder strakke politieke aansturing.

\section{Derde omslagmoment: nieuwe wetgeving en ambtelijke macht (1990)}

Politiek-ambtelijke verhoudingen verschuiven voortdurend. Inhoudelijke prioriteiten komen op of verdwijnen naar de achtergrond. De jarenlange politieke aandacht voor economisch beleid van het Provinciaal Bestuur kreeg eind jaren '80 concurrentie van andere beleidsvelden. Een van die beleidsvelden was de ruimtelijke ordening. Een nieuw omslagmoment diende zich aan.

Op 31 december 1990 eindigde formeel het economisch beleid dat de gehele jaren ' 80 had gedomineerd. De boegbeelden van dit Perspectievennotabeleid, gouverneur J. Kremers en gedeputeerde K.W. Buck, hadden eerder al afscheid genomen ${ }^{124}$. De regionale werkloosheidscomponent in Zuid-Limburg was in 1989 zelfs even onder het nationale gemiddelde gedoken. De economische verschillen tussen regio's in Nederland waren sterk genivelleerd. De politieke aandacht van de rijksoverheid voor de Provincie Limburg als herstructureringsgebied kwam daarmee ten einde. Economisch beleid was niet langer de dominante politieke prioriteit in het provinciehuis. Ruimtelijke ordening en met name milieubeleid waren de nieuwe thema's. Met het vertrek van Kremers en Buck was er eigenlijk maar één partij die hierdoor veel macht kreeg begin jaren '90. Dit was het ambtelijk apparaat. Het voelde zich gesteund door nieuwe ontwikkelingen in het rijksbeleid. In het economisch beleid en in het welzijnsbeleid groeide eveneens de ambtelijke macht, maar in geen van deze beleidsterreinen was de wettelijke onderbouwing zo sterk uitgebreid begin jaren ' 90 als in de ruimtelijke ordening.

Vanaf eind jaren ' 80 was er door de rijksoverheid een groot aantal wetten vervaardigd voor de inrichting van de openbare ruimte, specifiek ten aanzien van het onderwerp 'milieu'. Er was wet- en regelgeving gemaakt voor een verbetering van de waterhuishouding, natuur- en milieubescherming, het tegengaan van luchtverontreiniging, zure regen en de nitraatuitstoot door de landbouwsector. Dit waren nieuwe urgente omstandigheden waarvoor de rijksoverheid een omvangrijk pakket aan maatregelen introduceerde. Hiervoor werd nieuwe wetgeving ontwikkeld die sterk centralistisch van aard was. De rijksoverheid verwachtte van provincies dat zij op provinciaal niveau de nationale plannen van uitwerking en concretisering voorzagen. In de Vierde Nota Ruimtelijke Ordening Extra (1990) kreeg Limburg de mogelijkheid om in twee gebieden te experimenteren met de samenhang tussen milieubeleid en ruimtelijk ordeningsbeleid. Men startte met de programma's Ruimtelijke Ordening en Milieu in het Mergelland en de Nadere Uitwerking Brabant-Limburg in Noord-Limburg. Tegelijkertijd moest de Provincie Limburg de nieuwe wetgeving uitvoeren en hier provinciale plannen voor opstellen ${ }^{125}$. Zo kwamen er rond 1990 diverse provinciale nota's voor het behoud van natuur en landschap, het regelen van de waterhuishouding, het vormgeven van een milieubeleid en de omgang met afvalstoffen en bodemvervuiling. Een geheel nieuw 'sectorbeleid' ontstond zo binnen de ruimtelijke ordening. 
Om deze nieuwe ambities uit te voeren moest nieuwe kennis en specifieke expertise ontwikkeld worden, expertise die niet bij de nieuwe lichting provinciale bestuurders aanwezig was. Er was daarom maar één speler die door deze grote hoeveelheid nieuw sectorbeleid meer invloed kreeg: het ambtelijk apparaat. Men kan daarom spreken van een omslag in de politiek-ambtelijke verhoudingen begin jaren '90. Een verambtelijking van het provinciale beleid in de jaren '90 was het gevolg.

De wisseling van diverse bestuurders en de groeiende ambtelijke expertise, nieuwe urgente maatschappelijke ontwikkelingen zoals de milieuproblematiek en de introductie van een grote hoeveelheid centralistische sectorwetgeving, vormden een nieuw omslagmoment.

\subsection{Op zoek naar een integraal ruimtelijk beleid (periode 1990-2003)}

Net zoals de voorafgaande jaren behoorde het Limburgse ruimtelijke ordeningsbeleid tot ver in de jaren '90 niet tot de politieke prioriteiten van de opeenvolgende Colleges van Gedeputeerde Staten. Pas met de start van een nieuwe integraal streekplan voor geheel Limburg kwam de ruimtelijke ordening - en specifiek het streekplan - op de politieke agenda. De periode 1990-2003 is onder te verdelen in twee fases.

In de periode 1990-1996 lag de nadruk vooral op het opstellen van een ontwikkelingsperspectief voor het Noord-Limburgse Peelgebied en het Zuid-Limburgse Mergelland. De gedachte hierachter: in twee afgebakende gebieden kon worden geëxperimenteerd met een integrale aanpak van milieubeleid, ruimtelijke ordening en recreatieontwikkeling. Beide programma's werden in de jaren '90 uitgevoerd maar bleven vooral ambtelijke dossiers waarin de verantwoordelijke gedeputeerden slechts een beperkte rol vervulden. Op het moment dat de gedeputeerden zich hier wél actief mee gingen bemoeien - halverwege de jaren ' 90 - werd het ingezette beleid omgevormd van visie-ontwikkeling naar concrete projecten. In de periode 1996-2000 werden honderden projecten uitgevoerd.

Vanaf 1995 ontstond er in Provinciale Staten een discussie over een meer integraal ruimtelijk beleid. In de periode 1997-2003 probeerde men om sectorbeleid voor water, milieu, natuur, landschap, verkeer \& vervoer en bedrijventerreinen te integreren in één provinciaal streekplan. Daarbij werden de ervaringen gebruikt die in de eerste helft van de jaren '90 met het gebiedsgerichte beleid voor het Peelgebied en Mergelland waren opgedaan (zie ook Glasbergen \& Driessen, 1993: 155-156). Deze zoektocht naar een integraal ruimtelijk beleid was trouwens in andere provincies evenzeer een belangrijk item (Wissink, 2000: 175).

Voor de analyse van de eerste periode (1990-1996) zal het programma Nadere Uitwerking Brabant-Limburg centraal staan. De totstandkoming van één streekplan voor de gehele provincie, het Provinciaal Omgevingsplan Limburg is kenmerkend voor de tweede periode (1997-2003). Zowel de Nadere Uitwerking als het Provinciaal Omgevingsplan laat zien dat de ruimtelijke ordening in de jaren ' 90 niet alleen een zoektocht was naar integraal ruimtelijk beleid, maar tevens een poging om meetbare doelstellingen te formuleren. Daarmee werden nieuwe ambities ingebracht in de ruimtelijke ordening. 
Nieuwe ambities gaan vaak gepaard met politieke belangstelling, zeker als de ambities over meerdere portefeuilles gaan. Eind jaren ' 90 werd de ruimtelijke ordening steeds meer een politiek onderwerp. Vooralsnog was de ruimtelijke ordening in 1990 een sterk ambtelijk gedomineerd onderwerp zoals bleek uit het programma Nadere Uitwerking Brabant-Limburg.

\section{De Nadere Uitwerking Brabant-Limburg}

De Nadere Uitwerking Brabant-Limburg was als project opgenomen in de Vierde Nota Ruimtelijke Ordening Extra (1990). Het project beoogde een gecombineerde aanpak voor enerzijds een vermindering van de ammoniakgasuitstoot in het grondwater door de agrarische sector en anderzijds de aanpak van de verdrogingsproblematiek in het Noord-Limburgse Peelgebied ${ }^{126}$. Binnen het ministerie van Volkshuisvesting, Ruimtelijke Ordening en Milieubeheer (VROM) had de Rijksplanologische Dienst de coördinerende verantwoordelijkheid. Samen met het ministerie van Landbouw en Visserij en de provincies Noord-Brabant en Limburg moest er een ontwikkelingsperspectief opgesteld worden. Dit perspectief (de visie) moest voorzien worden van concrete projecten ${ }^{127}$. De Nadere Uitwerking zou uiteindelijk een onderdeel kunnen worden bij een herziening van de actuele streekplannen met de formele status van een 'uitwerkingsplan' van het streekplan.

De Rijksplanologische Dienst was in december 1988 al gestart met de voorbereidingen om te komen tot een 'bestuursakkoord' tussen de betrokken partijen. Er waren echter spanningen tussen de Rijksplanologische Dienst (onderdeel van het ministerie van VROM) en het ministerie van Landbouw \& Visserij. Dit laatste ministerie vreesde een inperking van de ontwikkelingsmogelijkheden van de agrarische sector. Zo duurde het tot najaar 1990 voordat het project echt kon beginnen ${ }^{128}$. In de zomer van 1990 was er topoverleg gevoerd tussen de beide ministeries. Pas in oktober van dat jaar, kwam er 'na veel wikken en wegen'129 een vleugje witte rook. In een brief aan de verantwoordelijke gedeputeerden van Noord-Brabant en Limburg meldde het ministerie van VROM dat er overleg was geweest tussen beide ministeries en dat zij het eens waren over een formulering in het bestuursakkoord ${ }^{130}$. De formuleringen waren voorzichtiger geworden en ook het ministerie van Verkeer en Waterstaat was nu partner in het bestuursakkoord vanwege de verdrogingsproblematiek in het gebied.

De Provincie Limburg en ook de Provincie Noord-Brabant reageerden terughoudend op de nieuwe aanpak. Beide provincies waren met name ontevreden over de financiële onduidelijkheid ${ }^{131}$. De Limburgse gedeputeerden H.W. Riem (PvdA) en P.G.G. Hilhorst (CDA) hadden op 6 maart 1991 informeel bestuurlijk overleg met hun Brabantse collegagedeputeerden. In het overleg werd duidelijk dat de bestuurders twijfels hadden of het project in deze vorm 'wel te managen' was ${ }^{132}$. Er werd een te sterke 'top-down-benadering' geconstateerd waarbij wel doelstellingen werden geformuleerd, maar onduidelijk bleef of deze doelen ook financieel uitvoerbaar waren. Men stelde voor om het bestuursakkoord af te zwakken tot een 'intentionele verklaring'. Parallel aan het opstellen van de ruimtelijke visie zou men met pilotprojecten en haalbaarheidsstudies starten ${ }^{133}$. 
Met name de Limburgse gedeputeerden hadden een terughoudende opstelling. Om het draagvlak te polsen onder de Limburgse gemeenten, was er in mei bestuurlijk overleg gevoerd over de te volgen aanpak. Bij de Limburgse gemeenten was nauwelijks politieke aandacht voor het plan $^{134}$. Ook werd aan intermediaire belangenorganisaties gevraagd om te reageren. Na de zomer werden de reacties geïnventariseerd. Zij zouden tot weinig aanpassingen leiden.

In de tussentijd waren de ambtelijke voorbereidingen gestart voor het uitvoeren van een aantal 'haalbaarheidsstudies'. Deze studies waren een 'praktijkproef op kleine schaal' vooruitlopend op een mogelijk project ${ }^{135}$. Vooralsnog was de bekostiging van deze studies de enige financiële tegemoetkoming die het ministerie van VROM kon bieden. $\mathrm{Na}$ twee maanden vertraging werd op 11 maart 1992 in Den Haag het 'Startconvenant Nadere Uitwerking Brabant-Limburg' ondertekend. Er werd een stuurgroep gevormd onder voorzitterschap van de gedeputeerde van Noord-Brabant, bijgestaan door het vicevoorzitterschap van de gedeputeerde van Limburg. De secretarisrol werd vervuld door de Inspectie Ruimtelijke Ordening Zuid ${ }^{136}$. In het communicatieplan van oktober 1992 was al te lezen:

"Bij andere uitwerkingen ... is steeds naar voren gebracht dat het ging om nieuwe plannen. Gegeven de voorgeschiedenis van de NUBL [Nadere Uitwerking Brabant-Limburg - HvE] en de plan-cavalcade die in de afgelopen periode over de regio uitgestrooid is, wekt een presentatie van de NUBL als een "Nieuw Plan" alleen maar onwil op. Een ander gevaar dat dreigt is dat de NUBL wordt beschouwd als het zoveelste plan dat over de hoofden van de belanghebbenden wordt opgesteld, waarbij ontzettend veel gepraat wordt, maar uiteindelijk niets wordt gedaan..."137

Toch is dit wat er in de periode tot 1996 gebeurde. Een ingewikkelde project-structuur ${ }^{138}$, politieke desinteresse ${ }^{139}$, toenemende spanningen tussen Brabant en Limburg over de te volgen koers $^{140}$, discussies over financiering van projecten ${ }^{141}$, wel of geen draagvlak van de lokale organisaties en betrokken burgers, regulier beleid versus nieuwe beleidsinitiatieven - het zijn elementen die de urgentie van het project vervaagden.

Het project bleef daarmee primair een ambtelijke activiteit. Toch bracht het project wel een belangrijke vernieuwing aan in het denken over het provinciale ruimtelijke ordeningsbeleid. De Voorlopige Integrale Visie die in juni 1993 werd gepresenteerd introduceerde een aantal zeer concrete doelstellingen ${ }^{142}$. Voor het eerst werd de Limburgse ruimtelijke ordening voorzien van meetbare doelen. In de Visie werd bijvoorbeeld gepleit voor een aaneengesloten netwerk van natuurwaarden (de zogeheten 'Ecologische Hoofdstructuur'), een vermindering van het aantal verdroogde gebieden met een kwart en een aanscherping van de doelstellingen die opgesteld waren om de verdere verzuring van gronden tegen te gaan ${ }^{143}$. Ook de uitstoot van mest door de agrarische sector moest worden teruggedrongen ${ }^{144}$. Deze doelstellingen waren de provinciale vertalingen van de verschillende nationale sectorwetten die begin jaren ' 90 waren geïntroduceerd door de rijksoverheid. Het provinciale beleid had hier enerzijds de functie van een concrete toepassing in de praktijk van het rijksbeleid, maar vormde anderzijds ook een aanscherping 
van de nationale doelstellingen.

Niet alleen werden er nieuwe doelstellingen geïntroduceerd, ook werden er nieuwe geografische indelingen gemaakt. De ambtelijke werkgroep onderscheidde in de Visie twee soorten gebieden: 'milieu-herstructureringsgebieden' en 'milieu-basisgebieden'. In de herstructureringsgebieden was sprake van een grote verzuring van de grond en het grondwater door het gebruik van ammonia door de landbouwsector. De aangekondigde landelijke maatregelen waren in de ogen van de werkgroep niet voldoende. De ambtenaren vonden dat de Visie een extra beleidsimpuls moest geven aan de aanpak van de problematiek met name in de herstructureringsgebieden ${ }^{145}$. Men ging hier redelijk ver in. Zo werd een cirkel met een straal van 1 kilometer getrokken rondom de grote, meest gevoelige delen in Noord-Limburg. Binnen die straal moesten extra maatregelen getroffen worden. Gedacht werd aan de verplaatsing of zelfs beëindiging van bedrijven, of de overschakeling van veehouderij naar andere 'teelten ${ }^{146}$. Het begeleidende kaartje maakte meteen duidelijk dat het hier niet ging om kleinschalige maatregelen. Het ging om ongeveer de helft (!) van het totale plangebied van de Nadere Uitwerking. In de overige 'basisgebieden' zou de agrarische sector ruimte krijgen om zich vrij te ontwikkelen. Zo ging een aanscherping van doelstellingen hand in hand met nieuwe scherp afgebakende geografische indelingen.

De geschiedenis herhaalde zich. Net zoals er in de eindfase van het streekplan Noorden Midden-Limburg eind jaren '70 door de agrarische sector werd geageerd tegen de 'onjuiste weging van belangen', gebeurde dit nu weer. Het Landbouwschap stelde dat er 'geen sprake ... van een integrale aanpak omdat de voorstellen vrijwel alleen betrekking hebben op de agrarische sector en dan ook nog beperkt zijn tot de onderdelen vermesting, verdroging en verzuring ${ }^{\prime 147}$. Het Landbouwschap wees de integrale visie dan ook onverkort af. Zo ook de Limburgse Land- en Tuinbouworganisatie ${ }^{148}$. Maar niet alleen de agrarische sector had kritiek op de Visie. Ook de Waterleidingmaatschappij Limburg was - zij het vanuit een andere invalshoek - niet tevreden over de visie, vanwege het feit dat met de 'voorgestelde aanpak van de verdroging ... geen integrale afweging van belangen en mogelijkheden heeft plaatsgevonden'. Volgens de organisatie kregen de natuurbelangen overmatig aandacht en werden de drinkwaterbelangen zonder enige onderbouwing 'uitsluitend met beperkingen ... geconfronteerd'149. De Kamer van Koophandel vond de plannen 'niet uitvoerbaar' en alleen daarom al kon er geen sprake zijn van 'nieuw' beleid ${ }^{150}$.

Kortom, er was weinig draagvlak voor de Visie. Het was niet gelukt om een echte integrale visie te presenteren. De sectorbelangen bleven domineren. De Limburgse verantwoordelijke gedeputeerden hadden zich tot die tijd terughoudend opgesteld in het proces. Daar kwam nu verandering in. De kritiek op de plannen was te groot om afwezig te blijven. In een bestuurlijk overleg dat beide provinciebesturen op 2 februari 1994 met de ministers J.G.M. Alders (PvdA) en P. Bukman (CDA) hadden, werden knopen doorgehakt. De tot dan toe gevoerde aanpak werd vervangen door een 'bottom-up' aanpak waarbij draagvlak in de regio en het uitvoeren van projecten centraal stonden ${ }^{151}$.

In de zomer van 1994 werd een projectbureau geformeerd dat in 1995 van start zou gaan. Onder het mom van 'sturing op maat'152 werd er gekozen om nu volop aan de 
slag te gaan met concrete uitvoeringsgerichte projecten. De basis voor deze projecten aldus de sturingsfilosofie - lag in diverse sectorwetten en sectorplannen ${ }^{153}$. In de praktijk betekende dit dat de voorlopige integrale visie ter zijde werd geschoven ${ }^{154}$. Er werd besloten het visietraject niet af te ronden ${ }^{155}$. Het voorstel om de nationale doelstellingen aan te scherpen, zoals in de Visie was voorgesteld, was daarmee van de baan. Projecten, projecten, en nog eens projecten was het nieuwe motto ${ }^{156}$. In de loop van $1995 \mathrm{kwam}$ er een kabinetsbesluit waarmee extra gelden beschikbaar kwamen voor de vervolgaanpak. In de periode na 1996 zijn zo honderden projecten gefinancierd in Noord-Limburg ${ }^{157}$.

De Nadere Uitwerking Brabant-Limburg was gestart als een experiment voor het zoeken naar meer samenhang in het milieubeleid en het ruimtelijke ordeningsbeleid. De vernieuwing die de Nadere Uitwerking Brabant-Limburg bracht was dat het provinciale ruimtelijke ordeningsbeleid werd voorzien van doelstellingen. Om scherpe doelstellingen te kunnen formuleren moest de ruimtelijke ordening zich daarbij bijna op het schaalniveau van het bestemmingsplan begeven. Het voorstel van een $1 \mathrm{~km}$-begrenzing in de Visie was daar een voorbeeld van. Deze doelstellingen bleven vooral ambtelijke doelstellingen. Het Provinciaal Bestuur koos midden jaren ' 90 bewust voor projectmatige aanpak waardoor de doelstellingen en Visie nooit tot politieke besluitvorming hebben geleid ${ }^{158}$. De provinciale ambtenaren die zich bezig hadden gehouden met het opstellen van de Visie, verlegden hun werkzaamheden naar een onderwerp dat langzaam in de vergetelheid was geraakt namelijk: een nieuw streekplan en wel een streekplan voor de gehele provincie Limburg ${ }^{159}$. Zij kregen daarbij een steuntje in de rug vanuit Provinciale Staten.

\section{Het Provinciaal Omgevingsplan Limburg}

Op donderdag 16 en vrijdag 17 februari 1995 vergaderden de Provinciale Staten van Limburg. Het was een paar weken voor de provinciale statenverkiezingen. De agenda van de vergadering was goed gevuld en er waren twee dagen uitgetrokken om de allerlaatste stukken van het huidige College van Gedeputeerde Staten te bespreken. Op de agenda stond o.a. Statenstuk nummer E-342 over de actualisering van het Waterhuishoudingsplan Limburg 1991-1995. Het statenlid W.H.G. Hermans (CDA) kreeg als eerste het woord:

\footnotetext{
"Mijnheer de Voorzitter. Alvorens in te gaan op het statenstuk E-342 wil ik even stilstaan bij de aanpak van de drie omvangrijke plannen die wij binnen een korte tijd in de Staten behandelen: het Streekplan Midden- Noord-Limburg, het Waterhuishoudingsplan en het Milieubeleidsplan. Het zijn drie zeer omvangrijke plannen die in belangrijke mate consequenties hebben voor het buitengebied [...]. Daarbij moeten wij dwars door de plannen heen kijken om te zien of ze met elkaar sporen. Het College heeft zelf al toegegeven dat de plannen ten aanzien van het buitengebied aanvankelijk niet helemaal met elkaar strookten. Daarbij komt nog dat er geweldige overlappingen in de plannen zitten; er zijn zaken die driemaal gedaan worden. [...] De fractie van het CDA vindt dan ook dat dit in de toekomst op deze manier niet meer kan. Dit zal ons inziens anders moeten. Bij de behandeling van het streekplan hebben we hier ook al over gesproken en toen hebben wij de suggestie gedaan om te komen tot één omgevingsplan."160
} 
Statenlid Hermans verwees naar drie andere provinciale plannen die de afgelopen maanden door Provinciale Staten waren behandeld. Er waren nog andere provinciale nota's waarnaar hij had kunnen verwijzen. Zo was er de Beleidsnota Natuur en Landschap 1995-1999 - een volgend agendapunt uit diezelfde Statenvergadering -, het Provinciaal Mobiliteitsplan 1996-1999 (besluitvorming eind 1995) en het in november 1994 vastgestelde Provinciaal Ontgrondingenplan. In al deze plannen werden uitspraken over het 'buitengebied' gedaan. Bovendien moesten twee streekplannen geactualiseerd worden. Een voorbereide motie werd in deze Statenvergadering ingetrokken, nadat het College van Gedeputeerde Staten de toezegging gedaan had om na de vorming van een nieuw College met een standpunt te komen ${ }^{161}$. De roep om een integrale omgevingsplanning was een direct gevolg van de sectorale rijksnota's die eind jaren ' 80 waren geïntroduceerd en die de provincies verplichtten om provinciale meerjarige uitwerkingsnota's op te stellen (zie ook Wissink, 2000: 173). Het resulteerde erin dat begin 1995 Provinciale Staten binnen een paar maanden maar liefst vijf omvangrijke beleidsnota's voor de kiezen kregen, waarvan de onderlinge samenhang grotendeels ontbrak ${ }^{162}$. Een ambtelijke notitie Op weg naar één omgevingsplan ${ }^{163} \mathrm{kwam}$ ter sprake in de coalitieonderhandelingen van het voorjaar 1995. Het leidde tot een voorzichtige passage in het nieuwe Basisakkoord 1995-1999 onder het kopje streekplanbeleid: "Er wordt naar gestreefd om binnen de wettelijke mogelijkheden te komen tot één geïntegreerd uitvoeringsprogramma op de terreinen milieu, water, ruimtelijke ordening en verkeer en vervoer, als aanzet tot één omgevingsplan"164.

De voorbereidende werkzaamheden voor het nieuwe omgevingsplan gingen eind 1996 van start ${ }^{165}$. Gedeputeerde Staten gaven toen opdracht tot een 'onderzoek (...) naar diverse aspecten van een nieuwe planvorm in plaats van onder meer het streekplan, het Milieubeleidsplan, het Waterhuishoudingsplan en het Provinciaal Mobiliteitsplan ${ }^{166}$. Niet alleen de bezorgdheid van Provinciale Staten over de samenhang tussen verschillende meerjarige plannen en beleidskaders ('plandichtheid') was hiervoor aanleiding geweest, in de praktijk ontstonden eveneens problemen. Bij de toepassing van al deze verschillende kaders ontstonden 'haasje-over effecten', waarbij belanghebbende organisaties 'shopgedrag' vertoonden tussen de verschillende beleidskaders ${ }^{167}$. De Provincie werd hier uitgespeeld door deze organisaties omdat provinciale beleidsregels onderling strijdig met elkaar waren. De rechtszekerheid leek hier in het geding. Een transparante verantwoording naar buiten toe en het spreken vanuit één provinciale visie ontbraken.

In april 1997 lag er een eerste tussenrapportage van de voorbereidende ambtelijke werkgroep. De opstellers van de tussenrapportage stelden Gedeputeerde Staten voor de keuze om wel of niet door te gaan op de weg van één integraal omgevingsplan. Politiek gezien was hierover nog altijd geen duidelijkheid. Het Basisakkoord 1995-1999 had immers zeer nadrukkelijk gekozen voor de uitvoering van vastgesteld beleid en nadrukkelijk niet voor nieuwe beleidsontwikkelingen. Er waren rijksbezuinigingen aangekondigd ${ }^{168}$ en de provinciale begroting was nog niet sluitend ${ }^{169}$. Bovendien was er een tekort aan personele capaciteit voor de uitvoering van de nieuwe, gedecentraliseerde taken ${ }^{170}$. Nieuw beleid in de vorm van een integraal omgevingsplan lag daarmee niet voor de hand. Toch was dit de belangrijkste aanbeveling die de werkgroep deed. Het College van Gedeputeerde Staten 
koos voor de voorzichtige weg. De gedeputeerde Ruimtelijke Ordening, W.G.N. Wijnen (VVD), werd aangewezen als coördinerend bewindspersoon. Overleg met de collegagedeputeerden was nodig omdat het hier om meerdere beleidsterreinen ging. Er werd besloten om een eerste globale schets op te stellen die eind 1998 klaar moest zijn. Zo kon er nog vóór de provinciale statenverkiezingen van 1999 een overzicht van de reikwijdte van een omgevingsplan aan Provinciale Staten aangeboden worden. Het College van Gedeputeerde Staten benadrukte dat gezien de brede aanpak een 'sterke betrokkenheid van GS en Staf' noodzakelijk was ${ }^{171}$.

In de eerste helft van 1998 werd er breed overleg gevoerd met diverse belanghebbende organisaties ${ }^{172}$. Gemeenten, waterschappen, ministeries, intermediaire en koepelorganisaties, deskundigen en statenleden leverden inbreng voor een eerste 'agendavorming ${ }^{173}$. Men had van de eerdere aanpak in de Nadere Uitwerking BrabantLimburg geleerd om in een vroegtijdig stadium draagvlak te creëren. In dit overleg werd het voorstel voor een brede aanpak besproken. Daarvoor was een begeleidende discussienota opgesteld waarin Limburg werd opgevat als een 'stelsel van voorraden' zoals grondstoffen, afvalstoffen, ecologisch en cultuurhistorisch erfgoed. Deze voorraden onderscheidden zich van 'voorzieningen', zoals infrastructuur, winkels, woningen, bedrijven of sport-, zorg- en culturele voorzieningen. In de schets van het omgevingsplan zouden voorraden en voorzieningen met elkaar in verband gebracht moeten worden, geordend naar omvang, waardering en onderlinge verdeling ${ }^{174}$. Om het verband tussen omvang - waardering - verdeling te onderbouwen werd het zogeheten 'driehoeksdenken' geïntroduceerd ${ }^{175}$. Men tekende een driehoek, met daarin een hoek 'welvaart', een hoek 'mens' en een hoek 'omgeving'. De diversie relaties tussen deze punten werden gewogen. Hiermee werd gepoogd een integraal kader te schetsen.

Ondanks de complexiteit van het model, heeft dit driehoeksdenken veel invloed gehad op het ruimtelijke ordeningsbeleid. Maar ruimtelijke ordening is geen technocratische aangelegenheid. De weging van belangen is een politieke afweging en daarbij zijn ambtelijk-planologische argumenten vaak niet de enige argumenten. Wat betekende dit denkmodel nu eigenlijk concreet in de regio? Juist op het regionale niveau vond er vaak een confrontatie tussen verschillende belangen plaats. Zonder deze regionalisering van de ambities en doelen bleef het Omgevingsplan een abstract stuk papier. "Gebleken is wanneer naar de provincie als geheel gekeken wordt, zich nauwelijks frictie of spanningsvelden voordoen", constateerde de ambtelijke werkgroep ${ }^{176}$. Geografische indelingen speelden dus (wederom) een belangrijke rol. In de verdere uitwerking van het Omgevingsplan werd de provincie opgedeeld in tien regio's bestaande uit vijf landelijke regio's en vijf stadsregio's. Voor elke regio werden uitspraken gedaan wat betreft de 'gewenste' ontwikkeling. In deze regio's zou met een nieuw College van Gedeputeerde Staten 'coalitievorming' moeten plaatsvinden om de verdere ontwikkeling en uitvoering van de schets gestalte te geven ${ }^{177}$.

In januari 1999 lag er een 'Ontwerpschets ${ }^{178}$. Daarin zaten een aantal 'richtinggevende uitspraken'. Zo vlak voor de provinciale verkiezingen ging men hierin redelijk ver. Zo werd o.a. instemming gevraagd voor het 'onaantastbaar verklaren' van een aantal natuurgebieden en was het 'natuurlijk draagvermogen [een] vertrekpunt voor alle 
ontwikkelingen in Limburg'179. Op 23 februari 1999 werd de Ontwerpschets door GS vastgesteld waarbij het nieuwe College de uitgangspunten moest vaststellen.

Met het aantreden van het nieuwe College van Gedeputeerde Staten in april 1999 werd het Omgevingsplan nu politiek gezien stevig verankerd. Het voorzichtige zinnetje uit het Basisakkoord van 1995 werd vier jaar later vervangen door: "De Provincie werkt [de] voorgestane duurzame ontwikkeling uit in het Provinciaal Omgevingsplan ... dat Provinciale Staten deze periode zullen vaststellen"180. J.H.M. Bronckers (CDA) werd coördinerend portefeuillehouder en beschouwde het Omgevingsplan als zijn politieke prioriteit. Ruimtelijke ordening was aan de vooravond van de 21e eeuw voor het eerst in de geschiedenis een belangrijk politiek dossier geworden. In twee jaar tijd (1999-2001) werd de globale schets omgewerkt tot een definitief Statenvoorstel dat op 29 juni 2001 zou worden vastgesteld. Het integrale streekplan voor heel Limburg bracht vier belangrijke vernieuwingen in de provinciale ruimtelijke ordening: een nieuw inhoudelijk kader, de samenwerking met regionale partners, nieuwe geografische indelingen en ten slotte, een nieuw politiek elan.

Het nieuwe Omgevingsplan presenteerde op de eerste plaats een nieuw ruimtelijk kader. De vertaling van het driehoeksdenkmodel resulteerde in het instrument van de 'Perspectieven'. Een Perspectief gaf de primaire kenmerken van een deelgebied aan waarmee tevens werd aangeven welke ontwikkelingen hierbinnen mogelijk waren. Er werden tien Perspectieven onderscheiden. Deze Perspectieven kenden een aflopend 'strengheidsregime' waarbij Perspectief 1 (Bos- en Natuurgebieden) een grotere beschermingswaarde kende dan de Perspectieven 7 t/m 10 (stedelijke en economische kerngebieden). De Perspectieven vormden het inhoudelijke afwegingskader waarmee de Provincie de belangen tussen woningbouw, bedrijvigheid, landbouw, natuur en recreatie kon ordenen. Op een drietal regiokaarten werden deze grenzen voor heel Limburg ingetekend. Daarmee gaf de Provincie tot op bijna het gemeentelijke niveau de ruimtelijke mogelijkheden aan. De nieuwe taken op het gebied van o.a. natuur en landschap die in 1996 naar de provincies waren overgeheveld, verplichtten de Provincie tot deze aanscherping. Een van de uitgangspunten in het omgevingsplan: hoe voorkomt men, dat gemeenten teveel woningbouw en bedrijventerreinen zullen inplannen? De stelregel was dat er geen nieuwe lokale bedrijventerreinen meer werden aangewezen. Het ging uitsluitend om zogeheten 'regionaal verzorgende' bedrijventerreinen ${ }^{181}$. Wat betreft de woningbouw kwam er een richtlijn die uitsluitend gemeentelijke woningbouwplannen bestemd voor de eigen bevolkingsgroei toestond ${ }^{182}$.

Maar met de aanscherping van de spelregels en een gedetailleerde geografische indeling naar verschillende Perspectieven, werden ook uitzonderingen mogelijk gemaakt. Het trekken van een grens bood voor de Provincie namelijk de mogelijkheid om uitzonderingen toe te staan. In diverse rijksdocumenten werd het principe 'Roodvoor-Groen' geïntroduceerd ${ }^{183}$. 'Rode' ontwikkelingen, zoals woningbouw of de bouw van veestallen, werden toegestaan in een gebied waar dit volgens het omgevingsplan en bestemmingsplan eigenlijk niet mocht, tenzij de initiatiefnemer of projectontwikkelaar 
een financiële bijdrage leverde voor compenserende 'groene' maatregelen (bijvoorbeeld de aanleg van nieuwe natuur). De gedachte hierachter was dat op deze manier private partijen financieel bij konden dragen aan bijvoorbeeld de realisatie van nieuwe natuur. Dit 'voor-wat-hoort-wat principe' werd eind december 1999 in Limburg geïntroduceerd ${ }^{184}$. De Provincie had moeten constateren dat er talloze ambities waren op het gebied van de aanleg van nieuw bos en het realiseren van nieuwe natuur, maar dat de concrete uitvoering beperkt bleef tot enkel goede voornemens. Daar kwam nog eens bij dat de strenge rijks- en provinciale kaders die in de loop van de jaren '90 waren ontwikkeld, door gemeenten als knellend werden ervaren ${ }^{185}$.

Naast de bovengenoemde instrumenten van Perspectieven en Rood-voor-Groen, verkende de Provincie in het omgevingsplan de mogelijkheid van een actief provinciaal grondbeleid. De grondprijzen waren de afgelopen jaren ook in Limburg dusdanig sterk gestegen dat hierdoor de uitvoering van beleid in de problemen kwam, met name door speculatiegedrag van particulieren en marktpartijen op strategische grondposities ${ }^{186}$. Hier waren nog diverse juridische obstakels te overwinnen. Het landelijke debat over de positie van de overheid in de grondmarkt moest nog op gang komen ${ }^{187}$, zodat dit instrument in het uiteindelijke Omgevingsplan louter in algemene bewoordingen kon worden beschreven. Zowel de instrumenten Rood-voor-Groen alsook de introductie van een provinciaal grondbeleid bleven vooralsnog papieren ambities. Het was nog een stap te ver. Het instrumentarium bleef beperkt tot de 10 Perspectieven als richtinggevend kader.

Met het Provinciaal Omgevingsplan werd op de tweede plaats nieuw leven ingeblazen in de samenwerking met de Limburgse gemeenten. De gemeenten hadden op het gebied van ruimtelijke ordening in de jaren ' 90 nieuwe taken erbij gekregen met meer ruimte voor eigen beleid. Een Provinciaal Omgevingsplan kon niet gerealiseerd worden zonder steun en draagvlak van de gemeenten. Nog voor de zomer van 1999 hield gedeputeerde Bronckers een eerste ronde van regionale bijeenkomsten waar hij het (politieke) draagvlak in de regio verkende ${ }^{188}$. Vanuit de Provincie werd voorgesteld om samen met gemeenten Regionale Volkshuisvestingsplannen op te stellen. Deze plannen moesten zowel de kwantitatieve als kwalitatieve omvang van de woningbouwbehoefte per regio in kaart brengen. Het overleg verliep erg moeizaam. Dit had ongetwijfeld te maken met het feit dat er eigenlijk teveel gemeenten aan tafel zaten om het overleg echt productief te laten worden. Maar de rijksoverheid speelde hierin evenzeer een rol. De samenwerking met het ministerie van VROM was in deze periode beperkt gebleven tot het informeren over de gezette stappen. Dat wil niet zeggen dat het rijksbeleid weinig invloed had. Voor de provinciale ambtenaren was het bestaande, nieuwe rijksbeleid wel degelijk een belangrijke stok achter de deur om de ambities van het Omgevingsplan door te voeren ${ }^{189}$. Het pleidooi voor een restrictief woningbouwbeleid werd uit diverse rijksnota's overgenomen en werd zelfs in een aparte uitwerking vastgelegd ${ }^{190}$. Het was een van de oorzaken die de samenwerking tussen Provincie en gemeenten bemoeilijkte.

Tegelijkertijd werd er met de intermediaire organisaties overleg gevoerd. Met de Limburgse Land- en Tuinbouworganisatie was in juli 2000 een uitvoeringsconvenant ondertekend met de afspraak om de ambities nader uit te werken via het opzetten van 
gezamenlijke projecten ${ }^{191}$. Meer dan ooit speelde het Provinciaal Bestuur hierin de intermediaire rol tussen enerzijds het uitvoering geven aan rijksbeleid en anderzijds het oog open houden voor de gemeentelijke belangen. Dit laatste verliep, juist na de vaststelling van het Omgevingsplan, erg moeizaam. Gemeenten namen bovenal een afwachtende houding aan. Uiteindelijk verzandde het overleg ${ }^{192}$. Toch was het een van de eerste serieuze pogingen van het Provinciaal Bestuur om samen met de gemeenten een gezamenlijk ruimtelijk ordeningsbeleid op te zetten.

Op de derde plaats introduceerde de Provincie met het Omgevingsplan een nieuwe regionale indeling. Zo werd er een onderscheid gemaakt tussen zogeheten 'beleidsregio's', 'functionele regio's' en 'coalitieregio's'. Met de coalitieregio werd het hierboven genoemde overleg met gemeenten bedoeld ${ }^{193}$. Verder werden 14 regio's als beleidsregio aangeduid. Dit waren regio's waar specifieke inhoudelijke opgaven lagen zoals natuurontwikkeling, de realisatie van bedrijventerreinen of recreatieve activiteiten. Daarnaast waren er functionele regio's die verwezen naar gebieden waarin rijksbeleid moest worden uitgevoerd ${ }^{194}$. De functionele en beleidsregio's hadden een sterk inhoudelijk karakter, terwijl de coalitieregio's meer een politieke afweging kenden. Het probleem van deze indeling was dat er spanning bestond tussen de meer politieke regio-indeling en de beleidsmatige, inhoudelijke indeling. In sommige gebieden was er inhoudelijk en beleidsmatig gezien namelijk minder aan de hand dan in andere gebieden. Met andere woorden, sommige regio's behoefden minder provinciale aandacht. Minder provinciale aandacht betekende al snel minder financiële ondersteuning voor de desbetreffende gemeenten ${ }^{195}$. Politiek gezien bleek deze scherpe regionale differentatie niet haalbaar. Het oude principe van 'elke regio iets' was nog steeds actueel. De regio-indeling was politiek gezien nog om een andere reden lastig. De indruk mocht niet ontstaan dat de voorgestelde regionale indelingen door gemeenten werden gezien als een voorbode van mogelijke nieuwe gemeentelijke herindelingen ${ }^{196}$. De nadruk op 'coalitieregio's' moest dus ook gezien worden als een uitnodiging voor het aangaan van de allianties en partnerships, in plaats van gesprekken over herindeling.

Ten slotte bracht het Omgevingsplan ook een nieuw politiek elan in de ruimtelijke ordening. Daarbij werden de politiek-ambtelijke verhoudingen binnen het Provinciehuis op de proef gesteld. Niet zozeer tussen de verantwoordelijk gedeputeerde Bronckers en zijn ruimtelijke afdeling, maar veel meer aangaande de inhoudelijke afstemming met de andere gedeputeerden. Dat vergde veel tijd en veroorzaakte spanningen. Met het Provinciaal Omgevingsplan Limburg werd een integrale benadering voorgestaan waarin niet alleen uitspraken werden gedaan over de ruimtelijke ordening, maar ook over de beleidsvelden economie, zorg, water, milieu, welzijn en infrastructurele ontwikkelingen. Vooral de relatie tussen het omgevingsplan en het economisch beleid zorgde voor interne spanningen ${ }^{197}$. De discussie spitste zich toe op de vraag hoeveel nieuwe bedrijventerreinen er in Limburg nog moesten worden aangelegd. Uiteindelijk werd er een politiek compromis bereikt tussen de gedeputeerde Bronckers (CDA, Ruimtelijke Ordening) en zijn collegagedeputeerde van Economische Zaken, J.J.M. Tindemans $(\operatorname{PvdA})^{198}$. Het was duidelijk: de ruimtelijke ordening stond sinds lange tijd weer centraal op de politieke agenda. Dat een nieuw politiek elan gepaard ging met de nodige spanningen doet daar niks aan af. 
Ruimtelijke ordening en het Omgevingsplan in het bijzonder was een politieke prioriteit geworden.

De Provincie wilde met de integrale afweging van belangen het sectorbeleid (dat begin jaren '90 was geïnitieerd) meer samenhang in het ruimtelijke beleid aanbrengen. Dit was voor een groot gedeelte gelukt in het nieuwe Omgevingsplan, waarbij moeilijke inhoudelijke afwegingen toch uiteindelijk politiek draagvlak verkregen. Het plan dat op 29 juni 2001 door Provinciale Staten werd vastgesteld was een streekplan, een milieubeleidsplan, een watershuishoudingsplan en een verkeers- en vervoersplan in één ${ }^{199}$. Minder succesvol was de poging om ook de verbintenis tot stand te brengen met het economische beleid, het sociaal-culturele beleid en het zorgbeleid. Een aantal 'witte vlekken' moesten nog via aanvullingen en uitwerkingen ingekleurd worden ${ }^{200}$. De hoofdlijnen lagen daarmee vast, de flexibiliteit en het inspelen op maatschappelijke ontwikkelingen moest op lokaal niveau worden gerealiseerd. Het was juist hier dat gemeenten en projectontwikkelaars tegen nieuwe grenzen aanliepen.

\section{Vierde omslagmoment: flexibiliteit in de ruimtelijke ordening (2003-2004)}

Het nieuwe Provinciaal Omgevingsplan Limburg had duidelijkheid gebracht. Door de integratie van het streekplan met het milieubeleidsplan, waterhuishoudingsplan en het verkeersplan, was er duidelijkheid over wat de ruimtelijke mogelijkheden in Limburg waren. De 10 Perspectieven waren op één overzichtelijke provinciale kaart aangegeven. Het waren met name de consequenties van dit provinciale beleid voor lokale woningbouw, waar een aantal Zuid-Limburgse gemeenten moeite mee had ${ }^{201}$.

Twee jaar na de vaststelling van het Omgevingsplan waren er bij de gemeenten wisselende geluiden over te horen. Enerzijds bood het provinciale beleid duidelijkheid voor een gemeente waar wel en niet gebouwd mocht worden. Het voorkwam bestuurlijke willekeur en stimuleerde bovendien gemeenten om meer te kijken naar nieuwbouw binnen de bebouwde kom. Het belang van de bescherming van het karakteristieke Heuvelland waardeerden de gemeenten eveneens in het provinciale beleid ${ }^{202}$. Anderzijds benadrukten sommige gemeenten de keerzijde hiervan. Zij vonden dat het Provinciaal Bestuur teveel op de stoel van de gemeente was gaan zitten. Het trekken van gedetailleerde grenzen betekende minder ruimte voor woningbouw in de gemeentelijke bestemmingsplannen. Met name voor de kleinere kernen binnen de Zuid-Limburgse plattelandsgemeenten had dit grote consequenties. In deze kernen was nauwelijks ruimte voor uitbreiding buiten de huidige bebouwde kom. Men moest lange procedures doorlopen, wanneer men om een uitzonderingspositie vroeg. Kort samengevat: het beleid was duidelijk en inhoudelijk verdedigbaar, maar ontbeerde de flexibiliteit en het maatwerk waar vooral plattelandsgemeenten behoefte aan hadden ${ }^{203}$. Daarbij kwam het feit dat de ZuidLimburgse bevolking afnam en jongeren wegtrokken uit de Provincie. Veel gemeenten zagen de nieuwbouw van woningen als een middel om de afname van haar inwoners tegen te gaan.

Het was vooral de kritiek op gebrek aan flexibiliteit in het provinciale beleid, die de 
nieuwe gedeputeerde voor ruimtelijke ordening, G.H.M. Driessen (CDA), zich aantrok. Hij kende de worsteling van gemeenten als geen ander. Na 17 jaar wethouder geweest te zijn in de gemeente Horst aan de Maas was hij in 1999 gedeputeerde agrarische zaken geworden. In het nieuwe College van 2003 werd zijn portefeuille verbreed met ruimtelijke ordening. Hij had grote ambities: "Ruimtelijke ordening zal zich meer moeten ontwikkelen van hindermacht naar ontwikkelingskracht"204. Het accent zou moeten komen te liggen op het ontwikkelen van instrumenten en concrete samenwerking met betrokken partijen. Pragmatisch handelen stond voorop ${ }^{205}$. Vanaf mei 2003 introduceerde hij een programma getiteld Heroriëntatie ruimtelijke ordening. De afdeling Ruimtelijke Ordening werd omgedoopt tot Ruimtelijke Ontwikkeling. Dit was meer dan alleen een naamswijziging. Er was sprake van een fundamentele omslag binnen het beleidsveld.

De nadruk leggen op het stimuleren van (economische) ontwikkelingen - in plaats van het beschermen en ordenen van landschappelijke waarde - paste perfect in de tijdgeest van begin 21e eeuw. Op nationaal niveau waren diverse rapporten verschenen waarin gepleit werd voor een nieuwe 'ruimtelijke ontwikkelingspolitiek ${ }^{206}$. Ruimtelijke ordening moest veel actiever inspelen op economische ontwikkelingen waarin samengewerkt werd met gemeenten, woningbouwcorporaties en projectontwikkelaars. Een nieuwe werkwijze die de naam 'gebiedsontwikkeling' meekreeg ${ }^{207}$. Deze nieuwe opvattingen over de invulling van ruimtelijke ordening vereisten een aanpassing van het wettelijk instrumentarium. Minister van VROM, S.M. Dekker (VVD), had de nieuwe Nota Ruimte (2004) van het motto 'decentraal wat kan, centraal wat moet' voorzien. Provincies en gemeenten kregen aan het begin van de 21e eeuw meer ruimte dan ze ooit hadden durven dromen. Het was gedeputeerde Driessen die de geboden ruimte van het rijk aangreep om de ruimtelijke ordening op provinciaal en gemeentelijk niveau te flexibiliseren.

De combinatie van de nieuwe wetgeving, een pleidooi voor meer flexibiliteit in de ruimtelijke ordening op zowel lokaal als nationaal niveau en een ambitieuze gedeputeerde die als geen ander de grenzen van de ruimtelijke ordening opzocht, zorgden ervoor dat er in 2003 een nieuwe wind ging waaien in het Limburgse provinciehuis. Er was sprake van een nieuw omslagmoment. Ruimtelijk ordeningsbeleid was niet langer een doel op zich, maar een instrument om ontwikkelingen mogelijk te maken. Het ruimtelijk ordeningsbeleid bood sterker dan ooit een gelegenheid voor 'whealing and dealing' met belanghebbenden.

\subsection{Van ordenen naar ontwikkelen (periode 2004-2007 en verder)}

In de periode 2004-2007 werden onder het motto Heroriëntatie ruimtelijke ordening verschillende veranderingen in gang gezet. Met de Heroriëntatie werd een nieuwe werkwijze geïntroduceerd in de provinciale organisatie. Onder stevige politieke aansturing van gedeputeerde Driessen veranderde langzaam de cultuur bij de ruimtelijke afdeling van het 'denken vanuit wettelijke taken en problemen', naar 'luisteren naar anderen en komen met oplossingen'208. Niet langer ordenen, maar ontwikkelen was het nieuwe motto in de provinciale planologie. Deze heroriëntatie in de ruimtelijke ordening voltrok zich langs drie lijnen. 
Op de eerste plaats werd onder regie van gedeputeerde Driessen de hand in eigen boezem gestoken. De provinciale ruimtelijke procedures en het instrumentarium werden kritisch tegen het licht gehouden en vereenvoudigd. De Provincie gaf de Limburgse gemeenten meer ruimte voor eigen lokale afwegingen en versoepelde bovendien het toezicht op de gemeentelijke bestemmingsplannen. Niet alleen de toezichtsrelatie tussen Provincie en de Limburgse gemeenten veranderde; een tweede ontwikkeling in deze periode was dat er actief met gemeenten werd samengewerkt. Dit keer niet zoals in het Omgevingsplan eind jaren '90 was gebeurd, via stroperige regionale overlegrondes met meerdere gemeenten samen, maar een individuele benadering. Het leidde tot 45 samenwerkingsprojecten tussen Provincie en Limburgse gemeenten. In elke gemeente één project. Het was deze nieuwe werkwijze waarmee, op de derde plaats, opnieuw naar het in 2001 vastgestelde Provinciale Omgevingsplan Limburg werd gekeken. Een actualisatie was nodig. Net zoals de streekplannen van de jaren '50 na het in werking treden van de Wet op de Ruimtelijke Ordening (1965) geactualiseerd moesten worden en de 'verordenende' passages eruit werden gehaald, herhaalde deze exercitie zich aan het begin van de 21e eeuw. Dit keer niet vanuit een wettelijke noodzaak, maar vanuit een politieke ambitie. Ruimtelijke ordening was een politiek item geworden.

Een nieuwe werkwijze, die de provinciale bevoegdheden en instrumenten wijzigde, een pleidooi voor actievere samenwerking tussen Provincie en gemeenten en ten slotte een ontwikkelingsgericht Omgevingsplan, leidden in de periode 2004-2007 tot een heroriëntatie van het ruimtelijke ordeningsbeleid.

Een van de eerste zaken die vanaf het begin werden aangepakt, was een verandering in de inzet van provinciale bevoegdheden en instrumenten. De toetsing van gemeentelijke bestemmingsplannen door de Provincie was een bevoegdheid die al sinds 1965 door de Provincie werd uitgeoefend. Eind jaren ' 80 was hiervoor zelfs een aparte Handleiding Bestemmingsplannen opgesteld. In de handleiding was tot op detailniveau vastgelegd wat gemeenten wel en niet mochten opnemen in hun bestemmingsplannen, met name voor de plannen buiten de bebouwde kom (het 'buitengebied'). Binnen de bebouwde kom hadden gemeenten meer vrijheid voor eigen afwegingen. De invoering van de Algemene Wet Bestuursrecht midden jaren '90 verscherpte de eisen voor de bestemmingsplannen buitengebied. In de praktijk betekende dit een uitbreiding van de voorschriften zoals die opgenomen waren in de provinciale Handleiding Bestemmingsplannen ${ }^{209}$. Eind jaren ' 90 waren er al aanpassingen gedaan om gemeenten meer vrijheid te geven ${ }^{210}$, maar aan het begin van de $21^{\mathrm{e}}$ eeuw bevatte de Handleiding nog steeds een groot aantal regels en voorschriften ${ }^{211}$. Een groot aantal van deze regels werd in de periode 2003-2004 geschrapt. De Handleiding kreeg de naam Handreiking ruimtelijke ontwikkeling Limburg ${ }^{212}$. Ook de lijst van 'verklaring van geen bezwaar' werd fors uitgebreid, waardoor individuele gemeenten meer ruimte en flexibiliteit kregen in de afwegingen en keuzes bij het opstellen van bestemmingsplannen ${ }^{213}$.

Maar niet alleen aan de toepassing van regelgeving werd iets gedaan, ook de procedures werden versneld. Enerzijds gebeurde dit door in het vooroverleg met 
gemeenten mogelijke meningsverschillen uit te praten, anderzijds door de provinciale doorlooptijden van procedures te versnellen door bijvoorbeeld de onderzoekslasten bij bestemmingsplannen te verlichten. Gemeenten moesten in de voorbereiding van een bestemmingsplan diverse onderzoeken doen met betrekking tot eventuele archeologische vondsten, milieuzaken, bodemgesteldheid, of natuur- en waterwaarden. Onder het motto 'slimmer en minder' werden diverse onderzoeksverplichtingen kritisch tegen het licht gehouden. In een gezamenlijke werksessie van Provincie en gemeenten werd op 27 april 2005 gezocht naar oplossingen, om de door gemeenten gesignaleerde knelpunten aan te pakken $^{214}$.

Naast de aanpassingen in het toepassen van bevoegdheden en de veranderingen binnen de bestaande instrumenten, werden er door de Provincie in korte tijd verschillende nieuwe instrumenten ontwikkeld. Een van die nieuwe instrumenten was de methodiek van 'Verhandelbare Ontwikkelingsrechten'. De methode - die sinds de jaren '70 al in de Verenigde Staten werd toegepast - was een regeling die er op neerkwam dat er bouwruimte werd geboden in een gebied waar dit eigenlijk niet was toegestaan. Deze bouwruimte werd alleen toegestaan indien er geen sprake was van een bijzonder kwetsbaar gebied én de initiatiefnemer een financiële tegenprestatie leverde. Met dit geld kon de overheid vervolgens nieuwe natuur realiseren. De eerder beschreven Rood-voor-Groen regeling had dezelfde gedachtengang, maar was nog erg beperkt van opzet gebleven. Met de methode van Verhandelbare Ontwikkelingsrechten waren in principe alle soorten bebouwing (de 'rode' functies) mogelijk, mits voldaan werd aan de gestelde voorwaarden.

De Provincie had in 2004 het Landbouw Economisch Instituut opdracht gegeven om - mede met het oog op de in ontwikkeling zijnde nieuwe Grondexploitatiewet en de nieuwe Wet Ruimtelijke Ordening - de mogelijkheden van dit nieuwe instrument voor Limburg te verkennen ${ }^{215}$. Het Limburgse experiment kon zo als juridische grondslag dienen voor de aanstaande nationale wetgeving. Hiervoor werd vanuit Limburg sterk gelobbyd. Met succes. Uiteindelijk werd het Limburgse experiment erkend door de rijksoverheid ${ }^{216}$. Men sprak van een 'opbrengend vermogen' ${ }^{217}$ in de ruimtelijke ordening, wat zoveel betekende als: financiële inkomsten genereren door het opstellen en toepassen van ruimtelijke spelregels. Ruimte is schaars. Schaarste betekent geld. Met het stellen van eisen en regels aan de openbare ruimte kan schaarste gecreëerd worden. Landbouwgrond is veel goedkoper dan grond die bestemd is voor woningbouw. "Grond is - afhankelijk van de bestemming - een schaars goed waarmee geld te verdienen valt", zo viel in $2001 \mathrm{al}$ te lezen in de Rijksnota Grondbeleid ${ }^{218}$. Het principe was dus niet nieuw. Veel gemeenten voerden al tientallen jaren een grondbeleid. Nieuw was dat de Provincie dit nu actief ging verkennen en toepassen. Daarvoor had men een tweede instrument nodig, een provinciaal grondbedrijf.

In de periode 2005-2006 richtte de Provincie Limburg als eerste provincie een eigen grondbedrijf op. Tot die tijd was van een 'actief' provinciaal grondbeleid geen sprake ${ }^{219}$. In februari 2006 stemden Provinciale Staten in met de oprichting van een provinciaal grondbedrijf dat ingepast werd binnen de provinciale organisatie. In oktober werd de Uitvoeringsnota Grondbedrijf vastgesteld ${ }^{220}$. Een nieuwe tak van sport kwam zo 
het provinciehuis binnen. Het Grondbedrijf ging zich onder andere bezig houden met marktanalyses, vastgoedtransacties, taxaties en planeconomie. Bovendien was het voeren van een gedegen projectmanagement een belangrijke compententie die de ambtelijke organisatie zich eigen moest maken. Deze compententie werd belangrijk geacht voor de samenwerking tussen Provincie en Limburgse gemeenten. Immers, bevoegdheden en instrumenten hebben weinig betekenis als ze niet toegepast en ingezet worden.

Een tweede belangrijke ontwikkeling in de periode 2004-2007 is de samenwerking tussen Provincie en gemeenten. De belangrijkste actor binnen de provinciale ruimtelijke ordening was altijd al de gemeentelijke overheid geweest, maar van een gelijkwaardige samenwerking kon in de afgelopen decennia toch niet gesproken worden. Van een afstandelijke relatie in de jaren ' 60 en '70, sterk gemotiveerd vanuit het subsidiariteitsbeginsel, naar een nogal hiërarchische opstelling in de jaren ' 80 en ' 90 , werd er nu gezocht naar samenwerking op basis van gelijkwaardigheid. Een nieuw partnership dat niet via een regionale aanpak - zoals in het Omgevingsplan was geprobeerd - maar met een individuele benadering van de 45 Limburgse gemeenten, werd opgezet. Onder het motto 'niet de regels, maar de doelen en resultaten moeten centraal staan ${ }^{221}$, werden gemeenten in de zomer van 2005 uitgenodigd om projecten aan te dragen.

Uiteindelijk werden 45 projecten geselecteerd, één per gemeente. Het moest gaan om projecten waarbij sprake was van een complexe opgave, die tegen de 'randen van de regelgeving bewogen' en die op termijn tot wijziging van bestemmingsplannen leidden ${ }^{222}$. In de periode 2005-2006 werd er samengewerkt aan deze voorbeeldprojecten met wisselend succes ${ }^{223}$. De meerwaarde zat vooral in de gezamenlijke aanpak tussen Provincie en gemeenten. Voor de ruimtelijke afdeling betekende dit een accentverschuiving in het denken over ruimtelijke planontwikkelingen ${ }^{224}$. Alhoewel de gemeenten primair verantwoordelijk waren voor de projecten, moesten de provinciale ambtenaren evenzo een zekere mate van mede-verantwoordelijkheid opbrengen. Het idee hierachter was dat de traditionele provinciale rol van 'plantoetser', vervangen werd door die van 'planontwikkelaar'. De betrokkenheid en identificatie van de Provincie met de gemeentelijke problematiek werd daarmee bevorderd ${ }^{225}$. Met een tweedaagse reis naar de stad Lille in januari 2007 werd het traject formeel afgesloten. Vele Limburgse wethouders ruimtelijke ordening zetten hun handtekening onder een symbolisch verdrag dat de nieuwe werkwijze tussen gemeenten en Provincie voor de toekomst moest bekrachtigen ${ }^{226}$.

Tot 2005 was er eigenlijk niet meer gesproken over het in 2001 vastgestelde Provinciaal Omgevingsplan Limburg. Hoe verhield het heroriëntatietraject zich tot het in 2001 vastgestelde Provinciale Omgevingsplan Limburg? Dit Omgevingsplan vormde nog steeds het juridische en inhoudelijke kader voor de ruimtelijke ordening in Limburg. $\mathrm{Nu}$ de politieke prioriteit door gedeputeerde Driessen vooral bij het ontwikkelen van nieuwe instrumenten en het realiseren van projecten met gemeenten was gelegd, was het Omgevingsplan Limburg naar de achtergrond gedrongen. De diverse planaanvullingen en uitwerkingen hadden de transparantie van het provinciale ruimtelijke ordeningsbeleid 
niet bevorderd. Sinds de vaststelling van het plan in juni 2001 waren er maar liefst tien aanvullingen op het Omgevingsplan door Provinciale Staten vastgesteld. Het overzicht raakte met deze aanvullingen zoek en op onderdelen moesten inmiddels ook al verlengingsbesluiten genomen worden ${ }^{227}$. Een actualisatie was nodig. Maar wel op een ontwikkelingsgerichte manier.

Uit een evaluatie van het Omgevingsplan bleek dat de meeste betrokken partijen aangaven geen behoefte te hebben aan een nieuw plan $^{228}$. Ook Provinciale Staten vonden een volledige vernieuwing niet nodig ${ }^{229}$. Volstaan kon worden met een aanpassing en actualisering van het huidige plan. De nadruk lag immers op de realisatie van plannen door instrumentontwikkeling en gezamenlijke projecten. In juni 2005 besloten Gedeputeerde Staten om het Provinciaal Omgevingsplan Limburg met 'een snelle actualisering en opschoning om te bouwen naar een flexibel plan op hoofdlijnen ${ }^{1230}$. Binnen een jaar lag er een geactualiseerd nieuw Omgevingsplan. Een van de belangrijkste veranderingen ten opzichte van het in 2001 vastgestelde plan was dat het College expliciet aangaf welke gebieden prioriteit kregen. Daarmee werd de regionaal verdelende rechtvaardigheid doorbroken. Niet elke deelregio werd even belangrijk gevonden. Het paste in de lijn waarin ruimtelijke ordening vooral werd gezien als een onderhandelingsinstrument tussen belanghebbenden.

$\mathrm{Al}$ in een van de eerste conceptnota's was er een kaart van Limburg opgenomen met daarop ingetekend, de zogeheten Provinciale Hoofdstructuur ${ }^{231}$. De kaart had geen bindende werking maar schetste de 'specifieke gebieden of zones waar de Provincie voor zichzelf of als vertegenwoordiger van de rijksoverheid extra aandacht en/of middelen wil inzetten... ${ }^{1232}$. Limburg werd ingedeeld in een beperkt aantal deelregio's, waarbij de Provincie ervan uitging dat dit de ruimtelijk-economische kerngebieden van Limburg waren. Met andere woorden, met de kaart maakte het College ook meteen duidelijk dat er gebieden waren waar de Provincie komende tijd niet of nauwelijks activiteiten zou ontplooien. De geselecteerde gebieden concentreerden zich rondom de steden. Het was niet verwonderlijk dat deze gebieden redelijk overeenkwamen met de zogeheten 'clusters van kracht' die in het najaar van 2005 aangewezen waren in de provinciale economische Versnellingsagenda (zie hoofdstuk 3 ). Hiermee werd in feite een nieuwe poging gedaan om het keurslijf van de 'verdelende rechtvaardigheid' in Limburg af te schudden.

Deze aanscherping van het provinciale beleid was een van de discussiepunten die in het bestuurlijk overleg tussen Provincie, gemeenten en intermediaire organisaties op 18 januari 2006 aan de orde kwamen. Was het toerisme en de recreatieve ontwikkeling voor het Noord-Limburgse gebied Maasduinen niet belangrijk? En hoe zat het met de status van het Peelgebied als Nationaal Landschap?, vroeg het Waterschap zich af. De gemeente Maasbracht vroeg zich in de middagsessie af waarom de Essent-terreinen binnen haar gemeente geen bijzondere status kregen? De ANWB zou graag de A2 als volwaardig onderdeel van de Provinciale Hoofdstructuur zien. De Universiteit Maastricht miste die avond vooral het cluster Health, Care \& Cure en een bestuurder van de regio Parkstad vroeg zich af waarom de internationale verbindingen (spoor en weg) niet waren ingetekend ${ }^{233}$. Met andere woorden, selectiviteit aanbrengen betekende: keuzes maken. 
Het zette de discussie met belanghebbenden op scherp. Onder de toezegging dat de kaart 'nog in ontwikkeling' was, werd hiermee aan het einde van de dag de discussie voorlopig afgesloten.

$\mathrm{Na}$ de informatieavonden, hoorzittingen en een tweetal commissievergaderingen werd het nieuwe geactualiseerde Provinciaal Omgevingsplan in de Provinciale Statenvergadering van 22 september 2006 met een aantal kleine wijzigingen vastgesteld. In een periode van anderhalf jaar was het streekplan herzien. Herschreven in een meer ontwikkelingsgericht taalgebruik, aangepast met het nieuw ontwikkelde instrumentarium en inspelend op de aankomende nieuwe Wet Ruimtelijke Ordening. De introductie van een Provinciale Hoofdstructuur had daarin weliswaar geen formele juridisch-planologische status, maar bood wel een eerste inzicht in de provinciale ambities en de selectieve inzet van middelen voor de toekomst.

Ruimtelijke ordening was onderhandelingsplanologie geworden. Onderhandelen over bouwen buiten de vastgestelde grenzen, onderhandelen over de hoogte van een tegenprestatie, onderhandelen over de selectieve inzet van financiële middelen. Een lijn die in de nieuwe coalitieperiode 2007-2011 verder zou worden uitgewerkt ${ }^{234}$. Daarmee was de ruimtelijke ordening blijvend veranderd. En niet alleen in Limburg. Het ministerie van VROM had in het opstellen van de nieuwe Wet Ruimtelijke Ordening en de bijbehorende Grondexploitatiewet die in 2006 werden vastgesteld, goed gekeken naar de Limburgse aanpak $^{235}$.

\subsection{Hoofdlijnen en voorlopige conclusies}

In dit hoofdstuk is het provinciale ruimtelijke ordeningsbeleid vanaf 1962 beschreven. Vier periodes zijn in deze 45 jaar te onderscheiden. Elke nieuwe periode werd voorafgegaan door een omslagmoment dat zich afspeelde in een betrekkelijk korte periode van 2 à 3 jaar. Het jaar 1962 was het startpunt van de analyse. In dat jaar werd de Wet op de Ruimtelijke Ordening aangenomen en werd het Streekplan voor de Oostelijke Mijnstreek vastgesteld. Provincies kregen de bevoegdheid om gemeentelijke bestemmingsplannen te toetsen waarbij het streekplan als richtsnoer diende in de beoordeling. In de jaren '60 richtte de Provincie zich vooral op de beoordeling van bestemmingsplannen.

Vanaf de jaren '70 werd er door de Provinciale Planologische Dienst aan twee grote streekplannen gewerkt. Een streekplan voor Zuid-Limburg en een streekplan voor Noord-en Midden-Limburg. Daarin speelde de Provinciale Planologische Commissie een belangrijke rol. De Commissie, bestaande uit een vertegenwoordiging van de belangrijkste ministeries en Limburgse belangengroepen en voorgezeten door de gouverneur, had formeel slechts een adviserende rol naar het College van Gedeputeerde Staten, maar was in de praktijk zeer bepalend in de uiteindelijke besluitvorming. In de loop van de jaren '70 werden met name tijdens de voorbereiding van het Streekplan voor Noord- en Midden-Limburg grote belangentegenstellingen zichtbaar tussen de agrarische sector en provinciale planologen. Er ontstond een machtsstrijd die eind jaren '70 voor grote vertragingen zorgde in het afronden van het streekplan en de politiek-ambtelijke verhoudingen op scherp zette. Het 
College van Gedeputeerde Staten kon niet langer afzijdig blijven in deze discussies en greep in. Met de komst van de nieuwe gouverneur J. Kremers in 1977 en een jaar later een nieuw College, werd de macht van de Planologische Commissie teruggedrongen en kwam de ambtelijke Planologische Dienst onder strakke politieke aansturing.

Vanaf 1979 was er slechts één provinciale prioriteit: het wegwerken van de Limburgse werkloosheid. De ruimtelijke ordening stond ten dienste van de economie. Het luidde een tweede omslagmoment in. Niet langer het opstellen van streekplannen was belangrijk, maar streekplanuitwerkingen stonden centraal. Als midden jaren ' 80 het volkshuisvestingsbeleid en de stadsontwikkeling gedecentraliseerd worden, krijgt de Provincie Limburg ook de bevoegdheden en financiële middelen om deze streekplanuitwerkingen te realiseren. Omdat het economisch beleid vooral gericht was op grote economische projecten voor Zuid-Limburg, zette het Provinciaal Bestuur het ruimtelijke ordeningsbeleid evenzo gericht in voor projecten in Noord-Limburg. De samenwerking met gemeenten verliep erg moeizaam vanwege de hiërarchische opstelling van de Provincie bij de toetsing van gemeentelijke bestemmingsplannen en het verdelen van subsidies voor lokale woningbouwplannen.

Toen eind jaren ' 80 de samenwerking tussen Provincie en rijksoverheid op economisch gebied beëindigd werd, bleek duidelijk dat Limburg op eigen kracht verder moest. In de Vierde Nota Ruimtelijke Ordening lag de nadruk op de ontwikkeling van de Randstad en niet meer op perifeer gelegen provincies als Limburg. Parallel hieraan werd er in een relatief korte periode rond 1990 een groot aantal sectorwetten aangenomen op het gebied van de openbare ruimte. Het thema 'milieu' kreeg prominente aandacht. Er werd voor het milieu-, water- en natuurbeleid nieuwe wetgeving geïntroduceerd. Deze nieuwe wetgeving vereiste in veel gevallen een provinciale vertaling. De jaren ' 90 was het decennium van het sectorbeleid. Het provinciaal beleid verbreedde zich naar allerlei beleidsvelden, waardoor eigenlijk maar één speler veel macht kreeg: het ambtelijk apparaat. Dat had expertise en kennis opgebouwd binnen deze nieuwe beleidsterreinen. Het College van Gedeputeerde Staten speelde slechts op deelonderwerpen een actieve rol. Ruimtelijk ordeningsbeleid moest in de politieke prioriteitstelling concurreren met milieubeleid, waterbeleid, infrastructuurbeleid, zorgbeleid en economisch beleid. De samenhang tussen met name het ruimtelijke ordeningsbeleid en het milieu-, natuur-, water- en landbouwbeleid werd verkend in de Nadere Uitwerking Brabant-Limburg. Dit bleek moeizamer te verlopen dan gedacht.

Toch werd halverwege de jaren ' 90 de roep om een 'integraal beleid' steeds luider. Met een nieuw streekplan, dit keer voor geheel Limburg, werd een nieuwe poging gedaan. Het Provinciaal Omgevingsplan Limburg dat in juni 2001 werd vastgesteld was een Streekplan, een Milieubeleidsplan, een Waterhuishoudingsplan en een Verkeer- en Vervoersplan in één. Een inhoudelijk kader was geschapen, gekoppeld aan specifieke doelstellingen. Maar de instrumenten om deze doelstellingen te realiseren en de gewenste gemeentelijke samenwerking moesten nog uitgewerkt worden.

Het waren deze twee elementen - het uitwerken van nieuwe instrumenten en een actieve samenwerking met gemeenten - die de gedeputeerde G.H.M. Driessen (CDA) centraal 
stelde. Hij benutte de tijdgeest en het rijksbeleid om trage besluitvorming en gebrek aan flexibiliteit aan te pakken. De Provincie ging een actieve ruimtelijke ontwikkelingspolitiek voeren met een nieuw instrumentarium. Daarbij diende rechtszekerheid hand in hand te gaan met het bieden van flexibiliteit. Een eigen provinciaal grondbedrijf werd opgericht als instrument om ambitieuze doelstellingen te realiseren. Via een individuele benadering van de Limburgse gemeenten werd deze nieuwe werkwijze uitgeprobeerd met 45 voorbeeldprojecten. Daarbij ging vooral op regionaal niveau de aandacht uit naar stedelijke gebieden. Daar zat de ruimtelijk-economische dynamiek voor de toekomst. Deze dynamiek werd uiteindelijk vastgelegd in een Provinciale Hoofdstructuur die een selectief aantal gebieden aanwees waar de Provincie haar menskracht en middelen op wilde richten. Ruimtelijke ordening was veranderd in een ruimtelijke ontwikkelingspolitiek.

Concluderend kan gesteld worden dat het provinciale ruimtelijke ordeningsbeleid in de afgelopen 45 jaar een ontwikkeling heeft doorgemaakt van voorzichtig ambtelijke verkenningen, naar een actieve ruimtelijke ontwikkelingspolitiek. De samenwerking van de Provincie met de Limburgse gemeenten is pas vanaf eind jaren '90 echt van de grond gekomen. Dat is opmerkelijk te noemen gezien het feit dat de regering met de Wet op de Ruimtelijke Ordening van 1962 juist beoogde om te komen tot een productief samenspel tussen het provinciale streekplanbeleid en de gemeentelijke bestemmingsplannen. Het zijn lange tijd gescheiden werelden gebleven.

De politieke aandacht voor de ruimtelijke ordening is altijd beperkt gebleven. Toch kreeg de Provincie op het gebied van de ruimtelijke ordening vanaf de jaren '80 en '90 steeds meer bevoegdheden en instrumenten tot haar beschikking. Er werden steeds meer ambities en doelstellingen in het beleid ingebracht. Pas eind 20e eeuw werd ruimtelijke ordening een instrument voor politieke profilering en onderhandelingen over de toekomstige ontwikkelingen van de Limburgse ruimte. Ruimte werd steeds meer gezien als een schaars goed. En met schaarste kun je twee dingen doen: beschermen of benutten. De streekplannen die vanaf de jaren '60 zijn opgesteld legden nog sterk de nadruk op het eerste aspect. Een ruimtelijke ontwikkelingspolitiek, zoals die aan het begin van de 21e eeuw neergezet werd, benadrukte vooral het laatste aspect. Het is dan ook niet vreemd dat vanaf dat moment ruimtelijke ordening een belangrijke portefeuille werd binnen het College van Gedeputeerde Staten. 


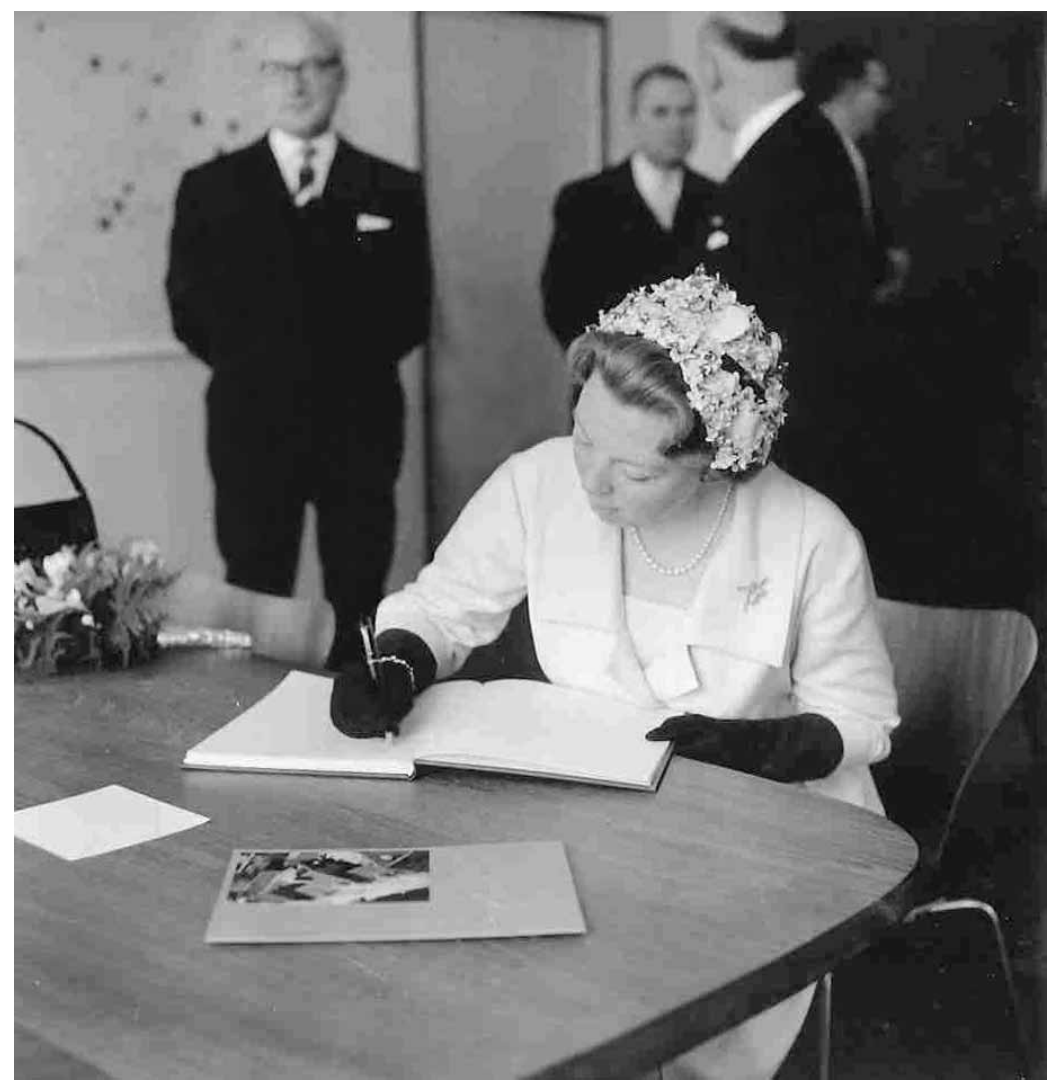

Prinses Beatrix opent op 7 mei 1960 het nieuwe gebouw van de Provinciale Planologische Dienst Limburg. De Dienst was in de jaren '50 sterk gegroeid o.a. door het toenemende streekplanwerk en opstellen van uitbreidingsplannen voor gemeenten. Foto: Provincie Limburg. 


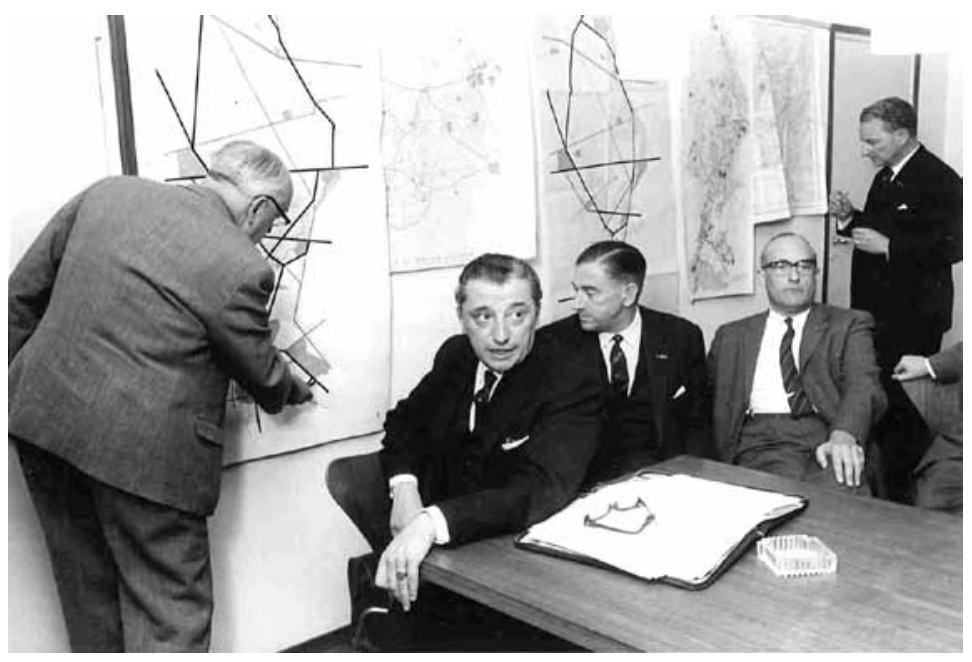

De minister van Verkeer \& Waterstaat, J. Aartsen (ARP), brengt op 23 september 1964 een werkbezoek aan Limburg en laat zich informeren over het regionale wegennetwerk. Rechtsachter de in datzelfde jaar aangetreden gouverneur Ch.J.M.A. van Rooy (KVP). Foto: Provincie Limburg.

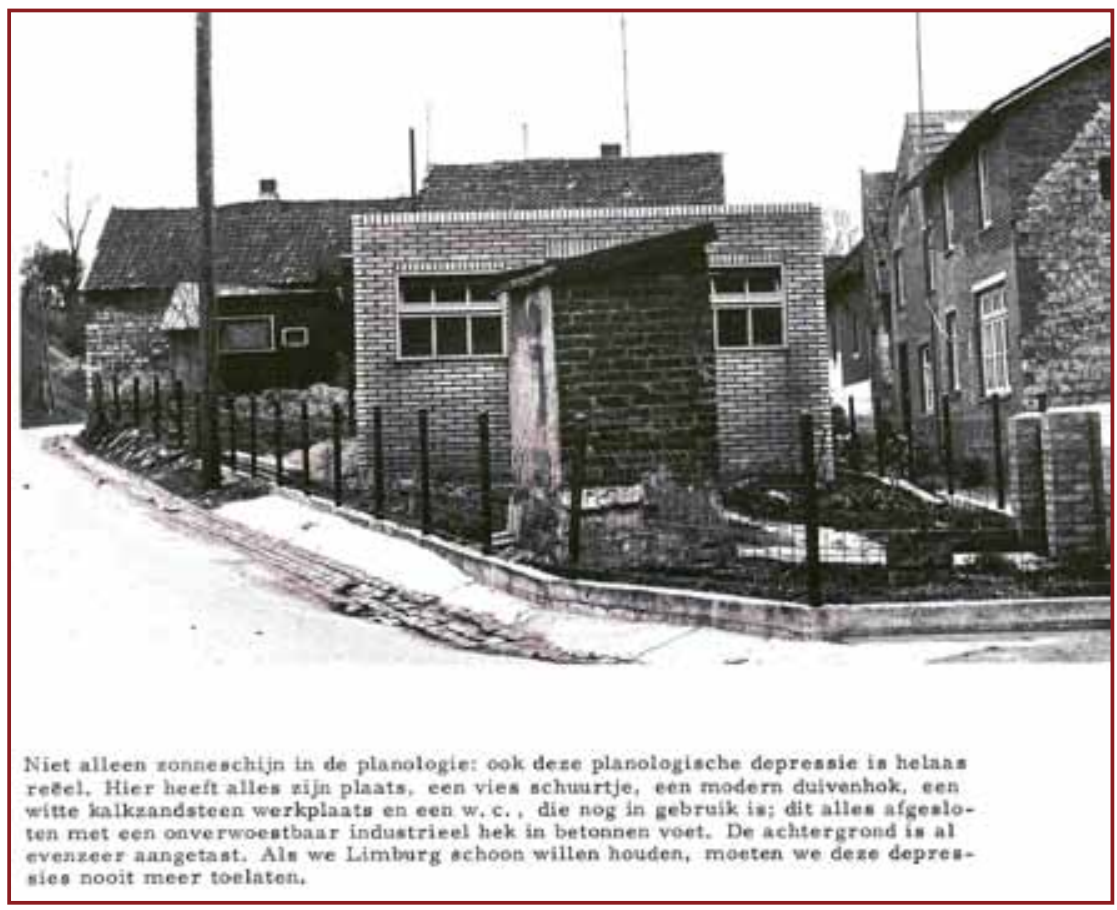

De ambtenaren van de Planologische Dienst (PPD) hadden weinig op met de vele kleine aanbouwen en lintbebouwing in de plattelandskernen, getuige het citaat van de PPD bij de foto komend uit de studie De Suburbanisatie in Limburg (1966). Foto: Provincie Limburg. 
In 1966 trad voor het eerst een PvdA-er toe tot het College van Gedeputeerde Staten. J. van der Woude werd verantwoordelijk voor het ruimtelijke ordeningsbeleid. Een streekplan moest in zijn ogen niet dienen 'als kapstok voor het uitdiepen van randfilosofieën'. Foto: Provincie Limburg.

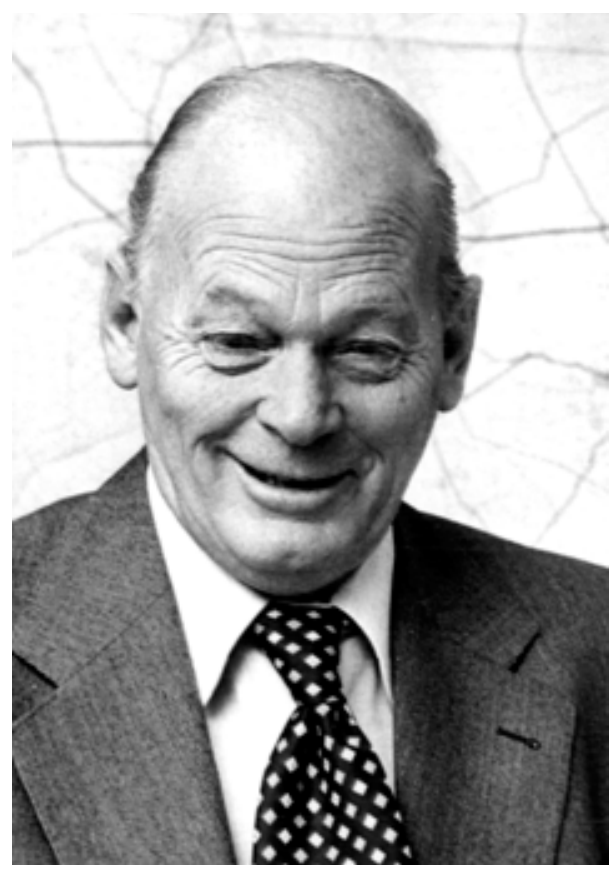

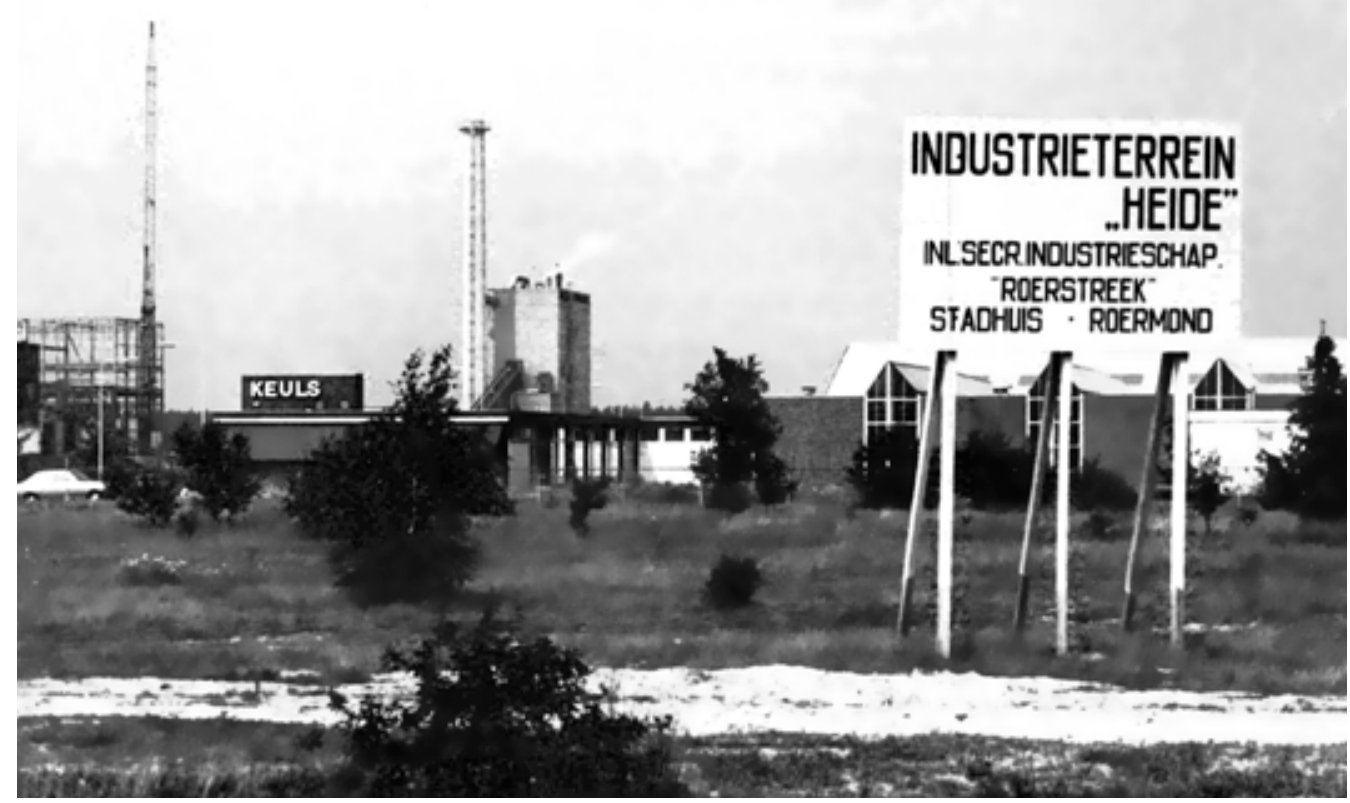

$\mathrm{Na}$ het definitieve besluit van de regering om de geplande staatsmijn Beatrix niet in werking te nemen, kreeg de regio Roermond ter compensatie ruimte om een nieuw industrieterrein te ontwikkelen, industrieterrein 'Heide'. Foto: Provincie Limburg. 


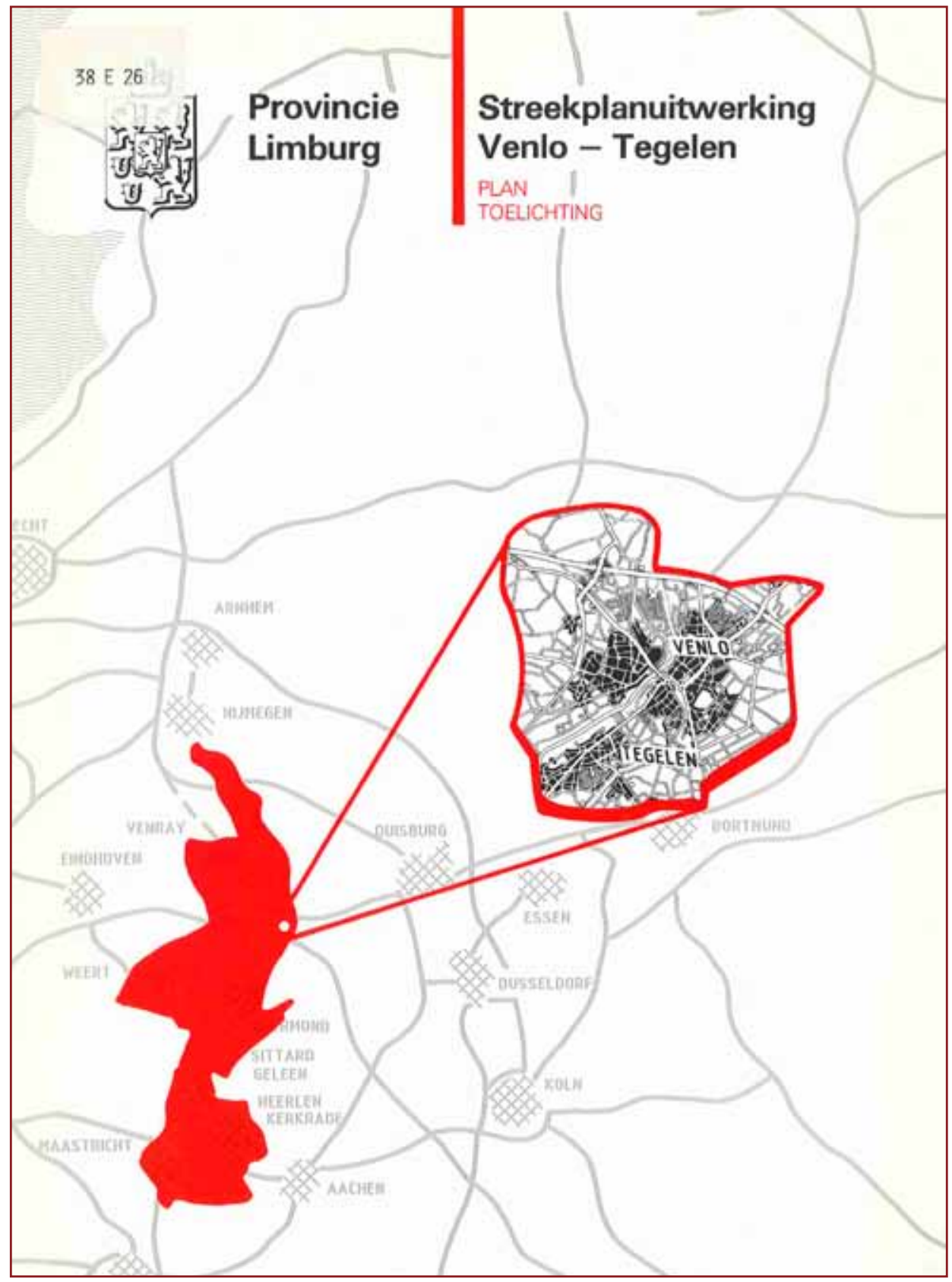

In de jaren ' 80 was het economisch beleid de belangrijkste prioriteit van het Provinciaal Bestuur. Ruimtelijke ordening stond ten dienste van de economische ontwikkeling, vandaar dat de streekplanuitwerkingen primair de functie hadden om de aanleg van bedrijventerreinen mogelijk te maken en gemeenten woningen te laten bouwen. Foto: Provincie Limburg. 


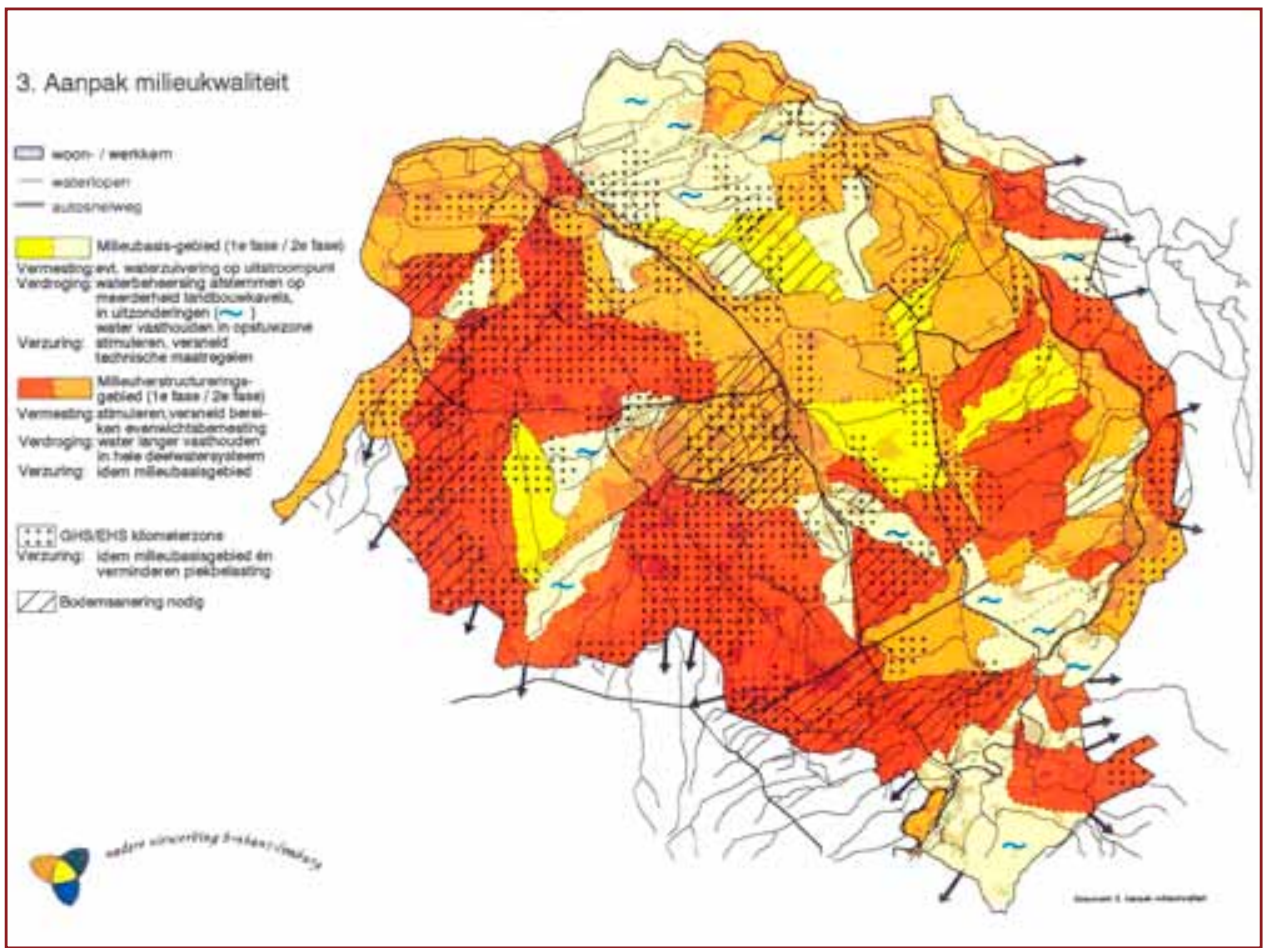

In de Nadere Uitwerking Brabant-Limburg werden zeer concrete doelen geformuleerd om de verdroging en de ammoniakuitstoot in het Peelgebied tegen te gaan. Het kaartje uit het Visiedocument is nooit door het College van Gedeputeerde Staten vastgesteld. Foto: Provincie Limburg.

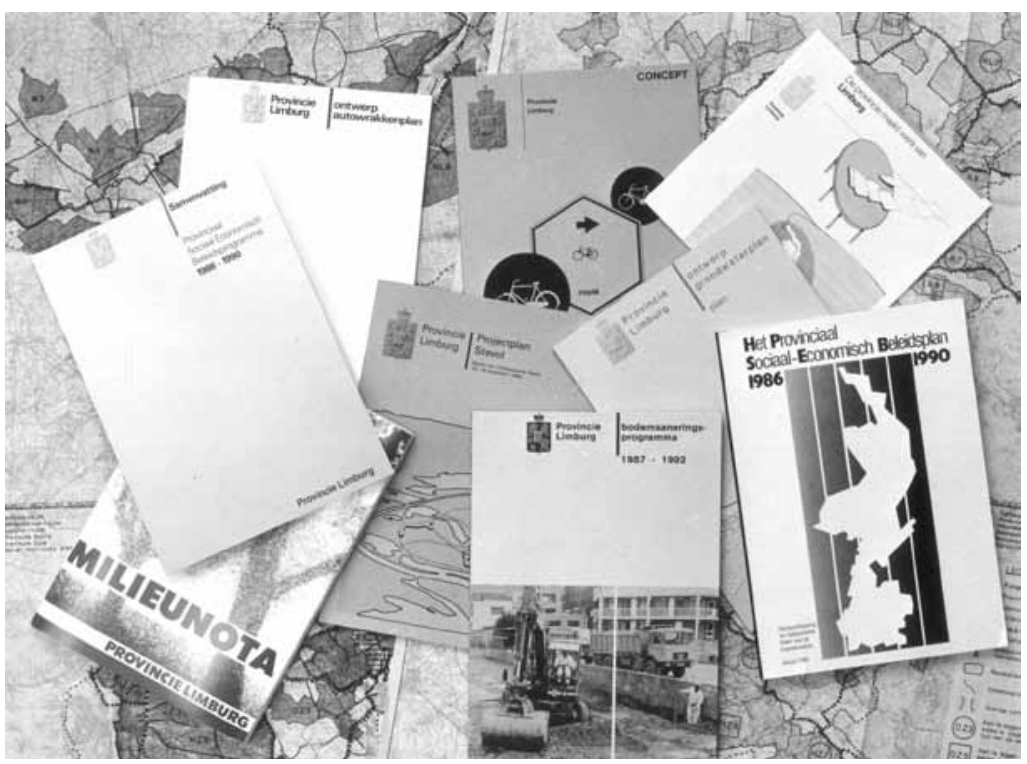

Nieuwe sectorwetten eind jaren ' 80 vereisten vaak een provinciale vertaling waardoor er een breed scala van plannen en beleidskaders werd ontwikkeld. In de loop van de jaren '90 groeide mede hierdoor de macht van het ambtelijk apparaat. Foto: Frits Widdershoven. 


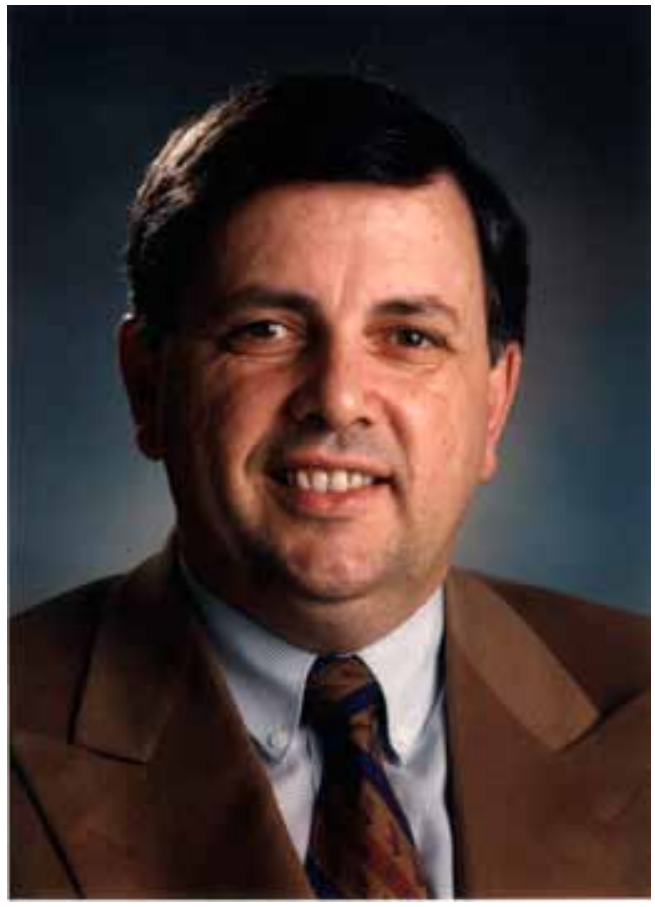

Onder leiding van gedeputeerde J.H.M. Bronckers (CDA) werd het beleidsterrein ruimtelijke ordening vanaf 1999 een belangrijke politieke portefeuille. Hij zocht voor de uitvoering van het omgevingsplan politiek draagvlak bij de Limburgse gemeenten. Foto: Provincie Limburg.

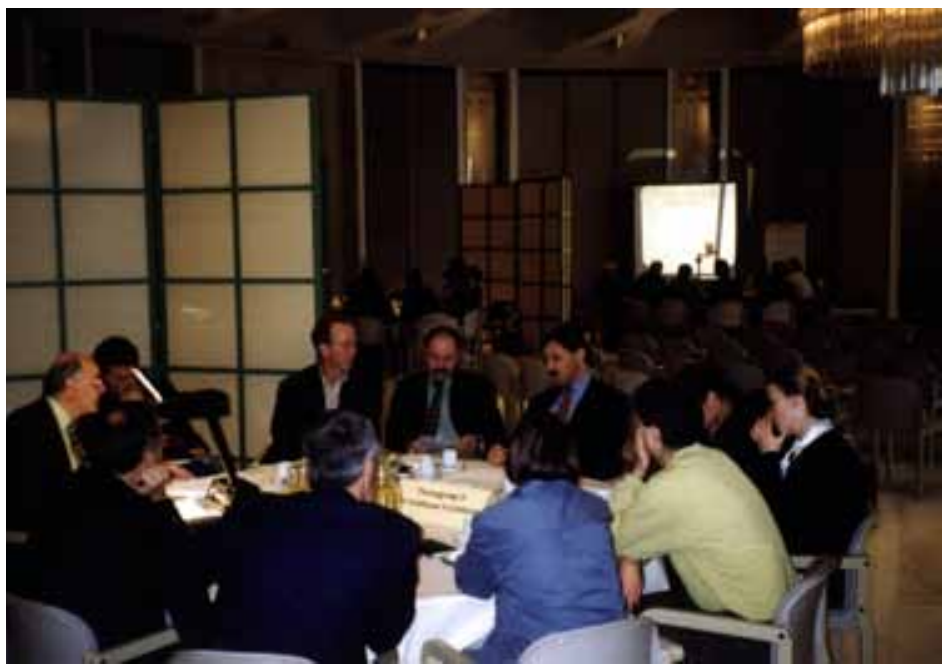

Het Provinciaal Omgevingsplan Limburg (1995-200I) was het eerste streekplan voor geheel Limburg. Het was tevens een plan voor de waterhuishouding, milieubeleid en mobiliteit. In de voorbereiding ervan waren er diverse ambtelijke afdelingen betrokken. Foto: Provincie Limburg. 


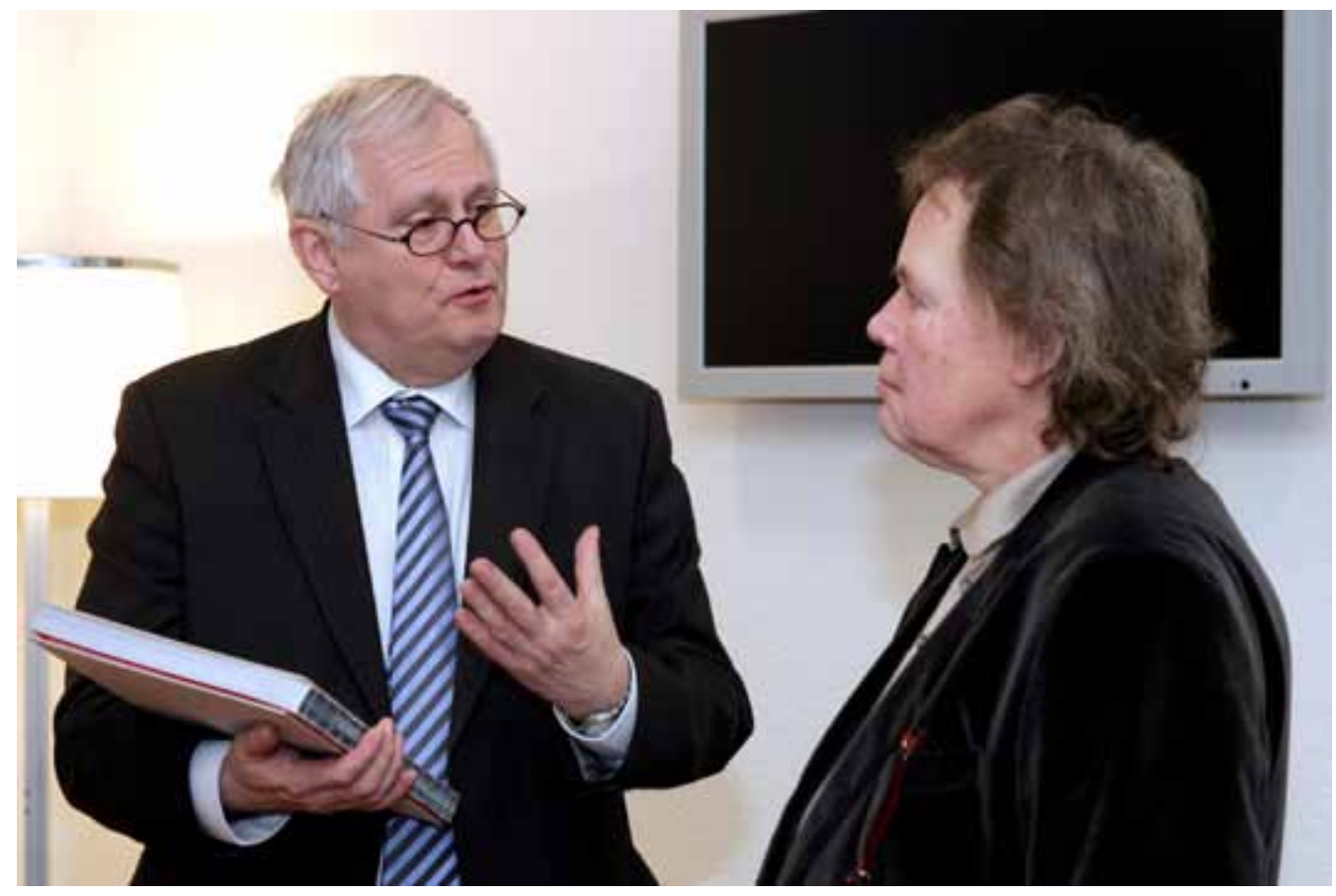

Gedeputeerde Driessen krijgt uit handen van stedenbouwkundige Riek Bakker het fotoboek van de gebiedsontwikkeling in Midden-Limburg (zomer 2008). Bakker was tevens voorzitter van de Commissie Gebiedsontwikkeling in 2005 ingesteld door de het ministerie van VROM. In Limburg werd onder verantwoordelijkheid van gedeputeerde Driessen geëxperimenteerd met deze nieuwe vorm van 'ontwikkelingsplanologie'. Foto: Provincie Limburg. 


\section{5 kernpunten voor de aanpak \\ van ontwikkelingsplanologie in Limburg}

'verdrag van Lille'

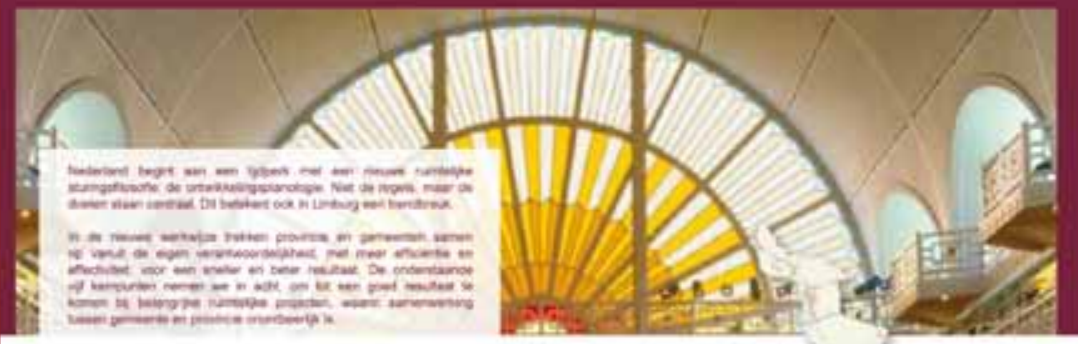

\section{Samenwerken}

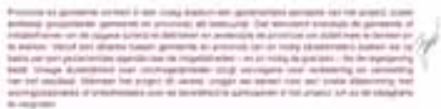

2 Project-en planmatig

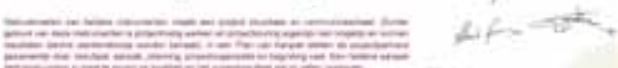

3 Snel en transparant

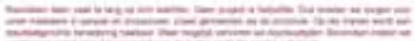

4 Professioneel en integraal

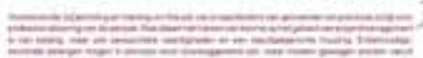

Open en oplossingsgericht
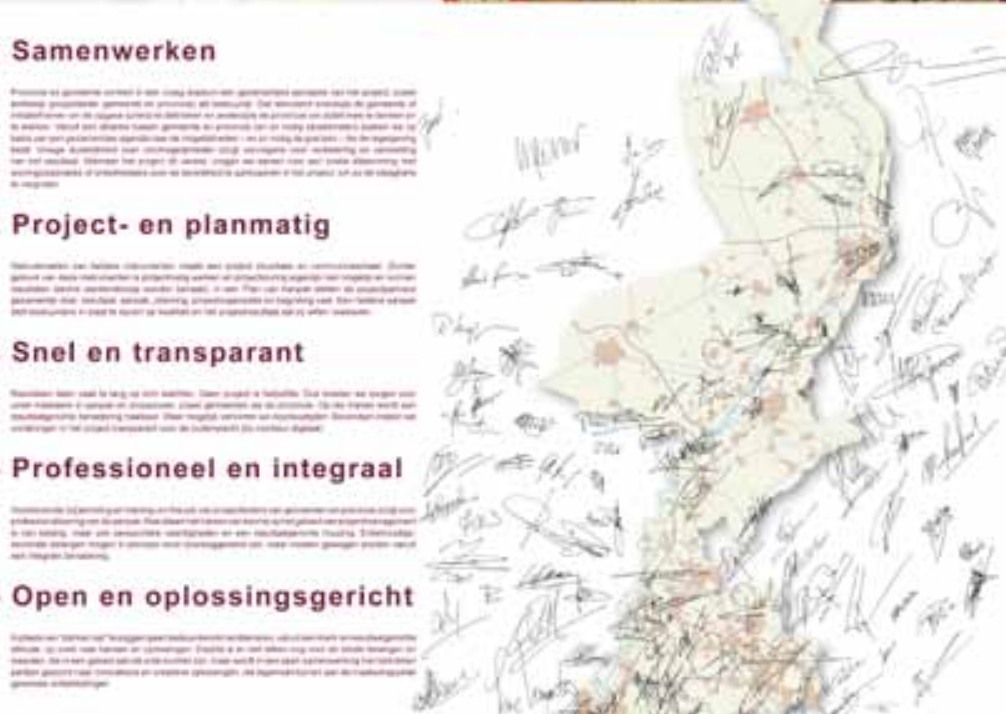


\title{
Provincie Limburg en het economisch beleid $1962-2007$
}

\begin{abstract}
"Regio's maken deel uit van naties: een belangrijk stuk van de regionale economische ontwikkeling wordt door het nationale gebeuren bepaald. Niets nieuws: maar Den Haag wordt juist de laatste tijd vaak door regionale instanties benaderd of het niet wat meer voor de regionale ontwikkeling kan doen. [...] [R]egionaal economisch beleid, bedoeld om evenwichtiger sociaal-economische structuren te krijgen in en tussen de verschillende landsdelen, kan niet worden gevoerd zonder dit af te stemmen op andere vormen van economisch beleid, met name ook het sectorbeleid. [...] Het economisch mechanisme is zo ingewikkeld geworden, dat macro-instrumenten alléén ontoereikend zijn. Mede daarom is de behoefte gegroeid aan sectorverkenningen en aan sectorbeleid ..."236
\end{abstract}

S. Miedema, 1975

In bovenstaand citaat is de directeur-generaal Prijzen, Ordening \& Regionaal Beleid van het ministerie van Economische Zaken, S. Miedema aan het woord. Hij was in de jaren '70 en '80 een belangrijke spil in de contacten tussen de Provincie Limburg en het ministerie. Het Provinciaal Bestuur had in 1975 net een eigen Limburgs acquisitiebureau opgericht, een thema dat erg gevoelig lag bij het ministerie. Het aantrekken van nieuwe bedrijvigheid voor regio's was tot die tijd immers een taak van de rijksoverheid geweest. In de loop van de jaren '70 kwam echter steeds meer kritiek op het centraal aangestuurde economisch beleid van de rijksoverheid, waarbij acquisitie - zeker in het Limburg van na de sluiting van de mijnen - een belangrijk thema was. De Provincie Limburg pleitte dan ook voor een verruiming van de mogelijkheden om zelfstandig economisch beleid te voeren.

In dit hoofdstuk staat op de eerste plaats de taakverdeling binnen het economisch beleid tussen rijksoverheid en de Provincie Limburg centraal. Bartels \& Van Duijn wijzen terecht op het feit dat deze taakverdeling 'geen constante grootheid' is geweest (Bartels \& Van Duijn, 1981: 40). Op de tweede plaats is er binnen deze taakverdeling een inhoudelijk onderscheid te maken tussen een algemeen voorwaardenscheppend beleid en een beleid gericht op specifieke economische sectoren, het zogeheten sectorbeleid (Atzema \& Wever, 1999: 126). Met een voorwaardenscheppend beleid beoogt de overheid randvoorwaarden te creëren voor economische ontwikkelingen door bijvoorbeeld de aanleg van bedrijventerreinen, infrastructuur, het bieden van een aantrekkelijk belastingklimaat voor bedrijven, investeringen in onderwijs of de nieuwbouw van woningen. Bij het voeren van een sectorbeleid zijn overheidsinspanningen gericht op het ondersteunen van specifieke economische sectoren, zoals de landbouw, de scheepsbouw of de voor Limburg belangrijke mijnindustrie en auto-industrie. Beide varianten spelen een rol in de analyse van het economisch beleid van de Provincie Limburg in de periode 1962-2007. Daarin zijn de taken tussen provinciale overheid en rijksoverheid voortdurend verschoven. De Provincie is in deze ontwikkeling gegroeid van een afwachtende overheidsinstantie 
naar een actieve speler in het regionaal economisch beleid voor Limburg. Formele bevoegdheden en verantwoordelijkheden liepen in deze ontwikkeling lang niet altijd gelijk op met de feitelijk ingezette instrumenten en gevoelde verantwoordelijkheid.

Het jaar 1962 vormt het startpunt van de analyse. Dit was het jaar waarin de Limburgse mijnindustrie (opnieuw) verlies leed, en zoals zou blijken in de daaropvolgende jaren, was dit een structureel verlies ${ }^{237}$. Het was tevens het jaar waarin de regering besloot om de in aanleg zijnde Staatsmijn Beatrix niet in exploitatie te nemen. In vier periodes wordt vanaf 1962 de ontwikkeling van het provinciale economisch beleid tot 2007 beschreven. Op de eerste plaats en centraal staat de relatie tussen de Provincie Limburg en de rijksoverheid in dit hoofdstuk. Verder zal er aandacht worden geschonken aan de provinciale bevoegdheden en instrumenten voor het economisch beleid. Daarnaast blijken geografische indelingen van belang te zijn. De politiek-ambtelijke verhoudingen, ten slotte, spelen ook een rol in de provinciale besluitvorming. Aan het eind van het hoofdstuk zullen de hoofdlijnen worden samengevat en voorlopige conclusies worden getrokken.

\subsection{Ontwikkelingen in het nationale regionaal economisch beleid ${ }^{238}$}

Het economisch rijksbeleid voor regio's, ook wel het regionaal economisch beleid genoemd, ontstond pas begin jaren '50 van de 20e eeuw (Bartels \& Van Duijn, 1981: 73; Atzema \& Wever, 1999: 125 e.v.). In de periode voor de Tweede Wereldoorlog had de regering langzaam de economische politiek van 'laissez-faire' laten varen en stegen vooral de uitgaven voor sociale zekerheid en onderwijs na 1914 (Van Zanden, 1997: 84-85).

In de jaren '30 ontstonden de eerste initiatieven op het gebied van een nationale industriepolitiek waarin vooral de Nederlandse arbeidskosten aandacht kregen (De Hen, 1980: 9). Bij de opeenvolgende regeringen heerste echter vooral de opvatting dat bedrijvenvestiging en economische ontwikkeling autonome processen waren, waarin de overheidsrol beperkt was. Deze rolopvatting bleef tot 1940 dominant in het nationale economisch beleid (Van Zanden, 1997: 16). In de eerste helft van de 20e eeuw voltrok zich wel langzaam de ontwikkeling 'van nachtwakersstaat naar verzorgingsstaat' (idem.61).

Beide elementen - het economisch beleid en de industriepolitiek - zouden pas na 1945 echt gestalte krijgen (Van Zanden \& Griffiths, 1989: 135). Met economische verschillen tussen regio's en provincies werd in het economisch beleid tot de jaren ' 50 geen rekening gehouden. Ondanks het feit dat men in de jaren '30 in een aantal provincies waaronder Limburg - was begonnen met de oprichting van Economisch-technologische instituten (de Eti's) en provinciale industriebanken, kon dit op weinig ondersteuning van de rijksoverheid rekenen (De Hen, 1980: 164). Men hield vooralsnog vast aan een algemeen voorwaardenscheppend beleid, gericht op het drukken van de arbeidskosten, een uitbreiding van diverse sociale voorzieningen en fiscaal-financiële maatregelen.

Dit veranderde in 1950 met de presentatie van de Tweede Industrialisatienota ${ }^{239}$ en de nota Landelijke spreiding der industrialisatie door regionale concentratie ${ }^{240}$. Op basis van eerste ervaringen in de regio Zuidoost Drenthe werden in deze nota's nog acht ontwikkelingsgebieden aangewezen om daar 'de industrievestiging te stimuleren ${ }^{241}$. 
Dit waren vooral rurale, economisch achtergebleven regio's, waarvoor de regering een actief industrialisatiebeleid wilde voeren. Een gelijke verdeling van de industrie in Nederland, dat stond de regering voor ogen. Naast de economische kerngebieden waar de basisindustrie zat (Hoogovens, Shell, Staatsmijnen), wilde de regering ook de acht ontwikkelingsgebieden van nieuwe industrieën voorzien (Atzema \& Wever, 1999: 126). De ontwikkelingsgebieden lagen op gepaste afstand van de kerngebieden. Elk gebied moest een 'ontwikkelingsplan' opstellen, op basis waarvan nieuwe industrieterreinen, verkeersvoorzieningen, nutsvoorzieningen en woningen aangelegd werden. De regering stelde hiervoor ruim 51 miljoen gulden beschikbaar, waarvan het merendeel besteed zou worden aan verkeersvoorzieningen ${ }^{242}$. Binnen deze negen regio's werden 42 kerngemeenten aangewezen die de status van 'ontwikkelingskern' kregen. In deze kernen zou de industrialisatie van de regio geconcentreerd worden. De selectie van deze kernen werd overgelaten aan de provinciebesturen. De industrialisatienota's, waarvan er in de periode 1949-1963 in totaal acht zouden verschijnen, betekenden de start van het regionaal economisch rijksbeleid. De laatste industrialisatienota verscheen in 1963, waarbij de regering aangaf dat de industrialisatie van Nederland op eigen kracht verder $\operatorname{kon}^{243}$.

Het regionaal economisch rijksbeleid breidde zich vanaf 1965 uit naar andere regio's die stimuleringsgebieden genoemd werden. Inhoudelijk legde de rijksoverheid steeds meer prioriteit bij het stimuleren van infrastructurele werken en woningbouw (Bartels \& Van Duijn, 1981: 85-86). Toen zich midden jaren '60 structurele problemen begonnen af te tekenen in de Zuid-Limburgse mijnindustrie en de Brabantse textielindustrie (Tilburg en omgeving) kregen beide regio's de speciale status van herstructureringsgebied. Voor beide gebieden kwamen speciale stimuleringsregelingen met premies en prijskortingen en kapitaalsubsidies voor bedrijven die zich in de regio op industrieterreinen wilden vestigen of uitbreiden (Bartels \& Van Duijn, 1981: 89; Messing, 1988: 380). Naar aanleiding van deze regelingen ontstond discussie of de rijksoverheid naast haar algemene voorwaardenscheppende beleid, ook een sectorspecifiek beleid moest voeren. De door minister J.M. den Uyl aangekondigde sluiting van de Limburgse mijnen wordt wel gezien als 'de eerste grote sectormaatregel' van de rijksoverheid (Van Aardenne, 1987: 323). Maar ook de textielindustrie en de scheepvaartindustrie werden in de jaren '60 en '70 hard getroffen. Het ministerie van Economische Zaken kreeg diverse verzoeken voor steunverlening. Onder druk van een dreigend verlies aan arbeidsplaatsen werd hier vaak aan tegemoet gekomen (Atzema \& Wever, 1999: 126).

Vanaf de jaren '70 werd er in het regionaal economisch beleid naast subsidies en premies ook een ander instrument ingezet, namelijk de geografische spreiding van rijksdiensten. Met name de uitvoerende rijksinstanties als het Centraal Bureau voor de Statistiek, Algemeen Burgerlijk Pensioenfonds, PTT en diverse inspecties, kregen (deel) locaties in de stimulerings- en herstructureringsgebieden. De industrialisatienota's werden vervangen door vierjaarlijkse nota's Regionaal Sociaal-Economisch Beleid. Daarin speelde het 'acquisitievraagstuk' - waarmee dit hoofdstuk opende - een rol. De rijksoverheid nam hierbij het standpunt in dat het aantrekken van nieuwe werkgelegenheid een 
rijksaangelegenheid was. In diverse provincies was echter steeds meer kritiek te horen over de resultaten van dit nationale acquisitiebeleid. Het lukte een aantal provincies om in de jaren '70 eigen regionale ontwikkelingsmaatschappijen op te richten, die echter via aandeelhoudersconstructies streng in de gaten werden gehouden door het ministerie van EZ.

Ondertussen was het aantal gebieden waar de regionale economie door het ministerie gestimuleerd werd, fors uitgebreid. Vanaf midden jaren '70 werden de financiële middelen voor met name de stimuleringsgebieden door het ministerie stopgezet en werden prioriteiten vastgesteld voor de overgebleven regio's. Dit ging zo ver dat alleen voor de drie noordelijke provincies en de regio Zuid-Limburg economische premies en subsidies werden verstrekt. Vanaf 1975 golden er zelfs beperkende (!) maatregelen voor nieuwe economische bedrijvigheid binnen de Randstad. Met de in dat jaar in werking tredende Wet op de Selectieve Investeringsrekening werd getracht de snelle economische groei van de Randstad af te remmen. De rijksoverheid kon via deze wet een vergunning voor uitbreiding of een nieuwe vestiging van een bedrijf in dat gebied weigeren. Het idee hierachter was dat ondernemers met hun investering zouden uitwijken naar de noordelijke of zuidelijke provincies ${ }^{244}$. Dit beleid was echter weinig succesvol en in 1983 werd de wet weer ingetrokken (Atzema \& Wever, 1999: 137).

De economische crisis verergerde begin jaren '80. In 1983 ging het Rijn-ScheldeVerolme (RSV) concern failliet. Het ministerie van EZ had in dit scheepsbouwbedrijf jarenlang vele miljoenen aan subsidies gestoken, vaak tegen beter weten in. Het leidde tot een parlementaire enquête die vernietigende conclusies trok over de rol van de rijksoverheid en het gevoerde sectorbeleid. De enquêtecommissie was bovendien zeer kritisch over de rol van het ministerie van EZ (Van Zanden \& Griffiths, 1989: 84). Het betekende het begin van een langzame terugtrekking van de rijksoverheid uit de regio. Het regionaal economisch beleid verloor haar dominante positie binnen de regeringsprioriteiten en binnen het ministerie van EZ. Het Integraal Structuurplan Noorden des Lands en de Perspectievennota Zuid-Limburg waren de twee resterende economische programma's waarin het ministerie van EZ in de jaren ' 80 nog participeerde.

'Het beleid houdt zich steeds minder bezig met regio's, steeds meer met Nederland als geheel', kenmerken Atzema \& Wever de jaren '90 treffend (Atzema \& Wever, 1999: 141). De participatie van de rijksoverheid in het bedrijfsleven werd teruggebracht. Diverse privatiseringen en verzelfstandigingen vonden plaats (DSM, KLM, PTT, Volvo). Het beleid van het ministerie kende steeds meer een macro-economische insteek en was daardoor minder regiospecifiek. Voor het arbeidsmarktbeleid, technologiebeleid en onderwijsbeleid bestonden generieke maatregelen en subsidieregelingen waar regio's en provincies gebruik van konden maken. Het regionaal economisch beleid dat resteerde, werd bovendien steeds meer een ruimtelijk economisch beleid (idem.141-142). De bedrijfsomgeving en in meer algemene zin het verbeteren van het vestigingsklimaat werden een belangrijk motief in het rijksbeleid. De aanleg van bedrijventerreinen, woningbouw, infrastructuur waren in eerste instantie voorwaardenscheppende maatregelen (Raspe \& van Oort, 2007: 7-8). Als er al een regionale prioritering plaatsvond, dan werd deze bij de Randstad gelegd. De 
Vierde Nota Ruimtelijke Ordening Extra (1990) bekrachtigde dit nog eens. Van het ooit zo machtige regionaal economische beleid van het ministerie van Economische Zaken was weinig meer over.

Aan het begin van de 2le eeuw ondernam men een nieuwe poging om het economische beleid voor regio's nieuw leven in te blazen. Onder de naam Pieken in de Delta (2004) werd er een nieuwe doelstelling geformuleerd: "Het kabinet wil de economische groei in àlle regio's stimuleren door regiospecifieke kansen van nationaal belang te benutten"245. Deze 'regiospecifieke kansen' lagen volgens het ministerie vooral op het gebied van technologie en innovatie. Binnen deze thema's werd o.a. door het in 2002 opgerichte Innovatieplatform een aantal sleutelgebieden benoemd. Opnieuw werd er een sectorbeleid in de steigers gezet, dit keer sterk gericht op technologische bedrijvigheid. Door het ondersteunen van 'stuwende' bedrijven ${ }^{246}$ met een internationale afzet, werd de economische structuur versterkt, zo was de gedachte (Atzema \& Wever, 1999: 128). De 'regio' was opnieuw aan zet.

\subsection{Limburgs economisch beleid voor 1962}

Het eerste initiatief van de Provincie Limburg op het gebied van economisch beleid is te vinden in dejaren'30van de20eeuw. Tot dietijd was politiekeinmenging (met uitzondering van de rijkssubsidies voor landbouw) in de economie afwezig. Limburg was sinds eind $19^{\mathrm{e}}$ eeuw sociaal-economisch georganiseerd in vak- en standsorganisaties die opkwamen voor de economische en sociale belangen van arbeiders en werkgevers (Righart, 1986: 211 e.v.). Het Provinciaal Bestuur, dat zich begin jaren ' 30 vooral bezig hield met infrastructuur en toezicht op de gemeentelijke financiën, had in 1930 een nieuwe provinciale functionaris aangetrokken. Deze functionaris moest de industrialisatieproblematiek in kaart brengen en nieuwe vormen van kredietverlening voor bedrijven mogelijk maken. Het ontslag van arbeiders was in deze crisisjaren aan de orde van dag, vooral in de voor Limburg belangrijke mijnindustrie (Jansen, 1997: 62).

In combinatie met het 'niet zoveel eisende directeurschap' van de provinciale Stroomverkoopmaatschappij, werd de uit Venlo afkomstige scheikundig ingenieur H.C.J.H. Gelissen benoemd (De Hen, 1980: 147). Hij organiseerde een excursie voor de regionale pers om de problemen van industrialisatie te verduidelijken en deed het voorstel aan de Provincie om een 'goed geoutilleerd technologisch-economisch instituut' op te richten (idem.147). Eerder had de ingenieur in Tilburg gewerkt aan de oprichting van een soortgelijk instituut ${ }^{247}$. In Limburg wilde Gelissen het accent echter op de praktijk van de industrialisatie leggen. Het instituut werd dan ook geen provinciale instelling, maar een uitvoeringsorgaan dat via een naamloze vennootschaps-constructie moest zorgen voor de 'bevordering van de industriële belangen in de provincie Limburg'. Het Economisch-technologisch Instituut Limburgen (Etil) werd op 11 december 1931 opgericht. Aandeelhouders waren de Provincie Limburg, de vier regionale Kamers van Koophandel en vijftien Limburgse gemeenten. Subsidies waren toegezegd door de Staatsmijnen, de Oranje Nassau Mijnen, het Provinciaal Waterleidingbedrijf en een aantal kleinere gemeenten (idem.148). Dit was een van de eerste provinciale activiteiten op het gebied van regionaal economisch beleid. Een paar jaar later, in 1935, werd het 
Etil versterkt met een aparte - maar onder aansturing van het Etil - NV Industriebank Limburg ${ }^{249}$. Dit financieringsorgaan moest dienen als intermediair tussen banken en industrie. Het Etil kon onder 'andere normen' kredieten verstrekken aan het bedrijfsleven (idem 150-158). Uiteindelijk, zo moest ook Gelissen constateren, waren de resultaten van de NV teleurstellend ${ }^{250}$. De industrialisatiecampagne van het Etil beperkte zich tot 'kleine en middelgrote veredelingsbedrijven, waarvan slechts een minderheid een lang leven was beschoren' (Jansen, 1997: 62).

In Den Haag werd - ondanks het feit dat Gelissen in 1935 tot ieders verrassing minister van Economische Zaken werd in het tweede en derde kabinet Colijn ${ }^{251}$ - een actief industrialisatiebeleid pas in de jaren '50 weer opgepakt. Voor Limburg betekende dit dat begin jaren '50 een aantal kernen in Noord-Limburg de status van 'ontwikkelingsgebied' kreeg. Het ministerie van EZ vroeg het Provinciaal Bestuur om een aantal kernen aan te wijzen die voor industrialisatie in aanmerking kon komen. Deze 'industrialisatiekernen' moesten een minimale omvang van 15.000 inwoners hebben (Bartels \& Van Duijn, 1981: 77). Het Provinciaal Bestuur wees een vijftal kernen aan ${ }^{252}$. De aanleg van wegen en het gereed maken van nieuwe industrieterreinen waren de belangrijkste doelstellingen ${ }^{253}$. Van het totaal beschikbare rijksbudget van 51 miljoen gulden ging slechts fl. 800.000 naar Noord-Limburg ${ }^{254}$.

De rol van het Provinciaal Bestuur was in de ontwikkelingen binnen het stimuleringsgebied bescheiden. De Provincie droeg zelf financieel bij aan het opstellen van het Ontwikkelingsplan voor de regio, maar de prioriteit lag in Zuid-Limburg. Zuid-Limburg had niet de status van ontwikkelingsgebied. De ontwikkelingen in de mijnindustrie baarde het Provinciaal Bestuur echter grote zorgen. Eind jaren '50 kwam er een kentering in de explosieve ontwikkeling van de mijnindustrie.

Nederland was na 1945 door de succesvolle industrialisatie en bevolkingsgroei een 'kolen importerend land' geworden (Messing, 1988: 141). De voorspoedige industrialisatie betekende dat de beschikbare energiebronnen ten volle benut moesten worden. Steenkool was in de jaren '50 één van de belangrijkste energiebronnen. De exploitatie van een nieuwe Limburgse mijn, de Staatsmijn Beatrix, moest in de toekomstige tekorten voorzien ${ }^{255}$. Maar al in 1950 gaf de Directie van de Staatsmijnen aan, dat zij de economische ontginning van deze mijn bij het Limburgse Vlodrop niet rendabel achtte (idem.141). Toch zette de rijksoverheid door, ondersteund door de Provincie Limburg. Een in 1954 opgerichte gezamenlijke overleginstantie (ministerie van EZ, Provincie Limburg en Staatsmijnen) regelde dat de rijksoverheid een bedrag van 36 miljoen gulden zou investeren in de economische en sociaal-maatschappelijke ontwikkeling van de regio. De Staatsmijnen namen de rechtstreekse investeringskosten voor hun rekening (idem.143).

Het mocht niet baten. Onder invloed van een haperend Europees beleid ${ }^{256}$, een kolencrisis (1958-1960), de concurrentie van goedkope Amerikaanse kolen en aardolie en de vondst van Gronings aardgas, werd in 1962 toch van exploitatie afgezien. Vanaf dat jaar werd er zowel bij de Staatsmijnen als bij de Oranje Nassau Mijnen structureel verlies geleden (Messing, 1988: 176; Peet \& Rutten, 2009: 291). Drie jaar later moest minister J.M. den Uyl (PvdA) een gefaseerde sluiting aankondigen. Niet langer kon het Provinciaal 
Bestuur zich afzijdig houden van de turbulente economische ontwikkelingen binnen haar provinciegrenzen.

\section{Eerste omslagmoment: provinciale belangenbehartiging (1962-1965)}

Het besluit van de regering om de staatsmijn Beatrix niet in exploitatie te nemen en het in werking treden van de nieuwe Provinciewet in 1962, waren slechts de aanleiding voor de Provincie Limburg om haar rol te herzien. Er waren drie elementen die uiteindelijk voor een omslagmoment zorgden.

Op de eerste plaats was dit de urgente economische situatie in de mijnindustrie die in de periode 1962-1965 uiteindelijk leidde tot de aankondiging van de sluiting van de Limburgse mijnen. Ten tweede was er in de voorbereiding en totstandkoming van dit besluit nauw samengewerkt tussen het ministerie van Economische Zaken, de Staatsmijnen en de Provincie Limburg. In het bijzonder was de persoonlijke samenwerking tussen minister J.M. den Uyl (PvdA), president-directeur van de Staatsmijnen, A.C.J. Rottier, en de nieuwe Limburgse gouverneur Ch.J.M.A. van Rooy (KVP) cruciaal. Het was deze samenwerking waarmee de Provincie Limburg tenslotte een basis legde voor een provinciaal economisch beleid met steun van de rijksoverheid. Het was een voorbeeld van het tonen van eigen initiatief zoals dat ook in de nieuwe Provinciewet van 1962 door de regering was benadrukt. Hieronder zal op deze drie elementen nader worden ingegaan.

Op 17 december 1962 bespraken Provinciale Staten de begroting voor 1963. In antwoord op schriftelijke statenvragen hadden Gedeputeerde Staten al laten weten dat er een commissie zou worden ingesteld ter 'bevordering van de welvaart in Limburg'. Deze commissie moest zich bezighouden met het 'bestuderen' van de 'problemen omtrent het behoud en de vermeerdering van de welvaart in Limburg' ${ }^{257}$. In januari 1962 was er al een subsidieregeling voor gemeenten opengesteld die voorzag in een tegemoetkoming van de voorbereidingskosten bij het bouwrijp maken van industrieterreinen ${ }^{258}$. Maar deze beperkt opgezette regeling was voor de leden van Provinciale Staten niet genoeg. Diverse statenleden zagen de instelling van deze Welvaartscommissie als een mogelijkheid voor een directe belangenbehartiging van de Limburgse economie. Volgens diverse statenleden was het een voorbeeld van een actievere opstelling van de Provincie, zoals die ook door de regering met de nieuwe Provinciewet was uitgedragen ${ }^{259}$.

De resultaten van de Welvaartscommissie waren echter beperkt. De commissie diende vooral als praatclub om de contacten tussen een veelheid aan partijen beter af te stemmen. Ook werden er verkennende onderzoeken uitgevoerd naar een mogelijke rol van de provinciale overheid. Daarbij werd vooral gekeken hoe andere provincies economisch beleid vorm gaven ${ }^{260}$. Voor de Provincie betekende het werk van de commissie een eerste kennismaking met de mogelijkheden van een provinciaal economisch beleid. Deze kennismaking bleek al snel minder vrijblijvend te worden.

Twee jaar na de startbijeenkomst van de Commissie (in 1963), verslechterde de situatie in de Zuid-Limburgse mijnen. De werkgelegenheid van 45.000 mijnwerkers stond op het spel. Op 3 maart 1965 had (demissionair) minister J.E. Andriessen (CHU) ${ }^{261}$ een 
gesprek met de Hoofddirectie van de Staatsmijnen. De minister vond dat van sluiting van de Staatsmijn Maurits - zoals president-directeur A.C.J. Rottier voorstelde - geen sprake kon zijn. Met de 'rationalisatie van het productieproces' en de winsten uit de chemische tak van de Staatsmijnen, moesten de verliezen gecompenseerd kunnen worden, vond minister Andriessen. Bovendien, zo stelde de minister, moest de hoofddirectie meer verantwoordelijkheid nemenvoorhetcreërenvan nieuwe werkgelegenheidinZuid-Limburg (Messing, 1988: 251). Daarmee zou een minder eenzijdige werkgelegenheidsontwikkeling worden bevorderd.

Men kwam er niet uit. Uiteindelijk besloot men een werkgroep op te richten onder voorzitterschap van de in 1964 aangetreden gouverneur Ch.J.M.A. van Rooy (KVP). President-directeur A.C.J. Rottier en staatssecretaris van Economische Zaken J.A. Bakker (ARP) namen hierin plaats, aangevuld met F.S. Dohmen van de Nederlands Katholieke Mijnwerkersbond en de burgemeester van Heerlen, F.J.W. Gijzels (KVP). Op deze manier raakte de provinciale overheid - via het voorzitterschap van gouverneur Van Rooy - direct bij de problematiek van de Limburgse economie betrokken. Het rapport van de werkgroep Van Rooy dat op 30 september 1965 aan de nieuwe minister van Economische Zaken, J.M. den Uyl (PvdA), werd aangeboden, had grote invloed op de Eerste Mijnnota van 14 december 1965 waarin de mijnsluiting aangekondigd zou worden (idem.266) ${ }^{262}$.

De urgentie was groot. Men was zich in de werkgroep zeer bewust van het belang van een goede onderlinge samenwerking. Maar de sleutelrol lag toch bij de opstelling van het ministerie van Economische Zaken die - als grootaandeelhouder - de toekomst van de mijnindustrie bepaalde. Het was opvolgend minister van Economische Zaken, Den Uyl, die de knoop doorhakte.

De Nota inzake de mijnindustrie en de industriële herstructurering van Zuid-Limburg (kortweg de Eerste Mijnnota genaamd), die minister Den Uyl op 14 december 1965 naar de Tweede Kamer stuurde, kwam voor de provinciale politiek niet als een verrassing. Den Uyl was, in tegenstelling tot zijn voorganger, een voorstander van de ontmanteling van de mijnen, zij het in een gefaseerde aanpak. Steenkolenwinning was op bedrijfseconomische basis te duur en het voortzetten van de ingeslagen weg bood geen toekomst ${ }^{263}$. In hoofdstuk vier van de nota werd een sluitingsprogramma aangekondigd voor alle mijnen, waarbij de Staatsmijn Maurits als eerste zou sluiten, gevolgd door de Wilhelmina en een particuliere $m i j n^{264}$. Voor de andere mijnen waren in de nota nog geen sluitingsdata genoemd.

Met de Mijnnota werd voor het eerst gekozen voor een actief sectorbeleid gericht op het behoud van werkgelegenheid (Van Zanden, 1997: 195-196; Atzema \& Wever, 1999: 134-135; Gales, 2000: 48). Dit sectorbeleid voor Zuid-Limburg kende drie belangrijke pijlers. Op de eerste plaats kondigde de regering aan dat er een vestiging van Van Doorne's Automobielfabrieken (DAF) in Born gerealiseerd zou worden. De rijksoverheid nam via de Staatsmijnen een aandeel in het bedrijf. De tweede pijler was het uitbreiden van de activiteiten van het chemisch bedrijf van de Staatsmijnen. Ten slotte als derde pijler was de hoop gevestigd op het acquisitiebureau van de Staatsmijnen ('Bureau Bloemendal'), dat moest zorgen voor de acquisitie van nieuwe bedrijven voor Zuid-Limburg ${ }^{265}$.

Toch werd in de Eerste Mijnnota een aantal voorwaardenscheppende maatregelen 
opgenomen. Voor het herstructureringsgebied Zuid-Limburg kwam een 'premie- en prijsreductieregeling' voor de vestiging en uitbreiding van bedrijven op industrieterreinen net zoals deze voor Noord-Limburgse ontwikkelingskernen gold. Er werden extra investeringen in de provinciale en gemeentelijke infrastructurele werken aangekondigd en er kwam een garantieregeling voor leningen van bedrijven. Ten slotte zou de Regering zich inspannen om diverse rijksinstellingen naar Limburg te verplaatsen ${ }^{266}$. Hiermee werd voor de administratieve medewerkers (de 'beambten' van de mijnindustrie), vervangende werkgelegenheid gecreëerd. Een definitieve beslissing over welke diensten men dacht te verplaatsen, moest nog genomen worden.

Minister Den Uyl kwam de mijnnota persoonlijk toelichten. In de Schouwburg van Heerlen presenteerde hij op 17 december 1965 zijn nota in aanwezigheid van de mijndirecties, vakbonden, lokale en regionale overheden en diverse maatschappelijke organisaties:

\begin{abstract}
"Alvorens dus de Regering een beslissing kon nemen over de sluiting van de mijn Maurits, waartoe een advies aanwezig was, diende eerst klaarheid te worden geschapen over het scheppen van vervangende werkgelegenheid. En dat moest niet alleen gelden voor de mijn Maurits, maar indien al besloten zou worden tot een program van inkrimping van de kolenproductie en sluiting van mijnen, dan diende dat gepaard te gaan met een program waarin zo groot mogelijk waarborgen aanwezig zouden zijn voor nieuwe vervangende werkgelegenheid [...]. Dat heeft mij geleid tot een drietal uitgangpunten, die gehanteerd zijn bij de uitstippeling van het beleid. Eerste uitgangpunt: Geen mijn-sluiting zonder redelijk perspectief op ander werk. Tweede uitgangspunt: Geen mijn-sluiting zonder redelijke regelingen, waarbij de belangen, de financiële belangen, van de werknemers worden gewaarborgd bij ontslag of bij herplaatsing. Derde uitgangspunt: geen mijn-sluiting zonder een redelijke zekerheid omtrent de voortzetting van de produktie van die mijnen die in bedrijf zouden blijven."267
\end{abstract}

Tot drie keer toe gebruikte Den Uyl het woordje 'redelijk' in de formulering van zijn uitgangspunten ${ }^{268}$. Het is een nuancering die in de daarop volgende 25 jaar vaak vergeten werd en verkort werd tot de mantra: 'geen mijnsluiting zonder vervangende werkgelegenheid'. Daarmee is de aankondiging van de sluitingen tevens een begin van een 'geschiedenis van een subsidie- en sociaal beleid, namelijk voor de ruim 45.000 werknemers in de mijnindustrie vervangende werkgelegenheid te zoeken' (Messing, 1988: 279).

De rede van de minister was een 'belofte van betrokkenheid en hulp' (Gales, 2000: 61). De reacties waren lovend. Minister Den Uyl kreeg groot applaus ${ }^{269}$. Er was groot vertrouwen in een goede afloop (Dohmen, 1986: 93). Gouverneur Van Rooy verwoordde de verwachtingen onder de aanwezigen wanneer hij stelde dat de nota gezien moest worden als 'een blauwdruk voor een nieuwe economische toekomst' (Derix, 1990: 16).

De acute economische urgentie, de samenwerking tussen een aantal invloedrijke Limburgse personen en het programma dat het ministerie van Economische Zaken opstelde, zorgden voor een omslagmoment in de provinciale rol in de eerste helft van de jaren '60. 


\subsection{Economische herstructurering: een rijksverantwoordelijkheid (periode 1965-1978)}

In de periode na de aangekondigde mijnsluiting (december 1965) verkende de Provincie Limburg haar rol. De verantwoordelijkheid voor de mijnsluiting en de daaruit voortvloeiende maatregelen werden door het Provinciaal Bestuur bij de rijksoverheid gelegd. Zuid-Limburg was in de Eerste Mijnnota door de regering tot 'herstructureringsgebied' verklaard, waarvoor speciale regelingen en maatregelen getroffen zouden worden. Voor Noord-Limburg gold bovendien nog steeds de status van 'stimuleringsgebied'. Het Limburgse economische herstructureringsbeleid lag tot ver in de jaren '70 in belangrijke mate in handen van het ministerie van Economische Zaken en niet in handen van het Provinciaal Bestuur.

Vlak voor Kerstmis 1965 ontving het College van Gedeputeerde Staten een brief van minister Den Uyl met het verzoek om nauw samen te werken in het in de Mijnnota voorgestelde pakket aan maatregelen ${ }^{270}$. Een van die maatregelen was de Stimuleringsregeling Industriële Omschakeling Zuid-Limburg, een premieregeling waarmee bedrijven subsidie kregen bij investeringen binnen bepaalde gebieden. Den Uyl zag voor de uitvoering van deze regeling een rol weggelegd voor de Provincie Limburg. Op het gebied van de 'maatschappelijke aspecten' achtte hij een nauwe samenwerking tussen rijksoverheid en Provincie eveneens noodzakelijk. Door de instelling van een 'veelzijdig samengesteld contactorgaan' konden zo 'de inzichten en verlangens die in Zuid-Limburg leven' in kaart gebracht worden ${ }^{271}$.

In een eerste reactie was het College van Gedeputeerde Staten niet enthousiast over het voorstel. Nog een commissie? Het Provinciaal Bestuur had in 1963 al de Welvaartscommissie voor economische ontwikkeling opgericht. Daarnaast bestond er een Recreatiecommissie voor de toeristische ontwikkeling en een Commissie voor de Sociale Begeleiding ${ }^{272}$. Met een telefoontje van minister Den Uyl aan gouverneur Van Rooy werd de lucht geklaard. ${ }^{273}$ Op 14 juli 1966 kwam de 'Provinciale Contactcommissie inzake het Herstructureringsbeleid in Limburg' voor het eerst bij elkaar. In feite was daarmee het werk van de in 1963 opgerichte Welvaartscommissie ten einde ${ }^{274}$.

De nieuwe 'Herstructureringscommissie' moest als tegenhanger dienen van de eveneens ingestelde departementale coördinatiecommissie op rijksniveau. Vanuit het ministerie van EZ waren plaatsvervangend secretaris-generaal W.A. van de Garde en plaatsvervangend directeur-generaal Energievoorziening J.A.M. Molkenboer vertegenwoordigd. Daarnaast zat een groot aantal regionale organisaties in de Commissie. Ook de president-directeur A.C.J. Rottier van de Staatsmijnen nam deel. Ondanks deze zware bezetting, was de ingestelde Provinciale Contactcommissie in de praktijk een 'contactorgaan' ${ }^{275}$. Zij nam geen besluiten maar was een 'gespreks- en overlegcentrum ${ }^{1276}$ tussen het ministerie van EZ enerzijds en de lokale en regionale Limburgse instellingen anderzijds. Besluiten werden genomen door de rijksoverheid waarbij de stem van de Staatsmijnen sterker doorklonk dan die van de Provincie en anderen. De primaire verantwoordelijkheid voor de herstructurering van Zuid-Limburg lag bij de rijksoverheid. Het Provinciaal Bestuur koos bewust voor deze rolverdeling. Door de brede samenstelling van de Commissie (mijnen, vakbonden, arbeidsvoorziening, Etil, 
gemeenten) kon men informatie uitwisselen, regionale cijfers en prognoses aanleveren over de voortgang, zonder zelf de verantwoordelijkheid te hebben voor het succes of falen van het economisch beleid ${ }^{277}$. Daarmee verschilde de Commissie niet zoveel van de eerdere Welvaartscommissie. Het verschil was dat in de Contactcommissie het accent lag op discussie en informatie-uitwisseling tussen rijksoverheid, regionale overheden en instanties, en minder op het uitvoeren van studies en onderzoeken. De uitgebreide verslaglegging van de bijeenkomsten geeft een goed beeld van de provinciale rol in de tweede helft van de jaren '60. Deze provinciale rol is te beschrijven als het besturen via commissies. De besluitvormingsmacht lag daarmee buiten het Provinciehuis.

De Provincie had - en heeft nog steeds (!) - weinig formele bevoegdheden en instrumenten als het gaat om het voeren van economisch beleid. Het belangrijkste provinciale instrument was een aantal subsidieregelingen. De Stimuleringsregeling Industriële Omschakeling Zuid-Limburg is hierboven al genoemd. In 1967 kwam daar de Investeringspremieregeling bij. Bedrijven die zich in Zuid-Limburg wilden vestigen, konden op basis van deze regeling, premies aanvragen ${ }^{278}$. De Provincie voerde beide regelingen samen met het Economisch-technologisch Instituut Limburg (Etil) uit, in opdracht van het ministerie van Economische Zaken. In de beginfase was de belangstelling hiervoor 'bevredigend'279, maar naarmate de regeling versoepeld en verbreed werd ${ }^{280}$ kregen vooral die arbeidsintensieve bedrijven steun, die weinig structuurversterkend, financieel zwak en slechts in beperkte mate rendabel waren (Jansen, 1997: 77-78).

In de periode 1966-1970 liep het aantal investeringsbesluiten in Limburg sterk terug ${ }^{281}$. Limburg ondervond een sterke concurrentie in de werving van andere mijnbedrijven in de steenkolenbekkens van Aken, Luik en Genk (idem.78). Bovendien had de regering al de bouw van een achtste medische faculteit in Maastricht toegezegd en waren er besluiten genomen over de vestiging van het Algemeen Burgerlijk Pensioenfonds in Heerlen en een NAVO-vestiging in Brunssum. Naast de subsidieregelingen en de acquisitie van nieuwe bedrijvigheid, was het verplaatsen van deze 'rijksdiensten' naar Limburg een ander instrument in het regionaal economisch beleid. Het provinciale beleid bestond dus vooral uit het uitvoeren van subsidieregelingen van de rijksoverheid.

Eind jaren '60 verdween echter de stille hoop op een nieuwe economische motor. De president-directeur van de Staatsmijnen moest in de vergadering van de Herstructureringscommissie van 6 maart 1968 met spijt constateren dat 181 projecten niet waren doorgegaan ${ }^{282}$. De roep om een intensievere acquisitiepolitiek van het ministerie van Economische Zaken werd sterker. Ook verkende het Provinciaal Bestuur of het zelf geen rol van betekenis kon spelen in de buitenlandse acquisitie van bedrijven. Het vroeg professor H.C.J.H. Gelissen - oprichter van het Etil in de jaren '30 en nu lid van de Contactcommissie - om 'via zijn contacten pogingen in het werk te stellen Amerikaanse bedrijven voor Limburg te interesseren'283. Verder werd oud-staatssecretaris van Financiën W.L.G.S. Hoefnagels (KVP) benaderd om advies uit te brengen over de mogelijkheid tot het verstrekken van provinciale rentesubsidies bij de nieuwbouw en uitbreiding van bedrijven ${ }^{284}$. Het rapport van Hoefnagels werd op 7 maart 1967 aan de staatssecretaris 
van Economische Zaken en de minister van Binnenlandse Zaken aangeboden. Beide bewindslieden zagen echter niets in het plan omdat hiermee het rijksbeleid 'doorkruist' zou worden ${ }^{285}$. Daarmee groeide de onrust in de Commissie ${ }^{286}$. Vakbondsleider F.S. Dohmen hamerde herhaaldelijk op een betere coördinatie tussen de diverse instellingen. Hij waarschuwde: "[W]anneer deze Commissie niets anders doet dan wederzijdse informatie [uitwisselen], heeft [sic! HvE] de Regering en het Provinciaal Bestuur er weinig aan"287. Hij werd niet tegengesproken.

Het besturen via commissies en de beperkte ruimte die het ministerie aan de Provincie gaf om zelf provinciale instrumenten te ontwikkelen, werd begin jaren '70 steeds problematischer. Ook de relatie tussen Provincie en ministerie van EZ stond onder druk. De diverse rijksnota's waarin Limburg een prominente plaats innam, waren zonder overleg met het Provinciaal Bestuur opgesteld ${ }^{288}$. Het beeld van de Limburgse situatie in Den Haag was, dat de problemen met betrekking tot de herstructurering grotendeels waren opgelost ${ }^{289}$. Het ministerie van EZ vroeg de Contactcommissie om de vergaderfrequentie te verlagen naar twee keer per jaar ${ }^{290}$. Een teken aan de wand. Overigens waren er bij gemeenten, zelfs binnen het College van Gedeputeerde Staten stemmen te horen die voorzichtig een soortgelijke conclusie trokken ${ }^{291}$. De conclusie van Messing dat het Provinciaal Bestuur 'ten einde raad' was (Messing, 1988: 392), is dus overdreven. Er was sprake van een politiek dilemma voor de Provincie: hoe kon de politieke aandacht van de rijksoverheid voor Limburg behouden worden, wanneer er sprake was van relatief gunstige arbeidsmarktcijfers? Veel verder dan het schrijven van een brandbrief aan de regering of het uitnodigen van minister of kamerleden voor een werkbezoek, kwam het College van Gedeputeerde Staten alweer niet. Tot overmaat van ramp vertrok in het najaar van 1970 - op verzoek van de minister van EZ! - het acquisitiebureau van de Staatsmijnen ('Bureau Bloemendal' ${ }^{292}$ ) naar Groningen om de regionale ontwikkeling in de noordelijke provincies te ondersteunen (Messing, 1988: 462).

Toen in 1971 duidelijk werd dat de in de Tweede Mijnnota (1967) aangekondigde olieraffinaderij van Shell in Urmond niet doorging, probeerde het College van Gedeputeerde Staten het opnieuw. Negen dagen voor de Tweede Kamerverkiezingen stuurde het een brief aan de ministerraad. Onderbouwd met cijfers van het Economisch-technologisch Instituut Limburg over het teruglopende aantal vestigingen en uitbreidingen en de 'verhullende' uitgaande pendel naar Duitsland van 11.225 personen ${ }^{293}$, pleitte het College van Gedeputeerde Staten voor het aantrekken van 'een nieuwe economische motor ${ }^{294}$. Verder werd gevraagd om de uitbreidingspremie voor bedrijven te verhogen tot $15 \%$. Ook moesten er meerdere rijksdiensten in Limburg gevestigd worden en was een verruiming van de provinciale acquisitiemogelijkheden zeer gewenst.

Het nieuwe kabinet Biesheuvel kwam Limburg in de regeringsverklaring van 3 augustus 1971 tegemoet door een 'nota over de perspectieven van Zuid-Limburg' aan te kondigen. Ook werd de verplaatsing van een aantal rijksdiensten naar Limburg toegezegd. Blij met deze toezeggingen vroeg het College van Gedeputeerde Staten de minister om 'opnieuw vorm te geven aan de in het verleden gekozen figuur van voorafgaand overleg ${ }^{129}$. De nieuwe minister van Economische Zaken, H. Langman (VVD), stemde hiermee in ${ }^{296}$. 
Pas in 1973 zou onder verantwoordelijkheid van minister R.F.M. Lubbers (KVP) een begin worden gemaakt met de voorbereiding van een Perspectievennota Zuid-Limburg. Dat dit zo laat pas gebeurde had te maken met het feit dat in de periode 1965-1973 het ministerie van EZ maar liefst zeven verschillende ministers kende ${ }^{297}$.

Naast de bevoegdheden en instrumenten zijn geografische indelingen van belang in het regionaal economisch beleid. Geografische indelingen zijn vaak bepalend voor de verdeling van rijkssubsidies voor een provincie of regio. Zo ook voor de Provincie Limburg.

In de jaren '50 had een deel van Noord-Limburg de status verkregen van 'ontwikkelingsgebied'. Na de aangekondigde mijnsluiting eind 1965 was daar ZuidLimburg aan toegevoegd als 'herstructureringsgebied'. Tot augustus 1971 kenden beide gebieden een bijzondere status als het ging om het verkrijgen van rijkssubsidies. Daarna bleef alleen Zuid-Limburg over als speciaal aandachtsgebied (Bartels \& Van Duijn, 1981: 92). Niet alleen voor het ministerie van Economische Zaken, maar ook voor andere ministeries waren deze indelingen bepalend voor de financiële steunverlening. Het ministerie van Binnenlandse Zaken coördineerde de spreiding van rijksdiensten en vond dat uitsluitend het Herstructureringsgebied Zuid-Limburg in aanmerking kwam als mogelijke nieuwe vestigingsplaats. Voor het ministerie van Cultuur, Recreatie en Maatschappelijk Werk had in het Bijzonder Regionaal Welzijnsbeleid zowel het Ontwikkelingsgebied Noord-Limburg als het Herstructureringsgebied Zuid-Limburg prioriteit. Toch verlegde vanaf 1973 dit ministerie de aandacht naar Zuid-Limburg in de toekenning van welzijnssubsidies ${ }^{298}$. Het ministerie van Volkshuisvesting en Ruimtelijke Ordening stelde in 1974 voor een periode van 10 jaar evenzo geld beschikbaar om de oude mijnterreinen te herstructureren via sloop- en grondverwervingpremies in de Westelijke en Oostelijke Mijnstreek ${ }^{299}$.

Naast deze regiospecifieke subsidies waren er natuurlijk generieke maatregelen die voor het gehele provinciale gebied ingezet konden worden. Zo waren er omvangrijke financiële middelen beschikbaar voor infrastructurele werkzaamheden in provincies. Daarbinnen was Limburg één van de districten die in aanmerking kwam voor subsidies voor Aanvullende Cultuurtechnische Werken (DACW-subsidies). Het kabinet Den Uyl reserveerde voor Limburg in de periode 1973-1977 bijna 40 miljoen gulden voor infrastructurele werken ${ }^{300}$. Het ministerie van Sociale Zaken verdeelde via het Regionaal Coördinatiecollege voor Openbare Werken, subsidies voor Aanvullende Werkgelegenheidsprojecten (AW-subsidies). Bovendien kwamen er in de jaren '70 extra Europese gelden beschikbaar voor de versterking van het internationale wegennet. Ter indicatie, Limburg kreeg in 1975 ruim 8 miljoen gulden subsidie voor het uitvoeren van verschillende openbare werken ${ }^{301}$. Een half jaar later kwam er 7,5 miljoen gulden beschikbaar vanuit het Europees Fonds voor Regionale Ontwikkeling voor de infrastructuur in de Oostelijke en Westelijke Mijnstreek (EFRO-subsidies) ${ }^{302}$. De Provincie zelf besteedde ongeveer 52,5 miljoen gulden in de periode 1974-1977 voor de aanleg en het onderhoud van provinciale wegen ${ }^{303}$.

De Provincie Limburg benutte deze deels regiospecifieke, deels provinciaal in te 
zetten rijksregelingen en subsidiepotten zeer effectief. Messing schat dat Limburg in de periode van 1965 tot 1978 ongeveer 3,2 miljard gulden (inclusief de staatssteun aan de mijnindustrie) aan overheidssteun heeft ontvangen (Messing, 1988: 529). Veel van deze subsidiestromen kwamen vooral vrij door de speciale status van herstructureringsgebied of ontwikkelingsgebied.

Ondanks deze grote financiële impulsen groeide in de jaren '70 de onrust binnen het Provinciaal Bestuur. Het besturen via commissies en de afhankelijkheid van de rijksoverheid gingen steeds meer in de weg zitten. De macht was erg versnipperd door de vele afzonderlijke subsidieregelingen en de grote hoeveelheid Limburgse instanties die zich allemaal met de herstructurering bezig hielden. De acquisitie van nieuwe bedrijvigheid verliep na het vertrek van acquisitiebureau Bloemendal chaotisch. Gemeenten en belangenorganisaties werkten langs elkaar heen en steeds meer Limburgse arbeiders gingen over de grens werken in Duitsland en België. Deze 'grenspendel' van Zuid-Limburg naar Duitsland bereikte in 1973 met bijna 17.000 pendelaars een hoogtepunt, onder andere doordat de lonen in Duitsland tussen de 12\% (1975) en 16\% (1979) hoger lagen (Bouwens, 2008: 49-50, 54). De pendelaars verhulden in feite de structurele problemen van de Limburgse economie. Het Provinciaal Bestuur kende hier - in afwijking van de overwegend afkeurende publieke opinie begin jaren '70 - een minder negatieve betekenis aan toe. De grenspendel hield immers mensen aan het werk $^{304}$.

In 1974 werd de balans opgemaakt. Een evaluerende studie door Bureau Berenschot naar de 'gewenste industrialisatie-opbouw in Zuid-Limburg' werd in maart 1974 gepresenteerd. De conclusies van het rapport waren vernietigend over het tot dan toe gevoerde beleid. De onderzoekers inventariseerden maar liefst 12 organen die zich op de een of andere manier, - nog los van diverse samenwerkingsverbanden en commissies - bezig hielden met de economische herstructurering ${ }^{305}$. De onderzoekers legden de vinger op de zere plek. De versnippering en verdeeldheid in het herstructureringsgebied waren volgens Berenschot een belangrijke oorzaak voor het onvoldoende benutten van de potenties in Zuid-Limburg ${ }^{306}$. Men liep elkaar voor de voeten (zie ook Janssen, 1997: 78; Messing, 1988: 394). Een van de aanbevelingen was om te komen tot een krachtige 'beheersorganisatie' die het Limburgse bedrijfsleven zou ondersteunen en nieuwe bedrijvigheid moest binnenhalen. Eerdere pogingen op dit gebied waren mislukt ${ }^{307}$.

$\mathrm{Na}$ de Provinciale Statenverkiezingen van maart 1974 trad er een nieuw College van Gedeputeerde Staten aan. Voormalig staatssecretaris K.W. Buck (KVP) ${ }^{308}$ werd als nieuwe gedeputeerde verantwoordelijk voor de Limburgse herstructurering. Hij zag zich voor de taak gesteld om de conclusies en aanbevelingen van het rapport Berenschot handen en voeten te geven. Buck benadrukte in het College van Gedeputeerde Staten dat er een 'anticiperend beleid' vanuit de Provincie nodig was, in plaats van de jarenlange passieve en afwachtende opstelling. Hij ondervond vooralsnog weinig steun van zijn collegagedeputeerden $^{309}$. Toch zette Buck deze 'nieuwe opvatting over de taak van de overheid' door $^{310}$. Hij had ondertussen een goede band opgebouwd met de Adviseur Prijzen, Ordening en Regionaal Economische Politiek van het ministerie van Economische Zaken, 
S. Miedema ${ }^{311}$. Samen met Miedema richtte hij de N.V. Industriebank Limburg Instituut voor Ontwikkeling en Financiering op, kortweg LIOF genaamd. Via een zogeheten 'halterconstructie' - waarin het ministerie 95\% van de aandelen bezat en de Provincie de resterende 5\% - werd een partnerschap tussen ministerie en Provincie uitgewerkt ${ }^{312}$. Voor het directeurschap werd P.W.A. Niessen benaderd, die tot die tijd directeur was geweest van de DAF in Born ${ }^{313}$.

Het LIOF startte op 1 mei 1975 met 22 mensen. Internationale acquisitie in de 'eerste fase' bleef een taak van de rijksoverheid, maar het LIOF ging wel een grotere rol spelen in de vervolgfase van acquisitieactiviteiten ${ }^{314}$. Het LIOF zou in de beginjaren nog nauwelijks toekomen aan de begeleiding van nieuwe bedrijven. Door de recessie was zij verreweg de meeste tijd kwijt aan het redden van in moeilijkheden geraakte lokale bedrijven ${ }^{315}$.

Zo kreeg de Provincie toch haar eigen acquisitiebureau, iets wat een paar jaar eerder ondenkbaar was geweest. Het was een teken van een groeiend zelfbewustzijn van het Provinciaal Bestuur. Niet langer kon de verantwoordelijkheid worden afgeschoven op de rijksoverheid. De Provincie moest zelf ook de handschoen oppakken. Het LIOF was daar een eerste voorbeeld van. Het gezamenlijk opstellen van een Perspectievennota voor Zuid-Limburg met het ministerie van EZ was een tweede voorbeeld van het nemen van verantwoordelijkheid.

De aankondiging van een Perspectievennota voor Zuid-Limburg was in 1971 gedaan in de regeringsverklaring van het kabinet Biesheuvel (1971-1973). Het was echter pas ten tijde van het kabinet Den Uyl (1973-1977) dat er samen met de nieuwe minister van Economische Zaken, R.F.M. Lubbers (KVP), echt werk van werd gemaakt ${ }^{316}$. In de provinciale organisatie was er tot die tijd geen aparte afdeling Economische Zaken. Voor zover er al echt sprake was 'economisch beleid' was dit een taak van de afdeling die zich vooral bezighield met verkeers- en vervoerszaken ${ }^{317}$. Met het opstellen van de Perspectievennota veranderde dit. Onder aansturing van gedeputeerde Buck kreeg de afdeling de taak om vooral de herstructurering en het economisch beleid prioriteit te geven. Het opstellen van de Perspectievennota samen met het ministerie van Economische Zaken zorgde voor nieuwe politiek-ambtelijke verhoudingen.

Een maand na zijn aantreden - dus nog voordat Buck gedeputeerde werd - kwam minister Lubbers naar Limburg voor een 'oriënterende gedachtewisseling'318. In het gesprek benadrukte hij dat 'het niet 'alleen' [ging] om het enkel 'maken' van de nota, maar dat o.a. ook de termijn, de inhoud (aspecten) van de nota en gebiedsafbakening hierbij een rol [zouden] spelen' ${ }^{139}$. Afgesproken werd dat de Provincie 'bouwstenen' zou aanleveren voor het opstellen van de nota. Een kleine ambtelijke werkgroep met daarin het ministerie en de Provincie ging aan de slag met de voorbereidingen ${ }^{320}$. Het zou nog tot 1977 duren voordat de nota klaar was, maar de gezamenlijke voorbereidingen zorgden voor een hernieuwd partnerschap tussen Provincie en ministerie, net zoals dit in de voorbereiding van de Eerste Mijnnota (1965) was gebeurd ${ }^{321}$.

In de voorbereiding waren de contacten met de rijksoverheid nog op ambtelijk niveau, terwijl binnen het Provinciehuis gedeputeerde Buck vanaf 1974 zich zeer 
nadrukkelijk bemoeide met de vorderingen van zijn ambtenaren. Hij vond daarbij vanaf oktober 1975 veel ambtelijke ondersteuning van A.G.H.M. Lohuis. Terugblikkend over de samenwerking met Buck schreef Lohuis:

"Hij verwachtte van zijn ambtenaren een ondernemers-mentaliteit en laakte bij hen een te afwachtende houding. Initiatief en verantwoordelijkheidsgevoel dienden volgens hem tot de bagage van iedere ambtenaar te behoren evenals snelheid en realiteitszin. (...) Zowel in het perspectievennota-beleid als in het reguliere provinciale beleid drong hij immer aan op deugdelijke financiële onderbouwing. Plannen zonder beproefde financiële paragraaf werden door hem gecorrigeerd danwel geretourneerd." ${ }^{\text {"22 }}$

Het was een nieuwe wind die midden jaren ' 70 waaide. De politiek-ambtelijke verhoudingen binnen het Provinciehuis veranderden. Lohuis kreeg de opdracht om een eerste schets van de Perspectievennota te vertalen naar concrete doelstellingen en deze te voorzien van een projecteninventarisatie en een tijdsplanning ${ }^{323}$. Als belangrijkste economische doelstelling zag hij: 'Het wegwerken van de regionale component in de structurele werkloosheid'324. Daarmee werd het verschil tussen het nationaal gemiddelde werkloosheidspercentage en het Limburgse gemiddelde bedoeld. Het was een doelstelling van verbluffende eenvoud. Duidelijk, maar vooral ook meetbaar. De werkloosheid in Limburg kon op elk moment afgezet worden tegen het nationale werkloosheidscijfer. Het benadrukte de afwijkende Limburgse situatie, waar men het ministerie van Economische Zaken altijd aan kon herinneren als het ging om de verdeling van schaarse rijksmiddelen. Tot 1990 zou dit de algemene provinciale doelstelling van het economische beleid blijven. Om de doelstelling ook te kunnen realiseren moesten projecten geformuleerd worden voorzien van een financiële raming ${ }^{325}$. Een provinciaal economisch beleid kreeg zo langzaam gestalte. En in dat economisch beleid werden regionale keuzes gemaakt. Dat riep vooral bij de Limburgse gemeenten en belangenorganisaties weerstand op.

Heel Zuid-Limburg was sinds de Eerste Mijnnota aangewezen als 'herstructureringsgebied'. Maar de deelregio's binnen Zuid-Limburg, de Oostelijke en Westelijke Mijnstreek, Maastricht, het Heuvelland en de regio Roermond, hadden verschillende economische structuren en problemen. Al in een allereerste gedachtebepaling over de Perspectievennota, werd de Westelijke Mijnstreek inhoudelijk gekoppeld aan de chemische en auto-industrie (DSM en DAF). Maastricht had haar universiteit en keramische industrie (Sphinx, Mosa), en voor het omliggende Heuvelland was volgens de ambtenaren de toeristisch-recreatieve sector van belang. Roermond had een voorspoedige industrialisatie gekend met het industrieterrein Heide ${ }^{326}$. Alleen in de Oostelijke Mijnstreek, toch het hart van de mijnindustrie, was er geen nieuwe industriële motor gekomen. Hier was de hoop gevestigd op nieuwe vestigingen van de rijksoverheid, de zogeheten 'schrijftafels'. Veel werd verwacht van deze opkomende dienstensector ${ }^{327}$. Bovendien werd gehoopt op de verhuizing van een aantal nieuwe rijksdiensten naar Zuid-Limburg ${ }^{328}$. De urgentie was in deze regio het grootst. De werkloosheid en de pendel waren er het hoogst, er was sprake van een grote sociale problematiek (echtscheidingen, arbeidsongeschiktheid, drankgebruik) en er lagen omvangrijke ruimtelijk infrastructurele opgaven ${ }^{329}$. 
Het probleem met deze geografische indeling in deelregio's was dat diverse rijksregelingen deze indeling niet kenden. Subsidies inzetten voor één specifieke deelregio betekende een aanpassing van de bestaande regelingen, iets waar de Haagse ministeries niet meteen op zaten te wachten ${ }^{330}$. Maar ook politiek gezien was deze indeling voor de Provincie niet onproblematisch. In een eerste concept van de Perspectievennota was bijvoorbeeld voorgesteld om het tekort dat de Oostelijke Mijnstreek had aan geschikte industrieterreinen, niet op te lossen door nieuwe terreinen te ontwikkelen, maar door bedrijven te wijzen op de beschikbare terreinen in de Westelijke Mijnstreek. Een gevoelig politiek thema, waar met name het stadsgewest Oostelijk Mijngebied fel tegen ageerde $^{331}$. Toch waren ook de gemeenten uit de Westelijke Mijnstreek kritisch op het concept van de Perspectievennota. In de nota werd de schijn gewerkt dat het met de toekomstperspectieven voor de Westelijke Mijnstreek wel goed $\mathrm{zat}^{332}$. De gemeenten stelden dat deze regio toch een toenemend tekort had aan arbeidsplaatsen. En waarom was er geen aandacht geschonken aan de dienstensector in de Westelijke Mijnstreek? ${ }^{333}$ Er was zelfs in de voorbereiding van de beleidsaanbevelingen heel even gedacht over de mogelijkheid om de regio's Roermond en Maastricht uit te sluiten in de Perspectievennota en het beleid te beperken tot de Oostelijke en Westelijke Mijnstreek ${ }^{334}$. Vanwege de onderlinge verbintenissen en het creëren van een breder speelveld - los nog van mogelijk politieke bezwaren - was hier al snel van afgezien. Maastricht werd gezien als de stad met de Europese uitstraling wat betreft haar positie in de dienstverleningssector, het onderwijs en als congrescentrum ${ }^{335}$. Ten slotte plaatsten de betrokken ministeries vraagtekens bij de positie van Roermond. Formeel gezien lag Roermond niet in het Herstructureringsgebied Zuid-Limburg. Bovendien was de problematiek in Roermond 'minder omvangrijk' dan in de andere deelgebieden ${ }^{336}$. Op deze manier gingen ambtelijke geografische indelingen hand in hand met politieke machtsposities en verdelingsvraagstukken.

Het was duidelijk, in de Perspectievennota zat een aantal 'uiterst sterke gevoeligheden' waarover politieke besluitvorming zou moeten plaatsvinden ${ }^{337}$. De voorbereidende ambtelijke gesprekken met de direct betrokken ministeries ${ }^{338}$ verliepen moeizaam en van financiële vertalingen was nauwelijks sprake. Wel vormden zich de eerste contouren van een aantal projecten dat in een latere fase prioriteit kreeg ${ }^{339}$.

Op 14 december 1976 werd de concept-Perspectievennota op ambtelijk niveau besproken met de betrokken ministeries en na een paar kleine wijzigingen vastgesteld. De concept-Perspectievennota werd door de regering én het College van Gedeputeerde Staten op 11 februari 1977 aangeboden aan de Tweede Kamer en Provinciale Staten van Limburg met de toezegging om 'op korte termijn tot een voorlopige standpuntbepaling' te komen ${ }^{340}$. Daarmee kwam een lange voorbereidingsperiode ten einde. De nota was voorzien van een gekwantificeerde doelstelling en een pakket van maatregelen en projecten dat een investeringsvolume van ongeveer 1 miljard gulden besloeg ${ }^{341}$. Afspraken over de realisatie van deze beleidsvoornemens moesten op korte termijn uit de politieke onderhandelingen tussen rijksoverheid en Provincie komen. De status van het stuk was tot dat moment nog die van een ambtelijk concept. 


\section{Tweede omslagmoment: een nieuw politiek moment (1978)}

Alvorens te kijken naar de oorzaken van het omslagmoment dat eind jaren '70 plaatsvond in de provinciale rol, is het van belang om het politieke klimaat van die tijd te analyseren. Het was namelijk deze politieke context waarbinnen de Provincie de grondslag kon leggen voor het toekomstige economische beleid. Bovendien moet er een onderscheid gemaakt worden tussen de ontwikkelingen in de provinciale Limburgse politiek en het nationale politieke klimaat eind jaren ' 70 .

In Limburg groeide in de jaren '70 het belang van de partijpolitiek. Ook in Limburg was er sprake van een versneld proces van deconfessionalisering (Korsten, 1990: 386). Bovendien was er een toenemende politisering van het maatschappelijk debat. In 1966 al was J. van der Woude de eerste gedeputeerde voor de Partij van de Arbeid in het College van Gedeputeerde Staten van Limburg geworden ${ }^{342}$. Vóór 1966 bestonden de Colleges van Gedeputeerde Staten in Limburg uitsluitend uit KVP-gedeputeerden (zie appendix IV) ${ }^{343}$. In de jaren '70 kreeg de PvdA ook in Limburg voet aan de grond, wat in 1978 resulteerde in een winst van 7 zetels (van 12 naar 19) bij de provinciale statenverkiezingen (zie appendix III). Deze 19 zetels waren goed voor 29\% van de Limburgse stemmen (Reerink et.al. 1989: 91). Stemde in 1962 nog $82 \%$ van de Limburgse kiesgerechtigden op de provinciale KVP, in 1974 was dit percentage gedaald naar 49,7 (Spoormans et.al.1990: 332). De PvdA was daarmee een factor van betekenis geworden in Limburg.

In Den Haag was na een moeizame onderhandelingsperiode eind 1977 het kabinet Van Agt tot stand gekomen. De nieuwe Limburgse gouverneur J. Kremers (KVP) wist als geen ander het nieuwe kabinet Van Agt de politieke spiegel voor te houden: de PvdA en andere partijen konden wel eens echt doorbreken in Limburg (Spoormans et.al. 1990: 326). De Limburgse KVP-achterban zou minister-president Van $\mathrm{Agt}^{344}$ daar zeker op aanspreken. De Perspectievennota was immers onder het kabinet Den Uyl opgesteld en het kon toch niet zo zijn dat de nieuwe CDA-VVD regering deze belofte aan Limburg niet zou gaan uitvoeren? Was het besluit van de mijnsluiting en de daaruit voortvloeiende grote sociale en economische gevolgen niet door diezelfde minister Den Uyl genomen? De boodschap was duidelijk, het nieuwe kabinet kon Limburg niet in de steek laten. De PvdA zou alleen maar groter worden en de Limburgse achterban van het CDA, zou dan weinig vertrouwen kunnen opbrengen in het nieuwe kabinet Van Agt. Het was ook de tijd dat de KVP, ARP en CHU fuseerden tot het Christen-Democratisch Appèl (CDA). Nationaal gezien waren de statenverkiezingen van 1978 een steun in de rug voor het kabinet Van Agt (Kroeger \& Stam, 1998: 100), maar binnen Limburg won de PvdA fors. Het was vooral gouverneur J. Kremers die op deze effectieve manier de Limburgse belangen verknoopte aan de nieuwe nationale partijpolitieke verhoudingen ${ }^{345}$. Het waren deze Limburgse en Haagse politieke contexten waarbinnen een nieuw omslagmoment zich voordeed. De urgentie van de Limburgse economische situatie, de goede contacten tussen een aantal personen, en de ruimte die de rijksoverheid bood, waren de belangrijkste oorzaken van het omslagmoment.

De politieke aandacht van het Provinciaal Bestuur voor de Perspectievennota was tot 
in de laatste fase beperkt gebleven tot gedeputeerde K.W. Buck. Dit veranderde met de komst van gouverneur Kremers. Kremers volgde in augustus 1977 gouverneur Van Rooy op die met pensioen was gegaan. Met het vertrek van Van Rooy werd in feite de herstructureringsperiode vanaf 1965 afgesloten. De herstructureringscommissie waar Van Rooy voorzitter van was, was in 1975 al formeel opgeheven. De Staatsmijnen waren in datzelfde jaar officieel omgedoopt tot de Dutch State Mines (DSM) en de DAF fuseerde met het Zweedse Volvo-cars. Het was het afscheid van een aantal iconen uit de herstructureringsperiode.

J. Kremers (CDA) was tot 1 augustus 1977 voorzitter van de Wetenschappelijke Raad voor het Regeringsbeleid (WRR) geweest en had goede contacten in Den Haag. Een paar maanden nadat Kremers als gouverneur in Limburg was begonnen, werd op 19 december 1977 A.A.M. van Agt (CDA) de nieuwe minister-president. Van Agt en Kremers kenden elkaar goed. Beiden waren eind jaren '60 als hoogleraar verbonden geweest aan de Nijmeegse universiteit (Van Merriënboer et.al. 2008: 56) ${ }^{346}$. Maar niet alleen was er een nieuwe gouverneur, na de Statenverkiezingen van 1978 werden ook twee jonge PvdA'ers gedeputeerde. In het nieuwe College van Gedeputeerde Staten van 1978 namen maar liefst vijf nieuwe gedeputeerden plaats ${ }^{347}$. Van een generatiewisseling was met uitzondering van de PvdA geen sprake ${ }^{348}$, wel van een College dat minder binding had met het beleid uit de periode van de herstructurering. Nieuwe personen zorgden voor een nieuwe koers. Een voorbeeld dat dit nieuwe Limburgse politiek klimaat illustreert, is het feit dat er voor het eerst in de provinciale geschiedenis een 'coalitieakkoord' tussen CDA-PvdA-VVD werd opgesteld. Tot die tijd was er na de verkiezingsuitslag slechts een 'taakverdeling' gemaakt tussen de verschillende gedeputeerden met de te verdelen vakportefeuilles ${ }^{349}$. Nu werd er een zogenaamd 'kernprogramma' ${ }^{1550}$ opgesteld met daarin afspraken en doelstellingen waar het College zich de komende vier jaar voor zou inspannen. Een nieuwe politieke agenda. Het belangrijkste onderdeel van het kernprogramma was de economische paragraaf.

In 1978 was de werkloosheid in Zuid-Limburg opgelopen tot 10,0\%. Afgezet tegen het gemiddelde nationale werkloosheid van 5,0\% was er dus sprake van een verdubbeling ${ }^{351}$. De arbeidspendel naar Duitsland was vanaf 1973 sterk teruggelopen ${ }^{352}$ waardoor het dempende effect voor Limburg was verdwenen (Bouwens, 2009: 49). De economische recessie uitte zich in Limburg het eerst. Daarbij kwamen de meer structurele problemen van de Limburgse economie in alle scherpte naar voren. Het LIOF, dat in 1975 opgericht was om nieuwe bedrijvigheid aan te trekken, had zich in haar beginjaren vooral noodgedwongen moeten bezig houden met het overeind houden van de reeds gevestigde bedrijven. Het waren vooral deze zwakkere bedrijven die gebruik hadden gemaakt van de vele premies en subsidies die door de rijksoverheid beschikbaar waren gesteld (Nijsten, 1980: 75). Bovendien was met de oprichting van het LIOF wel een eerste stap gezet in de richting van een gecoördineerde aanpak, maar er waren toch nog steeds verschillende organisaties die zich bezig hielden met de herstructurering en de acquisitie van bedrijven. Deze ineffectieve uitvoeringsstructuur zorgde er dus voor dat er weinig perspectief was om tot een nieuwe aanpak te komen. Negativisme overheerste (Derix, 1990: 71). Het 
was dan ook gouverneur Kremers die het wegwerken van de regionale werkloosheid tot belangrijkste prioriteit van het nieuwe College van Gedeputeerde Staten verklaarde. Maar om dat te realiseren had hij wel de rijksoverheid hard nodig. De goede contacten met de nieuwe minister-president werden daarin ten volle benut.

In de zomer van 1978 kwam het kabinet Van Agt met een bezuinigingspakket van 6,5 miljard gulden waarin de hoofdlijnen voor het financieel-economische beleid uiteen gezet werden ('Bestek '81'). De voor Limburg belangrijke ministeries zoals Sociale Zaken, Onderwijs, Cultuur, Recreatie \& Maatschappelijk Werk en niet in de laatste plaats Economische Zaken, moesten fors bezuinigen. Het was dus helemaal niet zo vanzelfsprekend dat Limburg op veel financiële steun kon rekenen van de rijksoverheid. Toch zouden onder het kabinet Van Agt I de voor Limburg belangrijkste structuurversterkende resultaten worden binnengehaald. De contacten over de Perspectievennota van de Provincie met het eerdere kabinet Den Uyl (1973-1977) waren vooral ambtelijk van aard geweest ${ }^{353}$. Nu werden de contacten naar een politiek niveau getild. De goede persoonlijke verhoudingen tussen Van Agt en Kremers waren daarbij van belang, maar net zozeer de goede contacten die gedeputeerde Buck had opgebouwd met directeur-generaal Regionaal Beleid van het ministerie van Economische Zaken, S. Miedema ${ }^{354}$. En tussen gedeputeerde Buck en gouverneur Kremers was vanaf het begin een hechte samenwerkingsband ontstaan. Deze drie persoonsgebonden 'tandems' waren cruciaal voor het latere succes van het Perspectievennotabeleid. De afspraken die dat jaar met de regering werden gemaakt zouden de basis leggen voor een Limburgs-Haagse politieke samenwerking die twaalf jaar zou duren.

\subsection{Politieke onderhandelingskracht: drie periodes PNL-beleid (periode 1978-1990)}

Het beleid dat in de jaren ná de vaststelling van de Perspectievennota Zuid-Limburg (het PNL-beleid) onder aanvoering van gouverneur J. Kremers en gedeputeerde K.W. Buck is gevoerd, kan gerekend worden tot de meest succesvolle periode van regionaal structuurversterkend overheidsbeleid (Hesse \& Kleinfeld, 1990: 217; Derix, 1990: 235; Jansen, 1997: 79; Peet \& Rutten, 2009: 418). De kern van dit succes lag in de politieke onderhandelingskracht, een gedegen voorbereiding en de heldere - maar vooral meetbare - doelstelling. Hoe functioneerde dit in de praktijk? Om die vraag te beantwoorden is het nodig om wat uitgebreider stil te staan bij de voorbereidingen van het bestuurlijk overleg dat plaatsvond in het voorjaar van 1978 tussen College van Gedeputeerde Staten en een groot gedeelte van het kabinet Van Agt. Deze voorbereidingen waren namelijk kenmerkend voor de manier waarop in de jaren ' 80 steeds opnieuw met de regering werd onderhandeld.

Nog ten tijde van het demissionaire kabinet Den Uyl was er in oktober 1977 een 'Begeleidingscommissie Perspectievennota Zuid-Limburg' ingesteld. Hierin waren de direct betrokken ministeries op hoog ambtelijk niveau vertegenwoordigd samen met een delegatie van de Provincie Limburg ${ }^{355}$. Een gedeeld Haags/Limburgs ambtelijk secretariaat bereidde de agendapunten voor. De functie van de commissie was enerzijds om op ambtelijk niveau al overeenstemming te vinden over gezamenlijke projecten, anderzijds werden 
in deze commissie de standpunten uitgewisseld en voorbereid waarover uiteindelijk in een politiek overleg tussen regering en College van Gedeputeerde Staten onderhandeld moest worden. Alle projecten die in het kader van de Perspectievennota Zuid-Limburg geformuleerd werden, waren voorbereid en besproken in deze Begeleidingscommissie. Ten slotte fungeerde de Begeleidingscommissie als een structuur waarmee het Provinciaal Bestuur het nakomen van de gemaakte afspraken en bereikte resultaten kon controleren ${ }^{356}$.

De werkwijze was als volgt. $\mathrm{Na}$ een eerste ambtelijke verkenning van mogelijke projecten volgden bilaterale besprekingen tussen de betrokken ministers en de Limburgse gedeputeerden. De nieuwe minister van Economische Zaken in het kabinet Van Agt, G.M.V. van Aardenne (VVD) was tevens benoemd tot coördinerend minister voor het Perspectievennotabeleid. Hij had aangeven zich in de ministerraad hard te zullen maken voor een productieve samenwerking van zijn collega-ministers met het Provinciaal Bestuur $^{357}$. De daarop volgende bestuurlijke besprekingen begin 1978 tussen de individuele ministers en de Limburgse gedeputeerden hadden echter vooralsnog weinig resultaat. Met name het ministerievan Financiën had grote bezwaren tegen dekwantitatieve taakstelling 358 met betrekking tot het terugbrengen van de regionale werkloosheidscomponent ${ }^{359}$. Het ministerie van Volkshuisvesting en Ruimtelijke Ordening weigerde om een passage op te nemen over de tweede fase van de spreiding van nieuwe rijksdiensten ${ }^{360}$. Het ministerie van Cultuur, Recreatie en Maatschappelijk Werk kon nog weinig zeggen over een eventuele Limburgse uitzonderingspositie in de bezuinigingstaakstelling die het ministerie moest realiseren ${ }^{361}$. De minister van Onderwijs en Wetenschappen wees op de mogelijke claims van andere ziekenhuizen naar aanleiding van het pleidooi van het College van Gedeputeerde Staten om een nieuw academisch ziekenhuis te bouwen in Maastricht. En wat betreft de mogelijke uitbouw van de Rijksuniversiteit Limburg kon de minister ook geen toezeggingen doen. Dit hing in grote mate af van de nog komende rijksbezuinigingen ${ }^{362}$. In het overleg met de minister van Sociale Zaken, W. Albeda (CDA), constateerde gouverneur Kremers dat vooral zijn ministerie en dat van Economische Zaken op 17 maart met oplossingen moesten komen ${ }^{363}$.

Op 17 maart 1978 was er een bestuurlijk overleg gepland tussen het College van Gedeputeerde Staten van Limburg en een grote delegatie van het kabinet van Agt. Een voltallig College van Gedeputeerde Staten werd ontvangen in de pauze van de ministerraad. Er waren negen ministers en een staatssecretaris aanwezig. Nooit eerder had het Limburgse College met zo'n grote delegatie van een kabinet gesproken. Het overleg in het Catshuis dat voorgezeten werd door de minister-president zelf verliep moeizaam. Met name over de taakstelling van de regionale werkloosheidscomponent en de uitbouw van de Rijksuniversiteit liep de discussie hoog op. Gouverneur Kremers sprak meerdere keren het woord 'onaanvaardbaar' uit ${ }^{364}$. De geplande bezuinigingen van het kabinet waren volgens hem juist in het herstructureringsgebied Limburg 'onverkoopbaar' ${ }^{\prime 365}$. Minister-president Van Agt en minister van Financiën, F.H.J.J. Andriessen (CDA), verweten Kremers in een schorsing 'ontoelaatbaar gedrag'. Zij vonden het handelen van Kremers in strijd met wat van een commissaris der koningin en daarmee de vertegenwoordiger van de rijksoverheid in de provincie, werd verwacht (Derix, 1990: 64). Pas in een vervolgoverleg, een kleine 
week later, kwam men nader tot elkaar ${ }^{366}$. De regering committeerde zich aan het 'behoud respectievelijk tot schepping van nieuwe arbeidsplaatsen tot een totaal van 11.000 16.000' waarvan 2.000 tot 3.000 overheidsplaatsen ${ }^{367}$. Bovendien werd er afgesproken dat de financiële middelen voor Limburg - in de eerste periode 25 miljoen gulden, in de twee latere periodes 45 miljoen gulden per jaar - uitsluitend ingezet konden worden als er ook cofinanciering plaatsvond door de individuele departementen. Daarmee had de Provincie Limburg een stok achter de deur gekregen waarmee zij de voortgang van de Perspectievennota structureel konden blijven agenderen. Op 10 en 19 april 1978 werd de Definitieve Standpuntbepaling verzonden aan de Provinciale Staten van Limburg en de Tweede Kamer. Een kleine maand later, op 7 juni 1978 trad het nieuwe College van Gedeputeerde Staten aan. Met maar liefst vijf nieuwe gedeputeerden, was er een nieuw elan ontstaan in de Limburgse provinciale politiek.

Hierboven is uitgebreid stilgestaan bij de Limburgse aanpak van de onderhandelingen met de regering. De procedure van zelf projecten formuleren, bespreken in de ambtelijke Begeleidingscommissie, bestuurlijk bilateraal overleg tussen individuele vakministers en gedeputeerden en het uiteindelijke 'politieke beraad' tussen regering en Limburgs College is in de daarop volgende jaren vaak herhaald. Het bleek te werken. Er was eind jaren '70 een nieuw politiek klimaat ontstaan op zowel provinciaal als nationaal niveau, waarin goede persoonlijke contacten cruciaal waren voor succes. Het nieuwe College van Gedeputeerde Staten had afscheid genomen van de provinciale opstelling waarin alle verantwoordelijkheid voor de Limburgse zaak bij de Rijksoverheid werd gelegd. Tevens was er afscheid genomen van de hoop op één nieuwe grote economische 'motor' voor Limburg $^{368}$. Vanaf nu zou het Provinciaal Bestuur met eigen voorstellen komen om de regionale economie te versterken en de werkloosheid terug te dringen. Projecten werden zelf door de Provincie bedacht en voor rijkssubsidieëring ingediend waarbij ook eigen geld werd ingezet. Een jaarlijks 'politiek beraad' tussen het College van Gedeputeerde Staten en de regering zorgde voor de politieke druk op de ketel. Het was een nieuwe aanpak waarin Provincie en Rijksoverheid als partners samen werkten en waar stevig politiek onderhandeld werd over de te bereiken resultaten. Het Perspectievennotabeleid, kortweg 'PNL-beleid' genoemd, zou 12 jaar overeind blijven, onderverdeeld in drie periodes van vier jaar. In de eerste periode (1978 t/m 1981) zijn de belangrijkste resultaten voor Limburg bereikt.

Wettelijke bevoegdheden of instrumenten voor dit nieuwe PNL-beleid had de Provincie net als in de jaren '70 nog nauwelijks. De Limburgse Ontwikkelingsmaatschappij (LIOF) was midden jaren '70 opgericht maar was nog niet echt toegekomen aan haar acquisitietaak. In de jaren ' 80 kreeg onder aansturing van Kremers en Buck de acquisitie van nieuwe bedrijven prioriteit. Het ministerie van Economische Zaken werkte hier als grootaandeelhouder aan mee. Naast het instrument van acquisitie, ging de Provincie ook zelf steeds meer projecten formuleren en uitvoeren. Alle initiatieven en projecten die in het kader van het PNL-beleid opgezet werden, moesten een aantoonbare bijdrage leveren aan het wegwerken van de regionale werkloosheidscomponent. De projecten hadden 
daarmee primair een economische insteek, echter ook woningbouw- en welzijnsprojecten vielen daaronder. Zolang de projecten maar arbeidsplaatsen opleverden. Maar lang niet alle projecten konden ingebracht worden bij de Begeleidingscommissie.

Op de eerste plaats was het PNL-beleid structuurbeleid voor Zuid-Limburg. Een economisch stimuleringsbeleid voor geheel Limburg was niet haalbaar in Den Haag. Wanneer men uit zou gaan van het totale Limburgse gemiddelde van diverse economische parameters, dan zou de noodzaak om in te grijpen dusdanig minder urgent lijken omdat deze cijfers nauwelijks verschilden met andere provincies. Vandaar dat ook de Provincie aandrong op een regionaal stimuleringsbeleid voor alleen Zuid-Limburg. Projecten konden dus ook alleen maar ingediend worden indien zij uitgevoerd werden in ZuidLimburg. Op de tweede plaats was er al in de voorbereiding van de Perspectievennota binnen Zuid-Limburg een uitsplitsing gemaakt naar vier deelregio's. Deze indeling werd door de Begeleidingscommissie gehanteerd in de verdeling van projecten over ZuidLimburg. De Westelijke Mijnstreek had de chemiesector en de auto-industrie, Maastricht was het internationale uithangbord voor de gehele regio en de Oostelijke Mijnstreek had als dienstencentrum een aantal grote rijksinstellingen. Daarnaast waren hier forse investeringen nodig in de infrastructuur (regionale wegennet). Het Heuvelland werd gezien als een economisch cluster voor toerisme en recreatie. Er was echter nog een derde selectiecriterium waaraan de projecten moesten voldoen. Door zowel het College van Gedeputeerde Staten als de betrokken ministeries moesten projecten de 'comparatieve voordelen' benutten ${ }^{369}$. Hiermee bedoelde men dat alleen die projecten opgezet moesten worden die niet alleen pasten bij de Zuid-Limburgse economische structuur, maar waarmee Limburg ook ten opzichte van andere regio's, onderscheidend kon zijn. Van een achterstand een voorsprong maken, was de gedachte. Bepaalde achterstanden waren specifiek voor Limburg zoals het ontbreken van een volwaardige universiteit, een academisch ziekenhuis of televisiebekabeling. Voor deze zaken werden projecten geformuleerd waarmee de achterstand in vergelijking met de rest van Nederland tot een voorsprong kon worden gemaakt. Geografische indelingen en vergelijkingen tussen provincies speelden dus een belangrijke rol in het economisch beleid.

Het overgrote deel van de projecten die in de periode 1978-1990 zijn geformuleerd, was afkomstig uit de Provincie Limburg zelf. De betrokken ministeries zaten vooral in de 'reagerende' rol. Daarmee waren de rollen omgekeerd ten opzichte van de periode 19621978. Dit betekende wel dat over elk project in principe onderhandeld moest worden met de rijksoverheid. Het jaarlijkse 'politiek beraad' tussen College van Gedeputeerde Staten en een delegatie van de regering, was daarom erg belangrijk. Hier vond de besluitvorming over de grote projecten plaats.

In de eerste PNL-periode (1978-1981) waren er twee belangrijke overlegmomenten tussen regering en College van Gedeputeerde Staten. In het 'politieke beraad' van 16 november 1979 werd de grootste slag geslagen. Voorafgaand daaraan was de behandeling van de Perspectievennota in de vergadering van de Bijzondere Tweede Kamercommissie van 4 december 1978, teleurstellend verlopen. Met name het uitblijven van duidelijkheid 
over de nieuwbouw van het Academisch Ziekenhuis, de vestiging van de Open Universiteit en de uitbouw van de Rijksuniversiteit waren een doorn in het oog van het College van Gedeputeerde Staten ${ }^{370}$. Deze grote projecten stonden op de agenda van het overleg in november 1979. Daarnaast was de manier waarop ministeries participeerden in de Begeleidingscommissie een agendapunt. Een aantal ministeries was 'op een lager ambtelijk niveau' vertegenwoordigd dan was afgesproken ${ }^{371}$. Een derde agendapunt was de wens van de Provincie om een groter aandeel te krijgen in de Europese subsidiefondsen voor infrastructuur. Deze subsidies werden verdeeld door het ministerie van Economische Zaken en waren voor de Provincie extra belangrijk, omdat het ministerie de eigen infrastructurele middelen vanwege de bezuinigingen van Bestek '81, aanzienlijk had verminderd. Een lastig punt voor minister Van Aardenne, omdat een groter aandeel voor Limburg ten koste zou gaan van het aandeel voor de noordelijke provincies.

In de aanloop naar het politieke beraad hadden diverse Limburgse belangenorganisaties kritiek geleverd op het College van Gedeputeerde Staten. Waar bleven de structuurversterkende projecten ${ }^{372}$ ? Alles zou moeten aankomen op het politieke beraad. Gouverneur Kremers had echter in de voorbereiding al met minister-president Van Agt politiek vooroverleg gevoerd ${ }^{373}$. Met succes. Het overleg van 16 november 1979 liep voorspoedig en bij het agendapunt 'spreiding rijksdiensten' deelde Van Agt tot ieders verbazing mee dat de Open Universiteit zou worden gevestigd in Zuid-Limburg met een voorkeur voor een locatie in de Oostelijke Mijnstreek ${ }^{374}$. Verder zou de Rijksuniversiteit Limburg uitgebouwd worden conform de motie Deetman ${ }^{375}$ en werd met de nieuwbouw van het Academisch Ziekenhuis uiterlijk in 1984 gestart. Kremers sprak 'zijn diepe respect' uit voor deze kabinetsbesluiten gezien de 'weerstand' tegen de Perspectievennota die het College van GS en regering ondervonden binnen de Limburgse samenleving ${ }^{376}$. Met dit onderhandelingsresultaat werd het echte fundament onder het PNL-beleid gelegd en was de kritiek van de regionale belangenorganisaties in Limburg gesmoord.

Naast de onderhandelingen via het politieke beraad, werd er langs partijpolitieke lijnen geschaakt. Naar Den Haag toe was de inzet van de Limburgse Kamerleden W.G. Bremen en P.R.H.M. van der Linden (beiden CDA), M.A.M. Wöltgens (PvdA) en vanaf 1982 ook J.F.B. van Rey (VVD) in de drie PNL-periodes van belang. De Limburgse zaak stond hier boven de partijpolitieke belangen. Er was zelfs een Bijzondere Kamercommissie Perspectievennota Zuid-Limburg ingericht waarin politieke verantwoording door de regering werd afgelegd ${ }^{377}$. Op 4 december 1978 werden in de bespreking van de definitieve standpuntbepaling van de regering op de Perspectievennota maar liefst 40 moties ingediend ${ }^{378}$. Hieronder waren de moties van W.J. Deetman (CDA) die opriep tot een uitbouw van de Limburgse universiteit tot 6000 studenten in 1990 en de vestiging van een Open Universiteit in Zuid-Limburg. Minister van Onderwijs en Wetenschappen A. Pais (VVD) had op beide verzoeken geen toezegging gedaan ${ }^{379}$. In het politieke beraad een jaar later werd dit - tot groot ongenoegen van de minister - verzilverd.

Ook binnen de Limburgse provinciegrenzen werd er onder aanvoering van Kremers en Buck gepoogd om met één stem te spreken. Zij wisten dat een van de oorzaken van de moeizame herstructurering in de periode 1965-1978 lag in diversiteit en 
belangentegenstelling tussen de diverse Limburgse organisaties en gemeenten betrokken in het economisch beleid van die tijd ${ }^{380}$. Het 'PNL-contract', het afgebakende geografische gebied van Zuid-Limburg en de prominente rol van de provinciale overheid, zorgden ervoor dat nu uitsluitend de Provincie Limburg voor de regering het aanspreekpunt was. Zowel op ambtelijke niveau, als via bilaterale bestuurlijke overlegrondes, de partijpolitieke lijn en het gezamenlijke geluid van de Limburgse belangenorganisaties, werden de belangen van Limburg door de Provincie behartigd. Deze gezamenlijke aanpak inclusief de machtsconcentratie in het Provinciehuis, was een belangrijk voordeel ten opzichte van de drie noordelijke provincies. Deze provincies hadden gezamenlijk het Integraal Structuurplan van het Noorden des Lands opgesteld, maar dit programma omvatte maar liefst drie provincies, en een veelvoud aan betrokken gemeenten en belangenorganisaties. Dat was tot in de jaren '70 eigenlijk op kleinere schaal ook in Limburg het geval geweest. Deze versnippering werd met de komst van Kremers en het Perspectievennotabeleid doorbroken. De Provincie Limburg was vanaf nu de enige gesprekspartner voor de regering.

De gedisciplineerde voorbereiding van projecten opzetten, uitwerken en financiële middelen hiervoor los krijgen bij de rijksoverheid, veranderden de politiek-ambtelijke verhoudingen in het provinciehuis. De provinciale organisatie had midden jaren '70 al kennis mogen maken met de veeleisendheid van gedeputeerde Buck. Maar dit viel in het niet bij wat de provinciale organisatie te wachten stond met het aantreden van gouverneur Kremers.

$\mathrm{Al}$ in de eerste maand na zijn aantreden had Kremers het adviesbureau Berenschot aan het werk gezet om de kwaliteit en effectiviteit van de provinciale organisatie onder de loep te nemen. In 1978 leverde Berenschot zijn rapport op waarmee tevens een langdurige reorganisatie begon. Uiteindelijk werd er in 1980 een kleine economische afdeling opgericht die volledig belast zou worden met de coördinatie en uitwerking van het PNLbeleid. Een aantal personele wisselingen op sleutelposities moest verder zorgen voor een nieuwe ambtelijke kwaliteitsimpuls van de gehele organisatie ${ }^{381}$. Daarbij werden diverse nieuwe ambtenaren aangetrokken die eerder hadden gewerkt bij de ministeries of andere rijksinstanties.

In de eerste twee jaar van het PNL-beleid was het voor het ambtelijk apparaat lastig om de goede projecten te selecteren. Gemeenten waren aangeschreven met het verzoek om projecten in te dienen, maar al snel bleek dat deze projecten niet voldeden aan de opgestelde criteria ${ }^{382}$. Het moest namelijk gaan om projecten die niet alleen arbeidsplaatsen opleverden, maar ook de algemene economische structuur van Limburg versterkten. Projecten moesten na het aflopen van de subsidieperiode effect blijven sorteren. Van de betrokken departementen, gemeenten en gewesten werd gevraagd om zelf een deel van de kosten voor eigen rekening te nemen ${ }^{383}$. Tegelijkertijd moesten de gereserveerde rijksmiddelen voor Zuid-Limburg (in periode 1978-1981 was dit 25 miljoen gulden per jaar) ook besteed worden ${ }^{384}$. De centrale doelstelling moest immers gehaald worden, de werkloosheid moest worden teruggedrongen. In dat opzicht gold deze 
kwantitatieve taakstelling niet alleen voor de regering, maar net zo zeer voor het College van Gedeputeerde Staten zelf. De rapportages over de maandelijkse werkloosheidscijfers en de gerealiseerde arbeidsplaatsen werden ook naar Provinciale Staten van Limburg gestuurd. Daar moest het College van Gedeputeerde Staten verantwoording afleggen over de behaalde resultaten van het beleid.

Het gevolg was dat het provinciale apparaat veel tijd kwijt was met het zelf formuleren en indienen van projecten ${ }^{385}$. De door Kremers in 1980 aangetrokken nieuwe adjunctgriffier, M.C.E. van Gendt ${ }^{386}$, bracht een groot internationaal netwerk van contacten met zich mee. Van Gendt werd belast met het formuleren van nieuwe innovatieve economische projecten voor Limburg. Samen met A.G.H.M. Lohuis, die inmiddels hoofd van de opgerichte economische afdeling was geworden, was hij de drijvende ambtelijke kracht in de provinciale organisatie begin jaren ' 80 .

Maar gemaakte afspraken moeten ook worden nagekomen. Begin 1980 bleek dit vooral voor de ministeries een moeilijke opgave ${ }^{387}$. Een nieuw politiek beraad in het najaar 1980 werd zelfs geannuleerd omdat er onvoldoende voortgang was ${ }^{388}$. Op 23 januari 1981 werd er toch een nieuw politiek beraad gepland, waarin ook gesproken werd over de nieuwe periode $1982 \mathrm{t} / \mathrm{m}$ 1985. In het overleg - een paar maanden voor de Tweede Kamerverkiezingen van mei 1981, dat werd voorgezeten door minister G.M.V. van Aardenne (VVD) - kwamen de knelpunten aan de orde. Besloten werd om het jaarlijkse PNL-budget met 10 miljoen gulden te verhogen. Voorts werd de toezegging gedaan dat de positie van de regionale ontwikkelingsmaatschappij (LIOF) op korte termijn versterkt zou worden. Ten slotte werd besloten dat er in Maastricht een internationaal instituut voor bestuurskunde gevestigd zou worden ${ }^{389}$. Eerder al had het College van Gedeputeerde Staten overleg gevoerd met minister Van Aardenne over het nieuwe Regionaal Sociaal-Economisch Beleid 1981-1985 waarin een accentverschuiving van een sectorbeleid naar een algemeen voorwaardenscheppend beleid werd aangekondigd ${ }^{390}$. De Investeringspremieregeling (IPR) voor bedrijven werd versoberd ${ }^{391}$. Al met al was duidelijk dat de regionale taakstelling in deze eerste periode niet gehaald zou worden ${ }^{392}$. Ten aanzien van een eventuele vervolgperiode zou een nieuw kabinet na de Tweede Kamerverkiezingen een definitief standpunt moeten innemen ${ }^{393}$.

Bijna was er geen tweede PNL-periode gekomen. Het kabinet Van Agt II (CDAPvdA-D66) was in september 1981 moeizaam tot stand gekomen. J.C. Terlouw (D66) werd minister van Economische Zaken. Na vier jaar PNL-beleid met diverse politieke beraden en vele toezeggingen was het gevoel in Den Haag ontstaan dat het nu genoeg was. De door Limburg opgestelde agenda ${ }^{394}$ ging diverse ministeries veel te ver (Derix, 1990: 128). Met name de financieringsopzet van het Maastricht Euro Center, was in de ogen van de Haagse ambtenaren een brug te ver ${ }^{395}$. Ook het voorstel aan de nieuwe regering om opnieuw een meerjarige regionale werkloosheidsdoelstelling op te nemen, vertaald in een jaarlijkse taakstelling van te realiseren arbeidsplaatsen, ging het ministerie te $\operatorname{ver}^{396}$. Men wist maar al te goed wat een dergelijke kwantitatieve taakstelling aan verplichtingen met zich mee zou brengen. Het politiek beraad tussen College van Gedeputeerde Staten en regering van 12 maart 1982 begon als volgt: 


\begin{abstract}
"Minister-president van Agt opent de vergadering en heet de aanwezigen welkom. Minister Terlouw kondigt aan dat het Kabinet een agenda heeft opgesteld die enigszins afwijkt van de door Limburg ingediende agenda. De heer Kremers kan daarmee niet akkoord gaan. Na een korte schorsing wordt besloten het beraad voort te zetten aan de hand van de door Limburg ingebrachte samengevatte agenda. Minister Terlouw deelt mede dat het de bedoeling was een totaalvoorstel van de zijde van de Regering over te leggen en het beraad aan de hand van dat voorstel te voeren. Hij meent echter dat er geen wezenlijk bezwaar tegen is aan de hand van de Limburgse agenda verder te praten." ${ }^{397}$
\end{abstract}

Dit was een sterk staaltje van de onderhandelingskunst van gouverneur Kremers. Het 'totaalvoorstel' waar minister Terlouw het over had, was in feite een voorstel voor een afkoopsom. Iets wat begin 1983 nog een keer geprobeerd zou worden ${ }^{398}$. Acceptatie van dit voorstel zou het einde van het PNL-beleid betekenen omdat hiermee de inhoudelijke basis van het PNL-beleid - de meerjarige kwantitatieve doel- en taakstelling - verlaten zou worden. Mede door de interventies van minister-president Van Agt bleef de doelstelling overeind en werd de nieuwe taakstelling voor de periode 1982-1985 opnieuw kwantitatief ingevuld ${ }^{399}$

Toch kon niet voorkomen worden dat in deze tweede periode het begin van het einde van het nationale regionaal economisch beleid werd ingeluid. De belangrijkste reden hiervoor was dat het ministerie van Economische Zaken onder steeds grotere druk kwam te staan, zeker na de Rijn-Schelde-Verolme affaire van 1983. In datzelfde jaar werd de Wet op de Selectieve Investeringsrekening ingetrokken. Toen in 1984 ook nog het ambtelijke boegbeeld van het ministerie van Economische Zaken, directeurgeneraal S. Miedema, vertrok uit de Begeleidingscommissie ${ }^{400}$ was het voor de Provincie duidelijk dat de onderhandelingen met de rijksoverheid moeilijker zouden worden ${ }^{401}$. Het was tevens het einde van het actieve steunbeleid voor de Nederlandse industrie. De opeenvolgende kabinetten Lubbers privatiseerden en verzelfstandigden een aantal bedrijven waarin de rijksoverheid tot dan toe had geparticipeerd ${ }^{402}$. In reactie op deze accentverschuivingen kwam de Provincie Limburg met een eigen sectorbeleid, het zogeheten 'speerpuntenbeleid ${ }^{403}$. Toerisme, energie en medische technologie waren de speerpunten die de Provincie Limburg midden jaren ' 80 aanwees als groeisectoren. Met de introductie van dit speerpuntenbeleid werd een voorzichtig begin gemaakt met een zelfstandig provinciaal economisch beleid.

Ook de projecten veranderden in de tweede PNL-periode (1982-1985). De projecten richtten zich nu op randvoorwaardelijke aspecten om de regionale economische structuur te versterken. Denk daarbij aan de uitbouwvan het vliegveld Beek, stedelijkeinfrastructurele voorzieningen, het versterken van de toeristisch-recreatieve industrie en het aantrekken van internationale instituten voor Maastricht. Daarbij werd de verantwoordelijkheid steeds meer bij de regio zelf gelegd. Dit uitte zich bijvoorbeeld in de versterking van de positie van de Limburgse ontwikkelingsmaatschappij $\mathrm{LIOF}^{404}$. LIOF kreeg de ruimte voor meer risicovolle participaties in bedrijven die een structuurversterkend effect hadden ${ }^{405}$. Vanaf begin jaren ' 80 werd een aantal kleinere budgetten van het regionaal economisch beleid van het ministerie van EZ naar de provincies overgeheveld. Ten slotte werd een 
deel van de uitvoering van de Investeringspremieregeling, bedoeld voor bedrijven die investeringsprojecten indienden tot een bedrag van 3 miljoen gulden, vanaf nu door de provincies afgehandeld ${ }^{406}$. Deze decentralisatie van taken was overigens zeer bescheiden in het licht van de decentralisaties die in de ruimtelijke ordening en het welzijnsbeleid midden jaren ' 80 plaatsvonden (zie hoofdstukken 2 en 4).

De politieke overlegrondes van 1983 en 1984 kenmerkten zich vooral door het herbevestigen van de eerder gemaakte afspraken. De opvolger van minister Terlouw, G.M.V. van Aardenne (VVD), nam een sterkere coördinerende rol in ${ }^{407}$. Mede dankzij deze VVD-minister, wist de Provincie Limburg in de periode 1982 t/m 1985 nog relatief veel resultaten binnen te halen ${ }^{408}$.

In de tweede helft van de jaren ' 80 werd het jarenlange uitgangspunt van het regionale beleid - het wegwerken van achterstanden in specifieke regio's - langzaam vervangen door een oriëntatie op sterke regio's. De gedachte hierachter was dat sterkere regio's in hun ontwikkeling de zwakkere regio's konden 'meetrekken' (Miedema, 1986: 107). Dat was ook de strekking van de nieuwe nota Regionaal Sociaal-Economisch Beleid 1986-1990 die op 12 juli 1986 aan de Tweede Kamer werd aangeboden ${ }^{409}$. Minister Van Aardenne schreef aan de Tweede Kamer: "Wij gaan er daarbij van uit dat de sociaal-economische situatie zich in deze jaren verder in positieve zin zal ontwikkelen. Het kabinet heeft daarom besloten dit beleid na 1990 te beëindigen" ${ }^{\prime 410}$. De regionale werkloosheidscomponent was in de periode 1983-1985 voor heel Limburg wel gedaald, maar bleef voor Zuid-Limburg met 3,3\% hoger dan het nationale gemiddelde ${ }^{411}$. De voorbereiding van een andere grote Haagse nota - de Vierde Nota Ruimtelijke Ordening - legde de nadruk op de ontwikkeling in het westen van het land. Bovendien wilden de ministeries zich niet langer vastleggen op de verplichte cofinanciering van de inmiddels jaarlijkse 42,7 miljoen gulden voor Zuid-Limburg op de begroting van het ministerie van EZ. Deze 'inspanningsverplichting' was in de eerdere twee periodes wel steeds opgenomen ${ }^{412}$. Allemaal tekenen aan de wand dat de formule van het PNL-beleid langzaam uitgewerkt raakte. Ten slotte verdwenen in deze derde periode - na het vertrek van Miedema in 1984 - nog drie andere belangrijke boegbeelden van PNLbeleid .

Twee dagen na de presentatie van de nieuwe regionale rijksnota nam G.M.V. van Aardenne afscheid als minister van Economische Zaken. Hij keerde niet terug in het nieuwe kabinet Lubbers II. Een jaar later zou K.W. Buck afscheid nemen als gedeputeerde en architect van de Perspectievennota. Zijn ambtelijke toeverlaat uit die tijd - A.G.H.M. Lohuis - zou in datzelfde jaar een functie aanvaarden bij DSM. Daarmee waren de drie krachtige persoonsgebonden tandems van eind jaren '70 - Van Agt/Kremers, Kremers/ Buck, Buck/Miedema - ontbonden. J.B.V.N. Pleumeekers (CDA) volgde in het voorjaar van 1987 Buck op als verantwoordelijk gedeputeerde voor de laatste PNL-periode. Buck maakte wel nog in april 1986 het eerste Provinciaal Sociaal-Economisch Beleidsprogramma 1986-1990 $\mathrm{mee}^{413}$. Hierin werd vooruit gelopen op het zelfstandige provinciaal economisch beleid waar het Provinciaal Bestuur in de jaren '90 op zou terugvallen. De strakke aansturing van het PNL-beleid zoals die door Kremers en Buck eind jaren '70 was ingezet, 
verschoof langzaam naar de ambtelijke Begeleidingscommissie ${ }^{414}$. De verschillende ambtelijke vertegenwoordigers van de ministeries in deze Commissie gingen steeds strengere financieringseisen stellen aan de ingebrachte projecten. Het doel was niet langer arbeidplaatsen creëren, maar het verhogen van de 'toegevoegde waarde van het regionaal produkt ${ }^{415}$. De twee politieke beraadslagingen die met het kabinet Lubbers $\mathrm{II}^{416}$ werden gehouden zijn te kenschetsen als plichtmatig. Een overleg op 20 november 1987 verliep moeizaam omdat bleek dat er vanuit de regering weinig concrete toezeggingen kwamen. De ergernis van gedeputeerde Pleumeekers dat het PNL-beraad 'er toch voor [was] om buiten de reguliere kaders ... goede zaken van de grond te krijgen ${ }^{417}$, was tekenend voor de ontstane onderlinge verhoudingen. Gouverneur Kremers trok aan het eind van de vergadering de conclusie dat kennelijk het kabinet 'problemen in andere landsdelen op wil lossen ten koste van Limburg ${ }^{418}$. De toezegging van 45 miljoen gulden rijksbijdrage aan de vestiging van een onderzoeksinstelling van de United Nations University te Maastricht en diverse bijdragen aan een aantal technologie-projecten, kon de teleurstelling niet verbergen.

\section{Derde omslagmoment: Limburg op eigen kracht (1990-1992)}

Toen eind november 1989 de regionale werkloosheidscomponent voor het eerst sinds lange tijd onder het nationale gemiddelde schoot, was daarmee de maatschappelijke urgentie en tevens inhoudelijke legitimatie van het Perspectievennotabeleid verdwenen. De Provincie Limburg had een werkloosheidspercentage dat in de pas liep met de rest van Nederland (Derks, 2005: 189). Gouverneur Kremers kwam de belofte na die hij in het begin van zijn gouverneurschap had gedaan: hij zou niet vertrekken voordat de regionale werkloosheidscomponent van Limburg teruggebracht zou zijn. Op 10 mei 1990 nam hij afscheid. Het allerlaatste politieke overleg van 1 juni 1990 werd vanuit Limburg aangevoerd onder leiding van waarnemend gouverneur E.M. Mastenbroek (CDA).

Het regionale economisch beleid van het ministerie van EZ was niet langer een ministeriële verantwoordelijkheid, maar een taak van de staatssecretaris. Naast staatssecretaris P. Bukman (CDA) was alleen minister van Onderwijs en Wetenschappen J.M.M. Ritzen (PvdA) namens het kabinet vertegenwoordigd. Een meerjarenprogramma voor de Oostelijke Mijnstreek kreeg nog een financiële impuls van 80 miljoen gulden voor de periode 1991-1994 en de regering zou een pleidooi houden in Brussel voor continuering van de EFRO-fondsen na 1991, maar het PNL-beleid voor Zuid-Limburg werd eind 1990 afgerond $^{419}$. De Limburgse Ontwikkelingsmaatschappij (LIOF) kreeg een sterkere zelfstandige rol om te participeren in bedrijven ${ }^{420}$. Het signaal was helder, de Provincie Limburg moest op eigen kracht verder. De kracht van het 'zelforganiserend vermogen' noemde de Sociaal-Economische Raad het ${ }^{421}$. Op 14 december 1990 werd de Begeleidingscommissie formeel opgeheven ${ }^{422}$.

De periode 1990-1992 was een moeilijke periode voor de Provincie Limburg. Er waren grote partijpolitieke meningsverschillen ontstaan in zowel Limburg als Den Haag, over de opvolging van gouverneur Kremers. Minister C.I. Dales (PvdA) had uiteindelijk waarnemend gouverneur Mastenbroek voor een tussenperiode benoemd, vanwege diverse 
politieke meningsverschillen over opvolging. In 1993 zou uiteindelijk de staatssecretaris van Defensie, baron B.J.M. van Voorst tot Voorst (CDA), tot nieuwe Commissaris der Koningin in Limburg benoemd worden. Naast de discussie over de opvolging, moest het in 1991 pas aangetreden College van Gedeputeerde Staten, al na een jaar twee nieuwe gedeputeerden zoeken. J.B.V.N. Pleumeekers (CDA) was burgemeester van Heerlen geworden en H.W. Riem (PvdA) tekende voor het burgemeesterschap in Brunssum. Deze laatste ondervond daar een vervelend vervolg van zijn politieke carrière. In februari 1992 kwam Dagblad de Limburger met een publicatie over het mogelijk aannemen van steekpenningen van een wegenbouwaannemer door een provinciaal ambtenaar. Het was het begin van een slepende affaire die tot 1995 zou duren en zich uitbreidde over diverse gemeentebestuurders in Zuid-Limburg. Daarin werd ook oud gedeputeerde Riem genoemd ${ }^{423}$. Dagblad Trouw noteerde in oktober 1993 dat het gewenste Limburgse beeld van het 'Balkon van Europa' in de kroegen werd omgedoopt tot het 'Palermo aan de Maas ${ }^{424}$. Het was een smet op het op 7 februari 1992 ondertekende Verdrag van Maastricht. De verschillende persoonswisselingen van gedeputeerden en opvolgende gouverneurs in combinatie met de politiek explosieve omkoopaffaires, leidden tot de behoefte aan rust en stabiliteit. Een ambtelijke organisatie heeft, zoals Peters opmerkt 'the advantages of permanence and stability' (Peters, 2001: 236). De politiek-ambtelijke verhoudingen verschoven opnieuw. Met het gedoe van de opvolging van Kremers, de bestuurlijke functiewisselingen en de affaires, werd impliciet het politieke primaat van de jaren ' 80 zoals door Kremers en Buck was ingezet, vervangen door een ambtelijk primaat. Een provinciaal beleid met Europese uitstraling was de richting van het economisch beleid voor de jaren '90.

Deze Europese uitstraling was met de komst van de diverse internationale instituten naar de stad Maastricht in de jaren '80 vergroot. Voor de Provincie Limburg was de terugtrekkende beweging van de rijksoverheid uit de regio een kans om de samenwerking met een nieuwe partner te verkennen: de Europese Commissie. Het uitwerken van de Europese gedachte was de nieuwe ambitie voor het provinciale economisch beleid. Dat had nog een andere reden. Nu het PNL-beleid was afgelopen waren ook de grote financiële geldstromen naar Limburg beëindigd. Bovendien waren er door de rijksoverheid grote bezuinigingen aangekondigd. Deze bezuinigingen troffen ook het economisch beleid. De Provincie zag mogelijkheden om veel meer dan tot nu toe was gebeurd, actief Europese subsidies binnen te halen. De ondertekening van het Verdrag van Maastricht was voor de Provincie een nieuwe impuls voor een internationaal georiënteerd economisch beleid. Daarnaast boden de Europese subsidies een welkome aanvulling op de eigen provinciale financiën om de bezuinigingsronde van de rijksoverheid begin jaren '90 op te kunnen vangen.

Het einde van het Perspectievennotabeleid betekende tevens de start voor een nieuwe omslag in het provinciaal economisch beleid. Een beleid met Europese allure. Het was niet voor niets dat het Limburgse coalitieakkoord van 1991 'internationalisering' als de 'meest in het oog springende trend' van de jaren ' 90 typeerde ${ }^{425}$. 


\subsection{Europese proefregio: een provinciaal technologiebeleid (periode 1992-2003)}

De ondertekening van het Verdrag van Maastricht in februari 1992 gaf een nieuwe richting aan het economisch beleid van de Provincie Limburg. In de jaren ' 90 groeide tevens de invloed van de Limburgse intermediaire organisaties en gemeenten op het provinciale beleid ${ }^{426}$. Er werd een begin gemaakt met een provinciaal arbeidsmarktbeleid waarin ook gemeenten een belangrijke partner waren. Na het in werking treden van de nieuwe Arbeidsvoorzieningenwet (1990), waren er Centrale en Regionale Bureaus Arbeidsvoorziening opgericht per provincie. Gemeenten en provincies kregen hierin een adviesstem (Kraaijestein, 1995: 227). De samenwerking in de arbeidsvoorziening verliep nog erg moeizaam. Vanaf 1995 werd deze structuur in Limburg dan ook omgebouwd tot een Europees programma: het Vertrouwenspact Werkgelegenheid Limburg ${ }^{427}$. Het was een van de voorbeelden van het actief benutten van de economische stimuleringsprogramma's, die de Europese Commissie in de jaren '90 ontwikkelde.

De geldstromen van het ministerie van Economische Zaken werden geleidelijk vervangen door subsidies uit de Europese Structuurfondsen. Ook werd de samenwerking versterkt tussen de Provincie Limburg en de directoraten-generaal van de Europese Commissie. Het hierboven genoemde Vertrouwenspact Werkgelegenheid Limburg was daar een voorbeeld van. Echter twee jaar eerder, eind 1993, was er door de Provincie al ingespeeld op een ander Europees experiment: het opstellen van Regional Technology Plans in vier Europese regio's. De Provincie Limburg was een van regio's die zich meldde als proefregio. De aanmelding werd gehonoreerd door de Europese Commissie. Het resulteerde in een nieuw economisch sectorbeleid gericht op technologie en innovatie. Dit sloot aan bij het 'speerpuntenbeleid' waar in de jaren '80 een voorzichtig begin mee was gemaakt.

Het Regionaal Technologieplan Limburg was om drie redenen kenmerkend voor het jaren ' 90 beleid $^{428}$. Op de eerste plaats was het een voorbeeld van provinciaal economisch beleid met een nieuwe strategische partner: de Europese Commissie. Vanuit de Europese Structuurfondsen waren er al contacten ontstaan met de Commissie en waren diverse projecten met Europees geld ondersteund. De nationale of regionale cofinanciering bij deze Europese subsidies verliep echter nog altijd via het ministerie van Economische Zaken. Ook de inhoud van de projecten werd vaak in onderling overleg tussen ministerie en Provincie afgestemd. Het Regionaal Technologieplan was een eerste poging van de Provincie Limburg om zonder directe betrokkenheid van het ministerie van EZ met de Europese Commissie regionaal beleid op te zetten. Dat was nieuw.

Op de tweede plaats was het Technologieplan voor de Provincie een inhoudelijke verkenning van een nieuw thema binnen het economisch beleid. Technologie en innovatie werden gezien als belangrijke onderdelen van de nieuwe kenniseconomie (Jacobs, 2009: 22-25). Het inzicht groeide dat concurrentie op arbeidsloon of kapitaalintensieve bedrijvigheid met het groeicontinent Azië, een ongelijke strijd was. Technologische ontwikkeling, research \& development en het toepassen van kennis, waren de overgebleven onderscheidende factoren voor Europeselanden en regio's, zo was de gedachte ${ }^{429}$. Maar welke 
economische rol vervulde een overheid nog in dit wereldwijde economische krachtenspel? En wat kon een provincie daar in betekenen? Met het Regionaal Technologieplan werd een nieuw technologisch gericht sectorbeleid verkend. Eerdere pogingen van de Provincie op dit gebied waren 'weinig coherent' geweest (Cobbenhagen \& Severijns, 2003: 42).

Ten slotte was het plan interessant vanwege het feit dat het Technologieplan vooral een ambtelijk project was. Net zoals in de ruimtelijke ordening de Nadere Uitwerking Brabant-Limburg een ambtelijk proces was in die tijd (zie hoofdstuk 2), of de fusie van een tiental welzijnsinstellingen tot Symbiose (zie hoofdstuk 4), gold dit ook voor het Technologieplan. De tijden van strakke politieke aansturing zoals in de jaren '80, waren voorbij. De politiek-ambtelijke verhoudingen waren veranderd. Door de diverse wisselingen van gedeputeerden (en bijbehorende portefeuilles) in de eerste helft van de jaren '90, was het ambtelijk apparaat de enige constante. In de jaren '90 kan daarom gesproken worden van een 'verambtelijking' van het provinciaal beleid. Het Regionaal Technologieplan Limburg was daar geen uitzondering op.

Het 'Regional Technology Plan' was een initiatief van de Europese Commissie zelf (Landabaso \& Reid, 2003: 30-34). In het najaar van 1993 was er contact ${ }^{430}$ gelegd met een aantal regionale overheden waaronder ook Limburg. $\mathrm{Na}$ eerdere goede ervaringen in Wales, wilde de Europese Commissie met dit initiatief een brug slaan tussen het regionale beleid en het technologiebeleid ${ }^{431}$. In feite wilde men een verbintenis creëren tussen een randvoorwaardelijk beleid en sectorspecifiek economisch beleid. De ambtenaren van de twee betrokken directoraten-generaa ${ }^{432}$ vonden dat het technologiebeleid beter verankerd moest worden in de economische structuur van regio's (idem.25). Een eerder vergelijkbaar Europees programma ${ }^{433}$ was sterk projectmatig opgezet en de samenhang tussen de projecten onderling liet te wensen over $^{434}$. Met een viertal proefregio's wilde de Europese Commissie alle partijen die zich binnen een regio bezighielden met technologie bij elkaar brengen en mobiliseren tot samenwerking. Verder wilde men dat er tussen regio's ervaringen werden uitgewisseld waarbij gedacht werd aan een internationaal netwerk van innovatieve regio's ${ }^{435}$.

Vanaf het begin benadrukten de ambtenaren van de Europese Commissie dat het opstellen van het plan 'in nauw overleg met alle betrokkenen' moest gebeuren, om een 'zo breed mogelijk draagvlak' te krijgen ${ }^{436}$. In de eerste concepten werd nog gesproken van een Technologieplan voor alleen Zuid-Limburg, maar al snel werd dit verbreed naar geheel Limburg ${ }^{437}$. Ongetwijfeld zal hier ook de vaak geuite kritiek uit de jaren ' 80 op het gevoerde Perspectievennotabeleid - beleid dat alleen voor Zuid-Limburg gold - een rol hebben gespeeld. Het was dan ook niet voor niks dat binnen de opgerichte stuurgroep twee Noord-Limburgse bedrijven (Océ en Inalfa) vertegenwoordigd waren ${ }^{438}$.

Onder coördinatie van een consultancybureau werd een plan van aanpak gemaakt ${ }^{439}$. Het plan van aanpak bestond uit drie onderdelen: een verkennende studie- en rapportagefase, het inrichten van een regionale uitwisselingsstructuur en het uitvoeren van projecten ${ }^{440}$. Voor de Europese Commissie lag het accent vooral op de eerste twee fasen. De Provincie Limburg - gewend aan het realiseren van projecten in de PNL- 
periodes - benadrukte vooral het uitvoeren van projecten ${ }^{441}$.

Het ministerie van Economische Zaken was in deze voorbereiding de grote afwezige. In een korte informele memo van 12 november 1993 werd het ministerie door de Provincie op de hoogte gesteld van de Limburgs-Brusselse activiteiten: "Ten aanzien van de cofinanciering van het [Regionaal Technologieplan] wordt in dit stadium geen bijdrage van EZ gevraagd. Wel zal straks verzocht worden om het voorstel formeel via de PV [Permanente Vertegenwoordiging - HvE $]^{442}$ aan Brussel aan te bieden"443. Dit was nodig omdat de projecten die in het kader van de Europese Structuurfondsen ${ }^{444}$ werden gefinancierd, formeel nog steeds via het ministerie van Economische Zaken gecoördineerd werden. Een zuinig briefje van het ministerie volgde drie maanden later: "Het plan heeft u op eigen initiatief opgesteld en reeds zelf ingediend bij de Commissie. Van enige inhoudelijke dan wel procedurele betrokkenheid van mijn zijde is tot op heden geen sprake" ${ }^{\prime 45}$. Omdat het ministerie na telefonisch contact met de Europese Commissie vernam dat het project zou worden goedgekeurd, stemde het ministerie in. Het ministerie merkte echter op: "Volledigheidshalve wijs ik u erop dat de totale verantwoordelijkheid voor de opzet en uitvoering van dit programma berust bij uw provincie" ${ }^{146}$. Er was een nieuwe machtsbalans ontstaan tussen Brussel, Den Haag en Limburg.

Op 23 maart 1994 presenteerden de vier pilotregio's - Leipzig, Lotharingen, Wales en Limburg - zich in Brussel. Een paar dagen eerder was de Limburgse stuurgroep, met daarin vertegenwoordigers uit het bedrijfsleven, intermediaire organisaties en de Provincie, voor het eerst bij elkaar gekomen. In deze eerste fase van het project lag de nadruk op het inventariseren van de diverse initiatieven binnen Limburg op het gebied van technologie en innovatie. Daarbij werd ook gekeken naar de sterktes en zwaktes van het Limburgse vestigingsklimaat ${ }^{447}$. Een ander beoogd doel, namelijk het vormen van een Europees netwerk met de andere pilotregio's, werd zo al vroeg uit het oog verloren.

De Provincie Limburg had weinig expertise op dit nieuwe terrein van technologie en innovatie. Om de potenties en mogelijkheden van Limburg in kaart te brengen werden er diverse onderzoeken uitbesteed aan externe bureaus. Ook voor de projectleiding werd een externe consultant ingehuurd, gezien het feit dat het managen van Europese programma's toch een aparte expertise was, waar de Provincie nog weinig ervaring mee had. Het versterkte de afstand die er toch al bestond tussen het provinciale ambtelijke apparaat en de gedeputeerde voor Economische Zaken, C.E.M. de Waal (CDA). De politiek-ambtelijke verhoudingen waren nog eens extra gecompliceerd, omdat collega-gedeputeerde J.H.M. Bronckers (CDA), voorzitter was van het Comité van Toezicht voor de voor Limburg relevante Europese programma's. Het bleef onduidelijk wie er vanuit het College van Gedeputeerde Staten eindverantwoordelijk was voor het Regionaal Technologieplan ${ }^{448}$.

In een zestal onderzoeken werd in de zomer van 1994 een beeld geschetst van de positie van Limburg in het Nederlandse en internationale technologiebeleid ${ }^{449}$. De algemene conclusie was dat er voldoende potentie in Limburg en de omliggende euregio aanwezig was, maar dat deze potenties onvoldoende benut werden door een gebrek aan strategische samenwerking ${ }^{450}$. Een 'clusterbenadering ${ }^{451}$ zou in het op te stellen Regionaal Technologieplan centraal moeten komen te $\operatorname{staan}^{452}$. Na deze globale probleemanalyse 
werd de concrete behoefte van het Limburgse bedrijfsleven in kaart gebracht. Dit gebeurde via zogeheten technology-audits. $\mathrm{Bij} 17$ grotere Limburgse bedrijven en een 6-tal kennisinstellingen werd een gestandaardiseerd prestatieonderzoek (een audit) uitgevoerd, dat in beeld bracht hoe Limburgse organisaties omgingen met technologische vernieuwing en innovatie ${ }^{453}$. De audits waren een nieuw instrument voor de Provincie in haar economisch beleid. Daarbij benutte men de ervaringen van de Europese Commissie die soortgelijke audits eerder had laten uitvoeren. De audits brachten in kaart hoe het stond met de technologische kennis van het Limburgse bedrijfsleven. Daarmee kreeg de Provincie inzicht in wat er achter de voordeur van het Limburgse bedrijfsleven speelde. Voor de bedrijven boden de resultaten inzicht in de wensen van hun klanten en toeleveranciers ${ }^{454}$ (Cobbenhagen \& Severijns, 2003: 49). Tot die tijd was het economisch beleid gericht op het scheppen van randvoorwaarden voor bedrijven. Met de inzichten die uit de audits kwamen, dacht men beter te kunnen inspelen op de wensen en vragen die technologiebedrijven hadden ten aanzien van het te voeren overheidsbeleid. Daarmee verdiepte de Provincie zich in de interne bedrijfsprocessen en bedrijfsstrategieën. De audits waren daarin een nieuw beleidsinstrument voor de Provincie.

De audits werden dan wel uitgevoerd door een extern bureau ${ }^{455}$, maar de uitkomsten en conclusies hiervan moesten door de Provincie omgezet worden in beleid. Dat was nog niet zo eenvoudig. Vanaf de start hadden de betrokken provinciale ambtenaren erg geleund op de ingehuurde externe adviseurs. Met name L.F.H.C. Broos van het consultancybureau $\operatorname{Erac}^{456}$ heeft in de beginfase als externe projectleider een bepalende rol gespeeld. Hij had goede ambtelijke contacten met de ambtenaren van de Europese Commissie en hij schreef ook het plan van aanpak ${ }^{457}$. Het was echter aan de Provincie om hier ook nieuw beleid voor te ontwikkelen.

Toen in de zomer van 1995 de eerste resultaten van de audits binnenkwamen, vroeg de Provincie het onderzoeksbureau Merit ${ }^{458}$ om een second opinion te leveren op het materiaal ${ }^{459}$. In september leverde Merit een vernietigend commentaar op het materiaal en twijfelde aan de representativiteit van de conclusies van de audits ${ }^{460}$. De Provincie besloot daarop om het hoofdrapport niet vrij te geven voor publicatie $e^{461}$. Toch moest er voor 26 maart 1996 een Regionaal Technologieplan Limburg in Brussel ingediend worden ${ }^{462}$. Met een aantal workshops polste de Provincie het draagvlak voor het definitieve plan bij het Limburgse bedrijfsleven en de intermediaire organisaties ${ }^{463}$. Tegelijkertijd waren er in het najaar 1995 vijf pilots geselecteerd, gericht op de innovatie van kleinere ondernemers ${ }^{464}$. Daarmee werd de focus verlegd van de grotere bedrijven naar het midden- en kleinbedrij ${ }^{465}$. Ook werd de definitie van 'innovatie' opgerekt. "Naast aandacht voor de versterking van de technologische positie van de bestaande bedrijvigheid, hoort er daarnaast aandacht te zijn voor zaken als human capital, marketing en management" was te lezen in het nieuwe beleidskader ${ }^{466}$.

De nieuwe gedeputeerde Economische Zaken, J.J.M. Tindemans (PvdA), presenteerde het Regionaal Technologieplan op 5 maart 1996. Een maand later werd het plan met de ambtenaren van de Europese Commissie besproken die het een 
'kwalitatief goed product' vonden dat als 'voorbeeld voor andere regio's in Europa zou moeten dienen ${ }^{1467}$. Het plan stelde een 'innovatiestrategie' voor die zich richtte op 'het versterken van het industriële bedrijfsleven in Limburg, met name het MKB [Midden- en Kleinbedrijf - $\mathrm{HvE}$ ] en het verbeteren van de aansluiting en de toegankelijkheid van de kennis- en opleidingsinfrastructuur ${ }^{468}$. In de periode na de vaststelling van het Regionaal Technologieplan Limburg werden er meer dan 100 projecten uitgevoerd. De projecten hadden een totale financiële omvang van 120 miljoen euro ${ }^{469}$. In 1999 liep het programma af en werd het op verzoek van de Europese Commissie opgevolgd door het programma Regionale Innovatie Strategie Plus. De gedachte hierachter was dat het technologiebeleid selectiever moest worden ${ }^{470}$. De Provincie had behoefte aan 'meer samenhang en consistentie in activiteiten ${ }^{471}$. De praktijk was echter een verdere verbreding van het technologiebeleid ${ }^{472}$. De provinciale rol in de begeleiding van deze grote hoeveelheid projecten werd eind jaren '90 langzaam overgenomen door de intermediaire organisaties, de ontwikkelingsmaatschappij LIOF en de stichting Syntens die steeds vaker als uitvoerders van het provinciale innovatiebeleid optraden. Ook werd er steeds meer samengewerkt op het gebied van innovatie met het agentschap van het ministerie van Economische Zaken, SenterNovem.

Het Regionaal Technologieplan Limburg was een eerste verkenning van het opzetten van een provinciaal technologiebeleid. Het was ook de eerste keer dat er een economisch programma gemaakt was dat voor heel Limburg gold, gestart vanuit de ambitie van de Europese Commissie om met een aantal regio's meer samenhang in dit thema te brengen. Via een aantal audits van technologische bedrijven werden de mogelijkheden voor economisch beleid onderzocht. Daarvoor werd sterk geleund op de inbreng van consultants en - in een latere fase - op uitvoerende intermediaire organisaties als LIOF en Syntens.

De Provincie heeft met het Regionaal Technologieplan twee zaken nooit bereikt. Op de eerste plaats was het beleid geen echt politiek item geworden. Daarvoor was de afstand tussen College van Gedeputeerde Staten en het ambtelijk apparaat te groot en werden de opzet alsook de uiteindelijke projecten teveel toevertrouwd aan ingehuurde consultants en uitvoerende organisaties. Ten tweede is het Plan, dat van start ging als een Europees proefproject, paradoxaal genoeg steeds meer een Limburgs programma geworden. Van de uitwisseling met de andere regio's kwam - afgezien van een klein aantal gezamenlijke projecten - weinig terecht, evenals de grensoverschrijdende samenwerking waar in de beginfase nog aan werd gedacht (Cobbenhagen \& Severijns, 2003: 51). Het realiseren van Limburgse projecten met Europees geld was in de plaats gekomen van de oorspronkelijke doelstelling van interregionale kennisuitwisseling en grensoverschrijdende samenwerking. De uiteindelijk geselecteerde projecten werden over heel Limburg uitgevoerd door de intermediaire organisaties LIOF en Syntens. Daarmee verdween de Provincie weer via de achterdeur uit het bedrijfsleven, waar zij begin jaren ' 90 was binnengestapt.

Toch droeg het Regionaal Technologieplan bij aan een vernieuwing van het economisch beleid van de jaren '90. Op de eerste plaats was er ervaring opgedaan met 
een nieuwe strategische samenwerkingspartner, de Europese Commissie. Daarmee had de Provincie zich in haar economisch beleid minder afhankelijk gemaakt van het ministerie van Economische Zaken. Door de samenwerking met de Europese Commissie werden ook nieuwe Europese fondsen en geldstromen benut. Op de tweede plaats werd er ervaring opgedaan met nieuwe instrumenten en nieuwe expertise. De uitgevoerde audits waren een kijkje in de keuken van het Limburgse bedrijfsleven, waardoor de Provincie een beter gevoel kreeg voor de behoeftes en problemen van bedrijven ten aanzien van technologische innovatie. Dit was een nieuw werkgebied, waarbij de Provincie dankbaar gebruik maakte van de expertise en kunde van externe consultants. Niet alleen door de inhoudelijke expertise van deze consultants, maar ook de expertise op het gebied van Europees programmamanagement, werd nieuwe kennis en kunde de provinciale organisatie ingebracht. Op de laatste plaats was het Technologieplan een voorbeeld van een economisch sectorbeleid dat van toepassing was voor de gehele provincie. Zo'n 'provinciedekkend' economisch beleid, waar geen onderscheid werd gemaakt tussen Noord-, Midden- of Zuid-Limburg, was in de periode na de mijnsluiting nog niet opgezet. Dat was tevens ook de kritiek die de Provincie eind jaren ' 90 kreeg op haar beleid. De samenhang en selectiviteit ontbraken in het technologiebeleid. Dit gemis, in combinatie met de beperkte mogelijkheden voor politieke profilering, waren de aanleiding om het technologiebeleid aan het begin van de 21e eeuw te herzien. Daarin speelde het audit als instrument opnieuw een rol. Dit keer werd niet het bedrijfsleven onder de loep gelegd, maar het gevoerde economisch beleid van de Provincie zelf.

\section{Vierde omslagmoment: de ambitie van technologische topregio (2003-2004)}

In het Provinciaal Economisch Beleidsprogramma 2000-2003 werd, terugblikkend op de jaren '90, de rol van de provincie als 'minder geprononceerd' beschreven ${ }^{473}$. Verwezen werd naar de rol die intermediaire organisaties speelden in het provinciale beleid. De regionale ontwikkelingsmaatschappij LIOF richtte zich op de acquisitie van nieuwe bedrijvigheid en de uitvoering van beleid voor bedrijventerreinen. De stichting Syntens voerde het regionale innovatiebeleid uit (vervolg van het hiervoor geschetste Regionaal Technologieplan), de Limburgse VVV's voerden een provinciaal beleid voor toerisme en recreatie en het samenwerkingsverband Vertrouwenspact Werkgelegenheid Limburg hield zich bezig met het arbeidsmarktbeleid ${ }^{474}$. Op al deze terreinen werden subsidies verstrekt voor diverse projecten. Daarbij was subsidieverlening 'een soort doel op zich' geworden ${ }^{475}$ en waren het vooral de Limburgse intermediaire organisaties die grote invloed hadden op het economische beleid van de Provincie. In twee jaar tijd ging het roer om. Opnieuw speelden het samengaan van externe urgenties, de samenwerking tussen personen en de relatie met de rijksoverheid, een beslissende rol. Daarbij waren er drie omgevingsfactoren die in de periode 2003-2004 voor een externe druk zorgden: een aantal incidenten in de uitvoering van het beleid, een kritisch audit-rapport en een dreigend banenverlies in de Limburgse industrie.

Op de eerste plaats waren er verschillende incidenten. De Provincie had binnen haar economisch beleid verschillende uitvoeringsstructuren opgezet. Beleid moest 
ook uitgevoerd worden en de Provincie had verschillende constructies uitgedacht om de voornemens ook daadwerkelijk te realiseren. Bij een aantal van deze constructies ontstonden problemen. Zo pakte de reorganisatie van de VVV-structuur minder succesvol uit dan gedacht. Onder regie van de Provincie was geprobeerd om met de oprichting van een Limburgs Bureau voor Toerisme meer samenwerking af te dwingen tussen de drie regionale VVV's. In 2003 ging dit Bureau echter failliet ${ }^{476}$. Ook het idee om een transnationale Universiteit Limburg (tUL) op te richten, verliep moeizaam, met name door de uitblijvende financiële ondersteuning van de rijksoverheid ${ }^{477}$.

Het gevolg van deze incidenten was - ten tweede - dat het gevoerde economische beleid steeds meer ter discussie kwam te staan. Toen gedeputeerde van Economische Zaken, J.J.M. Tindemans (PvdA) in het voorjaar van 2002 bekend maakte zijn functie te verruilen voor het directeurschap van het vliegveld Maastricht-Aachen-Airport, ontstond er ruimte voor een nieuwe koers. Provinciale Staten speelden hier feilloos op in door per motie een audit af te dwingen naar de effecten van het gevoerde economisch beleid over de periode 1999-2002 ${ }^{478}$. Het rapport Audit economisch beleid Provincie Limburg 1999-2002 werd op 6 februari 2003 gepresenteerd, een maand voor de provinciale Statenverkiezingen. De hoofdconclusie was dat er in de periode 1999-2002 belangrijke stappen waren gezet, maar dat de effectiviteit van het beleid moeilijk aan te tonen was ${ }^{479}$. Het was deze conclusie en de eerder geconstateerde 'mindere geprononceerdheid' van het provinciaal beleid die de nieuwe gedeputeerde van Economische Zaken wilde veranderen.

Een derde en laatste omgevingsfactor die voor extra druk zorgde was de verslechterde economische situatie in Limburg. Met name de Limburgse industrie kreeg grote klappen te verwerken ${ }^{480}$. In het voorjaar van 2004 dreigde het autobedrijf NedCar - ooit gestart als DAF-fabriek en de beloofde nieuwe economische motor na de mijnsluiting - gesloten te worden. Voor de nieuwe portefeuillehouder Economische Zaken was dit een aanleiding om een nieuwe koers in te zetten.

Vijf van de zes gedeputeerden die deel uitmaakten van het in april 2003 gevormde nieuwe College van Gedeputeerde Staten, zaten ook al in het vorige College (periode 19992003). Het verschil was echter dat de meeste gedeputeerden een andere portefeuille hadden gekregen $^{481}$. M.J.A. Eurlings (CDA) werd gedeputeerde voor Economische Zaken. In het coalitieakkoord was de ambitie opgenomen om van Limburg een Europese technologische topregio te maken. Eurlings had het audit-rapport van februari 2003 goed gelezen. Hij vond dat hij in het economisch beleid op zoek moest gaan naar nieuwe samenwerkingspartners om de ambitie van technologische topregio te realiseren. Niet langer de intermediaire en vertegenwoordigende organisaties ${ }^{482}$ werden door hem als belangrijkste partner gezien, maar het internationale bedrijfsleven (DSM, Sabic, Océ), de kennisinstellingen (Universiteit Maastricht, Rheinisch-Westfälische Technische Hochschule Aachen) de ziekenhuizen (Academisch Ziekenhuis Maastricht, Orbis Medisch en Zorgconcern) en de grotere gemeenten (Maastricht, Venlo). Zowel bij de Universiteit Maastricht als het Academisch Ziekenhuis Maastricht waren in 2003 nieuwe bestuurders aan het roer gekomen. Het was gedeputeerde Eurlings die beide nieuwe bestuurders in contact bracht met DSM. De samenwerking tussen de universiteit, ziekenhuis en DSM achtte Eurlings cruciaal. 
Vlak na de totstandkoming van het nieuwe College van Gedeputeerde Staten maakte het petrochemische bedrijf Sabic bekend dat het haar Europese hoofdkantoor in het Limburgse Sittard zou vestigen ${ }^{483}$. Een jaar eerder had DSM haar bulkchemie aan dit Saoedische bedrijf verkocht. Daarmee werd voor DSM een lange transformatieperiode afgesloten ${ }^{484}$ en kon het bedrijf zich volledig gaan richten op de ontwikkeling van hoogwaardige biotechnologische en chemische producten en nieuwe materiaaltechnieken $^{485}$. Een deel van haar bedrijfsterrein werd ontwikkeld tot een onderzoekscampus waar nieuwe bedrijvigheid moest ontstaan. De Provincie Limburg zag hier in 2003 een kans om het bedrijf onderdeel te laten worden van haar strategie om Limburg als 'technologische topregio' te profileren. De keerzijde van deze verkoop van de petrochemie aan Sabic was dat DSM zich daarmee ook had 'losgekoppeld' van de regio. De klassieke vestigingsvoordelen als geografische ligging, bestaande infrastructuur, waren nu minder van belang voor het bedrijf ${ }^{486}$. Kennis en innovatie waren belangrijker geworden. Maar deze expertise kon ook in Delft, Basel of zelfs China ontwikkeld worden. DSM was met de verkoop van de locatiegebonden petrochemie, meer footloose geworden. Vandaar dat gedeputeerde Eurlings de samenwerking tussen DSM, universiteit en ziekenhuis zag als een mogelijkheid om het bedrijf aan de regio te binden.

De beide nieuw aangetreden voorzitters van het College van Bestuur van de Universiteit Maastricht, J.M.M. Ritzen en van het Academisch Ziekenhuis Maastricht, G.J.H.C.M. Peeters, zagen de potenties van een nauwere samenwerking met DSM. Ook de Raad van Bestuur van DSM en de directeur van DSM Limburg, J.J. Fransen van de Putte in het bijzonder, zagen meerwaarde in de samenwerking. De betrokken bestuurders vonden elkaar in een door de Provincie opgerichte Regiegroep Life Sciences. Men besloot vervolgens om gezamenlijk het idee uit te werken in een nieuw op te zetten onderzoekscampus. De Regiegroep kwam al snel erachter dat er een partner ontbrak, die een belangrijke rol kon spelen in het realiseren van de nieuwe ambities. Die partner was een oude bekende, het ministerie van Economische Zaken.

Het ministerie van Economische Zaken had zich - zoals eerder is geschetst - vanaf de tweede helft van de jaren '80 langzaam teruggetrokken uit de regio. Aan het begin van de 21e eeuw kwam men daar echter van terug. In de eerste concepten van de nieuwe Nota Ruimte (2004) van het ministerie van VROM was het regionale perspectief nieuw leven ingeblazen. Het ministerie van Economische Zaken reageerde hier op met de nieuwe regionale economische beleidsnota Pieken in de Delta (2004) ${ }^{487}$. Daarin werd gesproken van 'economische kerngebieden'. Na een stevige lobby vanuit de Provincie ${ }^{488}$ was Limburg als economisch kerngebied opgenomen. Samen met Brabant maakte het onderdeel uit van de 'technologische topregio Zuidoost-Nederland ${ }^{489}$. Daarmee was er voor de Provincie en bestuurders van de Regiegroep een kans gecreëerd, die met beide handen werd aangrepen om het technologiebeleid verder uit te werken.

\subsection{Het ontstaan van de Versnellingsagenda (periode 2004-2007 en verder)}

De ambitieuze doelstelling om van Limburg een technologische topregio te maken, was gelanceerd in het Coalitieakkoord van april 2003. Begin 2004 bevatte de ambitie nog 
weinig inhoud. Er waren wel twee opdrachten verstrekt aan externe adviseurs om het speelveld te verkennen. Wat werd verstaan onder een technologische topregio? Waar zou dit beleid zich inhoudelijk op moeten richten? Wie waren de belangrijkste spelers? Welke rol had de Provincie? ${ }^{490}$

De rapporten ${ }^{491}$ die in opdracht van de Provincie eind 2003, begin 2004 ter beschikking kwamen, vertoonden opvallende gelijkenissen met de conclusies die tien jaar eerder waren getrokken in de voorbereiding van het Regionaal Technologieplan. Nog steeds was de Limburgse economische structuur erg gevoelig voor conjunctuurschommelingen. Er was nog steeds sprake van een 'versnipperde kennisinfrastructuur ${ }^{492}$ en een gebrek aan denken vanuit de 'kennisketen ${ }^{493}$. Bovendien werden de potenties in de omliggende euregio 'onvoldoende benut ${ }^{494}$. Sterker dan ooit was het verplaatsen van productieactiviteiten van bedrijven naar de zogeheten lage lonen-landen ('delocalisatie') anno 2004 toegenomen ${ }^{495}$. Dit kwam door het relatief grote aandeel van de kapitaal- en arbeidsintensieve industrie in de Limburgse economie. De adviseurs bakenden het geografische gebied van de technologische topregio grofweg af als het gebied tussen de stedendriehoek EindhovenLeuven-Aken. Het advies was om vooral daarbinnen contacten te leggen tussen overheid, kennisinstellingen en met name de 'grotere spelers ${ }^{496}$ in het bedrijfsleven. De inhoudelijke focus zou moeten liggen op (bio)medische technologie, auto-industrie, voedsel en agribusiness en hoogwaardige materialen ${ }^{497}$.

Op 7 april 2004 werden de bevindingen besproken in de eerste vergadering van de door de Provincie ingestelde Regiegroep Life Sciences. Hierin waren DSM, de Universiteit Maastricht, het Academisch Ziekenhuis, het LIOF, de gemeente Maastricht en het ministerie van Economische Zaken op bestuurlijk niveau vertegenwoordigd ${ }^{498}$. In onderling overleg werden de ICT/elektronica, het domein van de life sciences en de auto-industrie, benoemd als speerpunten in het beleid. Vervolgens zou er 'een gemeenschappelijke agenda' opgesteld moeten worden. In de vergadering werd besloten om - net als bij het Technologieplan een extern adviseur te belasten met het opstellen van een plan van aanpak. P. Tindemans (GKS\&P) kreeg van de Provincie de opdracht om de partijen dichter bij elkaar te brengen en één gezamenlijke agenda met concrete projecten te maken $^{499}$.

Ondertussen was de Provincie Limburg ook op nationaal niveau actief. Het ministerie van Economische Zaken had in juli 2004 de nieuwe regionale nota Pieken in de Delta aan de Tweede Kamer gezonden. Hierin werd Nederland ingedeeld naar een zestal 'gebiedsgerichte economische perspectieven'. Zuidoost-Nederland (Midden- \& OostBrabant en geheel Limburg) was aangewezen als 'technologische topregio ${ }^{1500}$. Het ministerie had nooit onder stoelen of banken gestoken dat het zwaartepunt van het economisch perspectief voor dit gebied bij de regio Eindhoven lag ${ }^{501}$. Twee maanden daarvoor was de Nota Ruimte verschenen. Hierin was de regio Eindhoven expliciet aangewezen als Brainport ${ }^{502}$. Dergelijke benamingen en kwalificaties brachten grote financiële middelen met zich mee. Daarom was de Nota Ruimte, als het ging om mogelijk binnen te halen subsidies, voor de Provincie veel belangrijker dan de nieuwe nota Pieken in de Delta ${ }^{503}$. De Provincie Limburg had in de voorbereiding van de Nota Ruimte de boot gemist, maar hield bij de presentatie van de nieuwe economische nota een pleidooi om alsnog de regio 
Zuidoost-Nederland (in plaats van het oorspronkelijke concept 'zuidoost-Brabant') op te nemen als economische regio ${ }^{504}$. Het pleidooi werd gehonoreerd. Regionale indelingen speelden net als in de jaren ' 80 een belangrijke rol in de verdeling van rijkssubsidies.

In beide nota's lag de nadruk uitsluitend op die regionale aspecten die van 'nationaal belang' waren ${ }^{505}$. Op het schaalniveau van zuidoost-Nederland was door het ministerie van Economische Zaken daarom een Regiegroep ingesteld waarin een groot aantal partijen vertegenwoordigd waren waaronder zowel de provincies Noord-Brabant als Limburg. De samenwerking tussen beide provincies verliep erg moeizaam. ${ }^{506}$ Een gezamenlijk op te zetten imagocampagne mislukte nog datzelfde najaar ${ }^{507}$. Binnen de Limburgse Regiegroep liep het evenmin vlot. Men had grote moeite om te komen tot een selectie van projecten. Ook ontbrak het nog aan een algemeen kader van waaruit men inhoudelijk wilde opereren. Voor de Provincie was het dus spelen op twee schaakborden. Op nationaal niveau werd geschaakt met het ministerie van Economische Zaken en de provincie Noord-Brabant. Op provinciaal niveau moest de Provincie met nieuwe partners zorgen voor de goede Limburgse projecten.

Zelfs binnen de provinciale organisatie liep het niet vlekkeloos. Vanuit Provinciale Staten kwam er steeds meer kritiek op de ambitie om technologische topregio te worden. Waar bleven de concrete projecten? Waar was de samenhang tussen diverse beleidsterreinen? Waarom was de Limburgse passage in de Nota Ruimte zo marginaal? ${ }^{508}$ De kritiek van de Staten zette de politiek-ambtelijke verhoudingen onder druk. Gedeputeerde M.J.A. Eurlings (CDA) had in de beginperiode bewust gekozen voor een aantal nieuwe partners als DSM, Universiteit Maastricht, Academisch Ziekenhuis en de gemeente Maastricht. Hij legde bovendien zijn politieke prioriteiten bij het voeren van een technologisch sectorbeleid. Het gevolg was dat het in de jaren '90 ontwikkelde voorwaardenscheppend beleid op het gebied van onderwijs, toerisme, arbeidsmarkt en bedrijventerreinen, minder politieke aandacht kreeg. De provinciale ambtenaren kregen in hun externe contacten met diverse intermediaire organisaties te horen dat men de politieke aandacht voor alleen het technologiebeleid te beperkt vond. Het leidde er toe dat de politiek-ambtelijke verhoudingen onder druk kwamen te staan. Een aantal ambtelijke personele wisselingen waren het gevolg.

Toch kon gedeputeerde Eurlings de kritische geluiden van de intermediaire organisaties niet geheel negeren. Als antwoord op de kritiek werd er met zes intermediaire organisaties in april 2004 een gezamenlijk manifest opgesteld met daarin de intentie om samen verder te werken aan een 'florerende Technologische Topregio ${ }^{1509}$. Dit kon niet verhullen dat het nieuw uit te zetten economisch beleid vooral via de ingestelde Regiegroep zou gaan plaatsvinden en niet meer - zoals dat in de jaren ' 90 gebruikelijk was geweest via overleg met de Limburgse intermediaire organisaties.

In een bestuurlijk overleg in de zomer van 2004 tussen Provincie en staatssecretaris van Economische Zaken, C.E.G. van Gennip (CDA), concludeerden beide partijen dat projecten alleen niet voldoende waren. Er was een 'strategisch document' nodig om de projecten van een inhoudelijk kader te voorzien ${ }^{510}$. In september 2004 werd er in de Regiegroep een concept besproken getiteld Limburg: een toekomst met kennis ${ }^{511}$. In deze 
vergadering, eind september 2004, werd besloten om vooral het eigen Limburgse verhaal neer te zetten in plaats van te investeren in de samenwerking met Brabant.

De strategie was om bij het ministerie van EZ alles te zetten op een zogeheten 'fiftyfifty verdeling' van de beschikbare subsidies voor Brabant en Limburg. Die subsidies zouden worden ingezet op projecten binnen de economische sectoren van de autoindustrie, hoogwaardige materiaaltechniek en medische technologie. DSM zou daarin een soort 'vlaggenrol' voor de Limburgse belangen spelen, vergelijkbaar met de rol die Philips voor de regio Eindhoven vervulde ${ }^{512}$.

Binnen de Regiegroep werd voorts geconstateerd dat de benoemde speerpunten zich vooral concentreerden in Zuid-Limburg, met name de regio Maastricht-Geleen. Vanuit het oogpunt van verdelende rechtvaardigheid moesten de regio's Parkstad Limburg en Noord-Limburg in de strategienota 'meer profilering' krijgen ${ }^{513}$. Na de discussie met het ministerie over de status van Zuidoost-Brabant of Zuidoost-Nederland in de nota Pieken in de Delta, speelden nu de Limburgse subregionale indelingen opnieuw een belangrijke rol. Zoals Zuid-Limburg in de jaren '80 in de Perspectievennota werd onderverdeeld naar vier deelregio's, zo werd Limburg nu ingedeeld naar vijf regio's met elk een onderscheidend thema. Vooral de agrarische en logistieke sector waren het speerpunt voor Noord-Limburg. Besloten werd om de burgemeester van Venlo uit te nodigen als lid van de Regiegroep. Het thema ICT en Zorg werden voor de deelregio Parkstad benoemd als speerpunt ${ }^{514}$.

Toch zou het nog tot begin 2005 duren voordat er een echte stap vooruit werd gezet. Bij autofabrikant NedCar dreigde een verlies van werkgelegenheid. Bovendien had de regering besloten om een aantal Limburgse rijksdiensten te (re)centraliseren. Om de problemen van dreigend ontslag bij autofabrikant NedCar af te wenden, zette de Provincie zich vanaf 2006 actief in voor het oprichten van een mobiliteitscentrum om mensen van werk naar werk te begeleiden. Dit werd een $\operatorname{succes}^{515}$. De discussie over het vertrek van een aantal rijksdiensten uit Limburg was - in tegenstelling tot het verleden - een thema dat door de Provincie aan de Tweede Kamer werd overgelaten ${ }^{516}$. Met name de Limburgse Kamerleden uitten in diezelfde tijd steeds meer kritiek op de (verschillende) geluiden die vanuit Limburg kwamen ${ }^{517}$. De roep om te komen met 'één heldere visie' uit Limburg nam toe ${ }^{518}$. Toen ook nog duidelijk werd dat van de Limburgse projecten die waren ingediend voor subsidie bij het ministerie van EZ slechts één project was gehonoreerd, moest er iets gebeuren.

Op 7 maart 2005 was er opnieuw bestuurlijk overleg tussen staatssecretaris Van Gennip, de Limburgse gouverneur Van Voorst tot Voorst en gedeputeerde Eurlings. Er werd afgesproken dat er een 'taskforce' kwam, die een Versnellingsagenda voor de regio Limburg moest opstellen. Deze Versnellingsagenda ${ }^{519}$ moest bestaan uit een economische visie voor Limburg 2012, een route op weg daar naar toe en een actieplan voor de korte termijn ${ }^{520}$. De bestaande Regiegroep werd (tijdelijk ${ }^{521}$ ) omgevormd tot deze taskforce, aangevuld met twee externe adviseurs ${ }^{522}$.

Een eerste concept van de Versnellingsagenda werd op 1 juli 2005 gepresenteerd ${ }^{523}$. Drie zogeheten clusters van kracht stonden centraal: een cluster Chemie, een cluster 
Healthcare \& Cure en een cluster Agro-food ${ }^{524}$. 'Het zijn sectoren waar de recessie minder te voelen is en waar juist nu kansen benut worden', was de achterliggende gedachte van de leden van de taskforce ${ }^{525}$. In de zomerperiode werd het concept in een aantal regiobijeenkomsten met diverse partijen besproken. Er bleek een breed draagvlak voor deze aanpak te bestaan. De voorstellen van de clusters van kracht sloegen aan.

In de definitieve Versnellingsagenda die de Provincie op 12 oktober 2005 met de leden van de taskforce in Den Haag presenteerde, waren de drie clusters van kracht gehandhaafd ${ }^{526}$. Daarnaast was er een apart 'kansencluster' opgenomen rondom het door de regio Parkstad en gemeente Heerlen geagendeerde thema 'Nieuwe Energie'. Dit moest nog nader uitgewerkt worden. In totaal omvatten de clusters 16 grote projecten met een financiële omvang van 600 miljoen euro. Tweederde van deze financiering moest komen vanuit het bedrijfsleven zelf. Bij de regering werden twee financiële claims gelegd. Een claim van 31,6 miljoen euro uit het Fonds Economische Structuurversterking en een tweede claim van 22,2 miljoen euro uit het Gebiedsgericht Innovatiebeleid en andere rijksfondsen ${ }^{527}$.

In een reactie op de Versnellingsagenda benadrukte staatssecretaris Van Gennip vooral het belang van de onderlinge samenwerking in Zuidoost-Nederland. Zij stelde daarvoor vanaf 2007 een budget beschikbaar van 27 miljoen euro. In competitieverband met andere regio's konden projecten daaruit financiering krijgen ${ }^{528}$. Ook ministerpresident J.P. Balkenende (CDA) liet per brief weten de visie 'aansprekend' te vinden ${ }^{529}$. Op 18 oktober 2005 kreeg de in 2004 opgerichte Regiegroep Technologische Topregio een formele status als 'provinciale commissie ${ }^{1530}$. Het kwam nu aan op de uitvoering en realisatie van de Versnellingsagenda.

Alhoewel de Versnellingsagenda op een breed enthousiasme zowel in Limburg als in Den Haag kon rekenen, moest de uitvoering van de plannen nog georganiseerd worden. In september waren er al notities verschenen over het opzetten van een projectorganisatie ${ }^{531}$. Daarbij ging het vooral om de vraag of de uitvoering van de Versnellingsagenda niet volledig bij de regionale ontwikkelingsbank LIOF gelegd moest worden of bij een onafhankelijke opererende programmadirecteur met projectbureau. Het probleem met het LIOF was dat deze op dat moment nog zonder directeur zat ${ }^{532}$. Bovendien verliep het samenspel tussen de Provincie en het LIOF niet altijd vlekkeloos.

In de regiegroep-vergadering van 23 november 2005 werden knopen doorgehakt $t^{533}$. Er kwam een klein programmabureau onder leiding van een directeur voor de periode van twee jaar. Er werden trekkers per cluster van kracht aangewezen die verantwoordelijk waren voor de inhoud van de projecten. Het programmabureau zou zorgen voor de algemene ondersteuning, maar had tevens de taak te zorgen voor de acquisitie van nieuwe projecten $^{534}$. In januari 2006 stelde de Provincie de Regiegroep voor om het afdelingshoofd Economische Zaken van de gemeente Venlo, H. Hoogervorst, tot directeur te benoemen van de Uitvoeringsorganisatie Versnellingsagenda. Hij kwam op de loonlijst te staan van de Provincie Limburg maar zou verantwoording moeten afleggen aan de gezamenlijke Regiegroep ${ }^{53}$. De afspraak om het programmabureau te huisvesten bij het LIOF ketste af, zodat uiteindelijk het programmabureau niet alleen op de loonlijst van de Provincie kwam 
te staan, maar daar ook fysiek ondergebracht werd. Het versterkte het beeld dat, gezien het voorzitterschap van gedeputeerde Eurlings in de Regiegroep, de verantwoordelijkheid voor de Versnellingsagenda langzaam bij de Provincie Limburg kwam te liggen. De oorspronkelijke gedachte was altijd geweest dat de verantwoordelijkheid voor het succes of falen van de Versnellingsagenda zou liggen bij de gezamenlijke Regiegroep. De Provincie was zich hier terdege van bewust, gelet op het feit dat zij in de brief met de bekendmaking van de programmamanager benadrukte dat de uitvoeringsorganisatie vooral een organisatie 'voor en van de partners' was ${ }^{536}$.

Ondanks deze lastige provinciale positie bij de start van de uitvoeringsorganisatie, kwam er, mede door de inzet van de nieuwe programmamanager, veel waardering voor de provinciale aanpak. Niet alleen van de direct betrokken partners, ook van de Limburgse gemeenten, intermediaire organisaties en pers. Eind 2006 waren veruit de meeste projecten uit de Versnellingsagenda gestart, waren nieuwe projecten geformuleerd en kwamen rijksgelden van de nota Pieken in de Delta naar Limburg ${ }^{537}$. In december 2007 bedroeg het geraamde investeringsvolume van alle projecten 2,1 miljard euro. Van deze projecten bevond ongeveer een derde zich in de uitvoeringsfase ${ }^{538}$. Dat de Versnellingsagenda geen tijdelijke activiteit was, bleek wel uit het feit dat in de periode na 2007 de werkwijze gecontinueerd werd door het nieuwe College van Gedeputeerde Staten en een nieuwe gedeputeerde $\mathrm{e}^{539}$.

Met de Versnellingsagenda was een nieuwe werkwijze geïntroduceerd in het provinciaal economisch beleid. Op de eerste plaats was er selectiviteit in het beleid aangebracht door de prioriteit te leggen bij het technologiebeleid. Ten tweede werd er nauw samengewerkt met een aantal nieuwe economische partners. Vanuit een gedeelde verantwoordelijkheid was de Versnellingsagenda een poging de Limburgse economie structureel te versterken. Het provinciale beleid werd vormgegeven in direct 'partnerschap' met het bedrijfsleven, kennisinstellingen en ziekenhuizen. Het was een aanpak die moeizaam op gang was gekomen, maar die na de presentatie in oktober 2005 met veel enthousiasme in Limburg en Den Haag werd ontvangen. Ten slotte was de keuze voor een beperkt aantal inhoudelijke speerpunten, de zogeheten clusters van kracht, een gouden zet. Deze drie clusters waren slim gepositioneerd in de stedelijke gebieden van zowel Zuid-Limburg als Noord-Limburg.

In twee jaar tijd overtrof de agenda alle verwachtingen ${ }^{540}$. De enige verwachting die vooralsnog niet was ingelost, bleek de internationale samenwerking met Duitsland en België. In 2003 was de ambitie van technologische topregio nadrukkelijk in een internationale context geplaatst. Binnen de driehoek Eindhoven-Leuven-Aken zou meer samengewerkt moeten worden tussen bedrijfsleven, kennisinstellingen en overheden. Van deze grensoverschrijdende samenwerking was in 2007 nog weinig terecht gekomen. Daarvoor was er te veel energie gaan zitten in de positionering binnen ZuidoostNederlands verband en binnen Limburg zelf. Wel waren er eerste contacten gelegd tussen Provincie, DSM en de Rheinisch-Westfälische Technische Hochschule Aachen (RWTH). Ook de Universiteit Maastricht en de Université de Liège hadden nader kennis gemaakt met elkaar. De internationale dimensie van de Versnellingsagenda werd een van 
de prioriteiten van het nieuwe College van Gedeputeerde Staten dat in april 2007 zou aantreden. Dat dit niet vanzelf zou gaan bleek wel uit het rapport dat een commissie onder voorzitterschap van L.M.L.H.A. Hermans op 16 juni 2007 aan de regering en de Provincie aanbood. De titel was veelzeggend: De toekomst van Limburg ligt over de grens ${ }^{541}$.

\subsection{Hoofdlijnen en voorlopige conclusies}

De Provincie Limburg heeft in haar economisch beleid in de gehele periode 1962-2007 over weinig wettelijke bevoegdheden en instrumenten beschikt. Anders dan bijvoorbeeld in de ruimtelijke ordening of het welzijnsbeleid, kwam het er in het economisch beleid veel sterker op aan om partners te overtuigen, te committeren en te laten participeren in de provinciale voorstellen.

Tot het jaar 1962 kan er eigenlijk niet gesproken worden van een provinciaal economisch beleid. Het was het jaar waarin langzaam duidelijk werd dat Limburgs belangrijkste economische sector, de mijnindustrie, geen toekomst meer had. De Provincie Limburg werd na de aankondiging van de mijnsluiting geconfronteerd met een economische herstructureringsopgave van formaat. Provinciale Staten en diverse Limburgse belangenorganisaties drongen er bij het College van Gedeputeerde Staten op aan om zijn verantwoordelijkheid te nemen. Tot ver in de jaren '70 heeft de Provincie deze verantwoordelijkheid bij de rijksoverheid weten te leggen. Om toch aan de kritiek tegemoet te komen richtte het College van Gedeputeerde Staten diverse commissies op. De Provincie bestuurde in de jaren '60 en '70 via commissies. Deze commissies waren weinig effectief als het ging om de aanpak van de economische verslechtering. Wel boden zij voor de Provincie een eerste kennismaking met en bewustwording van de mogelijkheden van een provinciaal economisch beleid. De oprichting van de regionale ontwikkelingsmaatschappij LIOF in 1975 was daar een voorbeeld van, maar ook de samenwerking tussen het ministerie van Economische Zaken en de Provincie in het opstellen van een Perspectievennota voor Zuid-Limburg.

De provinciale rol veranderde met de komst van gouverneur J. Kremers. In 1978 onderhandelde hij met het kabinet Van Agt over de politieke consequenties van de Perspectievennota. Beiden zagen het terugdringen van de Limburgse werkloosheid als een gezamenlijke verantwoordelijkheid. Het belangrijkste instrument dat Kremers inzette was zijn ijzersterke onderhandelingskracht en een eenvoudige, maar zeer resultaatgerichte doelstelling: het wegwerken van de bovengemiddelde werkloosheid in Limburg ten opzichte van het nationale werkloosheidspercentage. In een jaarlijks 'politiek beraad' werd onderhandeld tussen de regering en het College van Gedeputeerde Staten. Twaalf jaar lang was de Perspectievennota Zuid-Limburg (het 'PNL-beleid') een prioriteit in Limburg. In dit kader werden de uitbreiding van de universiteit, de nieuwbouw van het academisch ziekenhuis, de komst van diverse kennisinstellingen en rijksdiensten gerealiseerd. Deze grote projecten zorgden voor een verbreding en versterking van de Limburgse economische structuur. Het PNL-beleid was een randvoorwaardelijk economisch beleid waarin de Provincie Limburg zelf de projecten aandroeg. De verschillende betrokken ministeries stelden vele miljoenen aan subsidies ter beschikking. 
Vooral de goede persoonlijke contacten tussen Provincie en rijksoverheid zorgden ervoor dat de PNL-formule tot 1990 overeind bleef. Vanaf de tweede helft van de jaren ' 80 trok het ministerie van Economische Zaken zich echter langzaam terug uit het regiobeleid. Het nationale regionale beleid kwam na de RSV-affaire steeds meer onder vuur te liggen. De politieke beraden tussen College van Gedeputeerde Staten en regering verliepen moeizamer. Toen de werkloosheid in Zuid-Limburg eind 1989 onder het nationaal gemiddelde lag, verviel daarmee de economische urgentie voor het gevoerde beleid.

In de eerste helft van de jaren ' 90 waarin diverse Limburgse bestuurders van functie en portefeuille wisselden, kreeg het provinciale ambtelijke apparaat meer macht; het economische beleid 'verambtelijkte'. Een van de eerste vormen van een sectorgericht economisch beleid - het Regionaal Technologieplan Limburg - bleef ondanks het feit dat het een van de vier Europese pilotprojecten op technologiebeleid was, een ambtelijk dossier. Naast dit technologie- en innovatiebeleid werd er beleid geformuleerd voor Onderwijs, Arbeidsmarkt, Toerisme en Bedrijventerreinen. De Provincie moest op eigen kracht verder en breidde haar economische beleidsactiviteiten uit. Diverse intermediaire Limburgse instellingen voerden voor de Provincie deze beleidskaders uit. De herkenbare rol die het Provinciaal Bestuur in de jaren ' 80 had gespeeld, vervaagde in de jaren ' 90 . Subsidieverlening - een van de beperkte instrumenten die de Provincie wel had - was een doel op zich geworden.

Gedeputeerde M.J.A. Eurlings (CDA) stelde het politieke primaat in het economisch beleid weer centraal. Niet langer de intermediaire en uitvoerende organisaties in Limburg waren de belangrijkste economische partners voor de Provincie, maar de grote bedrijven als DSM en kennisinstellingen als de Universiteit Maastricht en het Academisch Ziekenhuis. Bij deze organisaties waren rond 2003 nieuwe mensen in bestuurlijke posities gekomen. Gedeputeerde Eurlings bundelde deze nieuwe bestuurskracht in een Regiegroep die in 2005 de Limburgse Versnellingsagenda presenteerde in Den Haag. Een agenda met nieuw elan, een drietal regionale clusters van innovatiekracht en een aantal omvangrijke projecten. Het realiseren van Limburg als een technologische topregio was de ambitie waar men elkaar in vond. Selectiviteit aanbrengen in activiteiten en het realiseren van technologieprojecten was de nieuwe strategie. De formule sloeg aan en er werd handig gebruik gemaakt van de financiële middelen die in het nationale beleid waren vrijgemaakt voor de Nota Ruimte en de regionale economische nota Pieken in de Delta.

Al met al bleef het provinciaal economisch beleid sterk afhankelijk van de opstelling en de beschikbare financiële middelen van de rijksoverheid. Het is niet voor niets dat de opstelling van de rijksoverheid een cruciale factor vormde in de beschreven vier omslagmomenten. De afhankelijkheid van de rijksoverheid, en specifiek voor dit hoofdstuk de afhankelijkheid van het ministerie van Economische Zaken, is een constante in 45 jaar provinciaal economisch beleid. Ondanks het feit dat de economische structuur van Limburg anno 2007 minder gevoelig was geworden voor conjuncturele schommelingen, bleek de vernieuwing in het provinciaal economisch beleid juist op momenten van economische neergang een nieuwe impuls te krijgen. 



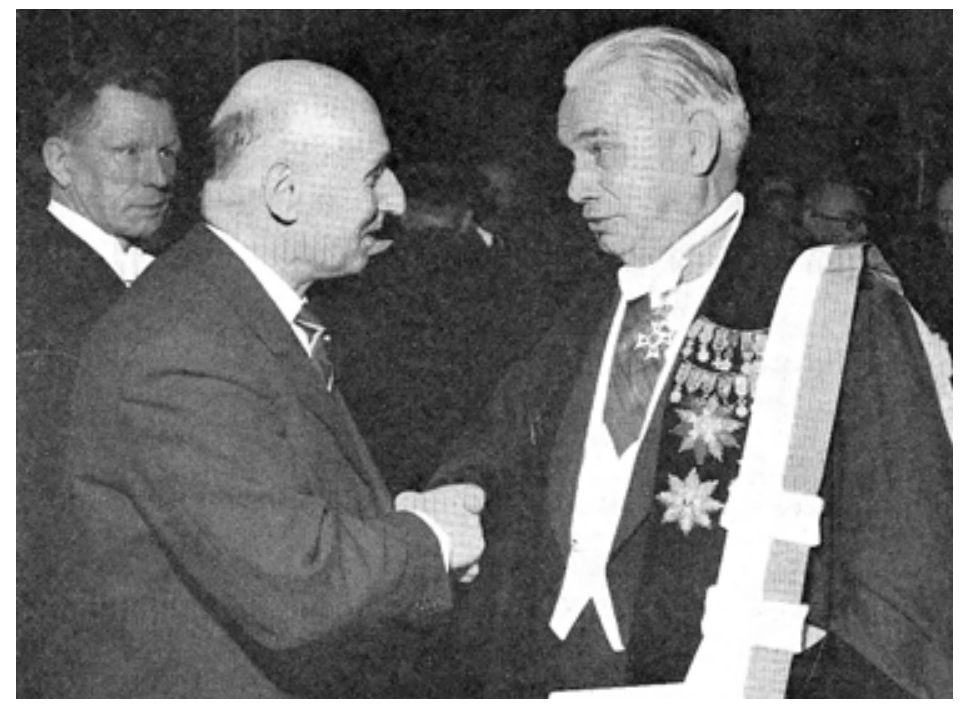

Gouverneur Houben schudt de hand van prof. dr. H. Gelissen bij diens Leuvense erepromotie in 1960. Gelissen was in de jaren '30 de drijvende kracht achter de oprichting van het Economisch-technologisch Instituut Limburg (E'til). Foto: Provincie Limburg.

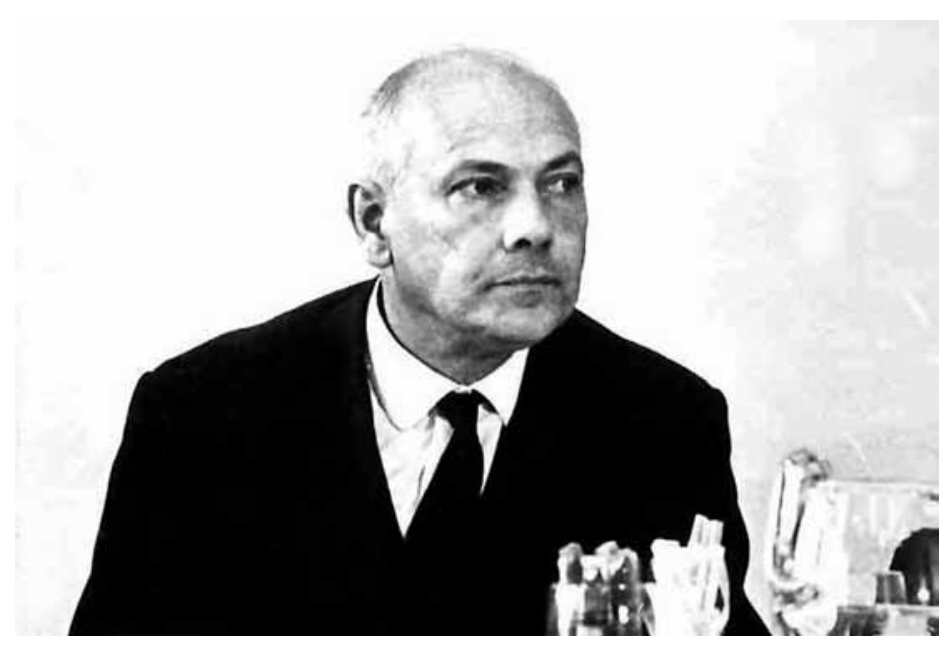

Minister van Economische Zaken, J.M. den Uyl (PvdA) brengt in mei 1965 een werkbezoek aan de Provincie Limburg om te overleggen met de werkgroep Van Rooy over de toekomst van de mijnindustrie. Foto: Provincie Limburg. 
Het vertrouwelijke rapport dat in 1965 onder voorzitterschap van gouverneur Van Rooy werd opgesteld en een belangrijke basis heeft gelegd voor de contouren van de Eerste Mijnnota van minister Den Uyl. Foto: Provincie Limburg.

\section{RAPPORT}

ianake de werkgelegenherideituatie in Zuid- en een deel van Yidhlen-limbleorg in verhasat met het vrangstuk van de indastrill le hecoriêntering van bet Mịngelied.

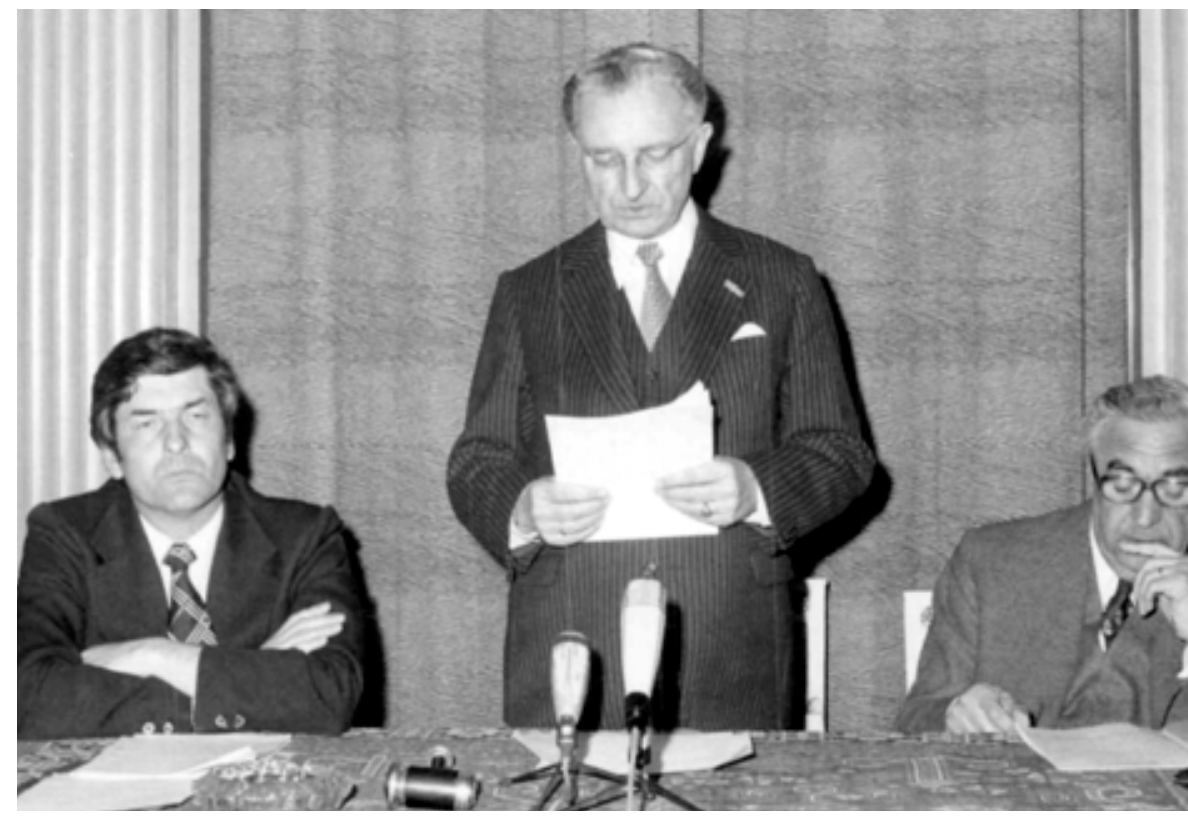

GouverneurVan Rooy leest een verklaring voor na het overleg met de nieuwe minister van Economische Zaken, R.F.M. Lubbers op 25 juni 1973. Foto: Provincie Limburg. 


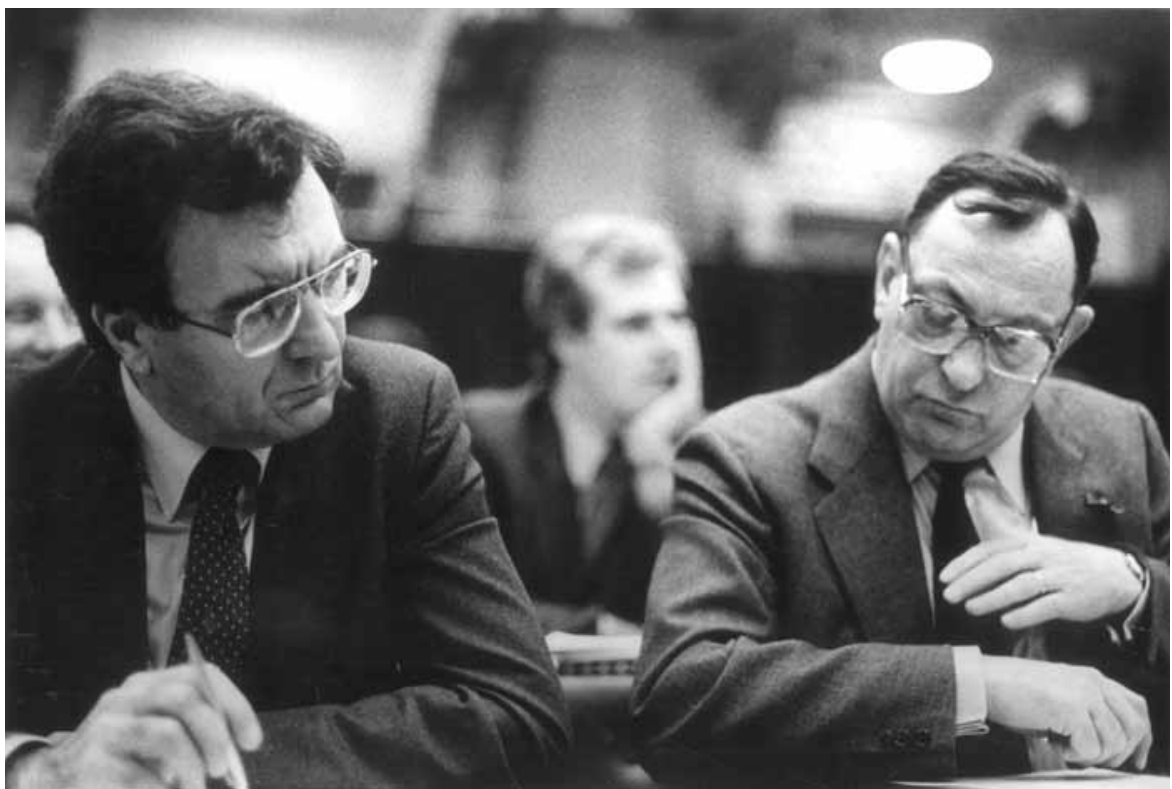

De twee drijvende krachten vanuit het Provinciaal Bestuur achter het Perspectievennotabeleid, gouverneur J. Kremers (CDA) en gedeputeerde K.W. Buck (CDA), hier in 1978 tijdens een zitting van bijzonder Tweede Kamercommissie Perspectievennota Zuid-Limburg. Foto: Bob Friedländer.

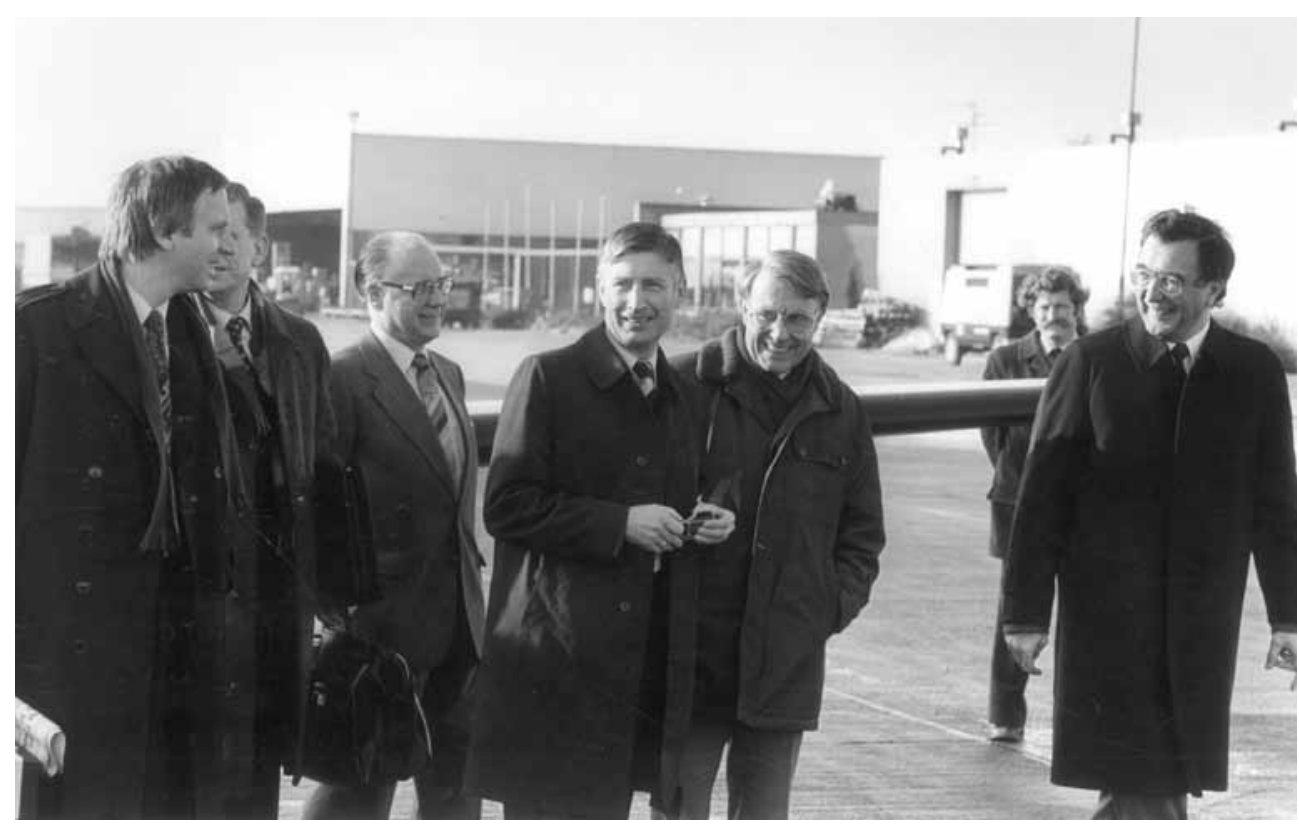

Voorafgaand aan de Provinciale Statenverkiezingen van maart 1978 brengt minister-president Van Agt een bezoek aan Limburg. Op vliegveld Beek wordt hij ontvangen door gouverneur Kremers (rechts). Foto: Frits Widdershoven. 


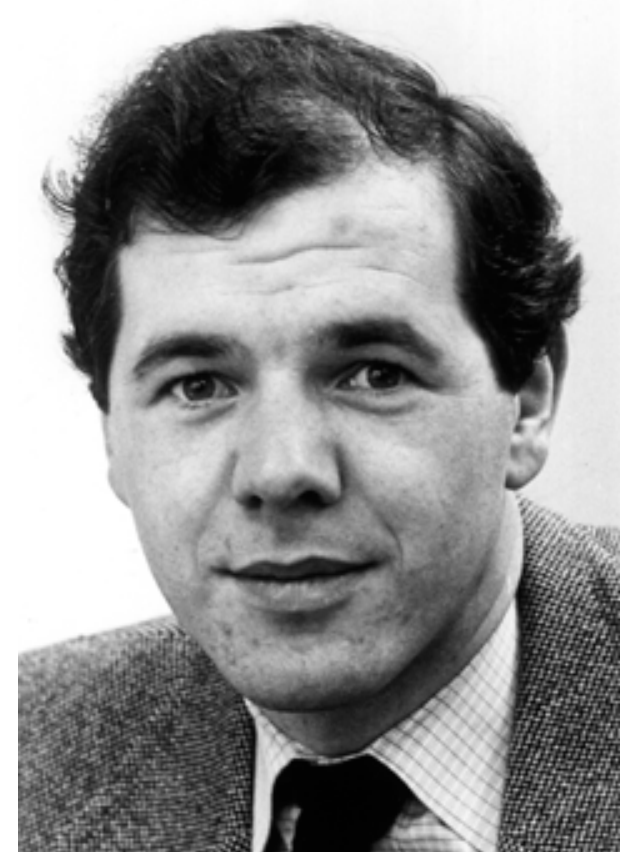

In 1980 werd Rien van Gendt door gouverneur Kremers aangetrokken als adjunct-griffier. Een speciale functie waarin Van Gendt volledig werd vrijgesteld om nieuwe (internationaal georiënteerde) projecten voor Limburg op te zetten. Foto: Paul Mellaart.
Provinciaal ambtenaar Alois Lohuis kreeg in de tweede helft van de jaren '70 de opdracht van gedeputeerde K.W. Buck om de Perspectievennota samen met het ministerie van Economische Zaken voor te bereiden. Foto: Provincie Limburg.

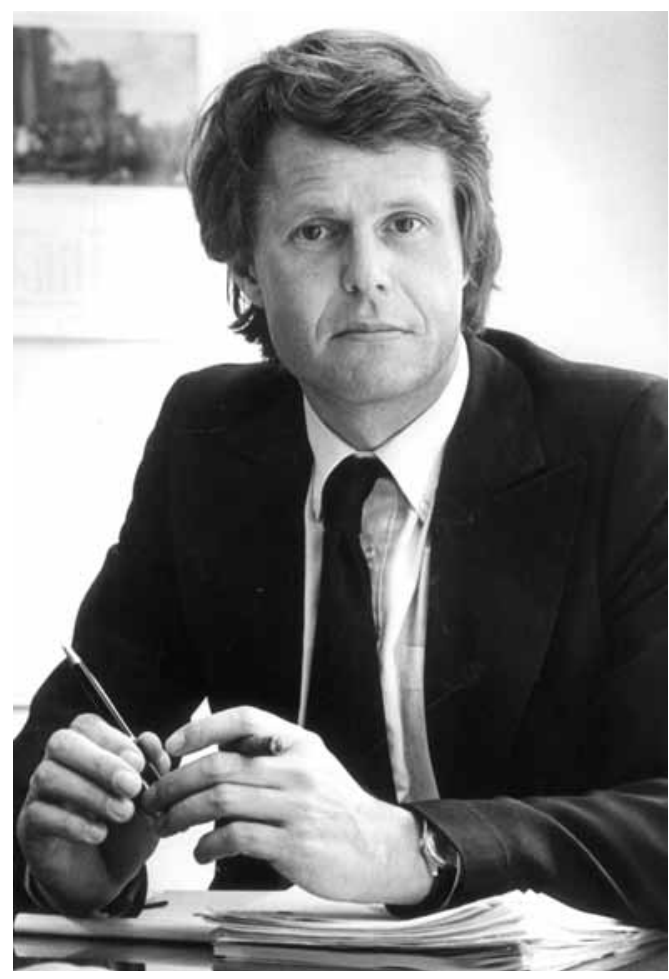




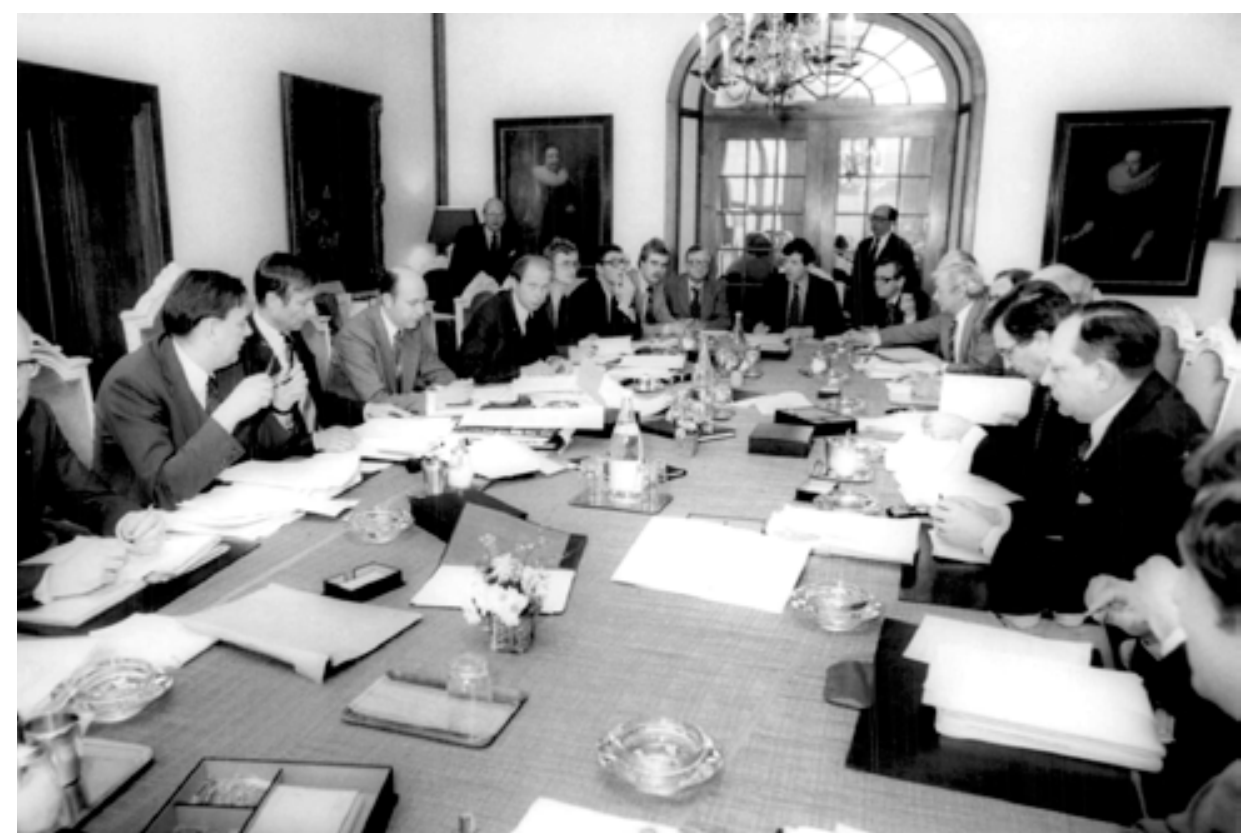

Maart 1978, overleg in het Catshuis tussen een deel van de ministerraad en het voltallige College van Gedeputeerde Staten van Limburg. Hier werd de politieke basis gelegd onder het Perspectievennotabeleid van de jaren '80. Foto: Fotobureau Hendriksen/Valk.

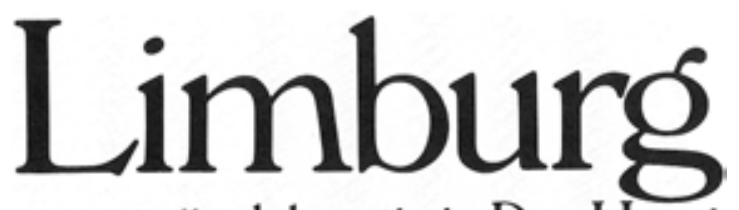

wenst zijn delegatie in Den Haag veel succes!
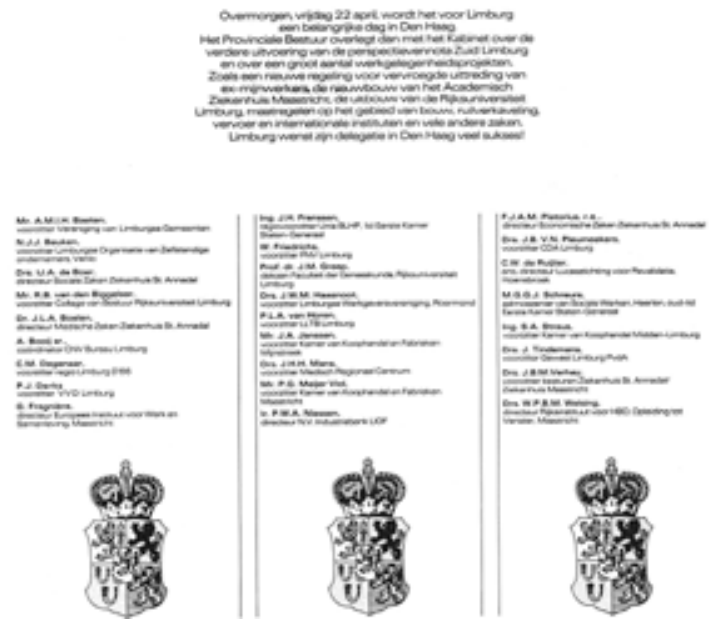

De Limburgse belangenorganisaties stonden begin jaren '80 eensgezind achter het Limburgse Provinciaal Bestuur. Foto: Provincie Limburg. 


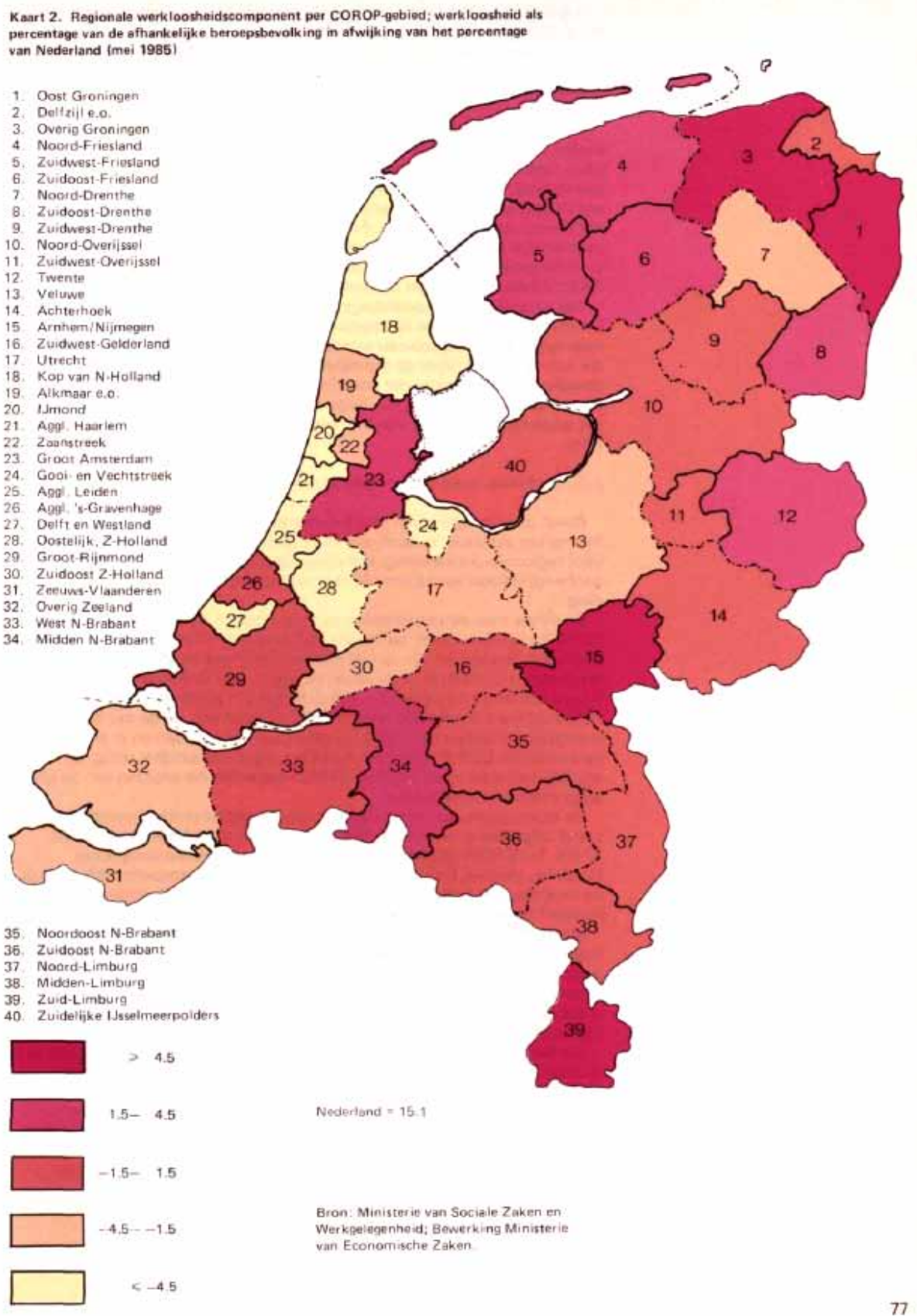

Het Perspectievennotabeleid kende een helder en eenvoudige doelstelling: het wegwerken van de regionale werkloosheid. De 'regionale werkloosheidscomponent' gaf het verschil aan tussen het regionale werkloosheidspercentage en het nationaal gemiddelde percentage. Figuur: Ministerie van Economische Zaken uit de Nota Regionaal Economisch Beleid 1986-1990. 


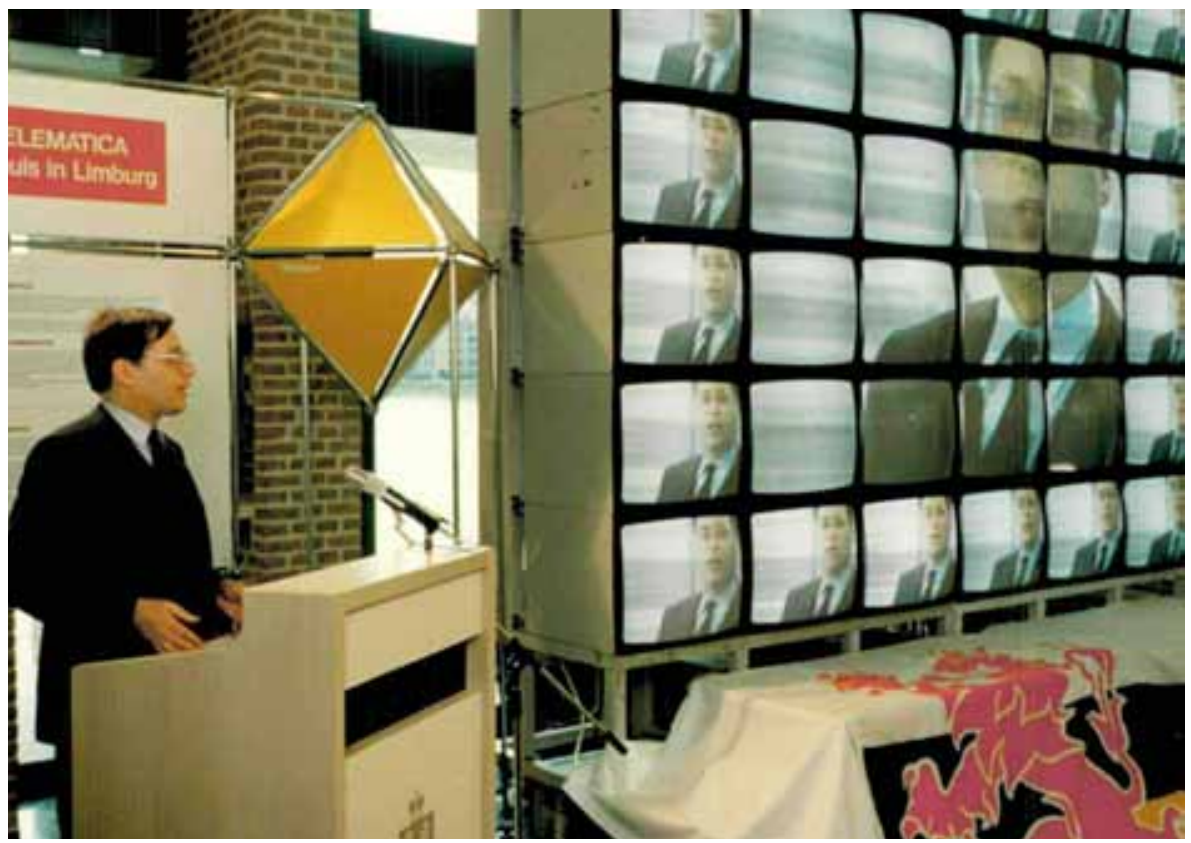

In de tweede helft van de jaren '80 werd er ook gewerkt aan een nieuwe 'technologiebeleid'. Minister van Onderwijs, Deetman, opent hier de conferentie over het onderwerp 'telematica', nu beter bekend onder de afkorting ICT. Foto: Rob Holthuis.

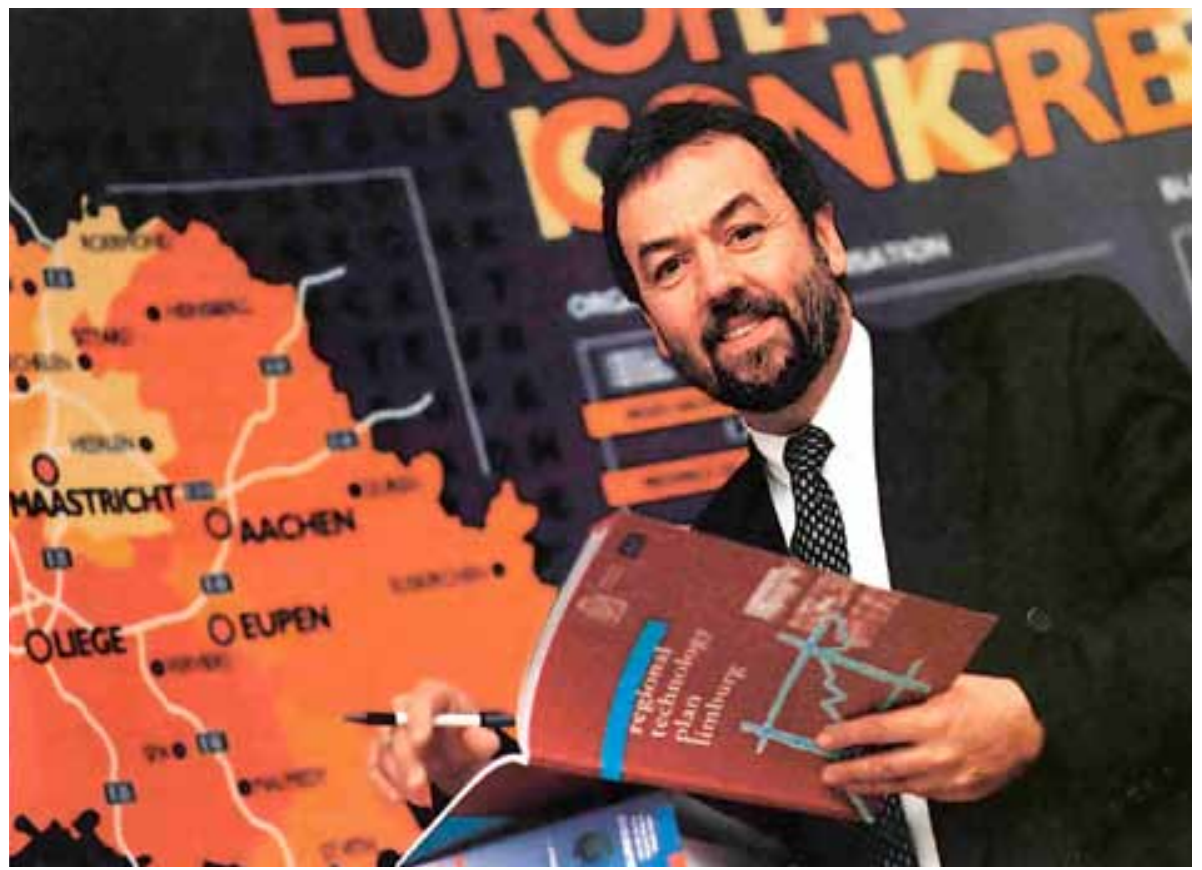

Het Regionaal Technologieplan Limburg was een Europees pilotproject en een uitwerking van het in de jaren '80 gestarte speerpuntenbeleid van de Provincie Limburg. Ambtenaar Jean Severijns was in 1998 projectleider. Foto: Frans Bastings. 


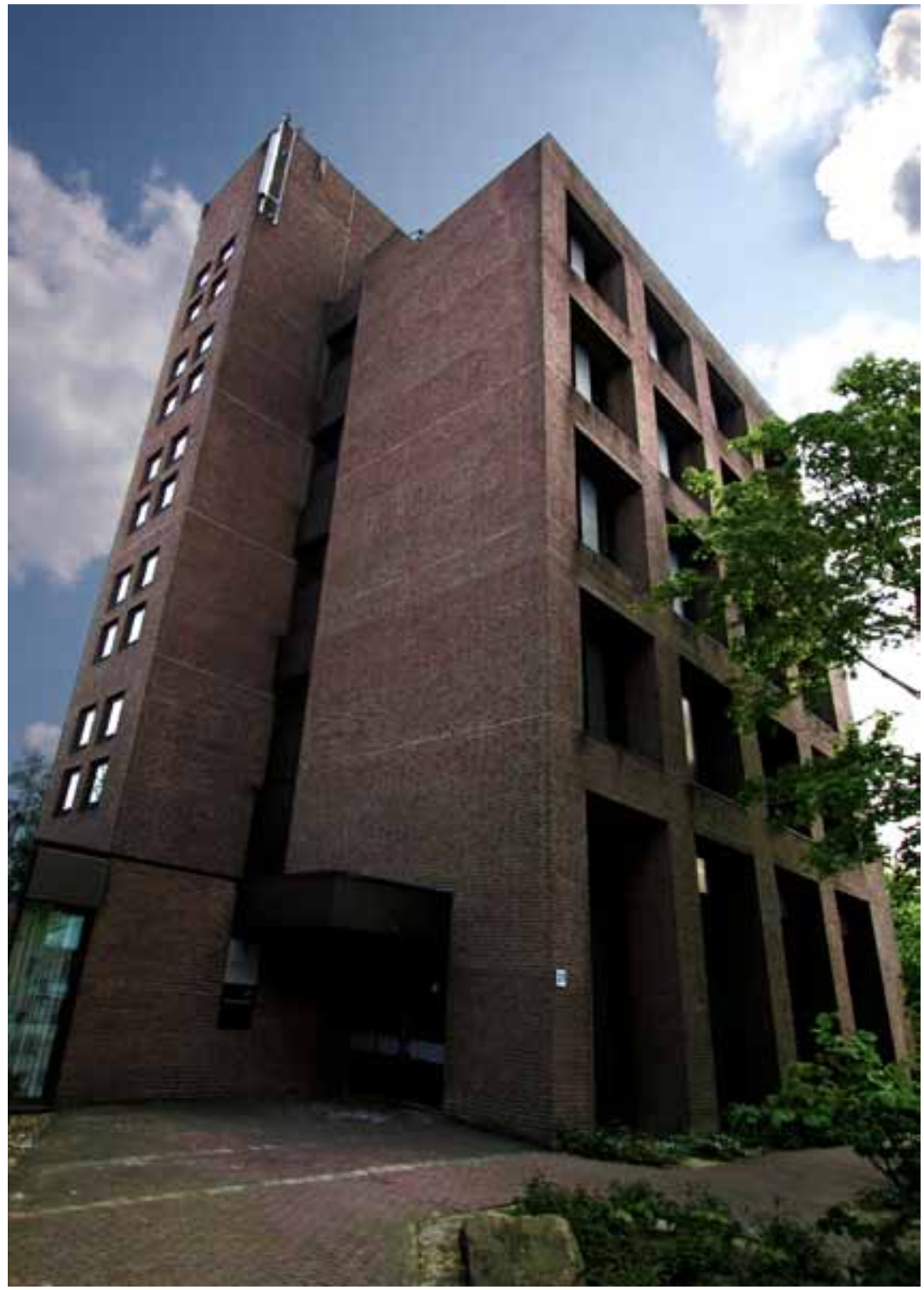

De Sittardse locatie van het agentschap Senter-Novem van het ministerie van Economische Zaken. Het agentschap (momenteel Agentschap.NL genaamd) was een van de vele intermediaire organisaties waar de Provincie Limburg in de jaren '90 zaken mee deed. Foto: Hendrik Jan van Elmpt. 


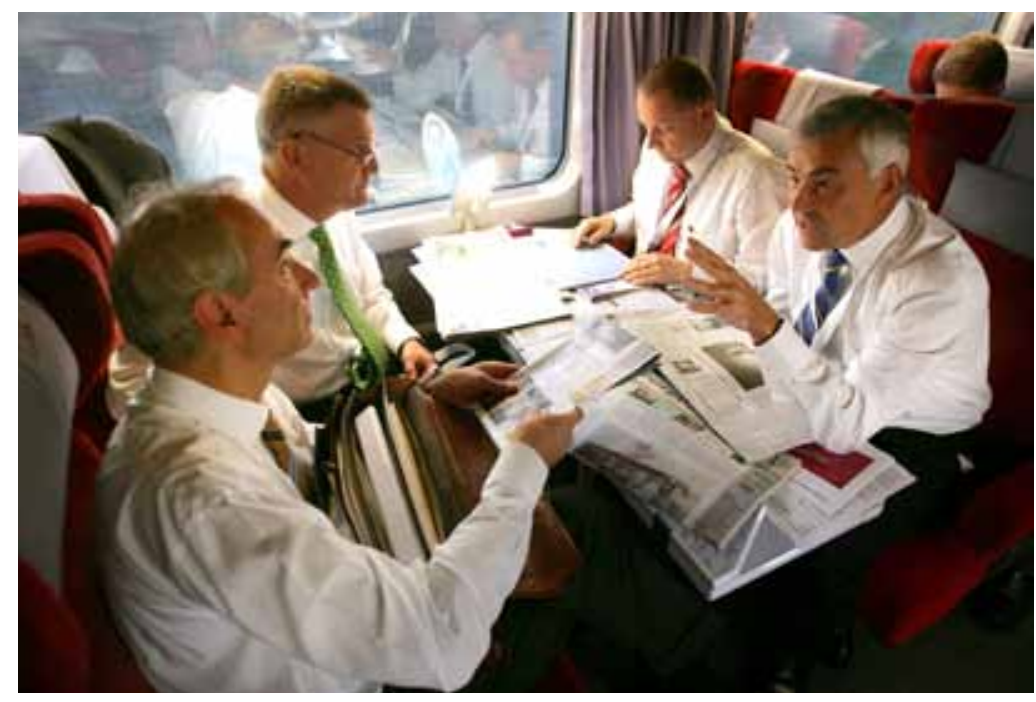

Gedeputeerde Martin Eurlings in gesprek met burgemeester Gerd Leers op weg naar Den Haag waar de gezamenlijke Taskforce op 12 oktober 2005 de Versnellingsagenda presenteerde. Linksboven gouverneur Léon Frissen. Foto: Provincie Limburg.

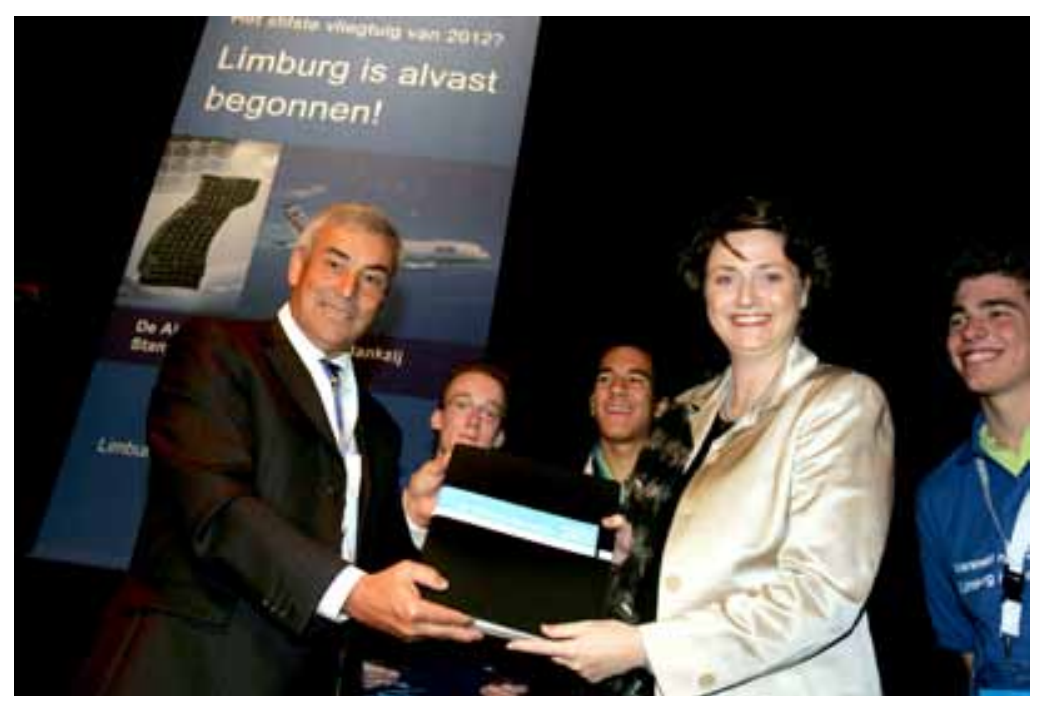

De Versnellingsagenda wordt aangeboden aan staatssecretaris van Economische Zaken, Karien van Gennip. Foto: Provincie Limburg. 


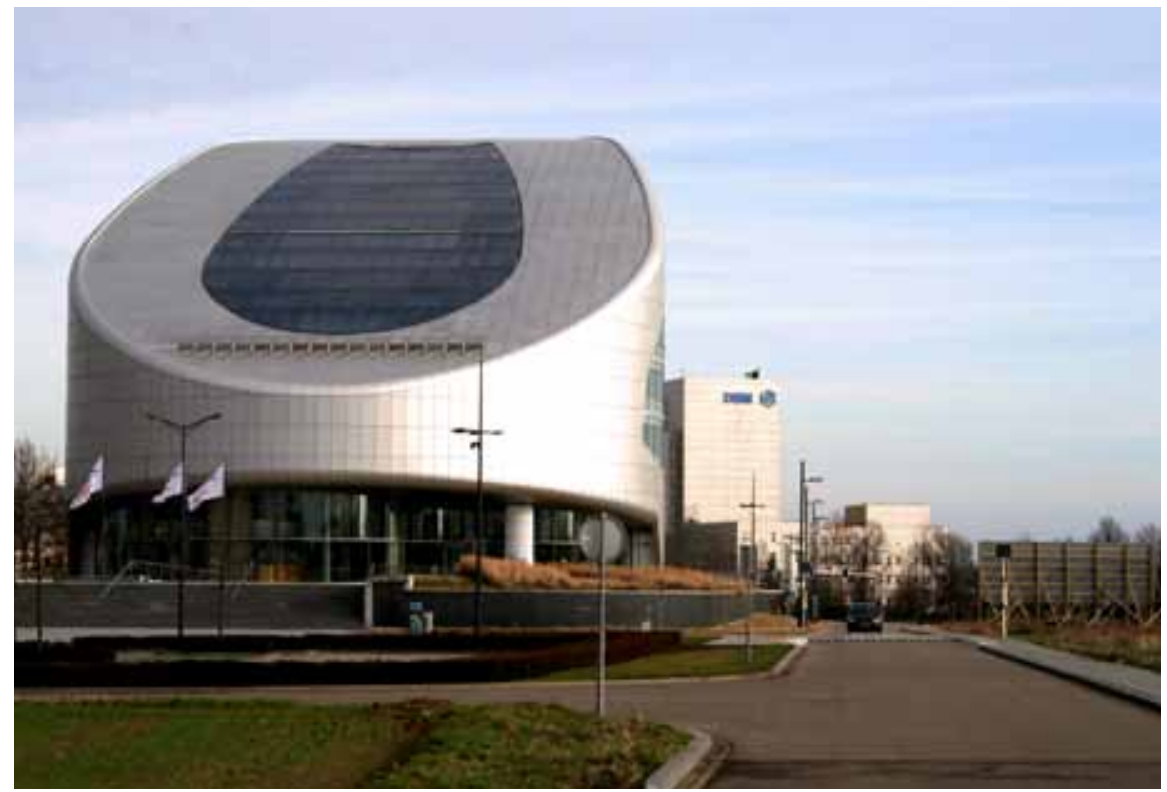

In 2003 verkocht DSM de zware petrochemie aan het Saoedische bedrijf Sabic. In juli van dat jaar maakte Sabic bekend haar Europese hoofdkantoor van Londen naar Sittard te verplaatsen. Foto: Hendrik Jan van Elmpt. 


\title{
4 \\ Provincie Limburg en het welzijnsbeleid \\ $1962-2007$
}

\begin{abstract}
"Het gaat in casu niet om een eenvoudig vraagstuk. Men worstelt ermee in alle provincies. Het is duidelijk dat geen een-pans-antwoord gereed kan worden gemaakt. Het is ook geen zaak, die met een naar buiten simpel lijkende formule kan worden afgedaan, noch een aangelegenheid waarbij een doorslaand succes kan worden behaald, indien zij financieel maar zo goedkoop mogelijk wordt gerund. Bij het zoeken naar de juiste structuur, in een zich ook wettelijk sterk gewijzigde situatie, moet men zich rekenschap ervan geven, dan niet alleen rationele, maar ook emotionele overwegingen in deze een rol spelen; dat in casu ook de verhouding overheid / particulier initiatief in het geding is, waardoor mede politieke opvattingen in de gedachtewisseling moeten worden betrokken." ${ }^{42}$
\end{abstract}

Hoofd 3e Afdeling (Welzijn) van de Provinciale Griffie J.H. Dassen, 6 november 1979

Bovenstaand citaat lijkt erg mysterieus. Waar heeft deze ambtenaar het over? Hij 'worstelt' ergens mee, 'succes' lijkt weinig verzekerd, hij zoekt naar een 'juiste structuur', wetgeving en geld zijn kennelijk van belang en bovendien spelen ook nog eens 'emotionele overwegingen' en 'politieke opvattingen' mee. Het citaat gaat over de kerntaak van zijn afdeling: het provinciale welzijnsbeleid. De worsteling van het afdelingshoofd is typerend. Het typeert de ongrijpbaarheid van het begrip 'welzijn' en de daaruit voortvloeiende discussies over de inhoudelijke afbakening, de bevoegdheden en verantwoordelijkheden, de structuren en financiering van het beleidsterrein. Het afdelingshoofd stond daar overigens niet alleen in. Engbersen \& Sprinkhuizen constateren: 'Beleidsmakers hebben steeds met het begrip welzijn geworsteld' (Engbersen \& Sprinkhuizen, 1999: 217).

In dit hoofdstuk wordt geanalyseerd hoe de Provincie Limburg in de periode 19622007 getracht heeft grip te krijgen op het welzijnsbeleid. Daarbij ligt de inhoudelijke nadruk op wat Hortulanus het specifiek welzijn noemt, namelijk de organisatie en inrichting van maatschappelijke zorg en maatschappelijke dienstverlening (Hortulanus, 1993: 6). Het algemene welzijnsbeleid, waarmee de sectoren onderwijs, gezondheidszorg, cultuur, recreatie, sociale zekerheid en volkshuisvesting worden bedoeld, zal hier niet aan bod komen. Dit specifieke welzijnsbeleid wordt volgens Peper gekenmerkt 'door improvisatie, door een onoverzienbaar aantal subsidieregelingen met even zo vele verschillende inhouden' (Peper, 1976: 124). Zo ook op provinciaal niveau. Twee elementen spelen een rol in het provinciale welzijnsbeleid.

Op de eerste plaats is de relatie tussen de Provincie Limburg en het zogeheten particulier initiatief van belang. Onder het particulier initiatief worden organisaties verstaan die bereid zijn een specifiek publiek belang te behartigen, zonder actieve inmenging van de overheid (zie Couwenberg, op cit. in Van Doorn, 1978: 25). Deze maatschappelijke organisaties komen op voor de belangen van bijvoorbeeld gehandicapten, vrouwen, minderheden, of patiënten in de gezondheidszorg. Maar ook muziekgezelschappen, 
verenigingen voor amateurtoneel of de lokale heemkundeclubs vallen hieronder. In de loop van de $20^{\mathrm{e}}$ eeuw is de relatie tussen deze organisaties en de Provincie Limburg via subsidieverlening steeds hechter geworden, maar daarmee ook complexer.

Ten tweede is de verhouding tussen rijksoverheid en Provincie Limburg in het welzijnsbeleid van belang. Deze interbestuurlijke relatie is voortdurend veranderd. Met name in de jaren ' 80 werd de onderlinge taakverdeling tussen ministerie en Provincie aanzienlijk gewijzigd. De Provincie Limburg was de eerste provincie waar met deze nieuwe taakverdeling werd geëxperimenteerd. De relatie van de Provincie Limburg tot enerzijds het particulier initiatief en de rijksoverheid anderzijds staat centraal in dit hoofdstuk.

Allereerst worden de ontwikkelingen van het nationale beleid (\$4.1) geschetst die invloed hebben gehad op het welzijnsbeleid van de Provincie Limburg. Vervolgens wordt kort stilgestaan bij de ontstaansgeschiedenis van het Limburgse welzijnsbeleid vóór 1962 (\$4.2). Het jaar 1962 is het startpunt van de analyse. Onderverdeeld naar vier periodes $(\$ 4.3 \mathrm{t} / \mathrm{m} \$ 4.6)$ wordt de veranderende provinciale rol in het Limburgse welzijnsbeleid voor de periode 1962-2007 beschreven. Daarbij zal worden gekeken naar de provinciale bevoegdheden en instrumenten, de relevante en invloedrijke actoren, de manier waarop geografische indelingen een rol spelen, en naar de politiek-ambtelijke verhoudingen. Ten slotte zullen de hoofdlijnen samengevat worden en zijn voorlopige conclusies te trekken (\$4.7).

\subsection{Ontwikkelingen in het nationale welzijnsbeleid ${ }^{543}$}

Het 'welzijnsbeleid' heeft in de afgelopen eeuw verschillende benamingen gekend. Eind $19^{\mathrm{e}}$ eeuw werd gesproken van de 'sociale kwestie' waarover in eerste instantie de armenzorg en charitas $^{544}$ (Neij, 1989: 26) en later ook de overheid, zich zorgen maakten over de ongewenste 'externe effecten' zoals armoede of werkloosheid (De Swaan, 1989: 13). Na 1945 was 'volksherstel' een veelgebruikte term (Schuyt, 1980: 39) gevolgd door het sterk ruimtelijk gedefinieerde begrip 'leefbaarheid' ${ }^{545}$. Ongeveer gelijktijdig kwam er in de jaren '60 aandacht voor het algemene welbevinden van burgers, oftewel 'welzijnszorg' (Hueting, 1989: 193). Dit welzijnsbegrip werd in de jaren '70 in een ideologische tegenstelling geplaatst tegenover het begrip 'welvaart'. Onder kabinetten Lubbers verloor het ideologische welzijnsbegrip haar betekenis en waren 'herstructurering' en 'decentralisatie' de kernwoorden in het beleid. In de jaren '90 was het begrip welzijn 'uit de gratie' (Hortulanus, 1993: 6). Beleidsmakers spraken liever van 'sociale vernieuwing' (Richelle, 1993: 138; Van der Pennen, 1995: 12), 'lokaal sociaal beleid' (De Boer, 1993: 168), 'sociale cohesie' (De Haan \& Duyvendak, 2002: 266) of de 'sociale pijler' (Hoenderkamp, 2008: 15). Meer recent heeft de term 'leefbaarheid' een wederopstanding ${ }^{546}$ gemaakt (Leidelmeijer \& Van Kamp, 2003: 9).

Achter al deze benamingen gaan verschillende betekenissen schuil, alsook sturingsvraagstukken en percepties over de rol van de overheid. Steeds opnieuw werd er naar nieuwe aangrijpingspunten gezocht in het overheidsbeleid op nationaal, provinciaal een gemeentelijk niveau. 
De Wijziging van de Armenwet (1912) wordt door diverse auteurs gezien als het begin van toenemende overheidsbemoeienis als het gaat om de sociale gevolgen van de snelle economische ontwikkelingen (Neij, 1989: 23; Hortulanus et.al., 1993: 7). Dit 'sociale beleid' werd tot die tijd vooral uitgevoerd door kerkelijke en particuliere instanties, die zorg en diensten verleenden aan armen en hulpbehoevenden. Met de nieuwe Armenwet legde de regering vast dat naast deze hulpverlening ook de overheid een rol had in de armenzorg, met name op het gebied van de coördinatie tussen diverse instanties. Er werd een wettelijke regeling ontworpen voor een 'Armenraad', waarin de verschillende kerkelijke en particuliere organisaties konden samenwerken. In de wet werd benadrukt dat het subsidiariteitsbeginsel voorop bleef staan. Hulp door kerkelijke en particuliere instanties was en bleef het belangrijkste, de rol van overheid was slechts die van 'aanvullende ondersteuning' (Neij, 1989: 23).

Deze aanvullende ondersteuning werd door de rijksoverheid vooral aan gemeenten overgelaten die hiervoor met name in de jaren '20 en '30 steeds grotere subsidies ontvingen. De lokale armenraden werden langzaam geïntegreerd in het gemeentelijk ambtelijke apparaat (idem.27-28). Zeker in de crisisjaren '30 ontstond er een nieuwe taakverdeling waarbij de overheid zich vooral richtte op de materiële hulpverlening en de kosten voor werkverschaffing. Het kerkelijk en particulier initiatief zorgde daarnaast voor het (immateriële) maatschappelijk werk. Steeds meer organisaties richtten zich op deze maatschappelijke dienstverlening. Zoveel zelfs, dat er al in 1940 sprake was van een 'woud van instellingen' en een 'overvoering van de markt' (idem.29). In verschillende provincies werkt een aantal instellingen al samen in een provinciaal opbouworgaan. Dit opbouworgaan coördineerde de verschillende activiteiten binnen de provincie ${ }^{547}$. Het waren de voorlopers van de naoorlogse provinciale opbouworganen (Peper, 1976: 67).

Wat betreft de nationale overheid werd in de eerste helft van de 20e eeuw een begin gemaakt met een aantal collectieve voorzieningen onder andere op het terrein van de sociale zekerheid. Het legde een basis voor 'een brede acceptatie van overheidsinterventies', die na 1945 zouden volgen (Hortulanus et.al., 1993: 7). Na de oorlog werkten de particuliere en kerkelijke organisaties samen in het orgaan Nederlands Volksherstel. Een gecoördineerde aanpak van de wederopbouw per provincie was de belangrijkste doelstelling. In de periode 1947-1952 kwamen hier de provinciale opbouworganen uit voort. Tot begin jaren '60 domineerden nog vooral de 'economische motieven' in het sociale beleid van opvolgende regeringen.

In 1952 was het ministerie van Maatschappelijk Werk opgericht, maar van een 'welzijnsbeleid' was geen sprake (idem.8). De zorg voor het welzijn van burgers was in de sterk verzuilde jaren '50 nog steeds toebedeeld aan de particuliere en kerkelijke organisaties. Het nieuwe ministerie ging zich wel nadrukkelijker bezig houden met de financiering van deze organisaties en probeerde een coördinerende rol te vervullen met de andere betrokken ministeries van Sociale Zaken en Binnenlandse Zaken (De Haan \& Duyvendak, 2002: 59-64). In de Industrialisatienota's van het ministerie van Economische Zaken waren gebieden aangewezen waar nieuwe industrieën gevestigd moesten worden. Het ministerie van Maatschappelijk Werk had hierop ingespeeld door geld beschikbaar te 
stellen voor de 'sociale begeleiding' bij de economische ontwikkeling van deze gebieden (idem.76-81). In de provincies werden hiervoor Commissies voor de Sociale Begeleiding opgericht.

Minister M.A.M. Klompé (KVP) pleitte eind jaren '50 voor een meer zelfstandige plaats van het sociale beleid in de ontwikkelingsgebieden (Hueting, 1989: 30, 51). Daarvoor moest zij haar beleid losweken uit de financiële en materiële inhoud zoals die was vormgegeven sinds de Armenwet. In de periode 1962-1963 werkte zij aan de Algemene Bijstandswet die de Armenwet van 1912 verving. Samen met de Werkloosheidswet (1952), de Algemene Ouderdomswet (1957) en de Wet Arbeidsongeschiktheid (1967) nam de rijksoverheid in die jaren de verantwoordelijkheid op zich voor het realiseren van een minimale financiële bestaanszekerheid (Engbergsen \& Sprinkhuizen, 1999: 225). Met de Bijstandswet werd financiële hulp losgekoppeld van 'immateriële dienstverlening' (Hueting, 1989: 60; De Haan \& Duyvendak, 2002: 89). Het ministerie van Maatschappelijk Werk ging zich begin jaren ' 60 binnen het welzijnsbeleid vooral richten op deze immateriële dienstverlening (Peper, 1976: 76). In hetzelfde jaar dat het kabinet over de Bijstandswet besloot, werd ook de Rijkssubsidieregeling Uitvoering Algemeen Maatschappelijk Werk (1962) van kracht. Deze regeling stelde inhoudelijke kwaliteitseisen aan de uitvoering van het maatschappelijk werk. Welzijnswerkers en opbouwwerkers die voor maatschappelijke organisaties actief waren, moesten voldoen aan kwaliteitscriteria waarbij het bezit van een diploma een van de eisen van deze professionaliseringsslag was.

In 1965 werd het ministerie omgedoopt in het ministerie van Cultuur, Recreatie \& Maatschappelijk Werk (CRM). Het ministerie ontwikkelde zich in tien jaar tijd tot een waar 'subsidiedepartement'. In de periode 1966-1976 liepen de uitgaven alleen al voor maatschappelijke dienstverlening op van 41 naar 948 miljoen gulden (Hortulanus et.al., 1993: 10). Al vrij snel werd in de tweede helft van de jaren '60 het sociale beleid voor de regionale ontwikkelingskernen verzelfstandigd tot het Bijzonder Regionaal Welzijnsbeleid $^{548}$. Voor de provincies waarin deze ontwikkelingskernen lagen - en na 1967 ook voor het herstructureringsgebied Zuid-Limburg - werden extra subsidies beschikbaar gesteld. Deze subsidies werden vooral besteed aan het realiseren van sociaal-culturele voorzieningen (sporthallen, gemeenschapshuizen, zwembaden) en 'doe-activiteiten' (sociale werkplaatsen, buurtwerk, bibliotheekwerk) ${ }^{549}$. Het welzijnsbeleid van de jaren '60 en '70 richtte zich niet langer op het bieden van financiële zekerheid voor mensen - dit was immers wettelijk geregeld in de Bijstandswet en diverse andere sociale wetten maar op het realiseren van sociaal-culturele voorzieningen en het aanbieden van diverse activiteiten.

Het Bijzonder Regionaal Welzijnsbeleid werd in de jaren '70 versoberd en uiteindelijk in 1984 beëindigd. Dit had alles te maken met de groeiende kritiek in de jaren '70 op het gevoerde welzijnsbeleid. De dissertatie van Bram Peper had in 1972 de discussie op scherp gesteld met de conclusie dat welzijnsorganisaties 'rijden in een soort niemandsland' ... 'zonder herkenbare identiteit of achterban' (Peper, 1976: 366). De door het kabinet Den Uyl (1973-1977) ingestelde Beraadsgroep Knelpunten, Harmonisatie Welzijnsbeleid en Welzijnswetgeving presenteerde in 1974 een vernietigende kritiek op het tot dan 
toe gevoerde welzijnsbeleid in haar invloedrijke Knelpuntennota. Hierin werd een beeld geschetst van de welzijnswereld als een 'onbeheerste wildgroei' van activiteiten, organisaties, regelingen, projecten en subsidies ${ }^{550}$. Een van de oplossingen dacht de regering te vinden in nieuwe wetgeving.

In 1977 werd de Kaderwet Specifiek Welzijn naar de Tweede Kamer gestuurd. De wet was een voorstel voor nieuwe taakverdeling tussen rijk, provincie en gemeenten. Er werd veel belang gehecht aan de decentralisatie van delen van het nationale welzijnsbeleid. Tevens was de wet een experiment waarbij de regering eerst in de praktijk wilde uitproberen hoe de wet zou uitpakken alvorens met een definitief wetsvoorstel te komen. Hiervoor werden tien (samenwerkende) gemeenten als proefgebied aangewezen. In 1979 werd de Provincie Limburg als enige provincie gevraagd hieraan deel te nemen. Het kabinet van Agt (1977-1981) nam de wet over maar legde een sterker accent op de beheersing van de kosten en het streven naar grotere doelmatigheid in het beleid (Hortulanus, 1993: 12). In de proefgebieden moesten hiervoor ervaringen worden opgedaan. Het ministerie zelf bundelde in 1978 ook de vele subsidieregelingen in één nieuwe Rijksbijdrageregeling Sociaal Cultureel Werk. Provincies en gemeenten konden daar op inschrijven wanneer zij vierjarenplannen opstelden (De Haan \& Duyvendak, 2002: 127). Het was het begin van de decentralisatie van het welzijnsbeleid.

Minister L.C. Brinkman (CDA) maakte hier in de jaren '80 echt werk van. In 1983 trok hij de Kaderwet Specifiek Welzijn in. De Haan \& Duyvendak constateren treffend: "Voor de oplossing - decentralisatie - was ... genoeg steun, maar voor het middel alomvattende wetgeving en centrale planning - niet meer" (De Haan \& Duyvendak, 2002: 129). In 1985 sloot de minister een convenant met de Provincie Limburg, vooruit lopend op de algehele decentralisatie van een groot aantal welzijnstaken twee jaar later. Een nieuwe Welzijnswet (1987) formaliseerde deze decentralisatie. In deze wet werd een groot deel van het welzijnsbeleid gedecentraliseerd naar provincies en gemeenten. Als vanaf 1 januari 1989 ook de financiële budgetten naar het Provinciefonds en Gemeentefonds worden overgemaakt, is het nationale welzijnsbeleid eind jaren '80 geen primaire rijksverantwoordelijkheid meer (Hortulanus, 1993: 14).

In de jaren '90 beperkte de rijksoverheid haar welzijnsbeleid tot het 'scheppen van een kader waardoor burgers zelfredzaam kunnen zijn' (Engbersen \& Sprinkhuizen, 1999: 219). Gemeenten kregen daarbinnen een steeds belangrijkere rol. Onder het kopje 'sociale vernieuwing' haalde de regering begin jaren '90 de banden aan met de gemeenten. Dat dit in eerste instantie gebeurde door het ministerie van Binnenlandse Zaken en niet het ministerie van Volkgezondheid, Welzijn en Sport (VWS) zoals het vanaf 1994 heette, was kenmerkend. Het ministerie ging zich vooral op de 'v' richten in haar nieuwe naamgeving: volksgezondheid (De Haan \& Duyvendak, 2002: 302).

Het grotestedenbeleid dat door het eerste kabinet Kok (1994-1998) geïntroduceerd werd, benoemde de 'sociale pijler' tot een van de drie kernonderdelen. Welzijnsbeleid was 'sociaal beleid' geworden. Daarin hadden vooral gemeenten een belangrijke taak. Provincies ondersteunden de gemeenten met de zogeheten steunfuncties. Dit waren coördinerende organisaties die dienstverlenend waren voor gemeenten en particulier 
initiatief op een specifiek terrein. Er bestonden steunfuncties voor het bibliotheekwerk, cliëntenorganisaties, cultureel werk, zorg, sport. De provincies financierden deze steunfuncties. Toch stonden deze steunfuncties op redelijke afstand van het lokale welzijnsbeleid en ondervonden steeds meer concurrentie van de steeds groter wordende welzijnsinstellingen. In de decentralisatie van de jaren ' 80 had minister Brinkman altijd de 'gescheiden verantwoordelijkheden' tussen taken en overheidslagen benadrukt (De Haan \& Duyvendak, 2002: 308).

Eind jaren ' 90 werd dit echter steeds meer als een probleem gezien en werd onder de noemer 'leefbaarheid' weer de samenhang tussen welzijn, zorg en de kwaliteit van de woonomgeving opgezocht. Deze aanpak kreeg aan het begin van de 21e eeuw een nieuwe impuls met de zogeheten wijkenaanpak. Leefbaarheid in de wijk was het vervolg van het grotestedenbeleid. Eind 2002 sprak de minister van Volkshuisvesting, Ruimtelijke Ordening en Milieu, H.G.J. Kamp (VVD), in een brief aan de Tweede Kamer over 50 probleemwijken waar een integrale leefbaarheidsaanpak nodig $\mathrm{was}^{551}$. Opvolgende ministers ${ }^{552}$ zetten deze wijkenaanpak voort. Daarmee was het welzijnsbeleid weer terug op het schaalniveau waar het ooit begonnen was: de wijk. Het ministerie sloot prestatiecontracten af met de betrokken gemeenten. Het was dan ook niet verwonderlijk dat in de nieuwe Wet Maatschappelijke Ondersteuning (2006) de gemeenten de primaire verantwoordelijkheid kregen voor de maatschappelijke ondersteuning van haar burgers. De provinciale overheid behield de taak voor de instandhouding van de provinciale steunfuncties, maar kende verder geen prominente plaats in de nieuwe wet. Welzijnsbeleid was een gemeentelijke aangelegenheid geworden. Net zoals de armenzorg, een eeuw tevoren, een taak voor de gemeenten was geworden.

\subsection{Limburgs welzijnsbeleid voor 1962}

In Limburg waren het vooral de katholieke organisaties en voorname Limburgers ${ }^{53}$ die aan het begin van de $20^{\mathrm{e}}$ eeuw veel initiatieven ontplooiden voor het groeiend aantal arbeiders in de industrie (Alberts, 1983: 248). In de periode na de Eerste Wereldoorlog nam de subsidiëring door de Limburgse gemeenten van het particulier initiatief toe (Pennings, 1992: 58-59554). Het Bisdom Roermond maakte zich in die tijd zorgen over de explosieve bevolkingsgroei en hoe deze groei opgevangen moest worden binnen de bestaande parochiestructuur (Alberts, 1983: 254; De la Haye \& Hamans, 2009: 433). In de nieuwbouw van kerken zocht het Bisdom samenwerking met de belangrijkste drager van de Limburgse industrialisatie, de mijnindustrie ${ }^{555}$. De zorg voor de arbeiders was in Limburg een primaire taak voor kerkleiders en mijndirecties. Zij hadden grote invloed op de maatschappelijke ontwikkeling van Limburg (Ubachs, 2000: 425).

Een provinciaal politieke visie op de armenzorg ontbrak. Sinds 1928 werden 'provinciale' zaken besproken in de Diocesane Commissie van Samenwerking. In deze commissie waren de belangrijkste Limburgse standsorganisaties vertegenwoordigd en werd er met het Bisdom Roermond overlegd over 'alle maatschappelijke signalementen' (Wijnen \& Koopmanschap, 1981: 72; De la Haye \& Hamans, 2009: 459). Roes \& Schreurs beschrijven deze Commissie van Samenwerking als 'het centrum van de maatschappelijke 
en politieke macht' (Roes \& Schreurs, 2002: 13). Ook de provinciale politiek kwam hier aan de orde waarbij 'van de Katholieke Volkspartij ... vervolgens [werd] verwacht dat het overeengekomen beleid in politieke daden werd omgezet' (idem.13). Diverse belangenorganisaties hadden ook een politieke vertegenwoordiging in de Limburgse Provinciale Staten. Een groot gedeelte van het particulier initiatief behoorde daarmee tot de katholieke zuil die aan de provinciale politiek de KVP en later het CDA hun 'electorale trouw' gaven (Spoormans, Welten \& Dittrich, 1990: 327). Tot begin jaren '60 speelden kerk, mijn en particulier initiatief deze maatschappelijke rol. Toch groeide ook de invloed van de overheid, met name na de Tweede Wereldoorlog.

In de periode 1947-1952 werden er in Nederland verschillende provinciale en gemeentelijke opbouworganen opgericht (Schuyt, 1980: 39). Deze kwamen voort uit de naoorlogse provinciale initiatieven van het Nederlands Volksherstel. In Limburg was het Limburgs Volksherstel op 12 februari 1946 in aanwezigheid van de Limburgse gouverneur W.G.A. van Sonsbeeck (KVP) opgericht. De Limburgse afdeling functioneerde als een samenwerkend 'particulier initiatief' bestaande uit 32 sociale en charitatieve organisaties ${ }^{556}$. Omdat vanaf de oprichting duidelijk was dat de nationale en provinciale Volksherstel-initiatieven een tijdelijk karakter hadden, werd hun taak op 6 augustus 1948 overgenomen door een nieuw op te richten stichting: het Provinciaal Opbouworgaan Limburg. Deze stichting wilde fungeren als 'primus inter pares' tussen het particulier initiatief en de overheid. Zij bood ondersteuning en coördinatie aan de maatschappelijke organisaties. De provinciale overheid voorzag zij van advies en onderzoek ${ }^{557}$. De Provincie Limburg subsidieerde het Opbouworgaan. Het Opbouworgaan werd in het begin, vanuit zowel de provinciale overheid ${ }^{558}$ - met name de Katholieke Volkspartij (KVP) - alsook het particulier initiatief, met de nodige argwaan bekeken ${ }^{559}$. Beide partijen vreesden dat het opbouworgaan een te grote macht zou krijgen in de provincie (Neij, 1989: 278; De Haan \& Duyvendak, 2002: 52).

Een van de eerste grote klussen van het Opbouworgaan was het uitvoeren van een 'sociaal onderzoek' in de regio Noord-Limburg. De Provincie Limburg had de kernen Gennep, Bergen, Helden en Venray voorgedragen bij de rijksoverheid als ontwikkelingsgebied. In elk ontwikkelingsgebied moest een sociaal onderzoek ingesteld worden (Den Haan \& Duyvendak, 2002: 76). Het Opbouworgaan wist met het uitvoeren van dit onderzoek zijn positie te versterken. Vervolgens werd via een provinciale plancommissie waarin ook de Provincie Limburg participeerde onder leiding van het ministerie van Sociale Zaken de geïnventariseerde sociale problematiek besproken. Gemeenten werden hierin niet betrokken (Peper, 1976: 112). Een Interdepartementale Commissie Ontwikkelingsgebieden moest na advies van de Provincie de plannen en subsidieverzoeken beoordelen.

Tegelijkertijd werkte het ministerie van Klompé aan de oprichting van verschillende provinciale adviesraden. In 1956 werden er ook in Limburg provinciale Raden voor de volksgezondheid, jeugd, cultuur en sport opgericht. Naast het Opbouworgaan waren deze Raden ingesteld om als aanspreekpunt te dienen voor de provinciale overheid. Deze zogeheten functionele Raden werden bemand door vertegenwoordigers uit het particulier 
initiatief en zorgden voor een belangenbehartiging van de organisaties naar de provinciale overheid. De Provincie Limburg subsidieerde ook deze Raden. Naast het opbouworgaan en de Raden had de Provincie Limburg een directie subsidierelatie met een groot aantal maatschappelijke organisaties. Dit waren vooral subsidies voor de instandhouding van deze organisaties. Van inhoudelijke bemoeienis was geen sprake. Deze instellingen dienden een algemeen maatschappelijk belang. Overigens is het subsidiëren van maatschappelijke organisaties tot op de dag van vandaag nog steeds een miljoenenpost op de provinciale begroting $^{560}$.

De provinciale rol tot 1962 was vooral subsidiërend. Het Bisdom, de mijnindustrie, het Opbouworgaan, de functionele Raden en de maatschappelijke organisaties waren de belangrijkste spelers in het naoorlogse 'welzijnsbeleid'. Het provinciale beleid was daarin begin jaren '60 stilaan uitgegroeid tot een omvangrijk subsidiebeleid. Samen met de begrotingspost 'volksontwikkeling en opvoeding' besloeg 'maatschappelijk werk' bijna een derde van de provinciale uitgaven in 1962. Dit was evenveel als er gezamenlijk voor Provinciale Waterstaat, verkeer en vervoer op de begroting stond ${ }^{561}$. Op deze manier was er sprake van een fijn vertakte machtsbalans tussen kerk en mijn, particulier initiatief en provinciale overheid. Daar kwam begin jaren '60 verandering in.

\section{Eerste omslagmoment: inhoudelijke bemoeienis (1962-1965)}

Begin jaren '60 trokken de mijnindustrie en de katholieke kerk zich in betrekkelijk korte tijd terug uit het maatschappelijke leven. De Staatsmijnen en particuliere mijnen leden vanaf 1962 voor het eerst structureel verlies. De mijnindustrie zag zich niet alleen genoodzaakt om een economische heroriëntatie door te voeren, maar versoberde meteen ook haar 'sociale beleid'. De subsidies voor sociaal-culturele projecten als de bouw van sporthallen, kerkenbouw, schouwburgen en muziekonderwijs namen na 1962 snel af (Messing, 1988: 93-96). In het verstrekken van deze subsidies hadden de mijnen altijd zeer nauw samengewerkt met de katholieke kerk $^{562}$. Een positief advies van de plaatselijke pastoor was voor een maatschappelijke organisatie of gemeente vaak een voorwaarde om subsidie te krijgen (idem. 93). Voor het Bisdom Roermond was op zijn beurt de samenwerking met de mijnen een manier om het opkomende socialisme 'de wind uit de zeilen te nemen' (Ubachs, 2000: 425).

Maar ook het Bisdom had het moeilijk. Het proces van ontkerkelijking was begin jaren '60 niet aan Limburg voorbij gegaan. Diverse maatschappelijke organisaties wilden af van hun confessionele grondslag. Ook de sexuele moraal veranderde, waarbij 1962 het jaar was dat de anticonceptiepil in brede kring ter beschikking kwam ${ }^{563}$. Het was het begin van het einde van de 'gloriejaren van de katholieke zuil' (Wijnen \& Koopmanschap, 1981: 14; Roes \& Schreurs, 2002: 13). Volgens Nissen gold voor Limburg in het bijzonder de wet van de uitgestelde reactie. Door de vertraagde reactie op de maatschappelijke ontwikkelingen eind jaren '50, traden de veranderingen daarna in verhevigde vorm op (Nissen, 1990: 303). De actieve inmenging in 'politieke' zaken werd langzamerhand een probleem voor het Bisdom met als gevolg dat de kerk zich terugtrok uit het maatschappelijk georganiseerde leven en een meer apolitieke positie innam (Bakvis, 1981: 121). Met de aankondiging van 
de mijnsluiting door minister J.M. den Uyl (PvdA) eind 1965 ontstond er niet alleen een economische urgentie, maar net zozeer een sociale urgentie. In de mijnstreken stegen de percentages echtscheidingen, drankmisbruik, uitkeringen, en arbeidsongeschiktheid explosief (Messing, 1988: 510-514). In zeer korte tijd viel de jarenlange 'beschermde omgeving $^{\prime 564}$ van kerk en mijn weg. De rijksoverheid kon niet langer op afstand blijven. De Provincie Limburg evenmin.

De inhoudelijke afstand die het Provinciaal Bestuur altijd had gehouden tot het particulier initiatief, was niet langer houdbaar. De mogelijkheden voor een inhoudelijke bemoeienis in het welzijnsbeleid werden ook gestimuleerd door de rijksoverheid. Met het in werking treden van de Algemene Bijstandswet in 1965 was er een wettelijk minimum van bestaanszekerheid gecreëerd. Dat schiep ruimte voor een beleid dat zich meer richtte op de 'immateriële' zaken. De aanpak van de sociale problematiek, die in Limburg was ontstaan rondom de sluiting van de mijnen, richtte zich juist op deze 'welzijnsaspecten'. Daar waar eerst de kerk en de mijn borg hadden gestaan voor de realisatie van diverse maatschappelijke activiteiten en sociaal-culturele voorzieningen, nam nu de overheid deze rol langzaam over. Het Provinciaal Bestuur ging steeds meer bepalen waar en welke activiteiten en voorzieningen plaats moesten vinden in Limburg. Het was een van de eisen in de subsidievoorwaarden van de rijksoverheid, die de Provincie verdeelde. De regeling Uitvoering Algemeen Maatschappelijk Werk van 1962 stelde bovendien kwaliteitseisen aan provinciale subsidieverstrekking. Wanneer een welzijnsinstelling subsidie wilde ontvangen, moest de organisatie gediplomeerde welzijnswerkers in dienst hebben. Met andere woorden, de rijksoverheid en de Provincie Limburg gingen zich voor het eerst met de inhoud en de kwaliteit van het welzijnsbeleid bemoeien. Daarvoor kreeg het Provinciaal Bestuur extra financiële middelen van de rijksoverheid. Het Provinciaal Bestuur speelde vanaf begin jaren '60 zeer actief in op deze beschikbare rijkssubsidies.

De verdeling van de rijkssubsidies gebeurde via een commissie. De Provinciale Commissie voor Sociale Begeleiding was op 14 november 1960 ingesteld ${ }^{565}$. Deze commissie was voortgekomen uit een commissie die zich bezig had gehouden met de sociale planning van het ontwikkelingsgebied Noord-Limburg ${ }^{566}$. Het College van Gedeputeerde Staten vond het echter van belang om het werkgebied te verbreden naar geheel Limburg. Men constateerde dat er niet alleen in Noord-Limburg welzijnsproblemen speelden, maar zeker ook ná 1965 in Zuid-Limburg. Bovendien kon de commissie een rol spelen als 'contactpunt' voor het in heel Limburg groeiend aantal welzijninstellingen ${ }^{567}$. De commissie werd voorgezeten door gedeputeerde P.J.C. Lebens (KVP). Het secretariaat was in handen van de provinciaal ambtenaar P.M.J.A. Tops. In de commissie zaten verder drie burgemeesters en een 12-tal belangenorganisaties waaronder de provinciale Jeugdraad en het Bureau Limburg van het ministerie Cultuur, Recreatie \& Maatschappelijk Werk. Maar het waren vooral voorzitter Lebens en secretaris Tops die veel invloed hadden op de te verdelen subsidies. Na een bescheiden start kwamen er vanaf 1962 nieuwe grote stromen rijkssubsidies naar Limburg ${ }^{568}$. Secretaris Tops was bovendien zeer bedreven in het napluizen van de diverse ministeriële begrotingen, op zoek naar nieuwe subsidiemogelijkheden. In de wandelgangen werd daarom ook wel gesproken van de 
'Commissie Tops'. Daarbij werd enerzijds subsidie gegeven aan de sociaal-culturele infrastructuur (sporthallen, gemeenschapshuizen, zwembaden) en anderzijds aan maatschappelijke activiteiten (sociale werkplaatsen, buurtwerk, bibliotheekwerk). Daarbij bemoeide de Provincie Limburg in de personen van Tops en Lebens zich actief met het vormgeven van het Limburgse welzijnsbeleid.

Veranderende omstandigheden, een nieuw welzijnsbeleid door de rijksoverheid en de persoonlijke inzet van gedeputeerde Lebens en secretaris Tops zorgden voor een nieuw omslagmoment in het Limburgse provinciale welzijnsbeleid. Niet langer de kerk, mijnindustrie of particulier initiatief gaven vorm aan het sociale beleid in Limburg, maar de provinciale overheid, met omvangrijke financiële steun van de rijksoverheid.

\subsection{Een voorzieningenbeleid (periode 1965-1979)}

In de Eerste Mijnnota van minister van Economische Zaken J.M. den Uyl (PvdA) stond slechts één alinea waarin 'begeleidende maatregelen met betrekking tot sociaal welzijn' werden toegezegd ${ }^{569}$. De paragraaf bevatte slechts drie regels en moest nog nader uitgewerkt worden. De Provincie Limburg greep deze formulering aan om een 'sociale blauwdruk' op te stellen. De nota Sociale Begeleiding van de industriële herstructurering van Zuid-Limburg was een van de eerste activiteiten in het formuleren van een provinciaal welzijnsbeleid (Schellen \& Philipsen, 1990: 259). Het Provinciaal Bestuur beschouwde de Mijnnota als een 'economische blauwdruk', die door Provincie voorzien werd van een 'maatschappelijke blauwdruk ${ }^{1570}$. Met het wegvallen van de mijnindustrie in Zuid-Limburg viel niet alleen een gehele economische sector weg, maar ook de sociale infrastructuur van ruim 45.000 mijnwerkers en hun gezinnen. Het sociale beleid van de mijnen was na 1962 al sterk versoberd, maar in de tweede helft van de jaren '60 werden deze activiteiten geheel beëindigd. Voor de provinciale overheid was het allerbelangrijkste dat 'de rust in het betrokken gebied [werd] bewaard ${ }^{1571}$. De Sociale Blauwdruk - zoals men de nota ging noemen - werd op 16 mei 1966 gepresenteerd en was opgesteld door de Provincie in nauw overleg met de mijnen en diverse instellingen (Messing, 1988: 496).

Het Provinciaal Bestuur pleitte bij de rijksoverheid voor een 'bijzonder beleid op maatschappelijk, cultureel en hygiënisch terrein' voor Zuid-Limburg ${ }^{572}$, net zoals dit sinds de jaren ' 50 bestond voor Noord-Limburg. Met name de sociale problematiek van de mijnarbeiders stond in de nota centraal, waarbij gesproken werd over de omscholing, vervroegde pensionering, opvang van inkomensverlies en het scheppen van nieuwe arbeidsplaatsen. Van het mijnwerkersgezin werd een 'meer-zelf-doen' mentaliteit gevraagd ${ }^{573}$. Daarbij was 'voorlichting' over allerlei zaken (budgetteringshulp, medisch advies, individuele werkbegeleiding ${ }^{574}$ ) het sleutelwoord. Een provinciale coördinatie 'zowel van beleid als van uitvoering' werd nodig geacht ${ }^{575}$. Het was een eerste vingeroefening van het Provinciaal Bestuur met een beleid dat verder ging dan de subsidiëring van maatschappelijke organisaties en sociaal-culturele voorzieningen. Het was een verkenning van een welzijnsbeleid voor de individuele problematiek van de mijnwerker. De Provincie legde de primaire verantwoordelijkheid voor de aanpak hiervan echter bij de rijksoverheid en vroeg om een 'bijzonder beleid' voor Zuid-Limburg. 
Dit bijzondere beleid werd in september 1966 gehonoreerd met het besluit van minister M.A.M. Klompé (KVP) om het herstructureringsgebied Zuid-Limburg vanaf 1967 onderdeel te laten maken van het Bijzonder Regionaal Welzijnsbeleid ${ }^{576}$. Met de subsidies die in dit kader beschikbaar kwamen, werden diverse projecten en activiteiten in de regio voor de werkloze beroepsbevolking gerealiseerd. Met deze werkwijze had de Provincie Limburg al vanaf de jaren '50 ervaring. In 1967 was het nieuwe bijzondere rijksbeleid voor Zuid-Limburg aanleiding om de bestaande Commissie voor Sociale Begeleiding om te vormen tot twee afzonderlijke commissies: de Commissie Projecten en de Commissie Activiteiten ${ }^{577}$. In de Commissie Projecten zaten het Opbouworgaan en het ministerie van Cultuur, Recreatie en Maatschappelijk Werk. Het particulier initiatief was vertegenwoordigd door de vier functionele $\operatorname{Raden}^{578}$. De Commissie Projecten verdeelde exploitatiesubsidies voor de bouw van diverse gemeentelijke sociaal-culturele voorzieningen als sporthallen, zwembaden, buurthuizen en bibliotheken. De Commissie Activiteiten bestond uit maar liefst 13 leden waarin vooral de confessionele vakorganisaties en welzijnsinstellingen waren vertegenwoordigd. Zij verdeelden de subsidies voor sociaalculturele activiteiten als buurtwerk, sociaal-psychologische hulpverlening, jeugdprojecten en ouderenhulp.

Beide commissies werden door gedeputeerde P.J.C. Lebens (KVP) voorgezeten. Gemeenten hoefden bij projecten nauwelijks eigen subsidiegelden bij te leggen. De rijksbijdragen en provinciale bijdragen liepen vaak op tot $85 \%$ van de kosten van een project $^{579}$. Een blik op de agenda's van de eerste vergadering van beide commissies maakt het verschil duidelijk. Op de agenda van de projecten-commissie stond een lijst van 35 voorzieningen die in voorbereiding waren om na subsidietoekenning gebouwd te worden ${ }^{580}$. Op de agenda van activiteiten-commissie stonden naast een aantal activiteitensubsidies vijf verzoeken voor extra bijdragen in exploitatietekorten van een aantal voorzieningen ${ }^{581}$. Wat de ene commissie aan nieuwe voorzieningen investeerde, moest de andere commissie (vaak in een latere fase) in de gemeentelijke exploitatie van diezelfde voorzieningen weer afdekken. In de periode 1967-1970 was er 8 miljoen gulden voor 'projecten' en 1,7 miljoen gulden voor 'activiteiten' beschikbaar ${ }^{582}$.

Toen vanaf 1 januari 1969 de subsidieregeling werd uitgebreid en in principe alle voorzieningen en activiteiten voor subsidie in aanmerking kwamen, kreeg het voorzieningenbeleid een forse impuls ${ }^{583}$. De coördinerende ambities en het pleidooi voor een integrale aanpak uit 'de sociale blauwdruk' waren langzaam overgegaan in de ambitie om zoveel mogelijk subsidies binnen te halen voor lokale voorzieningen. Het welzijnsbeleid van de Provincie Limburg was daarmee vooral een voorzieningenbeleid geworden. Overigens werden in heel Nederland in deze periode dit type 'overheadvoorzieningen' gerealiseerd (Nijkamp, Bouman \& Verhoef, 1986: 44; Hueting, 1989: 49; De Haan \& Duyvendak, 2002: 79). In de periode 1953 t/m 1974 werd er door de rijksoverheid met deze extra geldstroom meer dan 100 miljoen geïnvesteerd in 955 accommodaties $^{584}$. Limburg werd niet onderbedeeld. Alleen al voor Zuid-Limburg ontving de Provincie in de periode $1967 \mathrm{t} / \mathrm{m} 1976$ bijna 28 miljoen gulden ${ }^{585}$. In de loop van de jaren '70 kwam dit voorzieningenbeleid steeds meer onder druk te staan. 
Dat begon al vanaf 1 januari 1973 omdat de regering had besloten om Noord- en Midden-Limburg geen onderdeel meer te laten zijn van het Bijzondere Regionaal Welzijnsbeleid. Alleen het herstructureringsgebied Zuid-Limburg kreeg nog financiële steun van de rijksoverheid. Het ministerie van Cultuur, Recreatie en Maatschappelijk Werk (CRM) vond dat de voorzieningenstructuur in de regio's van voldoende omvang was. Er moest meer nadruk worden gelegd op 'activiteiten op het gebied van voorlichting, vorming en onderwijsbegeleiding'. Bovendien moest er een versterking van 'deskundige mankracht op het gebied van samenlevingsopbouw, maatschappelijke dienstverlening en volksgezondheid' plaatsvinden ${ }^{586}$. Eerder al had het ministerie geprobeerd om de subsidies voor sociaal-culturele voorzieningen in Limburg te beëindigen en uitsluitend nog activiteitensubsidies te verstrekken ${ }^{587}$. Dit was na een negatief advies van de Interdepartementale Commissie niet gelukt. Wel adviseerde de Commissie dat de middelen selectiever moesten worden ingezet, wat voor Limburg betekende dat slechts één of hooguit enkele projecten in de Oostelijke en Westelijke Mijnstreek subsidie konden krijgen $^{588}$.

Voor de periode 1973-1976 betekende dit dat er 8 miljoen gulden beschikbaar kwam voor Zuid-Limburg voor 'activiteiten' en slechts 3 miljoen gulden voor 'projecten'589. Deze 'korting' van het ministerie van CRM werd door het Provinciaal Bestuur handig opgevangen met de beschikbare investeringssubsidies van het ministerie van Sociale Zaken ${ }^{590}$. Zo konden ook projecten buiten het geografische gebied van de Oostelijke en Westelijke Mijnstreek doorgang vinden. Toch drong bij het Provinciaal Bestuur wel het besef door, dat een selectieve en geplande inzet van middelen nodig was. Dit kwam door de toenemende verzoeken om subsidiëring van exploitatietekorten en garantstellingen door gemeenten. Vanaf 1974 professionaliseerde de Provincie haar subsidiebeleid en vond de beoordeling van welzijnsprojecten plaats op basis van scherpere criteria ${ }^{591}$. Ook de Commissies Projecten en Activiteiten werden in datzelfde jaar gereorganiseerd tot één nieuwe commissie: de Provinciale Commissie Planning Sociale Ontwikkeling Limburg. De jarenlange voorzitter van beide commissies, gedeputeerde P.J.C. Lebens, nam afscheid van de provinciale politiek. Gedeputeerde L. Stals (KVP) volgde hem als voorzitter op. De secretariaatsrol werd nog steeds vervuld door P.M.J.A. Tops. De nauwe banden die de Provincie in de loop van de jaren via deze commissie met het particulier initiatief en de functionele Raden had ontwikkeld, zorgde ervoor dat men elkaar stevig in de greep hield. Er zijn diverse pogingen geweest van het Provinciaal Bestuur om het subsidiebeleid af te bouwen $^{592}$. Met name de functionele Raden verkregen in de loop van de jaren '70 steeds meer macht en benutten hun politieke contacten voortdurend om invloed te behouden. De macht in de commissie verschoof daarmee in de jaren '70 meer van de Provincie naar het particulier initiatief.

In de jaren '70 werkte de Provincie samen met het ministerie van Economische Zaken aan het opstellen van een Perspectievennota Zuid-Limburg (zie hoofdstuk 3). Het was de ambitie van Provincie en ministerie om een integrale nota voor Zuid-Limburg op te stellen waarin de economische, ruimtelijke en sociale doelstellingen geformuleerd moesten worden. Het was een nieuwe kans - na de Sociale Blauwdruk - om het welzijnsbeleid op 
een nieuwe manier vorm te geven. In de voorbereiding van de Perspectievennota werd een apart hoofdstuk gewijd aan de 'sociaal-culturele ontwikkelingen' in Zuid-Limburg. Een nieuw element was dat hier gewerkt werd met het formuleren van een zo concreet mogelijke doelstelling voor nieuw beleid. Dat bleek een moeilijke opgave. Men kwam niet verder dan de voorlopige doelstelling van 'het bevorderen van het maatschappelijk, cultureel en lichamelijk welzijn van de bevolking ${ }^{1593}$. Vernieuwend was ook het type projecten die onder de Perspectievennota werd ingebracht. In 1976 al had de ambtelijke groep die de Perspectievennota voorbereidde, mogelijke activiteiten en initiatieven geïnventariseerd voor het sociaal-culturele beleid. Een lijst van ruim 30 projecten was opgesteld, zoals een betere samenwerking tussen de sociale diensten, uitbreiding van het buurtwerk, de begeleiding jeugdige risicogroepen, oprichting van diensten voor geriatrische zorg en de uitbouw van preventieafdelingen in de geestelijke gezondheidszorg ${ }^{594}$. Dit waren andersoortige projectvoorstellen dan de ambtelijke afdeling tot die tijd had voorbereid. Niet langer sporthallen, kruisgebouwen of gemeenschapshuizen, maar 'probleemgerichte activiteiten' met aandacht voor 'kwetsbare doelgroepen' was de insteek.

In de ambtelijke organisatie waaide een nieuwe wind. Het afdelingshoofd van de 3e Afdeling, J.H. Dassen had midden jaren '70 ondersteuning gekregen van een jonge ambitieuze ambtenaar die praktijkervaring had vanuit het Rotterdamse welzijnswerk en het opbouwwerk in de Limburgse Oostelijke Mijnstreek. Samen met zijn afdelingshoofd, zou M.A.C. Schellen jarenlang het ambtelijke gezicht worden van het provinciale welzijnsbeleid in de jaren ' 80 en ' 90 . Zij benutten de Perspectievennota om het welzijnsbeleid meer inhoud te geven. Maar er was meer nodig. De in de jaren '70 gegroeide macht van het particulier initiatief - de functionale Raden - moest eerst doorbroken worden. De professionalisering van de subsidieverlening midden jaren '70 was een eerste stap geweest om orde te scheppen in de veelheid aan provinciale subsidies aan het particulier initiatief.

Eind 1978 werd er een landelijk evaluatieonderzoek uitgevoerd naar het Bijzonder Regionaal Welzijnsbeleid in opdracht van het ministerie van Cultuur, Recreatie en Maatschappelijk Werk. Het uitvoerende onderzoeksbureau sprak ook met de Provincie Limburg over haar ervaringen met het gevoerde welzijnsbeleid van het afgelopen decennium. De twee geïnterviewde provincieambtenaren - Schellen was een van die ambtenaren - spraken van een 'rommelig beleid', dat vooral gericht was op het realiseren van diverse maatschappelijke voorzieningen, waarvan er nu teveel waren. Bovendien was er in de verschillende Commissies Sociale Begeleiding nauwelijks sprake geweest van een objectieve keuze voor projecten en domineerden politieke afwegingen. Wat betreft de Commissie Activiteiten was er in de ogen van de ambtenaren, een zeer versnipperd voorlichtingswerk door welzijnsinstellingen gesubsidieerd, waarbij instellingen graag graaiden 'in de grabbelton' van provinciale subsidiepotten. Men trok de conclusie dat het subsidiegeld niet was verdeeld naar behoefte, maar verdeeld naar die personen of instellingen die er snel bij waren ${ }^{595}$. Een duidelijk beleidskader moest volgens hen opgesteld worden waarop instellingen hun organisatieplannen en activiteiten konden afstemmen.

Het evaluatierapport betekende het einde van het Bijzondere Regionale 
Welzijnsbeleid. Een laatste periode van dit beleid werd nog afgemaakt, maar stond al sterk in de schaduw van twee ontwikkelingen die de jaren ' 80 zouden gaan domineren: de vergaande decentralisatie van rijkstaken naar provincies en een herstructurering van de gesubsidieerde welzijnsorganisaties. De Provincie Limburg speelde daar eind jaren '70 actief op in.

\section{Tweede omslagmoment: de macht van het particulier initiatief doorbroken (1979)}

Voor de Provincie Limburg was in de jaren '70 'subsidieverlening' een van de belangrijkste instrumenten geweest binnen het welzijnsbeleid. Diverse maatschappelijke organisaties, welzijnsinstellingen en gemeenten waren sterk afhankelijk geworden van de provinciale subsidies. Deze subsidies waren niet alleen belangrijk voor het realiseren van diverse lokale sociaal-culturele voorzieningen, maar ook voor het in stand houden van diverse organisaties en samenwerkingsverbanden. De verschillende provinciale Raden werden grotendeels door de Provincie gesubsidieerd. Toch hadden de Raden ondanks deze provinciale afhankelijkheid in de jaren '70 een steeds dominantere positie gekregen in het welzijnsbeleid. Het subsidiariteitsbeginsel was nog prominent aanwezig in het Provinciehuis. De Provincie bemoeide zich niet met de inhoudelijke werkzaamheden van het particulier initiatief. De Provincie had echter wel invloed op het personeelsbeleid van de Raden. In de vergaderingen van het College van Gedeputeerde Staten was hierover dikwijls discussie geweest in de jaren ' $70^{596}$.

Begin 1979 kwamen er min of meer toevallig gelijktijdig drie vacatures beschikbaar. De directeur van het Provinciaal Orgaan Welzijnsbevordering Limburg (voorheen het 'Opbouworgaan') ging met pensioen. De Raad voor het Jeugdbeleid en de Raad voor de Volksgezondheid hadden beide een vacature voor de functie van voorzitter. De Provincie zag haar kans om dit moment aan te grijpen om naar analogie van de landelijke Harmonisatieraad de Limburgse Radenstructuur om te vormen tot één 'Welzijnsraad'597. Het waren vooral gedeputeerden L. Stals en K.W. Buck (beiden CDA) die hiermee een belangrijke kostenbesparing wilden realiseren. De vier provinciale Raden kregen immers gezamenlijk ongeveer 2 miljoen gulden per jaar subsidie ${ }^{598}$. Belangrijker nog was de gedachte om tevens de macht van deze instellingen te beperken en meer inhoudelijke controle te verkrijgen over de activiteiten van de Raden. Het College van Gedeputeerde Staten besloot in mei 1979 om per direct een vacaturestop in te stellen en de directeur- en voorzittersfuncties voorlopig niet in te vullen ${ }^{599}$. Het was het begin van de herstructurering van de Limburgse welzijnssector.

Een tweede element dat voor een omslag in het provinciaal welzijnsbeleid zorgde, was de aangepaste Kaderwet Specifiek Welzijn die de minister van Cultuur, Recreatie en Maatschappelijk Werk, M.H.M.F. Gardeniers-Berendsen (KVP), in 1979 naar de Tweede Kamer stuurde. Het was een wetsontwerp waarin werd voorgesteld om via een aantal regionale experimenten ervaring op te doen met de decentralisatie van een aantal welzijnstaken. Daarna zou pas moeten blijken of het ook een definitief wetsvoorstel werd. Elf proefgebieden waren hiervoor geselecteerd (in elke provincie één). In Limburg werkten acht gemeenten in het Oostelijke Mijngebied samen aan een pilotproject. 
In het najaar van 1979 werd echter als enige provincie ook de Provincie Limburg benaderd als twaalfde proefgebied, de enige provinciale proeftuin. Het ministerie wilde in één provincie ervaringen opdoen met een provinciaal welzijnsbeleid. De status van provinciaal proefgebied bereidde de overdracht van een groot aantal welzijnstaken voor van de rijksoverheid naar de Provincie Limburg.

De taakverdeling in het welzijnsbeleid tussen rijksoverheid, provincies en gemeenten was in de jaren '70 steeds onduidelijker geworden. Daarbij kwam de onduidelijkheid tussen provinciale verantwoordelijkheden en de verantwoordelijkheden van het particulier initiatief. Het subsidiariteitsbeginsel werd steeds meer vervangen door een betere planning en coördinatie van het welzijnsbeleid door de overheid ${ }^{600}$. De organisaties die zich met 'welzijn' bezighielden in Limburg kenden de afgelopen jaren 'een welhaast ongecontroleerde groei $^{1601}$. Daarbij was er tussen diverse organisaties, commissies, raden en opbouworganen een grote overlap in activiteiten ontstaan ${ }^{602}$. Met de omvorming van het Opbouworgaan tot Provinciaal Orgaan Welzijnsbevordering Limburg kreeg de organisatie in 1971 de taak om 'een op de ontwikkeling in de samenleving afgestemd, samenhangend welzijnsbeleid te bevorderen ${ }^{1603}$. Eind jaren '70 maakte de Provincie de balans op en constateerde dat van deze taakstelling weinig terecht was gekomen en dat de subsidiëring van welzijnsactiviteiten niet alleen sterk was toegenomen, maar ook nog eens erg versnipperd werd ingezet. Bovendien had het ministerie aangekondigd om de subsidiëring van de provinciale opbouworganen stop te zetten ${ }^{604}$. Deze bezuinigingsmaatregel in combinatie met ongecoördineerde en ineffectieve uitvoeringsstructuur van het welzijnsbeleid creëerden voor de Provincie een nieuwe externe urgentie om van koers te veranderen. Deze urgentie betekende samen met de ruimte die de rijksoverheid bood met de provinciale proeftuin en de drie vacatures op sleutelposities binnen een aantal provinciale welzijnsinstellingen, een nieuw omslagmoment in het provinciale welzijnsbeleid.

\subsection{Herstructurering en decentralisatie (periode 1979-1992)}

Vanaf 1979 tot begin jaren ' 90 stonden de herstructurering van de Limburgse welzijnssector en de decentralisatie van welzijnstaken van de rijksoverheid naar de Provincie centraal in het provinciale welzijnsbeleid ${ }^{605}$. Beide zaken liepen gelijktijdig en hadden onderling invloed op elkaar. Zo kon de echte herstructurering van de welzijnssector pas geëffectueerd worden na 1985 toen het Provinciaal Bestuur met de minister van Welzijn, Volksgezondheid en Cultuur een decentralisatie-overeenkomst sloot. Met de overeenkomst kreeg de Provincie ook de bevoegdheden om een groot aantal welzijnstaken zelf te organiseren. Daarmee kwam een einde aan de jarenlange, formeel gedeelde verantwoordelijkheid tussen overheid en particulier initiatief. Omgekeerd bracht de herstructurering van de welzijnssector ook nieuwe inzichten in de rolverdeling tussen Provincie en gemeenten, op basis waarvan de Provincie met voorstellen voor decentralisatie naar gemeenten kwam.

In januari 1979 had de provinciale welzijnsafdeling informatie ingewonnen bij andere provincies over de vraag, hoe bij hen het welzijnswerk, de opbouworganen en adviesraden waren georganiseerd. Wat bleek? In de meeste provincies was men druk bezig met het herstructureren van advies- en opbouworganen. Wel constateerde men 
dat Limburg 'bepaald niet voorop' liep in deze ontwikkelingen ${ }^{606}$. Na het instellen van de vacaturestop in mei 1979 had het College van Gedeputeerde Staten het Provinciaal Orgaan Welzijnsbevordering Limburg (POWL) opdracht gegeven om advies uit te brengen over de 'totale toekomstige structuur voor de beleidsvoorbereiding'. Daarbij moest men rekening houden met de voorkeur van Gedeputeerde Staten om te komen tot één adviesorgaan ${ }^{607}$. Het was een laatste kans om het particulier initiatief zelf met voorstellen te laten komen voor de nieuwe structuur. Het uitgebrachte advies bracht pijnlijk de verschillende inzichten over de toekomstige structuur naar voren. Het POWL 'claimde' het opstellen van de conceptplannen, de vier Raden en de Provinciale Commissie Planning ('commissie Tops') wilden vooral de status-quo handhaven ${ }^{608}$. Het was duidelijk, men kwam er niet uit. Het was de voorwaarde van een 'democratische voorbereiding' die in de ontwerp Kaderwet Specifiek Welzijn was gesteld, die werd angegrepen om vooral niets te veranderen. In een nota aan het College verzuchtte het hoofd van de $3^{e}$ Afdeling: "Wat al dan niet onder 'demokratisch' wordt verstaan, is niet meer bij te houden. Het is derhalve niet verwonderingwekkend, dat de geesten nog lang niet één zijn in hun interpretatie van het fenomeen 'demokratische planning'"'609.

Het College van Gedeputeerde Staten hakte vervolgens zelf de knoop door en koos ervoor om de beleidsvoorbereiding te laten gebeuren door het POWL en niet langer door de Raden of de Commissie Planning Sociale Ontwikkeling ${ }^{610}$. Daarmee was tevens de discussie die speelde over het voortbestaan van het POWL beslecht. Maar de voorwaarde die de Provincie stelde, was wel dat het POWL nauwer met het Provinciaal Bestuur moest samenwerken. In de praktijk betekende dit dat de beleidsvoorbereiding wel door het POWL werd gedaan, maar onder nauwe controle van de Provincie stond ${ }^{611}$. De verantwoordelijk gedeputeerde L. Stals (CDA) werd tevens voorzitter van een 'Bestuurscommissie' waaraan de nieuwe directeur van het POWL verantwoording moest afleggen ${ }^{612}$. Bij de uiteindelijke reorganisatie in 1983 werden de medewerkers van het POWL provinciaal ambtenaar en veranderde men de naam in Provinciaal Bureau Welzijnsplanning (PBW). Daarmee was een eerste stap gezet in de herstructurering. Met deze keuze waren de provinciale Raden in feite buiten spel gezet en zouden 'niet meer rechtstreeks' door de Provincie in de beleidsvoorbereiding worden betrokken ${ }^{613}$. De reorganisatie van de provinciale Raden moest echter nog plaatsvinden. Eerst wilde de Provincie echter de benodigde bevoegdheden van de rijksoverheid krijgen. De Raden waren ooit door de rijksoverheid ingesteld en ook al lag de financiering hiervoor volledig bij de provincies, in afwachting op de definitieve Kaderwet Specifiek Welzijn kon de Provincie Limburg hier weinig reorganiseren. Daarom werd er een omweg gevolgd. De status van provinciaal proefgebied bood hier uitkomst.

Het Provinciaal Bestuur had als voorwaarde voor deelname aan het experiment gesteld dat er voldoende financiële middelen beschikbaar werden gesteld door het ministerie ${ }^{614}$. Juist dit laatste punt zorgde een jaar lang voor discussie tussen Provincie en ministerie. Op nationaal niveau was er in opdracht van het ministerie een Stuurgroep Ontwikkelingsprojecten ingesteld die de voortgang in de proefgebieden coördineerde. Een jaar lang was er discussie tussen Provincie en Stuurgroep over de financiering van het project, maar uiteindelijk werd de Provincie Limburg eind 1980 definitief kandidaat voor 


\section{het Provinciaal proefprojekt ontwerp-Kaderwet Specifiek Welzijn ${ }^{615}$.}

In dat jaar had men echter niet stilgezeten. Op de eerste plaats was er op ambtelijk niveau een analyse gemaakt van de structurele problemen in het Limburgse welzijnswerk. Daarin werd gepleit voor een 'probleemgerichte aanpak' via wijkprojecten en gericht op specifieke doelgroepen. In het rapport werd geconstateerd dat de gemeenten weliswaar de verantwoordelijkheid hadden voor het meer uitvoerende welzijnswerk ${ }^{616}$, maar zich vooral beperkten tot die taken waarvoor zij rijksgelden ontvingen ${ }^{617}$. Bovendien was de afstand tussen het welzijnswerk en de bevolking te groot en werkten instellingen vooral langs elkaar heen ${ }^{618}$. In feite was het rapport een Limburgse vertaling van de in 1974 landelijk gepresenteerde Knelpuntennota. Op de tweede plaats was er een inventarisatie gemaakt van alle Limburgse welzijnstaken, ingedeeld naar bestuurlijke verantwoordelijkheden. Zo onderscheidde men taken waarvoor uitsluitend de gemeenten verantwoordelijk waren, taken voor gemeenten én gewesten ${ }^{619}$, gewestelijke taken en provinciale taken. Haar eigen rol zag de Provincie weggelegd voor de instandhouding van de zogeheten steunfuncties. Het begrip steunfunctie was in 1978 voor het eerst door de rijksoverheid geïntroduceerd in de Rijksbijdrageregeling Sociaal-Culturele Activiteiten. In artikel 3 van de regeling was de volgende definitie opgenomen:

"1. Onder de steunfunctie wordt verstaan de begeleiding gericht op ontwikkeling en vernieuwing van beleid en uitvoering, alsmede op verbetering van de kwaliteit van sociaalculturele activiteiten. 2. Onder steunfunctie wordt mede begrepen de begeleiding welke is gericht op samenwerking of integratie van sociaal-culturele activiteiten met andere activiteiten of voorzieningen op het terrein van zorg, educatie of recreatie" (cursivering HvE) ${ }^{620}$.

In feite waren deze steunfuncties voor een overgroot deel de maatschappelijke organisaties die de Provincie al sinds de jaren '50 subsidieerde. Vanaf 1978 werden deze organisaties 'steunfuncties' genoemd. Zij hielden zich niet bezig met het lokale uitvoerende welzijnswerk, maar leverden ondersteunende taken ${ }^{621}$ als onderzoek, advies, coördinatie en subsidieaanvragen. Een precieze definitie is nooit geformuleerd. Provincies pasten ook verschillende definities toe (Claassen \& Pouwels, 1991: 25). De Provincie Limburg zag de steunfuncties vooral als maatschappelijke instellingen die ondersteunde taken voor het lokale welzijnswerk organiseerden. De Provincie subsidieerde steunfuncties voor het kruiswerk, kindercentra, bejaardenwerk, gezinsverzorging, sportorganisaties en het sociaal-culturele werk. Begin jaren ' 80 had de Provincie de financiële verantwoordelijkheid voor ruim 40 steunfuncties, die ongeveer 40 miljoen gulden per jaar aan provinciale subsidies ontvingen ${ }^{622}$.

$\mathrm{Na}$ deze eerste snelle inventarisatie waren de jaren tot 1983 weinig productief ${ }^{623}$. Een ingestelde provinciale stuurgroep waarin ook het particulier initiatief vertegenwoordigd was, discussieerde vooral over procedures, werkwijzen, en betrokkenheid van de welzijnsinstellingen in het experiment ${ }^{624}$. De Provincie op haar beurt ergerde zich aan de macht en invloed van de landelijke Stuurgroep Ontwikkelingsprojecten die alle proeftuinen coördineerde ${ }^{625}$. Ook op nationaal niveau sloeg de stemming over de Kaderwet om (Hueting, 1989: 374). De ontwerpwet was langzamerhand verworden tot 'te veel 
bureaucratie, was te technisch ... en te veel belast met centralistische randvoorwaarden' (De Haan \& Duyvendak, 2002: 128). Pas met het op 4 november 1982 gevormde eerste kabinet Lubbers kwam hier verandering in. De nieuwe minister voor Welzijn, Volksgezondheid en Cultuur, L.C. Brinkman (CDA), trok in 1983 de Kaderwet Specifiek Welzijn in ${ }^{626}$. Onder druk van grote bezuinigingen die het kabinet doorvoerde, ging hij pragmatisch te werk. De tijd van alomvattende wetgeving en centralistische planning was voorbij (idem.129). Een heldere taakverdeling tussen gemeenten, provincies en rijk moest op korte termijn gerealiseerd worden. De Provincie Limburg was voor de minister de provincie, waar hij de ambitie snel dacht te realiseren.

In 1979 werd de draad door de Provincie weer opgepakt waar men in 1979 zo voortvarend mee was begonnen: een inventarisatie van de taken die voor overdracht van rijk naar Provincie in aanmerking kwamen. In totaal waren er 88 provinciale welzijnstaken geïnventariseerd. Hiervan werd ongeveer een vierde in volledige autonomie uitgevoerd door de Provincie. De overige taken waren de zogeheten 'medebewindstaken' waarin een onderlinge taakverdeling tussen Rijk en Provincie was afgesproken. Voor het merendeel ging het hier om rijksbijdrageregelingen en doeluitkeringen waar de rijksoverheid financiële middelen aan de provincies beschikbaar stelde en provincies een eigenstandige rol hadden in de besteding daarvan. Het Provinciaal Bestuur vond dat 41 taken voor 'volledige decentralisatie' naar de Provincie in aanmerking kwamen. Hiermee bedoelde men de overdracht van alle financiële, plannings- en coördinatie-verantwoordelijkheden. Ongeveer de helft van deze 41 taken waren steunfuncties. Acht provinciale taken konden overgedragen worden aan de gemeenten, en vier taken konden 'terug' naar het rijk ${ }^{627}$. In een eerste bestuurlijk overleg met de minister en staatssecretaris op 10 maart 1983 was er nauwelijks discussie over het Limburgse voorstel voor een nieuwe taakverdeling ${ }^{628}$. De minister had 'geen bemerkingen' ${ }^{129}$.

$\mathrm{Na}$ gedegen ambtelijk vooroverleg ${ }^{630}$ tussen Provincie en het ministerie lag er in oktober 1984 een eerste ontwerp van de bestuursovereenkomst. Er waren vijftien taken opgenomen die voor overdracht in aanmerking kwamen. In vergelijking tot de eerdere inventarisatie ging het in de bestuursovereenkomst om een vierde van het aantal taken. Echter, de 15 onderwerpen die nu in de ontwerptekst stonden, waren taken waarover uitsluitend het ministerie van Welzijn, Volksgezondheid \& Cultuur bevoegdheden had. Bij de eerder geïnventariseerde andere taken lagen verantwoordelijkheden bij andere ministeries. Die waren nauwelijks bereid tot vergaande decentralisatie. Met het intrekken van de Kaderwet had minister Brinkman afscheid genomen van het breed uiteenlopende karakter van het welzijnsbeleid en zich beperkt tot de taken van zijn eigen departement. Vanuit dat perspectief was de Provincie zeer tevreden: "... vrijwel alle taken waarvoor door de Provincie om overdracht van bevoegdheden en middelen is gevraagd en waarvoor uitsluitend het Ministerie van WVC competent is, [is] thans in het kader van de ontwerpbestuursovereenkomst een regeling ... getroffen"631. Elf taken werden in de toekomst nog bezien en bovendien was er een lijstje van onderwerpen opgenomen waarvoor de Provincie grotere 'beleidsvrijheid' kreeg van de rijksoverheid ${ }^{632}$. Daarbij ging het om financiële overdracht van 12 miljoen gulden structureel per jaar ${ }^{633}$. 
Toen op 20 december 1984 Provinciale Staten instemden met de ontwerptekst was de weg vrij om op 16 januari 1985 tot formele ondertekening over te gaan. De Bestuursovereenkomst zou lopen tot 1 januari 1990. Gouverneur J. Kremers (CDA) noemde het een 'historische dag', omdat de Provincie vanaf nu voor ongeveer de helft van haar welzijnstaken een autonoom beleid kon voeren ${ }^{634}$. Minister Brinkman sprak van een 'groeimodel' waarbij zijn ministerie en de Provincie jaarlijks bekeken of en in hoeverre uitbreiding van de overeenkomst gewenst was ${ }^{635}$. In de jaren erna werd de Bestuursovereenkomst nog uitgebreid met een aantal nieuwe taken dat gedecentraliseerd werd ${ }^{636}$.

Met het intrekken van de Kaderwet Specifiek Welzijn en de ondertekening van de Bestuursovereenkomst veranderde ook de machtspositie van de Provincie. Het Provinciaal Bestuur had nu de bevoegdheden en de financiën over een groot aantal welzijnstaken. De verplichting die in de Kaderwet was opgenomen van een 'democratische voorbereiding', dat wil zeggen, de instemming van het particulier initiatief voor de plannen, was vervallen. Maar niet alleen het particulier initiatief speelde nauwelijks meer een rol, ook de Limburgse gemeenten waren pas laat geïnformeerd over de nieuwe bestuursovereenkomst. Dit was opmerkelijk, omdat in de overeenkomst eveneens uitspraken werden gedaan over het decentraliseren van provinciale taken naar de gemeenten. Pas in het voorjaar van 1983 had de Provincie voor het eerst overlegd met de gemeenten. Daarbij bleek dat de overheveling van rijkstaken naar het provinciale niveau op weinig weerstand stuitte, maar dat de decentralisatie van een aantal provinciale taken naar het gemeenteniveau in eerste instantie moeilijk lag ${ }^{637}$. De gemeenten vreesden grote financiële nadelen bij het overnemen van de voorgestelde provinciale taken ${ }^{638}$. Toch zette de Provincie door. Gedeputeerde L. Stals was hier eind 1983 duidelijk over:

"Wat de Provincie nu voor ogen staat is het functioneren los van de landelijke stuurgroep en van andere overlegstructuren. De Provincie wil haar eigen visie in de planning neerleggen en daarbij niet door derden gehinderd worden. Om die reden wordt gestreefd naar een andere overeenkomst met het Rijk. [...] Voor wat de gemeenten betreft; deze zullen bij het experiment betrokken worden voor zover dit zinvol wordt geacht door het College. Het experiment is primair een provinciaal experiment en moet zich dan ook tot de provinciale taken beperken."639

Het was duidelijk. De Provincie ging vanaf nu haar eigen weg. De reactie van de Vereniging van Limburgse Gemeenten, dat zonder medewerking van de gemeenten de Provincie weinig zou kunnen realiseren ${ }^{640}$, werd voor kennisgeving aangenomen. Uiteindelijk verliep het overleg met gemeenten toch verrassend soepel ${ }^{641}$. De gemeenten kregen in het provinciale voorstel de ruimte om financiële middelen vrij en naar eigen inzicht te besteden ${ }^{642}$. De individuele gemeenten stemden uiteindelijk in en Provinciale Staten namen eind december 1986 hierover formeel het besluit ${ }^{643}$.

Vanaf midden jaren ' 80 kreeg de Provincie alle ruimte om een eigen welzijnsbeleid te formuleren en om de in 1979 ingezette herstructurering van het particulier initiatief versneld door te voeren. Nog voor de ondertekening van de bestuursovereenkomst 
had gedeputeerde Stals de uitgangspunten van de herstructurering op papier gezet. Hij constateerde dat de minister ervoor had gekozen om de integrale planning en samenhang los te laten en de sectorwetgeving te laten prevaleren ${ }^{644}$. Volgens de gedeputeerde hoorden bij sectorale wetgeving ook een sectorale beleidsuitwerking en adviesfunctie.

Zijn partijgenoot en collega-gedeputeerde K.W. Buck (CDA) - die Financiën in zijn portefeuille had - kwam met een ander voorstel. Hij presenteerde een schema waarin niet een sectorale, maar een 'categorale' aanpak centraal stond ${ }^{645}$. In dit schema, dat later 'het A4'tje van Buck' werd genoemd ${ }^{646}$ stelde Buck een 'categorale' aanpak voor, waarmee hij een 'geïntegreerde, probleemgerichte aanpak van de noden van een bepaalde bevolkingscategorie' bedoelde ${ }^{647}$. Daarin combineerde Buck het sectorale rijksbeleid met een Limburgs probleemgericht doelgroepenbeleid. Deze insteek bood het College van Gedeputeerde Staten, zowel inhoudelijk als ook politiek gezien, veel ruimte. Inhoudelijk, omdat de welzijnsproblematiek van doelgroepen als bejaarden, werklozen of gehandicapten, zich niet lieten oplossen door sectorale rijksplannen of voorzieningen. Een beleid voor specifieke doelgroepen was tot die tijd nooit gevoerd ${ }^{648}$. Een meer samenhangende en vooral probleemgerichte aanpak was gewenst ${ }^{649}$. Tegelijkertijd betekende dit - en daarin kwam het politieke element naar voren - dat individuele Limburgse welzijnsinstellingen deze problemen nooit alleen konden oplossen. Samenwerking was hiervoor nodig. Samenwerking die volgens beide gedeputeerden nooit zou lukken met de huidige versnipperde structuur van het welzijnswerk.

In de nota De vernieuwing van welzijnsbeleid in Limburg (mei 1984), werd dit probleemgerichte doelgroepenbeleid uitgewerkt. De Provincie benoemde daarin een aantal specifieke doelgroepen die extra prioriteit moesten krijgen. Het is belangrijk om te benadrukken dat het hier ging om een welzijnsbeleid voor de gehele provincie. In tegenstelling tot het economische Perspectievennotabeleid, dat alleen voor Zuid-Limburg gold, was het welzijnsbeleid een beleid voor heel Limburg. Daarvoor werd zeer bewust gekozen. Zo kreeg het gehandicaptenbeleid in de regio Noord-Limburg extra aandacht en kon de Oostelijke Mijnstreek ervaringen opdoen met het ouderenbeleid. Een meer probleemgerichte aanpak voor 'randgroepjongeren' zou in de Limburgse steden opgezet worden ${ }^{650}$. Het principe van regionaal verdelende rechtvaardigheid - 'voor elke regio iets' - kreeg zo een nieuwe invulling. Op deze manier kon het College van Gedeputeerde Staten de kritiek pareren die op het Perspectievennotabeleid was gekomen. Dit beleid zou zich veel te veel richten op alleen maar Zuid-Limburg. Het welzijnsbeleid - en ook de ruimtelijke ordening (zie hoofdstuk 2) - waren in de jaren ' 80 beleidsterreinen die voor een balans moesten zorgen in de politieke aandacht voor de gehele provincie.

Om dit provinciebrede welzijnsbeleid ook te realiseren vond het College van Gedeputeerde Staten dat het aantal steunfuncties drastisch teruggebracht moest worden. Men sprak van het 'beruchte lappendeken-probleem'651. In november 1984 kwam het College met een 'Structuurschets' voor de welzijnssector. Vier onderdelen stonden centraal. Op de eerste plaats werden ruim $40^{652}$ provinciale steunfuncties teruggebracht naar vijf ${ }^{653}$. Op de tweede plaats werd er in de Provinciale Statenvergadering van juni 1985 het besluit genomen om de vier Raden alsnog te bundelen in één nieuwe organisatie: het Instituut voor 
Kategoriaal Overleg Limburg (IKOL) ${ }^{654}$. Daarbinnen moesten 'overlegplatforms' gevormd worden die belangen van jeugdigen, ouderen en gehandicapten behartigden. Zij zouden een eigen verantwoordelijkheid krijgen om voor het particulier initiatief 'samenhangend ontwikkelingsbeleid' te voeren ${ }^{65}$. Wat hiermee precies werd bedoeld, bleef onduidelijk. Op de derde plaats werd de subsidierelatie tussen Provincie en 70 andere maatschappelijke organisaties gesaneerd. De hoogte van de subsidie werd voor deze organisaties gekoppeld aan het ledenaantal. Bovendien konden alleen nog die instellingen op subsidie rekenen die ook een provinciaal belang dienden ${ }^{656}$. Ten slotte werd er een 'Ontwikkelingsfonds' opgericht om vernieuwende initiatieven en projecten uit het veld te honoreren. Zo werd het nieuwe welzijnsbeleid organisatorisch en financieel geherstructureerd in de twee helft van de jaren ' 80 .

Net als bij de decentralisatievoorstellen had de Provincie in de periode voorafgaand aan het besluit van Provinciale Staten van 20 juni 1985 om de welzijnsstructuur te herstructureren, nauwelijks overleg gevoerd met de betrokken instellingen ${ }^{657}$. Pas in de periode daarna vond er een eerst overleg met de welzijnsinstellingen plaats ${ }^{658}$. Om de reorganisatie van de steunfuncties uit te voeren werkte de Provincie met zogeheten 'formateurs'. Dit waren mensen uit het particulier initiatief zelf, 'deskundig en het vertrouwen genietend van het betreffende werkveld'659. Zij waren begin 1987 door Gedeputeerde Staten gevraagd om als formateur een rapport op te stellen over de structuur, taakopvatting en werkwijze van de nieuwe steunfunctie-instellingen. In oktober 1987 leverden drie informateurs hun eindrapport op. Over het werken als formateur voor een van de steunfuncties (tevens burgemeester van Margraten) schreef H.J. Kaiser (CDA):

\footnotetext{
"Nadrukkelijk heb ik mij willen (en moeten) conformeren aan de randvoorwaarden die door het Provinciaal Bestuur waren vastgesteld. Het feit dat deze in een democratisch besluitvormingsproces waren vastgesteld maakte mijn uitgangspositie op voorhand ijzersterk t.o.v. de deelnemende instellingen. [...] Ik heb mij bewust niet willen opstellen als een zetbaas van het provinciaal bestuur. Deze opstelling wekte vertrouwen. Met dit vertrouwen kon ik aan de slag. Hierin sluit het geheim van het succes van mijn formatieopdracht." ${ }^{160}$
}

In zijn eindrapport signaleerde Kaiser ook een groot aantal 'aandachtspunten' waar hij als formateur tegen was gekomen. Een heldere taakafbakening tussen het nieuwe steunfunctie-instituut en de 70 identiteitsgeboden maatschappelijke organisaties (particulier initiatief) was een belangrijk punt. Bovendien had geen enkele instelling een passende kantoorlocatie voor de nieuwe instellingen, zodat er naar een nieuwe locatie gezocht werd. Eveneens waren er diverse personele en arbeidsrechtelijke aspecten die in de opzet van de nieuwe steunfunctie geregeld moesten worden ${ }^{661}$. Deze 'aandachtspunten' zouden een belangrijke rol gaan spelen in een tweede reorganisatieronde in de jaren ' 90 . In de periode 1988-1989 waren de meeste steunfunctie-instellingen opgericht, werkend vanuit de over Limburg verspreide huisvestingen van de oude instellingen.

De welzijnssector was eind jaren ' 80 gereorganiseerd van ruim 40 naar 5 steunfuncties, en van 4 functionele Raden naar 1 overlegorgaan. De overige 70 gesubsidieerde 
maatschappelijke organisaties vielen nu onder één provinciale regeling ${ }^{662}$. De Bestuursovereenkomst met het rijk uit 1985 had daarvoor de formele ruimte geschapen, maar het Provinciaal Bestuur had in 1979 een eerste uitwerking gegeven. De Provincie Limburg benutte met de decentralisatievoorstellen de ruimte die zij kreeg van de rijksoverheid. Zij greep deze ruimte aan om de machtspositie van het Limburgs particulier initiatief af te breken met een forse herstructurering. Tien jaar lang gingen nieuwe taakverdelingen tussen rijk, Provincie en gemeenten en de herstructurering van de sector hand in hand. Op 1 januari 1989 trad de nieuwe Welzijnswet in werking. De rijksbijdrageregelingen voor het welzijnsbeleid werden vanaf dat moment overgeheveld naar het Provincie- en Gemeentefonds. Een bedrag van 53,7 miljoen gulden werd rechtstreeks in het Provinciefonds gestort waarmee de financiële autonomie gerealiseerd werd. Van de voorgenomen bezuinigingen op de provinciale welzijnssector was vooralsnog weinig terecht gekomen. De noodzaak hiervoor liet echter niet lang op zich wachten. Een jaar later liep de Bestuursovereenkomst af. In de tweede helft van de jaren ' 80 waren er in totaal 26 taken gedecentraliseerd van de rijksoverheid naar de Provincie Limburg ${ }^{663}$. De nieuwe Welzijnswet regelde dit vanaf 1989 voor alle provincies. Limburg was daarvoor een belangrijke proeftuin geweest. Claassen \& Pouwels concluderen begin jaren '90 dat met de nieuwe Welzijnswet, het provinciaal steunfunctiebeleid 'de status van volwassenheid' bereikte (Claassen \& Pouwels, 1991: 63). Ze maakten de balans wel te vroeg op.

\section{Derde omslagmoment: 'Carte blanche' voor een provinciaal welzijnsbeleid (1990-1992)}

Het begin van de jaren '90 was een lastige periode voor de Provincie Limburg. Niet alleen werd eind 1990 het jarenlange Perspectievennotabeleid afgesloten, ook de Bestuursovereenkomst die de Provincie in 1985 met minister Brinkman had afgesloten, liep af. Zo kwam er een einde aan twee belangrijke samenwerkingsovereenkomsten tussen Provincie en rijksoverheid. De Provincie moest vanaf nu op eigen kracht verder. Zij kreeg daarmee 'carte blanche' van de rijksoverheid voor het voeren van een autonoom provinciaal welzijnsbeleid.

De beëindiging van beide overeenkomsten pakte voor het provinciale welzijnsbeleid bijzonder nadelig uit. De afkoopsom van het Perspectievennotabeleid en het tegelijkertijd in werking treden van de nieuwe Welzijnswet, gingen gepaard met forse bezuinigingen door de rijksoverheid. Tientallen gesubsidieerde arbeidsplaatsen in diverse welzijnsinstellingen stonden onder druk. Nieuwe rijksbezuinigingen waren in de loop van 1991 aangekondigd. Door deze nieuwe financiële urgentie zag het Provinciaal Bestuur zich genoodzaakt om 17,8 miljoen gulden structureel te bezuinigen ${ }^{664}$. Het grootste gedeelte van deze bezuiniging moest gehaald worden uit het welzijnsbeleid ${ }^{665}$. Het was aan het in 1991 nieuw aangetreden College van Gedeputeerde Staten om dit uit te werken. Maar ook de provinciale steunpunten zelf dachten na over kostenbesparingen. In november 1991 hadden vier steunpunten al een plan bij de Provincie ingediend voor een nieuwe centrale huisvesting onder de naam Symbiose. Een half jaar later, op 15 mei 1992, besloten Provinciale Staten tot een nieuwe herstructureringsronde. Het doel was het realiseren van één grote welzijnsinstelling voor de Provincie Limburg: de stichting Symbiose. 
In het College van de Gedeputeerde Staten dat in 1991 aantrad, had binnen de coalitiepartijen een vernieuwing plaatsgevonden. De gedeputeerden uit de jaren ' 80 hadden binnen zowel de PvdA en het CDA plaats gemaakt voor een nieuwe garde bestuurders. Toen echter al snel twee gedeputeerden in 1992 overstapten naar burgemeestersposten, waren er diverse portefeuillewisselingen. Voor de portefeuille welzijnsbeleid was dit problematisch, gezien de forse bezuinigingen die hier moesten plaatsvinden. In de periode 1990-1992 waren maar liefst drie verschillende gedeputeerden verantwoordelijk portefeuillehouder. De ambtelijke afdeling was in die periode de enige constante; die heeft dan ook een beslissende rol gespeeld in de aanzet tot een nieuwe reorganisatie van het welzijnsbeleid en vorming van de stichting Symbiose.

De Provincie kreeg alle ruimte van de rijksoverheid. Immers, met de decentralisatie van taken en middelen had het ministerie van Welzijn, Volksgezondheid en Cultuur in 1989 bijna alle bevoegdheden van het welzijnsbeleid aan provincies en gemeenten gedecentraliseerd. Vanaf dat moment was er eigenlijk geen sprake meer van een nationaal welzijnsbeleid. Met het aflopen van de Bestuursovereenkomst en het Perspectievennotabeleid kreeg de Provincie Limburg alle ruimte voor een autonoom welzijnsbeleid. De ruimte van de rijksoverheid, de forse bezuinigingsopgave met het besluit te komen tot één provinciale welzijnsinstelling en de macht van het ambtelijk apparaat, zorgden voor een nieuw omslagmoment begin jaren '90. Welzijnsbeleid was een verantwoordelijkheid van de lagere overheden geworden. Maar hoe ging men hier mee om? Voor de Provincie Limburg ontwikkelde het welzijnsbeleid zich in de jaren '90 steeds meer van een ambitieuze politieke portefeuille tot een ambtelijk hoofdpijndossier.

\subsection{Het einde van het welzijnsbeleid (periode 1992-2003)}

In de jaren '90 veranderde er bijzonder veel in de aangrenzende beleidsterreinen van het welzijnsbeleid. In 1992 kregen de provincies extra bevoegdheden in het kader van de Wet op de Bejaardenoorden. Ouderenzorg mocht ook aan huis geleverd worden en daarmee kwam de zorgverlening in de wijk, ook op het terrein van het welzijnswerk (De Vries \& Schippers, 2002: 65). Provincies kregen eveneens de wettelijke bevoegdheid voor de planning en financiering van de jeugdhulpverlening. Het Provinciaal Bestuur legde steeds meer de politieke prioriteit bij deze nieuwe zorgtaken en steeds minder bij het autonome welzijnsbeleid. De aandacht van de bouw van drie nieuwe musea ging evenzo ten koste van de politieke aandacht voor het welzijnsbeleid ${ }^{666}$. De interbestuurlijke verhoudingen veranderden begin van de jaren '90 drastisch. De rijksoverheid had na de decentralisatie van het welzijnsbeleid naar de provincies, de aandacht verlegd naar de gemeenten. Gemeenten kregen extra taken op het gebied van de bijstand, lokale zorg en arbeidsmarktbeleid. Langzaam groeide de macht van gemeenten in wat wel het 'sociale domein' wordt genoemd.

Binnen het provinciale welzijnsbeleid moest er bezuinigd worden. Het einde van het Perspectievennotabeleid en de in 1991 aangekondigde rijksbezuinigingen ${ }^{667}$, vormden de aanleiding voor het College van Gedeputeerde Staten om (nogmaals!) 
de Limburgse welzijnssector kritisch door te lichten. Men dacht met een 'tweede herstructureringsoperatie ${ }^{1668}$ forse besparingen te kunnen realiseren ${ }^{669}$. De Provinciale Bestuurscommissie Welzijnsplanning werd gevraagd hierover advies uit te brengen. Het advies was de inzet voor het debat over de Voorjaarsnota in Provinciale Staten op 15 mei 1992. Gedeputeerde Staten stelden voor om - in navolging van het advies - te kiezen voor een nieuwe welzijnsstructuur waarin de huidige 8 welzijnsinstituten ondergebracht werden in één nieuw te huisvesten stichting. Deze nieuwe stichting zou door de Provincie gefinancierd worden op basis van 'output-budgetfinanciering'. De voordelen van deze 'schaalvergroting' in het welzijnswerk zouden ten gunste komen van de 'klantengroepen'670. 'Outputfinanciering', 'schaalvergroting', 'klantgroepen', 'effectiviteit en efficiency' - het zijn woorden die het welzijnsbeleid van de jaren '90 typeren.

De terminologie paste in het new public management gedachtengoed dat in verschillende overheidsorganisaties rond die tijd erg populair was. De gedachte achter dit new public management was dat met het toepassen van marktprincipes de kwaliteit van de publieke dienstverlening efficiënter en effectiever zou worden (Ball \& Peters, 2005: 249). Letting the managers rule beperkte de rol van de politiek tot het stellen van doelen en (output-)resultaten op hoofdlijnen (Pierre \& Peters, 2000: 64). Dat was precies wat in Limburg gebeurde. Het nieuwe 'economisch vocabulaire' werd door de provinciale ambtenaren gebruikt om deze nieuwe herstructurering te onderbouwen. Dit was overigens een nationale ontwikkeling. De beheersbaarheid van de arrangementen van de verzorgingstaat nam overal in Nederland in de jaren ' 90 een centrale plaats in (Van der Veen, 1999: 46). In het welzijnsbeleid sprak men van 'klanten' en 'kwalitatieve dienstverlening'. Jos van der Lans beschrijft de ontwikkeling in het werk van de 'uitvoerend professional' treffend:

"Waren ze in de jaren zestig en zeventig hun vanzelfsprekende machtsoverwicht op burgers kwijtgeraakt, in de jaren tachtig en negentig werd hun professionele autonomie steeds verder ingekaderd door een oprukkend managementgeest, die mensenwerk als product betitelde, zich voor de opdracht gesteld zag om met minder geld betere waar te verkopen en dat met kracht wilde bewijzen. Het gevolg was dat kwantitatieve productienormen inhoudelijke werkprocessen ging bestieren, dat er individuele prestatie-eisen werden gesteld die ontleend waren aan kwantitatieve doelen van de organisatie, maar steeds vaker wezensvreemd waren in de context van persoonlijke dienstverlening. [...] De overheid wil waar voor haar geld en vraagt om bewijzen" (Van der Lans, 2008: 17).

Ook de Provincie Limburg eiste waar voor haar geld. De Provincie Limburg gaf in totaal aan de steunfunctie-instellingen een jaarlijkse subsidie van 17,8 miljoen gulden. De instellingen boden werk aan 268 personen ${ }^{671}$. Het ging hier om aanzienlijke bedragen en eventuele bezuinigingen konden niet anders dan grote personele consequenties hebben.

$\mathrm{Na}$ het besluit tot de oprichting van Symbiose door Provinciale Staten in 1992, werd er nog diezelfde maand een interim-bestuur samengesteld om de plannen uit te werken. Drie personen uit de betrokken steunfuncties en twee onafhankelijke deskundigen 
werden hiervoor benaderd ${ }^{672}$. De provinciale afdeling had een leidraad voor het interimbestuur opgesteld. Daarin werd gesproken van acht instellingen die moesten worden ondergebracht in één 'modern, flexibel kantoorgebouw'. Het budget van de huidige instellingen zou per direct 2,2, miljoen gulden gekort worden om de rijksbezuinigingen op te kunnen vangen ${ }^{673}$. De te behalen 'integratiewinst' werd door de Provincie geschat op 1,5 miljoen gulden ${ }^{674}$. Met de nieuwe instelling zou de 'herstructurering van het tot voor kort nog sterk versnipperde provinciaal welzijnsbestel voltooid ${ }^{1675}$ worden.

Het interim-bestuur vroeg twee onderzoeksbureaus om de integratiewinsten te onderzoeken. In deze onderzoeken werden nu ook de Limburgse Immigratiestichting en Vereniging van Patiënten- en Consumentenorganisaties betrokken. Daarmee kwam het aantal te fuseren instellingen op tien. Beide bureaus constateerden dat er de nodige inhoudelijke verschillen waren tussen de instellingen. Eén bureau concludeerde zelfs dat de fusie 'schier onmogelijk' was ${ }^{676}$. Het interim-bestuur stelde daarop in mei 1993 voor om niet alle tien instellingen te laten fuseren, maar slechts zeven ${ }^{677}$.

De reacties van de betrokken instellingen waren negatief. Geen inhoudelijke meerwaarde, geen draagvlak, vage onderbouwing, fundamentele bezwaren, en sommigen vonden het rapport zelfs uitgesproken slecht ${ }^{678}$. Ook het interim-bestuur was verdeeld. De als extern deskundige aangetrokken bestuurskundige A.F.A. Korsten had een minderheidsstandpunt ingenomen bij het voorstel. Hij vond dat de nieuwe instelling zich niet bezig moest houden met belangenbehartiging van doelgroepen, maar juist 'een dienstverlenende en innovatieve functie' naar het maatschappelijk middenveld moest innemen ${ }^{679}$. Ook de voorzitter van het interim-bestuur, M.A.T.H. de Wit, had in het eindadvies aan Gedeputeerde Staten een minderheidsstandpunt ingenomen, omdat hij het niet eens was met het voorstel om 'slechts' zeven instellingen te laten fuseren ${ }^{680}$.

Tot twee keer toe werd de besluitvorming in het College van Gedeputeerde Staten uitgesteld. Uiteindelijk namen Gedeputeerde Staten eind september 1993 het besluit om de fusie van de tien instellingen toch door te zetten. Efficiencywinst, meer doelmatige samenwerking, integratiewinst en een vermindering van de overheadkosten waren de begeleidende argumenten in het persbericht ${ }^{681}$. Een financiële bezuiniging ('ombuiging') van 4,7 miljoen gulden werd mogelijk geacht. Het nieuwe instituut kreeg daarbij als voorlopige titel: Symbiose, Limburgs instituut voor begeleiding en ontwikkeling. Daarmee trok de Provincie de regie weer naar zich toe en bedankte het interim-bestuur voor de verleende diensten. Symbiose moest en zou er komen. Het was vooral de ambtelijke hoofdgroep die de druk opvoerde en de nieuwe gedeputeerde, M.C. GreweldingerBeudeker (CDA), hiervan overtuigde. Provinciale Staten stemden op 5 november 1993 in met het voorstel. Een nieuw bestuur waarin uitsluitend mensen van 'buiten de kring van de betrokken instellingen' zaten, moest de fusie realiseren ${ }^{682}$.

In februari 1994 werd de Stichting Symbiose opgericht en in het najaar lag er een programma van eisen waarin de inhoudelijke taken beschreven waren, maar waarin de belangrijkste knelpunten onopgelost bleven. Er was sprake van een 'impasse' ${ }^{1683}$. BDO CampsObers, het adviesbureau dat als nieuw stichtingsbestuur functioneerde, constateerde eind 1994 dat Symbiose wel bestond op papier, maar nog geen sterke formele positie had. De 
besturen van de te fuseren instellingen weigerden verantwoordelijkheden over te dragen en de Provincie had 'geen reëel zicht' op het te volgen proces ${ }^{684}$. Een harde fusiedatum kon niet worden vastgesteld ${ }^{655}$ en de Provincie ondermijnde het gezag van Symbiose ${ }^{686}$. Met de provinciale statenverkiezingen voor de deur werd de problematiek uitgesteld. In het nieuwe Basisakkoord 1995-1999 werd het eerder genomen besluit herbevestigd: "De totstandkoming van Symbiose zal worden voortgezet en afgerond conform de door Provinciale Staten genomen besluiten"687. M.J.A. Eurlings (CDA) werd verantwoordelijk gedeputeerde. Hij legde zijn politieke prioriteiten niet bij het welzijnsbeleid, maar bij de beleidsterreinen ouderenzorg, jeugdhulpverlening en cultuur ${ }^{688}$. De realisatie van de welzijnsinstelling Symbiose liet hij over aan zijn ambtenaren.

Met deze nieuwe politieke prioritering van gedeputeerde Eurlings, was 'welzijn' definitief van het politieke toneel verdwenen. Met de herbevestiging van het besluit over Symbiose in het nieuwe collegeakkoord werden in een half jaar tijd de bouw, de fusie en de inhoudelijke organisatie doorgedrukt. Dit was vooral een ambtelijk proces. Onder de dreiging van het beëindigen van de subsidierelatie was het slikken of stikken voor de tien steunfuncties ${ }^{689}$. De coalitieafspraak moest uitgevoerd worden.

Op 1 januari 1996 werden de instellingen formeel gefuseerd tot de stichting Symbiose op de nieuwbouwlocatie aan het spoor in Sittard. Met een budget van 20 miljoen gulden per jaar zou de Provincie via subsidie-eisen sturing geven aan vooraf gestelde 'prestatieresultaten ${ }^{1690}$. Dit was een hoger bedrag dan het College van Gedeputeerde Staten in 1992 met Provinciale Staten had afgesproken.

Reorganisaties en de financiële tekorten bij Symbiose volgden elkaar op in de periode na de fusie. Het was gedeputeerde J.B. Haazen (VVD) die uiteindelijk de knoop in 1999 doorhakte ${ }^{691}$. Symbiose moest verzelfstandigd worden en de onderdelen sport, zorg en bibliotheekwerk werden ondergebracht in een drietal 'huizen': het Huis voor de Sport, het Huis voor de Zorg en het Bibliotheekhuis. Later volgde ook nog een Huis voor de Kunsten. In 1997 was er al een Monumentenhuis opgericht om de kennis en expertise van de monumentenzorg te bundelen in een afzonderlijke organisatie. Daarmee werd de fusiegedachte van één grote Limburgse welzijnsinstelling verlaten. De overgebleven taken zou Symbiose vanaf 1 januari 2004 zelf moeten financieren. Op die datum zou de Provincie de subsidie intrekken ${ }^{692}$.

Met deze koerswijziging werd eigenlijk de situatie van begin jaren ' 90 teruggebracht: die van de vijf steunfunctie-instellingen. Zij heetten vanaf nu 'huizen'. In de tweede helft van 2003 bleek dat Symbiose deze verzelfstandiging niet kon waarmaken. De stichting vroeg faillissement aan. Het door Provinciale Staten ingestelde onderzoek naar de gang van zaken, concludeerde in 2005 dat het hele proces vooral was 'ingegeven door bezuinigingen en minder door de notie dat een fusie een onderlinge versterking van de partners zou betekenen' ${ }^{1693}$.

Een tussentijdse reflectie

Alvorens in te gaan op het vierde omslagmoment in het provinciale welzijnsbeleid rond 
2003, is het nodig om even pas op de plaats te maken. In de jaren ' 80 had het Provinciaal Bestuur zich nog hard gemaakt voor het binnenhalen van bevoegdheden en van financiële middelen om een eigen welzijnsbeleid te kunnen voeren. In 1989 was dit uiteindelijk ook gelukt met het in werking treden van de Welzijnswet. Een kleine tien jaar later kwam het woordje 'welzijn' niet eens meer voor in de prioriteiten van het nieuwe coalitieakkoord ${ }^{694}$. De beleidsterreinen zorg en cultuur waren de nieuwe politieke speerpunten van het College van Gedeputeerde Staten. Het welzijnsbeleid was van een ambitieuze portefeuille een ambtelijk hoofdpijndossier geworden. Hoe is dit te verklaren?

Een eerste verklaring ligt in de manier waarop het welzijnsbeleid was georganiseerd. De provinciale steunfuncties die voor de Provincie het welzijnsbeleid moesten uitvoeren, hebben nooit echt goed kunnen functioneren. Zij moesten hun werkzaamheden uitvoeren onder een voortdurende dreiging van bezuinigingen van rijksoverheid en Provincie. Daarbij waren deze organisaties zelf nauwelijks in staat hun maatschappelijk belang helder naar voren te brengen naar de overheidsinstanties. Paul Schnabel heeft er op gewezen dat - in tegenstelling tot de gezondheidszorg - de welzijnssector weinig tot geen wetenschappelijke onderbouwing kent voor haar werkzaamheden (op cit. in De Haan \& Duyvendak, 2002: 350).

Dat had niet op de laatste plaats, een tweede verklaring, ermee te maken dat de definitie van specifiek welzijn nooit scherp is gedefinieerd. In dat opzicht is welzijn altijd een soort 'restcategorie' gebleven in het algemene sociaal beleid van sociale zekerheid, onderwijs, arbeidsmarktbeleid en zorgbeleid (Engbersen \& Sprinkhuizen, 1999: 219). De worsteling van het afdelingshoofd J.H. Dassen, waarmee dit hoofdstuk begon, is niet beëindigd. Een heldere definitie van het welzijnsbegrip, laat staan van wat een welzijnsbeleid precies inhield en welke doelstellingen hieraan verbonden konden worden, is evenmin geformuleerd.

Een derde verklaring moet gezocht worden in de gelaagdheid van verantwoordelijkheden. Het welzijnsbeleid was versnipperd tussen Provincie, provinciale steunfuncties, (samenwerkende) gemeenten en de in de jaren '90 sterk opkomende regionaal werkende welzijnsinstellingen. Bovendien waren gemeenten zich actiever gaan bezighouden met wat genoemd werd 'lokaal sociaal beleid'. De samenwerking tussen deze verschillende organisaties werd pas eind jaren '90 voorzichtig door de Provincie vorm gegeven ${ }^{695}$. Daarnaast waren er eenvoudigweg teveel organisaties met sterk uiteenlopende belangen om een samenhangend welzijnsbeleid te ontwikkelen.

Een vierde en laatste verklaring voor het einde van het provinciale welzijnsbeleid ligt in het feit dat dit in de jaren ' 90 geen politiek item is geweest, waarmee gedeputeerden zich konden profileren. Enerzijds lag dit aan de minder aantrekkelijke opgave om fors te bezuinigen, anderzijds kwam dit door snel opeenvolgende gedeputeerden. In de periode 1990-2003 waren maar liefst 5 gedeputeerden verantwoordelijk voor het welzijnsbeleid. $\mathrm{Zij}$ werden voortdurend geconfronteerd met eerder genomen politieke besluitvorming die uitgevoerd moest worden. Het is niet verwonderlijk dat het welzijnsbeleid in de jaren '90 vooral tot een ambtelijke aangelegenheid was verworden. Het doorzetten van de fusie van een tiental welzijnsinstellingen tot één provinciale welzijnsorganisatie, was een brug te 
ver. Het faillissement van Symbiose eind 2003 was niet alleen het einde van een jarenlange herstructurering, het was tevens het einde van het provinciale welzijnsbeleid.

\section{Vierde omslagmoment: de Provincie in de wijk! (2003)}

Het faillissement van Symbiose eind 2003 kwam ruim een half jaar nadat er een nieuw College van de Gedeputeerde Staten in mei was aangetreden. Ook al was het voor dit nieuwe College nog niet duidelijk dat Symbiose failliet zou gaan, er heerste wel een sterk gevoel om het 'sociale domein' met een nieuwe schone lei te benaderen ${ }^{696}$. In de opzet van het coalitieakkoord stonden vijf thema's centraal die de komende jaren politieke prioriteit zouden krijgen. Het thema Samen bouwen aan vitale kernen, wijken en buurten (hierna Vitale Kernen) was een van die thema's. Niet langer een provinciebreed welzijnsbeleid, maar een beleid gericht op het bevorderen van de leefbaarheid in de wijk, was de centrale boodschap. Dit thema kwam niet uit de lucht vallen.

Eind 2002 had de minister van Volkshuisvesting, H.G.J. Kamp (VVD), in een brief aan de Tweede Kamer gesproken over 50 probleemwijken in Nederland waar snel iets moest gebeuren. In deze wijken waren grote problemen waar het met 'de leefbaarheid slecht gesteld' was ${ }^{697}$. Ook een aantal Limburgse wijken in Maastricht, Sittard, Heerlen en Venlo kwam voor op deze lijst ${ }^{698}$. De nieuwe gedeputeerde voor het coalitiethema Vitale Kernen was H.T.J. Vrehen (CDA). Hij was zich er terdege van bewust dat een wijkenaanpak primair een verantwoordelijkheid was van de Limburgse gemeenten en niet van de Provincie. Een van zijn eerste acties was: het gesprek aangaan met een aantal wethouders om te bekijken waar Provincie en gemeenten elkaar konden ondersteunen. Daarbij stonden twee vragen centraal. Is de 'maatschappelijke problematiek' van de wijken en buurten goed neergezet in het coalitieakkoord? En: 'wat kan en moet de rol van de Provincie zijn?'699 Het was een nieuwe, meer bescheiden opstelling van de Provincie ten opzichte van de gemeenten. In de jaren ' 80 waren de gemeenten nauwelijks betrokken bij het provinciale welzijnsbeleid en in de ontwikkeling van Symbiose speelden gemeenten geen enkele rol. De gemeenten hadden hun eigen ervaringen opgedaan. De meeste bevoegdheden op het gebied van sociale uitkeringen, bijstand, lokale welzijnsproblematiek, de sloop en nieuwbouw van wijken waren allemaal lokale zaken waar de Provincie nauwelijks bij betrokken was. De Provincie had vooral vanuit haar subsidieverlening contacten met de gemeenten. Het provinciale welzijnsbeleid en het lokale welzijnsbeleid hadden altijd ver uit elkaar gelegen. Met het thema Vitale Kernen werd de verbintenis gezocht tussen de Provincie en de gemeente. Rondom het thema leefbaarheid werd hier een nieuw 'partnerschap' gevormd.

De problematiek in de wijk vormde daarbij de urgentie voor een nieuw provinciaal beleid, waarbij slim ingespeeld werd op de nationale ontwikkelingen met de wijkenaanpak. De persoonlijke contacten tussen de gedeputeerde en een aantal wethouders versterkten het onderlinge besef dat hier een gezamenlijke aanpak nodig was tussen Provincie en gemeenten. Welzijnsbeleid was leefbaarheidsbeleid geworden, een nieuw omslagmoment diende zich aan. 


\subsection{Einde van welzijn, leve de leefbaarheid! (periode 2003-2007 en verder)}

Met het thema Vitale Kernen werden drie veranderingen in gang gezet ten opzichte van het verleden. Op de eerste plaats werd 'de wijk' het schaalniveau voor provinciaal beleid ${ }^{700}$. Zelfs met de probleemgerichte aanpak van begin jaren ' 80 was de Provincie niet zover gegaan. Daarmee begaf de Provincie zich heel nadrukkelijk binnen de gemeentelijke bevoegdheden. Men was dus genoodzaakt - en daarin zit de tweede vernieuwing - om zeer nauw samen te werken met de Limburgse gemeenten. Zeker gezien de provinciale opstelling in de jaren ' 80 en ' 90 was dit een hernieuwde kennismaking. De Provincie had eind jaren '90 wel in navolging van de rijksoverheid een provinciaal grotestedenbeleid opgezet, maar de resultaten hiervan waren niet tot ieders tevredenheid ${ }^{701}$. Ook in het programma Wonen-Welzijn-Zorg dat ongeveer gelijktijdig met het grotestedenbeleid uitgevoerd werd, was de Provincie nog steeds erg sturend aanwezig. Met het thema Vitale Kernen werd de primaire verantwoordelijkheid bij gemeenten gelegd en stelde de Provincie zich op als partner. Immers, 'niet de Provincie, maar gemeenten hebben kernen en buurten'702 constateerde de Provincie zelf. De Provincie zag haar rol vooral in

"... initiatieven vanuit de basis, gericht op de verbetering van de vitaliteit, versterken door haar eigen aanvullende inzet van instrumenten. Daar waar gemeenten samen met bewoners en lokale partners verbeteropgaven per kern of wijk [...] ontwikkelen, kan de Provincie deze partners ondersteunen bij het opstellen van de verbeterprogramma's" 703 .

In de beginfase werd nog gesproken over 'vitaliteit', maar in de uitwerking werd steeds vaker gesproken over de 'leefbaarheid'704 van kernen en buurten. De derde vernieuwing in het provinciale beleid zat in de definitie van het begrip leefbaarheid. De Provincie definieerde leefbaarheid als 'de aanwezigheid van winkels, openbaar vervoer, ontmoetingsruimten, rust en ruimte, recreatiemogelijkheden'. En vervolgde: 'Wat leefbaarheid is, wordt bepaald door de wensen en behoeften van inwoners op het gebied van wonen, welzijn en zorg'705. Daarmee ging het de Provincie vooral om verbeteringen in de fysieke leefomgeving en de beleving en waardering van burgers hiervoor. Men sprak van een 'passend woningaanbod 706 , het realiseren van 'multifunctionele centra' en 'brede scholen' en een breed toegankelijk openbaar vervoer ${ }^{707}$.

Welke bevoegdheden en instrumenten kon de Provincie inzetten voor het thema Vitale Kernen? Zoals gezegd lagen de meeste wettelijke bevoegdheden bij gemeenten (en woningcorporaties). De Provincie kende wel drie subsidieregelingen die voor het thema relevant waren. Op de eerste plaats was er het Investeringsbudget Stedelijke Vernieuwing, waarvoor gemeenten projecten konden indienen. Dit was een aanzienlijke subsidiepot van 31 miljoen euro waarmee o.a. de herstructurering van woonwijken gefinancierd kon worden. Daarnaast was er een tweede subsidieregeling voor projecten gericht op het realiseren van woningen voor mensen die zorgverlening nodig hadden. Ook de nieuwbouw van zogeheten multifunctionele accommodaties kon hiermee betaald worden ${ }^{708}$. Dit waren locaties zoals een postkantoor waar verschillende vormen van andere dienstverlening als bankzaken, apotheek, zorgverlening, verzekeringszaken werden aangeboden ${ }^{709}$. Het ging 
hier om een jaarlijks budget van 2,1 miljoen euro. Deze subsidies werden verdeeld over negen regio's in de provincie. Een samenwerkingsverband tussen welzijnsinstellingen, zorginstellingen, woningcorporaties, gemeenten en Provincie coördineerde dit. Ten slotte was er nog de subsidieregeling voor maatschappelijke organisaties die al een lange geschiedenis kende.

Gedeputeerde H.T.J. Vrehen (CDA) heeft geprobeerd om deze drie subsidieregelingen om te vormen naar een nieuw 'Leefbaarheidsfonds'. Het doel was om 'via een integrale aanpak, geldstromen gecoördineerd in [te] kunnen zetten zodat ze elkaar versterken ${ }^{1710}$. Daarmee werd meteen invulling gegeven aan een motie die eind 2003 in Provinciale Staten was aangenomen. Deze bundeling van middelen bleek een brug te ver. De regeling die in maart 2004 gepresenteerd werd, was een nieuwe aparte subsidiepot van bijna 1,2 miljoen euro - naast de drie bestaande regelingen - die zich specifiek richtte op multifunctionele accommodaties en brede scholen ${ }^{711}$. Eén groot flexibel inzetbaar budget zou niet gerealiseerd worden ${ }^{712}$.

Maar, een gebrek aan formele bevoegdheden of beperkte financiële middelen, zegt lang niet alles over de provinciale rol. Het beschikbaar stellen van menskracht, uitwerken van nieuwe instrumenten, de lobby verzorgen naar de rijksoverheid of het participeren in gemeentelijke projecten, zijn ook mogelijkheden om een thema uit te werken. Wat de Provincie Limburg in feite in de periode 2003-2004 deed, was een charme-offensief naar de Limburgse gemeenten. Men verdiepte zich in de problematiek van de wijk, keek naar mogelijkheden voor pragmatische samenwerking en bood mankracht, expertise en kennis aan. Deze verkennende contacten met de gemeenten moesten wel tot resultaten leiden. Met de gemeenten waarmee overstemming was bereikt over samenwerking, werden vanaf december 2004 zogeheten Afsprakenkaders afgesloten. Dit waren een soort bestuursconvenanten die door gedeputeerde Vrehen en de betrokken wethouder werden ondertekend. Zoals de naam al aangaf, werden hierin de afspraken vastgelegd over de projecten die jaarlijks gezamenlijk uitgevoerd zouden worden. $\mathrm{Na}$ een jaar werd de stand van zaken opgemaakt en kon eventueel een actualisatie plaatsvinden van nieuwe projecten. In de periode 2005-2007 werden 20 Afsprakenkaders met gemeenten ondertekend.

Alvorens nader in te gaan op de precieze functie van deze Afsprakenkaders en relatie met de gemeenten, moet er stilgestaan worden bij een laatste instrument dat door de Provincie werd ingezet, namelijk de lobby naar de rijksoverheid. Op nationaal niveau speelden twee onderwerpen die voor het thema Vitale Kernen van belang waren. Op de eerste plaats werd er gewerkt aan de nieuwe Wet Maatschappelijke Ondersteuning en op de tweede plaats kreeg de nationale wijkenaanpak concreter vorm. Voor beide items gold dat de Provincie Limburg graag zag, dat de Provincie hierin een stevigere rol kreeg.

Op 21 december 2004 verstuurde het College van Gedeputeerde Staten een brief aan de staatssecretaris van Volksgezondheid, Welzijn en Sport met het verzoek om Limburg als proeftuin aan te wijzen voor de implementatie van de Wet Maatschappelijke Ondersteuning. De ontwerpwet, die op 23 april 2004 naar de Tweede Kamer was gestuurd, verving de Welzijnswet van $1994^{713}$. In het wetsvoorstel kwam het woordje 'provincie' 
nauwelijks voor. De nieuwe wet regelde dat de verantwoordelijkheden voor de taken die vroeger als 'specifiek welzijn' werden aangeduid en niet gedecentraliseerd waren in de jaren '90, naar de gemeenten gingen. De provincies bleven in het wetsontwerp verantwoordelijk voor het steunfunctiewerk. De Provincie Limburg had in haar brief aan het ministerie aangegeven graag op provinciaal niveau te willen experimenteren voor de uitwerking van de nieuwe wet. De ervaringen met het programma Wonen-Welzijn-Zorg pasten volgens de Provincie goed in de basisgedachte van een integrale aanpak ${ }^{714}$.

Een provinciale proeftuin - zoals begin jaren ' 80 wel was gelukt - kwam er niet. Het ministerie van Volksgezondheid, Welzijn \& Sport koos uiteindelijk voor 26 regionale proeftuinen. In Limburg kregen de regio Helden en geheel Zuid-Limburg de status van pilotregio. Het voortrekkerschap van deze twee proeftuinen lag bij de betrokken gemeenten. De Provincie participeerde wel in deze twee projecten, maar een trekkende provinciale rol zoals in de jaren ' 80 , werd niet toegekend. De tijden waren veranderd. De rijksoverheid had in de jaren ' 90 de prioriteit bij de gemeenten gelegd. In dat opzicht was de nieuwe wet een slotakkoord op een ontwikkeling die al jaren geleden was ingezet. Wilde de Provincie iets betekenen in het 'sociale domein', dan moest zij samenwerken met de gemeenten en erkennen dat deze de eerst verantwoordelijke waren voor het sociale beleid van de 21e eeuw.

Rond de tijd dat de Provincie Limburg lobbyde voor een grotere rol in de Wet Maatschappelijke Ondersteuning, schreef de Wetenschappelijke Raad voor het Regeringsbeleid (WRR) een rapport over de leefbaarheid in de Nederlandse buurten. Onder voorzitterschap van P. Winsemius (VVD) werd een analyse gemaakt van het buurtgerichte beleid. Een 28-tal casussen waren geanalyseerd, waarbij ook de Provincie een aantal Limburgse casussen had ingebracht ${ }^{715}$. Het eindrapport, getiteld Vertrouwen in de buurt, werd op 14 maart 2005 aangeboden aan de regering. De Provincie had Winsemius uitgenodigd om het rapport twee maanden later persoonlijk toe te lichten in Limburg. Dit werd gecombineerd met het opmaken van de tussenbalans van het thema Vitale Kernen. De aanbevelingen in het rapport waren vooral gericht aan gemeenten en 'sociale spelers'. Toch richtte Winsemius zich in het rapport tevens tot de rijksoverheid en de provincies: "Zorg voor harde kaderafspraken met de koepels van sociale spelers"716. Daarbij werden vooral de woningcorporaties aangesproken die in de ogen van Winsemius een te grote mate van vrijblijvendheid vertoonden bij de invulling van hun sociale taakstelling. Voor de Provincie Limburg betekende het rapport van Winsemius op de eerste plaats een nieuwe impuls om de aanbevolen 'kaderafspraken' met gemeenten te intensiveren. Eind 2006 werd een poging gedaan om met de Limburgse woningcorporaties tot afspraken te komen $^{717}$. Op de tweede plaats werd met de aanwezigheid van Winsemius het provinciale coalitiethema Vitale Kernen van goede communicatieve uitstraling voorzien.

De Afsprakenkaders tussen Provincie en gemeenten gaven goed de onderlinge verhoudingen weer. Drie elementen waren in deze interbestuurlijke verhoudingen van belang.

Op de eerste plaats vormden de afsprakenkaders een 'gespreksbasis' tussen Provincie en gemeenten. De gemeenten bespraken met de Provincie projecten die zich nog in een 
conceptfase bevonden. Vanuit de Provincie werd de nadruk gelegd op een integrale aanpak die niet 'te lokaal' moest zijn. Op basis van een gezamenlijke inhoudelijke overeenstemming werden zo financiële middelen toegekend. Daarmee voerde de Provincie de druk op naar gemeenten die nog geen Afsprakenkader hadden ondertekend ${ }^{718}$. Omdat de voortgang jaarlijks werd besproken, konden dan ook nieuwe projecten worden ingediend. De Provincie kreeg zo een aardig beeld van de leefbaarheidinitiatieven per gemeente $^{719}$. De initiatieven werden op de provinciale website geplaatst. Niet elke gemeente was enthousiast over de provinciale aanpak. Vooral de kleinere gemeenten waren erg te spreken over de gerealiseerde afspraken en hadden baat bij de geboden ambtelijke en financiële ondersteuning. Grotere gemeenten zagen minder de meerwaarde in deze provinciale rol $^{720}$. Toch had uiteindelijk bijna de helft van de Limburgse gemeenten in 2007 een Afsprakenkader ondertekend.

De Afsprakenkaders hadden nog een tweede functie. Zij brachten de spanning naar boven tussen het regionale en het lokale beleid van de Provincie. Naarmate de Provincie met meerdere gemeenten afspraken maakte, kwam de vraag naar voren hoe deze projecten zich verhielden met het regionale beleid op andere beleidsterreinen. Met de programma's Wonen-Welzijn-Zorg, de Regionale Volkshuisvestingsplannen en het Reconstructieen plattelandsbeleid, werden vooral op regionaal schaalniveau afspraken gemaakt. De provinciale rol richtte zich in het thema Vitale kernen echter op het lokale schaalniveau van de wijk. Het was een telkens terugkerende spanning. Er werd wel geprobeerd om hierin een compromis te zoeken. Op lokaal niveau zocht men ernaar om 'juist die projecten te formuleren ... die een relatie zichtbaar maken met [de] regionale dossiers ${ }^{1721}$. Eerder al had de Provincie naar de gemeenten aangegeven dat de projecten niet 'te lokaal' moesten zijn ${ }^{722}$. De afstemming tussen lokaal/regionaal bleef tot 2007 een moeilijke zaak. De regionale beleidsprogramma's bleken onvoldoende duidelijkheid te bieden om op gemeentelijk niveau in het thema Vitale Kernen de juiste projecten te selecteren. Andersom kwamen gemeenten ook met projecten die nauwelijks iets met de provinciale thematische aanpak van Vitale Kernen te maken hadden. Gemeenten zagen het overleg met de Provincie in een aantal gevallen als een nieuwe gemeentelijke financieringsbron ${ }^{723}$. De vraag over de provinciale rol werd met de discussie over de lokale of regionale invulling expliciet. Zowel binnen de provinciale organisatie alsook in de contacten met gemeenten en regionale overlegkaders bleef men stoeien met de wisselende schaalniveaus. De lokale benadering zorgde wel voor een aanscherping van het type projecten waarin de Provincie wenste te participeren.

Op de derde plaats zorgden de Afsprakenkaders voor een meer integrale en afgestemde inzet van geld. In de jaren ' 90 waren er diverse subsidieregelingen ontstaan voor uiteenlopende zaken. Zo waren er regelingen voor de jeugdzorg, ouderenzorg, participatie van minderheden, culturele instellingen, sociale ontwikkeling, sport, maatschappelijke organisaties en de - na het debacle van Symbiose - 'Huizen'. In de Afsprakenkaders stond niet het provinciale beleid centraal, maar de verbeteropgaven en projecten in Limburgse wijken. Deze nieuwe rol ging verder dan de zoektocht naar het passende subsidiekader voor een project. Geld en subsidieverlening moesten niet de primaire focus worden van de 
afspraken met gemeenten ${ }^{724}$. Veel meer ging het om gezamenlijke projectontwikkeling, het benutten en opzoeken van de ruimte in mogelijk belemmerende provinciale regelgeving (bijvoorbeeld in de ruimtelijke ordening). Het beschikbaar stellen van expertise en kennis was net zo belangrijk als de financiële steun. Dit vroeg om een andere manier van werken in de provinciale organisatie ${ }^{725}$. De Afsprakenkaders zorgden ervoor dat medewerkers van de afdelingen Ruimtelijke Ontwikkeling, Gemeentefinanciën, Sociale Ontwikkeling, Zorg en Mobiliteit in teamverband samenwerkten. Een complicerende factor daarin waren de politiek-ambtelijke verhoudingen en de onderlinge politieke afstemming tussen gedeputeerden.

Het werkveld van gedeputeerde Vrehen moest anders dan zijn collega-gedeputeerden inhoudelijk 'gevuld' worden door meer dan 10 provinciale afdelingen ${ }^{726}$. Wat deze 'vulling' bemoeilijkte, was de keuze uit het coalitieakkoord om naast de themaportefeuilles de sectorportefeuilles in stand te houden. Zo kon het zijn dat de gedeputeerde die verantwoordelijk was voor het sectorbeleid Welzijn en Zorg (PvdA-gedeputeerde O.M.T. Wolfs), niet de gedeputeerde was die verantwoordelijk was voor het thema Vitale Kernen (CDA-gedeputeerde H.T.J. Vrehen). Het was de politieke spanning tussen sectoren themaverantwoordelijkheid die het sterkst naar voren kwam in het thema Vitale Kernen. In andere thema's - zoals Ruimte voor Limburg of Ondernemend Limburg - was de gedeputeerde van het thema én de sector verenigd in één persoon en speelde dit veel minder. Deze dubbele verantwoordelijkheden bemoeilijkten ook de politiekambtelijke verhoudingen. Werkte de ambtenaar voor een thema of werkte hij/zij voor een beleidsterrein? Door de politieke verantwoordelijkheid voor beide elementen - thema en beleidsveld - apart in stand te houden, werkte dit in de ambtelijke organisatie door. Er is dan ook veel tijd gaan zitten in de eerste fase van het thema Vitale Kernen om een scherpe inhoudelijke richting te bepalen. Hierbij waren immers maar liefst 10 beleidsafdelingen betrokken.

De Afsprakenkaders vormden samen met de werkwijze in het Heroriëntatietraject Ruimtelijke Ordening en de economische Versnellingsagenda (zie hoofdstukken 2 en 3) belangrijke praktijkvoorbeelden van een nieuwe provinciale rol in de periode 2003-2007. Dat dit geen kortstondige rolverandering betrof, bleek wel uit het feit dat het ingezette thematische beleid en de nauwe samenwerking met gemeenten binnen Vitale Kernen, in de volgende Collegeperiode (2007-2011) een vervolg kreeg ${ }^{727}$.

De teleurstellende opzet van een nieuw Leefbaarheidsfonds, of de voortdurende spanning tussen de regionale beleidsprogramma's en de Afsprakenkaders laten tegelijkertijd zien dat deze nieuwe rol niet vanzelf ging. De provinciale rol van subsidieverstrekker - die het welzijnsbeleid altijd heeft gedomineerd -, bleek uiteindelijk in het thema Vitale Kernen anno 2007 moeilijk los te laten ${ }^{728}$. In totaal werden er ruim 300 projecten gesubsidieerd waarvan 23 multifunctionele voorzieningen. Maar toch, zo concludeerde verantwoordelijk gedeputeerde Vrehen in een terugblik op het thema Vitale kernen 'de afsprakenkaders met de gemeenten [waren] het belangrijkst'729. Provinciaal welzijnsbeleid was daarmee gemeentelijk leefbaarheidsbeleid geworden. 


\subsection{Hoofdlijnen en voorlopige conclusies}

De 'worsteling' van de provinciale ambtenaar, waarmee dit hoofdstuk begon, is nooit opgelost. De Provincie Limburg heeft in de hiervoor geschetste periode steeds opnieuw geworsteld met het welzijnsbeleid. Aan de bevoegdheden en instrumenten heeft het niet gelegen. De Provincie had in de jaren '60 en '70 omvangrijke subsidiepotten. In de jaren ' 80 kreeg de Provincie hier een groot aantal formele bevoegdheden en taken van de rijksoverheid bij. De sticks (bevoegdheden) en carrots (subsidies) gaven de Provincie alle ruimte om een provinciaal welzijnsbeleid handen en voeten te geven. Wat ontbrak was het sermon, de preek oftewel het inhoudelijke verhaal ${ }^{730}$. Vanaf eind jaren '70 is de Provincie vooral bezig geweest met het reorganiseren, herstructureren, opnieuw ordenen en fuseren van instellingen en steunfuncties. Het welzijnsbeleid was dan ook eerder een zoektocht naar de juiste welzijnsstructuur in Limburg, dan het formuleren van een inhoudelijk welzijnsbeleid.

Mogelijk is dit te verklaren door het nog steeds impliciet ervaren beginsel van subsidiariteit. De overheid bemoeit zich niet met de inhoud van het welzijn van individuele mensen of groepen, maar biedt slechts randvoorwaarden voor burgers, particulier initiatief en maatschappelijke instellingen.

De voortdurende onduidelijkheid over wat er onder 'specifiek welzijn' precies verstaan moet worden, is een tweede verklaring voor het feit dat de Provincie zich vooral op de welzijnsstructuur richtte. Welzijnsbeleid in de jaren '60 en '70 betekende het subsidiëren van lokale maatschappelijke voorzieningen en organisaties. Toen deze organisaties eind jaren '70 wel erg veel invloed kregen en er een overdaad aan gesubsidieerde voorzieningen dreigde te ontstaan, moest er een nieuwe invulling aan het welzijnsbeleid worden gegeven. Diverse gesubsidieerde instellingen werden onder aansturing van het Provinciaal Bestuur samengevoegd en kregen de taak om ondersteuning te bieden aan het lokale welzijnswerk. De samengevoegde instellingen werden provinciale 'steunfuncties'.

De nieuwe Welzijnswet (1987) die minister Brinkman invoerde en waarvoor de Provincie Limburg als enige proefprovincie was geweest, herverdeelde de bevoegdheden en financieringsstromen tussen rijksoverheid, provincies en gemeenten. Met de wet werd een duidelijke afbakening gemaakt wie waar verantwoordelijk voor was. De relatie tussen provincie enerzijds en rijksoverheid en gemeenten anderzijds was daarmee duidelijk. Minder duidelijk was de relatie tussen provinciale overheid en particulier initiatief. De provincies waren dan wel verantwoordelijk voor de steunfuncties, maar de vraag of de steunfuncties er enerzijds waren om provinciaal beleid uit te voeren, of anderzijds om de belangen van het particulier initiatief en lokaal welzijnswerk te behartigen, bleef onduidelijk. In de jaren '90 was het vooral het ambtelijk apparaat dat steeds meer neigde naar het eerste antwoord. Symbiose zou één grote Limburgse welzijnsinstelling moeten worden waarmee tegelijkertijd een forse kostenbesparing van de Provincie gerealiseerd kon worden. $\mathrm{Na}$ de herstructureringsronde van de jaren ' 80 werd begin jaren '90 een tweede fusieronde ingezet.

Waar er in de jaren ' 80 een sterke politieke druk achter het welzijnsbeleid zat, was dit beleid in de jaren '90 uit de politieke gratie geraakt. Andere sociale thema's als jeugdzorg, 
arbeidsmarktbeleid, onderwijs, ouderenzorg en cultuur waren belangrijker dan het ongrijpbare welzijnsbeleid. Bovendien hadden de gemeenten in die jaren steeds meer een positie ingenomen binnen wat 'lokaal sociaal beleid' werd genoemd. De gemeenten hadden voor de uitvoering van de Bijstandsregeling nieuwe taken gekregen van de rijksoverheid. Tegelijkertijd groeide een aantal welzijnsinstellingen uit tot grote regionaal werkende organisaties. Zij waren steeds vaker een concurrent van de provinciale steunfuncties. De tijden waren veranderd. Welzijnsbeleid was niet langer een politiek item meer, de fusie van de vijf steunfuncties mislukte uiteindelijk in 2003 met het faillissement van Symbiose en de Provincie veranderde opnieuw haar koers.

Inspelend op de landelijke wijkenaanpak kwam de Provincie met een nieuwe thematische aanpak. In het coalitiethema Vitale Kernen werd nadrukkelijk de samenwerking met de Limburgse gemeenten opgezocht. Niet eerder was de samenwerking met gemeenten zo expliciet vormgegeven als in 2003. Tot die tijd was er in het provinciale welzijnsbeleid sprake geweest van een redelijke afstand tot het gemeentelijke beleid. De onderlinge contacten beperkten zich tot het verlenen van provinciale subsidies. Met het thema Vitale kernen werd de gemeente gezien als eerst verantwoordelijke en bood de Provincie haar kennis, instrumenten, lobby - en uiteindelijk ook subsidiegelden - aan voor projecten om de leefbaarheid van wijken en buurten te verbeteren. Welzijnsbeleid was leefbaarheidsbeleid geworden. Niet langer de rijksoverheid of de steunfuncties waren gesprekspartner, maar de gemeenten. Niet langer stonden de provinciale prioriteiten centraal, maar de problematiek in de wijk. Deze themagerichte benadering werd in de periode 2003-2007 uitgewerkt. Het was een nieuwe provinciale rol binnen het sociale domein. Een rol die in de volgende coalitieperiode zou worden gecontinueerd. 



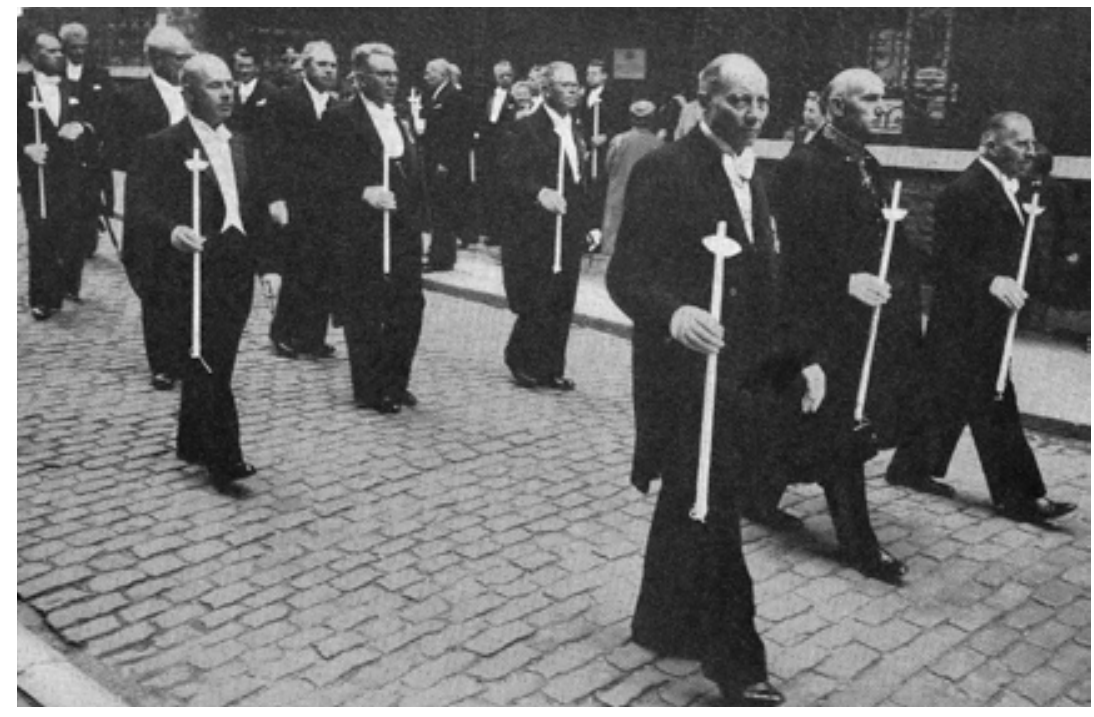

Het voltallig College van Gedeputeerde Staten loopt mee in de Servaesprocessie, mei 1958. De Provincie onderhield tot begin jaren '60 een nauwe band met de katholieke kerk. Foto: Provincie Limburg.

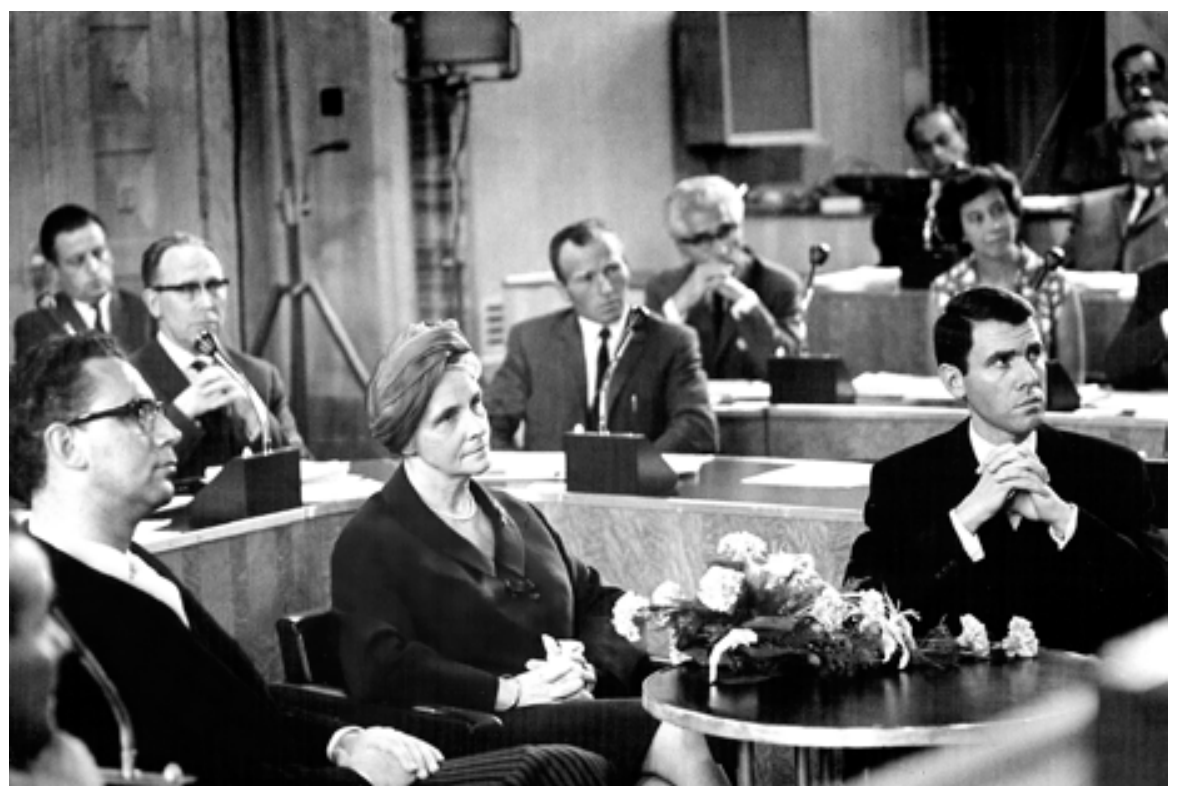

Minister van Maatschappelijk Werk Marga Klompé luistert in de Statenzaal tijdens een werkbezoek aan Limburg op 20 mei 1968. Foto Provincie Limburg. 


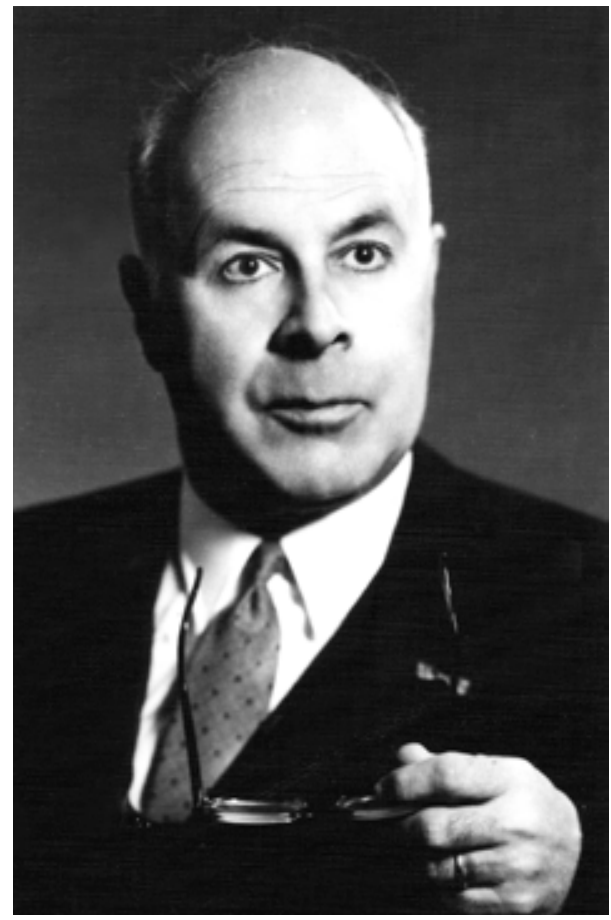

Gedeputeerde P.J.C. Lebens (KVP) was voorzitter van verschillende commissies waarin subsidies verdeeld werden voor projecten op het gebied van welzijn. Met dank aan Remie Lebens voor het beschikbaar stellen van de foto. Foto: Provincie Limburg.

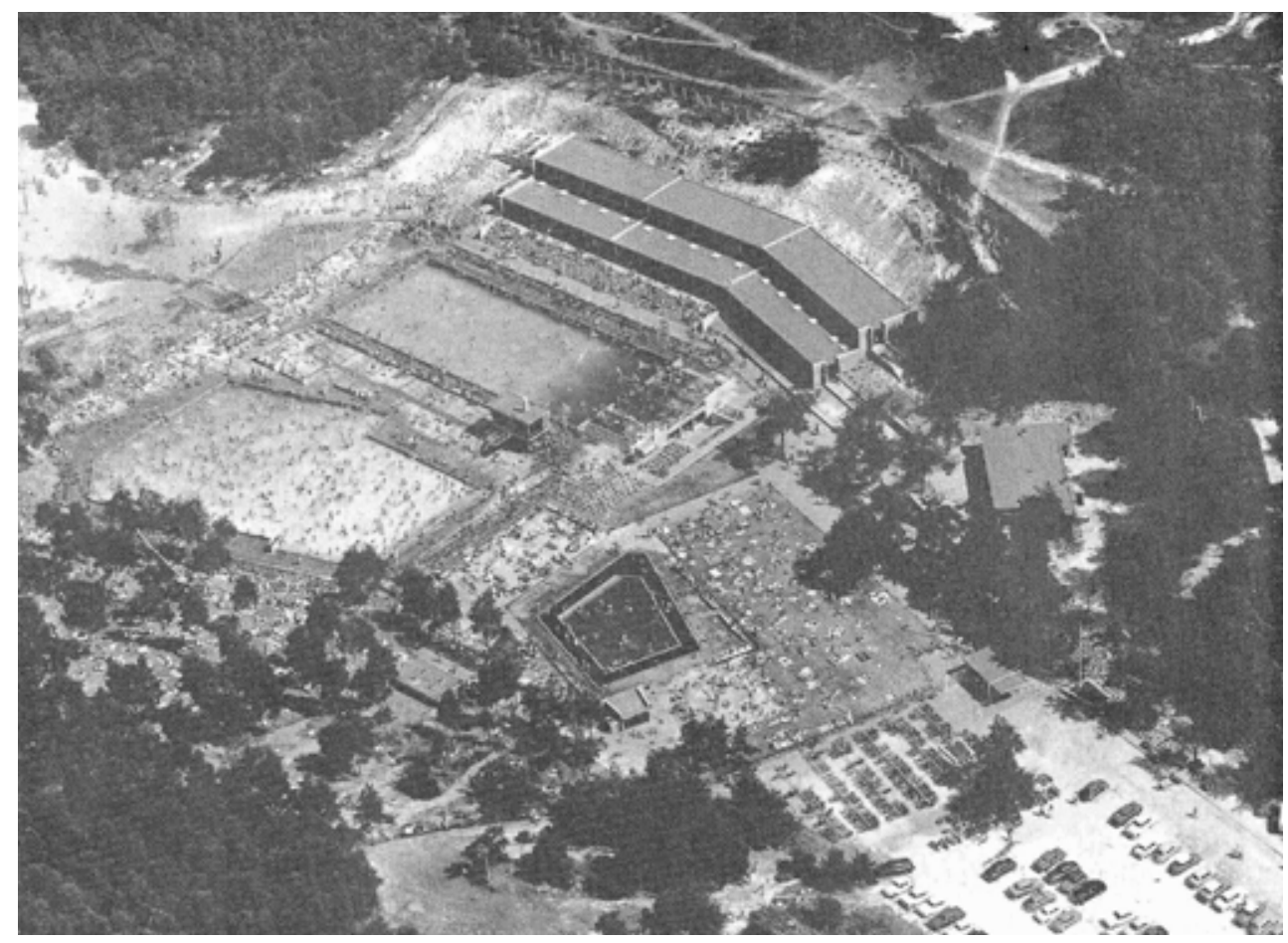

De Provincie subsidieerde in de jaren '60 en '70 honderden maatschappelijke voorzieningen. Hier het openluchtzwembad van Heerlen midden jaren '60. Foto: Provincie Limburg. 


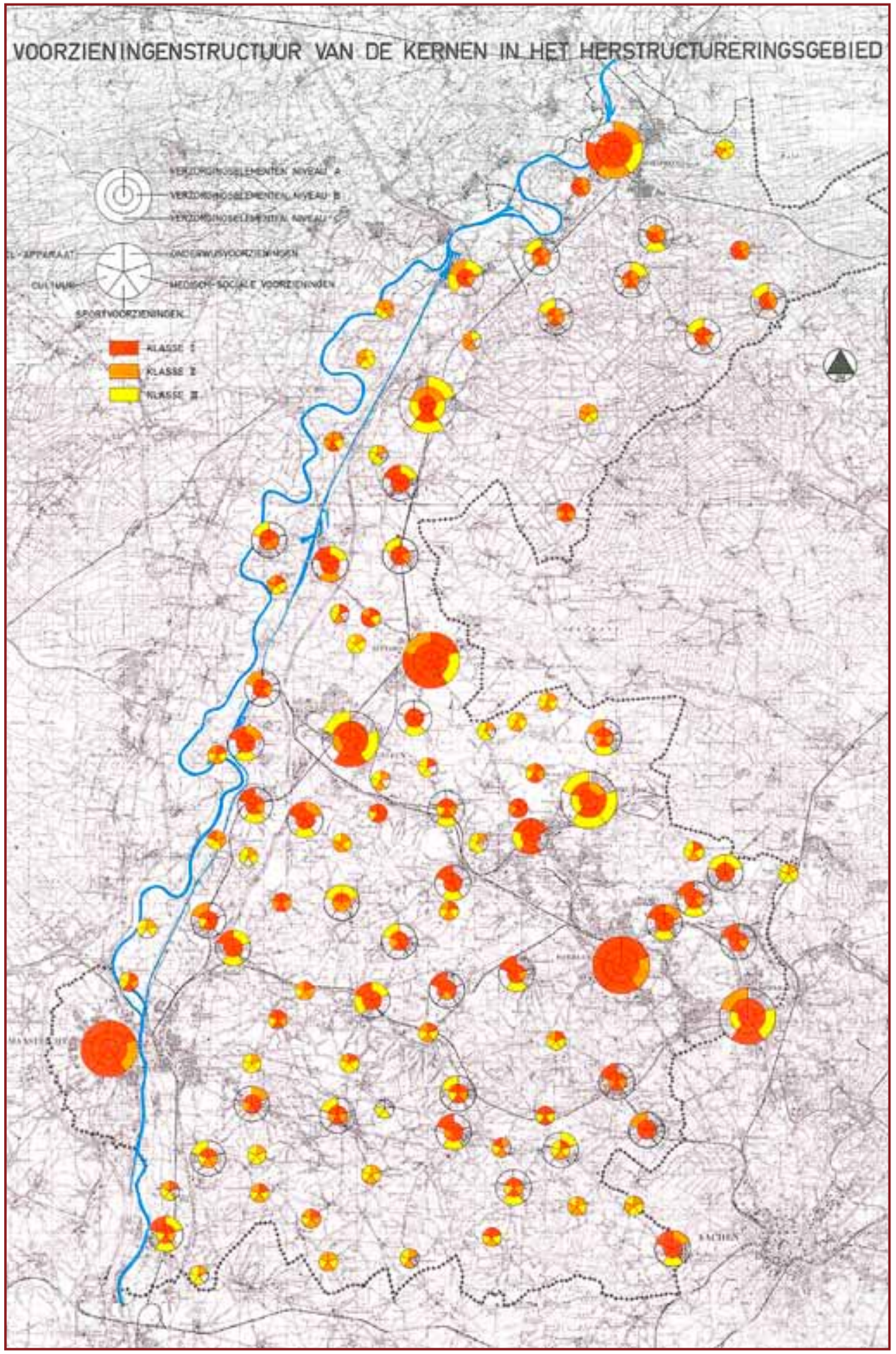

Overzichtskaart van de voorzieningenstructuur (zwembaden, sporthallen, kruisgebouwen, gemeenschapshuizen etc.) in Zuid-Limburg anno 1975. Figuur: Concept Perspectievennota Zuid-Limburg, 1977. 


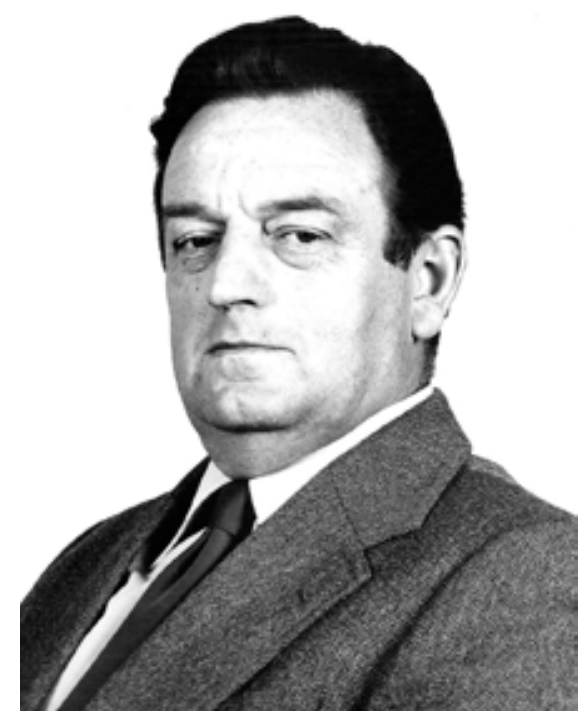

In de jaren ' 80 was gedeputeerde L. Stals (CDA) verantwoordelijk voor de reorganisatie van de Limburgse welzijnsstructuur. Subsidies aan diverse organisaties werden afgebouwd, de macht van de Raden werden ingeperkt en Limburg was pilotregio voor een gedecentraliseerd welzijnsbeleid. Foto: Provincie Limburg.

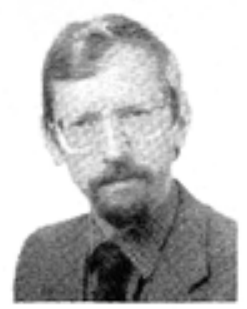

Drs. C.M.J.A. Grijsbach

\section{Het Provinciaal Bureau Welzijnsplanning van Roermond naar Maastricht}

$\mathrm{Na}$ aanvankelijke aarzeling over de juiste datum was het dan eindelijk zover: de verhuizing naar Maastricht stond vast op 2 en 3 december 1985.

Daarmee voltrok zich een gebeurtenis die haar schaduw reeds jaren vooruit had geworpen en waar geen van de medewerkers van het P.B.W. nu echt verlangend naar had uitgezien. Immers voorheen werkzaam bij het voormalige Provinciaal Orgaan Welzijnsbevordering Limburg, zijn ze nagenoeg allen in of nabij Roermond woonachtig.

Ook het na de oorlog opgerichte provinciaal Opbouworgaan kwam onder directe aansturing van de Provincie in de jaren '80. Uit het personeelblad Randschrift begin 1986. Foto: Provincie Limburg.
Maar zoals gezegd een verrassing was de verhuizing naar Maastricht niet: reeds in de P.O.W.L-tijd was hiervan meerdermale sprake. Bij de omvorming van P.O.W.L. naar P.B.W. en de indiensttreding van het personeel bij het provinciaal bestuur werd echter expliciet de huisvesting in het nieuwe provinciehuis in het vooruitzicht gesteld. 


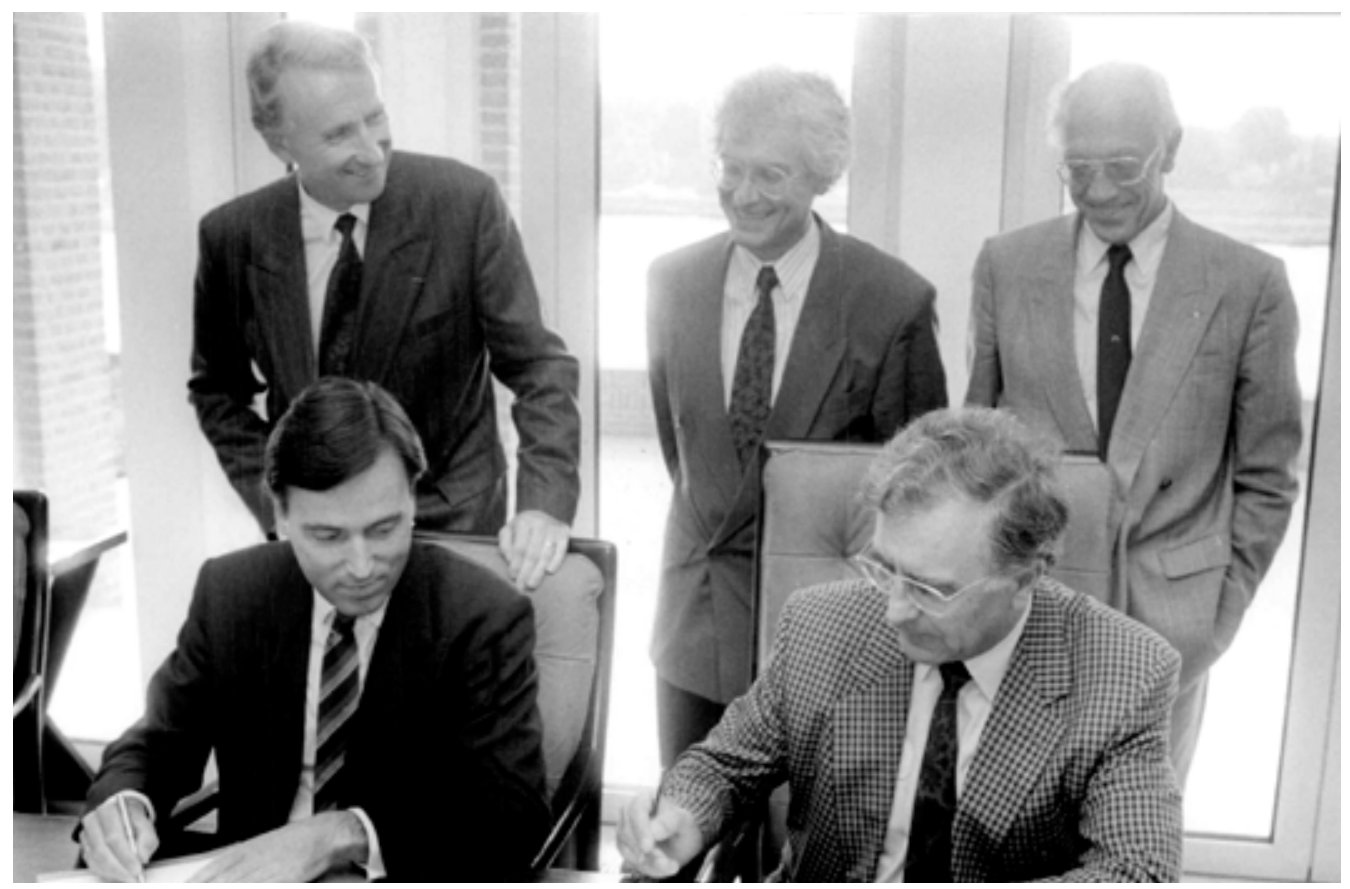

De 'afkoop' van arbeidsplaatsen in de welzijnssector aan het einde van het PNL-beleid. De Provincie werd verantwoordelijk voor tientallen banen in de sector. Minister van WVC L.C. Brinkman (CDA) en gouverneur J. Kremers (CDA) ondertekenen op 29 augustus 1989 de gemaakte afspraken. Foto: Frits Widdershoven

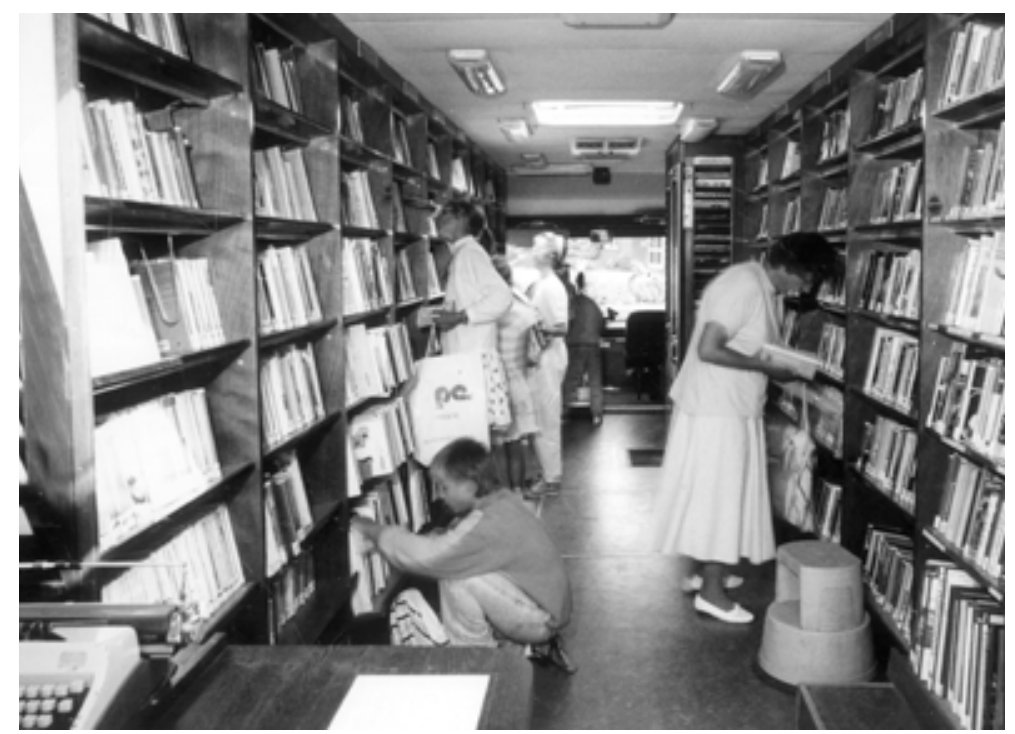

Het bibliotheekwerk werd in de jaren '80 vanuit de Provincie overgedragen aan de gemeenten. Foto: Bert Crombach. 


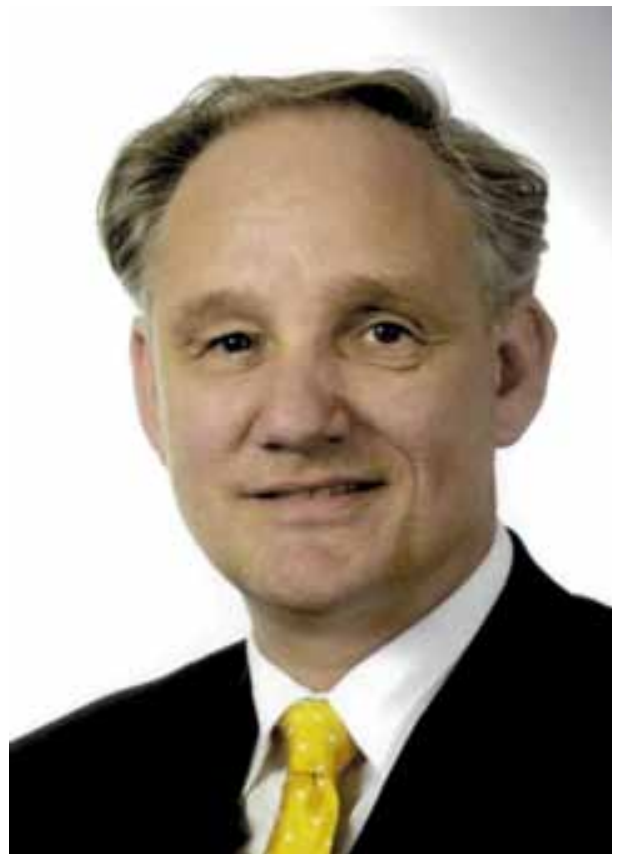

Bij de besluitvorming en uitwerking rondom Symbiose waren verschillende gedeputeerden betrokken. Gedeputeerde J.B. Haazen (VVD) hakte uiteindelijk de knoop van deze financiële molensteen door en stelde als eis dat eind 2003 Symbiose op eigen benen moest staan. Foto: Provincie Limburg.

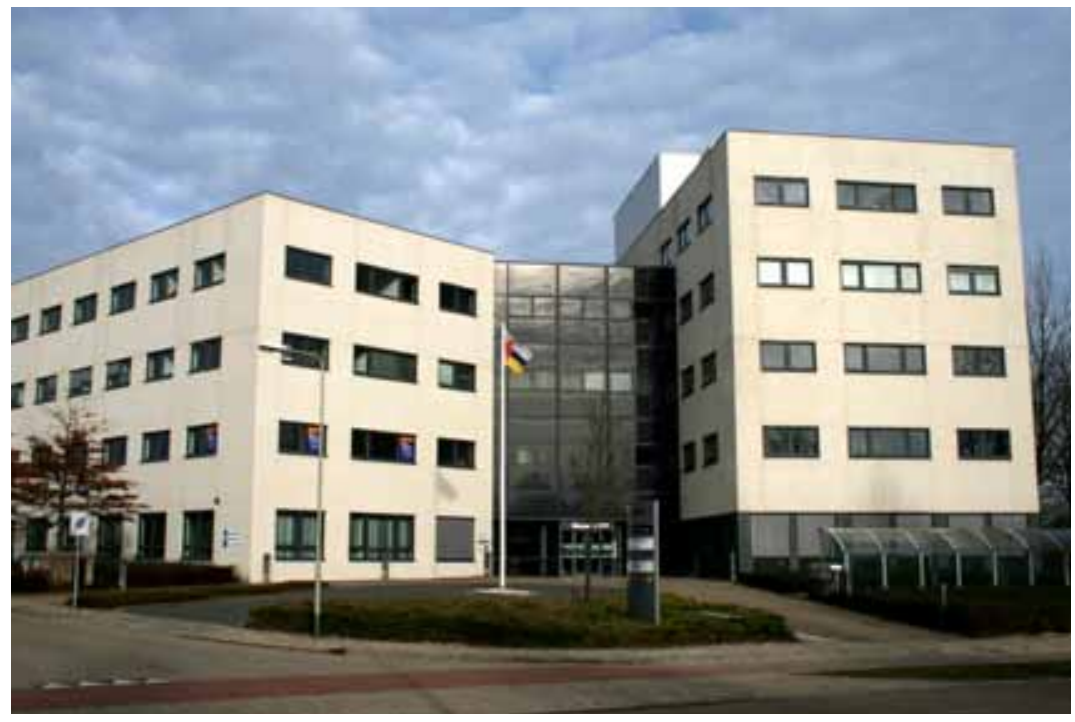

Begin jaren ' 90 volgde er een tweede reorganisatieronde in de welzijnssector. Tien provinciale steunfuncties moesten gefuseerd worden in één grote welzijnsinstelling: Symbiose. Foto: Hendrik Jan van Elmpt. 


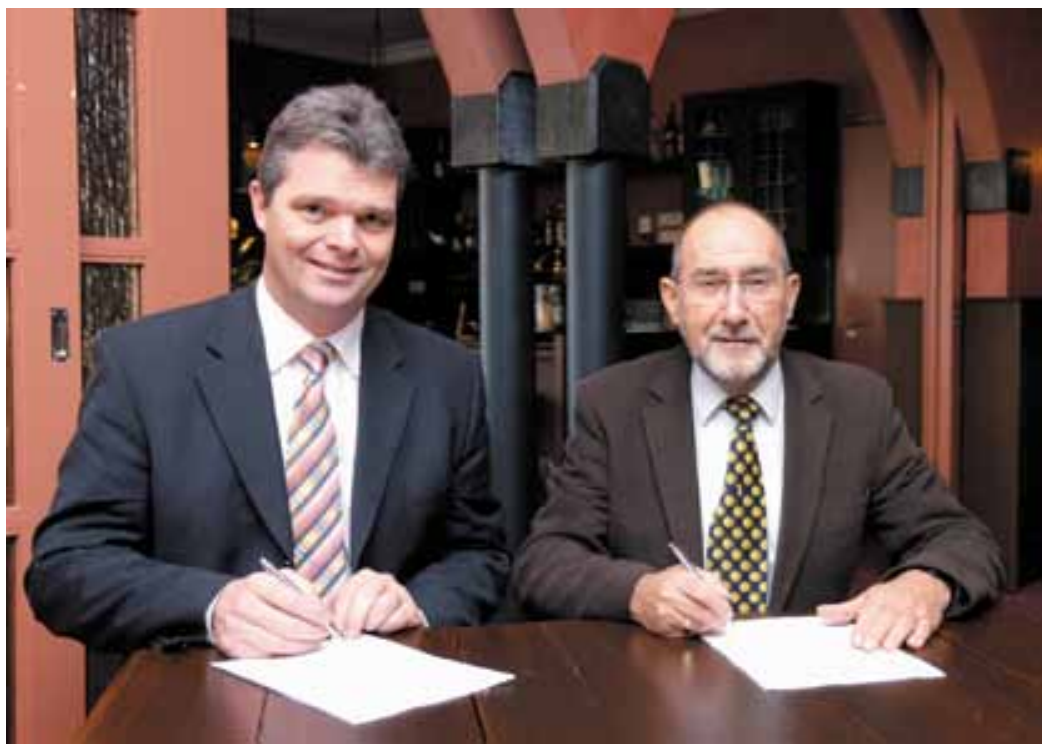

Einde van het welzijnsbeleid, leve de leefbaarheid. Gedeputeerde H.T.J. Vrehen (CDA) en wethouder A.J.J. Timmermans (gemeente Helden) ondertekenen begin 2006 het Afsprakenkader Helden. Foto: Gemeente Peel en Maas (voorheen Helden).

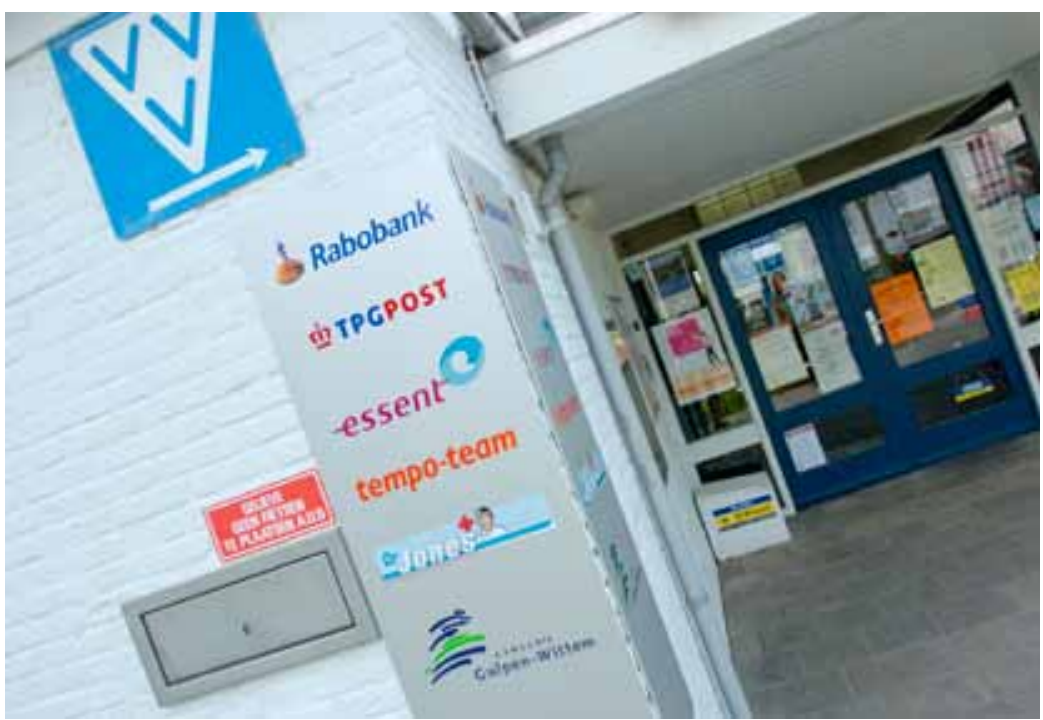

De Servicewinkel was een van de projecten binnen het provinciale thema Vitale kernen en buurten. Op een centrale locatie in een kleinere gemeente boden verschillende instellingen diensten samen aan. Hier de servicewinkel in Gulpen. Foto: Provincie Limburg. 


\title{
Een overzicht van 45 jaar Limburgse provinciale politiek
}

\author{
"Past actions affect future choices." \\ Aaron Wildavsky, 2007: 393.
}

In dit hoofdstuk worden de hoofdlijnen van de periode 1962-2007 samengevat. Het is een beschrijvend overzicht van de veranderende patronen in besluitvorming, de probleemstelling waarmee dit boek opende. Er wordt een diachroon overzicht geschetst van de ontwikkelingen in de provinciale politiek waarbij aandacht wordt besteed aan het gebruik van bevoegdheden en instrumenten (\$5.1), een analyse van de machtsverhoudingen (\$5.2), het gebruik van geografische indelingen (\$5.3) en een analyse van de politiekambtelijke verhoudingen (\$5.4). In het slothoofdstuk staat de conclusie centraal en wordt teruggekomen op de patronen in besluitvorming en de omslagmomenten.

\subsection{Het gebruik van bevoegdheden en instrumenten}

In de periode 1962-2007 is er sprake van een toename van het aantal provinciale bevoegdheden en instrumenten. Vooral in de jaren ' 80 en ' 90 is een groot aantal rijkstaken overgeheveld naar de provincies. Toch is niet zozeer het aantal taken voor een provincie relevant, veel belangrijker is de manier waarop deze bevoegdheden en instrumenten ingezet worden voor het beleid.

Het beste voorbeeld daarvan is het PNL-beleid. Dit economische beleid van de jaren ' 80 kwam tot stand door onderhandelingen en afspraken met de rijksoverheid en niet door formele bevoegdheden of economische instrumenten. Het formuleren van projecten en het verkrijgen van financiering hiervoor waren de belangrijkste instrumenten. In het ruimtelijke ordeningsbeleid is een vergelijkbare ontwikkeling te zien. Met de Wet op de Ruimtelijke Ordening (1962) kregen provincies de bevoegdheid om gemeentelijke bestemmingsplannen te beoordelen. Zeker in de tweede helft van de jaren '60 en in de jaren '70 heeft de Provincie Limburg ondanks deze bevoegdheid een afstandelijke houding ingenomen ten opzichte van gemeenten. De afstand tussen het provinciale streekplan en het gemeentelijke bestemmingsplan bleef groot. De kaart bij het streekplan was meer een schets van het gebied dan dat hier door de Planologische Dienst gedetailleerde grenzen werden getrokken. De Provincie wilde niet op het terrein van de gemeentelijke planologie komen. Binnen het welzijnsbeleid was er sprake van een omgekeerde situatie. De bevoegdheden en taken die de Provincie in de jaren ' 80 van de rijksoverheid overnam, zorgden juist voor nieuwe problemen. Hoe moest het provinciale welzijnsbeleid vorm gegeven worden? Jaren van herstructurering en bezuinigingen volgden. Het pleidooi van de Provincie voor de decentralisatie van taken en bevoegdheden begin jaren ' 80 bracht de Provincie veel problemen, met als uiteindelijk resultaat het faillissement van de Limburgse 
welzijnsinstelling Symbiose. Met andere woorden, een analyse van uitsluitend de beschikbare provinciale bevoegdheden en instrumenten zegt weinig over de positie en rol van de provincie. Het gebruik maken van bevoegdheden en het inzetten van instrumenten is veel belangrijker. Hoe zijn de provinciale bevoegdheden en instrumenten ingezet in de periode 1962-2007?

In de jaren '60 en '70 was de Provincie erg terughoudend met het inzetten van haar bevoegdheden en (beperkte) instrumenten. Voor zover er al sprake was van een provinciaal 'beleid' was dit vooral een uitwerking of navolging van het rijksbeleid. De Provincie maakte dankbaar gebruik van subsidies die door de rijksoverheid voor Limburg beschikbaar gesteld werden. Alleen voor het realiseren van diverse maatschappelijke voorzieningen (sporthallen, gemeenschapshuizen, bibliotheken) zette de Provincie eigen subsidiegelden in. Voor de verdeling van de verschillende subsidiestromen maakte de Provincie gebruik van een groot aantal commissies waar Limburgse belanghebbende organisaties en diverse rijksinstanties deel van uitmaakten. Deze commissies lieten vooral onderzoek en verkenningen uitvoeren en brachten advies uit aan het Provinciaal Bestuur. Die adviezen waren voor de Provincie vaak een middel om een pleidooi te ondersteunen voor meer aandacht van de rijksoverheid voor Limburg.

Midden jaren '70 veranderde deze provinciale opstelling. In de ruimtelijke ordening werd met twee streekplannen een voorzichtige aanzet gegeven tot het formuleren van eigen provinciale ambities. Ook de oprichting van een eigen Limburgs acquisitiebureau (LIOF) en de aanleg van diverse regionale provinciale wegen, getuigden van een groeiend zelfbewustzijn. Het LIOF was een eerste instrument dat de Provincie had om economisch beleid gestalte te geven, maar veel meer bevoegdheden had zij niet. De samenwerking tussen de Provincie en het ministerie van Economische Zaken in het kader van de Perspectievennota was een ander voorbeeld. Maar een nota verandert de wereld niet. De nieuwe gouverneur Kremers gaf eind jaren '70 de Perspectievennota een politieke vertaling. Niet door het claimen van extra bevoegdheden of overdracht van taken, maar door jaarlijks financiële afspraken te maken met de regering over belangrijke projecten voor Limburg, het jaarlijkse 'politiek beraad'. Er was een duidelijke doelstelling: het wegwerken van het verschil tussen het nationale werkloosheidspercentage en het hogere Limburgse percentage. De eenvoud van de doelstelling, het jaarlijks politiek beraad en het zelf initiëren van vele projecten waren de belangrijkste instrumenten van het Perspectievennotabeleid van de jaren '80. Ruimtelijke ordening, infrastructuur en welzijnsbeleid werden ten dienste gesteld van het economisch beleid. De streekplannen werden voorzien van regionale 'uitwerkingen' waarin afspraken werden vastgelegd over de aanleg van bedrijventerreinen, infrastructuur en woningbouw. Het welzijnsbeleid was een belangrijke sector voor het creëren van (gesubsidieerde) werkgelegenheid. Het realiseren van maatschappelijke voorzieningen leverde bovendien de bouwsector werk op. De decentralisatie van midden jaren ' 80 die o.a. taken op het gebied van de volkshuisvesting, stads- en dorpsvernieuwing, bejaardenzorg en welzijnsbeleid naar provincies overhevelde, werd door de Provincie in haar economisch beleid benut.

Toen het PNL-beleid in 1990 stopte, had de Provincie ervaring opgedaan met het 
binnenhalen van forse subsidies die ingezet werden voor projecten. Er was ervaring opgedaan met het werken met eigen ambities en de vertaling hiervan in heldere doelstellingen. Ten slotte had de Provincie ervaring opgedaan in het onderhandelen met de rijksoverheid. In de jaren '90 verbreedde de Provincie haar activiteiten en was het economisch beleid niet langer de dominante politieke prioriteit. Andere beleidsterreinen kregen politieke aandacht waarvoor nieuwe doelstellingen werden geformuleerd en projecten opgezet voor de realisatie ervan. Niet langer was het beleid uitsluitend gericht op Zuid-Limburg; het provinciale beleid werd zowel inhoudelijk als geografisch verbreed: nieuwe beleidsprogramma's die voor heel Limburg golden.

De wetten die begin jaren '90 door de rijksoverheid waren uitgevaardigd en een tweede decentralisatieronde midden jaren '90, zorgden ervoor dat de Provincie enerzijds nieuw beleid moest ontwikkelen, maar anderzijds nieuwe taken erbij kreeg met name in het ruimtelijke beleid. De verbreding van het provinciale beleid naar verschillen terreinen ('sectorbeleid') zorgde ervoor dat er bij het Provinciaal Bestuur de behoefte ontstond om een meer afgestemd, 'integraal' beleid te voeren. Eind jaren '90 werden verschillende initiatieven genomen om verschillende beleidsterreinen meer in samenhang te bezien. Het Provinciale Omgevingsplan Limburg ging daarin nog het verst door een plan te maken dat zowel de ruimtelijke, economische als sociale doelstellingen samenbracht. Wat ontbrak, waren concrete instrumenten om deze doelstellingen te realiseren.

Met het Coalitieakkoord van 2003 introduceerde het College van Gedeputeerde Staten een thematische aanpak, gericht op het realiseren van zichtbare resultaten. Niet langer het beleid of de plannen stonden centraal, maar een beperkt aantal maatschappelijke thema's die in een periode van vier jaar profiel en uitvoering moesten krijgen. Daarbij werd er expliciet gezocht naar het aanpassen van bestaande en het ontwikkelen van nieuwe instrumenten om de voorgenomen ambities uit te kunnen voeren. Zowel in de ruimtelijke ordening, als in het economisch beleid en in het nieuwe beleid dat gericht was op het verbeteren van de lokale leefbaarheid, werden nieuwe instrumenten en werkwijzen geïntroduceerd. In de periode na 2007 werd deze nieuwe werkwijze gecontinueerd.

\subsection{Een analyse van invloed en macht}

Net zoals de Provincie van haar bevoegdheden en instrumenten gebruik maakt om besluiten uit te voeren, kunnen actoren (personen, groepen, organisaties) invloed uitoefenen op basis van de voor hen beschikbare hulpbronnen. Een provincie heeft altijd partners nodig om beleid te realiseren. De manier waarop de Provincie in de periode 1962-2007 externe actoren betrokken heeft bij haar besluitvorming, wisselde. Daarbij is gebleken dat de scheidslijn tussen politieke invloed (samenstelling van het menu van alternatieven) en informele macht (substantiële inperking van het menu met het oog op het laten prevaleren van specifieke belangen) soms zeer dun is.

Tot de jaren '60 waren de katholieke kerk en de mijnindustrie dominant aanwezig in de Limburgse maatschappij. De Provincie hield in haar besluitvorming sterk rekening met de opvattingen en belangen van beide partijen. Vaak waren er directe relaties tussen de provinciale politiek, het bisdom en de mijnindustrie zoals de totstandkoming van 
het Streekplan Oostelijke Mijnstreek (1962) aantoont. Subsidies voor maatschappelijke activiteiten of voorzieningen werden vaak voorgelegd aan dekerk. De Diocesane Commissie van Samenwerking fungeerde daarin als een belangrijke link tussen samenleving en provinciale politiek. Het was voor iedereen duidelijk welke plaats personen, groepen of organisaties hadden binnen de Limburgse samenleving.

Begin jaren '60 veranderden deze machtsverhoudingen. Zowel de katholieke kerk als de mijnindustrie verdwenen in een korte periode van het maatschappelijke en politieke toneel. De Provincie werd geconfronteerd met het wegvallen van twee bepalende instituties die tot die tijd een belangrijke economische, ruimtelijke maar ook sociale functie vervulden. Om toch de relatie tussen Limburgse samenleving en provinciale politiek te behouden versterkte de Provincie de reeds eerder ingezette tendens van het werken met commissies. In deze commissies zaten belanghebbenden, ministeries en vertegenwoordigers van Limburgse organisaties, die het Provinciaal Bestuur van advies voorzagen. Provinciale politiek was in feite besturen via commissies. In de jaren '60 en '70 groeide het aantal commissies waarin het College van Gedeputeerde Staten formeel zitting had. Lang niet elke commissie had invloed op het provinciale beleid. Slechts een paar commissies waren werkelijk belangrijk. In de ruimtelijke ordening was de Provinciale Planologische Commissie een knooppunt van politieke invloed en informele macht, zeker in de voorbereiding van de twee streekplannen van de jaren '70. In het welzijnsbeleid waren er de Commissies Sociale Begeleiding die de vele provinciale en rijkssubsidies verdeelden over de gemeenten. Een inventarisatie van de voortgang van het economische herstructureringsbeleid na de mijnsluiting, leert dat in het economisch beleid diverse commissies en instanties vaak naast elkaar werkten en afzonderlijk soms strijdige activiteiten ontplooiden. Kortom, de Provincie had dan wel de formele macht, maar deze werd gedomineerd door de politieke invloed en informele macht van commissies, de rijksoverheid met haar ministeries en de Limburgse belangenorganisaties.

Tegelijkertijd groeide in de jaren '70 het besef bij het Provinciaal Bestuur dat er vanuit het Gouvernement sterker gecoördineerd moest worden. Het besturen via commissies begon steeds meer in de weg te zitten. Het herstructureringsbeleid waarvoor de Provincie altijd de verantwoordelijkheid bij de rijksoverheid had gelegd, stagneerde. Teveel organisaties waren hierbij betrokken. De Provincie kreeg steeds vaker te maken met de vraag om tekorten in de exploitatie van de vele gesubsidieerde gemeentelijke en maatschappelijke voorzieningen te dichten. Ook groeide in die tijd het belang van partijpolitiek. De Partij van de Arbeid kreeg meer aanhang in Limburg wat zich na de provinciale statenverkiezingen van 1978 vertaalde in twee PvdA-gedeputeerden aan de collegetafel.

Het was deze maatschappelijke en politieke context die er eind jaren '70 toe leidde, dat de Provincie de regie terug in handen nam. Onder leiding van gouverneur Kremers en gedeputeerde Buck werd de macht van de diverse commissies teruggedrongen of gereorganiseerd onder dreiging van het intrekken van de provinciale subsidie. De acquisitie van nieuwe bedrijven moest beter gecoördineerd worden, de door de Provincie gesubsidieerde welzijnsinstellingen werden beperkt danwel samengevoegd 
en de Planologische Commissie werd gereorganiseerd. De Provincie werd het enige aanspreekpunt voor de regering als het ging om het economisch beleid. In het Perspectievennotabeleid onderhandelde het College van Gedeputeerde Staten zelf met de rijksoverheid over de financiering van grote projecten voor Limburg.

Niet langer was het de rijksoverheid die subsidies en projecten voor Limburg bepaalde; het was de Provincie zelf die initiatief nam. Nieuwe machtsverhoudingen ontstonden waarbij de Provincie en de rijksoverheid de belangrijkste actoren waren. In een jaarlijks politiek beraad werd stevig onderhandeld over de door de Provincie Limburg ingediende projecten. De goede contacten tussen gouverneur Kremers en ministerpresident Van Agt (en later minister Van Aardenne) speelden hierin een belangrijke rol, evenals de relatie tussen gedeputeerde Buck en topambtenaar Miedema van het ministerie van Economische Zaken.

In de loop van de tweede helft van de jaren ' 80 trok de rijksoverheid zich langzaam terug uit de regio. Het regionale beleid van verschillende ministeries werd afgebouwd ${ }^{731}$. De provincies moesten maar op eigen kracht verder, was de heersende gedachte. Toen in 1990 het PNL-beleid en de Bestuursovereenkomst voor het welzijnsbeleid afliepen, betekende dit het einde van de jaarlijkse politieke onderhandelingen. Een nieuwe periode brak aan met nieuwe machtsverhoudingen en nieuwe actoren. Een van deze nieuwe actoren was in het begin van de jaren '90 de Europese Commissie. De ondertekening van het Verdrag van Maastricht (1992) had de Provincie een nieuwe impuls gegeven om ook beleid met de buurregio's (Duitse, Waalse en Vlaamse overheden) op te zetten. Het Regionaal Technologieplan Limburg en het benutten van diverse Europese fondsen zijn daar voorbeelden van. Toch was deze samenwerking met de Brusselse ambtenaren slechts van korte duur. De uitvoering van een aantal nieuwe taken en beleidsterreinen vertrouwde de Provincie in de jaren ' 90 steeds meer toe aan intermediaire organisaties. Het heldere politieke profiel van de Provincie uit de jaren '80 verdween naar de achtergrond. Het College van Gedeputeerde Staten profileerde zich op onderdelen van portefeuilles. Het beleid werd verbreed. Het was vooral het ambtelijk apparaat dat met de overdracht van nieuwe taken en de grotere aandacht voor beleidsterreinen als natuur, water, zorg en cultuur, meer invloed kreeg. Daarbij kwam ook dat de rijksoverheid in de jaren ' 90 nadrukkelijk de samenwerking met gemeenten opzocht en niet langer de provincies als haar natuurlijke partner in de regio zag. De provincies werden op zichzelf teruggeworpen. Zij ging haar provinciale beleid in steeds nauwere samenwerking met de regionale intermediaire partners voorbereiden en uitvoeren.

De samenwerking met de intermediaire partners had als consequentie dat de expliciete provinciale rol zoals die in jaren ' 80 naar voren kwam, minder geprononceerd werd. Bovendien pakte de structurele samenwerking tussen Provincie en een aantal partners minder positief uit dan gedacht. De fusie van een tiental welzijnsinstellingen tot een grote Limburgse welzijnsinstelling liep uit op een fiasco. Ook de samenwerking op toeristisch gebied (het Limburgs Bureau voor Toerisme), euregionaal onderwijs (transnationale Universiteit Limburg) en de intergemeentelijke samenwerking (Provinciaal Omgevingsplan Limburg) haperden. 
Het College van Gedeputeerde Staten dat in 2003 aantrad, had de ambitie om zaken anders aan te pakken. Een van de belangrijkste wijzingen in het provinciale beleid was de selectie van de partners waarmee zaken gedaan moesten worden. Niet langer de vertegenwoordigende intermediaire instanties, maar het bedrijfsleven, kennisinstellingen en individuele gemeenten werden belangrijk in de beleidsvoorbereiding. De Provincie stelde zich niet op als beleidsbepaler, maar als beleidspartner. Bovendien werd het provinciaal beleid niet langer met elke belanghebbende vorm gegeven, maar vooral met die partners die echt wilden. Zowel in het ruimtelijke ordeningsbeleid, als het economisch beleid en het nieuwe welzijnsbeleid (leefbaarheid), werd er gekozen voor een select aantal actoren. Niet langer was de blik uitsluitend gericht op Den Haag, maar vooral op de eigen regio. Niet langer de Provincie op eigen kracht, maar de regio - Provincie én Limburgse partners - op eigen kracht.

\subsection{Het gebruik van geografische indelingen}

Het maken van regionaal of lokaal onderscheid is een belangrijke manier om besluitvorming te structureren. In de onderzochte periode heeft de provinciale politiek hiervan voortdurend gebruik gemaakt, hetzij onder druk van de rijksoverheid, hetzij door eigen keuzes en prioriteiten.

Na de aangekondigde sluiting van de mijnindustriewerd Limburg door de rijksoverheid ingedeeld in twee gebieden. Noord-Limburg was stimuleringsgebied en Zuid-Limburg was herstructureringsgebied. Binnen het stimuleringsgebied waren er op voordracht van de Provincie speciale ontwikkelingskernen aangewezen. Deze kernen konden rekenen op extra financiële middelen voor de ontwikkeling van nieuwe infrastructuur, bedrijventerreinen en woningen. De provinciale rol in het stimuleringsgebied was bescheiden, de prioriteit lag na 1965 bij het herstructureringsgebied Zuid-Limburg. Daar was niet alleen de economische, maar ook de ruimtelijke en sociale opgave het grootst. Bovendien had deze regio te maken met een omvangrijke arbeidspendel van Limburgers die in Duitsland gingen werken. De interregionale verschillen tussen Limburg en het Duitse Ruhrgebied o.a. op het gebied van de lonen en overheidssubsidies aan de industrie waren groot.

De ingestelde Herstructureringscommissie die advies moest uitbrengen aan zowel de rijksoverheid als de Provincie, was bijzonder geïnteresseerd in de manier waarop andere provincies het regionaal economisch beleid vormgaven. Vooral in de jaren '60 en '70 werd deze interprovinciale vergelijking door het College van Gedeputeerde Staten regelmatig gemaakt. Het was een verkenning van de eigen mogelijkheden om autonoom beleid te voeren. Niet alleen wat betreft het economisch beleid, ook in de ruimtelijke ordening en in het welzijnsbeleid werden het beleid en de initiatieven van andere provincies geïnventariseerd. De Provincie Limburg constateerde dat andere provincies al 'welvaartsplannen' hadden opgesteld, voortvarend aan de slag waren gegaan met het organiseren van de inspraak van burgers op verschillende provinciale beleidsterreinen en dat in de welzijnssector diverse reorganisaties door provincies werden doorgevoerd. Deze interprovinciale vergelijkingen evenals de geografische indelingen die de rijksoverheid 
voor Limburg hanteerde, stimuleerden een groeiende bewustwording van het feit dat de Provincie meer eigen initiatief moest tonen.

Reeds bij de voorbereiding van de Perspectievennota midden jaren '70 introduceerde de Provincie in overleg met het ministerie van Economische Zaken een nieuwe geografische indeling binnen Zuid-Limburg. Het herstructureringsgebied Zuid-Limburg kende verschillende deelregio's waar specifieke maatregelen en keuzes nodig waren. Zo kende de Oostelijke Mijnstreek geen goede uitgangspositie als het ging om de aanleg van nieuwe bedrijventerreinen. Daarvoor bestonden betere mogelijkheden in de Westelijke Mijnstreek. Een ander voorbeeld van het maken van regionale verschillen was de aanpak van nieuwe infrastructuur. Voor de Provincie en de rijksoverheid lag de prioriteit bij de Oostelijke Mijnstreek als het ging om de aanleg van nieuwe wegen. Ook in de spreiding van de rijksdiensten die naar Limburg werden verplaatst, kreeg de Oostelijke Mijnstreek prioriteit. De vestiging en uitbreiding van kennisinstellingen als de rijksuniversiteit en het academisch ziekenhuis daarentegen, werden in de regio Maastricht geconcentreerd. De chemische industrie (DSM) en de auto-industrie (DAF/Volvo) waren vooral gevestigd in de Westelijke Mijnstreek, en het Limburgse heuvelland was het toneel voor toeristische en recreatieve activiteiten. In de Perspectievennota Zuid-Limburg waren deze geografische indelingen ambtelijk voorbereid. Ze zouden vanaf 1978 ook in de politieke afwegingen van het PNL-beleid leidend zijn.

Het Provinciaal Bestuur zag zeer goed in dat het PNL-beleid vooral Zuid-Limburgs beleid was. De Provincie motiveerde de keuze voor deze prioriteitstelling met het argument dat in Zuid-Limburg de problematiek het grootst was, wat leidde tot kritiek van gemeenten en organisaties in Noord- en Midden-Limburg. De Provincie probeerde hier evenwicht in te brengen door in de jaren ' 80 de subsidies en projecten van het welzijnsbeleid en het ruimtelijke ordeningsbeleid ook voor Noord- en Midden-Limburg in te zetten. Deze subsidies waren voor geheel Limburg beschikbaar, in tegenstelling tot de subsidies en premieregelingen voor bedrijven van het ministerie van Economische Zaken die alleen voor Zuid-Limburg konden worden ingezet. Niet alleen inhoudelijke regionale verschillen speelden dus een rol, ook politieke overwegingen waren van belang. Deze 'verdelende rechtvaardigheid' tussen Noord- en Zuid-Limburg verliep lang niet altijd soepel.

Het is dan ook niet zo verwonderlijk dat na een periode van twaalf jaar PNL-beleid (1978-1990), het provinciale beleid in de jaren '90 een 'provinciedekkend' beleid werd. Het Regionaal Technologieplan was een plan voor technologische innovatie van het gehele Limburgse bedrijfsleven. De fusie-instelling Symbiose moest haar welzijnsdiensten voor heel Limburg aanbieden. Zowel voor het Noord-Limburgse Peelgebied werd een ruimtelijke visie opgesteld, als voor het Zuid-Limburgse Mergelland. Dit provinciedekkende beleid werd aan het begin van de 21e eeuw zelfs samengebracht in een groot integraal provinciaal plan: het Provinciaal Omgevingsplan Limburg. Daarbinnen werden wel regionale verschillen en accenten erkend, maar het ruimtelijke beleid was gericht op heel Limburg. Ook de in aantal sterk toegenomen subsidieregelingen voor de verschillende beleidsterreinen waren vaak provinciedekkende regelingen waar organisaties of bedrijven uit geheel Limburg aanspraak op konden maken. 
In 2003 wijzigde de Provincie haar beleid. Net zoals er voorheen keuzes gemaakt werden welke actoren betrokken zouden worden in de totstandkoming van nieuw beleid, werden er nu keuzes gemaakt bij welke regio's de Provincie haar politieke, organisatorische en financiële prioriteit ging leggen. De Provincie richtte zich in dit nieuwe beleid op de economische kerngebieden van Limburg. Deze gebieden concentreerden zich rondom de Limburgse steden. In de economische Versnellingsagenda werd gesproken van clusters van kracht en in het geactualiseerde Omgevingsplan werden gebieden aangegeven waarvoor de Provincie extra aandacht had en financiële middelen beschikbaar wilde stellen. In het leefbaarheidsbeleid van de Provincie werden ook keuzes gemaakt, niet zozeer op basis van regionale verdelingen, maar vooral op basis van de vraag welke gemeenten dit thema samen met de Provincie wilden aanpakken. In de praktijk bleken het vooral de kleinere en middelgrote gemeenten te zijn die hierover afspraken met de Provincie wilden maken. Op deze manier gebruikte de Provincie nieuwe varianten van geografische indelingen in de totstandkoming en uitvoering van haar beleid.

\subsection{Inzicht in de politiek-ambtelijke verhoudingen}

De afstand tussen ambtenaar en gedeputeerde heeft weinig te maken met de grootte van de organisatie. In de periode 1962-2007 is de ambtelijke formatie gegroeid van 358 naar $894 \mathrm{fte}$ (zie appendix I). De afstand tussen ambtenaar en gedeputeerde in 1962 was veel groter dan in 2007. Op zichzelf genomen zegt dat weinig over de kwaliteit van de politiekambtelijke verhoudingen. Als de afstand groot is, maar besluiten conform politieke doelstellingen uitgevoerd worden, is er geen probleem. Het wordt een probleem als de ambtelijke organisatie naar de buitenwereld andere signalen afgeeft dan de politiek of als een College weinig vertrouwen meer heeft in de kwaliteit van haar organisatie.

De relatie tussen het College van Gedeputeerde Staten en het ambtelijke apparaat is te beschrijven als een pendelbeweging. In de ontwikkelingen tussen 1962-2007 zijn er duidelijk periodes aan te geven waarin het politieke 'primaat' domineerde en ook periodes waarin de invloed, zo niet informele macht, van het ambtelijk apparaat groot was.

In de jaren '60 en de eerste helft van de jaren '70 bestond er een grote afstand tussen het College van Gedeputeerde Staten en de ambtelijke organisatie. Het beroep van 'gedeputeerde' was tot begin jaren '70 voor velen een deeltijdfunctie. De contacten met ambtenaren waren beperkt. Deze afstand werd nog eens extra geaccentueerd door de formele organisatiestructuur, het zogeheten griffie-diensten model. De meer technisch-uitvoerende diensten als de Provinciale Waterstaat en de Planologische Dienst zaten op redelijke (fysieke en politieke) afstand van de wekelijkse besluitvorming in het Gouvernement. Daarnaast bestond de ambtelijke organisatie uit vijf afdelingen die met het College vooral via memo's en nota's communiceerden. Direct contact met de gedeputeerde was alleen voorbehouden aan de afdelingshoofden. De verdere contacten tussen de ambtelijke organisatie en de politiek verliepen vooral via de vele tientallen commissies waarin tevens externe belanghebbenden zaten.

De provinciale organisatie was sterk afhankelijk van andere organisaties voor het verkrijgen van relevante informatie en data. De economische cijfers werden geleverd door 
het Etil, de natuur- en boskaarten kwamen van Staatsbosbeheer, de mijnindustrie leverde het kaartmateriaal aan van de wingebieden, en het Opbouworgaan bracht de sociale problematiek voor de Provincie in beeld. Deze afhankelijkheid van externe organisaties en de afstand tussen ambtelijk apparaat en College van Gedeputeerde Staten leidde in de loop van de jaren '70 tot toenemende spanningen. De twee streekplannen die door de Planologische Dienst werden opgesteld, kenden een zeer lange doorlooptijd wat leidde tot onvrede bij het College. Ook was de Provincie afhankelijk van andere organisaties als het ging om de gezamenlijke coördinatie van het economische herstructureringsbeleid. Deze coördinatie verliep moeizaam. Het ambtelijk apparaat had geen afzonderlijke economische afdeling; de economische expertise was beperkt tot een paar individuen binnen de afdeling Verkeer en Vervoer.

In het welzijnsbeleid bestond wel een nauwe samenwerking tussen de secretaris van de Commissie Sociale Begeleiding en de voorzitter, gedeputeerde P.J.C. Lebens (KVP). Van een brede betrokkenheid van de provinciale welzijnsafdeling of het provinciaal Opbouworgaan was echter nauwelijks sprake. Mede door de groeiende politisering en processen van democratisering in de Limburgse samenleving, werd het Provinciaal Bestuur steeds vaker gedwongen standpunten in te nemen over heikele kwesties. Zoals bijvoorbeeld over de hoeveelheid huizen die gemeenten mochten bouwen in het kader van het Streekplan Noord- en Midden-Limburg. Een ander voorbeeld waren de toenemende exploitatietekorten van maatschappelijke voorzieningen die door de Provincie waren gesubsidieerd. Het zette de relatie tussen politiek en ambtelijk apparaat op scherp. De in 1977 aangetreden gouverneur J. Kremers (CDA) kondigde al in zijn eerste weken een meerjarige provinciale reorganisatie aan waarmee voor sleutelposities in de organisatie nieuwe personen werden aangetrokken. Een nieuwe afdeling werd belast met de voorbereidingen van het Perspectievennotabeleid. De rest van de ambtelijke organisatie kwam onder strakke politieke sturing en moest bijdragen aan het formuleren en realiseren van projecten die werkgelegenheid creëerden. De coördinatie van deze projecten en de voorbereidingen van het politieke overleg met de ministeries en de regering verliepen via de nieuwe economische afdeling. Voor de nieuwe sleutelposities waren ambtenaren aangetrokken die zorgden voor een nieuwe dynamiek in de organisatie. De politiekambtelijke verhoudingen waren inniger dan ooit, waarbij het College onder leiding van gouverneur Kremers en gedeputeerde K.W. Buck (CDA) stevig stuurde.

Toen in 1987 gedeputeerde Buck en in 1990 gouverneur Kremers afscheid namen van de provinciale politiek, ontstond er een machtsvacuüm. Nieuwe gedeputeerden moesten zich inwerken en bovendien ontstond er grote commotie rondom een bouwfraude-affaire waarbij Limburgse bestuurders en ook de Provincie imagoschade leden. De opvolging van gouverneur Kremers was uitgelopen op een impasse, zodat gedeputeerde E.M. Mastenbroek (CDA) tijdelijk door de minister van Binnenlandse Zaken tot gouverneur werd benoemd. Tegelijkertijd had de rijksoverheid begin jaren ' 90 een groot aantal nieuwe wetten geïnitieerd waardoor de provincies nieuwe beleidsplannen moesten opstellen. Het ambtelijk apparaat moest in korte tijd veel nieuw 'sectorbeleid' ontwikkelen vooral als het ging om natuur- water- en milieubeleid. Hierdoor werd nieuwe expertise ontwikkeld die 
in een aantal gevallen zeer specialistisch was. Het vergrootte de macht van het ambtelijk apparaat. Binnen het College van Gedeputeerde Staten werden juist (onderdelen van) portefeuilles erg belangrijk gevonden.

Met de groeiende expertisemacht van het ambtelijk apparaat en de profilering van gedeputeerden op deelportefeuilles, nam de afstand tussen provinciale politiek en ambtelijk apparaat toe. Een aantal omvangrijke dossiers, zoals de fusie van tien welzijnsinstellingen, de Nadere Uitwerking Brabant-Limburg en het Europese pilotproject Regionaal Technologieplan Limburg, bleven ambtelijke dossiers. In het algemeen kan men stellen dat het provinciale beleid in de jaren '90 'verambtelijkte' waarbij de uitvoering van het beleid werd overgelaten aan intermediaire organisaties.

Eind jaren '90, in de zoektocht naar wat 'integraal beleid' werd genoemd, trok de politiek de teugels weer aan. Het opzetten van een provinciaal grotestedenbeleid en een programma voor de samenhang tussen volkshuisvestingsbeleid, welzijnsbeleid en zorgbeleid kregen politieke prioriteit. Binnen de ruimtelijke ordening was het integrale Provinciale Omgevingsplan Limburg een belangrijk politiek dossier dat de portefeuilles van meerdere gedeputeerden raakte. Van een politiek primaat was echter pas sprake in de periode vanaf 2003, met de introductie van de vijf prioritaire thema's in het coalitieakkoord. Het was een nieuwe werkwijze die zich uitte in de manier waarop de voorbereiding van beleid tot stand $\mathrm{kwam}$. In de provinciale organisatie werden vijf teams geformeerd om de vijf thema's uit te werken en van concrete projecten te voorzien. Dat leverde tevens spanning op met de afdelingen die het 'reguliere' beleid uitwerkten. De afstemming tussen themagerichte aanpak en het 'sectorbeleid' verliep moeizaam, maar werd wel in de volgende coalitieperiode doorgezet. De provinciale organisatie veranderde zo langzaam in een matrixorganisatie onder een strakke politieke aansturing. 


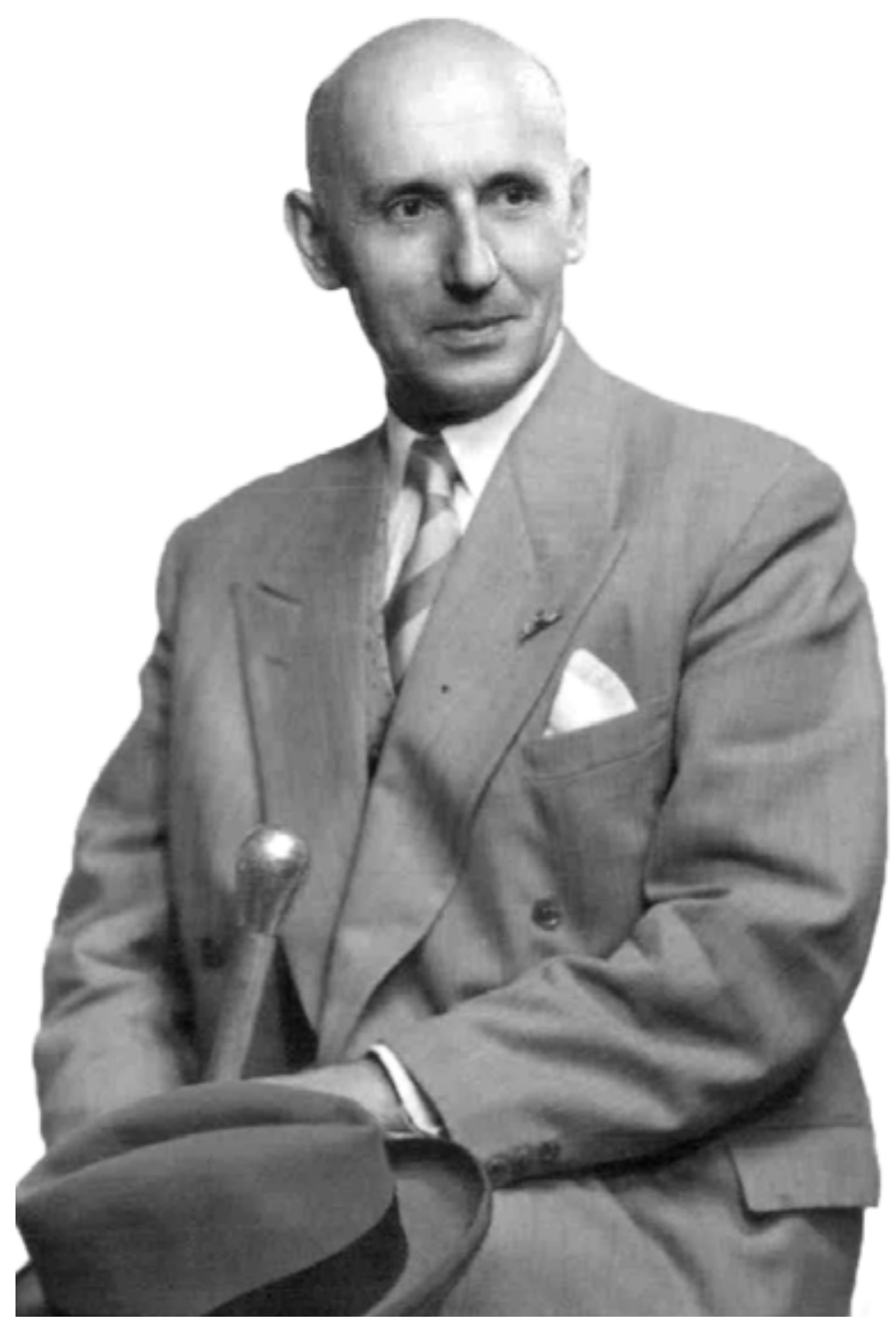

Dr. F.J.M.A.H. Houben (1898-1976) was gouverneur (KVP) in de periode 1947-1963. Houben kreeg bij zijn benoeming door koningin Juliana de opdracht mee om vooral tussen de mensen te staan en niet erboven. In de naoorlogse periode kreeg hij niet alleen te maken met de wederopbouw en het terugdringen van de woningnood in Limburg, ook zag hij in zijn laatste jaren als gouverneur de economische voorspoed die de mijnindustrie gebracht had sterk verminderen. Foto: Provincie Limburg. 


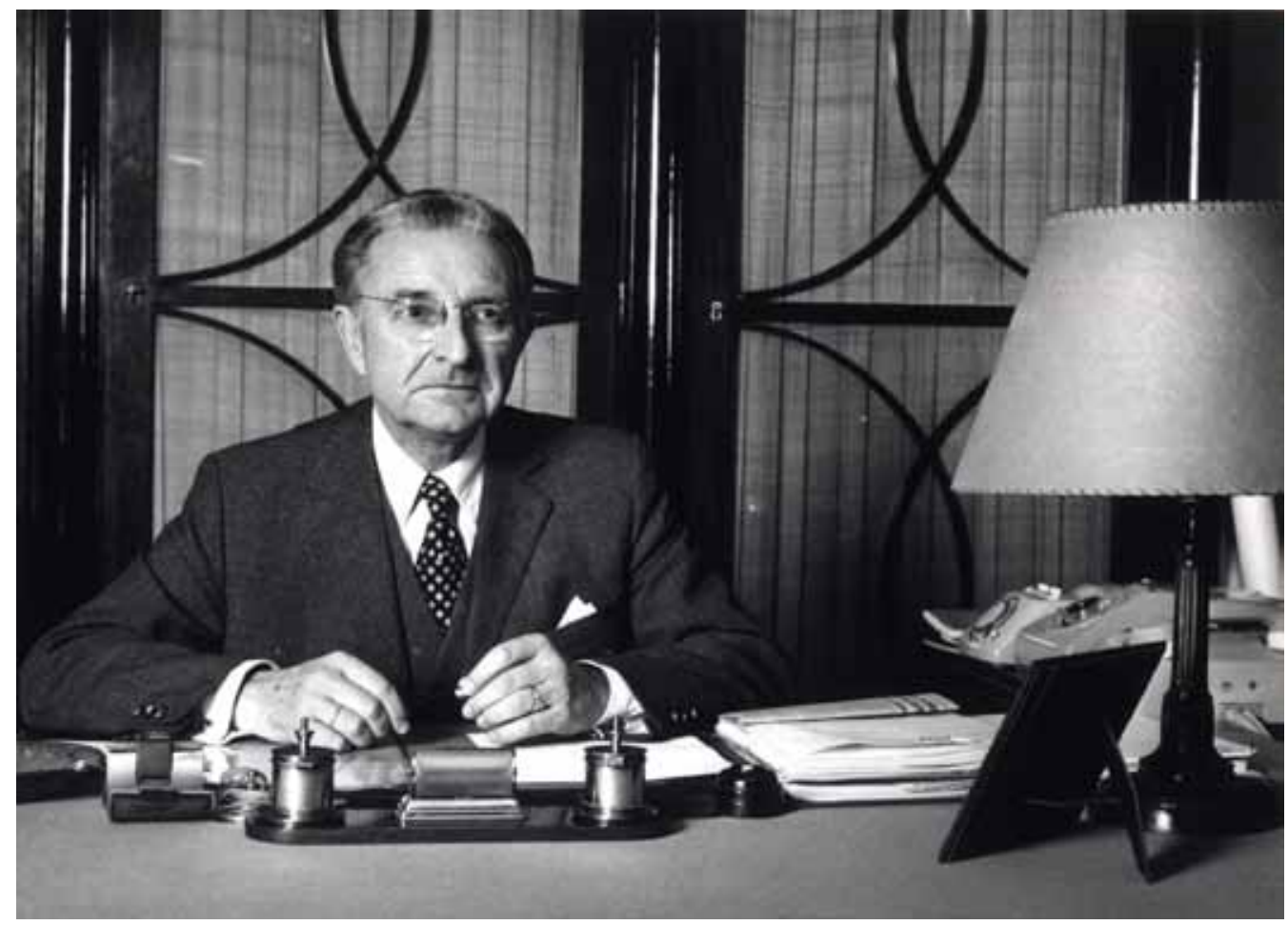

Dr. Ch.J.M.A. van Rooy (1912-1996) was gouverneur (KVP) in de periode 1964-1977. Daarvoor bekleedde hij diverse burgemeestersfuncties o.a. in Venlo, Eindhoven en Heerlen en was hij twee jaar minister van Sociale Zaken \& Volksgezondheid (1959-196I) in het kabinet De Quay. Van Rooy speelde een belangrijke rol in de voorbereiding van de Eerste Mijnnota van minister Den Uyl en was oprichter van de Stichting Wetenschappelijk Onderwijs Limburg. Was tevens geïnteresseerd in ruimtelijke ordening en infrastructurele zaken. Foto: Provincie Limburg. 


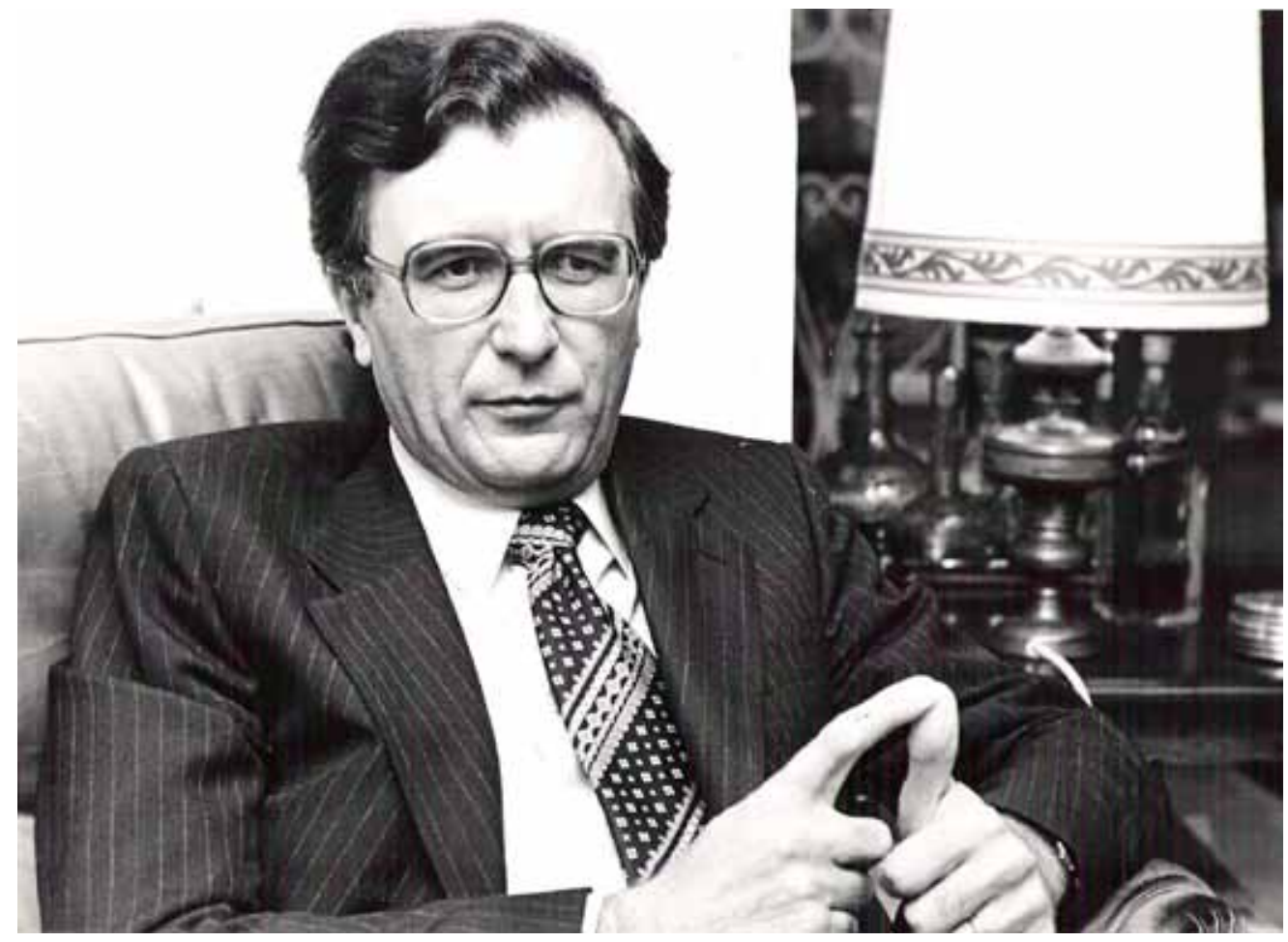

Dr. J. Kremers (1933- ) was gouverneur (CDA) in de periode 1977-1990. Voelde zich eind jaren '70 verplicht (als mijnwerkerszoon uit Nieuwenhagen) om de werkloosheid in Limburg aan te pakken. Kremers had een goede relatie met minister-president A.A.M. van Agt waarmee hij de basis legde voor het Perspectievennotabeleid van de Provincie en de rijksoverheid. Onder zijn leiding werd er bijna jaarlijks een politiek beraad gehouden tussen het voltallig College en een groot deel van de ministerraad waar besluitvorming plaatsvond over de grote projecten voor Limburg. Foto: Provincie Limburg. 


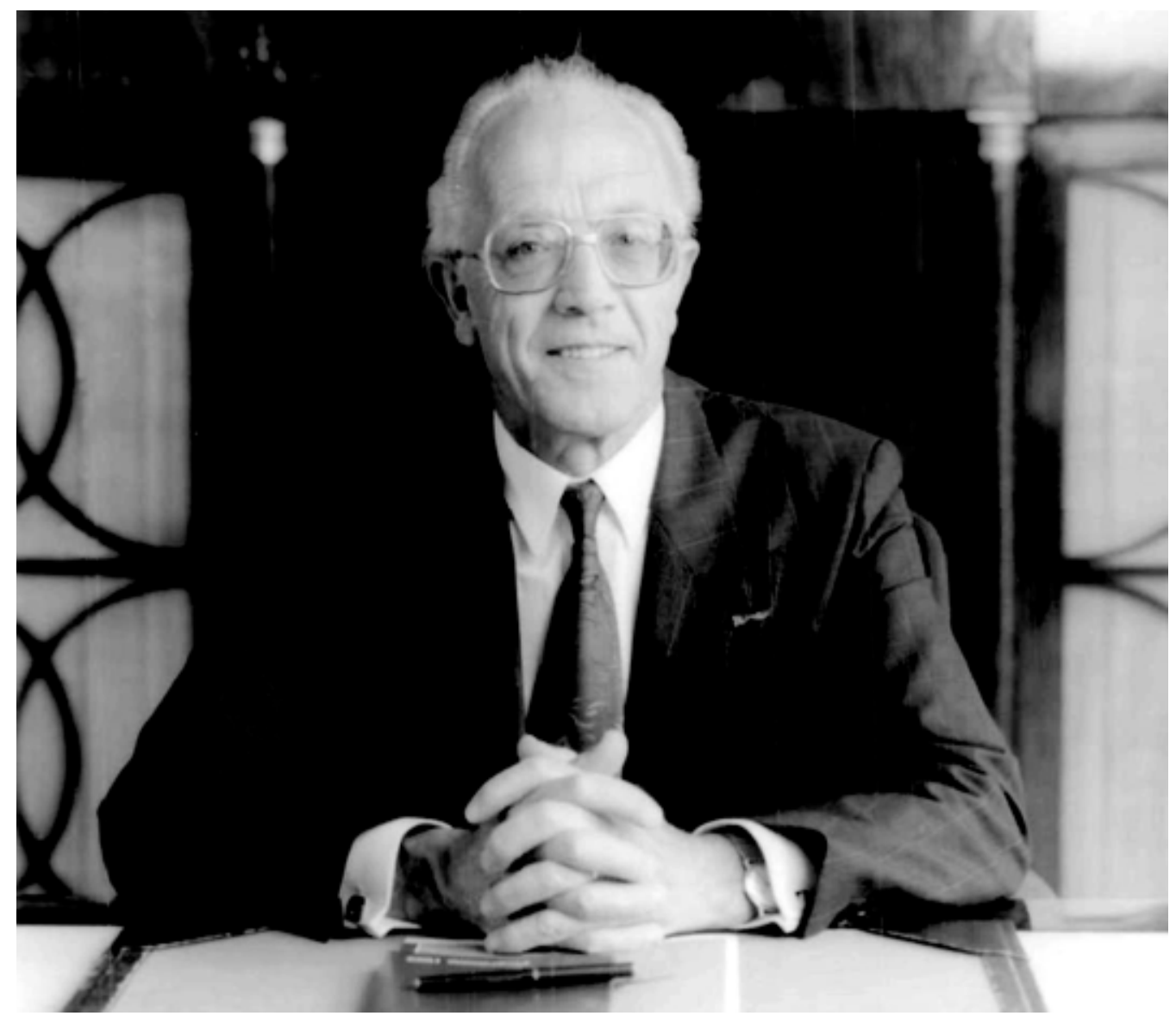

Ing. E.M. Mastenbroek (1930-2005) was gouverneur (CDA) in de periode 1990-1993. Was door het kabinet Lubbers III uiteindelijk benoemd voor een tijdelijke periode van 3 jaar omdat er grote partijpolitieke meningsverschillen bestonden over de andere potentiële kandidaten. Was daarvoor jarenlang gedeputeerde voor o.a. ruimtelijke ordening en milieu.Vanaf $1992 \mathrm{kreeg}$ Mastenbroek te maken met een lang slepende fraudeaffaire in de bouwsector waar diverse Zuid-Limburgse gemeenten en ook de Provincie Limburg betrokken in waren. Foto: Provincie Limburg. 


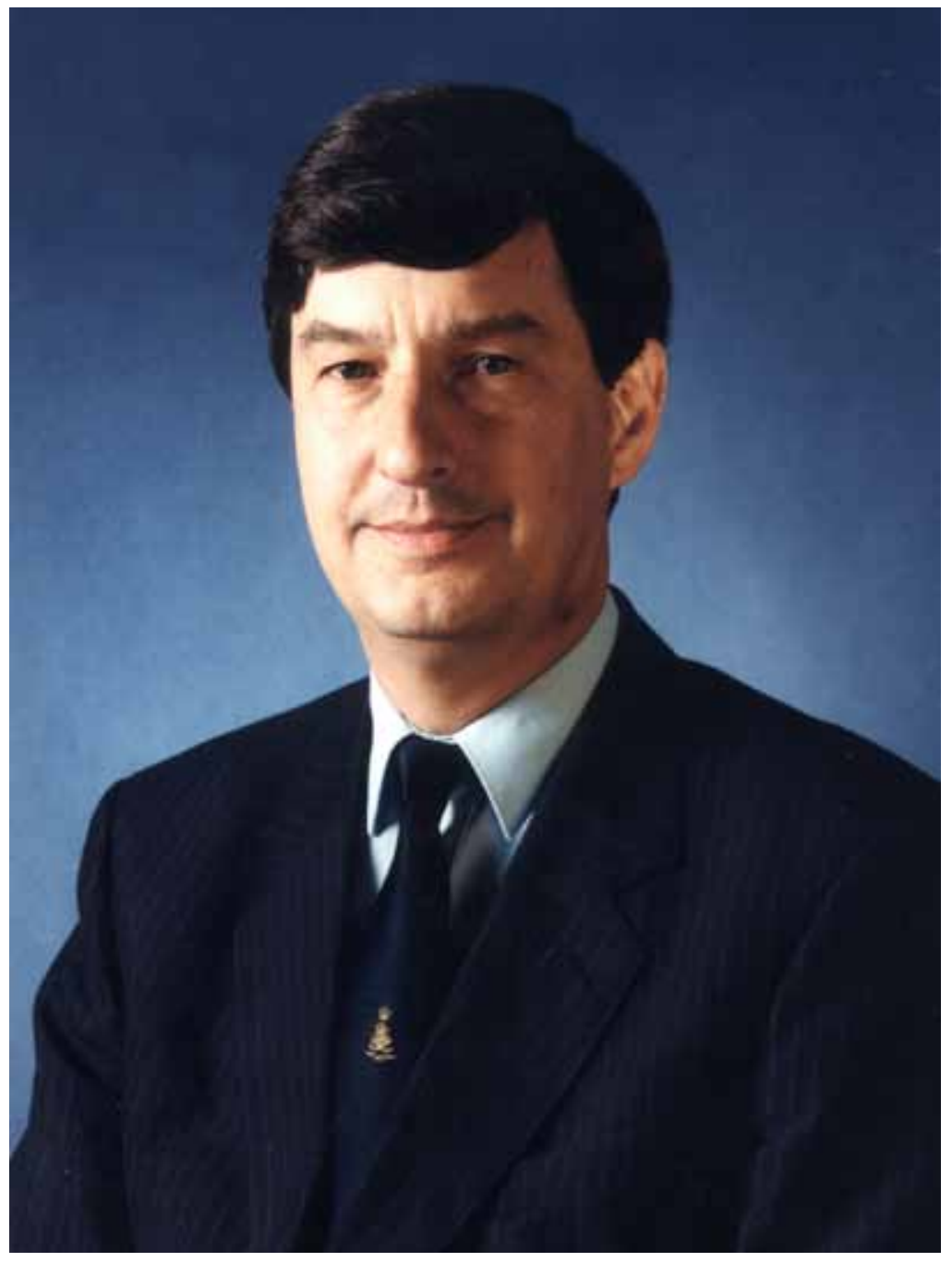

Mr. B.J.M. baron Van Voorst tot Voorst (1944- ) was gouverneur (CDA) in de periode 19932005. Kreeg vrij snel na zijn aantreden te maken met de watersnoodramp in Limburg. Hechtte veel waarde aan de internationale contacten en de Europese samenwerking, ervaring die hij vanuit zijn eerdere functies (o.a. directeur-generaal buitenlandse betrekkingen bij het ministerie van Economische Zaken en twee staatssecretariaten) had opgedaan.Werkte veel achter de schermen, voerde stille diplomatie en was een toonbeeld van onkreukbaarheid. Foto: Provincie Limburg 


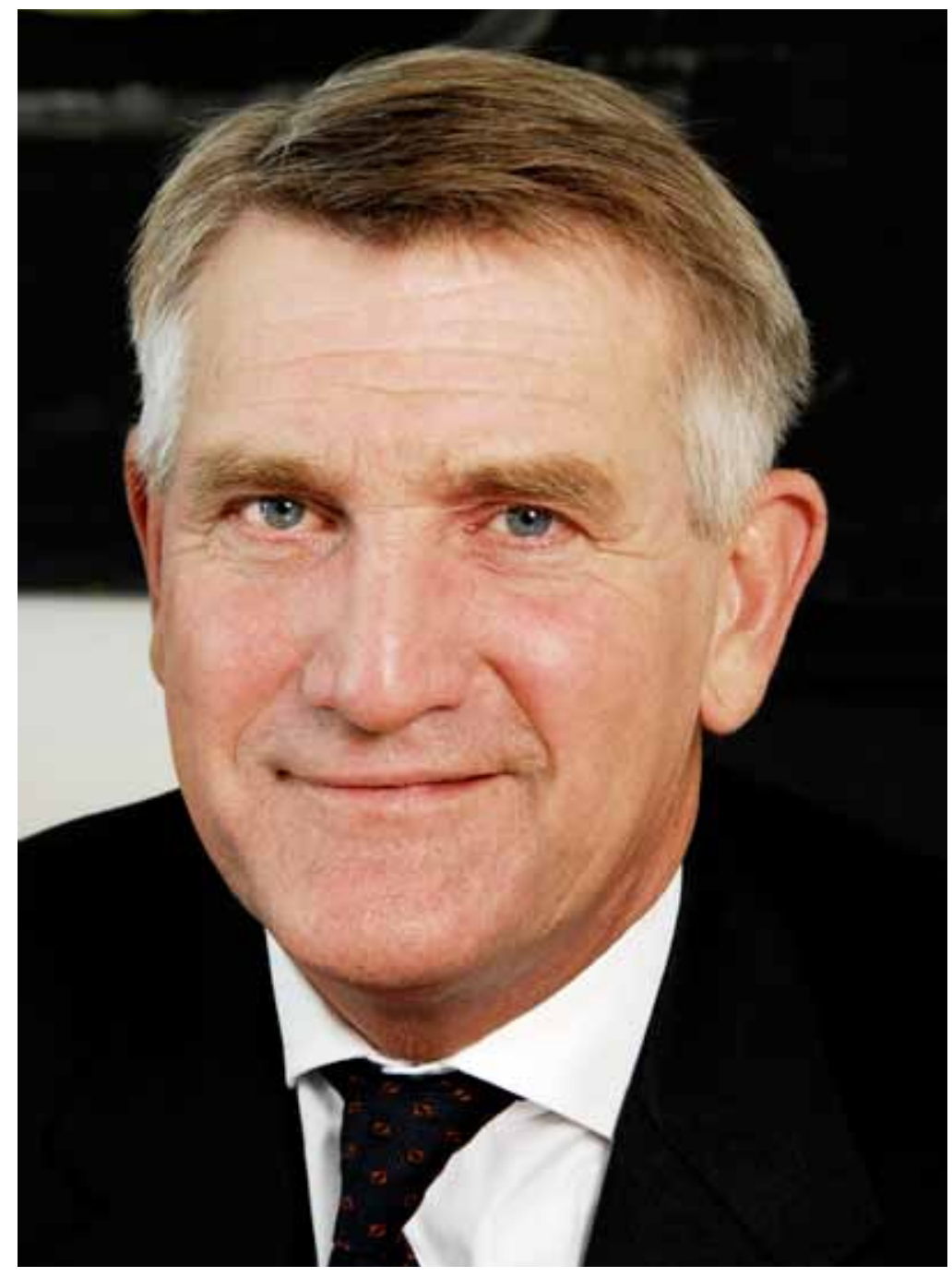

L.J.P.M. Frissen (1950- ) is vanaf 2005 gouverneur (CDA). Was daarvoor burgemeester van de Limburgse gemeenten Horst aan de Maas en Arcen \& Velden, voorzitter van het CDA Limburg en acht jaar Tweede Kamerlid voor het CDA. Hechtte net als zijn voorganger veel waarde aan de Europese samenwerking en de internationalisering van de provinciale werkzaamheden. Had een goede band met zijn Belgisch-Limburgse collega gouverneur S.R.J. Stevaert (sp.a) en benutte ook zijn politieke ervaring in de lobby naar de rijksoverheid. Gouverneur Frissen stopt per I juli 20 II als gouverneur. Foto: Provincie Limburg. 


\title{
6 \\ Conclusie
}

\begin{abstract}
"Om te vernieuwen zal er veranderd moeten worden. Als wij veranderingsgezind zijn stellen wij ons open voor de toekomst. Alleen vasthouden aan het verleden biedt geen perspectief voor de jongere generatie die wij hard nodig hebben om voort te bouwen. En dat vraagt om een gedurfde koers, tegen de wind in en op eigen kracht!"732
\end{abstract}

Gouverneur in de Provincie Limburg L.J.P.M. Frissen (CDA), 1 juli 2005

'Alleen vasthouden aan het verleden biedt geen perspectief', aldus gouverneur Frissen in zijn installatierede als Commissaris der Koningin. Het omgekeerde is echter ook waar: alleen gericht zijn op de toekomst negeert de patronen en de lessen uit het verleden.

In de vorige hoofdstukken zijn het ruimtelijke ordeningsbeleid, het economisch beleid en het welzijnsbeleid van de Provincie Limburg beschreven. Het jaar 1962, met de vaststelling van de Provinciewet, was het vertrekpunt van deze analyse. Feitelijk veranderde er echter met het inwerkingtreden van de Provinciewet niet zo heel veel voor de Provincie Limburg. Het wegvallen van de mijnindustrie en een versneld proces van ontkerkelijking zorgden daarentegen wel voor ongekende economische en sociale veranderingen in Limburg. Veranderingen die tevens grote invloed hadden op de Limburgse provinciale politiek.

Het Provinciaal Bestuur en de ambtelijke organisatie hadden zich tot begin jaren '60 erg afhankelijk opgesteld ten opzichte van de mijnindustrie, bisdom, de maatschappelijke organisaties en de rijksoverheid. Formeel gezien lag de besluitvorming wel bij het College van Gedeputeerde Staten en Provinciale Staten, maar in de praktijk werden de besluiten sterk beïnvloed door actoren buiten het Limburgse provinciehuis. De mijnindustrie en de rijksoverheid bepaalden in grote mate de koers van het economische en het ruimtelijke beleid en het bisdom had veel invloed op de verdeling van subsidies in het sociale beleid van de Provincie. Binnen de gedecentraliseerde eenheidsstaat was de Provincie Limburg vooral een uitvoeringsorgaan van de rijksoverheid die als vooruitgeschoven post in de regio nationaal beleid uitvoerde en toezicht hield op de lokale overheid.

Deze provinciale rolopvatting werd vanaf het begin van de jaren '60 onhoudbaar. Het Limburgse College van Gedeputeerde Staten dat in 1962 aantrad, zette de eerste stappen richting een provinciaal economisch beleid, een welzijnsbeleid en een ruimtelijke ordeningsbeleid. Wat begon als een overheidsorganisatie die zich afhankelijk opstelde en vooral reactief reageerde op gebeurtenissen in de Limburgse samenleving, groeide de Provincie in de daarop volgende decennia uit tot een initiatiefrijke politieke speler.

In dit slothoofdstuk wordt antwoord gegeven op de probleemstelling zoals die in hoofdstuk 1 is geïntroduceerd: 
Op welke manier komt provinciale besluitvorming tot stand, welke meerjarige patronen zijn hierin te onderscheiden en onder welke omstandigheden veranderen deze patronen?

In dit hoofdstuk wordt antwoord gegeven op de vragen hoe besluitvorming tot stand kwam (\$6.1), welke meerjarige patronen daarin zijn te ontdekken (\$6.2) en onder welke omstandigheden die patronen veranderden (\$6.3). Ten slotte zal er worden gereflecteerd op de bevindingen uit de voorafgaande hoofdstukken in relatie tot het debat over de provincies (\$6.4).

\subsection{De praktijk van besluitvorming}

Formeel gezien is er in de manier, waarop de Provincie in de periode 1962-2007 besluiten nam, weinig veranderd. Het College van Gedeputeerde Staten en Provinciale Staten waren en zijn nog steeds - staatsrechtelijk gezien - de besluitvormingsorganen van de Provincie Limburg. Besluiten worden voorbereid, genomen en geïmplementeerd. Wanneer men echter kijkt naar de praktijk van besluitvorming en met name naar de manier waarop besluiten door de Provincie werden voorbereid en geimplementeerd, dan worden belangrijke veranderingen zichtbaar. De formele bevoegdheid om over iets te besluiten zegt weinig over het daadwerkelijk gebruik van die bevoegdheid. De Provincie kon op elk moment besluiten projecten te initiëren om zo gestalte te geven aan een 'eigen' economisch beleid. Zij heeft altijd de mogelijkheid gehad om zelf nieuwe instrumenten voor het ruimtelijke ordeningsbeleid te ontwikkelen of om vast te stellen welke organisaties subsidie kregen. Niets stond de Provincie formeel in de weg om de samenwerking met gemeenten te versterken of om samenwerking aan te gaan met het Limburgse bedrijfsleven. Toch was er pas aan het begin van de 21 e eeuw echt sprake van een hechte samenwerking tussen Provincie, kennisinstellingen, bedrijfsleven en Limburgse gemeenten.

De meest in het oog springende verandering is de groei van het aantal provinciale taken. De Provincie had bijvoorbeeld tot begin jaren '60 nauwelijks wettelijke taken op het gebied van het welzijnsbeleid of economisch beleid. Vanaf eind jaren '60 kreeg de Provincie van de rijksoverheid meer bevoegdheden op het gebied van milieu, ruimtelijke ordening, volkshuisvesting, welzijn, cultuur en bejaardenzorg, bevoegdheden die zij vanaf de jaren ' 80 ook actief ging inzetten in het provinciale beleid.

Niet alleen zijn de provinciale activiteiten vanaf de tweede helft van de 20 e eeuw uitgebreid, ook de manier waarop besluiten werden voorbereid en geïmplementeerd veranderde. Door de Provincie werden nieuwe actoren benaderd bij het vormgeven van provinciaal beleid waardoor nieuwe samenwerkingsverbanden ontstonden tussen Provincie en belanghebbende partners. Ook met betrekking tot de manier waarop bevoegdheden en instrumenten werden ingezet, veranderde het provinciale beleid.

De praktijk van besluitvorming werd tevens beïnvloed door de manier waarop de Provincie geografische indelingen hanteerde. Was er sprake van beleid voor uitsluitend Zuid-Limburg of richtte het beleid zich vooral op de grote Limburgse steden? Waren andere provincies misschien een concurrent als het ging om het binnenhalen van 
subsidies van de rijksoverheid, of juist een inspiratiebron voor de ontwikkeling van nieuw beleid voor Limburg? Tegelijkertijd kan uit het gebruik van geografische indelingen worden opgemaakt hoe de Provincie haar financiële middelen inzette en haar politieke prioriteiten bepaalde.

Ten slotte werd de provinciale besluitvorming beïnvloed door de relatie tussen politici en ambtenaren. Kennis van het krachtenveld rondom een bepaald thema, het in kaart brengen van alternatieven en risico's, afwegingen ten aanzien van haalbaarheid en uitvoering, maar vooral de afstand tussen het ambtelijk apparaat en de politiek waren factoren die een rol speelden. De persoonlijke voorkeur van een politicus en de politieke afwegingen die vervolgens werden gemakt tijdens de voorbereiding van een besluit, speelden ook een rol.

Er kan worden geconcludeerd dat de praktijk van provinciale besluitvorming wordt beïnvloed door de manier waarop bevoegdheden, instrumenten en geografische indelingen worden ingezet om beleid vorm te geven en dat maatschappelijke actoren ('stakeholders') en het samenspel tussen politici en ambtenaren daarbij een belangrijke rol vervullen.

\subsection{Patronen in besluitvorming: vier periodes, vier strategieën}

Door de jaren heen verandert de manier waarop besluiten worden voorbereid en uitgevoerd. In hoofdstuk 5 is een algemeen overzicht gegeven van de ontwikkelingen in de provinciale beleidsvorming. In het bestudeerde tijdsbestek (1962-2007) zijn vier periodes te onderscheiden. Elke periode besloeg ongeveer 12 tot 16 jaar, hetgeen omgerekend overeenkomt met drie tot vier zittingstermijnen van een College van Gedeputeerde Staten. Elke periode laat een consistent patroon zien in de reeks van genomen besluiten. Er kan met andere woorden, worden gesproken van een specifieke, herkenbare provinciale opstelling en beleidsstrategie.

In de periode 1962-1978 verkende de Provincie Limburg haar rol. Zij onderzocht de mogelijkheden van een nieuw eigen instrumentarium om beleidsvoornemens te implementeren, zij keek hoe andere provincies vergelijkbaar beleid gestalte gaven en ze liet onderzoek doen om een beeld van de maatschappelijke problemen te krijgen. De rijksoverheid werd - zeker na de aankondiging van de mijnsluitingen in 1965 - door de Provincie verantwoordelijk gehouden voor de gevolgen voor Limburg van dat besluit. De gemeenten, industrieschappen, DSM, diverse raden en welzijnsorganisaties moesten de uitvoering en realisatie van het herstructureringsbeleid op zich nemen. De Provincie kreeg de taak om de vele rijkssubsidies regionaal te verdelen. Zij deed dit via een groot aantal commissies en samenwerkingsverbanden. In de loop van de jaren ' 70 groeide bij het Provinciaal Bestuur het besef, in de context van deze regionale verdelingsvraagstukken, de interprovinciale vergelijkingen en het ontwikkelen van eigen instrumenten voor de implementatie van beleid, dat men meer eigen verantwoordelijkheid moest nemen voor de Limburgse maatschappelijke vraagstukken. De invloed van een aantal Limburgse organisaties zoals de Land- en tuinbouworganisatie, de Raden, het Etil en de Kamers van Koophandel, in belangrijke commissies als de Planologische Commissie, de 
Commissies Sociale Begeleiding en de Herstructureringscommissie, was echter nog zeer dominant. Bovendien was de Provincie afhankelijk van de informatievoorziening (cijferen kaartmateriaal) en expertise van andere organisaties om het provinciale beleid te onderbouwen en vorm te geven.

Gedurende de periode 1978-1990 werd het provinciale beleid gedomineerd door het economisch beleid. Het was een unieke periode in de provinciale geschiedenis. Over de decentralisatie van een groot aantal taken in de jaren ' 80 werd door het College van Gedeputeerde Staten onder leiding van gouverneur J. Kremers (CDA) effectief onderhandeld tijdens het jaarlijkse politieke overleg met de regering. Midden jaren ' 80 kreeg de Provincie ook een belangrijke taak in de planning van de volkshuisvesting en het welzijnsbeleid, maar het economisch beleid kreeg prioriteit van het College. Honderden projecten werden in het kader van het Perspectievennotabeleid door de Provincie geïnitieerd en uitgevoerd. De rijksoverheid financierde het grootste gedeelte hiervan. De noodzaak van een actieve provinciale opstelling werd vanaf midden jaren ' 80 alleen maar sterker omdat de rijksoverheid zich steeds meer uit de provincies begon terug te trekken. Het Perspectievennotabeleid werd in december 1990 formeel afgesloten. Een jaar eerder was de Bestuursovereenkomst die de decentralisatie in het welzijnsbeleid bekrachtigde, al beëindigd. De jarenlange samenwerking met de rijksoverheid kwam ten einde, maar er was een basis gelegd voor een Provincie die zelf initiatief nam en taken en bevoegdheden inzette om beleid vorm te geven en te realiseren.

In de periode 1990-2003 groeide de macht van het ambtelijk apparaat. De rijksoverheid verplichtte de provincies om sectorbeleid op te stellen. Vooral op het gebied van milieu, natuur en zorg vaardigde de rijksoverheid nieuwe wetten uit die op provinciaal niveau moesten worden uitgewerkt. Aanvankelijk zocht de Provincie Limburg vooral naar samenwerking met de Europese Commissie. In de tweede helft van de jaren '90 waren het vooral de intermediaire organisaties waarmee gezamenlijk beleid werd ontwikkeld. De rijksoverheid had zich teruggetrokken uit de provincies en richtte haar aandacht nu vooral op het versterken van de positie van gemeenten. De politieke onderhandelingen tussen Provincie en regering bleven in de jaren '90 beperkt tot bilaterale contacten tussen gedeputeerden en ministers of staatssecretarissen. In de jaren '80 was uitsluitend de doelstelling om de werkloosheid weg te werken van belang; nu werden meerdere doelstellingen binnen diverse beleidsterreinen geformuleerd. Zo waren er provinciale doelstellingen op het gebied van technologiebeleid, pogingen om meetbare doelstellingen in het welzijnsbeleid te formuleren en zeer specifieke doelstellingen in het ruimtelijke ordeningsbeleid. Deze doelstellingen waren een uiting van een meer autonome opstelling van de Provincie. De Provincie formuleerde zelf ambities en beleidsdoelen. Om deze doelen ook te kunnen bereiken was er expertise nodig op de verschillende beleidsterreinen, expertise die vooral het ambtelijk apparaat een sterke positie gaf. Rijksoverheid en gemeenten speelden in deze periode slechts een beperkte rol.

In de periode 2003-2007 probeerde het College van Gedeputeerde Staten opnieuw gestalte te geven aan een wederom gewijzigde opvatting omtrent de rol van de provinciale overheid. Diverse uitvoeringsproblemen in de voorafgaande periode en de verslechtering 
van de economie vanaf 2004 zorgden voor een nieuwe politieke profilering. Er werd door de Provincie samenwerking gezocht met nieuwe actoren zoals de gemeenten, de kennisinstellingen en het bedrijfsleven. Nieuwe instrumenten, organisatievormen en samenwerkingspartners veranderden de provinciale strategie. In de behartiging van de Limburgse belangen werd de Provincie één van de partners, maar met het selecteren van een beperkt aantal nieuwe partners waarmee vervolgens een gezamenlijke aanpak werd opgezet, speelde de Provincie Limburg wel actief in op het rijksbeleid.

\subsection{Nieuwe agendavorming: vier omslagmomenten}

De veranderingen in de provinciale strategie verliepen, zoals uit vorige hoofdstukken is gebleken, schoksgewijs. In een relatief korte periode van twee tot drie jaar vond er telkens een fundamentele omslag plaats inzake de bestuurlijke rol en de strategische koers van de Provincie. Op deze momenten was er sprake van nieuwe agendavorming in de provinciale politiek. Er zijn vier omslagmomenten aan te wijzen: 1962-1965, 1978-1979, 1990-1992 en 2003-2004. Daarbij speelden telkens drie factoren een rol: externe urgente omstandigheden, allianties tussen personen en de ruimte die de rijksoverheid bood.

Externe omstandigheden zijn vaak financieel-economisch van aard. Werkloosheid, bezuinigingen, of financiële tekorten kunnen een aanleiding zijn om de koers te wijzigen. Maar ook incidenten, affaires of problemen in de uitvoering van beleid kunnen van invloed zijn. Allianties tussen personen zijn een tweede factor van betekenis. In de provinciale geschiedenis waren deze personen vooral politici (gedeputeerden en gouverneurs) die op het juiste moment de goede netwerken en persoonlijke contacten benutten om een nieuwe bestuurlijke strategie te initiëren. Het is daarom niet toevallig dat de omslagmomenten steeds plaatsvonden in een periode dat er een nieuw College van Gedeputeerde Staten aantrad $(1962,1978,1991,2003)$. De vorming van een nieuw College is tevens een politiek moment om afscheid te nemen van het 'oude' beleid. Dat dit lang niet altijd bij elk nieuw gevormd College van Gedeputeerde Staten aan de orde is, blijkt wel uit de vorige hoofdstukken. Ten slotte, als derde factor, speelde de rijksoverheid een belangrijke rol. Voor de Provincie was het van groot belang dat er ook ruimte werd geboden (of werd afgedwongen) om de externe omstandigheden aan te kunnen pakken. De rijksoverheid kan wetgeving initiëren of bijstellen, uitzonderingen maken of beleid herzien. Op deze manier kon de Provincie de politieke omgeving (rijksoverheid) benutten om met het oog op problemen in de Limburgse economie, het onderwijs of andere maatschappelijke functiesystemen beleid te formuleren.

Het was de gelijktijdige combinatie van deze drie elementen die op gezette momenten nieuwe agendavorming mogelijk maakte. Ontbrak een van deze drie elementen, dan was er ook geen sprake van een fundamentele koerswijziging. Zo was er bijvoorbeeld midden jaren '70 sprake van een grote werkloosheid in Limburg en was gedeputeerde Buck een nieuwe kracht in het College van Gedeputeerde Staten die een goede band ontwikkelde met de nieuwe directeur van het LIOF. Het ontbrak echter nog aan een effectieve combinatie van provinciale ambities en de benodigde ruimte in het rijksbeleid. De Perspectievennota was nog in de ambtelijke voorbereidingsfase en nog geen enkele minister had zich 
uitgesproken over de politieke uitwerking hiervan. Mede daarom was er midden jaren '70 geen sprake van een omslagmoment.

Een ander voorbeeld zien we in zowel 1985 als in 1996. In beide jaren werd een groot aantal taken en bevoegdheden van de rijksoverheid naar de provincies overgedragen en werden de provincies bijgevolg geconfronteerd met nieuw rijksbeleid. Er was in die jaren echter nauwelijks sprake van een urgent maatschappelijk probleem, noch van sterke persoonlijke allianties. De rijksoverheid handelde eerder vanuit bezuinigingsmotieven, dan met het oog op het oplossen van een maatschappelijk probleem. Voor de Provincie Limburg pasten beide decentralisaties in de reeds eerder uitgezette strategie van het nemen van eigen verantwoordelijkheid en vormden dus ook geen aanleiding tot een verandering van de bestuurlijke strategie.

De vier omslagmomenten vonden gelijktijdig plaats op alle drie van de onderzochte beleidsterreinen, in een betrekkelijk korte periode van twee tot drie jaar. Dat is opmerkelijk te noemen. Een eerste verklaring hiervoor is dat externe omstandigheden vaak op meerdere beleidsterreinen doorwerken en daarmee het algemene provinciale beleid wijzigen. De economische achteruitgang in de jaren '70 was bijvoorbeeld nauw verbonden met het individuele welzijn van duizenden werklozen. Een ander voorbeeld van een externe omstandigheid was de beëindiging in 1990 van twee belangrijke 'contracten' met de rijksoverheid. Zowel het Perspectievennotabeleid als de Bestuursovereenkomst voor het welzijnsbeleid stopten, waarmee het jarenlange speciale rijksbeleid voor Limburg ten einde kwam. Zowel de Haagse politieke context als de Limburgse economische conjunctuur, hebben grote invloed op het totale provinciale beleid laten zien.

Een tweede verklaring is dat een nieuwe bestuurlijke strategie verder reikt dan een strategie voor een enkel beleidsterrein. Veel meer gaat het hier om een verandering van de algemene principes die ten grondslag liggen aan het proces van besluitvorming. De onvrede van het Provinciaal Bestuur over de manier waarop beleid tot stand kwam en werd uitgevoerd, was zowel eind jaren '70 (besturen via commissies) als aan het begin van de 21e eeuw (besturen via intermediaire organisaties) aanleiding om de beleidsvoorbereiding te wijzigen.

\subsection{Een reflectie op de bevindingen: opnieuw het debat over provincies}

In de vorige paragrafen is antwoord gegeven op de probleemstelling zoals die in hoofdstuk 1 werd geïntroduceerd. Wat betekenen de gepresenteerde inzichten nu voor het debat over de provincies? In hoofdstuk 1 is voorgesteld om het debat over provincies te voeren in termen van processen van besluitvorming per provincie in plaats van een benadrukking van de formeel-juridische aspecten of de gewenste structuur en schaal van de provincies.

De manier waarop een provincie zich opstelt in het interbestuurlijke en maatschappelijke krachtenveld, inspeelt op omstandigheden, positie kiest en bevoegdheden en instrumenten daadwerkelijk inzet, zeggen meer over de positie en het functioneren van een provincie dan een analyse van de formele taken of de gewenste regionale schaal. De provincie is een regionaal politiek systeem dat besluiten neemt binnen de context 
van de gedecentraliseerde eenheidsstaat, maar tevens inspeelt op invloeden van andere maatschappelijke functiesystemen zoals de economie, het onderwijs, de zorg of de media. In de voorafgaande hoofdstukken is gebleken dat naast de invloed van de rijksoverheid, juist deze niet-politieke invloedssferen het provinciale beleid en de provinciale rol beïnvloeden.

In deze paragraaf worden de vier onderwerpen uit het provinciedebat (zie hoofdstuk 1) in een nieuw perspectief geplaatst.

\section{Het takenpakket en de rollen van een provincie}

Wanneer we op basis van de voorafgaande hoofdstukken het takenpakket en de provinciale rol van de Provincie Limburg analyseren, kan worden geconcludeerd dat het zogeheten 'beleid in medebewind' in de loop der jaren fors is uitgebreid. Taken op het gebied van milieu, gezondheidszorg, welzijn, cultuur, infrastructuur, ruimtelijke ordening en plattelandsontwikkeling zijn door de rijksoverheid aan provincies opgedragen. Daarnaast is ook het 'autonome beleid' zowel in financiële als inhoudelijke zin sterk toegenomen. De constatering van Van Schendelen en De Vries dat het takenpakket meer en meer zou zijn uitgehold (Van Schendelen, 1987: 256; De Vries, 2003: 115), is daarmee - althans wat de Provincie Limburg betreft - onjuist. Ook een analyse van de financiële uitgaven van Provincie maakt duidelijk dat deze in de loop der jaren sterk zijn gestegen (zie voor Limburg appendix II). Maar het feit dat een provincie beschikt over een bepaalde bevoegdheid of taak, zegt weinig over de daadwerkelijke invulling hiervan.

Wanneer we vanuit het oogpunt van de invulling van bevoegdheden de rol van de Provincie Limburg analyseren zijn het vooral de autonome taken geweest die deze rol sterk hebben beïnvloed. Met name op het gebied van regionale economie is de Provincie Limburg sinds de aankondiging van de sluiting van de mijnen zeer actief geweest. De Provincie had tot die tijd nauwelijks enige activiteiten ontplooit op dit gebied, laat staan dat zij hier medebewindstaken van de rijksoverheid in toebedeeld had gekregen. De Provincie Limburg werd echter vanaf de jaren '60 steeds actiever op dit terrein. Deze actieve rol, die overigens wisselde in verschillende periodes (zie hoofdstuk 5 en paragraaf 6.2), had ook consequenties voor de manier waarop beleid werd gemaakt in andere domeinen. Het functioneren van de Provincie Limburg lijkt daarbij in belangrijke mate beïnvloed te worden niet door het formele takenpakket of algemene rolaanduidingen als toezichthouder, regisseur of bemiddelaar, maar vooral door de maatschappelijke context waarin zij acteert. De regionale en soms zelfs lokale problematiek binnen de provinciegrenzen - die overigens ook door nationale of internationale ontwikkelingen beïnvloed wordt - is een belangrijke trigger voor provinciale besluitvorming. De rol die een provincie daarbij kan innemen hangt af van andere actoren. Dat brengt ons op het tweede onderwerp in het debat over de provincies.

\section{Het interbestuurlijke samenspel}

De positie van een provinciale overheid in relatie tot de rijksoverheid en de gemeenten is gewijzigd in de loop der jaren. Volgens Van Schendelen $(1987,1990)$ en De Vries (2003, 
2011) zou de positie van de provincie verzwakt zijn omdat de rijksoverheid liever direct zaken doet met gemeenten en verder mogelijke regionale of provinciale taken toebedeelt aan zelfstandige bestuursorganen of geprivatiseerde organisaties. Deze ontwikkeling geldt inderdaad voor een aantal beleidsterreinen waarbij vanaf eind jaren '90 het welzijnsbeleid het meest in het oog springt. Daar zijn, zeker na de invoering van de Wet Maatschappelijke Ondersteuning (2006), primair degemeenten voorverantwoordelijk. Ookvoor de uitvoering van de Wet op de Jeugdzorg (2005) lijkt een prominentere rol van gemeenten voor de hand te liggen. Op andere beleidsterreinen (ruimtelijke ordening, plattelandsontwikkeling, milieu, economie, cultuur) spelen provincies echter nog een nadrukkelijke rol. Maar nogmaals, de positie van een provincie ook op deze beleidsterreinen is afhankelijk van de manier waarop een provincie positie kiest en instrumenten en bevoegdheden wil en kan inzetten. Dat verschilt per provincie.

Het regionale samenspel tussen diverse actoren is overigens - en dat blijft vaak onopgemerkt in het debat - breder dan de interbestuurlijke contacten. In de voorafgaande hoofdstukken is aangetoond dat diverse maatschappelijke actoren (bedrijfsleven, intermediaire organisaties, burgerinitiatieven, individuele gemeenten, Europese directoraten-generaal, adviesbureaus etc.) een rol spelen in wat Van Schendelen de 'politieke markt' heeft genoemd (Van Schendelen, 1990: 28). De contacten met het maatschappelijk middenveld waren voor de Provincie in de jaren '60 en '70 belangrijk voor het voeren van een welzijnsbeleid. In de ruimtelijke ordening was niet alleen het contact met individuele gemeenten van belang, maar zeker vanaf de jaren '70 ook het contact met burgers, intermediaire organisaties, en bedrijfsleven als het ging om inspraakprocedures bij streekplannen. De positionering van een provincie zal dus niet alleen afgewogen en beoordeeld moeten worden op de relatie tot de rijksoverheid en gemeentelijke overheid, maar tevens bezien moeten worden in relatie tot de maatschappelijke partners. De werking van de politieke markt in provincies kan dus niet alleen aan de opstelling van een provincie worden afgemeten, maar ook aan de kracht en positie van andere actoren.

\section{De schaal van provinciale besluitvorming}

Het provinciale beleid is lang niet altijd provinciedekkend beleid. Een provincie hanteert voortdurend verschillende schaalniveaus en gebiedsindelingen om beleid gestalte te geven. In de jaren '50 waren de streekplannen beperkt tot regio's als de Oostelijke Mijnstreek, Venlo en omstreken of Midden-Limburg ten oosten van de Maas. In de daarop volgende decennia kwamen er streekplannen voor Zuid-Limburg en Noord- en Midden-Limburg en uiteindelijk zelf één streekplan voor heel Limburg. Ook in het het economisch beleid werd er voortdurend gespeeld met geografische indelingen. Het beleid van de Provincie vanaf 2003 om de leefbaarheid in wijken en buurten te verbeteren richtte zich daarentegen weer op het lokale niveau. Deze voorbeelden maken duidelijk dat er niet zoiets bestaat als de schaal voor provinciale besluitvorming. Geografische indelingen wisselen al naar gelang de omvang en urgentie van de problematiek, de probleemdefinitie, de betrokken actoren, de politieke voorkeuren of de inschatting van draagvlak voor beleid. Het denken in schaalniveaus is bij uitstek een politieke aangelegenheid die lang niet altijd bepaald 
wordt door wat experts of inhoudelijk gedreven ambtenaren als het 'juiste' schaalniveau typeren (wat dit ook moge zijn).

Het is juist het schakelen tussen verschillende schaalniveaus die de provinciale politiek ruimte geeft om te experimenteren, te kiezen of om draagvlak te verwerven. In de vorige hoofdstukken is gebleken dat de keuze voor een bepaald schaalniveau historisch contingent is, dat wil zeggen: voor een bepaalde periode is de keuze van een schaalniveau relevant tot het moment dat er veranderende omstandigheden optreden, nieuwe actoren verschijnen of nieuwe politieke voorkeuren dominant worden.

\section{Intermezzo: agendavorming, strategie en sturingsmodellen}

Alvorens in te gaan op het laatste argument, de vraag of een analyse van de provincie eigenlijk wel mogelijk is, is een tussenstap nodig. Hierboven is benadrukt dat vooral de provinciale opstelling van belang is om de positie van een provincie te kunnen beschrijven. De ontwikkeling van de Provincie Limburg is schoksgewijs verlopen gemarkeerd door vier omslagmomenten waarmee een nieuwe provinciale strategie werd ingezet (zie paragraaf $6.3)$.

Deze provinciale strategieën kunnen ook worden gelezen als tijdsgebonden sturingsmodellen ${ }^{733}$. Een nieuwe koers zal altijd op de een of andere manier verwijzen naar een eerdere koers. In zijn model voor agendavorming benadrukt Kingdon het feit dat agendavorming 'historisch contingent' is. "What happens at one time depends on what happened previously" (Kingdon, 2003: 224). Inzicht in voorafgaande condities kan de toekomst niet voorspellen, maar laat wel patronen zien en helpt om te begrijpen wat er gebeurt en onder welke omstandigheden nieuwe agendavorming tot stand komt. Hieronder vatten we de eerder gepresenteerde vier strategieën in de periode 1962-2007 op als vier verschillende sturingsmodellen.

Zo kan de provinciale strategie in de periode 1962-1978 getypeerd worden als een vorm van corporatistische sturing. Diverse maatschappelijke actoren vervulden hierin een rol waarbij de Provincie vooral handelde vanuit het subsidiariteitsbeginsel. Het werken met commissies en adviesorganen zorgde er voor dat er naar consensus werd gezocht tussen verschillende en soms strijdige belangen, waarbij de stem van het provinciaal bestuur vooral inventariserend en luisterend was. Adviezen van deze commissies werden in de provinciale besluitvorming vaak gevolgd.

De periode 1978-1990 kan aangeduid worden als een periode waarin politiekbestuurlijke sturing dominant was. Het meest in het oog springend zijn natuurlijk de politieke onderhandelingen tussen het Limburgse College en de kabinetten Van Agt en Lubbers over het economische beleid in Limburg. Maar ook de reorganisatie van diverse belangrijke commissies in de welzijnssector en de ruimtelijke ordening laten zien dat de tijd van consensus en overleg voorbij was. De Provincie benutte haar autonome bevoegdheden en onderhandelde op basis daarvan met de rijksoverheid.

Beleids- en organisatorische sturing is kenmerkend voor het provinciale beleid van de jaren '90. In de organisatie en structurering van het welzijnsbeleid domineert het New Public Management denken en de verbreding van het provinciale beleid, vooral binnen 
het ruimtelijke en economische beleid, past binnen een beleidsmatig sturingsmodel. Het formuleren van doelstellingen, outputresultaten evenals het aansturen van uitvoeringsorganisaties zijn daarvan kenmerken.

De periode vanaf 2003 zou kunnen worden gekwalificeerd als alliantie-sturing. Partnerships met bedrijfsleven, kennisinstellingen en gemeenten domineren in deze periode de beleidsontwikkeling. In het provinciale beleid wordt nadrukkelijk de input van maatschappelijke partners en gemeenten opgezocht om samen doelen te formuleren en projecten op te zetten.

Deze vier sturingsvarianten zijn hier slechts beknopt weergegeven en verdienen nadere verdieping en concretisering. Met name is daarbij interessant in hoeverre deze typeringen ook voor andere provincies in deze periodes relevant zijn geweest. Enerzijds zijn er aanwijzingen dat deze algemene grove lijnen ten dele ook in andere provincies zijn aan te wijzen (zie ook Van de Vijver, 1995 en Nieuwenhuijsen, 1999). Anderzijds is het functioneren van deze sturingsmodellen afhankelijk van de kracht of zwakte van actoren in de maatschappelijke omgeving en de aard en omvang van de regionale problematiek. Daarmee zijn we bij het laatste argument in het debat over provincies aangeland.

\section{Een debat over dé provincie?}

In hoofdstuk 1 is uitgegaan van de constatering dat de verschillen tussen de provincies groter zijn dan de overeenkomsten. Zeker, het Limburgse provinciale beleid - en dat zal bij andere provincies niet veel verschillen - is door de jaren heen sterk afhankelijk geweest van het beleid van de rijksoverheid. Alhoewel de rijksoverheid kan differentiëren in haar voorstellen, is veel wet- en regelgeving geldig voor alle provincies. De Algemene Wet Bestuursrecht kan in Groningen niet op een andere manier geldig zijn dan in Limburg en (vooralsnog) hebben alle provincies een verantwoordelijkheid voor het organiseren van goede jeugdzorg en de verdeling van cultuursubsidies. Zo was de zoektocht naar een integraal ruimtelijk beleid in de jaren ' 90 geen Limburgse uitvinding, evenals het verruilen van het griffie-dienstenmodel voor het sectorenmodel. De new public management benadering in de welzijnssector was ook geen Limburgse uitvinding. Dit zijn zaken die in meerdere, zo niet alle provincies speelden.

Maar dit impliceert nog niet dat deze zaken in alle provincies een gelijke uitwerking kregen. De aard van de besluiten die in de provinciale context genomen worden en de allianties die met rijksoverheid, bedrijfsleven, gemeenten of maatschappelijke instellingen werden gesloten, kunnen per provincie verschillen.

Op de basis van de hier geschetste empirische analyse van het Limburgse welzijnsbeleid, het economische beleid en het ruimtelijke ordeningsbeleid, zou vervolgonderzoek bij andere provincies uitsluitsel moeten geven of hier vergelijkbare patronen speelden. Daarmee zou tevens antwoord kunnen worden gegeven op de vraag of de provinciale rol en het gevoerde Limburgse beleid vanaf jaren '60 met de sluiting van de mijnindustrie en het versneld terugtrekken van de kerk uit de samenleving, uniek is Nederlandse provinciegeschiedenis. Hoe uniek is de dominantie van de Katholieke 
Volkspartij in de provinciale politiek en haar vertakkingen in diverse maatschappelijke geledingen? Een provincie als Noord-Brabant kent bijvoorbeeld een aantal parallelle ontwikkelingen. Om hier nadere vergelijkende uitspraken over te doen is een verdere bestudering van de overige 11 provincies noodzakelijk.

\section{Tot besluit}

Net zoals de Provinciewet van 1962 formeel gezien weinig wijzigingen aanbracht in de interbestuurlijke verhoudingen tussen rijksoverheid, provincies en gemeenten, heeft ook de Wet Dualisering Provinciebestuur van 2003, door sommigen wel 'de grootste verandering van het bestuurlijke bestel sinds Thorbecke' genoemd ${ }^{734}$, de politiek in de Limburgse Statenzaal (nog) niet fundamenteel veranderd. Het benadrukt andermaal het feit dat het beschikken over bevoegdheden en instrumenten op zichzelf nog weinig zegt over de manier waarop besluitvorming tot stand komt. Het gaat steeds om het gebruik van deze bevoegdheden, iets wat niet in een (Provincie)wet vast te leggen valt. Evenmin volstaat het om de provincie te zien als een scharnier tussen rijksoverheid en gemeente, dat wil zeggen als een instantie die slechts bemiddelt of subsidies verdeelt. Taken veranderen, subsidiepotten raken leeg en bestuurders komen en gaan.

Dat de patronen van het verleden toekomstige besluitvorming beïnvloeden moge uit het voorafgaande blijken. Hoe dat in de toekomst precies in de praktijk zal uitpakken, is niet te voorspellen. Dat er nieuwe patronen zullen ontstaan evenals nieuwe omslagmomenten staat vrijwel vast. In het herkennen van deze patronen heeft dit boek met een blik in de keuken van de provinciale politiek in de afgelopen 45 jaar hopelijk een bijdrage kunnen leveren. 


\section{Eindnoten}

\section{Voorwoord}

1 Onderdelen uit dit voorwoord zijn mede geïnspireerd door de bijdrage van Pieter Caljé (2011). 'Maastricht en zijn universiteit. Interacties tussen universiteit, stad en regio', pp.233-259 in Van Royen [ed.] Maastricht kennisstad, 850 jaar onderwijs en wetenschap. Vantilt - Nijmegen.

\section{Hoofdstuk 1}

2 Tweede Kamer 1958-1959, 5460, Nr.3, Nieuwe bepalingen met betrekking tot de inrichting, samenstelling en bevoegdheid van het provinciaal bestuur (Provinciewet). 'Memorie van Toelichting', 13 maart 1959, p.14. Online beschikbaar via statengeneraaldigitaal.nl.

3 Bibliotheek Provincie Limburg. Notulen vergadering Provinciale Staten van Limburg, No.70, 6 juni 1962, p.25.

4 In Limburg wordt de Commissaris der Koningin $(\mathrm{CdK})$ ook 'gouverneur' genoemd. In het vervolg zal worden gesproken van gouverneur. Wanneer het de voorzitter van het College van Gedeputeerde Staten van een andere provincie betreft, zal Commissaris der Koningin worden aangehouden.

5 Met uitzondering van de provinciale belastingverordeningen en besluiten over de inrichting van de waterschappen. Deze provinciale taken bleven met de Provinciewet aan 'preventief toezicht onderworpen' door de rijksoverheid. Tweede Kamer 1958-1959, 5460 Nr.3 (MvT), p.14.

6 In het vervolg zal 'provincie' met een kleine letter worden geschreven als het gaat om andere provinciale organisaties of het geografisch gebied Limburg. Wanneer er verwezen wordt naar de 'Provincie' met een hoofdletter gaat het om de Limburgse provinciale overheid als politiek systeem. Daar waar relevant zal er een onderscheid gemaakt worden binnen het provinciale politieke systeem tussen Gedeputeerde Staten (GS), Provinciale Staten (PS), het ambtelijk apparaat, commissies, werkgroepen en/of individuele personen.

7 Eerste Kamer 1961-1962, 17e vergadering, 23 januari 1962. Minister van Binnenlandse Zaken, E. Toxopeus (VVD) verantwoordde deze keuze als volgt: "Ik geloof, dat het noch gewenst, noch mogelijk zou zijn geweest om zulk een taakomschrijving voor de toekomst te geven. (...) Zij [provincies - HvE] hebben allerlei taken ter hand genomen waarvan het kunnen bestaan in de toekomst niet zo voor de hand heeft gelegen", p.2104

8 Tweede Kamer 1958-1959, 5460 Nr.3. "De ontwikkeling van het maatschappelijk leven heeft dit medegebracht en Grondwet zowel als Provinciale wet laat het provinciaal bestuur in beginsel vrijheid elk belang dat naar zijn oordeel tot de 'huishouding der provincie' behoort, ter behartiging aan zich te trekken", p.13.

9 Zie voor een globaal historisch overzicht van de gevoerde debatten sinds 1946: Boogers, M. \& Hendriks, F. (2005). Middenbestuur in discussie. Analyse van en reflectie op de naoorlogse discussie over middenbestuur in Nederland. Eindrapportage. November 2005.

10 Er zijn meer onderwerpen te noemen die in het debat over de provincies naar voren komen. Zo wordt er door Herweijer op gewezen dat sommige provincies zich als 'hoeder' van de regionale identiteit opwerpen (Herwijer, 1996: 68). Terecht merkt Peters hierover op dat de waardering van lokale of regionale symbolen, weinig zegt over de band die burgers hebben met hun provinciaal bestuur (Peters, 2007: 36). Een ander onderwerp dat vaker terugkomt in het debat betreft de democratische legitimiteit van provincies. Peters vraagt zich af wat de consequenties zijn als het relatief lage opkomstpercentage bij provinciale Statenverkiezingen blijft dalen (Peters, 2007: 8). Zij stelt voor om de provinciale verkiezingen af te schaffen en de provincies tot een 'administratieve tussenlaag' te maken die de 'nuttige, niet-politieke middenbestuurstaken kan vervullen' (idem.151). Derksen en Berkhout gaan niet zo ver, maar stellen dat provincies het beste hun taak uitoefenen als zij achter de schermen kunnen werken (Derksen, 1999; Berkhout, 1999: 76; 
Berkhout, 2002: 11). Neelen vindt daarentegen dat het debat in de statenzaal sterker gepolitiseerd zou moeten worden om duidelijk te maken (Neelen, 1999: 101). In het verlengde van het debat over de democratische legitimiteit van provincies wordt ook de efficiency en effectiviteit van het werk van provincies ter discussie gesteld. Peters constateert dat er weinig inzicht bestaat in of provincies de zichzelf gestelde doelen en maatschappelijke effecten ook daadwerkelijk bereiken. Op deelonderwerpen zijn er wel evaluaties en kosten-baten analyses beschikbaar, maar gedegen onderzoeksmateriaal op veel terreinen ontbreekt (Peters, 2007: 136-137).

11 Gemengde Commissie Decentralisatievoorstellen Provincies ('Commissie Lodders') (2008). Ruimte, regie en rekenschap. 17 maart 2008. Online beschikbaar [laatst geraadpleegd 18-3-2011]: www.rijksoverheid.nl/bestanden/documenten-en-publicaties/publicaties-pb51/rapportcommissie-lodders-ruimte-regie-en-rekenschap/07br2008g105.pdf.

12 IPO / Commissie Regionaal Bestuur in Nederland ('Commissie Geelhoed') (2002). Op schaal gewogen. Regionaal bestuur in Nederland in de 21e eeuw. IPO - Den Haag.

\section{$\$ 1.2$ Provincie als politiek systeem}

13 Elzinga (1995) beschrijft de functie van de provincies tot aan de jaren '60 als een 'postbusfunctie' (zie p.31). Enerzijds is de provincie een doorgeefluik van Haagse wetgeving, anderzijds moet zij toezicht houden op de gemeenten als lokale uitvoerder van rijksbeleid.

14 Raad voor het Openbaar Bestuur (1999). Het bestuurlijk kraakbeen, december 1999. Online beschikbaar [laatst geraadpleegd 22-11-2010]: www.rob-rfv.nl/GetFile.aspx?id=137.

15 In de tekst wordt de term 'Provinciaal Bestuur' gehanteerd als verzamelnaam voor Provinciale Staten én het College van Gedeputeerde Staten samen. Indien er alleen sprake is van het 'College van Gedeputeerde Staten' (GS) of uitsluitend 'Provinciale Staten' (PS) zal dat zo in de tekst worden aangegeven. In het geraadpleegde archiefmateriaal lopen deze definities echter door elkaar, waarbij met Provinciaal Bestuur soms alleen het College van Gedeputeerde Staten wordt bedoeld. In die gevallen is gekozen voor de letterlijke benaming zoals die wordt gehanteerd in het archiefmateriaal.

\section{\$1.3 Een conceptueel kader voor provinciale besluitvorming}

16 Dit is het aantal gemeenten op 1 januari 2010 volgens het CBS. Online beschikbaar [laatst geraadpleegd 29-10-2010] www.cbs.nl/nl-NL/menu/themas/dossiers/nederland-regionaal/ publicaties/artikelen/archief/2010/2010-3008-wm1.htm.

17 Gemengde Commissie Bestuurlijke Coördinatie (2005). Je gaat erover of niet. Advies. 30 mei 2005. Online beschikbaar [laatst geraadpleegd 1-10-2010]: www.rijksoverheid.nl/bestanden/ documenten-en-publicaties/rapporten/2007/05/30/eindrapport-commissie-de-grave-je-gaat-erover-of-niet/eindadviesdegrave.pdf

18 Het begrip macht wordt hier gebruikt in de fase van voorbereidende besluitvorming. De begrippen invloed en macht zijn ook relevant in de fase van uitvoering van beleid. Nadat een besluit is genomen kunnen er in de uitvoering van dat besluit wijzigingen optreden waarmee zelfs het voorgestelde beleid door de uitvoering (de uitvoerende actoren) kan veranderen. Zie voor drie mooie bijvoorbeelden Pressman \& Wildavsky (1984).

19 Zie Rijk-IPO-VNG (2009). Interbestuurlijk Actieplan Bevolkingsdaling. Krimpen met kwaliteit, 27 november 2009. Online beschikbaar [laatst geraadpleegd 3-11-2010]: www.rijksoverheid. $\mathrm{nl} /$ bestanden/documenten-en-publicaties/rapporten/2009/11/27/actieplan-bevolkingsdalingkrimpen-met-kwaliteit/krimpenmetkwaliteitdefinitief.pdf.

\section{Hoofdstuk 2}

20 Rijksarchief Limburg 04.09/3390; Citaat van gouverneur Houben uit de installatierede van de Bijzondere Commissie Streekplan Oostelijke Mijnstreek, 26 oktober 1960. 


\section{$\$ 2.1$ Ontwikkelingen in het nationale ruimtelijk ordeningsbeleid}

21 Voor een beschrijving van de algemene geschiedenis van het nationale ruimtelijke ordeningsbeleid is in deze paragraaf gebruik gemaakt van Pijnenburg (1956), Van der Cammen \& De Klerk (2006) en de diverse Nota's Ruimtelijke Ordening en wetteksten die beschikbaar zijn via www. statengeneraaldigitaal.nl.

22 Tweede Kamer 1901-1902, 34, No.39 Ontwerp Woningwet. Artikel 12 kende een groot belang toe aan een 'gezondheidscommissie' die een oordeel moest vellen over het wel of niet bewoonbaar verklaren van woningen. Online beschikbaar via www.statengeneraaldigitaal.nl.

23 Tweede Kamer 1930-1931, 44, No.15 Wijziging van de Woningwet. Artikel 32 van de oude woningwet werd aangevuld met: "Indien de raden van twee of meer gemeenten wenschelijk achten, dat voor het gezamenlijk gebied dier gemeenten een Streekplan wordt vastgesteld, kunnen zij met toepassing van artikel 121 der Gemeentewet een regeling treffen tot instelling van een commissie, welker taak is zoodanig plan voor te beulden, vast te stellen, en, zoo noodig, te herzien. Een streekplan wijst, voor zoover de belangen van het gebied, waarover het zich uitstrekt, dat vorderen, de bestemming aan van in dat gebied gelegen gronden", p.72. Online beschikbaar via www.statengeneraaldigitaal.nl.

24 Tweede Kamer 1955-1956, 4233 Ontwerp Wet op de Ruimtelijke Ordening. Artikel 40 regelde de relatie tussen streekplan en bestemmingsplan: "Met betrekking tot het gebied, waarvoor een streekplan is vastgesteld, kunnen Gedeputeerde Staten, de provinciale planologische commissie gehoord, voor zover bovengemeentelijke belangen dat vorderen aanwijzingen geven omtrent de inhoud van een bestemmingsplan", lid 3, p.4. Online beschikbaar op www.statengeneraaldigitaal. $\mathrm{nl}$. Van het geven van een 'gemeentelijke aanwijzing' is in de provinciale politiek weinig gebruik gemaakt.

25 Het ging hier om de nieuwe regelgeving zoals de Hinderwet, Wet Bodemsanering en Afvalstoffenwet. Provincies kregen na de vaststelling van deze wetten nieuwe taken toebedeeld door de rijksoverheid.

26 Met als sluitstuk in 1980 de invoering van de Wet Openbaarheid van Bestuur.

27 Tweede Kamer 1970-1971, 10914, No.2 Rapport van de Commissie voorbereiding onderzoek toekomstige maatschappijstructuur, 17 september 1970, p.6-7. Online beschikbaar op www. statengeneraaldigitaal.nl

28 Dit waren de Derde Nota Ruimtelijke Ordening (1973), de Verstedelijkingsnota (1976) en de Nota Landelijke Gebieden (1977).

29 Tweede Kamer 1990-1991, 21879, No.2 Vierde Nota Ruimtelijke Ordening Extra, 14 november 1990, p.117. Online beschikbaar via www.statengeneraaldigitaal.nl.

30 In de periode 1987-1991 werden achtereenvolgens het Besluit Milieueffectrapportage (1987), Tweede Structuurschema Verkeer en Vervoer (1988), Natuurbeleidsplan, Nationaal Milieubeleidsplan, Wet op de Waterhuishouding (1989), Actieplan Gebiedsgericht Milieubeleid, Nitraatrichtlijn (1990) en de Nota Landschap (1991) vastgesteld.

31 De eerste decentralisatieronde had midden jaren ' 80 plaatsgevonden toen taken op het gebied van de volkshuisvesting en stads- en dorpsvernieuwing naar provincies waren overgeheveld. Zie ook Heij \& Schrijver, 1991: 60-61.

32 De decentralisatie van het regionaal verkeer en vervoer werd in 1996 geregeld in het VERDIaccoord. 'VERDI' stond voor Verkeer En Vervoer, Regionaal, Decentraal, Integraal.

33 Zie Wetenschappelijke Raad voor het Regeringsbeleid (1998). Ruimtelijke Ontwikkelingspolitiek. Rapport 53, 20 februari 1998; Sociaal-Economische Raad (2001). Advies Vijfde Nota Ruimtelijke Ordening. Advies 2001/07, 21 september 2001. Online beschikbaar via www.wrr.nl en www.ser.nl.

34 Het ging hier om instrumenten als Rood-voor-Groen, de Ruimte-voor-Ruimte regeling, Bouwkavel op Maat of de methode van Verhandelbare Ontwikkelingsrechten.

35 Ministeries VROM. LNV, VenW en EZ (2004/2006). Nota Ruimte. Ruimte voor Ontwikkeling. 
Deel 4: tekst na parlementaire instemming, p.24-34 (paragraaf over de sturingsfilosofie). Online beschikbaar [laatst geraadpleegd 10-12-2010]: http://notaruimteonline.vrom.nl/download/ download/NotaRuimteCompleet.pdf

36 Eerste Kamer 2005-2006, 28916A, Wet Ruimtelijke Ordening, 23 februari 2006. Met artikel 3.19 lid 1 introduceerde de regering het provinciale 'inpassingsplan': "Indien sprake is van provinciale belangen kunnen provinciale staten, de betrokken gemeenteraad gehoord, voor de daarbij betrokken gronden een inpassingsplan vaststellen met uitsluiting van de bevoegdheid van de gemeenteraad om voor die gronden een bestemmingsplan vast te stellen", p.12. Online beschikbaar via www.statengeneraaldigitaal.nl.

\section{\$2.2 Limburgse ruimtelijke ordening voor 1962}

37 Ch.J.M. Ruys de Beerenbrouck (RKSP) werd in datzelfde jaar benoemd tot gouverneur van Limburg en volgde daarmee zijn vader op. Echter al na een paar maanden werd hij ministerpresident. Hij zou drie kabinetten leiden in het interbellum. Zie voor een biografisch overzicht: www.parlement.com.

38 Bibliotheek Provincie Limburg. Provincie Limburg (1959). 25 jaar planologie in Limburg, p.15.

39 idem.18-19.

40 idem.19.

41 Rijksarchief Limburg 04.10/150; Notulen van Provinciale Staten, Buitengewone Zitting van 13 maart 1934, No.21, p.15.

42 Rijksarchief Limburg 04.10/150; Nota van de 1e Afdeling voor Provinciale Staten Limburgsche Streekplannendienst van 21 juni 1935.

43 Bibliotheek Provincie Limburg. Provincie Limburg (1959), p.26.

44 Het eerste echte streekplan na de wetwijziging van 1931 bracht de waterwingebieden in ZuidLimburg in kaart. Het was vooral een beschouwing over de Limburgse bodemgesteldheid. De snelle naoorlogse industrialisatie en verstedelijking zorgden voor problemen in de drinkwatervoorziening. Met dit streekplan beoogde het Provinciaal Bestuur de 'waterwingebieden' te beschermen. Zie Rijksarchief Limburg 04.09/3381; Vaststelling en goedkeuring over Facetstreekplan Waterwingebieden in Zuid-Limburg (1946-1952). Vooruitlopend op dit plan was in 1938 een bodemanalyse gemaakt. Zie ook de eerste vooroorlogse verkenning voor het uiteindelijk streekplan, Bibliotheek Provincie Limburg; Limburgsche Streekplannendienst (1938). Streekplan Zuid-Limburg. De Bodem, Maastricht.

45 Rijksarchief Limburg 04.09/3382; Streekplan Westelijke Mijnstreek (1954).

46 Als de nieuwe mijn in werking zou treden, kon volgens de provinciale planologen de huisvesting van de mijnarbeiders niet langer binnen de gemeentegrenzen van Roermond plaatsvinden. De Planologische Dienst beschouwde daarom het gebied Roermond-Maasniel als één economischgeografische eenheid in het streekplan. De gemeente Roermond greep dit aan om een voorstel voor herindeling met buurgemeente Maasniel bij de Provincie in te dienen. Uiteindelijk werd dit voorstel ook door de Provincie goedgekeurd. Zie Beckers (2006) voor een uitgebreide historische beschrijving.

47 Rijksarchief Limburg 04.09/3387; Zie bijvoorbeeld 'Verslag van een oriënterende bespreking met de gemeente Hoensbroek', 20 januari 1960, p.1.

48 Rijksarchief Limburg 04.09/3387; Notitie Provinciale Planologische Dienst (PPD) 'Conceptbeschrijving van de in het streekplan 'De Oostelijke Mijnstreek' te treffen voorzieningen en bestemmingen ten aanzien van de industrie', april 1959, p.6.

49 Rijksarchief Limburg 04.09/3387: Verslag van het overleg tussen PPD en de gemeente Brunssum, 15 januari 1960, p.1

50 Met de nieuwe Wet op de Ruimtelijke Ordening (1962) verviel de wettelijke status van het streekplan. Voorheen moesten gemeenten in het opstellen van hun bestemmingsplannen rekening 
houden met hetgene in het provinciale streekplan was opgenomen. Met de nieuwe wet verviel deze verplichting.

51 Rijksarchief Limburg 04.09/3387; Zie verslagen van overleg met gemeenten Brunssum en Hoensbroek op 15 en 20 januari 1960.

52 Rijksarchief Limburg 04.09/3387: PPD-notitie 'Wensen gemeenten. Standpunt p.p.d., cq. opmerkingen', ongedateerd maar waarschijnlijk februari/maart 1960.

53 Rijksarchief Limburg 04.09/9540; PPD Limburg (1963). Verslag over de jaren 1961 en 1962, rapport no.106: "Tijdens de verslagperiode werd weer regelmatig overleg gepleegd met het Bisdom Roermond, i.c. met de 'Bisschoppelijke Situeringscommissie', dit teneinde bij de uitgroei van steden en dorpen tijdig rekening te kunnen houden met de in ruimtelijk opzicht van betekenis zijnde maatregelen, welke van kerkelijke zijde moeten worden genomen", p.7.

54 Rijksarchief Limburg 04.09/3387; PPD-nota 'Uitgangspunten Streekplan De Oostelijke Mijnstreek', 30 november 1959, p.3. Zie ook; Brief gemeente Simpelveld aan PPD 'Voorbereiding streekplan Oostelijke Mijnstreek' van 25 februari 1960 waarin werd opgemerkt dat de dorpskern Huls over een pas gebouwde 'hulpkerk' beschikte die in de toekomst 'toch zeker een rectoraatskerk' zou worden. Een beperking van het 'zielenaantal' (lees: aantal inwoners) tot 600, zou deze groei tot rectoraatskerk niet mogelijk maken. Daarvoor waren namelijk minimaal 1.200 inwoners nodig; p.1.

55 Rijksarchief Limburg 04.09/3391; Notulen van de 7e vergadering van de Bijzondere Commissie, 12 september 1961, p.3: Raedts zelf vroeg in de desbetreffende vergadering aan de leden van zijn Commissie of hij tijdens de behandeling van de bezwaarschriften van zijn eigen Oranje NassauMijnen als voorzitter kon blijven functioneren. De Commissie vond dat hier 'generlei bedenking' tegen bestond.

56 Rijksarchief Limburg 04.09/3391; Bijzondere Commissie uit Provinciale Staten in verband met het streekplan De Oostelijke Mijnstreek. Zie verslag van 11 oktober 1961, p.3.

57 Rijksarchief Limburg 04.09/3389; Zie verslagen van de in totaal acht Bijzondere Commissievergaderingen (in de periode 26 oktober 1960 - 26 september 1961) waar vooral de directeur van de PPD, J.C. van Poppel (en niet gedeputeerde A.H.M.H. Hendrickx, KVP) een actieve inbreng had.

58 Rijksarchief Limburg 04.09/9540; PPD Limburg (1967). Verslag over de jaren 1965 en 1966, oktober 1967. Bijlage 1 'Inleiding P.C.A.'t Hoen voor de Conferentie voor Ruimtelijke Ordening in Noord-West Europa op 10 oktober 1966', pagina c.

59 Rijksarchief Limburg 04.09/9540; PPD Limburg (1967). Verslag over de jaren 1965 en 1966, juni 1967, p.3.

60 Het begrip 'streekplan nieuwe stijl' kwam uit het Memorie van Toelichting bij de Wet op de Ruimtelijke Ordening. Zie Tweede Kamer 1955-1956, 4233, No.3 Wet op de Ruimtelijke Ordening, Memorie van Toelichting, 23 januari 1956, p.11. Online beschikbaar op www.statengeneraaldigitaal. nl.

61 Rijksarchief Limburg 04.09/9540; PPD Limburg (1967). Verslag over de jaren 1965 en 1966, juni 1967, p.11.

62 Ch.J.M.A. van Rooy (KVP) was voor zijn ministerschap burgemeester geweest in de gemeenten Hontenisse, Etten-Leur, Venlo en Eindhoven. Na zijn vroegtijdig aftreden als minister van Sociale Zaken in 1961 werd hij burgemeester van Heerlen. In 1964 volgde hij gouverneur Houben op. Zie voor verdere biografische gegevens: www.parlement.com.

63 Rijksarchief Limburg 04.09/9540; PPD Limburg (1965). Verslag over de jaren 1963 en 1964. Rapport nr.107, p.2.

\section{\$2.3 De hoogtijdagen van het streekplan (periode 1965-1979)}

64 Zie de notulen van de vergaderingen van Gedeputeerde Staten van Limburg in de periode 
1967-1970. Archiefnummers Rijksarchief Limburg 04.09/11435 (1967) t/m 04.09/11438 (1970). Belangrijke besluiten inzake de provinciale ruimtelijke ordening werden in die periode niet of nauwelijks genomen.

65 Zie bijvoorbeeld het aantal uitgebrachte rapporten van de Provinciale Planologische Dienst in de jaren '60: De woningbehoefte in Limburg (1963), Vertrek uit het dorp (1964), De kleine dorpen in Limburg (1966), De boer als gastheer (1967), Limburgs toekomst (1967), De migratie in Limburg (1967), De tweede woning in Limburg (1970) en De suburbanisatie in Limburg (1970).

66 Bibliotheek Provincie Limburg. Provincie Limburg (1967). Limburgs toekomst. Uitgangspunten voor een welvaartsbeleid, 1967, p.35, 38.

67 Rijksarchief Limburg 04.09/3405; PPD Limburg (1970). 'Streekplan Zuid-Limburg. Eerste ontwerp (verkorte uitgave)'. December 1970, p.4. Zie ook: Bibliotheek Provincie Limburg. PPD Limburg (1970). De suburbanisatie in Limburg, p.35: "Zo konden streekplannen ontstaan die uitgingen van een sterke groei van de stedelijke gemeenten, doch die tevens de mogelijkheid openlieten dat iedere gemeente en zelfs het kleinste dorp een eigen uitbreidingsplan vaststelde. Hierdoor ontstond ruimte voor een uitgebreide suburbanisatie".

68 Het College van Gedeputeerde Staten had dit al eerder geconstateerd en had in 1969 een ingrijpend herindelingsvoorstel voor Zuid-Limburg bij de minister van Binnenlandse Zaken neergelegd. Zie Rijksarchief Limburg 04.09/11437; Notulen van de vergaderingen van Gedeputeerde Staten van Limburg van 6, 20 januari, 24 februari, 3 en 10 maart 1969; Rijksarchief Limburg 04.09/11436; Notulen van de vergadering van Gedeputeerde Staten van Limburg van 19 februari 1968, p.1; Tweede Kamer 1978-1979, 15521, No.3 Memorie van Toelichting bij het Wetsontwerp Gemeentelijke Herindeling Zuid-Limburg, p.3. www.statengeneraaldigitaal.nl.

69 Twee jaar eerder was ook nog het Streekplan Venlo en Omstreken (1967) door Provinciale Staten vastgesteld. Dit was bestempeld als een 'overgangsplan' om vooral de gemeente Venlo meer ruimte voor haar woninbouw te bieden. Binnen een paar jaar was het plan echter al verouderd. Zie Rijksarchief Limburg 04.09/3419; Provincie Limburg (1974). Streekplan Noord- en MiddenLimburg. Informatiebulletin voor de inspraakprocedure, No.1, december 1974, p.1.

70 Rijksarchief Limburg 04.09/3405; PPD Limburg (1970). Streekplan Zuid-Limburg. Eerste ontwerp (verkorte uitgave). December 1970, p.2.

71 Tweede Kamer 1970-1971, 10914, No.2 Rapport van de Commissie voorbereiding onderzoek toekomstige maatschappijstructuur, 17 september 1970, p.7. Online beschikbaar op www. statengeneraaldigitaal.nl.

72 Er was tijdens de besluitvorming over het Streekplan Zuid-Limburg kritiek gekomen van de Rijksplanologische Commissie dat het streekplan te weinig gedetailleerd zou zijn. Zie Rijksarchief Limburg 04.09/3438; 'Notulen van de 11e vergadering van de Stuurgroep Streekplan Noord- en Midden-Limburg', 22 februari 1979, p.3.

73 Tweede Kamer 1972-1973, No. 1417, p.2839. De schriftelijke vragen waren ingezonden op 20 februari 1973: "Is het de bewindslieden bekend, dat ten gevolge van het ontbreken van zowel een streekplan voor geheel Noord-Limburg, alsmede het ontbreken van voldoende coördinatie op regionaal en provinciaal niveau de ontwikkeling met betrekking tot de ruimtelijke ordening, speciaal ter zaken van openluchtrecreatie en milieubehoud, chaotisch verloopt, waarbij een grote versnippering en aantasting van de natuur- en landschappelijk waardevolle gebieden optreedt in dit deel van de provincie Limburg?" Online beschikbaar op www.statengeneraaldigitaal.nl.

74 idem.2839. Ook in Provinciale Staten van Limburg werden vervolgens vragen gesteld, waarop Gedeputeerde Staten de toezegging deden dat er gestart ging worden met een streekplan, maar dat de prioriteit nog primair lag bij het streekplan voor Zuid-Limburg gezien de 'beschikbare beperkte mankracht'. Bovendien, aldus het College van Gedeputeerde Staten, deed het feit zich voor dat de provinciale goedkeuring van het betreffende bestemmingsplan had plaatsgevonden 'in een tijd, waarin de zorg voor een goed natuur- en landschapsbeheer nog niet de aandacht kreeg, welke naar 
de huidige inzichten daaraan dient te worden gegeven'.

75 Rijksarchief Limburg 04.09/3436; Notitie n.a.v. het gesprek tussen de dagelijkse besturen van de gewesten en de heer J. van der Woude, 16 augustus 1973.

76 Rijksarchief Limburg 04.09/3436; Memo Hoofd 1e Afdeling aan gedeputeerde Van der Woude, 21 juni 1973. "In de januaribijeenkomst is afgesproken, dat het overleg zal lopen via de [planologische - HvE] dienst en dat men over 8 maanden weer bijeen zou komen [...]. De vermelde overlegmomenten zijn nog niet aangebroken, omdat kennelijk de PPD met de voorbereidende werkzaamheden voor de streekplannen nog niet ver genoeg is gevorderd."

77 Rijksarchief Limburg 04.09/11474; PPD 'Notitie betreffende inspraak bij de regionale planning', januari 1974. Zeer uitgebreid (p.16-34) werd ingegaan op de organisatie van de inspraak bij andere provincies.

78 Rijksarchief Limburg 04.09/3437; Notulen van de le vergadering van de 'Stuurgroep ter begeleiding van de totstandkoming van het streekplan voor Midden- en Noord-Limburg en structuurplannen voor die regio's', p.1. Hierna 'Stuurgroep' genaamd.

79 Rijksarchief Limburg 04.09/3437; Notulen 2e vergadering Stuurgroep, 5 april 1974, p.3.

80 Rijksarchief Limburg 04.09/3419; PPD 'Grondgedachten. Als basis voor een streekplan. Ter discussie'. Definitieve versie is van oktober 1974, p.1, cursivering HvE. Een concept van de nota was in april van dat jaar al klaar.

81 In 1972 had de Club van Rome haar invloedrijke rapport Limits to Growth gepubliceerd waarin ook de grenzen van de voortschrijdende welvaart werden belicht.

82 In de nota Grondgedachten waren maar liefst 89 'verwachtingspatronen' geïdentificeerd door de Planologische Dienst. Van de 'behoefte aan frisse lucht', 'autonomie', 'gemakzucht' tot de 'verwachting van een onaangetast landschap', 'kernhiërarchie' en 'arbeid ter plaatse'. Zie Rijksarchief Limburg 04.09/3419; PPD 'Grondgedachten', tabel II van de bijlage.

83 Rijksarchief Limburg 04.09/11441; Notulen van de GS-vergadering van 10 december 1973, agendapunt 2 .

84 Rijksarchief Limburg 04.10/64; Zie de opmerkingen van gouverneur Van Rooy en gedeputeerde Van der Woude in de bespreking van de Uitgangspuntennota en Grondgedachtennota in de vergadering van de Provinciale Planologische Commissie, 22 augustus 1973, p.5, 7. Beide politici neigden sterk naar een aanpak zoals die werd gevolgd in het Streekplan Zuid-Limburg. Er was dus al vanaf het begin sprake van een spanning tussen politiek (Gedeputeerde Staten) en ambtelijke dienst (Provinciale Planologische Dienst).

85 Dit bleek onder andere uit de opmerking van gedeputeerde Van der Woude tijdens de eerste vergadering van de Stuurgroep waarin hij stelde dat 'het college van Gedeputeerde Staten in elke fase van de procedure moet worden ingeschakeld, omdat het college het streekplan voorbereidt en niet de Provinciale Planologische Dienst'. Zie Rijksarchief Limburg 04.09/3437, Notulen 1e vergadering van de Stuurgroep, 8 februari 1974, p.2.

86 Rijksarchief Limburg 04.09/3419; Provinciaal Bestuur van Limburg (1974). Informatiebulletin voor de inspraakprocedure Streekplan Noord- en Midden-Limburg, no.1, december 1974, p.4.

87 Een eerste conceptversie van de Uitgangspuntennota was op 22 augustus 1973 besproken in de Provinciale Planologische Commissie. R.C.J.M. Rijssenbeek, voorzitter van de Kamer van Koophandel en Fabrieken Noord-Limburg blikte in 1979 terug op die vergadering: "De toenmalige gouverneur, mr.dr. Ch. v. Rooy, merkte op dat hij twijfelde aan de thesis dat vervulling van verwachtingen de mens gelukkiger zou maken, en herinnerde aan het spreekwoord: het bezit van de zaak is het einde van het vermaak. Ik heb - niet zonder inwendige verkneukeling - meegemaakt hoe deze PPD-nota aan de PPC-vergadering een filosofendebat ontlokte, waarin common sense het tenslotte op punten won van intellectualistische humbug. Na thuiskomst heb ik de PPD een exemplaar in Nederlandse vertaling toegezonden van de Ethica Nicomachea van Aristoteles...", in Rijssenbeek (1979). Wie is er baas in Limburg, p.42. Zie ook Rijksarchief Limburg 04.10/184; 
Memo Rijssenbeek aan de secretaris van de PPC, 22 september 1973.

88 Rijksarchief Limburg 04.09/3437; Uittreksel uit Voorbesprekingen van de 5e vergadering van de PPC, $4-5$ juni 1974, p.1-2.

89 idem.1-2. De Agrarisch Planologische Commissie fungeerde als een voorbereidende (zogeheten 'subcommissie') van de Provinciale Planologische Commissie. Deze voorbereidende commissie werd voorgezeten door gedeputeerde G.A.A. Horsmans (KVP), die in het College van GS de portefeuille Landbouw had. Het was in die tijd gebruikelijk dat de belangen van de Limburgse Land- en Tuinbouworganisatie (LLTB) ook via de vertegenwoordiging van een 'eigen' gedeputeerde in het College werden verzekerd.

90 idem.2.

91 Het Provinciaal Bestuur had in het rapport Limburgs toekomst (1967) dit standpunt overgenomen en als uitgangspunt verklaard voor toekomstige besluitvorming. In het Streekplan Zuid-Limburg had men dit instrument ook al toegepast, met als doel om het Mergelland te beschermen tegen de uitbreidingsplannen van (kleinere) gemeenten. Bibliotheek Provincie Limburg. Provinciaal Bestuur van Limburg (1977). Streekplan Zuid-Limburg, 20 januari 1977, p.3.

92 Rijksarchief Limburg 04.09/3419; PPD 'Uitgangspunten. Als basis voor een streekplan Noord- en Midden-Limburg. Ter discussie.' Oktober 1974, p.4.

93 Rijksarchief Limburg 04.09/3428. Provinciaal Bestuur (1980). Voorontwerp Streekplan Noord- en Midden-Limburg. Samenvatting, juli 1980, p.44-45.

94 Rijksarchief Limburg 04.09/3425; PPD (1977). Facetstudies. Als basis voor een streekplan Noord- en Midden-Limburg. Facetstudie no.6 Natuurlijk Milieu en Milieu-zorg, december 1977. Op p.3 werd als belangrijkste taakstelling geformuleerd het 'behoud van alle nog aanwezige landschapsecologische waarden, opbouw (uitbouw) van bepaalde aanwezige potentiële waarden'.

95 Rijksarchief Limburg 04.09/3437; Zie bijvoorbeeld de notitie van het Stadsgewest Roermond 'Enkele gedachten over het meedenken bij de opbouw van het Streekplan Midden- en NoordLimburg', 17 september 1974. Daarin werden vijf regionale commissies ingesteld binnen het stadsgewest, onder aansturing van een kerncommissie. Aan deze kerncommissie werden vervolgens deskundigen toegevoegd. De Stadsgewestraad zou vervolgens een 'geïntegreerde mening' geven op basis van de 'gemeentelijke rapportering' en die van de streekcommissie. Binnen één gewest waren er dus vijf organisatiestructuren die de inspraak begeleidden.

96 Rijksarchief Limburg 04.09/3437; Notulen 5e vergadering Stuurgroep, 12 maart 1975, p.2.

97 Rijksarchief Limburg 04.09/11443; Notulen vergadering van Gedeputeerde Staten van 27 januari 1975, p.1. Planje had in de periode 1966-1974 in Provinciale Staten gezeten namens de KVP.

98 Rijksarchief Limburg 04.09/3437; Notulen 1e vergadering Stuurgroep, 8 februari 1974. Gedeputeerde Van der Woude had deze ambtelijke status van de facetstudies al in de eerste vergadering van de Stuurgroep medegedeeld. In het verslag stond: "De functie van Gedeputeerde Staten ziet hij [Van der Woude - HvE] als een brievenbus, slechts belast met de ontvangst en doorzending van de deelnota's". Zie ook de herbevestiging van dit standpunt door het College vier jaar later in: Rijksarchief Limburg 04.09/3426; Brief College van Gedeputeerde Staten aan directeur PPD van 14 augustus 1978 ter gelegenheid van het gereedkomen van Facetstudie 7 Landen Tuinbouw. "Wij [College van GS - HvE] verzoeken $\mathrm{U}$ in de toezendingsbrief bij die facetstudie aan de verschillende personen en instanties te benadrukken dat deze studie een ambtelijk stuk is".

99 Peters volgde 't Hoen op die met pensioen ging.

100 Rijksarchief Limburg 04.09/9561; A. Peters (1977). Discussie-nota. Opzet van de organisatie en de werkwijze bij de P.P.D. in Limburg. September 1977, p.4.

101 idem.5. Ook de samenwerking met die andere provinciale dienst, de Provinciale Waterstaat, verliep moeizaam. Daar behartigde vooral de Cultuurtechnische Afdeling in de ogen van de Planologische Dienst veel te veel de belangen van de agrariërs.

102 Rijksarchief Limburg 04.09/3438; Brief Streekcommissie Noord-Limburg aan Stuurgroep, 22 
december 1977, p.1.

103 Rijksarchief Limburg 04.09/3438; Notulen 9e vergadering Stuurgroep, 14 december 1977, p.2.

104 Rijksarchief Limburg 04.09/3438; Bijlage bij de 9e vergadering van de Stuurgroep; Twijnstra \& Gudde (1977). Oriëntatienota voorbereiding Streekplan Noord- en Midden-Limburg, 11 oktober 1977.

105 Het Provinciaal Orgaan Welzijnsbevordering Limburg (POWL) moest in opdracht van de Provincie de inspraak gaan organiseren. De keuze voor het POWL was overigens niet met enthousiasme door het College van Gedeputeerde Staten ontvangen. Het POWL was benaderd door de inspraakcoördinator Planje om hem te ondersteunen bij de organisatie van de inspraak. Zie Rijksarchief Limburg 04.09/3438; Memo Peters aan gedeputeerde Van der Woude, 27 april 1978, p.2, 'de positie van het POWL als sekretariaat van de CBI [Centrale Begeleidingscommissie Inspraak - HvE], [is] een door het College van GS slechts de facto erkende situatie'.

106 idem.1-2, 4.

107 Rijksarchief Limburg 04.09/3438; Zie memo Peters aan gedeputeerde Van der Woude, 27 april 1978, p.2.

108 Rijksarchief Limburg 04.10/84; Notulen van 4e vergadering Provinciale Planologische Commissie van 17 mei 1978, p.2 en 5 .

109 idem.3.

110 Rijksarchief Limburg 04.09/11452; Brief College van Gedeputeerde Staten aan Provinciale Staten 'Benoeming c.q. herbenoeming vertegenwoordigers provinciaal bestuur in commissies, raden, stichtingen e.d.', 27 september 1978. Hier werd gesproken van 'commissies', waaronder ook de lidmaatschappen van gedeputeerden in stichtingen, raden, instellingen vielen. Niet inbegrepen waren de commissies ex artikel 64 van de Provinciewet. In 1971 was dit aantal zelfs 60 geweest. Zie Rijksarchief Limburg 04.09/11452; Brief Gedeputeerde Staten aan leden van de samenwerkende christelijke partijen KVP-ARP-CHU uit Provinciale Staten, 27 april 1971.

111 Rijksarchief Limburg 04.09/11446; Notulen vergadering Gedeputeerde Staten van 24 oktober 1978, p.1 en Rijksarchief Limburg 04.10/86, Notulen van de vergadering nr.8/1978 van de Provinciale Planologische Commissie, 8 november 1978, p.3.

112 Uiteindelijk zou eind 1981 zonder al te veel vertraging het Streekplan Noord- en Midden-Limburg aan Provinciale Staten aangeboden worden. Hiermee kwam na negen jaar voorbereidingen en vertragingen formeel een einde aan het Streekplan Noord- en Midden-Limburg. Op 4 maart 1982 werd het streekplan door Provinciale Staten vastgesteld.

\section{\$2.4 Ruimtelijke ordening in dienst van de economie (periode 1979-1990)}

113 Rijksarchief Limburg 04.10/154; Toespraak door gouverneur J. Kremers in: PPD Limburg (1984). PPD 50 jaar, 1934-1984. Toespraken en inleidingen op het Symposium en een thema-overzicht van de tentoonstelling ter gelegenheid van het 50-jarig bestaan van de Provinciale Planologische Dienst in Limburg, 22 november 1984, p.11.

114 idem.13.

115 Zie bijvoorbeeld de paragraaf 'Regionale economie' in de ROV-jaarverslagen van 1987-1990.

116 Bibliotheek Provincie Limburg. Provincie Limburg: Jaarlijks Verslag Ruimtelijk Beleid 1986; 1987; 1989.

117 Deze ontwikkeling werd overigens met de nodige argwaan door de hoofdgroep Ruimtelijke Ordening en Volkshuisvesting (ROV) gevolgd. Zie bijvoorbeeld Rijksarchief Limburg 04.10/218; Werkgroep taakstructurering afdeling Gemeentelijke Zaken (1986). $1^{\mathrm{e}}$ rapportage, 30 januari 1986, p.1.

118 Het Provinciaal Bestuur moest wel nog het voorgestelde 'verdeeladvies' ter goedkeuring naar de minister voor Volkshuisvesting en Ruimtelijke Ordening sturen.

119 Bibliotheek Provincie Limburg; Provincie Limburg (1985). Begroting 1986, p.194. 
120 Daarnaast werd de Permanente Adviesgroep Buitengebieden, een commissie die de bestemmingsplannen Buitengebied beoordeelde, opgeheven. De taken van deze adviesgroep vielen vanaf nu onder de verantwoordelijkheid van de Subcommissie Landelijk Gebied. Zie Rijksarchief Limburg 04.09/10476. Zie GS-besluitvorming van 17 april 1984 n.a.v. GS-nota 'Organisatieonderzoek van de Provinciale Planologische Dienst', april 1984. Specifiek t.a.v. de PPC-reorganisatie, zie voorstellen op p.16-19.

121 Bibliotheek Provincie Limburg. Provincie Limburg (1987). Jaarlijks verslag ruimtelijk beleid 1986, p.15-16. In het verslagjaar over 1988 stond dat er werd gewerkt aan 'een verdere verbetering en structurering van [het] gemeentelijk-provinciaal overleg', zie Bibliotheek Provincie Limburg. Provincie Limburg (1990). Jaarlijks verslag ruimtelijk beleid 1989, p.14. Zie ook Rijksarchief Limburg 04.10/217; ROV/Werkgroep (1985). 'De bestuurscultuur heeft zich verhard. (...) Het laten doorklinken van het eigen provinciaal beleid in gemeentelijke plannen zal meer argumentatie en overleg vragen dan voorheen', p.14.

122 Rijksarchief Limburg 04.09/10476; Centrale dienst Personeel \& Organisatie (1983). 'Vertrouwelijke Nota aan Gedeputeerde Staten betreffende verdere voortgang van het organisatie-onderzoek van de Provinciale Planologische Dienst', augustus 1983, p.1; Rijksarchief Limburg 04.09/10476; Centrale dienst Personeel \& Organisatie (1984). 'Onderzoek naar de externe kontakten vanuit het provinciale apparaat', februari 1984, p.4.

123 Rijksarchief Limburg 04.09/10476; Zie besluit GS op 6 september 1983 over Nota betreffende verdere voortgang van het organisatieonderzoek van de PPD van 29 augustus 1983. Zie ook besluit van Gedeputeerde Staten van 17 april 1984 n.a.v. nota 'Organisatieonderzoek van de Provinciale Planologische Dienst', april 1984.

124 Gedeputeerde K.W. Buck (CDA) zou na de provinciale statenverkiezingen van 1987 niet langer deel uitmaken van het nieuwe College van Gedeputeerde Staten. Gouverneur J. Kremers (CDA) nam in het voorjaar van 1990 afscheid. Beide mannen hadden bijna 13 jaar onderdeel uitgemaakt van het College van Gedeputeerde Staten.

125 Bibliotheek Provincie Limburg. Provincie Limburg (1991). Basisaccoord 1991-1995 CDA-PvdA$V V D$, p.1. Zie ook de uitgebreide paragraaf in het Basisaccoord op het gebied van 'milieubeheer'.

\section{\$2.5 Op zoek naar een integraal ruimtelijk beleid (periode 1990-2004)}

126 Tweede Kamer 1990-1991, 21 879, No.2 Vierde Nota Ruimtelijke Ordening Extra, 14 november 1990, p.190. www.statengeneraaldigitaal.nl.

127 Zie bijvoorbeeld het eerste concept van de overeenkomst. Archief Provincie Limburg 54604; RPD (1988). 'Overeenkomst inzake het opstellen van de nadere uitwerking van het Ontwikkelingsperspectief voor het gebied Midden-Brabant, Oost-Brabant en de Noordelijke Maasvallei'. Concept van 13 december 1988.

128 De vertragingen in de periode 1988-1990 hadden meer oorzaken. Op rijksniveau was er sprake van een machtstrijd tussen beide betrokken ministeries. De Vierde Nota Ruimtelijke Ordening was een product van het ministerie van VROM en was kritisch over de milieubelasting door de agrarische sector. Maar doordat de Vierde Nota van 1988 door de val van het kabinet Lubbers II geen parlementaire behandeling had gehad, was de status van de Nota onduidelijk. In het nieuwe kabinet Lubbers III dat in november 1989 gevormd werd werd minister G.J.M. Braks (CDA) opnieuw minister van Landbouw maar moest in 1990 aftreden vanwege kritiek op zijn aanpak van visfraude. Hij werd opgevolgd door P. Bukman (CDA). Minister E.H.Th.M. Nijpels (VVD) werd opgevolgd door J.G.M. Alders (PvdA). Deze laatste presenteerde in 1990 de aangepaste Vierde Nota met een sterkere nadruk op de thema's milieu en volkshuisvesting. De aanpassingen in de Vierde Nota en de diverse ministeriële wisselingen vertraagden de aanpak van de Nadere Uitwerking Brabant-Limburg. Zie Archief Provincie Limburg 54604; Geannoteerde agenda voor de bijeenkomst op 14 maart 1989: "Gelet op de terughoudende opstelling van L+V lijkt het 
verstandig om simultaan aan de inhoudelijke discussie over de nadere uitwerking een MINIMAAL startconvenant mee te ontwikkelen", p.1. In hetzelfde archiefdossier zit een door L+V met de hand becommentarieerde conceptversie van de concept-overeenkomst van december 1988. De conceptversie is voorzien van veel doorhalingen en nieuwe tekstvoorstellen met voorstellen tot afzwakking van met name de passages over de projectvoorbereiding en de uitwerking van concrete instrumenten.

129 Archief Provincie Limburg 54604; Brief aan leden van de voorbereidingsgroep van de Nadere Uitwerking Brabant-Limburg, 17 oktober 1990.

130 Archief Provincie Limburg 12490; Brief directeur-generaal van VROM aan beide gedeputeerden Ruimtelijke Ordening van de Provincies Noord-Brabant en Limburg, 12 oktober 1990.

131 Archief Provincie Limburg 54604; Notulen van voorbereidingsgroep gehouden op 8 november 1990.

132 Archief Provincie Limburg 12490; Notulen 'Resultaat informeel bestuurlijk overleg BrabantLimburg', 6 maart 1991.

133 idem. 1

134 Van de Noord-Limburgse gemeenten waren slechts vijf van de zestien gemeenten aanwezig op de bijeenkomst, waarvan twee gemeenten zich ook nog ambtelijk lieten vertegenwoordigen. Zie Archief Provincie Limburg 12490; Gewest Noord-Limburg 'Verslag van overleg tussen provincie en gewestgemeenten inzake startconvenant Brabant-Limburg', 15 mei 1991.

135 Archief Provincie Limburg 54604; Notitie van het directoraat-generaal Milieubeheer - Directie Geluid en Omgeving 'Haalbaarheidsstudies Nadere Uitwerking Brabant-Limburg', 7 november 1991.

136 Zie Archief Provincie Limburg 12493; Notulen 1 $1^{\mathrm{e}}$ vergadering van de stuurgroep, 20 mei 1992.

137 Archief Provincie Limburg 12493; Nadere Uitwerking Brabant-Limburg - Communicatieplan. Oktober 1992, p.1

138 Naast de stuurgroep was er nog een coördinerende projectgroep, drie werkgroepen en drie klankbordgroepen.

139 Dit bleek wel uit een ambtelijke nota van de Hoofdgroep Ruimtelijke Ordening en Volkshuivesting (ROV) aan het College van maart 1991. Gewezen werd op de ruimtelijke en milieuproblemen in het gebied die van 'nationaal belang' waren. Niet zonder gevoel van overdrijving probeerde de Hoofdgroep de politieke urgentie duidelijk te maken: 'De noodzakelijke herstructurering van het plangebied heeft weliswaar niet die impact als de mijnsluitingen in de 60er/70er jaren, maar er is zeker sprake van een vergelijkbare bestuurlijke opgave', zie Archief Provincie Limburg 12490; GSnota van Hoofdgroep ROV, maart 1991, p.2.

140 Archief Provincie Limburg 28483; Gefaxte memo Provincie Limburg aan Projectburo Nadere Uitwerking Brabant-Limburg 'Het functioneren van de stuurgroep verbeteren', 13 januari 1995.

141 Archief Provincie Limburg 12493; Notulen $8^{\mathrm{e}}$ vergadering van de Stuurgroep, 19 mei 1993.

142 Archief Provincie Limburg 12493; Stuurgroep Nadere Uitwerking Brabant-Limburg (1993). Voorlopige integrale visie, juni 1993.

143 Men ging zelfs zover om hier ook streefwaarden aan te koppelen. Zo werd er een doelstelling opgenomen om de verzuringsgraad van de bodem terug te dringen tot 600 zuureq. NH3/ha in het jaar 2010.

144 idem.2-3. Om de uitstoot van mest tegen te gaan werden scherpere normen voorgesteld, om zo te komen tot wat men noemde een 'evenwichtsbemesting'.

145 Archief Provincie Limburg 9818; Zie bijvoorbeeld de eerste 'NUBL-krant', zomer 1993, p.1

146 Archief Provincie Limburg 12493; Nadere Uitwerking Brabant-Limburg. 'Voorlopige Integrale Visie - Deel IV Verkenning Instrumentarium', concept van 16 juni 1993, p.20-21.

147 Archief Provincie Limburg 9818. Brief van de Gewestelijke Raad voor Limburg van het Landbouwschap aan het College van Gedeputeerde Staten van Limburg, 19 juli 1993. 
148 Archief Provincie Limburg 9818. Verslag $2^{\mathrm{e}}$ vergadering Klankbordgroep Noordelijke Maasvallei, 24 juni 1993.

149 Archief Provincie Limburg 9818; Brief van Waterleiding Maatschappij Limburg aan het secretariaat Klankbordgroep Nadere Uitwerking Brabant-Limburg / gebied 'De Peel', 27 augustus 1993. In een uitgebreide notitie van maar liefst 16 pagina's lichten zij hun afwijzing toe.

150 Archief Provincie Limburg 9818; Zie gemaakte opmerking van KVK tijdens Tweede vergadering Klankbordgroep Noordelijke Maasvallei, 24 juni 1993.

151 Archief Provincie Limburg 9820; Verslag bestuurlijk overleg Nadere Uitwerking Brabant-Limburg Provincies Limburg en Brabant met Alders en Bukman, 2 februari 1994.

152 Archief Provincie Limburg 9820; Conceptnota aanpak Nadere Uitwerking Brabant-Limburg t.b.v. de $17^{\mathrm{e}}$ stuurgroepbijeenkomst, 30 september 1994, p.1.

153 idem.1.

154 Archief Provincie Limburg 9820. In een vergadering van de Klankbordgroep Noordelijke Maasvallei van 29 september 1994 werd gesproken van het 'in de koelkast leggen' van de Voorlopige Integrale Visie. Zie notulen, p.3.

155 Archief Provincie Limburg 28483; Zie o.a. GS-nota 'Vaststelling NUBL [Nadere Uitwerking Brabant-Limburg - HvE]', eind november 1995. "Nadat in eind 1993 de Integrale Visie voor het NUBL-gebied gepubliceerd was, leek de Nadere Uitwerking op dood spoor te zijn geraakt [...]. Er is dan ook besloten om aan de Integrale Visie geen zware status toe te kennen", p.2.

156 Archief Provincie Limburg 9820; Conceptnota NUBL-aanpak t.b.v. de $17^{\mathrm{e}}$ stuurgroepbijeenkomst, 30 september 1994.

157 Een soortgelijk proces speelde zich - ongeveer gelijktijdig - ook af in Zuid-Limburg bij een andere gebiedsgerichte aanpak: Ruimtelijke Ordening en Milieu Mergelland (ROM Mergelland). Ook hier werd midden jaren ' 90 afgestapt van het formuleren van een grote visie en werd overgegaan op het realiseren van concrete projecten. Zie Bibliotheek Provincie Limburg. Stuurgroep ROM Mergelland (1995). Plan van aanpak ROM Mergelland, p.3. Zie ook voor een kritische reflectie over de behaalde resultaten Bibliotheek Provincie Limburg. Provincie Limburg (2000). Auditrapport van de controller over ROM Mergelland, 17 januari 2000, p.3.

158 Bibliotheek Provincie Limburg. Projectbureau NUBL (2000). Integrale plattelandsontwikkeling. Vijf jaar werk in uitvoering in Noord-Brabant en Limburg.

159 Het projectbureau NUBL dat in 1995 werd opgericht, kende ook een andere ambtelijke samenstelling dan de voorbereidingsgroep uit de periode 1988-1995. Beleidsmakers werden vervangen door projectmanagers.

160 Bibliotheek Provincie Limburg. Provinciaal Blad van Limburg (1995), 15, No.2. Notulen Provinciale Staten der vergadering van 16 en 17 februari 1995, p.28.

161 idem. 33 .

162 Dit leidde in de bewuste Provinciale Statenvergadering bij de behandeling van het Milieubeleidsplan 1995-1999 tot het indienen van een motie door de VVD waarin stond: "Provinciale Staten van Limburg $[\ldots]$ verzoeken het College: de tekst van de formulering van dit beleid uit dit streekplan integraal op te nemen in het Milieubeleidsplan, de tegenstrijdigheden met deze tekst in het voorliggende concept plan te verwijderen en deze aanpassingen ter informatie aan de Staten voor te leggen". Motie no.3. Provinciaal Blad (1995), p.109.

163 Archief Provincie Limburg 33963; Notitie Op weg naar één Omgevingsplan, op 7 februari 1995 verzonden aan de leden van Provinciale Staten.

164 Bibliotheek Provincie Limburg. Provincie Limburg (1995). Basisaccoord 1995-1999 CDA-VVD$P v d A, 11$ april 1995, p.16.

165 In de periode 1995-1996 speelde namelijk een aantal andere zaken. Zo moest de overdracht van een groot aantal taken naar de provincie (Decentralisatie-Impuls) worden geregeld. Tevens namen Gedeputeerde Staten op 17 september 1996 het besluit om de provinciale advies- en overlegcultuur 
binnen de ruimtelijke ordening te 'versoberen'. Zie Bibliotheek Provincie Limburg. Provincie Limburg / Hoofdgroep Ruimte, Groen en Verkeer (1997). Verslag van het ruimtelijk beleid over het jaar 1996, p.4-5.

166 Archief Provincie Limburg 33963; GS-besluit van 3 december 1996 bij de nota 'Onderzoek omtrent Integraal Omgevingsplan'.

167 Archief Provincie Limburg 33964; In de notitie van 1995 Op weg naar één omgevingsplan werd al gesproken van de haasje-over-methode. Wissink (2000) ziet het haasje-over-springen voortkomen uit de gevolgde aanpak in de Nadere Uitwerkingen (Wissink, 2000: 174-175).

168 Tweede Kamer 1993-1994, 23715, Nr.11 (Herdruk) Regeerakkoord PvdA-VVD-D66, 13 augustus 1994, p.40. In het regeerakkoord werden bezuinigingen aangekondigd voor zowel het Gemeenteals het Provinciefonds. Beginnend met een bezuiniging van 0,3 miljard gulden in 1994 en oplopend naar 0,7 miljard gulden in 1998.

169 Bibliotheek Provincie Limburg. Provincie Limburg (1995). Basisakkoord 1995-1999 CDA-VVD$P v d A, 11$ april 1995. Letterlijk stond er: "Voor de uitvoering van dit Basisaccoord zijn op dit moment in de begroting nog niet voldoende middelen opgenomen", p.2.

170 Archief Provincie Limburg 33964; zie nota 'Tussenrapportage Omgevingsbeleid Limburg', april 1997, p.4.

171 Archief Provincie Limburg 33964; Tekst bij besluit van 14 oktober 1997 bij GS-nota 'Omgevingsplan Limburg', nota d.d. 7 oktober 1997.

172 Archief Provincie Limburg 33964; Zie diverse verslagen van overlegmomenten in de periode april-mei 1998.

173 Zie voor de lijst van betrokkenen: Archief Provincie Limburg 33964; Brief GS aan betrokkenen 'Agenda van het POL' van 15 juni 1998.

174 Bibliotheek Provincie Limburg. Provincie Limburg (1998). Discussienotitie. Agenda van het provinciaal omgevingsplan. Verkenningsopdrachten voor de tweede ronde van het POL. 2 april 1998, p.10-12.

175 Het driekhoeksmodel dat voor het Omgevingsplan werd gebruikt was uitgedacht door het International Centre for Integrative Studies van de Universiteit Maastricht. Zie voor achtergronden Rotmans (1998).

176 idem.9.

177 Archief Provincie Limburg 52118; Zie nota bij besluit van 23 maart 1999 'Aanpak vierde ronde POL: coalitievorming'. Het College besloot niet langer te spreken van 'coalitievorm' maar van 'draagvlak creëren en inspraak'.

178 Archief Provincie Limburg 50382; Projectgroep POL (1999). 'Investeren in kwaliteit. Schets van het omgevingsbeleid voor Limburg', januari 1999.

179 Archief Provincie Limburg 50382; Zie GS-nota bij besluit van 26 januari 1999 'Ontwerp-SCHETS van het POL', p.6.

180 Bibliotheek Provincie Limburg, Provincie Limburg (1999). Basisakkoord 1999-2003. CDA - VVD - PvdA. 'Limburg, innovatief en waardenvast'. April 1999, p.3.

181 idem.88-89.

182 Zie het definitieve POL. Bibliotheek Provincie Limburg. Provincie Limburg (2001). Liefde voor Limburg, provinciaal omgevingsplan, p.128.

183 In de rijksnota's het Bosbeleidsplan, het Structuurschema Groene Ruimte, de Visie stadslandschappen en de Actualisering Vinex-afspraken was dit voor-wat-hoort-wat principe geïntroduceerd.

184 ArchiefProvincie Limburg 97408; Zie'Sonderingsnotitie Rood voor Groen. Het experimentenspoor en het POL-spoor', december 1999. Eerder was het rood-voor-groen principe al geïntroduceerd in de provinciale Bosnota (1998) en de Nota Natuur en Landschapsbeheer 2000-2010 (1998), maar was nog niet uitgewerkt en toegepast.

185 idem.3-4. 
186 Archief Provincie Limburg 97408; Gespreksnotitie bestuurlijk overleg 2 en 3 februari 2000, p.39.

187 Het Centraal Planbureau (Bibliotheek Provincie Limburg) had in opdracht van het ministerie van Economische Zaken in 1999 een studie uitgevoerd naar de rol van de overheid in de grondmarkt. Zie Bibliotheek Provincie Limburg (1999). De grondmarkt - een gebrekkige markt en een onvolmaakte overheid, 25 februari 1999. Pas met de Nota Ruimte (2004) en de Grondexploitatiewet (2005) zou hier een nieuwe impuls aan worden gegeven.

188 Zie voor een overzicht van de reacties én de standpuntbepaling van GS: 'Reactienota VoorontwerpPOL', 19 december 2000.

189 Archief Provincie Limburg 50382; Zie bijvoorbeeld de notitie 'Samenhang POL met grote projecten en nieuw rijksbeleid' van 27 mei 1999 waarin stond: "Vanuit de POL-organisatie geldt enerzijds, dat het doorklinken van rijksbeleid in de bijdragen vanuit de lijnorganisatie voor het (ontwerp-)POL als vanzelfsprekend zal plaatsvinden. Echter het vanuit POL-optiek anticiperen in het proces van het Rijk en het toezien op de onderlinge consistentie is nog niet/onvoldoende geregeld", p.3.

190 idem.6

191 Zie de folder POL-nieuws van oktober 2000, p.3. Het convenant was een compromis tussen de POL-doelstellingen en het LLTB visiedocument 'Limburgs Land-Goed'.

192 Dat de uitvoering en het verkrijgen van draagvlak in de regio moeilijk was, bleek ook uit de in 2005 uitgevoerde evaluatie van het POL. Zie NovioConsult/Van Spaendonck (2005). Lessen uit het POL. Evaluatie van het Provinciaal Omgevingsplan Limburg. Januari 2005, p.3, 6-7, 12-13. Zie met name paragraaf 4.4.5: 'Integrale proces en karakter van de regionale opgaven zijn in verval'.

193 De 'coalitieregio's' werden ook wel de 'POL-regio's' genoemd in de periode na de vaststelling. In totaal waren er 11 coalitieregio's.

194 Onder'specifiek rijksbeleid' werd verstaan de uitvoering van de Nadere Uitwerking Brabant-Limburg, of het volkshuisvestingsbeleid van de Vierde Nota Extra (Vinex) en het Reconstructiebeleid voor de intensieve veehouderij.

195 Een voorbeeld hiervan was de status die de steden Weert/Nederweert en Venray hadden gekregen in het voorontwerp. Deze steden werden aangeduid als 'stedelijk gebied', terwijl de steden Venlo, Roermond en Maastricht de status 'stadsregio' kregen. Dit ogenschijnlijk subtiele onderscheid had concrete consequenties voor bijvoorbeeld de ruimte die gemeenten nodig hadden om nieuwe woningen te laten bouwen. Op 8 februari 2000 vergaderde het College van Gedeputeerde Staten hierover en besloot dat de steden Weert/Nederweert en Venray dezelfde status kregen als de andere steden. Zie 97408; 'Aantekeningen in kort bestek van GS-beraadslaging POL, d.d. 8-22000 '.

196 Archief Provincie Limburg 97408; Zie 'Aantekeningen in kort bestek van GS-beraadslaging POL, d.d. 22 februari 2000'.

197 Zie het artikel in Dagblad de Limburger met de kop 'GS verdeeld over invulling van ruimte', d.d. 14 september 1999. In het artikel werd gedeputeerde J.J.M. Tindemans (PvdA) geciteerd uit een interne brief die hij aan zijn collega-gedeputeerden zou hebben geschreven. Volgens het Dagblad de Limburger gaf de gedeputeerde aan het volstrekt overbodig te vinden om de bestaande bedrijventerrein-prognoses weer opnieuw tegen het licht te houden in het kader van het Omgevingsplan. Gewaakt moest worden om van het POL 'geen allesomvattend evangelie te maken. [...] Dat plan moet zich volgens mij beperken tot puur ruimtelijke ontwikkelingen'. De interne brief zit niet in het provinciale archief, wel het krantenartikel. Er zijn in het archief ook andere stukken beschikbaar die aantonen dat de gedeputeerde niet enthousiast was over delen van het Provinciaal Omgevingsplan Limburg. Zie notulen van de POL-stuurgroepvergadering van 14 juni 1999 onder het kopje follow up naar aanleiding van een bespreking van het POL in het College: "M.u.v. de bekende kanttekening zijdens de gedeputeerde EZ eveneens zonder voorbehoud positief". 
198 Het compromis bestond eruit dat in het Omgevingsplan gewerkt zou worden met 'bandbreedtes' als het ging om concrete aantallen hectares bedrijventerreinen. Zie Archief Provincie Limburg 50382; Ongedateerde notitie 'Tussenstand POL-adviesgroep Prognoses', t.b.v. discussie in GS op 19 oktober 1999. Zie ook 97403; Notulen POL Regiegroep van 13 september 1999; Zie voor het uiteindelijke compromis: 'Antwoorden van Gedeputeerde Staten in eerste termijn op de vragen over het ontwerp POL, gesteld door de Vaste Commissie Ruimte en Groen Plus op 1 juni 2000', juni 2000, p.2.

199 Zie GS-nota 'Provinciaal Omgevingsplan Limburg (POL)' van 24 april 2001.

200 Zie het definitieve POL voor een opsomming: Provincie Limburg (2001). Liefde voor Limburg, provinciaal omgevingsplan, p.268.

201 Tijdens het opstellen van het Omgevingsplan was er al een uitwerking gemaakt waarin eisen werden gesteld aan bouwlocaties. Voor Zuid-Limburg waren deze afspraken in december 1999 vastgelegd in een streekplanherziening die door Provinciale Staten werd vastgesteld op 17 december 1999. Bibliotheek Provincie Limburg. Provincie Limburg (1999). Partiële Streekplanherziening Open ruimte- en bufferzonebeleid Zuid-Limburg.

202 Archief Provincie Limburg 78427. Verslag van de Conferentie van 10 juni 2004 over de 'POLherziening Contourenbeleid Limburg - Deel 1 - Zuid-Limburg', p.7-8.

203 idem p.7-8.

204 Bibliotheek Provincie Limburg, Provincie Limburg (2003). Limburg verlegt grenzen. Coalitieakkoord 2003-2007. 26 mei 2003, p.31.

205 In het coalitieakkoord werd gesproken van 'pragmatische afwegingskaders'. Zie Limburg verlegt grenzen, p.31.

206 Zie o.a Wetenschappelijke Raad voor het Regeringsbeleid (1998). Ruimtelijke Ontwikkelingspolitiek. Rapport 53, 20 februari 1998; Sociaal-Economische Raad (2001). Advies Vijfde Nota Ruimtelijke Ordening. Advies 2001/07, 21 september 2001. Online beschikbaar via www.wrr.nl en www.ser.nl.

207 De gedachte achter het concept van 'gebiedsontwikkeling' was dat in een afgebakend gebied meerdere doelstellingen tegelijkertijd gerealiseerd konden worden. Dit kon bijvoorbeeld door betere samenwerking tussen partijen en het zoeken naar de verbinding van elkaars belangen. Het bouwen van nieuwe woningen kon geld opleveren voor de aanleg van nieuwe natuur (iets wat geld kost). Een ander voorbeeld is de aanleg van nieuwe infrastructuur waarmee een gebied werd voorzien van een betere toegankelijkheid. Hierdoor stijgt dikwijls de waarde van de grondprijzen van bedrijven die in de nabijheid zijn gevestigd. Zie voor achtergronden: www.vrom.nl/pagina. html?id=10343 [laatst geraadpleegd 2-9-2010].

\section{\$2.6 Van ordenen naar ontwikkelen (periode 2004-2007 en verder)}

208 Bibliotheek Provincie Limburg. Provincie Limburg (2007). Evaluatie Coalitieakkoord 2003-2007. Gedeputeerde G.H.M. Driessen (CDA) over de resultaten van zijn aanpak: "Vroeger werd vanuit de wettelijke taken gekeken waar er zich problemen voor deden en werden acties opgelegd aan partijen om die problemen te tackelen. Nu wordt vooral geluisterd naar de andere spelers in de samenleving en worden oplossingen aangedragen. Hoewel deze cultuurverandering nog niet ten einde is ... mag dit wel een succes genoemd worden", p.27.

209 Bibliotheek Provincie Limburg. Zie bijvoorbeeld Provincie Limburg (1997). Verslag van het ruimtelijk beleid over het jaar 1996, p.15-17. Een toename van het aantal 'geschillenzaken' was het gevolg.

210 In oktober 1998 was door de Provincie een poging gedaan om meer flexibiliteit te realiseren door de lijst van objecten waarvoor een 'verklaring van geen bezwaar' van de Provincie nodig was, uit te breiden. Ook werden er meer bestemmingsplannen in het vooroverleg tussen gemeenten en Provincie besproken en afgehandeld. Bij 'niet-ingrijpende plannen' werd zelfs van vooroverleg afgezien waarmee de provinciale betrokkenheid slechts een formaliteit was. Zie Bibliotheek 
Provincie Limburg. Provincie Limburg (1999). Jaarlijks RO-verslag 1998. Augustus 1999, p.18.

211 Deze voorschriften gingen bijvoorbeeld over de eisen die aan woningen, bijgebouwen, bedrijfsgebouwen en vakantiewoningen werden gesteld.

212 Bibliotheek Provincie Limburg. Provincie Limburg (2004). Handreiking Ruimtelijke Ontwikkeling Limburg. Ordening en ontwikkeling in balans. Juli 2004. Cursivering HvE.

213 idem.4-5.

214 Verslag van de workshop 'Bestemmingsplannen maken: kan het beter en sneller?' die 27 april 2005 werd gehouden in de Oranjerie te Roermond. Online beschikbaar [laatst geraadpleegd 14-122010]: www.limburg.nl/upload/pdf/herorientatie_ro_verslag_workshop_27_april_2005.pdf

215 LEI (2004). Verhandelbare Ontwikkelingsrechten in Limburg. Rechten voor kwaliteit, kwaliteit voor rechten. December 2004. In juni 2004 was er een eerste beknopte notitie door het LEI opgesteld. Het LEI had in 2001 al onderzoek gedaan naar de Verhandelbare Ontwikkelingsrechten methode (VORm). Online beschikbaar [laatst geraadpleegd 14-12-2010]: www.lei.dlo.nl/publicaties/ PDF/2004/4_xxx/4_04_06.pdf.

216 Zie bijvoorbeeld Tweede Kamer 2006-2007, 27581, Nr.32, waarin door de Kamer vragen gesteld werden over het Limburgse instrument. De ministers van VROM en LNV antwoordden schriftelijk: "Dat de provincie deze zaken op zich neemt past binnen de sturingsfilosofie, volgens welke de overheden in het ruimtelijk beleid samenwerken sinds de vaststelling van de Nota Ruimte. Bij de verdeling van de verantwoordelijkheden tussen provincie en Rijk wordt als motto gehanteerd «decentraal wat kan, centraal wat moet». In dit geval ligt de verantwoordelijkheid bij de provincie Limburg. Zij is bedenker en uitvoerder van VORm en heeft het instrument opgenomen in haar provinciaal ruimtelijk beleid". www.statengeneraaldigitaal.nl.

217 idem.57-59.

218 Ministerie van VROM/Financiën (2001). Op grond van nieuw beleid. Nota Grondbeleid. Januari 2001, p.8. Online beschikbaar [9-6-2010]: www.vrom.nl/get.asp?file=docs/publicaties/ ruimte1048.pdf\&dn=1048\&b=vrom

219 'Actief grondbeleid' wil zeggen dat de overheid ook zelf voor de grondexploitatie zorg draagt en de grond bouwrijp maakt. Dit in tegenstelling tot een 'faciliterend grondbeleid' waarin de exploitatie overgelaten wordt aan marktpartijen. De provincies voerden tot die tijd vooral een faciliterend grondbeleid, bijvoorbeeld bij de aankoop van gronden voor de aanleg van provinciale wegen. Zie ook Ecorys (2005). De weg naar de herberg.... Inventarisatie van het grondbeleid binnen de provincie Limburg, 26 augustus 2005, p.19-20. Online beschikbaar [laatst geraadpleegd 14-122010]: portal.prvlimburg.nl/psonline/documenten/15219/051123-0262.pdf.

220 Provincie Limburg (2006). Uitvoeringsnota Grondbedrijf Provincie Limburg. 3 oktober 2006. Online beschikbaar[10-6-2010]: http://portal.prvlimburg.nl/poldigitaal/documenten/8309/ uitvoeringsnota_nota_versie_GS_06-10-03.pdf.

221 Provincie Limburg (2006). Praktijkschool voor ontwikkelingsplanologie. Provincie en gemeenten samen op weg naar klinkende resultaten in ruimtelijke ontwikkeling. Eindrapport, november 2006, p.9.

222 idem.15.

223 In de eindrapportage eind 2006 constateerde de Provincie dat een periode van 10 maanden te kort was om te spreken van daadwerkelijk meetbare resultaten. De projecten waren onderling erg verschillend waardoor het moeilijk te beoordelen was of projecten 'sneller en beter' waren verlopen. Verder was de periode van 10 maanden te kort om te kunnen beoordelen in hoeverre de nieuwe werkwijze blijvend effecten heeft opgeleverd. De aard van het project, betrokken personen, kennis en kunde en flexibiliteit van de regelgeving bleken belangrijke succesfactoren te zijn. Zie Praktijkschool, p.31.

224 In organisatorische zin werd hier ook op ingespeeld door de voorheen twee ruimtelijke afdelingen 
(Ruimtelijke Inrichting Zuid en Ruimtelijk Inrichting Noord) in 2004 samen te voegen in een nieuwe afdeling 'Ruimtelijke Ontwikkeling'.

225 Zie voor de opgedane ervaringen: Praktijkschool, p.35 en verder. In de eindrapportage kwamen gemeente-ambtenaren aan het woord die ook een aantal kritische noten kraakten.

226 Provincie Limburg (2007). 5 kernpunten voor de aanpak van ontwikkelingsplanologie in Limburg. 'Verdrag van Lille', januari 2007. Online beschikbaar [10-6-2010]: www.limburg.nl/upload/pdf/verdrag\%20van\%20Lille\%20ondertekend.pdf.

227 Het Omgevingsplan zou na 8 jaar geactualiseerd moeten worden, wat betekende dat uiterlijk 2009 een algehele herziening zou moeten plaatsvinden. Echter, omdat het plan ook het water- en milieubeleid omvatte en deze onderdelen een wettelijke termijn kenden van 4 jaar, zou hiervoor al in 2005 een (gedeeltelijke) herziening moeten plaatsvinden.

228 NovioConsult/Van Spaendonck (2005). Lessen uit het POL. Evaluatie van het Provinciaal Omgevingsplan Limburg. Januari 2005, p.13. Online beschikbaar [10-6-2010]:

www.limburg.nl/upload/pdf/POLvoortraject_LessenUitPOLeindrapportNovioconsult4febr2005. pdf.

229 Verwezen kan worden naar de PS-vergadering van 16 juli 2004 waar een voorstel van GS om te komen tot een 'integrale en strategisch uitgebouwde opvolger van het POL' aan de kant werd geschoven. Zie PS-nota 'Dynamisch POL op hoofdlijnen', 10 mei 2005, p.2.

230 Aldus het voorstel gedaan in de PS-nota 'Dynamisch POL op hoofdlijnen', 10 mei 2005.

231 Provincie Limburg (2005). 'Sonderingsnota POL 2006. Veranderingen in en samenhangend met POL', 20 december 2005. Online [10-6-2010] www.limburg.nl/upload/pdf/POL_ SonderingsnotaPOL2006.pdf. Het begrip 'hoofdstructuur' kwam uit de Nota Ruimte (2004) waarin een kaart was opgenomen met de Nationale Ruimtelijke Hoofdstructuur van Nederland. Daarop werden gebieden (en netwerken) van nationaal belang aangegeven. De rijksoverheid zag voor zichzelf een 'grotere verantwoordelijkheid' weggelegd dan andere gebieden. Zie ministerie van VROM, LNV, VenW \& EZ (2004). Nota Ruimte Deel 4: tekst na parlementaire instemming, p.31-33.

232 Sonderingsnota, p.3.

233 Zie gemaakte opmerkingen in 'Verslag bestuurlijke overleggen over de Sonderingsnota POL2006 op 18 januari 2006'. Online beschikbaar [laatst geraadpleegd 14-12-2010] www.limburg.nl/upload/pdf/POLproces_VerslagBestuurlijkeOverleggen18jan.pdf.

234 Zie bijvoorbeeld Provincie Limburg (2007). Coalitieakkoord 2007-2011 CDA-PvdA-PNL. Investeren en verbinden, april 2007. Online beschikbaar [laatst geraadpleegd 17-6-2010]: www.limburg.nl/upload/pdf/Coalitieakkoord20072011.pdf

235 In de nieuwe Wet Ruimtelijke Ordening verviel de toetsingsbevoegdheid van Gedeputeerde Staten op de gemeentelijke bestemmingsplannen. Daarvoor in de plaats kregen provincies de bevoegdheid om zelfstandig projecten te realiseren en grondbeleid te voeren, mede door de nieuwe Grondexploitatiewet. Ook kregen provincies de bevoegdheid om een eigen 'inpassingsplan' op te stellen, vergelijkbaar met de status van een gemeentelijk bestemmingsplan. Met name het planologisch verankeren van de mogelijkheid dat provincies autonoom projecten konden oppakken en het grondbeleid waren elementen die door de Provincie Limburg in de periode 20032007 werden verkend. Zie Provincie Limburg (2007). Nieuwe wet ruimtelijke ordening. Omgaan met nieuwe instrumenten. September 2007, p.4. Online beschikbaar [laatst geraadpleegd 14-122010] www.limburg.nl/upload/pdf/sturingsdocument\%20definitief.pdf.

\section{Hoofdstuk 3}

236 Rijksarchief Limburg 04.09/6852. Miedema, S. (1975) 'De regie van de REP', p.13-14. REP stond voor Regionale Economische Politiek, zoals ook de afdeling binnen het Directoraat-Generaal voor de Prijzen, Ordening en Regionaal Beleid heette. Onduidelijk is waarin dit artikel is gepubliceerd. 
Miedema werd in 1985 secretaris-generaal van het ministerie van Sociale Zaken (tot 1990).

237 De Staatsmijnen hadden al in 1959 een verliesjaar achter de rug. Voor de particuliere Oranje Nassaumijnen gold dit niet. Vanaf 1962 hadden echter zowel de Staatsmijnen als de Oranje Nassaumijnen te maken met een negatieve balans (Messing, 1988: 176; Peet \& Rutten, 2009: 291).

\section{\$3.1 Ontwikkelingen in het nationale regionaal-economisch beleid}

238 Voor deze nationaal historische paragraaf is gebruik gemaakt van De Hen (1980), Bartels \& Van Duijn (1981), Van Zanden \& Griffiths (1989), Atzema \& Wever (1999) en diverse nota's van het ministerie van Economische Zaken.

239 Tweede Kamer 1950-1951, 1900 X No.6. Bijlage IV van de Memorie van Toelichting Tweede Nota in zake de Industrialisatie van Nederland. Online beschikbaar via www.statengeneraaldigitaal.nl.

240 Tweede Kamer 1950-1951, 2322 No.7 Bijlage D van Memorie van Toelichting Rapport van de Hoofdcommissie voor de Industrialisatie inzake Landelijke spreiding der industrialisatie door regionale concentratie. Online beschikbaar via www.statengeneraaldigitaal.nl.

241 Tweede Kamer 1951-1952, 2322 No.3 Wetsontwerp Deelneming van het Rijk in de uitvoering van de eerste phase van de ontwikkelingsplannen voor Z.W. en Oostelijk Groningen, Oostelijk Friesland, N.O. Overijssel, Oostelijk West-Friesland (N.H.), Z.W. en N.O. Noord-Brabant en Noordelijk Limburg, 10 oktober 1951, p.1. De ambities van de Tweede Industrialisatienota werden een jaar later in een drietal wetsvoorstellen verankerd. Online beschikbaar via www.statengeneraaldigitaal. nl.

242 idem.4.

243 Tweede Kamer 1962-1963, 7169, No.1-2 Achtste nota inzake de industrialisatie van Nederland, 24 april 1963. De regering gaf aan: "Het is duidelijk, dat bij de vaststelling van het komende regionale beleid met de boven aangeduide inzichten in de 'natuurlijke' ontwikkelingsmogelijkheden van de verschillende landsdelen rekening moet worden gehouden", p.78.

244 Zie voor een uitgebreidere beschrijving van de Wet op de Selectieve Investeringsrekening: Bartels \& Van Duijn, 1981, p.95-100.

245 Tweede Kamer 2003-2004, 29697, No.1 Brief aan Tweede Kamer Gebiedsgerichte economische perspectieven en Interdepartementaal beleidsonderzoek Regionaal Economisch Beleid, 12 juli 2004, p.18. De nota is te downloaden op: www.rijksoverheid.nl/bestanden/documenten-en-publicaties/notas/2004/07/01/nota-pieken-inde-delta-gebiedsgerichte-economische-perspectieven/nota-piekenindedelta.pdf.

246 Dit zijn bedrijven die hun afzetmarkt hebben buiten de regio waarin zij zijn gevestigd.

\section{\$3.2 Limburgs economisch beleid voor 1962}

247 H.C.J.H. Gelissen had in Tilburg samen met zijn collega-professor H.A. Kaag in de periode 19271930 een wetenschappelijk instituut voor technologisch-economisch onderzoek voorbereid. De statuten hiervan waren op 5 mei 1930 vastgesteld. Zie De Hen, 1980, p.148.

248 De volledige naam luidde Economisch-Technologisch Instituut van de NV ter bevordering van de industriële belangen in de provincie Limburg, in het vervolg zal de afkorting Etil worden gehanteerd.

249 De NV Industriebank Limburg werd opgericht op 12 april 1935. Het was de eerste ontwikkelingsbank van Nederland.

250 In de periode 1935-1937 werden slechts 13 ondernemingen financieel gesteund. In de periode tot 1940 werd er voor niet meer dan fl. 200.000 op jaarbasis aan kredieten verleend. Zie De Hen 1980, p.171.

251 Als minister van Economische Zaken zorgde hij in 1936 voor de Wet op industriefinanciering. Hiermee werd overheidsdeelname in individuele bedrijven mogelijk. Hij was minister van 19351937 voor de RKSP.

252 Dit waren de kernen Gennip, Bergen, Mook, Venray en Panningen. 
253 Tweede Kamer 1950-1951, 2322 No.3 Ontwerpwet wijziging tiende hoofdstuk der Rijksbegroting voor het dienstjaar 1951 (Deelneming van het Rijk in de uitvoering voor de eerste phase van de ontwikkelingsplannen ...), 10 oktober 1951,p.4. Online beschikbaar via www.statengeneraaldigitaal. nl.

254 idem.4.

255 Ook werd gekeken naar de mogelijke exploitatie van mijnvelden in het Peelgebied.

256 De Europese Gemeenschap van Kolen en Staal (EGKS) was in 1951 opgericht en beoogde een geharmoniseerd beleid voor kolen en staal in Frankrijk, West-Duitsland, Italië en de drie Beneluxlanden.

257 Bibliotheek Provincie Limburg; Provinciale Staten van Limburg (1962/1963). Notulen der vergadering van nov/dec. 1962/jan.1963. No.31; 'Antwoord van Gedeputeerde Staten op het verslag van het verhandelde in de vier afdelingen en in de commissie van voorzitters en rapporteurs betreffende het voorstel tot vaststelling van de begroting van inkomsten en uitgaven voor het dienstjaar 1963 alsmede tot heffing van opcenten op de hoofdsommen der grond- en personele belasting', p.122.

258 Rijksarchief Limburg 04.09/6808; Provinciaal Blad van Limburg, 1962, No.14 'Subsidie voorbereidingskosten industrieterreinen', 29 januari 1962. De regeling voorzag in een subsidie van $40 \%$ van de gemeentelijke voorbereidingskosten zoals studie van het terrein, opmaken van plannen, berekeningen en tekeningen. Heel succesvol was de regeling niet. Zie Rijksarchief Limburg 04.09/6808; Bijlage 1 bij 'Pre-advies omtrent het oprichten van een Provinciaal Ontwikkelingsfonds', 26 april 1965, p.8 van de bijlage.

259 Idem. Zie o.a. bijdragen van de KVP-statenleden F.C.M. Wijffels, J.P.D. van Banning, C.E.P.M. Raedts en PvdA-Statenlid J.G.H. Tans.

260 Zie Rijksarchief Limburg 04.09/6804, 6814. In totaal waren er zes rapporten door de Welvaartscommissie opgesteld. Deze gingen over de regionale ontwikkelingsorganen, voorlichting van de bevolking, technisch onderwijs, industrievestiging, verkeersverbindingen en tot slot de industrieschappen. Zie bijlage I van Interimrapport inzake een welvaartsplan voor Limburg, oktober 1965.

261 Het kabinet Marijnen (1963-1965) was op 27 februari 1965 gevallen en J.E. Andriessen was vanaf maart 1965 demissionair minister. Een maand later, 14 april 1965, werden de nieuwe bewindslieden beëdigd. J.M. den Uyl werd minister van Economische Zaken. Het nieuwe kabinet hield stand tot 14 oktober 1966 (de nacht van Schmelzer).

262 De provinciale rol in de voorbereiding van de uiteindelijke Mijnnota was beperkt gebleven tot de input die de werkgroep onder leiding van gouverneur Van Rooy leverde. In het provinciale archief zijn nauwelijks documenten terug te vinden over deze periode. De beschrijving vanaf maart 1965 is gebaseerd op Messing (1988), p.250-252; 266-267, die zich weer baseert op de DSM-archieven.

263 Bibliotheek Provincie Limburg. Tweede Kamer 1965-1966, 8424 No.2 Nota inzake de mijnindustrie en de industriële herstructurering van Zuid-Limburg van 14 december 1965, p.2.

264 idem.16. De sluiting van de Staatsmijn Maurits zou in april 1966 moeten plaatsvinden en uiterlijk in een periode van drie jaar afronding moeten vinden. De sluiting van de Staatsmijn Wilhelmina zou in 1970 beginnen.

265 idem. 24.

266 idem.24-25.

267 Den Uyl (1965). Transcriptie van rede uitgesproken op 17 december 1965 te Heerlen. Integraal opgenomen in Derix (1990). Perspectief voor Limburg. Stappen en obstakels in het beleid rond de Perspectievennota Zuid-Limburg, 1965-1990. Bijlage II, p.250.

268 In de Mijnnota stond het zelfs nog voorzichtiger: "Het is in de gegeven omstandigheden niet juist te stellen, dat het aantal te creëren aanvullende arbeidsplaatsen exact zal moeten overeenstemmen met het aantal uit de mijnsluiting vrijkomende arbeiders...", p.15. 
269 Zie de terugblik door gouverneur Van Rooy bij de opening van de Provinciale Contactcommissie: "De 17e december 1965 was voor Limburg een historische dag. U hebt toen te Heerlen met kloeke lijnen de situatie van de mijnindustrie en de wegen, die leiden tot een nieuwe vormgeving, geschetst. Zowel de ademloze stilte tijdens Uw betoog als het enorme applaus, dat op Uw rede volgde, waren veelbetekenend. De reactie op Uw nota inzake de mijnindustrie en de industriële herstructurering van Zuid-Limburg is hier zeer positief geweest". Rijksarchief Limburg 04.09/6823; 'Ontwerp-antwoord van de voorzitter van de provinciale contactcommissie inzake het herstructureringsbeleid in Limburg na de installatie-rede van de minister van Economische Zaken op donderdag, 14 juli te 10.30 in de Statenzaal', p.1.

\section{\$3.3 Economische herstructurering: een rijksverantwoordelijkheid (periode 1965-1978)}

270 Rijksarchief Limburg 04.09/6822; Brief van het ministerie van Economische Zaken aan het College van Gedeputeerde Staten van de provincie Limburg, 24 december 1965.

271 idem.2.

272 Rijksarchief Limburg 04.09/6822; Brief GS aan minister van EZ, 10 januari 1966.

273 Rijksarchief Limburg 04.09/6822; zie brieven van ministerie van EZ aan GS van 9 februari 1966 en 29 april 1966.

274 De commissie werkte in de periode 1966-1967 nog aan het rapport Limburgs Toekomst (1967) waarvan een definitieve versie verscheen in 1967, maar zou daarna niet meer bij elkaar komen. In 1971 werd de commissie opgeheven. Zie Rijksarchief Limburg 04.09/6804; PS-nota 'Opheffing commissies als bedoeld in artikel 65 der Provinciewet', 11 november 1971.

275 Rijksarchief Limburg 04.09/6823; Verslag $1^{\mathrm{e}}$ vergadering Provinciale Contactcommissie, 14 juli 1966. Zie p.4 bij monde van gedeputeerde J.H. Ensinck (KVP) en gouverneur Van Rooy waarin zij constateerden dat deze commissie 'een contactorgaan, geen beleidscommissie' was.

276 Rijksarchief Limburg 04.09/6823; Zie bijvoorbeeld Verslag $4^{\text {e }}$ vergadering Provinciale Contactcommissie, 9 december 1966, p.2. Deze constatering zou nog enkele keren in volgende vergaderingen worden herhaald.

277 Rijksarchief Limburg 04.09/623; Zie o.a. Verslag $4^{\text {e }}$ vergadering Provinciale Contactcommissie, 9 december 1966. Voorzitter Van Rooy merkte op '...dat het provinciaal bestuur t.a.v. de herstructurering een mede-verantwoordelijkheid, niet de uitsluitende verantwoordelijkheid bezit', p.7.

278 Het ging hier om een tegemoetkoming van 50\% van de grondprijs van het industrieterrein voor bedrijven die een nieuwe vestiging wilden beginnen op de aangewezen industrieterreinen. Hierbij moest er sprake zijn van een investering van minimaal fl. 500.000 in vaste activa en een eigen financiering van minimaal $30 \%$.

279 Rijksarchief Limburg 04.09/6823; Verslag $1^{\mathrm{e}}$ vergadering Provinciale Contactcommissie, 14 juli 1966, p.2.

280 Rijksarchief Limburg 04.09/6824; Verslag $8^{\text {e }}$ vergadering Provinciale Contactcommissie, 24 oktober 1967, p.1; Zie ook opmerking burgemeester F.J.W. Gijzels, Rijksarchief Limburg 04.09/6825; Verslag 12e vergadering, 9 oktober 1968, p.3.

281 Rijksarchief Limburg 04.09/6846; Etil-cijfers geciteerd in de brief van GS aan ministerraad van 19 april 1971. Zie ook Rijksarchief Limburg 04.09/6831; Etil-cijfers geciteerd in een notitie van de $4^{\mathrm{e}}$ afdeling 'Beantwoording vragen m.b.t. situatie herindustrialisatie Zuid-Limburg', 28 februari 1974, p.2. In de periode $1966 \mathrm{t} / \mathrm{m} 1968$ waren er 58 vestigingsbesluiten genomen, goed voor 12.000 arbeidsplaatsen (incl. DAF). In de periode 1969 t/m 1973 lag het aantal op 41 besluiten die slechts 3.479 arbeidsplaatsen opleverden.

282 Rijksarchief Limburg 04.09/6825; Verslag 9e vergadering Provinciale Contactcommissie, 6 maart 1968, p.5.

283 Rijksarchief Limburg 04.09/6823; Verslag $4^{\text {e }}$ vergadering Provinciale Contactcommissie, 9 
december 1966, p.3-4. Van de Garde (ministerie EZ) adviseerde de Provincie terughoudend te zijn en '...bij het doen van acquisitie niet te zeer te trachten de topfiguren te benaderen'. Acquisitie was immers een rijksaangelegenheid.

284 Rijksarchief Limburg 04.09/6832; Zie Concept-mededelingen aan Provinciale Staten inzake de voortgang van de herstructurering, met enige gegevens inzake de bestrijding der werkloosheid, 16 oktober 1967, p.3.

285 idem.3-4. Zie ook Rijksarchief Limburg 04.09/11435; Notulen GS-vergadering van 1 mei 1967, p.1.

286 Rijksarchief Limburg 04.09/6823; Verslag $4^{\text {e }}$ vergadering Provinciale Contactcommissie, 9 december 1966: 'De voorzitter is van oordeel, dat de commissie meer productief zal moeten gaan werken'.

287 idem.7.

288 De Tussentijdse Mijnbrief (1967), de Nota Regionaal Beleid 1969 t/m 1972 (1968) en de daarop volgende Tweede Mijnnota van 18 september 1969 waren redelijk solitair door het ministerie van Economische Zaken opgesteld. Dit tot onvrede van het College van Gedeputeerde Staten. Zie Rijksarchief Limburg 04.09/11437; Notulen GS-vergaderingen van 8 en 29 september 1969.

289 Zie Rijksarchief Limburg 04.09/11438; Notulen GS van 4 mei 1970. 'De heer Heiligers vraagt of het College van Gedeputeerde Staten nog iets zal ondernemen om te voorkomen, dat in Den Haag de indruk gaat ontstaan, dat de Limburgse problemen met de eerste fase van de herstructurering zouden zijn opgelost, temeer nu de aandacht van de centrale overheid zich thans nadrukkelijk richt op het noorden des lands', p.1.

290 Zie Rijksarchief Limburg 04.09/11438; Notulen GS van 27 maart 1970, p.1.

291 Rijksarchief Limburg 04.09/11437; Notulen GS van 17 november 1969: "De heer Van de Voort meent ook, dat het industrialisatievraagstuk voor een groot deel is opgelost. Hij acht het belangrijker de aandacht te vestigen op de dienstensector, die momenteel zeer sterk groeit en de industrie overvleugelt", p.1. Ook de gemeente Born had zich naar het oordeel van gedeputeerde J. van der Woude (PvdA) in een publicatie zodanig uitgelaten dat het leek alsof de aangekondigde vestiging van een Shell-olieraffinaderij aldaar 'niet noodzakelijk zou zijn'. Zie Rijksarchief Limburg 04.09/114381; Notulen GS van 4 mei 1970, p.1. Een notitie over de 'Recente en toekomstige ontwikkeling van de werkgelegenheid voor mannen in Limburg' van september 1969 die werd besproken in de Provinciale Contactcommissie van 2 oktober 1969, kende eenzelfde strekking. Zie Rijksarchief Limburg 04.09/6826; Ongedateerde bijlage bij uitnodigingsbrief van gouverneur aan de leden van de Provinciale Contactcommissie, 12 september 1969.

292 Formeel heette dit bureau 'Stafgroep Industrialisatie van de Staatsmijnen'. Deze stafgroep was in 1965 opgericht om vanuit de Staatsmijnen de herstructurering van de regio te bevorderen onder leiding van J. Bloemendal

293 De cijfers werden door het ministerie dikwijls betwist. Zie bijvoorbeeld Rijksarchief Limburg 04.09/6835; Verslag overleg minister van Economische Zaken met College van Gedeputeerde Staten aangaande het nieuwe regionale stimuleringsbeleid, 5 juni 1968, p.2-3.

294 Rijksarchief Limburg 04.09/6846; Brief Gedeputeerde Staten van Limburg aan de ministerraad, 19 april 1971.

295 Rijksarchief Limburg 04.09/6831; Zie het antwoord van GS op vragen van statenlid J.P. Planje. 23 augustus 1971, p.2.

296 Rijksarchief Limburg 04.09/11439; Notulen van GS, 23 augustus 1971, p.2.

297 Achtereenvolgens waren dit de ministers: J.E. Andriessen (CHU, 1963-1965), J.M. Den Uyl (PvdA, 1965-1966), J.A. Bakker (ARP, 1966-1967), L. De Block (KVP, 1967-1970), R.J. Nelissen (KVP, 1970-1971), H. Langman (VVD, 1971-1973), R.F.M. Lubbers (KVP, 1973-1977). Strikt genomen was minister-president P.J.S. de Jong (KVP) in januari 1970 ook nog een week ad interim minister van Economische Zaken geweest, na het aftreden van minister De Block. Dit bracht het totaal op 
acht ministers van Economische Zaken in de periode 1965-1973.

298 Tweede Kamer 1972, 12 000, Nr.2, Rijksbegroting voor het Dienstjaar 1973 Hoofdstuk XVI Cultuur, Recreatie en Maatschappelijk Werk - Memorie van Toelichting, 19 september 1972, p.23. Online beschikbaar via www.statengeneraaldigitaal.nl.

299 In het Besluit Bijdragen Reconstructie- en Saneringsplannen (december 1974) was geregeld dat er voor gemeenten een $80 \%$ vergoeding kwam voor de verwervings- en excessieve sloopkosten en een $50 \%$ tegemoetkoming in de kosten voor bijzondere openbare werken in de Oostelijke Mijnstreek. Het was een succesvolle aanpak die uiteindelijk in 1985 haar afronding vond. De aanpak stond bekend onder de naam 'Van zwart naar groen' (zie Messing, 1988: 520).

300 Rijksarchief Limburg 04.09/11441; Notulen GS-vergadering van 22 oktober 1973. In het voorjaar van 1977 was dit al opgelopen tot 100 miljoen gulden. Zie Rijksarchief Limburg 04.09/11445; Notulen GS-vergadering van 7 maart 1977.

301 Rijksarchief Limburg 04.09/11443; Notulen GS-vergadering van 28 juli 1975.

302 Rijksarchief Limburg 04.09/11443; Notulen GS-vergadering van 20 oktober 1975.

303 Rijksarchief Limburg 04.09/11441; Notulen GS-vergadering van 13 augustus 1973.

304 Rijksarchief Limburg 04.09/6813; Eerste toespraak van gouverneur Van Rooy in de Provinciale Statenvergadering, 17 februari 1964, p.10. Zie ook Rijksarchief Limburg 04.09/6812; Interim rapport inzake een welvaartsplan voor Limburg, p.29.

305 Rijksarchief Limburg 04.09/6979; Berenschot (1974). 'Conclusies en aanbevelingen economische ontwikkeling Herstructurerings-gebied Zuid-Limburg 1974-1978', 28 maart 1974, p.31. Het bureau inventariseerde alle betrokken instanties: het provinciaal bestuur, 71 gemeenten, de Regionale Raad voor de Arbeidsmarkt, de Herstructureringscommissie, drie Kamers van Koophandel, DSM en de particuliere mijnen, het Districtbureau voor de Arbeidsvoorziening, het Etil, de SEOL, drie Industrieschappen, Industriebank en de STIKOL.

306 Deze conclusie was te lezen in een conceptversie van het rapport en werd op aandringen van de Provincie geschrapt in het uiteindelijke rapport. Zie Rijksarchief Limburg 04.09/6979; Memo van het hoofd van de $4^{\mathrm{e}}$ afdeling aan Gedeputeerde Staten van 5 februari 1974. Verontrust over de conclusies schreef het afdelingshoofd: "De in dit rapport neergelegde uitingen over 'versnippering' ... en de lange duur voor het verkrijgen van investerings- en uitbreidingspremies (blz.24) lenen zich totaal niet voor publicatie. [...] Publicatie van deze uitingen van Berenschot zal echter veel onnodige opschudding en krantenkoppen veroorzaken. [...] De zinsnede op blz. 19: "een belangrijke oorzaak van het achterwege blijven van de effectuering van de aanwezige potenties achten wij interne versnippering en verdeeldheid binnen het herstructureringsgebied" is een onbewezen en onbewijsbare stelling". Zie ook Rijksarchief Limburg 04.09/6979; Memo $4^{\text {e }}$ afdeling aan gedeputeerde Van de Voort, 11 maart 1974, p.1.

307 Zie o.a. Rijksarchief Limburg 04.09/11624; Verslag overleg minister EZ, p.1; Rijksarchief Limburg 04.09/6845; Statuten van de SEOL, artikel 4.17 april 1972, p.1; 04/09/6845; Memo aan gouverneur Van Rooy, 5 april 1972, p.1; Rijksarchief Limburg 04.09/11440. Notulen van GS-vergadering van 4 september 1972 .

308 K.W. Buck was staatssecretaris van Volkshuisvesting en Ruimtelijke Ordening geweest in het kabinet Biesheuvel (1971-1973). Daarvoor was hij jarenlang wethouder en loco-burgemeester geweest in Kerkrade.

309 Getuige ook het feit dat in de GS-notulen van de periode juni 1974 tot september 1976 nauwelijks sprake was van enige inhoudelijke discussie. Gedeputeerde Buck deelde vooral de stand van zaken mede. Pas in de fase van de uiteindelijke concept-Perspectievennota en specifiek in de GSvergadering van 27 september 1976 werd de afspraak gemaakt dat de individuele gedeputeerden een overleg zouden aanvragen met hun ministeriële counterpart van de regering. Het doel van dit overleg was om na te gaan wat de afzonderlijke ministeries aan beleidsmaatregelen konden treffen in het kader van de Perspectievennota. Zie Rijksarchief Limburg 04.09/11444; Notulen GS- 
vergadering van 27 september 1976, p.1. Zie ook Rijksarchief Limburg 04.09/11442; Notulen van GS-vergadering van 14 oktober 1974. In het verslag van de bespreking over het conceptrapport van adviesbureau Berenschot stond: "De heer Buck kiest duidelijk voor een zwaar accent en nauwe betrokkenheid van de provincie. De heer Van de Voort opteert voor een wat meer afstandelijke betrokkenheid". Zie ook notulen van 28 oktober 1974 en 2 januari 1975.

310 idem.2.

311 Zie ook de bijdrage van Miedema aan het Vriendenboek Werner Buck dat bij zijn afscheid uit de Limburgse politiek in mei 1987 werd gepresenteerd; De Bruyn, Lohuis, Ringens \& Spronck [ed.] (1987). Vriendenboek Werner Buck, mei 1987, p.71-74.

312 Rijksarchief Limburg 04.09/6980; Brief van minister van Economische Zaken aan Tweede Kamer, 5 december 1974, p.4. Beide overheden namen zitting in de Raad van Commissarissen waarbij het ministerie van EZ 95\% van de aandelen bezat en de Provincie Limburg 5\%. Dit was de 'halterconstructie'.

313 Ongeveer gelijktijdig met de oprichting van het LIOF was op 1 mei 1975 DAF gefuseerd met het Zweedse Volvo-cars. Niessen maakte toen de overstap naar het LIOF. Hij zou 12 jaar lang (tot 1987) deze regionale ontwikkelingsmaatschappij leiden.

314 idem.8.

315 Rijksarchief Limburg 04.09/6863; Ongedateerde deelnotitie als bijlage van Verslag $5^{\mathrm{e}}$ vergadering van de Coördinatiecommissie, 'II.E. Bestuurlijk Kader', p.6. De notitie is van begin 1976.

316 In de regeerperiode van het kabinet Biesheuvel (1971-1973) lag het werk rondom de nieuwe 'Limburgnota' stil. Minister Langman deelde in een overleg op 24 januari 1972 met Gedeputeerde Staten mede dat hij 'nog geen concrete gedachten heeft over de Limburg-nota'. Zie Rijksarchief Limburg 04.09/11624, Verslag overleg minister van EZ met GS, p.8. De mankracht op het ministerie was vooral bezig met de Interim-nota voor het Noorden des Lands en de Helmondnota. Langman stelde: 'Het zijn dezelfde ambtenaren, die dit werk zullen doen', p.9. In een overleg met de minister op 11 september 1972 bleek vervolgens dat eerst het 'pendelonderzoek' afgerond moest zijn. Zie Rijksarchief Limburg 04.09/11624; Kort verslag van een gedachtewisseling tussen minister van EZ en GS, 11 september 1972, p.1.

317 Rijksarchief Limburg 04.09/10450; Brief Gedeputeerde Staten aan Provinciale Staten 'Resultaten organisatieonderzoek', 5 mei 1969, p.2. Dit was de zogeheten '4e Afdeling', die naast de taken van verkeer en vervoer zich ook bezighield met wateroplossingen, landbouw, ontgrondingen, woningbouwprojecten en in zeer beperkte mate 'economische zaken'.

318 Rijksarchief Limburg 04.09/11624; Verslag van de gedachtewisseling tussen de minister van Economische Zaken c.s., de staatssecretaris van Sociale Zaken c.s., en Gedeputeerde Staten van Limburg, 25 juni 1973.

319 idem.6.

320 idem.10.

321 Gedeputeerde Buck meldde in 1975 aan zijn collega-gedeputeerden dat 'hetgeen aanvankelijk als een rijkstaak werd gezien, nu zou geschieden door de Haags-Limburgse commissie'. De totstandkoming van de Perspectievennota was vanaf dat moment een 'co-productie' tussen ministerie en Provincie. Zie Rijksarchief Limburg 04.09/11443; Notulen GS van 16 juni 1975, p.2. en Rijksarchief Limburg 04.09/11443; Notulen GS van 7 juli 1975, p.1. Het College van GS stemde hier na een aantal interne discussies (op 16 en 30 juni 1975) uiteindelijk formeel in met 'de gedachte [van] een soort co-productie, conform de totstandkoming van het LIOF'.

322 Lohuis in De Bruyn, Lohuis, Ringens \& Spronck (1987). Vriendenboek Werner Buck, p.72.

323 Rijksarchief Limburg 04.09/6850; Notulen vergadering van de Stuurgroep Perspectievennota Zuid-Limburg, 28 oktober 1975, p.1-2.

324 Rijksarchief Limburg 04.09/6853; Concept-Eindnota Beleidsgroep Perspectievennota, 28 september 1976, p.4. Op p.9 constateerde de Beleidsgroep: "Bovendien is de problematiek op 
andere deelterreinen tot op zekere hoogte mede veroorzaakt door de gewijzigde economische omstandigheden. Derhalve wegen economische argumenten zwaar in het afwegingsproces".

325 Rijksarchief Limburg 04.09/6853; Verslag van de $1^{\text {e }}$ vergadering van de Beleidsgroep Perspectievennota, 9 juli 1976, p.3.

326 Rijksarchief Limburg 04.09/6852; Notitie $4^{e}$ afdeling 'Het perspectief in de Perspectievennota', 12 juni 1975. Zie p.3 voor de regionale indeling van Zuid-Limburg. De ontwikkeling van dit industrieterrein was een compensatie geweest voor het besluit van de regering in 1962 om de staatsmijn Beatrix niet in exploitatie te nemen.

327 Rijksarchief Limburg 04.09/6852; Zie bijvoorbeeld de briefreactie van Miedema (ministerie van EZ) aan gedeputeerde Buck op de notitie 'Het perspectief in de Perspectievennota' (12 juni 1975). In zijn brief van 2 oktober 1975 schreef hij: "In dat verband meen ik dat wij bij onze verdere beschouwingen bijzondere aandacht moeten schenken aan de dienstensector. Het ziet er immers naar uit dat naast de landbouw ook de bouwnijverheid en de industrie meer structureel gezien eerder mensen afstoten dan dat zij nieuwe werkgelegenheid creëren", p.2.

328 Ook onderdelen van de Belastingdienst, ministeries van Landbouw en Defensie, het Kadaster en de Dienst Verkeersongevallenregistratie waren voorbeelden van rijksdiensten die naar Limburg kwamen. Fase 1 van dit spreidingsbeleid was met de Nota Herstructurering Zuid-Limburg (1972), ook wel de 'Nota Langman' genaamd, aangekondigd. De tweede fase (1977-1985) - gesproken werd van ' 3.000 stoelen' - moest nog ingevuld worden.

329 Rijksarchief Limburg 04.09/6853; 'Discussienotitie voor de Beleidsgroep Perspectievennota t.b.v. de eerste vergadering op 9 juli a.s.', 5 juli 1976, p.4.

330 Bibliotheek Provincie Limburg; Voorlopige Standpunt concept-Perspectievennota (mei 1977): "Aan differentiaties binnen dit gebied zijn namelijk onvermijdelijk beperkingen verbonden, in die zin dat wanneer bepaalde subregio's van sommige (extra) faciliteiten verstoken zouden blijven, dit belemmerend kan werken voor het scheppen van werkgelegenheid in die sub-regio's zonder dat vaststaat, dat hiervoor voldoende compensatie wordt geboden in andere deelgebieden, die wel over (extra) faciliteiten kunnen beschikken", p.5. Toch werd er in de standpuntbepaling de voorkeur voor uitgesproken om regionaal te differentiëren met een extra accent op initiatieven in de Oostelijke Mijnstreek.

331 Rijksarchief Limburg 04.09/6853; Gezamenlijk brief van het Stadsgewest en Industrieschap Oostelijk Mijngebied aan de voorzitter van de stuurgroep K.W. Buck, 19 juli 1976, p.5.

332 Rijksarchief Limburg 04.09/6853; Brief van de gemeente Geleen aan de Coördinatiecommissie Perspectievennota, 5 augustus 1976, p.2.

333 idem.7.

334 Rijksarchief Limburg 04.09/6853; Zie verslag van het gesprek tussen Van Rooy, Buck en Lohuis op 4 augustus 1976. Onder punt 3 'Beperking Herstructureringsgebied' is te lezen: '... a) Roemond uitsluiten: ja, vanwege het karakter van problematiek aldaar / nee, vanwege euregio aansluiting W-Dld, nieuwe provinciale indeling, evt opvang problemen Z-Limburg, 'nat' industrieterrein aanwezig b) Maastricht uitsluiten: nee vanwege interdependente oplossingsmogelijkheden in Z-Limburg', p.1. De gemeente Maastricht benadrukte in haar reactie op de Integratieschets dat het 'veiligstellen' van voldoende woningbouw, een spoedige start van de bouw van de universiteit en financiële ondersteuning voor het stadsvernieuwingsprogramma voor het stadsbestuur prioriteit hadden. Zie Rijksarchief Limburg 04.09/6851; Brief van de gemeente Maastricht aan de Stuurgroep, 15 oktober 1976.

335 idem.1.

336 Rijksarchief Limburg 04.09/6853; Zie verslag $2^{\mathrm{e}}$ vergadering Beleidsgroep Perspectievennota, 5 augustus 1976, p.2-3.

337 Rijksarchief Limburg 04.09/6866; Notitie 'Inventarisatie toetsingsreakties naar aanleiding van de concept-Integratieschets Perspectievennota', november 1976, p.5. 
338 Er waren gesprekken gevoerd met de ministeries van Economische Zaken, Sociale Zaken, Binnenlandse Zaken, Rijksplanologische Dienst, Onderwijs en Wetenschappen, Cultuur, Recreatie en Maatschappelijk Werk, Verkeer en Waterstaat en Volkgezondheid en Milieuhygiëne.

339 Zoals de projecten met betrekking tot de aanpak van de jeugdwerkloosheid, uitbreiding acquisitiemogelijkheden voor LIOF, vestiging internationale instellingen, spreiding rijksdiensten $2^{\mathrm{e}}$ tranche, uitbreiding en nieuwbouw Rijksuniversiteit Limburg en Academisch Ziekenhuis Maastricht. Zie voor een overzicht Rijksarchief Limburg 04.09/6853; Bijlage bij $5^{\mathrm{e}}$ vergadering Beleidsgroep: 'Voornaamste conclusies van de besprekingen die tussen de provincie Limburg en de verschillende departementen gehouden zijn in de periode $11 \mathrm{t} / \mathrm{m} 29$ oktober [1976]'.

340 Rijksarchief Limburg 04.09/6854; Persbericht Provincie Limburg / ministerie van Economische Zaken van 11 februari 1977, p.1

341 idem. Zie bijlage 'Financiële consequenties van de beleidsaanbevelingen'. Onduidelijk bleef voor een groot aantal onderdelen over welke tijdsperiode deze investeringen gedaan moesten worden. Ruim 500 miljoen gulden zou moeten worden besteed aan de uitbouw van de universiteit en de nieuwbouw van het academisch ziekenhuis.

342 J. van der Woude was vier jaar eerder, in 1962, ook al kandidaat-gedeputeerde geweest voor de PvdA. Dit was toen door de Katholieke Volkspartij (KVP) 'geweigerd' (Spoormans et.al.1990: 337). De macht van de KVP was begin jaren '60 groot, zo groot dat men zelfs de deelname van andere politieke partijen in de collegevorming van Gedeputeerde Staten konden weigeren.

343 In 1962 leidde deze dominantie van de KVP nog tot een scherpe discussie tussen de PvdA fractieleider J.G.H. Tans en F.V.M. Wijffels (KVP), toen bleek dat het te vormen College van Gedeputeerde Staten uit uitsluitend KVP-leden zou bestaan. Tans claimde dat er ten minste één gedeputeerde namens de PvdA in het College zou moeten zitten, op basis van de verkiezingsuitslag. Van de 59 zetels waren er 50 naar de KVP gegaan, 8 naar de PvdA en 1 restzetel. Zie Bibliotheek Provincie Limburg Notulen PS-vergadering No.70, 6 juni 1962, p.8-17.

344 Van Agt was bovendien in 1958 in Maastricht getrouwd met de Limburgse E.J.Th. Krekelberg. Van Merriënboer et.al. suggereren zelfs dat minister De Gaay Fortman Van Agt het gouverneurschap in Limburg al had beloofd (Van Merriënboer, 2008: 239). De KVP Limburg had volgens Derix gedeputeerde K.W. Buck in die tijd naar voren geschoven als kandidaat-gouverneur, zie Derix, 1990, p.53.

345 Ondanks het feit dat Van Agt het voorzitterschap van de ministeriële Commissie voor het Regionale Beleid 'vervelend' vond en vooral overliet aan zijn minister van EZ G.M.V. van Aardenne (VVD), was een van zijn stokpaardjes de economische steun voor Zuid-Limburg (Merriënboer et.al. 2008: 304).

346 Kremers was later ook samen met E. van Thijn informateur voor het kabinet Van Agt/Den Uyl in 1981.

347 Het College van Gedeputeerde Staten bestond in 1978 uit zeven gedeputeerden waarvan er vier van het CDA waren (K.W. Buck, L. Stals, E.M. Mastenbroek en C.J.J. van den Broek), twee van de PvdA (H.W. Riem en G.M.K. Kockelkorn) en één van de VVD (M.H.C. Lodewijks). Gouverneur J. Kremers was ook lid van het CDA. Een groot deel van dit College zou ook in de volgende periode (1982-1987) nog deel uitmaken van het College. Zie ook appendix IV.

348 Bij het CDA vond de 'generatiewisseling' pas eind jaren ' 80 en begin jaren '90 plaats (bij de statenverkiezingen van 1987 en 1991). De PvdA had in 1978 ervoor gezorgd dat de 'gevestigde, meer autoritair ingestelde bestuurders' waren vervangen (Reerink et.al.1989: 85). PvdAgedeputeerde Van der Woude was daarvan in 1978 het 'slachtoffer'. Overigens kwam er ook eind jaren ' 80 opnieuw vernieuwing binnen die partij.

349 Rijksarchief Limburg 04.09/11452; Zie eerdere 'Taakverdelingen' van de gevormde Colleges van 1962, 1966, 1970, 1974. Overigens kwam uit de taakverdeling van het College van 1974 al een eerste, meer politieke, verdeling naar voren. De twee niet-KVP gedeputeerden - Van der 
Woude (PvdA) en Haverschmidt (VVD) - moesten hun portefeuille 'delen' met een KVP-collega. Buck werd als tweede man verantwoordelijk voor de ruimtelijke ordening in Zuid-Limburg en Stals moest Haverschmidt 'assisteren' met de Stichting Maasplassen. Zie Rijksarchief Limburg 04.09/11452; Nota $1^{\mathrm{e}}$ afdeling 'Taakverdeling voor het College van Gedeputeerde Staten', 21 juni 1974, p.2.

350 Rijksarchief Limburg 04.09/11452; Per begeleidende brief van 17 augustus 1978 van CDAvoorzitter J.J.G. Drummen: 'Kernprogramma van de fracties van het CDA, de PvdA en de VVD t.b.v. het College van Gedeputeerde Staten'.

351 Provincie Limburg (1981). 'Persbericht bij het Jaarrapport 1980 van de Begeleidingscommissie Perspectievennota Zuid-Limburg', 9 april 1981, p.7. Genoemde werkloosheidscijfers kwamen van het Etil.

352 Op het hoogtepunt van de arbeidspendel naar Duitsland werkten er 16.900 Limburgers in Duitsland wat neer kwam op 6\% van de Zuid-Limburgse beroepsbevolking (Bouwens, 2009: 53). In 1978 was dit aantal al gehalveerd.

353 Met uitzondering van het eerste kennismakingsgesprek met minister Lubbers en staatssecretaris Mertens op 25 juni 1973 en een overleg op 20 december 1977 over de Nota Regionaal SociaalEconomisch Beleid 1977-1980, waren er op politiek niveau nauwelijks contacten geweest over de invulling van de Perspectievennota.

354 Vriendenboek Werner Buck (1987). Zie bijdrage van Miedema: "Dank zij Werner is de ongelijkheid in status tussen ons beiden nooit een probleem geweest. Integendeel, niet alleen in de vergaderingen, maar ook in de bijna steeds daaraan voorafgaande voorbesprekingen is er, voor zover ik me herinner, materieel van volledige gelijkwaardigheid sprake geweest, m.n. ook voor wat betreft openheid voor elkaar. Daar is een vriendschapsband mee gesmeed. Maar zakelijk gezien nog belangrijker is, dat daardoor op een onderlinge vertrouwensbasis kon worden gewerkt, waarin enigerlei achterdocht volstrekt afwezig was en waardoor het belangrijkste werk dat wij moesten helpen voorbereiden beter en sneller kon worden gedaan", p.69.

\section{\$3.4 Politieke onderhandelingskracht: drie periodes PNL-beleid (periode 1978-1992)}

355 Het instellingsbesluit zou pas op 31 augustus 1978 in de Staatskrant gepubliceerd worden. De Begeleidingscommissie functioneerde ondertussen als de informele voorloper van deze commissie.

356 Rijksarchief Limburg 04.09/6884; Concept-instellingsbeschikking Begeleidingscommissie Perspectievennota Zuid-Limburg, 18 januari 1978, p.1-2.

357 Rijksarchief Limburg 04.09/6867; Notulen overleg minister van EZ met Provinciaal Bestuur, 25 januari 1978, p.12.

358 De regionale taakstelling zou op basis van de werkloosheidscijfers van december 1977 uitkomen op het creëren van 11.000 arbeidsplaatsen tot 1981. De taakstelling tot en met 1985 lag tussen de 23.000 en 33.000 arbeidsplaatsen. Zie Rijksarchief Limburg 04.09/6867; Brief GS aan minister van Financiën, 7 maart 1978, p.1

359 Rijksarchief Limburg 04.09/6889; Notulen $4^{\mathrm{e}}$ vergadering Begeleidingscommissie van 2 maart 1978, p.4.

360 idem.5.

361 idem.4.

362 Rijksarchief Limburg 04.09/6867; Notulen overleg minister van Onderwijs en Wetenschappen en Provinciaal Bestuur van 22 februari 1978, p.2.

363 Rijksarchief Limburg 04.09/6867; Verslag overleg met minister en staatssecretaris van Sociale Zaken met Provinciaal Bestuur, 7 maart 1978, p.4.

364 Rijksarchief Limburg 04.09/6879; Verslag van het overleg tussen een delegatie uit de ministerraad en het College van Gedeputeerde Staten van Limburg, 17 maart 1978. Zie citaten p.2 en p.5. 
365 idem.4.

366 Tussen de twee 'Catshuis-overleggen' vergaderde ook nog de Begeleidingscommissie. Ruim 37 pagina's met tientallen tekstvoorstellen, amendementen en wijzigingen van Provincie en de betrokken ministeries werden hier door het secretariaat doorgenomen. In de kantlijn stond de uitkomst van het ambtelijke tussenoverleg bijgeschreven: 'accoord', 'compromis', 'niet', 'aanpassen', 'do a.s.' [donderdag aanstaande - HvE]. Zie Rijksarchief Limburg 04.09/6890; Diverse bijlagen bij het verslag van de $5^{\mathrm{e}}$ (spoed) vergadering van de Begeleidingscommissie, 21 maart 1978.

367 Rijksarchief Limburg 04.09/6890; Zie bijlage 1 'Communiqué van 28 maart 1978' bij de nota aan Provinciale Staten met het definitieve standpunt, 10 april 1978, p.2.

368 Tweede Kamer 1977-1978, 13969 No.5 Perspectievennota Zuid-Limburg. Nota Definitieve Standpuntbepaling van de Regering en het Provinciaal Bestuur van Limburg met betrekking tot de beleidsaanbevelingen in de concept-Perspectievennota Zuid-Limburg en de resultaten van de inspraakprocedure, april 1978, p.27. Online beschikbaar via www.statengeneraaldigitaal.nl.

369 De theorie van het 'comparatief kostenvoordeel' komt uit de internationale economie. Zie voor een nadere uitleg hierover Cuyvers, Embrechts \& Rayp (2009), hoofdstuk 3. Met dank aan Rien van Gendt voor dit inzicht.

370 Rijksarchief Limburg 04.09/11447; GS-notulen van 2 januari 1979. De resultaten na stemming over de ingediende moties tijdens het debat van 4 december werden door het College als 'alleszins bevredigend' bestempeld.

371 Rijksarchief Limburg 04.09/6868; Verslag van overleg Regering en College van Gedeputeerde Staten van Limburg, 16 november 1979, p.5. Van Agt kaartte dit aan en Kremers bevestigde hem daarin.

372 Zo waren er diverse kritische reacties van de intermediaire organisaties bij de presentatie van het eerste Jaarrapport PNL 1978 door de Begeleidingscommissie. Zie Rijksarchief Limburg 04.09/6964 voor alle reacties op het Jaarrapport PNL 1978.

373 Op 8 november 1979 bezocht Van Agt Zuid-Limburg voor een werkbezoek aan het herstructureringsgebied. In de Begeleidingscommissie was toen reeds overeenstemming bereikt over een aantal minder majeure punten en in de ministerraad was op 9 november de inzet van de regering voor het overleg met Limburg al voorbesproken (Derix, 1990: 97-99).

374 Rijksarchief Limburg 04.09/6868; Verslag van overleg Regering en College van Gedeputeerde Staten van Limburg, 16 november 1979, p.8.

375 De motie Deetman was eerder in de Tweede Kamer aangenomen en droeg de regering op om de Rijksuniversiteit Limburg te laten uitgroeien tot 6.000 studenten in 1990.

376 idem.11-12.

377 Het Limburgse tweede kamerlid W.G. Bremen (CDA) was de voorzitter van deze Bijzondere Kamercommissie Perspectievennota Zuid-Limburg in de periode 1978-1981. De verschillende jaarrapporten en de standpuntbepalingen waren terugkerende onderwerpen die in de commissie werden besproken. Ook Provinciale Staten van Limburg hadden begin 1979 naar analogie van de Kamercommissie een bijzondere Vaste Commissie PNL ingesteld. Zie Rijksarchief Limburg 04.09/10798; Instellingsbesluit, 23 februari 1979.

378 In een werkbezoek van de Kamercommissie aan Limburg op 27 november 1978 werden naar aanleiding van de beantwoording van de schriftelijke vragen al standpunten uitgewisseld tussen regering en het College. Ook bij de stemmingen over de ingediende moties werd er vanuit het College geschakeld met de Limburgse Kamerleden. Zie Rijksarchief Limburg 04.09/11446; Notulen GS van 5 december 1978: Een dag na het Kamerdebat werd druk gespeculeerd over de mogelijke meerderheidsstandpunten tussen de verschillende politieke partijen. Uiteindelijk werden 18 moties aangenomen waaronder de twee van Deetman.

379 Tweede Kamer OCV/UCV 1978-1979; Verslag $1^{\mathrm{e}}$ vergadering Bijzondere Commissie voor de Perspectievennota Zuid-Limburg, 4 december 1978, p.491 en 506 (moties) en p.502 (antwoord 
minister Pais). Online beschikbaar via www.statengeneraaldigitaal.nl.

380 Rijksarchief Limburg 04.09/11641; 'Kort resumé van de informele gedachtewisseling tussen de Sociale Partners en Gedeputeerde Staten', 28 september 1979, p.3. De afstemming tussen Provincie en sociale partners verliep vanaf het eerste overleg in mei 1978 moeizaam. Rijksarchief Limburg 04.09/6964; PS-nota 'Rapportage Perspectievennota over 1978', 24 april 1979, p.7-8. Ook het overleg met de gemeenten Maastricht, Heerlen en Roermond verliep stroef. Alledrie de gemeenten hadden zich bijvoorbeeld afzonderlijk van elkaar kandidaat gesteld voor vestiging van de Open Universiteit, dit tot grote ergernis van Gedeputeerde Staten. Zie ook Rijksarchief Limburg 04.09/11447; GS-notulen van 6 februari 1979, p.1.

381 In de periode 1977-1980 kwam er een nieuw hoofd voor de Centrale dienst Personeel en Organisatie (CPO) en kregen de Provinciale Planologische Dienst en de Provinciale Waterstaat een nieuwe directeur. Een nieuwe functie werd gecreëerd van adjunct-griffier die volledig belast werd met het initiëren van nieuwe projecten. Bovendien kwamen er nieuwe mensen op de posten van de griffier en kabinetschef. Binnen het gehele provinciale apparaat moest het PNL-beleid de hoofdprioriteit worden. Er werd een intern 'coördinatieoverleg' ingericht waarin de gedeputeerden onderling in aanwezigheid van de afdelingshoofden regelmatig projecten overlegden en afstemden. Zie Rijksarchief Limburg 04.09/6953; Notulen eerste coördinatievergadering PNL, 25 september 1978: Voorzitter Buck deelde mede dat 'de begeleiding [van de PNL-projecten - HvE] actief en administratief behoorde te zijn en prioriteit te krijgen t.o.v. de overige afdelingszaken', p.1.

382 In een overzicht van alle projecten van september 1978 bleek dat van de 124 ingediende projecten er maar 37 voldeden aan de opgestelde criteria. Veel afgewezen projecten (het ging hier om de realisatie van niewe maatschappelijke voorzieningen als sporthallen, jongerenaccommodaties, bibliotheken, gemeenschapshuizen en muziekscholen) waren ingediend door het Stadsgewest Oostelijke Mijnstreek. Deverplichte eigen bijdrage van de gemeenten ontbrak dikwijls, maar was een voorwaarde om voor financiering in aanmerking te komen. Zie overzicht in Rijksarchief Limburg 04.09/6953; GS-nota 'Projecten PNL 1978' van de 4 e Afdeling, 21 september 1978. Anderhalf jaar later werd bij de bespreking van het jaarrapport PNL 1979 in de Vaste Commissie eenzelfde conclusie getrokken: "Aan de gemeenten en gewesten is medegedeeld dat voor PNL-bijdragen slechts die projecten in aanmerking komen die een zodanig werkgelegenheidsbevorderend en structuurverbeterend karakter hebben dat zij voor het hele herstructureringsgebied en/of grote delen daarvan van aanzienlijk belang zijn. De meeste projecten die worden ingediend voldoen hier niet aan", Rijksarchief Limburg 04.09/10798; Verslag van de Vaste Commissie PNL, 21 april 1980, p.2-3.

383 De criteria voor financiering van PNL-projecten waren vastgelegd in de definitieve standpuntbepaling van april 1978. Met name de criteria van structuurversterking (criterium d) en cofinanciering (criterium g) bleken lastig te vertalen naar voorstellen voor projecten. Tweede Kamer 1977-1978, 13969 No.5 Perspectievennota Zuid-Limburg. Nota Definitieve Standpuntbepaling van de Regering en het Provinciaal Bestuur van Limburg met betrekking tot de beleidsaanbevelingen in de concept-Perspectievennota Zuid-Limburg en de resultaten van de inspraakprocedure, april 1978, p.64. Overigens was er ook al rekening gehouden met 'enige soepelheid' bij de toetsing aan deze criteria, met name wanneer het ging om experimenten of enkele andere 'zwaarwegende argumenten', idem. p.64. Online beschikbaar via www.statengeneraaldigitaal.nl.

384 Daar kwam nog eens 1 miljoen gulden bij vanuit het ministerie van CRM zodat er in totaal 26 miljoen gulden per jaar voor de periode 1977 t/m 1980 beschikbaar was voor de herstructurering. Elke jaar zou er in oktober/november een inventarisatie plaats hebben van de projecten voor het komende jaar.

385 Rijksarchief Limburg 04.09/6953; Verslag $1^{\mathrm{e}}$ Interne coördinatievergadering PNL, 25 september 1978, p.2.

386 M.C.E. van Gendt had voordat hij bij de Provincie Limburg kwam bij de Organisation for Economic 
Co-operation and Development en de Wetenschappelijke Raad voor het Regeringsbeleid gewerkt. In deze laatste functie had hij ook J. Kremers leren kennen (die voorzitter van de eerste WRR was geweest) die hem in 1980 vroeg om adjunct-griffier te worden. Dit was een speciale vrijgestelde functie met maar één doel: nieuwe projecten in het kader van het Perspectievennotabeleid te formuleren. Van Gendt werd later o.a. directeur van de Van Leer Group Foundation.

387 Rijksarchief Limburg 04.09/6869; GS-nota 'Stand van zaken m.b.t. uitvoering afspraken met de Regering dd. 16 november 1979', 4 juni 1980. Het was met name de uitvoering van het Arbeidsplaatsenplan, de uitbouw van de rijksuniversiteit en de verruiming van de mogelijkheden van het LIOF, die naar oordeel van het College 'onbevredigend' verliepen.

388 Rijksarchief Limburg 04.09/6869; Brief minister-president Van Agt aan College van GS Limburg, 26 november 1980.

389 Dit was eerder toegezegd door Van Agt. Zie Rijksarchief Limburg 04.09/6869; Brief ministerpresident Van Agt aan College van GS Limburg, 26 november 1980, p.4-5.

390 Rijksarchief Limburg 04.09/6868; Verslag overleg ministers van Economische Zaken en Sociale Zaken en Gedeputeerde Staten van Limburg in het kader van de voorbereiding van de nota Regionaal Sociaal-Economisch Beleid 1981-1985, 4 december 1980, p.2. Overigens werd er in diezelfde nota een bedrag van 10,1 miljoen gulden voor Limburg uitgetrokken om de bouwsector te stimuleren.

391 Het herstructureringsgebied Zuid-Limburg, de regio Roermond en Venlo en Venray behielden hun premie-percentages in de nieuwe periode. Weert en Gennep werden geschrapt als 'premiekernen'. De Nota Regionaal Sociaal-Economisch Beleid 1981-1985 zou uiteindelijk op 17 februari 1981 aan de Tweede Kamer worden aangeboden.

392 Pas in 1981 was het hoge woord er ook publiekelijk uit, zo merkte het Dagblad voor NoordLimburg op na de aanbieding van het Jaarrapport over 1980. Zie Rijksarchief Limburg 04.09/6915; Dagblad voor Noord-Limburg 'Commissie geeft toe: Doelstellingen van perspectievennota worden niet gehaald', 10 april 1981. De Limburger (editie Maastricht) sprak van een falend beleid: 'Commissie geeft falen toe. Beleid PNL deels mislukt', 10 april 1981. Het Financiële Dagblad had een minder pessimistische kop: 'Ontwikkeling werkloosheid in Zuid-Limburg minder ongunstig dan in gehele land', 10 april 1981.

393 Op 3 juni 1981 vond er ook nog een politiek beraad plaats met de inmiddels demissionaire regering. Daarbij werd uitgesproken dat in de tweede periode het wegwerken van de regionale werkloosheidscomponent nog steeds als doelstelling overeind stond. Zie Rijksarchief Limburg 04.09/6870; Verslag overleg Regering en Provinciaal Bestuur van Limburg, 3 juni 1981, p.6.

394 De Provincie Limburg stelde altijd zelf de conceptagenda op voor het overleg met de regering en deed daarbij tevens tekstvoorstellen voor de te nemen besluiten. In onderling overleg werd vervolgens de definitieve agenda vastgesteld. Na het overleg werd er consequent een persbericht opgesteld met daarin de bereikte punten van overeenstemming.

395 In een voorbereidend overleg met de staatssecretaris van Economische Zaken, P.H. van Zeil (CDA), bleek dat de ambtenaren van zijn ministerie veel kanttekeningen plaatsten bij de gevraagde investering van 10 miljoen gulden. Zie Rijksarchief Limburg 04.09/6871; Verslag overleg staatssecretaris van EZ met gedeputeerde Mastenbroek, 27 januari 1982, p.1-3.

396 Rijksarchief Limburg 04.09/6872; Verslag overleg tussen regering en Provinciaal Bestuur van Limburg, 12 maart 1982, p.2-3.

397 idem.2.

398 Zie ook Rijksarchief Limburg 04.09/10800; Verslag van besloten vergadering van de Vaste Statencommissie PNL, 10 maart 1983 waar gedeputeerde E.M. Mastenbroek (CDA) meedeelde dat 'het Kabinet (...) wenst te komen tot het ter beschikking stellen van financiële middelen, hetgeen beschouwd zou kunnen worden als een afkoopsom (...)', p.3.

399 Er werd door de regering 34 miljoen gulden beschikbaar gesteld voor het creëren van 1.350 extra 
tijdelijke arbeidsplaatsen in 1982 en nog eens 10 miljoen gulden in het kader van de regionale arbeidsmarktafspraken overeenkomend met nog eens 300 extra tijdelijke arbeidsplaatsen. Rijksarchief Limburg 04.09/6872; Besluitenlijst van het overleg tussen regering en GS Limburg dd. 12 maart 1982, p.1. De besluitenlijst werd op 16 maart 1982 naar de Tweede Kamer toegestuurd.

400 In eerste instantie werd S. Miedema voorzitter van de nieuwe gevormde Interdepartementale Commissie voor Regionaal Beleid, die de gelijknamige ministeriële Commissie adviseerde. Per 1 januari 1986 vertrok hij bij het ministerie van EZ om secretaris-generaal van het ministerie van Sociale Zaken en Werkgelegenheid te worden.

401 Het vertrek van Miedema was een grote teleurstelling voor het Provinciaal Bestuur. Zie Rijksarchief Limburg 04.09/6874; Verslag overleg tussen minister van EZ en GS, 10 februari 1983, p.2.

402 Voor Limburg was op de eerste plaats de privatisering van DSM in de tweede helft van de jaren '80 een belangrijk item. De discussie startte in 1985 en ging vooral over de aardgasrevenuen. De beursgang zou uiteindelijk in 1989 plaatsvinden. Zie Lintsen [ed] (2000). Research tussen vetkool en zoetstof. Zestig jaar DSM Research 1940-2000, p.106. Een tweede item betrof de privatisering van het provinciaal grondbezit van de Maasplassen. Uiteindelijk werd er in 1986 een deal gesloten met Aqua Terra N.V. voor een gebied van 3.000 ha.

403 Het voeren van een 'speerpuntenbeleid' was een van de centrale aanbevelingen uit de verschillende adviezen die de Adviescommissie inzake het Industriebeleid (Commissies onder leiding van G.A. Wagner) begin jaren '80 deed. De commissie was ingesteld in 1981, nadat in 1980 de Wetenschappelijke Raad voor het Regeringsbeleid een kritisch rapport had uitgebracht over het beleid van de regering voor de Nederlandse industrie. Een van de WRR-auteurs, M.C.E. van Gendt zou in dat jaar adjunct-griffier worden bij de Provincie Limburg. Online beschikbaar [laatst geraadpleegd 13-9-2009]: www.wrr.nl/content.jsp?objectid=2671 Zie ook: Rijksarchief Limburg 04.09/10799; Notitie 'Doel- en taakstellingen $2^{\mathrm{e}}$ planperiode PNL', 2 juli 1982, p.7-8. Bijlage 3 bij stukken aan Vaste Statencommissie PNL, brief van 16 november 1982.

404 Rijksarchief Limburg 04.09/6877; Brief van de Directie van LIOF aan de Raad van Commissarissen, 20 oktober 1983. Daarin pleitte de directie voor een 'ontwikkelingsfunctie' van het LIOF. Hiermee kon het LIOF dieper in projecten betrokken raken en gerichter advies uitbrengen aan de Provincie. De voorbeelden die werden aangehaald waren de investeringen rondom de Oost-westbaan en de projecten in het kader van medische technologie. Zie p.2-3.

405 SER (1984). Advies sociaal-economisch beleid op middellange termijn 1984-1987. No. 84/09, 27 april 1984, p.221. Vanaf 1981, zo constateerde de SER, had het LIOF zich steeds meer bezig gehouden met een verbreding van het aantal risicodragende financieringen. Online beschikbaar via www. ser.nl.

406 Tweede Kamer, 1987-1988, 20390 No.1 Herijking Regionaal Beleid, 10 december 1987, p.10. Daarnaast werden een aantal budgetten gedecentraliseerd voor het opstellen van economische plannen en planning van kleinere randvoorwaardelijke aspecten. Online beschikbaar via www. statengeneraaldigitaal.nl.

407 Zie bijvoorbeeld Rijksarchief Limburg 04.09/6883; Verslag overleg minister van EZ R.W. de Korte en staatssecretaris EZ A.J. Evenhuis met Provinciaal Bestuur van Limburg, 17 februari 1987. Gouverneur Kremers verwees hier nadrukkelijk naar de goede coördinatierol die minister De Korte's voorganger, Van Aardenne, had gespeeld, p.3.

408 Redenerend vanuit een partijpolitieke logica zou het veel meer voor de hand hebben gelegen dat Van Aardenne als VVD-minister warmere banden zou onderhouden met de noordelijke provincies (met de VVD- commissarissen der koningin H. Wiegel en H.J.L. Vonhoff). Dat dit in de praktijk toch niet het geval was blijkt wel o.a. uit het feit dat hij in 1987 (na zijn ministerschap) president van de Raad van Commissarissen bij het LIOF werd naast diverse andere - meer internationaal prestigieuze - commissariaten. Toch moest er ook met Van Aardenne stevig onderhandeld worden. Zie Rijksarchief Limburg 04.09/6876; Gecombineerde verslag van het overleg tussen 
Regering en Provinciaal Bestuur van Limburg op 25 maart en 22 april 1983, p.2; Rijksarchief Limburg 04.09/6876; Gecombineerde verslag overleg regering en College van GS van 25 maart en 22 april 1983, p.34; Derix, 1990: 145; Rijksarchief Limburg 04.09/6879; Gecombineerde verslag van het overleg tussen kabinet en Provinciaal Bestuur van Limburg op 26 juni, 10 en 12 juli 1984.

409 Tweede Kamer 1984-1985, 19084 No.2; Nota Regionaal Sociaal-Economisch Beleid 1986-1990, 12 juli 1986. Online beschikbaar via www.statengeneraaldigitaal.nl. Zie p.10: "Dient dan ook het regionale beleid nog een rol te spelen ten aanzien van de sociaal-economische ontwikkeling van het westen des lands? Het antwoord hierop moet bevestigend luiden, nl. in zoverre het regionale beleid met inbegrip van het arbeidsvoorzieningsbeleid, meer in het algemeen de sociaaleconomische ontwikkeling op het niveau van de regio's beoogt te bevorderen".

410 idem.31.

411 idem.91. Zie ook Archief Provincie Limburg 54060; Etil-rapportage van september 1987.

412 Overigens ging deze derde en laatste PNL-periode over een periode van vijf in plaats van de eerdere periodes van vier jaar.

413 Bibliotheek Provincie Limburg; Provincie Limburg (1986). Provinciaal Sociaal Economisch Beleidsprogramma 1986-1990. April 1986.

414 Zie bijvoorbeeld Rijksarchief Limburg 04.09/6880; Verslag overleg staatssecretaris van EZ Van Zeil en gedeputeerde Mastenbroek van 20 november 1985. Een van de gemaakte afspraken luidde: "Voorts wordt gestreefd naar een eenvoudiger opzet van het politiek beraad, nl. daar alleen afconcluderen van goed voorbereide zaken. Dus geen 'verrassingen' meer, maar reeds bilateraal overeengekomen zaken", p.3.

415 Rijksarchief Limburg 04.09/6950; Persbericht ministerie van Economische Zaken, No.511 'Regioprogramma's 1986 vastgesteld', 18 december 1986, p.5.

416 Minister-president Lubbers zelf heeft nooit een politiek beraad met het Limburgse College van GS voorgezeten. Hij liet dat over aan de ministers van Economische Zaken G.M.V. van Aardenne (VVD, 1982-1986), R.W. de Korte (VVD, 1986-1989) en staatssecretarissen P. Bukman en I.C.M.Th. Van Rooy (CDA, 1989-1993). Op belangrijke momenten in de voorbereiding was er wel overleg op het Torentje, zoals in 1983 met de nieuwbouw van het Academisch Ziekenhuis en later ook met de Oost-Westbaan. Zie Derix, 1990: 145.

417 Archief Provincie Limburg 54060; Verslag van het overleg tussen kabinet en het Provinciaal Bestuur, 20 november 1987, p.4.

418 idem.9.

419 Archief Provincie Limburg 14370; Verslag overleg tussen delegaties van het kabinet en Provinciaal Bestuur van Limburg, 1 juni 1990.

420 Tweede Kamer 1989-1990, 21571 No.2 Nota Regionaal-Economisch Beleid 1991-1994, 25 juni 1990, p.38. Online beschikbaar via www.statengeneraaldigitaal.nl.

421 SER (1990). Advies Regionaal-economisch beleid. Advies no. 19 inzake het regionaal-economisch beleid 1991-1994, 19 oktober 1990, p.12. Online beschikbaar via www.ser.nl.

422 In totaal was de Begeleidingscommissie sinds haar oprichting 82 keer bij elkaar geweest en waren er 9 politieke beraden geweest sinds 1978. In een persbericht meldde de Provincie dat er ongeveer 2,3 miljard gulden aan financiële middelen sindsdien zijn besteed. Zie Rijksarchief Limburg 04.09/6884; Provincie Limburg (1990). Persbericht 217/90 'PNL-commissie voor laatste keer bijeen', 14 december 1990.

423 De affaire staat bekend als de 'vriendenrepubliek', naar het gelijknamige boek uit 1996 van een van de betrokken onderzoeksjournalisten, J. Dohmen. Uiteindelijk werden de burgemeesters van Gulpen en Brunssum, een wethouder van Maastricht en twee betrokken provinciale ambtenaren veroordeeld. Oud-gedeputeerde Riem werd in 1997 als burgemeester van Brunssum veroordeeld wegens valsheid in geschrifte. De affaire leidde tot een landelijke aanscherping van de aanbestedingsregels. Het aannemen van steekpenningen werd nooit aangetoond. 
424 Trouw (1993). 'Palermo aan de Maas', 23 oktober 1993. Online beschikbaar [laatst geraadpleegd 14-8-2009]: www.trouw.nl/krantenarchief/1993/10/23/2689948/PALERMO_AAN_DE_MAAS. html?all=true.

425 Bibliotheek Provincie Limburg. Provincie Limburg (1991). Basisaccoord 1991-1995 CDA-PvdA$C D A$, april 1991. Zie inleiding.

\section{\$3.5 Europese proefregio: een provinciaal technologiebeleid (periode 1992-2004)}

426 De gemeente Maastricht ontwikkelde samen met het Algemeen Burgerlijk Pensioenfonds begin jaren ' 90 het Sphinx/Ceramiqueterrein. Diverse grote binnenstedelijke herstructureringen zouden volgen. De gemeenten in de Oostelijke Mijnstreek verenigden zich onder de naam Parkstad Limburg en de gemeente Venlo versterkte haar internationale positie met de uitbouw van bedrijventerreinen voor logistiek en agri-business. Het grotestedenbeleid van de rijksoverheid zorgde ervoor dat vanaf 1994 een groot aantal financiële geldstromen rechtstreeks naar de grotere Nederlandse gemeenten liepen. Uiteindelijk zou de Provincie Limburg in 1999 met een provinciaal grotestedenbeleid komen voor de gemeenten Maastricht, Venlo en Heerlen (later aangevuld met de gemeente Sittard-Geleen).

427 Zie voor de ontstaansgeschiedenis en evaluatie van het Vertrouwenspact Werkgelegenheid Limburg: Boot (2002). 'National report on the overall performance of the TEP program: Netherlands', in Ecotec Research and Consulting (2002). Thematic Evaluation of the Territorial Employment Pacts. Final report to Directorate General Regional Policy. Annex III: National and case study reports, oktober 2002. Het Vertrouwenspact was in 1996 voorbereid en werd een jaar later door de meest betrokken sociale partners ondertekend. De ondertekening viel samen met de ondertekening van het Verdrag van Amsterdam (1997) waarin bevordering van de werkgelegenheid in Europa een officiële doelstelling werd van de Europese Commissie.

428 Het Regionaal Technologieplan Limburg (RTP) was niet het enige economische programma binnen het provinciale economische beleid van de jaren '90. Het arbeidsmarktbeleid onder de naam Vertrouwenspact Werkgelegenheid Limburg zou in de tweede helft veel politieke aandacht krijgen. Maar ook op de beleidsvelden onderwijs, toerisme \& recreatie, land- en tuinbouw, en transport $\&$ logistiek werden door de Provincie activiteiten ondernomen. Zie Archief Provincie Limburg 20173; Provincie Limburg (1994). Economisch Beleidskader - Op weg naar 2000, 28 oktober 1994, p.12-17. Zie ook Bibliotheek Provincie Limburg; Provincie Limburg (2000). Sociaal Economische Hoofdstructuur. Bijlage bij Durven en Doen.

429 Deze notie was begin jaren '80 door de Commissie Wagner bepleit. In 1984 stuurde de minister van Economische Zaken een brief naar de Tweede Kamer over het onderwerp 'Project Technologiebeleid'. Het was een eerste proeve van uitwerking voor een nationaal technologiebeleid. Tweede Kamer 1983-1984, 17 973, No.5. Brief van 13 februari 1984. Online beschikbaar via www. statengeneraaldigitaal.nl.

430 Het contact was tot stand gekomen via het EFRO-programmamanagement en het consultancybureau Erac.

431 Archief Provincie Limburg 14127; 'Minutes of the inter services meeting on Regional Plans held in DG XVI on $19^{\text {th }}$ october 1993'. Zie ook de interne memo 'Regional Technology Plans - Pilot studies under art. 7 of ERDF' van R. Miège (Directorate-General XIII Telecommunications, information market and exploitation of research) aan zijn collega R. Shotton (Directorate-General XVI Regional Policies), 29 oktober 1993. Zie ook de fax van Luc Broos (Erac) aan de provinciale afdeling Economie en Gemeentefinanciën van 20 oktober 1993, p.1.

432 Het ging hier om het Directorat-General XVI Regional Policies en het Directorat-General XIII Technology. M. Landabaso (DG XVI Regional Policies) was de initiatiefnemer van het RTP. In een op persoonlijke titel geschreven artikel benadrukte hij de koppeling tussen algemeen regionaal economisch beleid en het technologiebeleid. Zie 14127; Landabaso, M. (1992). 'Community's 
regional development and innovation: promoting 'innovative millieux' in practice', p.3. Hij noemde deze discrepantie het 'technology gap'. Een bewerking van het artikel verscheen een jaar later in European Planning Studies, 1993, Vol.1 No.3.

433 Dit was het Europese 'STRIDE-programma' geweest, dat van 1991 tot 1994 liep. STRIDE stond voor Science and Technology for Regional Innovation and Development.

434 Archief Provincie Limburg 14127; Zie commentaar van Luc Broos in zijn persoonlijk verslag van de $4^{e}$ STRIDE-Conference te Metz op 7 en 8 februari 1994, p.2. Verslag is uitgebracht aan de Provincie Limburg op 10 februari 1994 per fax.

435 Archief Provincie Limburg 14127; Fax van L. Broos (Erac) aan de provinciale afdeling Economie en Gemeentefinanciën van 20 oktober 1993, p.1-2.

436 Archief Provincie Limburg 14127; Fax van L. Broos aan D. Ruijters, 25 oktober 1993. In de bijlage zit een notitie met de algemene opzet van het plan. Zie p.2. Overigens was een brede lokale en regionale samenstelling ook een eis die de Europese Commissie stelde.

437 Archief Provincie Limburg 14127; Memo 'Conclusies overleg op 8 november 1993 te Brussel over het Regionaal Technologieplan Zuid-Limburg'. In de memo was een van de eerste bespreekpunten de geografische afbakening van het plan. Het ging hier om de vraag 'heel Limburg of slechts delen van Limburg', p.1. Aangezien het project een aanvraag zou doen voor Europese subsidie in het kader van de Doelstelling 2 (gericht op de regio Zuid-Limburg), was men ervan uitgegaan dat het Regionaal Technologieplan ook een Zuid-Limburgs plan zou worden. De ambtenaren van de Europese Commissie bleken geen bezwaren tegen het verzoek van de Provincie om het programma te verbreden naar heel Limburg.

438 Archief Provincie Limburg 20173; 'Nota voor Gedeputeerde Staten Regionaal Technologieplan, bijeenkomst 6/7 juni 1994', mei 1994. In de bijlage was de samenstelling van de stuurgroep opgenomen: LIOF, KVK Midden-Limburg, 2 Innovatiecentra, Océ Nederland, Inalfa bv., Erac consulting, Europese Commissie/DGXIII, het adviesbureau Marketing High-tech Projects en de Provincie Limburg. Helaas zijn de notulen van de vergaderingen van de RTP-stuurgroep vernietigd zodat er geen direct zicht is op de verschillende standpunten geuit door betrokken partijen. Uit de overige dossierstukken blijkt echter niet dat de stuurgroep een zeer actieve sturende rol in het proces heeft gespeeld. In 1996 werd bovendien besloten om de stuurgroep om te vormen tot 'platform'. Zie 34326; Provincie Limburg (1996). RTP Limburg. Beleidsdocument, mei 1996, p.42.

439 Archief Provincie Limburg 14127; Provincie Limburg (1993). Regionaal Technologie Plan Limburg. Plan van aanpak, 16 november 1993, p.13. De stuurgroep heette in het begin nog 'platform', maar begin 1994 werd de naam gewijzigd in 'stuurgroep' om verwarring met het bestaande 'platform industrie' te voorkomen.

440 idem.4.

441 Archief Provincie Limburg 14127; Verslag intern overleg van 2 november 1993, p.1. In het verslag van het overleg tussen de ambtelijke afdeling van de Provincie het DG XIII, benadrukte de ambtenaren van de Europese Commissie: "Bij de aanpak van het RTP moet er voor gewaakt worden dat het RTP niet het karakter krijgt van een projectenlijst en teveel de aandacht komt te liggen op de ontwikkeling van nieuwe perspectiefvolle technieken. [...] Centraal staat het creëren van draagvlak en gezamenlijke ontwikkeling van publieke en private partijen met het oog op technologie". Zie Fax van L. Broos aan Provincie, 30 mei 1994, p.2.

442 Dit is een vertegenwoordiging van Nederlandse rijksambtenaren en diplomaten die in Brussel de regeringscontacten onderhielden tussen Europese Commissie en de Nederlandse overheid.

443 Archief Provincie Limburg 14127; Mail van D. Ruijters (Provincie Limburg) aan W. Bruinsma (ministerie van EZ), 12 november 1993. Een formele brief aan het ministerie volgt op 15 november 1993.

444 Het ging hier concreet om een project dat viel onder Europees Fonds voor Regionale Ontwikkeling (EFRO) Doelstelling 2 Regio Zuid-Limburg. 
445 Archief Provincie Limburg 14127; Brief van ministerie van de plaatsvervangend DG Economische Structuur van het ministerie van Economische Zaken aan het College van GS Limburg, 3 februari 1994.

446 idem. 1

447 Archief Provincie Limburg 20173; Provincie Limburg (1994). Regionaal Technologie Plan. Werkplan mei 1994, p.4.

448 Het betrof hier Doelstelling 2, onderdeel van de Europese Structuurfondsen die voor ZuidLimburg bestemd waren. Gedeputeerde J.H.M. Bronckers (CDA) was bovendien verantwoordelijk voor de Provinciale Financiën. De onduidelijkheid over wie het bestuurlijk aanspreekpunt was bleek o.a. uit het voorstel dat het College van Gedeputeerde Staten werd voorgelegd. Beide CDAgedeputeerden (C.E.M. de Waal en J.H.M. Bronckers) waren verantwoordelijk voor onderdelen van het programma. De vraag wie van het College zou deelnemen aan de openingsconferentie van het Regionaal Technologieplan Limburg werd expliciet gesteld door de economische afdeling. Het College besloot dat gedeputeerde De Waal het College zou vertegenwoordigen. Zie Archief Provincie Limburg 14127; GS-nota van 15 maart 1994.

449 Technologiebeleid was ook een item dat in de nationale verkiezingsprogramma's van 1994 veel aandacht kreeg. In het voorjaar van 1994 had de Adviesraad voor het Wetenschaps- en Technologiebeleid (AWT) een advies uitgebracht aan het ministerie van Economische Zaken over de relatie tussen economische structuur en technologiebeleid. Strekking van het advies was dat niet de overheid, maar het bedrijfsleven zelf de technologiegebieden moest bepalen waar zij potenties zagen. De Raad pleitte voor een sterker 'bedrijfsgericht technologiebeleid'. Zie AWT (1994). Technologiebeleid en economische structuur, april 1994. Samenvatting online beschikbaar [laatst geraadpleegd 20-8-2009]: www.awt.nl/?id=105\&s=kh.

450 20173; Notities Erac in de periode juni-juli 1994.

451 De clusterbenadering is sterk beïnvloed door de denkbeelden van de Amerikaanse bedrijfseconoom Michael Porter. In de ogen van Porter is vooral de samenhang (netwerk) tussen uitbesteders en toeleveranciers van belang om de regionale concurrentiekracht te versterken. Zie Porter (2004); Atzema et.al (2002): 157-159, 162-167.

452 Archief Provincie Limburg 20173; Erac Notitie 6 'Beoordeling van en visie op kennistransfer in Limburg. Beoordeling en visie gebaseerd op notities voor het RTP-onderzoek', 1 juli 1994, p.2-3.

453 Archief Provincie Limburg 20173; GS-nota 'Aanvraag offertes voor fase twee van het onderzoek t.b.v. het RTP', 15 november 1994. Voor een overzicht van de geselecteerde bedrijven en kennisinstellingen zie bijlage bij de nota.

454 Het was ook de tijd dat DSM begon met het stellen van kwaliteitseisen aan haar toeleveranciers. Certificering was daarin een belangrijke voorwaarde voor het chemiebedrijf om zaken te doen met haar toeleveranciers.

455 Dit was het Limburgse bureau Marketing High-tech Projects (MHP). Zij hadden eind mei 1994 van de Provincie Limburg opdracht gekregen voor de uit te voeren audits. Zie Archief Provincie Limburg 20173; Nota voor Gedeputeerde Staten 'Regionaal Technologieplan, bijeenkomst 6/7 juni 1994', mei 1994.

456 De afkorting Erac stond voor 'European Regional Affairs Consultants'.

457 Dit ging zelfs zo ver dat Broos op de 4e Stride Conferentie in Metz het woord voerde namens de Provincie Limburg in de plenaire vergadering om het Regionaal Technologieplan te presenteren. Zie Archief Provincie Limburg 14127; Brief van STRIDE coördinator D. Moers aan J.D. Dovermann (Provincie Limburg), 15 december 2003; Presentatie Broos 'Regional Technology Plan Limburg', 10 februari 1994; Notitie Broos 'Kort verslag van de 4e STRIDE-Conference te Metz', 10 februari 1994, p.1.

458 De second opinion werd uitgevoerd door het Maastricht Economic Research Institute on Innovation and Technology (Merit). Het Merit is een instituut dat gelieerd is aan de Maastrichtse 
universiteit. Merit was door de Provincie gevraagd - mede op advies van de Europese Commissie - voor deze second opinion.

459 Archief Provincie Limburg 20173; Zie brief van Merit aan Provincie Limburg, 22 augustus 1995.

460 Archief Provincie Limburg 20173; Ongedateerde notitie van Merit 'Kanttekeningen n.a.v. studie MHP Onderzoek fase 1'. Waarschijnlijk september 1995. Het Merit concludeerde: "Deze studie moet zeer voorzichtig gebruikt worden. Hoewel er nuttige cijfers in staan zijn de conclusies dikwijls moeilijk te relateren aan die cijfers. De representativiteit van sommige cijfers mag overigens ook betwijfeld worden", p.1.

461 Archief Provincie Limburg 20173; Brief Provincie Limburg aan Marketing High-Tech Projects van 31 oktober 1995, p.2.

462 De Provincie had in eerste instantie met de Europese Commissie afgesproken dat december 1995 de deadline was voor het in te leveren plan. In een brief van 9 november 1995 verleende de Europese Commissie de Provincie uitstel tot 26 maart 1996.

463 Zie voor een beschrijving van de workshops: Bibliotheek Provincie Limburg. Provincie Limburg (1996). Regional Technology Plan Limburg. Working document. Maart 1996, p.111, appendix 1.

464 Archief Provincie Limburg 20173; GS-nota 'RTP-Merit betrokkenheid' van 23 augustus 1995.

465 Dit gebeurde op basis van de second opinion van Merit. 20173; Merit (1995). 'Kanttekeningen n.a.v. studie MHP Onderzoek fase I', september 1995, p.13. Hierbij werd vooral gedoeld op het midden- en kleinbedrijf, waarvoor alleen het ter beschikking stellen van kennis en expertise door grote bedrijven onvoldoende was, maar voorzien moest worden van een aantal 'essentiële vaardigheden [...] zoals de organisatie, de marketing en de financiën', p.11.

466 Archief Provincie Limburg 34326; Provincie Limburg (1996). RTP Limburg - Beleidsdocument, mei 1996, p.7.

467 Archief Provincie Limburg 34326; GS-nota 'Regionaal Technologie Plan (RTP)', 14 mei 1996, p.1.

468 Archief Provincie Limburg 34326; Provincie Limburg (1996). RTP Limburg. Beleidsdocument, mei 1996, p.27. De vier onderliggende actielijnen (technologie, scholing, netwerken en kennisoverdracht) waren ingedeeld naar vier doelgroepen (bedrijven, kenniscentra, opleidingsinstellingen en intermediaire organisaties). Men startte met 11 projecten.

469 Zie Bibliotheek Provincie Limburg. Jaarrapportages RTP van 1996/1997 en 1998. Zie ook Bibliotheek Provincie Limburg; Provincie Limburg, Syntens Limburg, LIOF (2002). RIS-Limburg. nl. Provinciaal Innovatiebeleid 2002-2004. Januari 2002, p.3. In totaal werd er in de periode 19961999 119,8 miljoen euro besteed aan projecten en namen in 2000 ongeveer 1.400 bedrijven deel aan RTP-activiteiten, p.14-15.

470 Bibliotheek Provincie Limburg. Provincie Limburg (1999). Rapportage Regionaal Technologie Plan Limburg 1998. Juni 1999, p.7.

471 idem.10.

472 Bibliotheek Provincie Limburg; Ecorys (2003). Audit economisch beleid Provincie Limburg 19992002. Eindrapportage. 6 februari 2003, p.41 en 44.

473 Bibliotheek Provincie Limburg. Provincie Limburg (2000). De Limburgse economie in een nieuw millennium. Durven en doen. Sociaal Economisch Beleid Provincie Limburg 2000-2003. Oktober 2000, p.5.

474 idem.33. Zie ook Bibliotheek Provincie Limburg; Provincie Limburg, Syntens Limburg, LIOF (2002), p.47 waar Syntens en LIOF als 'primaire partners' werden benoemd.

475 idem.9.

476 Zie voor het feitenrelaas Bibliotheek Provincie Limburg. Commissie voor Onderzoek (2005). De levenscyclus van het Limburgs Bureau voor Toerisme 2000-2003, 8 maart 2005.

477 Zie EIM/Commissie Evaluatie tUL (2007). Evaluatie tUL. 20 april 2007, p.18-19. Online beschikbaar [laatst geraadpleegd 30-7-2010]:

www.rijksoverheid.nl/bestanden/documenten-en-publicaties/kamerstukken/2007/12/03/bijlage- 
a-evaluatierapport/44337a.pdf.

478 De motie luidde: "Provinciale Staten van Limburg, in vergadering van 31-5-2002, constaterende dat binnen de portefeuille economie sprake is van een structurele onderuitputting van de beschikbare budgetten, overwegende dat herprioritering naar aard en omvang van de economische activiteiten gewenst is. Verzoekt het College van GS een beleidsaudit in te stellen naar de effecten van het gevoerde economische beleid en hiervan de resultaten voor 1 februari 2003 aan PS aan te bieden. En gaan over tot de orde van de dag." Motie geciteerd in Bibliotheek Provincie Limburg; Ecorys (2003). Audit economisch beleid Provincie Limburg 1999-2002. Eindrapportage. 6 februari 2003, p.11.

479 Bibliotheek Provincie Limburg; Ecorys (2003). Audit economisch beleid, p.9-10.

480 Eerder al had secretaris-generaal J.W. Oosterwijk van het ministerie van Economische Zaken in zijn traditionele nieuwjaarsartikel 2003 sombere economische vooruitzichten voorspeld. Zie Oosterwijk, J.W. (2003). 'Van euforie naar realisme', in Economische Statistische Berichten, Jaargang 88, No.4392, 10 januari 2003. Online beschikbaar [laatst geraadpleegd op 21-8-2009]: www.nbcc.co.uk/download/esbez03.pdf.

481 Gedeputeerde M.J.A. Eurlings (CDA) had in het vorige college de portefeuille Welzijn, Zorg en Cultuur die nu naar gedeputeerde O.M.T. Wolfs (PvdA) ging. Zij was eerder verantwoordelijk geweest voor Natuur en Landschap. Gedeputeerde G.H.M. Driessen (CDA) had Ruimtelijke Ordening bij zijn portefeuille Agrarische Zaken gekregen. Gedeputeerde H.T.J. Vrehen (CDA) was nieuw in het College met de portefeuille Financiën en Algemene Zaken. H.F.M. Evers (PvdA) had de Economie-portefeuille na vertrek van Tindemans in 2002 verruild voor Milieu en Water. Alleen M.J.H. Vestjens (VVD) behield zijn 'oude' portefeuille Verkeer en Vervoer. In 2005 volgde L.J.P.M. Frissen (CDA) gouverneur Van Voorst tot Voorst (CDA) op.

482 Hier worden met 'intermediaire en vertegenwoordigende organisaties' de volgende organisaties bedoeld: de Kamers van Koophandel Noord- en Zuid-Limburg, de Limburgse Werkgevers Vereniging, de Limburgse Organisatie voor Zelfstandigde Ondernemers, de Limburgse Land- en Tuinbouwbond, het agentschap Syntens, de VVV's, de vakbonden, Centra voor Werk en Inkomen en Uitkeringsinstituut Werkgevers Verzekeringen.

483 Sabic Limburg (2003). Persbericht. 'Europees hoofdkantoor Sabic naar Nederland', 14 juli 2003. Online beschikbaar [laatst geraadpleegd 21-8-2009]: www.sabic-limburg.nl/nieuws-en-pers/_ nl/6capqnc6v8rk.htm

484 Na de omschakeling van steenkolen naar chemie, betekende de verkoop een nieuwe transformatie binnen DSM van zware bulkchemie naar de verfijnde en hoogwaardige materialen- en productietechnieken. Zie voor een overzichtswerk: Lintsen, H. [ed.] (2000). Research tussen vetkool en zoetstof. Zestig jaar DSM Research 1940-2000.

485 DSM/Sabic (2002). Gezamenlijk persbericht. 'Sabic neemt petrochemische activiteiten over van DSM', 3 april 2002. Online beschikbaar [laatst geraadpleegd 21-8-2009]:

www.dsm.com/nl_NL/html/media/press_releases/Sabic_acquire_DSM_April32002.htm.

486 Merit/Soete, L. (2004). LELA (Leuven-Eindhoven-Luik-Aken). Naar een technologische topregio. Contouren voor een nieuw regionaal beleid. Maart 2004, p.19.

487 Ministerie van Economische Zaken (2004). Pieken in de delta. Gebiedsgerichte Economische Perspectieven. Juli 2004. Online beschikbaar [laatst geraadpleegd 4-8-2010]: www.rijksoverheid.nl/bestanden/documenten-en-publicaties/notas/2004/07/01/nota-pieken-inde-delta-gebiedsgerichte-economische-perspectieven/nota-piekenindedelta.pdf.

488 Er was door gouverneur B.J.M. van Voorst tot Voorst (CDA) en gedeputeerde M.J.A. Eurlings (CDA) begin 2004 bij staatssecretaris van Economische Zaken, C.E.G. van Gennip (CDA), stevig aangedrongen om de concepttekst van de nota aan te passen. In het concept werd nog gesproken van het economisch kerngebied 'Zuidoost-Brabant'. Uiteindelijk werd dit gewijzigd in 'ZuidoostNederland'. Zie ook Provincie Limburg (2004). Persbericht 12 juli 2004. 


\section{$\$ 3.6$ Het ontstaan van de Versnellingsagenda (periode 2004-2007 en verder)}

490 Zie bijvoorbeeld Bibliotheek Provincie Limburg; Notitie voor Provinciale Staten 'Thema Ondernemend Limburg', 13 april 2004, p.12.

491 Archief Provincie Limburg 90433; Merit/Soete, Luc (2004). LELA (Leuven-Eindhoven-LuikAken). Naar een technologische topregio. Contouren voor een nieuw regionaal beleid. Maart 2004. GKS\&P/Tindemans (2004). Advies Limburg over rol innovatieregio EL(L)MA. 25 maart 2004. In opdracht van het ministerie van Economische Zaken verscheen: GKS\&P/Tindemans (2004). Een innovatieregio EL(L)MA. 17 maart 2004.

492 Archief Provincie Limburg 90433; GKS\&P/Tindemans (2004): 15.

493 Met de kennisketen wordt bedoeld het ontwikkelen, valoriseren, exploreren, en uiteindelijk exploiteren van kennis. Zie ook 90433; GKS\&P/Tindemans (2004). Advies Limburg, p.5.

494 idem.2. Zie ook 90433; Merit/Soete (2003).

495 Archief Provincie Limburg 90433; Merit/Soete (2004), p.9.

496 idem.5-6. De aanbeveling aan de Provincie om vooral met de grotere bedrijven haar strategie te ontwikkelen was in de audit economisch beleid ook al gedaan. Zie Ecorys (2003), p.57.

497 idem.4.

498 De organisaties waren op hoog niveau vertegenwoordigd: J.M.M. Ritzen als bestuursvoorzitter namens de Universiteit Maastricht, burgemeester G.B.M. Leers namens de gemeente Maastricht, de voorzitter van de Raad van Bestuur van het Academisch Ziekenhuis Maastricht, G.J.H.C.M. Peeters. J.C. van Suijdam was als directeur Research \& Engineering vanuit DSM vertegenwoordigd, C. Dewulf namens het LIOF, F. Damen voor het ministerie van EZ en P. Tindemans als extern adviseur. Zie Persoonlijk archief Jan Maatjens (Provincie Limburg); Verslag $1^{\text {e }}$ bijeenkomst Regiegroep Life Sciences, 7 april 2004, p.1. Met dank aan J.P.P.M. Maatjens (Afdeling Economische Zaken, Provincie Limburg) voor het beschikbaar stellen van zijn persoonlijk archief. De hier gebruikte stukken zijn publiek toegankelijk. Om de stukken te raadplegen kan contact worden opgenomen met dhr. Maatjens.

499 Persoonlijk archief Jan Maatjens (Provincie Limburg); Verslag $2^{\text {e }}$ bijeenkomst Regiegroep TTR/ Life Sciences, 23 juni 2004, p.3.

500 Ministerie van Economische Zaken (2004). Pieken in de delta. Gebiedsgerichte Economische Perspectieven. Juli 2004, p.64-70. Online beschikbaar [laatst geraadpleegd 4-8-2010]: www.rijksoverheid.nl/bestanden/documenten-en-publicaties/notas/2004/07/01/nota-pieken-inde-delta-gebiedsgerichte-economische-perspectieven/nota-piekenindedelta.pdf.

501 Geheel onlogisch was dit ook niet gezien de concentratie van een aantal grote bedrijven als Philips, ASML en de aanwezigheid van de kennisinstellingen TNO en de Technische Universiteit Eindhoven.

502 Ministeries van VROM, LNV, VenW en EZ (2004/2006). Nota Ruimte. Ruimte voor ontwikkeling. Deel 4: tekst na parlementaire instemming (2006), p.80. Venlo en omstreken was aangewezen als 'greenport' en de steden in Zuid-Limburg hadden de status 'Stedelijk Netwerk Zuid-Limburg' gekregen. Online beschikbaar [laatst geraadpleegd 16-12-2010]: http://notaruimteonline.vrom.nl/download/download/NotaRuimteCompleet.pdf

503 De financiële middelen bij de Nota Ruimte kwamen voor een groot deel uit het Fonds Economische Structuurversterking (FES). Dit fonds was in 1995 opgericht en werd gevuld door de opbrengsten van de aardgasbaten. Hiermee werden vooral infrastructurele en grootschalige ruimtelijke projecten gefinancierd. Investeringen in de kenniseconomie werden pas vanaf 2005 mogelijk. In oktober 2004 werd duidelijk dat het ministerie van Economische Zaken voor de nota Pieken in de Delta slechts 7,5 miljoen euro voor 2004 beschikbaar had.

504 Provincie Limburg (2004). Persbericht 'Blij met erkenning Toptechnologische Regio Zuidoost 
Nederland', 12 juli 2004. Online beschikbaar [laatst geraadpleegd 21-8-2009]:

www.limburg.nl/nl/html/algemeen/Actueel/Persberichten/persberichtenarchief.asp?jaar= 2004\&nieuws_item=F1IQCP0UI3IJOWUK3116. Uiteindelijk kwam er steun uit onverwachte hoek. Tweede Kamerlid A.D. Bakker (D66) diende bij de begrotingsbehandeling van het ministerie van EZ in oktober 2004 een motie in die pleitte voor een 'beter gecoördineerde rijksinzet' tussen Nota Ruimte en Pieken in de delta. Zie Tweede Kamer, 2004-2005, 29 697, nr.7, 5 oktober 2004. Op deze manier kon de Provincie Limburg ook geld krijgen voor de projecten in het kader van de Technologische Topregio vanuit het Fonds Economische Structuurversterking.

505 Zie ook Interdepartementale Werkgroep / ministerie van VROM (2004). Regionaal economisch beleid in de toekomst. Interdepartementaal Beleidsonderzoek 2003-2004, nr.5, p.39. Online beschikbaar [laatst geraadpleegd 21-8-09] www.ez.nl/dsresource?objectid=53727\&type=PDF.

506 De samenwerking verliep niet alleen moeizaam tussen de beide provincies maar ook tussen de twee betrokken universiteiten (Maastricht en Eindhoven).

507 Persoonlijk archief Jan Maatjens (Provincie Limburg); Verslag Regiegroep Top Technologie Zuidoost-Nederland, 14 oktober 2004, p.1.

508 Zie bijvoorbeeld: Bibliotheek Provincie Limburg; Notulen statencommissie voor Economie, Onderwijs en Internationale Zaken (EOI), 23 april 2004 waar woordvoerder van het CDA M.L.C.M. van Lieshout de door GS voorgestelde acties en speerpunten ondersteunde, maar 'een totaalbeeld' miste. Zie de notulen statencommissie EOI, 11 juni 2004, p.7; Bibliotheek Provincie Limburg. Notulen Statencommissie, 17 september 2004, p.11; Notulen Statencommissie EOI, 3 december 2004, p.7-9.

509 Bibliotheek Provincie Limburg; Provincie Limburg en L6 (2004). 'Manifest. Time is running out', april 2004, p.1, bijlage bij 'Notitie voor Provinciale Staten Thema Ondernemend Limburg', 13 april 2004. De 'L6' bestonden uit de LWV, de LOZO, de LLTB, NV Industriebank LIOF, de Kamers van Koophandel Limburg Noord- en Zuid-Limburg en Syntens Limburg.

510 Persoonlijk archief Jan Maatjens (Provincie Limburg); Verslag Regiegroep TTR, 31 augustus 2004, p.1. Gouverneur Van Voorst tot Voorst en gedeputeerde Eurlings voerden in de zomer van 2004 overleg met de staatssecretaris van EZ. Een vergelijkbaar overleg zou in 2005 nog een keer plaatsvinden.

511 Provincie Limburg / Regiegroep TTR (2004). Limburg: een toekomst met kennis, november 2004. Het rapport werd op 24 november 2004 gepresenteerd. Online beschikbaar [laatst geraadpleegd 27-8-2009]:

www.limburg.nl/upload/pdf/Limburg_een_toekomst_met_kennis.pdf

512 Persoonlijk archief Jan Maatjens (Provincie Limburg); Verslag Regiegroep TTR, 28 september 2004, p.2-3.

513 Persoonlijk archief Jan Maatjens (Provincie Limburg); Verslag Regiegroep TTR, 10 november 2004, p.2. Zie ook Regiegroep Versnellingsagenda (2007). Jaarverslag 2006, p.7. Online beschikbaar [laatste geraadpleegd: 6-8-2010]:

www.versnellingsagenda.nl/upload/documents/jaarverslag2006.pdf

514 Bibliotheek Provincie Limburg; Notitie voor de Statencommissie EOI 'Samenwerken aan een Europese Technologische Topregio; aanbieding van het rapport 'Limburg: een toekomst met kennis", 23 november 2004, p.12. Als regionale 'accenten' werden genoemd: Venlo, agribusiness/ food en value added logistics; Sittard-Geleen, high-chem en automotive; Parkstad Limburg, ICT en zorg; Maastricht, life sciences.

515 Zie voor een beschrijving: Bos, Van Bochove \& Grijpstra (2008). Premiere van een klassieker. Bemiddeling van werk naar werk: het MobiliteitCentrum Automotive als succesvol voorbeeld. 7 maart 2008. Online beschikbaar [laatst geraadpleegd 27-8-2009]: http://docs.minszw.nl/ pdf/35/2008/35_2008_3_11924.pdf.

516 Uiteraard waren er wel contacten tussen het Provinciaal Bestuur, de Provinciale Staten en de 
landelijke fracties van de politieke partijen. Zie Notulen Statencommissie Economie, Onderwijs en Internationale Zaken van 25 februari 2005. Zie ook Tweede Kamer, 2004-2005, 29800 XIII, nr.77 'Brief van de minister van BZK', 10 juni 2005, p.1-2. Online beschikbaar via http://parlando. sdu.nl.

517 Zie bijvoorbeeld de kritiek van het Limburgse VVD-kamerlid F.H.H. Weekers in een algemeen overleg van 2 maart 2005 met staatssecretaris Van Gennip. Tweede Kamer, 2004-2005, 29800 XIII, nr.70: Weekers stelde dat '...de lobby van Limburg eronder lijdt dat belangrijke betrokken organisaties geen eenduidig beeld uitdragen. Dit geldt ook voor het Limburgse provinciaal bestuur', p.4. Online beschikbaar via http://parlando.sdu.nl.

518 Zie Tweede Kamer 2004-2005, nr. 56, 'Verslag Algemeen Overleg over de Economische situatie in Limburg', 8 maart 2005, p.3632. Daar werd in een motie de staatssecretaris opgeroepen om te komen tot een integraal advies en visie voor de situatie in Limburg. Online beschikbaar [laatst geraadpleegd 27-8-2009]:

http://parlis.nl/pdf/handelingen/HAN7809A09.pdf.

519 De term 'versnelling' was gekozen om aan te geven dat een reeks van later geplande projecten naar voren werden gehaald om daarmee sneller een economisch effect te sorteren. Zie Bibliotheek Provincie Limburg; Toelichting van gedeputeerde Eurlings in de Statencommissie Economie, Onderwijs en Internationale Zaken, verslag van 2 september 2005, p.4.

520 Persoonlijk archief Jan Maatjens (Provincie Limburg); Notitie 'Afspraken van het overleg van de staatssecretaris mevr. Van Gennip, de CDK van Limburg, dhr. Baron van Voorst tot Voorst en de gedeputeerde Economische Zaken, dhr. Eurlings d.d. 7 maart 2005'. Notitie is onderdeel van de stukken behorend bij de Regiegroep-vergadering van 29 maart 2005. Zie ook antwoord van staatssecretaris Van Gennip in het Algemeen Overleg met de Tweede Kamer van 8 maart 2005, p.3633-3634.

521 De benaming 'taskforce' werd gebruikt in de periode dat de Versnellingsagenda opgesteld werd. Na de presentatie op 12 oktober 2005 werd de oude naam van Regiegroep Versnellingsagenda weer gehanteerd.

522 Deze twee externe adviseurs waren op verzoek van de Tweede Kamer toegevoegd aan de Taskforce. Tweede Kamer, 2004-2005, 29 800, Nr.63 'Motie Van den Brink', 15 maart 2005. Online beschikbaar [laatst geraadpleegd 27-8-2009]: http://parlis.nl/pdf/handelingen/HAN7813A08.pdf

523 Archief Provincie Limburg 90433; Taskforce Versnellingsagenda (2005). De Versnellingsagenda. Limburg op weg naar 2012, 1 juli 2005.

524 Met de term 'agro-food' worden alle bedrijven bedoeld die zich bezig houden met de productie, verwerking, veredeling en distributie van agrarische producten.

525 Archief Provincie Limburg 90433; De Versnellingsagenda, 1 juli 2005, p.36. Naast dit specifieke sectorbeleid werd er in de Versnellingsagenda ook een nieuw innovatieprogramma voor het Limburgse midden- en kleinbedrijf gepresenteerd, evenals een programma voor grensoverschrijdende infrastructurele (spoor)voorzieningen.

526 Taskforce Versnellingsagenda (2005). Versnellingsagenda 2005. Limburg op weg naar 2012. Online beschikbaar [geraadpleegd 5-8-2010]: www.versnellingsagenda.nl/upload/documents/ versnellingsagenda.pdf

527 Archief Provincie Limburg 87032; Vertrouwelijke GS-nota 'Versnellingsagenda Limburg', 11 oktober 2005, p.2. Zie ook 'Toespraak van de CDK' bij gelegenheid van het in ontvangst nemen van het rapport Van Polymeer tot Preuvenemint, 11 oktober 2005, p.4. Online beschikbaar [laatst geraadpleegd 27-8-2009]: www.limburg.nl/upload/pdf/SpeechCdK_20051011_ledenvergLWVroermond.pdf.

528 Zie 'Speech van staatssecretaris van Gennip als antwoord op het aanbieden van de Limburgse Versnellingsagenda', 12 oktober 2005. Online beschikbaar [laatst geraadpleegd 27-8-2009]: http://blogs.prvlimburg.nl/weblog/martin.eurlings/archives/SpeechEurlings_20051012_ 
VersnellingsagendaGennip.doc.

529 Zie brief minister-president aan gedeputeerde Eurlings, 17 november 2005. Online beschikbaar [laatst geraadpleegd 27-8-2009]: www.limburg.nl/upload/pdf/VersnAgenda bevestigMinPresOntvangst.pdf.

530 Bibliotheek Provincie Limburg. Provinciaal Blad, 2005/68. In de GS-vergadering van 18 oktober 2005 werd de Regiegroep formeel een commissie ex artikel 82 van de Provinciewet. De vergaderingen zouden niet openbaar zijn.

531 Zie bijvoorbeeld LIOF-notitie 'Projectorganisatie voor de uitvoering van de versnellingsagenda: een tweetal scenario's', 16 september 2005.

532 C. Dewulf had op 22 maart 2005 aangekondigd dat hij per 15 april 2005 een functie in het bedrijfsleven zou gaan uitoefenen. De opvolging van Dewulf liet lang op zich wachten. Pas op 1 september 2006 zou Th.M.A.J. Verhagen als directeur van LIOF aan de slag gaan.

533 In een voorbereidend ambtelijk overleg tussen Provincie, Universiteit Maastricht, Academisch Ziekenhuis en gemeente Venlo, werd besloten om vooruitlopend op de uitvoeringsorganisatie niet per project een trekker te benoemen, maar per cluster van kracht. Voor het cluster Chemie bestond er al een projectstructuur en daar kon bij worden aangesloten. Voor het cluster Agro-food zou als trekker het hoofd van de gemeentelijke afdeling Economische Zaken, H. Hoogervorst, worden benaderd. Een voorstel van een onafhankelijke commissie van deskundigen die de projecten moest beoordelen werd afgewezen. De Provincie had dit voorgesteld om te voorkomen dat de Regiegroep 'eigen projecten [ging] beoordelen'. Persoonlijk archief Jan Maatjens (Provincie Limburg); Verslag Voorbereidingsgroep TTR Limburg/Versnellingsagenda (VA), 8 november 2005, p.2.

534 Persoonlijk archief Jan Maatjens (Provincie Limburg); Verslag Regiegroep TTR Limburg, 23 november 2005, p.2-3.

535 Persoonlijk archief Jan Maatjens (Provincie Limburg); Concept brief Provincie Limburg aan leden van de Regiegroep, 23 januari 2006.

536 idem.2.

537 Zie Brief van GS aan de Statencommissie EOI, 7 november 2006. Online beschikbaar [laatst geraadpleegd 27-8-2009]: http://portal.prvlimburg.nl/psonline/documenten/53770/061023-0259. doc

538 Stuurgroep Versnellingsagenda (2008). Jaarverslag 2007. Onderweg naar 2012 ... vernieuwing werkt, 21 februari 2008. Online beschikbaar [laatst geraadpleegd 6-8-2010]: www.versnellingsagenda.nl/upload/documents/jaarverslag2007.pdf

539 Provincie Limburg (2007). Coalitieakkoord 2007-2011 CDA-PvdA-PNL. Investeren en Verbinden, p.5. In 2008 werd de Versnellingsagenda geactualiseerd en werden prioriteiten gesteld binnen de oorspronkelijke clusters van kracht. Zie: Raad van Advies Versnellingsagenda (2008). Versnellingsagenda 2008-2011. Naar een hogere versnelling, september 2008. Op p.5 werd deze keuze nader toegelicht: "Ten opzichte van de eerste Versnellingsagenda is gekozen voor een vergaande vorm van focussering. Niet meer de clusters als zodanig maar geselecteerde speerpunten binnen die clusters, de zogenoemde groeimotoren, vormen de basis van deze nieuwe Versnellingsagenda". Online beschikbaar [laatst geraadpleegd 6-8-2010]: www.versnellingsagenda.nl/upload/documents/versnellingsagenda2008.pdf.

540 Zie ook het interview met de directeur van DSM Nederland, F. Pistorius in: Stuurgroep Versnellingsagenda (2008). Jaarverslag 2007, p.14.

541 Commissie Hermans / Provincie Limburg (2007). De toekomst van Limburg ligt over de grens. De euregio's als bruggenbouwer tussen de Lidstaten, 16 juni 2007. Online beschikbaar [laatst geraadpleegd 6-8-2010]:

www.limburg.nl/upload/pdf/Persbericht129_2007_RapportCommHermans_DeToekomst VanLimburgLigtOverDeGrens_NL_DU.pdf. 


\section{Hoofdstuk 4}

542 Rijksarchief Limburg 04.09/7247; Inleiding van J.H. Dassen (hoofd van de 3e provinciale afdeling) bij de nota 'Toekomstige plannings- en adviesstructuur op provinciaal niveau', 26 oktober 1979. Hij hield deze inleiding in de vergadering van Gedeputeerde Staten van Limburg op 6 november 1979.

\section{$\$ 4.1$ Ontwikkelingen in het nationale welzijnsbeleid}

543 Voor deze nationaal historische paragraaf is gebruik gemaakt van Neij (1989), Hueting (1989), Hortulanus, Liem \& Sprinkhuizen (1993) en De Haan \& Duyvendak (2002).

544 Onder 'charitas' werden de liefdadigheidsactiviteiten verstaan die verschillende (levenbeschouwelijke) groeperingen verzorgden. Zie Van der Pennen, 1995: 15.

545 Zie bijvoorbeeld het in 1966 opgestelde rapport van de Limburgse Provinciale Planologische Dienst Kleine dorpen in Limburg - een verkennende studie inzake de sociale leefbaarheidsproblematiek van het landelijk gebied in Limburg. Het begrip 'leefbaarheid' werd hierin door de Planologische Dienst nog sterk gekoppeld aan de volkshuisvesting en de vermeende problemen die de suburbanisatie zou opleveren.

546 De term 'leefbaarheid' werd vooral in de jaren '60 en '70 gebruikt in relatie tot de kleinere kernen. Met name in het ruimtelijke ordeningsbeleid stond de term direct in verband met de suburbanisatie, een ontwikkeling die door planologen werd gezien als een aantasting van de leefbaarheid op het platteland. Gemeenten brachten juist naar voren dat de uitbreiding van de dorpen noodzakelijk was omdat anders de leefbaarheid onder druk kwam te staan. Zie hiervoor de discussie over de 'kernenhiërarchie' in het streekplan voor Noord- en Midden-Limburg in het hoofdstuk over de ruimtelijke ordening.

547 Drenthe was een van die provincies waar dit opbouwwerk al vroeg werd gecoördineerd. De Centrale Vereniging voor de Opbouw in Drenthe (opgericht in 1926) was in de jaren '30 overgegaan in de Stichting Opbouw Drenthe en hield zich bezig met het 'bevorderen van de culturele, economisch en hygiënische reconstructie (opbouw) van Drenthe' (Peper, 1976: 66). Ook binnen Gelderland onstonden soortgelijke initiatieven.

548 Zie voor een overzicht van het Bijzonder Regionaal Welzijnsbeleid: Tweede Kamer 1980-1981, 16625, No.21 'Heroverweging collectieve uitgaven. Deelrapport 16 - Bijzonder Regionaal Welzijnsbeleid', 9 juni 1981. Online beschikbaar op www.statengeneraaldigitaal.nl.

549 Rijksarchief Limburg 04.09/7210; Verslag van gesprek over het bijzonder regionaal welzijnsbeleid na 1968 tussen de minister van Cultuur, Recreatie en Maatschappelijk Werk (CRM) en vertegenwoordigers van de betrokken provinciale besturen, 16 december 1968, p.5. Zie ook Tweede Kamer 1968-1969, 9800 No.2 'Memorie van Toelichting bij Rijksbegroting voor 1969 van het Ministerie van CRM', p.16. Online beschikbaar op www.statengeneraaldigitaal.nl.

550 Tweede Kamer 1973-1974, 12968 No.2; Beraadsgroep Knelpunten Harmonisatie Welzijnsbeleid en Welzijnswetgeving (1974). Knelpuntennota. Rapport van Beraadsgroep Knelpunten Harmonisatie Welzijnsbeleid en Welzijnswetgeving. Mei 1974, p.13. Online beschikbaar op www. statengeneraaldigitaal.nl.

551 Tweede Kamer 2002-2003, 28600 XI No.12 'Nota van wijziging', 6 november 2002, p.17. Online beschikbaar op www.statengeneraaldigitaal.nl.

552 De opvolgende ministers waren S.M. Dekker (VVD, 2003-2006), P. Winsemius (VVD, 2006-2007), C.P. Vogelaar (PvdA, 2007-2008) en E.E. van der Laan (PvdA, 2008-2010). De wijkenaanpak heeft in deze periode verschillende benamingen gehad, zoals 'probleemwijken', 'krachtwijken', 'prachtwijken' en 'Vogelaarwijken'. In het kabinet Balkenende IV (2007-2010) was er zelfs een apart ministerie Wonen, Wijken en Integratie voor opgericht. 


\section{\$4.2 Limburgs welzijnsbeleid voor 1962}

553 Limburgers als aalmoezenier H. Poels, mensen uit de arbeidersbeweging als H.G.M. Hermans, J.H. Maenen, politicus W.H. Nolens, architect P.J.H. Cuypers, vicaris-generaal F.J. Féron en bisschop J.H.G. Lemmens speelden een belangrijke maatschappelijke rol in deze tijd.

554 Pennings heeft onderzoek gedaan naar de subsidiëring van instellingen van het particulier initiatief door 45 Nederlandse gemeenten. Ook het subsidiebeleid van de Limburgse gemeenten Heerlen, Roermond, Weert en Eygelshoven is daarin onderzocht. Met name na 1915 vond er een verviervoudiging plaats van lokale subsidies aan instellingen (Pennings, 1992: 59). Hij constateerde bovendien dat de gemeente Heerlen de enige 'katholieke' gemeente was die ook vóór 1920 niet-katholieke instituties subsidieerde (idem.63). Een verklaring hiervoor ziet Pennings in het feit dat de mijnwerkers van buiten de regio kwamen en eigen verenigingen oprichtten.

555 Voor die tijd waren het vooral de leken binnen de katholieke kerk die zich uit christelijke naastenliefde bezig hielden met de sociale kwestie. De Roermondse bisschop J.H. Drehmanns liet zich in het begin van de $20^{\mathrm{e}}$ eeuw alleen privé uit over de sociale omstandigheden (Ubachs, 2000: 395).

556 Rijksarchief Limburg 04.09/7320; Bijlage bij brief van Provinciaal Opbouworgaan Limburg (POL), 16 oktober 1948, p.1.

557 idem.1.

558 Het subsidieverzoek dat het Opbouworgaan bij de Provincie Limburg dat jaar indiende was een voorwaarde om ook een rijkssubsidie te ontvangen. De Provincie vreesde echter een te 'papierlijk' orgaan met 'veel fraaie woorden' waar vervolgens 'niets gebeurt'. Onder druk van Gedeputeerde Staten trad het bestuur van het Opbouworgaan eind december 1949 af en moest een nieuw bestuur met fl. 5.000 een nieuwe start maken. Zie Rijksarchief Limburg 04.09/7320; Verslag van het overleg tussen het Opbouworgaan en GS, 13 mei 1949, p.1 en Rijksarchief Limburg 04.09/7320; Brief POL aan GS, 15 december 1949, p.1.

559 Zie bijvoorbeeld Rijksarchief Limburg 04.09/11436; Notulen van de GS-vergadering van 6 mei 1968. Gedeputeerde J.H. Ensinck (KVP) verwoordde dit in 1968 als volgt: "Bij en na de oprichting van het POL [...] heeft er een zeker wantrouwen bestaan tegen dit instituut omdat allerlei instanties vreesden dat het POL zich te zeer zou gaan mengen in wat zij zagen als hun eigen aangelegenheden. Dit wantrouwen is lang blijven doorwerken", p.1-2.

560 Zie bijvoorbeeld Provinciaal Blad van Limburg 2009/82. Subsidieplafonds voor diverse subsidiekaders, 17 december 2009. Online beschikbaar [laatst geraadpleegd op 3-2-2010]: http://portal.prvlimburg.nl/psonline/documenten/101714/Bibliotheek Provincie Limburg no._82_2009_Subsidieplafonds_2010_voor_diverse_subsidiekaders.doc. Zo stond er voor het jaar 2010 bijna 3 miljoen euro voor ruim 20 maatschappelijke organisaties op de provinciale begroting.

561 Bibliotheek Provincie Limburg; Provincie Limburg (1962). Begroting der inkomsten en uitgaven van de Provincie Limburg voor het dienstjaar 1962, p.27. Dit was na het beleidsterrein 'Waterstaat, verkeer en vervoer' met 2,1 miljoen gulden de grootste uitgavenpost op de provinciale begroting. De totale begroting van de Provincie Limburg bedroeg in 1962 bijna 77 miljoen gulden, daarbij de kapitaallasten en reserves inbegrepen.

562 Overigens was het sociale beleid van mijnen grotendeels ook gemotiveerd vanuit eigenbelang. Messing schrijft: "Een goed leefbare omgeving zal de arbeidsrust ten goeden komen [...] De enige verplichting om in aanmerking te komen voor subsidie is het stoken van kolen" (Messing, 1988: 93).

$563 \mathrm{Al}$ in 1964 trad er in Limburg een daling van het geboortecijfer op. In 1963 werden er nog 20.657 kinderen geboren, een jaar later nam dit al af en stabiliseerde zich vanaf de jaren ' 80 tussen de $12.000-13.000$ levendgeborenen per jaar. Vanaf 2001 daalde dit cijfer opnieuw tot zelfs 9.458 in 2007. CBS Statline; laatst geraadpleegd op 18-9-2009. 
564 Bibliotheek Provincie Limburg. Provincie Limburg (1966). 'Overwegingen inzake begeleidende maatregelen met betrekking tot het sociaal welzijn in het kader van de industriële herstructurering van Zuid-Limburg', 4 februari 1966, p.7.

565 Rijksarchief Limburg 04.09/7208; Brief ministerie van Maatschappelijk Werk aan de Commissie Sociale Planning Ontwikkelingsgebied Noordelijk Limburg, 30 mei 1960. De nieuwe commissie kreeg een jaarlijkse subsidie van het ministerie van fl. 24.000 .

566 Deze commissie was op 26 september 1955 ingesteld onder de naam 'Commissie Sociale Planning Ontwikkelingsgebied Noordelijk Limburg'. Zie Rijksarchief Limburg 04.09/7208; Brief Cie. 'Sociale Planning ...' aan Gedeputeerde Staten van Limburg, 9 maart 1960.

567 Rijksarchief Limburg 04.09/7208; Extract uit het register der besluiten van Gedeputeerde Staten van Limburg, No.B.5129, 14 november 1960.

568 Voor de periode 1960-1963 was er voor Limburg 1,8 miljoen gulden beschikbaar aan projectsubsidies. Deze kwamen van het ministerie van Sociale Zaken. Vanaf oktober 1962 kwamen hier de zogeheten 'activiteitensubsidies' van het ministerie van Maatschappelijk Werk bij en na de aankondiging van de mijnsluitingen in december 1965 nam de totale omvang aan subsidies sterk toe. Zie Rijksarchief Limburg 04.09/7214; Provinciale Commissie voor Sociale Begeleiding in Limburg, 'Verslag over de jaren 1960-1963', januari 1965, p.9.

\section{$\$ 4.3$ Een voorzieningenbeleid (periode 1965-1979)}

569 Tweede Kamer 1965-1966. 8424, No.2: Nota inzake de mijnindustrie en de industriële herstructurering van Zuid-Limburg, 14 december 1965, p.29. Online beschikbaar op www. statengeneraaldigitaal.nl.

570 Bibliotheek Provincie Limburg. Provincie Limburg (1966). Overwegingen inzake begeleidende maatregelen met betrekking tot het sociaal welzijn in het kader van de industriële herstructurering van Zuid-Limburg, 4 februari 1966, p.10. Het definitieve rapport werd in 1967 gepresenteerd.

571 idem.10.

572 Bibliotheek Provincie Limburg. Provincie Limburg (1966). 'Sociale Begeleiding van de Industriële Herstructurering van Zuid-Limburg', $2^{e}$ Ontwerp. Ongedateerd, maar waarschijnlijk najaar 1966, p.18.

573 idem. 14 .

574 idem.34, 37.

575 Bibliotheek Provincie Limburg. Provincie Limburg (1967). 'Sociale begeleiding van de industriële herstructurering van Zuid-Limburg', 2e ontwerp, 1967, p.33.

576 In totaal zijn er 5 periodes van het Bijzonder Regionaal Welzijnsbeleid (BRW-beleid) geweest: 1964-1968, 1969-1972, 1973-1976; 1977-1980; 1981-1984. Het stimuleringbeleid voor NoordLimburg liep tot 31-12-1972 en vanaf 1-1-1967 viel ook het Herstructureringsgebied ZuidLimburg onder het beleid. In 1977 werd dit beleid voor Zuid-Limburg integraal onderdeel van de drie opeenvolgende periodes van het Perspectievennotabeleid.

577 De discussie over de herstructurering van de Provinciale Commissie Sociale Begeleiding duurde het gehele jaar van 1967. Uiteindelijk werd in het najaar van 1967 de knoop doorgehakt door het College. Er werden twee commissies ingesteld waarbij ambtenaar P.M.J.A. Tops secretaris werd van de Commissie 'Projecten' en ambtelijk collega L. Siezenis secretaris van de Commissie 'Activiteiten'. Zie Rijksarchief Limburg 04.09/11435; Notulen GS-vergaderingen van 2 en 23 oktober 1967.

578 De vier 'Raden' waren de Raad voor de Volksgezondheid, de Jeugdraad, de Culturele Raad en (in een latere fase) de Sportraad. Het ministerie van Maatschappelijk Werk was in 1965 omgedoopt tot het ministerie van Cultuur, Recreatie en Maatschappelijk Werk en was vertegenwoordigd via het Bureau Limburg van het ministerie.

579 Rijksarchief Limburg 04.09/7210; Brief van de Provincie Limburg aan Limburgse gemeenten, 19 
februari 1968. Gemeenten werden in de brief verzocht om projecten in te dienen. Daarbij werd als voorwaarde gesteld dat gemeenten of particulier initiatief $15 \%$ per projectvoorstel zou bijdragen: "Bij het doen van Uw voorstellen ware rekening ermede te houden, dat rond 15\% van de kosten der projecten in ieder geval voor rekening van de streek (gemeente(n) en particulieren) zullen komen", p.1.

580 Rijksarchief Limburg 04.09/7219; Brief van de voorzitter aan de leden van de Provinciale Commissie Projecten Sociale Begeleiding, 5 april 1968. Bijlage met 'Projecten die in het kader van de A-regeling momenteel in voorbereiding zijn of waarover serieus van gedachten wordt gewisseld'. Op de lijst stonden 17 gemeenschapshuizen, 5 zwembaden, een aantal wijkcentra, sociale werkplaatsen, trefcentra en een gezondheidscentrum.

581 Rijksarchief Limburg 04.09/7223; Brief Provinciale Commissie Activiteiten Sociale Begeleiding, 5 juli 1968. Agenda vergadering van 10 juli 1968. De andere agendapunten ging over aanvullende subsidies voor een aantal reeds gestarte activiteiten.

582 Tweede Kamer 1969-1970, 19312, No.2 Tweede Nota inzake de mijnindustrie en de industriële herstructurering van Zuid-Limburg, 18 september 1969, p.7. Het bedrag van 1,7 miljoen gulden voor activiteiten was gereserveerd door het ministerie voor de periode $1967 \mathrm{t} / \mathrm{m} \mathrm{1969}$. Online beschikbaar op www.statengeneraaldigitaal.nl.

583 Zie ook de evaluatie die het Provinciaal Orgaan Welzijnsbevordering Limburg (POWL) in oktober 1974 opstelde. Rijksarchief Limburg 04.09/7211; Brief POWL aan Gedeputeerde Staten 'Evaluatie beschouwing over B.R.W.-beleid', 11 oktober 1974, p.2.

584 Tweede Kamer 1974-1975 13 434, No.2 Nota bijzonder regionaal welzijnsbeleid, 4 juni 1975, p.9. www.statengeneraaldigitaal.nl.

585 idem.41. Voor het stimuleringsgebied Noord- en Midden-Limburg is geen specificatie opgenomen, maar het totaalbedrag van het ministerie van CRM voor de stimuleringsgebieden in de periode $1953 \mathrm{t} / \mathrm{m} 1976$ bedroeg 104 miljoen gulden. Het is redelijk om aan te nemen dat Limburg daar ongeveer een kwart van heeft ontvangen. Het stimuleringsbeleid voor Noord- en Midden-Limburg werd per 1 januari 1973 beëindigd.

586 Tweede Kamer 1972; 12000 No.2, Rijksbegroting voor het Dienstjaar 1973 Hoofdstuk XVI Cultuur, Recreatie en Maatschappelijk Werk - Memorie van Toelichting, 19 september 1972, p.23. www. statengeneraaldigitaal.nl.

587 Rijksarchief Limburg 04.09/7210; Brief GS aan de minister van Cultuur, Recreatie en Maatschappelijk Werk (CRM) van 25 februari 1970, p.2.

588 Rijksarchief Limburg 04.09/7210; Brief van het ministerie CRM aan GS, 25 maart 1971, p.1.

589 Rijksarchief Limburg 04.09/7211; Brief van het ministerie CRM aan de Colleges van GS van alle provincies, 13 oktober 1972. Zie de bijlage met de 'voorgestelde verdeling van de middelen over de typen gebieden (1973-1976)'. In totaal was er 50,5 miljoen gulden beschikbaar. Zuid-Limburg ontving een fors deel van het budget, zeker gezien het feit dat de regio het Noorden des Lands ( 14,5 miljoen gulden) bestond uit drie provincies.

590 Met name via de financiële middelen in het kader van Aanvullende Werken (AW-subsidies) en de Cultuurtechnische Werken (DACW-subsidies) werden er sociale werkplaatsen en gemeenschapshuizen gefinancierd. De criteria om voor subsidie in aanmerking te komen waren minder streng dan de criteria bij de BRW-subsidies.

591 De professionalisering van het subsidiebeleid werd uitgewerkt door twee in 1974 nieuw aangetreden ambtenaren, M.A.C. Schellen ( $3^{\mathrm{e}}$ Afdeling) en A.M.A.A. De Baedts (hoofd $5^{\mathrm{e}}$ Afdeling). Na de provinciale verkiezingen van dat jaar kwam gedeputeerde P.J.C. Lebens (KVP) niet terug. Het bood ruimte om de rol en functie van de Commissies Sociale Begeleiding (Activiteiten en Projecten) opnieuw te bekijken en aan te scherpen. Ook kwam er een uniformering in de subsidies aan de maatschappelijke organisaties, waar bij bedragen boven de fl. 25.000 een jaarlijkse accountantsverklaring bij de Provincie moest worden ingediend. Zie o.a. Rijksarchief 
Limburg 04.09/11443; GS-notulen van 26 mei, 25 augustus, 1 september en 1 december 1975 en Rijksarchief Limburg 04.09/11444; GS-notulen van 12 en 19 januari, 16 augustus en 27 september 1976.

592 Al vanaf 1967 waren er voorstellen in het College besproken die de uitgaven aan het welzijnsbeleid probeerden terug te dringen, echter zonder veel resultaat. Zie Rijksarchief Limburg 04.09/11435; Notulen van de GS-vergadering van 29 mei 1967. Een nota van de financiële afdeling werd aangehouden omdat eerst in kaart gebracht moest worden hoe de bezuinigingen van de rijksoverheid zouden uitpakken in de sociale sector. Met name gouverneur Ch.J.M.A. Van Rooy (KVP) uitte zich eind jaren '60 en begin jaren '70 kritisch over de vele exploitatiesubsidies van de Commissie Sociale Begeleiding. Zie Rijksarchief Limburg 04.09/11443; Notulen vergadering GS van 1 september 1975. In de bespreking van de begroting voor 1976 stelde gouverneur Van Rooy vraagtekens bij de subsidieregeling 'Sociale Ontwikkeling Limburg'. In het verslag staat: "De voorzitter [Van Rooy - HvE] trekt de werking van de regeling in twijfel. Vele voorzieningen komen toch tot stand, ook zonder provinciale bijdrage", p.3.

593 Bibliotheek Provincie Limburg. Provincie Limburg / ministerie EZ (1977). Concept Perspectievennota Zuid-Limburg, april 1977, p.148-149.

594 Rijksarchief Limburg 04.09/6853; Bijlage 3: 'Schema voor een uitwerking van concrete beleidsmaatregelen en het wegen van kosten en effecten' bij de agenda van de bijeenkomst Beleidsgroep Perspectievennota voor 31 augustus 1976.

595 Rijksarchief Limburg 04.09/7212; 'Hoofdpunten van het gesprek tussen de heren Speth en Schellen (Provincie Limburg) en de heren Stalpers en Vervraak (IVA), 22 augustus 1978, p.1-2.

596 Zie bijvoorbeeld Rijksarchief Limburg 04.09/11442; GS-vergadering van 7 januari 1974 over promotievoorstellen bij de Culturele Raad; Rijksarchief Limburg 04.09/11442; GS-vergadering van 12 augustus 1974, waarin werd gesproken over de vacature van voorzitter van de Raad voor de Volksgezondheid; Rijksarchief Limburg 04.09/11443; Zie GS-vergadering van 1 december 1975 waarin werd gesteld dat een aantal Raden 'zich moeten conformeren over het beleid van de provincie' als het ging om de 'inpassingsvoorwaarden van functionarissen'. Zie Rijksarchief Limburg 04.09/11444; GS-vergadering van 27 september 1976 waarin het College zich boog over de vraag of de leden van de Raden 'presentiegeld' moest worden toegekend. Zie ook Rijksarchief Limburg 04.09/11445; GS-vergadering van 1 augustus 1977 waarin de rangverhoging van een zestal medewerkers van het Provinciaal Orgaan Welzijnsbevordering Limburg werd afgewezen door het College.

597 Rijksarchief Limburg 04.09/11447; GS-notulen van 24 april 1979.

598 Rijksarchief Limburg 04.09/7247; GS-nota 'De plannings- en adviestaak op provinciaal niveau', 13 februari 1979, p.5.

599 Rijksarchief Limburg 04.09/7247; Brief GS aan de 4 Raden en het Opbouworgaan, 1 mei 1979.

600 Of zoals het in de nota door de afdeling was geformuleerd: "Het ... laat een ontwikkeling zien van de overheid als belangstellende welzijnstoeschouwer naar beleidsbepalende en eindverantwoordelijkheid dragende overheid", Rijksarchief Limburg 04.09/7247; Nota aan Gedeputeerde Staten 'Toekomstige plannings- en adviesstruktuur op provinciaal niveau', 8 oktober 1979, p.4.

601 idem.2.

602 idem.5; Zie bijvoorbeeld de overlap van taken in het overzicht van de activiteiten van de zes provinciale adviesorganen op p.5.

603 idem.3.

604 Rijksarchief Limburg 04.09/7247; Notitie POWL 'De omvorming van het P.O.W.L. tot instrument ten behoeve van demokratische beleidsvoorbereiding en enkele gedachten over de toekomstige totale structuur voor de beleidsvoorbereiding', 31 augustus 1979, p.7. 


\section{\$4.4 Herstructurering en decentralisatie (periode 1979-1992)}

605 De periode 1979-1992 valt grotendeels gelijk met het Perspectievennotabeleid (1978-1990) zoals dat is beschreven in hoofdstuk 3 van dit boek. Onder de vlag van de Perspectievennota werd een groot aantal 'welzijnsprojecten' uitgevoerd. De zogeheten 'Arbeidsplaatsenplannen' subsidieerde het ministerie van Sociale Zaken. Een groot deel van deze werkplekken werd binnen de Limburgse welzijnssector gerealiseerd. De Provincie coördineerde dit beleid. Toen het PNL-beleid eind jaren 80 werd beëindigd, werd met name de provinciale welzijnssector met de gevolgen geconfronteerd. Deze paragraaf beperkt zich tot de onderwerpen decentralisatie en herstructurering van het welzijnsbeleid in de jaren ' 80 .

606 Rijksarchief Limburg 04.09/7247; Nota voor Gedeputeerde Staten 'De plannings- en adviestaak op provinciaal niveau', 13 februari 1979, p.5.

607 Rijksarchief Limburg 04.09/7247; Brief POWL aan GS, 31 augustus 1979, p.1.

608 Rijksarchief Limburg 04.09/7247; POWL 'De omvorming...', p.5-7.

609 Rijksarchief Limburg 04.09/7249; GS-nota van 22 februari 1980, p.1.

610 Rijksarchief Limburg 04.09/7247; GS-nota 'Toekomstige plannings- en adviesstruktuur op provinciaal niveau', 26 oktober 1979. De besluitvorming over de plannings- en adviesstructuur werd uitgesteld. Wel besloot het College dat het POWL moest blijven bestaan en dat de vacature voor een nieuwe directeur opengesteld kon worden; Rijksarchief Limburg 04.09/11447, GSnotulen van 6 november 1979 .

611 GS besloten dat het om te vormen 'nieuwe' POWL zich alleen moest gaan richten op provinciale activiteiten en dat er niet langer activiteiten voor gemeenten verricht mochten worden. Rijksarchief Limburg 04.09/11448; GS-notulen 26 februari 1980.

612 Rijksarchief Limburg 04.09/7247; Definitieve standpuntbepaling van GS over de nota 'Toekomstige planvoorbereidings- en adviesstructuur ten behoeve van het welzijnsbeleid op provinciaal nivo', 2 juni 1981.

613 Rijksarchief Limburg 04.09/7247; Nota voor GS 'De toekomstige planvoorbereidings- en adviesstruktuur op provinciaal niveau', juni 1980, p.2.

614 Rijksarchief Limburg 04.09/11447; GS-notulen van 14 augustus 1979.

615 Rijksarchief Limburg 04.09/7249; Brief Stuurgroep Ontwikkelingsprojecten aan GS, 3 oktober 1980. Zie ook Rijksarchief Limburg 04.09/7267; Welkomstwoord van gouverneur Kremers bij ondertekening Bestuursovereenkomst, 16 januari 1985. De regering volgde op 5 december 1980 het advies van de landelijke Stuurgroep Ontwikkelingsprojecten en wees Limburg aan als provinciaal proefgebied voor de Ontwerp Kaderwet Specifiek Welzijn. Zie Rijksarchief Limburg 04.09/7249; Brief ministerie CRM aan College van GS, 5 januari 1981.

616 Men bedoelde hiermee het gemeentelijke opbouwwerk, de sociale diensten, de gezinsverzorging, de consultatiebureaus, de wijkraden, de muziekscholen en de sportverenigingen.

617 Bibliotheek Provincie Limburg. Projektgroep Struktuur Welzijnswerk (1980). Strukturele Problemen in het Zuidlimburgse Welzijnswerk, december 1980.

618 idem.7.

619 In het overzicht werd niet gesproken van gewesten, maar van 'verlengd lokaal bestuur'. Rijksarchief Limburg 04.09/7249; GS-nota 'Kandidatuur Provinciaal Proefproject ontwerp-Kaderwet Specifiek Welzijn', 11 november 1980, p.2-4.

620 Tweede Kamer 1977-1978, 15156, No.2, Rijksbijdrageregeling Sociaal-culturele Activiteiten, 14 september 1978, p.5. Online beschikbaar via www.statengeneraaldigitaal.nl.

621 Zie bijvoorbeeld Rijksarchief Limburg 04.09/7249; 'Antwoord van Gedeputeerde Staten naar aanleiding van het verhandelde in de Vaste Commissie voor Maatschappelijk Werk en Volksgezondheid inzake het voorstel met betrekking tot het provinciaal proefgebied Kaderwet Specifiek Welzijn', 7 april 1981. In antwoord op een vraag van VVD-statenfractie over hoe de overdracht van taken er uit ging zien stelde het College: "In dit verband zij o.m. verwezen naar de 
Rijksbijdrageregeling Sociaal-Cultureel Werk, waarbij globaal gezien, de uitvoerende taken aan gemeenten en de ondersteunende taken aan de provincies worden toebedeeld", p.1 (cursivering $\mathrm{HvE})$.

622 Rijksarchief Limburg 04.09/7257; Bijlage 'Overzicht welzijnssubsidies 1983' bij $3^{\text {e }}$ Provinciale Stuurgroepvergadering, 11 augustus 1982.

623 Dit bleek onder andere uit een brief die de landelijke Stuurgroep Ontwikkelingsprojecten op 17 december 1982 schreef aan minister-president R.F.M. Lubbers en minister L.C. Brinkman. Daarin werd de bezorgdheid uitgesproken over 'de geringe voortgang van de projecten in Limburg'. Hierdoor dreigde 'de potentiële rol van het provinciaal bestuur ook in het geheel van de decentralisatie en afstemming van beleid onvoldoende uit de verf te komen'. Zie Rijksarchief Limburg 04.09/7257; Brief Stuurgroep aan minister-president en minister van Welzijn, Volkgezondheid en Cultuur, 17 december 1982, p.1-2. Zie ook: Rijksarchief Limburg 04.09/7257; Brief ministerie van Welzijn, Volksgezondheid en Cultuur aan Gedeputeerde Staten, 4 maart 1983, waarin het ministerie het uitstel van de behandeling van het wetsontwerp in de Eerste Kamer en de kabinetswisselingen als reden opgaf voor de vertraging.

624 Zie Rijksarchief Limburg 04.09/7263; Notulen van vergaderingen van de Provinciale Stuurgroep Bestuurlijk Experiment, periode 1982-1983.

625 Rijksarchief Limburg 04.09/7257; Brief Gedeputeerde Staten aan minister-president en minister van WVC, 1 februari 1983. De landelijke Stuurgroep was opgericht op 25 april 1978 en gaf advies over de 'werkbaarheid van het in de Kaderwet neergelegde bestuurlijke instrumentarium' (Hueting, 1989: 373).

626 Tweede Kamer 1983-1984, 18 111, no.1, Brief van de minister en staatssecretaris van WVC aan de Tweede Kamer, 26 september 1983. www.statengeneraaldigitaal.nl

627 idem.7.

628 Rijksarchief Limburg 04.09/7257; Verslag van de $2^{\mathrm{e}}$ vergadering van de Commissie ad hoc K.S.W.W.V.G., 10 maart 1983, p.3.

629 idem.3.

630 Rijksarchief Limburg 04.09/7265; Vooroverleg vond plaats op 23 augustus en 3 oktober 1984.

631 Rijksarchief Limburg 04.09/7264; Notitie 'Een vergelijking tussen de door Provinciale Staten vastgestelde nota 'Standpuntbepalingen bestuurlijk experiment Kaderwet Specifiek Welzijn' en de ontwerp-bestuursovereenkomst met het Ministerie van WVC', 31 oktober 1984, p.1, 4.

632 Rijksarchief Limburg 04.09/7265; Concept Bestuursovereenkomst tussen het ministerie van Welzijn, Volkgezondheid en Cultuur en de Provincie Limburg, 28 september 1984, p.5-6. Deze 'grotere beleidsvrijheid' kreeg de Provincie onder andere op het gebied van de jeugdhulpverlening, volwasseneneducatie en natuur- en milieubescherming.

633 Rijksarchief Limburg 04.09/7264; Verslag vergadering Provinciale Projectgroep Bestuurlijk Experiment, 12 november 1984, p.2.

634 Rijksarchief Limburg 04.09/7265; Welkomstwoord van gouverneur Kremers ter gelegenheid van de ondertekening van de bestuursovereenkomst, 16 januari 1985, p.1.

635 Rijksarchief Limburg 04.09/7265; Toespraak van minister L.C. Brinkman ter gelegenheid van de ondertekening van de bestuursovereenkomst, 16 januari 1985, p.2.

$636 \mathrm{Al}$ in december $1985 \mathrm{kwam}$ de Provincie Limburg met een voorstel voor verbreding van de Bestuursovereenkomst. Uiteindelijk werd in het najaar van 1986 overeenstemming bereikt met het ministerie over de overdracht van nog eens zeven taken op het gebied van welzijnsbeleid (o.a. het beleid voor minderheden, het ouderenbeleid en de jeugdhulpverlening). Zie Rijksarchief Limburg 04.09/7268; GS-nota 'Verbreding bestuursovereenkomst Limburg', november 1986.

637 Rijksarchief Limburg 04.09/7297; GS-nota 'Voorstellen voor uitzuivering van welzijnstaken', januari 1986, p.2.

638 Rijksarchief Limburg 04.09/7257; Bijlage 3 'Kort verslag van het overleg met de Limburgse 
gemeenten ...' bij het Statenstuk A-54 Standpuntbepalingen Bestuurlijk Experiment Kaderwet Specifiek Welzijn, 24 mei 1983.

639 Rijksarchief Limburg 04.09/7264; Verslag vergadering Provinciale Projectgroep Bestuurlijk Experiment, 14 december 1983, p.2.

640 idem.3; Bij monde van de vertegenwoordiger van de Vereniging van Limburgse Gemeenten in dezelfde vergadering.

641 Uiteindelijk ging het hier om overdracht van 2,9 miljoen gulden per jaar vanaf 1 januari 1987. De Vereniging van Limburgse Gemeenten had een werkgroep gevormd om het decentralisatievoorstel van de Provincie te beoordelen en afgezien van een paar kleine kanttekeningen, kwam men snel tot overeenstemming.

642 Dit tot grote schrik van de muziekscholen en de bibliotheken die nieuwe bezuinigingen vreesden en nu met een groot aantal gemeenten moesten gaan onderhandelen in plaats van met één provincie.

643 Rijksarchief Limburg 04.09/7297; Nota voor Provinciale Staten 'Uitzuivering van welzijnstaken', 25 juli 1986, p.9. Op 18 december 1986 stemden Provinciale Staten in met het voorstel van Gedeputeerde Staten.

644 Rijksarchief Limburg 04.09/7265; Notitie Stals 'Uitgangspunten ten behoeve van het overleg met de minister van Welzijn, Volksgezondheid en Cultuur op 12 januari 1984', 1 december 1983, p.1.

645 Rijksarchief Limburg 04.09/7265; Zie opmerkingen bij het GS-besluit van 13 december 1983 waar de notitie van gedeputeerde Stals in het College werd besproken: 'Op basis van de notitie van de $\mathrm{hr}$. Stals, nadat zij is bijgesteld (niet sectoraal, maar categoraal, als verwerkt in schema van de hand van de hr. Buck) zal hr. Stals ... een nieuwe nota voorbereiden'.

646 Het schema werd ook wel het 'schering-en-inslag-model' genoemd. Later werd vooral gesproken van 'het A4'tje van Buck'. Het schema was een matrix waarin 'sectoren' als cultuur, zorg, educatie, arbeidsmarkt, bouw in relatie werden gebracht met 'doelgroepen' als jeugdigen, ouderen, gehandicapten en minderheden.

647 Rijksarchief Limburg 04.09/7265; Notitie behorende bij de agendapunten voor het gesprek met de minister van WVC, de heer Brinkman, op 12 januari a.s.', januari 1984, p.2, in GS behandeld op 10 januari 1984.

648 Rijksarchief Limburg 04.09/7264; Provincie Limburg (1984). De vernieuwing van welzijnsbeleid in Limburg. Voorstellen voor een probleemgerichte aanpak. Mei 1984, p.2-3.

649 idem.3.

650 Rijksarchief Limburg 04.09/7266; GS-nota 'Probleemgerichte aanpak', mei 1984, p.4. De nota werd in het College vastgesteld op 15 mei 1984.

651 Rijksarchief Limburg 04.09/7295; GS-nota 'Ordening provinciale steunfunctiestructuur', 21 augustus 1984, p.1.

652 De Provincie hanteerde in de nota's verschillende cijfers als het ging om het totaalaantal van de Limburgse steunfuncties. In het voorstel aan Provinciale Staten van 18 september 1984 werd nog gesproken van 42 steunfunctie-instellingen. Zie Rijksarchief Limburg 04.09/7295; PS-nota 'Struktuurschets Provinciaal Welzijnsbeleid', 18 september 1984, bijlage 3 van H-174. Later werd er gesproken van 45 en zelfs 60 steunfuncties, zie bijv. Rijksarchief Limburg 04.09/7301; Provincie Limburg (1987). Naar een nieuwe welzijnsstructuur, december 1987, p.4. Verwezen werd hier naar de bijlage waar vervolgens weer 60 steunfuncties genoemd werden. Het merendeel van de steunfunctie-instellingen bestond uit deellocaties van muziekscholen (in totaal 11), 'kreatieve centra' (10) en instellingen met een specifiek deelgebied van de monumentenzorg (10). Het beleid voor muziekscholen en creatieve centra werd echter overgeheveld naar de gemeenten. Daarom werd in het besluit gesproken van 'ruim 40 ' steunfuncties.

653 Het betrof hier een fusie naar vijf steunfuncties die actief waren op het terrein van het sociaalcultureel en educatief werk, kunst en cultuur, sport en sportieve recreatie, gezondheidszorg en 
maatschappelijke dienstverlening, en tenslotte het bibliotheekwerk. De 40 steunfuncties ontvingen jaarlijks bijna 14 miljoen gulden subsidie van de Provincie. Zie Rijksarchief Limburg 04.09/7296; GS-nota 'Uitwerking provinciaal welzijnsbeleid', 19 maart 1985, p.6.

654 Rijksarchief Limburg 04.09/7268; Brief College van GS aan minister van WVC, 28 januari 1986, p.2.

655 Archief Provincie Limburg 7396; Provincie Limburg (1988). Rapportage Bestuursovereenkomst Limburg 1987, maart 1988, p.5.

656 Rijksarchief Limburg 04.09/7264; De vernieuwing van welzijnsbeleid in Limburg, p.3, 10-11.

657 Zie de gezamenlijke brief van 25 betrokken instellingen aan Provinciale Staten van Limburg op 29 mei 1985, p.3: "Dit overleg met de betrokken instellingen is niet alleen noodzakelijk omdat zij betrokkenen zijn, maar vooral omdat de uitwerking van het voorstel mede hoort te zijn gestoeld op hun kennis van de practijk en deskundigheid". Rijksarchief Limburg 04.09/7296, Brief Overleg Provinciale Welzijnsinstellingen aan Provinciale Staten, 29 mei 1985.

658 Het overleg met de welzijnsinstellingen verliep in eerste instantie alleen met de werknemers- en werkgeversorganisaties van de welzijnssector. Zie Rijksarchief Limburg 04.09/7297; Samenvattend verslag van het overleg tussen werknemers- en werkgeversorganisaties en de Provincie Limburg inzake de herstructurering van het provinciaal welzijnsbeleid, 31 oktober 1986.

659 Archief Provincie Limburg 7397; Provincie Limburg (1989). Bestuursovereenkomst Limburg. Verslag Studieconferentie 5 en 6 oktober 1989, inleiding, p.3.

660 Archief Provincie Limburg 7397; Kaiser, H.J. (1987). Formatie steunfunctie-instituut sociaalcultureel en educatief werk. Eindrapport. Mheer, 19 oktober 1987, p.1.

661 idem.13-14.

662 Rijksarchief Limburg 04.09/7397; Jaarrapportage Bestuursovereenkomst Limburg 1988, mei 1989, p.3.

663 Archief Provincie Limburg 7397; Provincie Limburg (1989). Bestuursovereenkomst Limburg 1988, mei 1989. Bijlage 2 geeft een overzicht van de overgedragen taken vanaf 1 januari 1985.

664 Bibliotheek Provincie Limburg; Nota voor Provinciale Staten 'Gevolgen rijksbezuinigingen', 10 maart 1992, p.2. Opgenomen in het Bronnnenboek Symbiose van de Commissie van Onderzoek (2005).

665 idem.4-12.

$\$ 4.5$ Het einde van het welzijnsbeleid (periode 1992-2003)

666 Bijna gelijktijdig met de aankondiging van de bezuinigingen in het welzijnsbeleid, nam de Provincie het besluit om te investeren in de bouw van drie nieuwe provinciale musea.

667 De stafgroep Provinciale Financiën van de Provincie schatte begin 1992 dat de financiële bezuinigingen een omvang zouden hebben van 18,7 miljoen gulden vanaf 1993. Een fors gedeelte daarvan zou moeten worden gevonden door bezuinigingen binnen de 'sector welzijn'. Zie Bibliotheek Provincie Limburg; Nota voor Provinciale Staten 'Gevolgen rijksbezuinigingen', 10 maart 1992, p.2, 4-14. Opgenomen in het Bronnnenboek Symbiose van de Commissie van Onderzoek (2005).

668 Bibliotheek Provincie Limburg; PS-nota 'Gevolgen rijksbezuinigingen', 10 maart 1992, p.11.

669 idem.8. Er werd gesproken van een 'taakstelling' van 5,8 miljoen gulden voor de acht betrokken instellingen.

670 Bibliotheek Provincie Limburg. Provinciale Bestuurscommissie Welzijnsplanning (1992). Nota Heroverweging, p.40-43, 47-49.

671 In totaal ging het om $236 \mathrm{fte}$ aan arbeidsplaatsen. Zie 6544; Cijfers per 1 januari 1993 uit Bakkenist (1993). 'Contourenplan Provinciaal Welzijnsinstituut Limburg, 27 mei 1993, p.10-11.

672 Archief Provincie Limburg 22988; Brief van GS aan de 8 steunfunctie-instellingen, 26 mei 1992. De twee externe deskundigen waren aangetrokken voor hun 'financieel-economisch, bestuurlijk- 
organisatorisch terrein, c.q. op het terrein van personeelsbeleid', p.1.

673 Archief Provincie Limburg 22988; Notitie 'Leidraad voor het interim-bestuur Provinciaal Welzijnsinstituut Limburg', 1 juli 1992. Daarnaast zou er een basisbudget - 'intern flexibel budget' - van ten minste 2,5 miljoen gulden moeten worden gecreëerd voor 'vernieuwende projecten', p.1.

674 idem.7.

675 idem.2.

676 Bibliotheek Provincie Limburg. Berenschot (1993). 'Rapportering uitgebracht aan het Provinciaal Welzijnsinstituut Limburg', maart 1993, p.8, opgenomen in het Bronnnenboek Symbiose van de Commissie van Onderzoek (2005).

677 Archief Provincie Limburg 6544; Bakkenist (1993). 'Contourenplan Provinciaal Welzijnsinstituut Limburg', 27 mei 1993, p.1-2. De 7 te fuseren instellingen waren: Instituut voor Kategoriaal Overleg Limburg, Limburgs Instituut ter ondersteuning van het sociaal-cultureel en educatief werk, Limburgse Integratie Stichting, Vereniging van Patiënten en Consumentenorganisaties in Limburg, Stichting voor Ondersteuning van de Gezondheidszorg en de Maatschappelijke Dienstverlening in Limburg, Stichting Provinciaal Emancipatiewerk Limburg en Instituut voor Emancipatie-ontwikkeling Limburg. De 3 instellingen die een meer autonome positie zouden behouden waren: Informatie en bibliotheekcentrale Limburg, Stichting Kunst en Cultuur Limburg en Stichting Sportservice Limburg. Volgens het interim-bestuur moesten deze organisaties een 'relatief autonome positie' behouden omdat zij niet een specifieke doelgroepfunctie kenden en te verschillend waren van de andere instellingen.

678 Archief Provincie Limburg 6544; Bijlage rapport Bakkenist met de 'Reacties instellingen op Contourenplan Provinciaal Welzijnsinstituut'.

679 Archief Provincie Limburg 6544; Bijlage bij rapport Bakkenist 'Toelichting bij het minderheidsstandpunt ter zake PCL en belangenbehartiging van prof.dr. A.F.A. Korsten', mei 1993.

680 Archief Provincie Limburg 6544; GS-nota 'Advies interim-bestuur Provinciaal Welzijnsinstituut', augustus 1993, p.4. Voorzitter De Wit adviseerde het College van GS om vast te houden aan de oorspronkelijke opdracht, een fusie van alle tien de instellingen. De Wit was voorzitter van Liose.

681 Bibliotheek Provincie Limburg; Provincie Limburg (1993), Persbericht: 'GS van Limburg houden vast aan één Limburgs welzijnsinstituut', 30 september 1993. Opgenomen in het Bronnnenboek Symbiose van de Commissie van Onderzoek (2005).

682 Archief Provincie Limburg 8493; PS-besluit van 5 november 1993 bij 'Voorstel voor de oprichting van het provinciaal instituut Symbiose van 28 september 1993'.

683 Archief Provincie Limburg 21709; GS-nota 'Symbiose' van 11 oktober 1994, p.1.

684 Archief Provincie Limburg 21709; Fax van BDO CampsObers aan Provincie Limburg van 5 oktober 1994, p.1.

685 Archief Provincie Limburg 21709; Vertrouwelijke brief van Stichting Symbiose (p/a BDO CampsObers) aan Gedeputeerde Staten van Limburg, 11 oktober 1994, p.2. De stichting constateerde dat 'de huidige manier van werken over de hele linie zo tijdrovend en ineffectief is dat het voor onze leden niet op te brengen is zo voort te gaan'.

686 Archief Provincie Limburg 21709; Vertrouwelijke GS-nota 'fusie en subsidiebeëindiging welzijnsinstellingen', 25 oktober 1994, p.7.

687 Bibliotheek Provincie Limburg; Provincie Limburg (1995). Basisakkoord 1995-1999. CDA-VVDPvdA, 11 april 1995, p.19.

688 idem. zie o.a. p.19-22.

689 Bibliotheek Provincie Limburg. Zie ook de conclusie van de Commissie voor Onderzoek/ Provincie Limburg (2005) 'Rapport van bevindingen onderzoek Symbiose', maart 2005: 'Er is sprake van een van bovenaf opgelegde fusie waarbij het instrument van concrete subsidiebeëindiging per individuele instelling een extra stimulans moest vormen om daaraan mee te werken', p.74. 
690 Bibliotheek Provincie Limburg. Provinciale Bestuurscommissie Welzijnsplanning (1998). Evaluatie Stichting Symbiose. Proces-evaluatie van de Stichting Symbiose, december 1998, p.1, 5. Eind 1995 werd deze zogeheten 'outputfinanciering' uitgesteld omdat er nog diverse 'overgangsperikelen' waren en twee jaar later werd er definitief van afgezien.

691 idem.2.

692 idem.2.

693 Bibliotheek Provincie Limburg; Provincie Limburg / Commissie voor Onderzoek (2005). Rapport van bevindingen onderzoek Symbiose, maart 2005, p.75.

694 Bibliotheek Provincie Limburg; Provincie Limburg (1999). Basisakkoord 1999-2003 CDA-VVDPvdA. 'Limburg, innovatief en waardenvast', 8 april 1999. "De komende statenperiode zal vooral accent worden gelegd op de beleidsspeerpunten groen en milieu, zorg en cultuur, en werk en infrastructuur", p.3.

695 Vanaf eind jaren '90 werden hier twee programma's voor opgezet. Het eerste programma heette Wonen-Welzijn-Zorg, waarmee vanuit de ambitie om de wachtlijsten voor Limburgse zorginstellingen aan te pakken de samenhang werd opgezocht met welzijninstellingen, gemeenten en woningcorporaties. Een tweede programma was het Kwaliteitsketen Welzijn Limburg waarin samen met gemeenten en welzijnsinstellingen gezocht werd naar 'ketensamenwerking' en 'kwaliteitscriteria' voor de welzijnsector. Zie Van Daal \& Bakker/PON (2005). Het project Kwaliteitsketen Welzijn Limburg. Eindevaluatie, augustus 2005. Online beschikbaar [laatst geraadpleegd 24-8-2010]: www.hetpon.nl/pdf/05-28.pdf.

696 Het faillissement vergde vanaf het najaar van 2003 veel aandacht van de ambtelijke organisatie en het College. In de periode na het faillissement moest de stichting Symbiose ontmanteld worden, verplichtingen moesten onderzocht worden, en het personeel moest worden ondergebracht bij andere instellingen. Het 'dossier' Symbiose viel onder de sectorportefeuille van gedeputeerde O.M.T. Wolfs (PvdA) en niet onder de thema-portefeuille Vitale Kernen van collega-gedeputeerde H.T.J. Vrehen (CDA). In die zin kon Vrehen wel met een schone lei beginnen aan zijn deputéschap.

697 Tweede Kamer 2002-2003, 28600 XI, Nr.88 'Brief van de minister van VROM aan de Tweede Kamer', 23 december 2002, p.2. Online beschikbaar op: https://zoek.officielebekendmakingen.nl.

698 De lijst werd in het voorjaar van 2003 in overleg met de 30 grootste gemeenten samengesteld. Daarin was sprake van 56 probleemwijken. De opvolgende ministers S.M. Dekker (VVD), P. Winsemius (VVD), C.P. Vogelaar (PvdA) en E.E. van der Laan (PvdA) zetten deze wijkenaanpak voort. Uiteindelijk werden in 200740 wijken definitief vastgesteld, dit keer onder de noemer van 'prachtwijk'. Het ministerie stelde extra financiële middelen voor deze wijken beschikbaar.

699 Persoonlijk archief Ben van Essen (Provincie Limburg); Notitie 'Klankbordbijeenkomst wethouders Thema 5', juli 2003. Van het overleg zelf is geen verslag gemaakt, de notitie beschreef de opzet en inzet van de provincie voor de bijeenkomst. Ik dank Ben van Essen (afdeling Strategie \& Innovatie van de Provincie Limburg) voor het beschikbaar stellen van zijn persoonlijk archief. Stukken zijn publiekelijk toegankelijk en kunnen geraadpleegd worden nadat contact is opgenomen met dhr. B.J.M. van Essen.

\section{\$4.6 Einde van welzijn, leve de leefbaarheid! (periode 2003-2007 en verder)}

700 Er is een verschil tussen een 'wijk' en een 'buurt'. De begrippen 'wijk' en 'kern' zijn administratieve eenheden die een gemeentelijke overheid hanteert. Het begrip 'buurt' is een subjectief begrip waarin de belevingswereld van bewoners centraal staat. Zie WRR, 2005b, p.20-21.

701 Provincie Limburg (2002). Tussenevaluatie Provinciaal Grotestedenbeleid 2000-2003, oktober 2002. Online beschikbaar [laatst geraadpleegd 27-8-2010]:

www.limburg.nl/upload/pdf/Bibliotheek Provincie LimburgOO_Tussenevaluatie_Provinciaal_ GSB.pdf

702 Persoonlijk archief Ben van Essen (Provincie Limburg); Notitie 'Thema 5 Vitale kernen en buurten 
- Themaplan 2005 met doorkijk tot medio 2007', 31 januari 2005, p.2.

703 Bibliotheek Provincie Limburg. Provincie Limburg (2003). Limburg verlegt grenzen. Coalitieakkoord 2003-2007, 26 mei 2003, p.34.

704 Zie bijvoorbeeld LimburGS, Jaargang 5, no.206. Het blad opende met: 'De leefbaarheid van kleine kernen, buurten en wijken vormt een van de vijf thema's binnen het huidige coalitieakkoord 'Limburg verlegt grenzen'. Online beschikbaar [laatst geraadpleegd op 13-1-2010]: www.limburg. nl/upload/pdf/limburGS_206.pdf.

705 Provincie Limburg (2006). Vitale kernen en buurten. Terug naar de (thuis)basis. Resultaten 2005, februari 2006, p.5. Online beschikbaar [laatst geraadpleegd 16-12-2010] www.limburg.nl/upload/pdf/Zorg_TerugNaarDeThuisbasis.pdf

706 Het actieprogramma 'passend woningaanbod' werd vooral uitgewerkt in het zogeheten 1000-woningenplan dat gedeputeerde G.H.M. Driessen (CDA) eind 2003 presenteerde vanuit zijn portefeuille volkshuisvesting. In deze paragraaf ligt de nadruk vooral op het voorzieningenbeleid en de Afsprakenkaders met gemeenten.

707 idem.35-36. De Provincie onderkende binnen het thema Vitale kernen twee actielijnen die een minder 'fysieke' inslag hadden te weten 'Sociale betrokkenheid' en 'Werk in kern en buurt'.

708 Persoonlijk archief Ben van Essen (Provincie Limburg); 'Nota Verbeteropgaven, versie 1 december 2003', p.6.

709 Een van deze multifunctionele accommodaties was de zogeheten servicewinkel. Het was een van de innovatieve projecten die door het thema Vitale kernen werden ondersteund. De servicewinkel was een gezamenlijk initiatief van de Rabobank Nederland, TPG Post, Essent, Tempo Team, de GGD, een zorginstelling en een aantal Parkstad-gemeenten. Door bankzaken, post, woon-enwerk informatie, zorg en overheidsdienstverlening op één locatie te bundelen, zo was het idee, kon de leefbaarheid in kleinere kernen in stand worden gehouden. Zie WRR (2005a). Buurtinitiatieven en buurtbeleid in Nederland anno 2004, hoofdstuk 10, p.147-152.

710 Persoonlijk archief Ben van Essen (Provincie Limburg); Notitie 'Uitlijning Thema 5 Vitale kernen, wijken en buurten', 15 januari 2004, p.6.

711 Provincie Limburg (2004). Persbericht 'Regeling Leefbaarheidsfonds voorzieningen 2004 gereed', 24 maart 2004. In het persbericht van 24 maart 2004 werd gedeputeerde H.T.J. Vrehen (CDA) geciteerd: "Het Leefbaarheidsfonds zou in samenhang met reeds bestaande beleidsregels op het terrein van Wonen-welzijn-zorg, Jeugdzorg, Investeringsbudget Stedelijke Vernieuwing en Sociale Ontwikkeling kunnen uitgroeien tot een Vitaliteitsfonds". Dit integrale 'vitaliteitsfonds' is echter nooit gerealiseerd. Online beschikbaar [laatst geraadpleegd 8-2-2010]:

www.limburg.nl/nl/html/algemeen/Actueel/Persberichten/persberichtenarchief.asp?nieuws_ite $\mathrm{m}=3$ T57M6R3N7NQ2656HE76\&jaar=2004\&maand.

712 Persoonlijk archief Ben van Essen (Provincie Limburg); Zie verslag 'Bestuurlijk Overleg VrehenWolfs, Thema Vitale kernen en buurten', 14 september 2004, p.1.

713 De wet verving ook de Wet Voorzieningen Gehandicapten en delen van de Algemene Wet Bijzondere Ziektekosten. De nieuwe wet zou na enige vertraging op 1-1-2007 in werking treden.

714 Persoonlijk archief Ben van Essen (Provincie Limburg); Brief Gedeputeerde Staten van Limburg aan de staatssecretaris van Volksgezondheid, Welzijn en Sport, 21 december 2004, p.1.

715 Een van de casussen was 'Voorzieningen in de Limburgse dorpen'. In dat kader waren ook interviews geweest met de Provincie Limburg over het thema Vitale kernen en werd een bezoek gebracht aan de Epense servicewinkel. Zie WRR (2005a). Buurtinitiatieven en buurtbeleid in Nederland anno 2004.

716 WRR (2005b). Vertrouwen in de buurt, p.13.

717 Eind 2006 was er een bestuurlijk overleg tussen de Provincie Limburg en een aantal bestuurders van de Limburgse woningcorporaties. In het overleg werd afgesproken om gezamenlijk een onderzoek uit te voeren naar de omvang en kwaliteit van de Limburgse woningvoorraad voor 
de komende 10 jaar. Het bestuurlijk overleg vond plaats in de context van de nationale discussie over een mogelijk 'afromen' van het vermogen van de corporaties. In de nieuwe coalitieperiode 2007-2011 werd dit door de Provincie Limburg nader uitgewerkt en zal hier verder niet behandeld worden. Het rapport Limburg TransforMEERt werd op september 2007 gepresenteerd. Online beschikbaar op [laatst geraadpleegd 26-8-2010]:

www.limburg.nl/upload/pdf/BouwenEnWonen_rapportLimburgTransforMEERt.pdf.

718 Persoonlijk archief Ben van Essen (Provincie Limburg); Zie memo 'Mededelingen cie. FAZ Portefeuillehouder thema Vitale kernen en buurten', 23 januari 2006.

719 Persoonlijk archief Ben van Essen (Provincie Limburg); Memo 'Actualisering Afsprakenkaders', 1 februari 2006, p.2.

720 Provincie Limburg / Visitatiecommissie Bestuurskracht Limburg (2006). Weging van de bestuurskracht van de provincie Limburg. Eindrapport, 1 december 2006, p.39-40. Online beschikbaar [laatst geraadpleegd 14-1-2010]: www.limburg.nl/upload/pdf/Bestuurskracht\%20 Provincie\%20Limburg\%20eindrapportage.pdf.

721 idem.3.

722 Persoonlijk archief Ben van Essen (Provincie Limburg); Ongedateerde notitie 'Intakeschema Vitale Kernen en Buurten', voorjaar 2004, p.3-5.

723 Persoonlijk archief Ben van Essen (Provincie Limburg); Notitie 'Thema 5 Vitale kernen en buurten - Themaplan 2006 met doorkijk tot medio 2007', 28 maart 2006, p.2.

724 Persoonlijk archief Ben van Essen (Provincie Limburg); Zie ook Presentatie in Statencommissie Financiën en Algemene Zaken op 14 mei 2004, $3^{\mathrm{e}}$ sheet.

725 Een mooi voorbeeld daarvan is de notitie die is opgesteld naar aanleiding van een overleg tussen de provinciale sectorafdeling Zorg (cluster gezondheidszorg) en het themamanagement Vitale kernen en buurten, 27 maart 2006. De nieuwe werkwijze van het thema riep de vraag op 'hoe intensief' [de afdeling] zich moest verdiepen in vraagstukken. Men constateerde dat men 'onvoldoende op de hoogte' is van zaken waar gemeenten mee bezig zijn en men liep tegen een 'té hoog verwachtingspatroon bij derden' aan. Persoonlijk archief Ben van Essen (Provincie Limburg); Notitie 'Thema Vitale kernen en buurten \& cluster GZ - Verbeterpunten 2006', 27 maart 2006, p.1-2.

726 Persoonlijk archief Ben van Essen (Provincie Limburg); Ongedateerd overzicht 'Bespreking t.a.v. de Jaarplannen van de afdelingen die aan thema 5 [Vitale kernen] gelieerd zijn', waarschijnlijk december 2003. In dit overzicht worden de raakvlakken opgesomd met 11 provinciale afdelingen.

727 Bibliotheek Provincie Limburg. Provincie Limburg (2007). Coalitieakkoord CDA-PvdA-PNL. Investeren en verbinden. De mens centraal in een vertrouwde omgeving, april 2007. Onder naam van het Programma Investeren in Steden en Dorpen werd de wijkenaanpak gecontinueerd: "In tegenstelling tot het Rijk, dat sterk inzoomt op een zeer beperkt aantal individuele stadswijken, willen wij samen met gemeenten tot de juiste prioriteiten komen. Ook en met name de woningbouwcorporaties zullen gezien de hun ter beschikking staande middelen hierin een gezamenlijke verantwoordelijkheid moeten nemen. Alleen zo kan in samenhang een forse sociale maar ook financiële en economische vernieuwingsimpuls worden gegeven, gericht op de realisatie van een vernieuwende wijkaanpak", p.8. Sterker dan in de periode 2003-2007 zouden met deze provinciale aanpak ook de woningcorporaties een rol gaan spelen.

728 Zie bijvoorbeeld het jaarverslag 2006 van het thema, 'Vitale kernen en buurten - Terug naar de (thuis)basis. Resultaten 2006', januari 2007. Het jaarverslag is vooral te lezen als een subsidieverslag van alle projecten die financiële ondersteuning hebben gekregen. Online beschikbaar [laatst geraadpleegd 16-12-2010]:

www.limburg.nl/upload/pdf/Zorg_TerugNaarDeThuisbasis_Resultaten2006.pdf.

729 idem.citaat op p.31. 


\section{$\$ 4.7$ Hoofdlijnen en voorlopige conclusies}

730 Naar analogie van Bemelmans-Videc, Rist \& Vedung [ed.] (1998). Carrots, sticks and sermons. Policy instruments and their evaluation. Transaction Publishers - New Brunswick.

\section{Hoofdstuk 5}

731 Het ging hier om de ministeries van Economische Zaken, Welzijn, Volksgezondheid \& Cultuur, Sociale Zaken, Binnenlandse Zaken en Volkshuisting, Ruimtelijke Ordening en Milieu.

\section{Hoofdstuk 6}

732 Speech van gouverneur Frissen gehouden bij de aanvaarding van het ambt van gouverneur van de Provincie Limburg op vrijdag 1 juli 2005 te Maastricht, p.3. Online beschikbaar [laatst geraadpleegd 27-11-2010]:

www.limburg.nl/upload/pdf/SpeechCdK_20050701_InstallatieInDeProvincieLimburg.pdf.

733 Ik dank Ad Knotter voor dit inzicht.

734 Zie bijvoorbeeld de bijdrage van senator W.J. Witteveen (PvdA) in de slotbehandeling van de ontwerpwet; Eerste Kamer 2003, 14e vergadering, 14 januari 2003, p. 421-422. 



\section{Geraadpleegde archieven}

\section{Rijksarchief Limburg}

- $\quad$ Archief Provinciale Griffie (1944 - april 1987)

- Archief Provinciale Planologische Commissie \& Provinciale Planologische Dienst / ROV (1957 - april 1987)

\section{Provincie Limburg}

- Archief Provincie Limburg (mei 1987 - heden)

- Bibliotheek Provincie Limburg

- Persoonlijke archieven van twee provinciale ambtenaren:

Ik dank dhr. J.P.P.M. Maatjens (afdeling Economische Zaken) en dhr. B.J.M. van Essen (afdeling Strategie \& Innovatie) voor het beschikbaar stellen van hun persoonlijke archieven. De geraadpleegde documenten zijn publiekelijk beschikbaar en op te vragen bij de desbetreffende provinciale ambtenaren (dhr. J.P.P.M. Maatjens, tel. 043-3897268 of per mail: jppm.maatjens@prvlimburg.nl en dhr. B.J.M. van Essen, tel. 043-3897091 of per mail bjm.van.essen@prvlimburg.nl).

\section{Internet}

- directe links

- $\quad$ www.statengeneraaldigitaal.nl 


\section{Literatuur}

Aardenne, G.M.V. van (1987). 'De industrie-politieke slingerbeweging' in Knoester, A. [ed] Lessen uit het verleden. 125 jaar Vereniging voor de Staatshuishoudkunde. H.E. Stenfert Kroese - Leiden.

Alberts, W.J. (1983). Geschiedenis van de beide Limburgen. Beknopte geschiedenis van het gebied omvattende de tegenwoordige Nederlandse en Belgische provincies Limburg. Deel II (vanaf 1632 tot \pm 1918). $2^{e}$ druk. Van Gorcum - Assen.

Assche, K. van (2006). Over goede bedoelingen en hun schadelijke bijwerkingen. Essay over flexibiliteit, ruimtelijke ordening en systeemtheorie. Innovatienetwerk - Utrecht.

Atzema, O., Lambooy, J., Rietbergen, T. van \& Wever, E. (2002). Ruimtelijke economische dynamiek. Kijk op bedrijfslocatie en regionale ontwikkeling. Tweede herziene druk. Countinho - Bussum.

Atzema, O. \& Wever, E. (1999). De Nederlandse industrie. Vernieuwing, verwevenheid en spreiding. Van Gorcum - Assen.

Bakvis, H. (1981). Catholic power in the Netherlands. McGill / Queen's University Press Kingston / Montreal.

Ball, A. R. \& Peters, B.G. (2005). Modern politics \& government. Seventh edition revised and updated. Palgrave MacMillan - New York.

Bartels, C.P.A. \& Duijn, J.J. van (1981). Regionaal-economisch beleid in Nederland. Van Gorcum - Assen.

Baumgartner, F.D. \& Jones, B.D. (1993). Agendas and instability in American politics. The University of Chicago Press - Chicago.

Beckers, T. (2006). De kwestie Maasniel. Strijd om eigen identiteit. Matrijs - Utrecht.

Bekkers, V.J.J.M. \& Lips, A.M.B. (1998). 'Spierballen, veel stroop en weinig water. Verdrogingsbeleid in de provincie Noord-Brabant', pp.153-168 in Hendriks \& Toonen [ed.] Schikken en plooien. De stroperige staat bij nader inzien. Van Gorcum - Assen.

Bemelmans-Videc, Rist \& Vedung [ed.] (1998). Carrots, sticks and sermons. Policy instruments and their evaluation. Transaction Publishers - New Brunswick. 
Berge, J.B.J.M. ten (1988). 'Provinciaal-gemeentelijk partnership', pp.12-29 in Ten Berge, Tijdhof \& Versteden [ed.] Provincie en gemeente: handdruk of handgemeen? Opstellen over de relatie tussen provincie en gemeenten aangeboden aan $m r$. P. van Zanten. VUGA - Den Haag.

Berkhout, D.M. (1999). 'Tussen Scylla en Charybdis: over voetangels en klemmen voor de provincies van de toekomst', pp.49-84 in Raad voor het openbaar bestuur (Rob) De provincie in het vizier. Opstellen over het Nederlands middenbestuur. Rob - Den Haag.

Berkhout, D.M. (2002). 'De provinciale knoop: doorhakken', pp.7-17 in IPO ad-hoc adviescommissie 'Regionaal bestuur in Nederland' (Commissie o.l.v. L.A. Geelhoed). Bijlagen. Op schaal gewogen. Regionaal bestuur in Nederland in de 21ste eeuw. IPO - Den Haag.

Blom, T. (1997). Complexiteit en contingentie. Een kritische inleiding tot de sociologie van Niklas Luhmann. Kok Agora - Kampen.

Blom, T. (2007). 'European Administrative Governance. Some reflections'. Unpublished draft.

Boer, N. de (1993). 'Naar een lokaal sociaal beleid' in Hortulanus, R.P. Contouren van een nieuw lokaal welzijnsbeleid. Een discussie over vernieuwing. VUGA - Den Haag.

Boogers, M. \& Hendriks, F. (2005). Middenbestuur in discussie. Analyse en reflectie op de naoorlogse discussie over middenbestuur in Nederland. Eindrapportage, november 2005. Tilburgse School voor Politiek en Bestuur - Universiteit van Tilburg.

Bordewijk, P. (1999). 'Maatschappelijke ontwikkelingen dwingen tot differentiatie in bestuur', pp.107-129 in Raad voor het openbaar bestuur (Rob) De provincie in het vizier. Opstellen over het Nederlands middenbestuur. Rob - Den Haag.

Bos, J., Bochove, A. van \& Grijpstra, D. (2008). Premiere van een klassieker. Bemiddeling van werk naar werk: het MobiliteitCentrum Automotive als succesvol voorbeeld. Blaauwberg - Leiden

Bouwens, S. (2008). Over de streep. Grensarbeid vanuit Zuid-Limburg naar Duitsland, 1958-2001. Verloren - Hilversum.

Brodocz, A. (2003). 'Das politische System und seine strukturellen Kopplungen', pp.80-94 in Hellmann, Fischer \& Bluhm [ed.] Das System der Politik. Niklas Luhmanns politische Theorie. Westdeutscher Verlag - Wiesbaden. 
Burger, B. (1964). De Provinciewet. Samsom - Alphen aan den Rijn.

Caljé, P. (2011). 'Maastricht en zijn universiteit. Interacties tussen universiteit, stad en regio', pp.233-259 in Van Royen [ed.] Maastricht kennisstad. 850 jaar onderwijs en wetenschap. Vantilt - Nijmegen.

Cammen, H. van der \& De Klerk, L. (2006). Ruimtelijke ordening. Van grachtengordel tot vinex-wijk. Het Spectrum - Utrecht.

Claassen, A.W.M. \& Pouwels, J.P.A.(1991). Rapportage welzijnswerk. Deel 1 Ontwikkelingen in het provinciaal steunfunctiebeleid. Sociaal Cultureel Planbureau - Rijswijk.

Cobbenhagen, J. \& Severijns, J. (2003). 'Towards a knowledge-intensive regional economy: the RTP process in Limburg', pp.40-56 in Morgan \& Nauwelaers [ed.] Regional Innovation Strategies. The Challenge for less-favoured regions. Routledge - London.

Cohen, M.D., March, J.G. \& Olsen, J.P. (1972). 'A garbage can model of organizational choice', pp.1-25 in Administrative Science Quarterly, Vol.17 No.1.

Cuyvers, L., Dejonghe, T., Embrechts, R. \& Rayp, G. (2009). Internationale economie. Garant - Antwerpen/Apeldoorn.

Damme, L. van \& Verdaas, C. (1996). Plannen laten zich niet plannen. De betekenis van WRO/Bro '85 voor de gemeentelijke beleidspraktijk. Eburon - Delft.

Derix, Jan (1990). Perspectief voor Limburg. Stappen en obstakels in het beleid rond de Perspectievennota Zuid-Limburg, 1965-1990. Eisma - Leeuwarden/Maastricht.

Derks, W. (2005). 'De arbeidsmarkt in Limburg 1960-2005: is de sluiting van de mijnen verwerkt?', pp.173-196 in Knotter, A. \& Rutten, W. Studies over de sociaal-economische geschiedenis van Limburg. Jaarboek van het Sociaal Historisch Centrum voor Limburg. Deel L-2005. Sociaal Historisch Centrum voor Limburg - Maastricht.

Derksen, W. (1999). 'Provinciale Staten moeten zich beperken tot bestuur' in NRC Handelsblad, 23 februari 1999.

Dohmen, F.S. (1986). Memoires. Het gezicht van een tijdperk. Herinneringen van een mijnwerker en vakbondsleider, verteld aan Jan Spanjaard. Winants - Heerlen.

Doorn, J.A.A. van (1978). 'De verzorgingsmaatschappij in de praktijk' in Van Doorn \& Schuyt [ed.]. De stagnerende verzorgingsstaat. Boom - Amsterdam. 
Elzinga, D.J. [ed.] (1995). Regionaal bestuur in Nederland. Samsom H.D. Tjeenk Willink - Alphen aan den Rijn.

Engbersen, R. \& Sprinkhuizen, A. (1999). 'Welzijnsbeleid tussen flexibiliteit en versnippering', pp.217-242 in Trommel \& Van der Veen, De herverdeelde samenleving. Ontwikkeling en herziening van de Nederlandse verzorgingsstaat. Amsterdam University Press - Amsterdam.

Etzioni-Halevy, E. (1983). Bureaucracy and democracy. A political dilemma. Routledge \& Kegan Paul - London.

Figee, E.L. (2003). 'Provincies: steunberen van het openbaar bestuur', pp.265-271 in Bestuurswetenschappen, No.3.

Gales, B. (2000). 'Houwen of in stof bijten? Maakbaarheid in de mijnstreek' pp.27-64 in Knotter, Ad \& Rutten, Willibrord [ed.], Maakbaar Limburg. De constructie van een samenleving in een eeuw van uitersten. Studies over de sociaal-economische geschiedenis van Limburg XLV. Sociaal Historisch Centrum voor Limburg - Maastricht.

Geelhoed, L.A. (1990). 'Plaats en functies van het bestuurlijk middenveld', pp.20-23 in Bestuurswetenschappen, No.1.

GemengdeCommissieDecentralisatievoorstellenProvincies('CommissieLodders')(2008). Ruimte, regie en rekenschap. 17 maart 2008. Online beschikbaar [laatst geraadpleegd 183-2011]: www.rijksoverheid.nl/bestanden/documenten-en-publicaties/publicaties-pb51/ rapport-commissie-lodders-ruimte-regie-en-rekenschap/07br2008g105.pdf.

Glasbergen, P. \& Driessen, P.P.J. [ed.] (1993). Innovatie in het gebiedsgericht beleid. Analyse en beoordeling van het ROM-gebiedenbeleid. SDU - Den Haag.

Graaff-Nauta, D.IJ.W de (1990). 'Zal de provincie een volwaardig bestuur blijven?', pp.913 in Bestuurswetenschappen, No.1.

Haan, I. de \& Duyvendak, J.W. [ed.] (2002). In het hart van de verzorgingsstaat. Het Ministerie van Maatschappelijk Werk en zijn opvolgers (CRM, WVC, VWS), 1952-2002. Walburg Pers - Zutphen.

Haas, W. de (2006). Planning als gesprek. Grondslagen voor ruimtelijke planning en beleid in de eenentwintigste eeuw. De Graaff - Utrecht.

Haye, R. de la \& Hamans, P. (2009). Bisdom langs de Maas. Geschiedenis van de kerk in Limburg. Uitgeverij TIC - Maastricht. 
Heij, P.R. \& Schrijver, J.F. (1991). 'Decentralisatie', pp.55-75 in De Kam \& De Haan [ed.] Terugtredende overheid: realiteit of retoriek. Een evaluatie van de grote operaties. Academic Service - Schoonhoven.

Hen, P.E. de (1980). Actieve en re-actieve industriepolitiek in Nederland. De overheid en de ontwikkeling van de Nederlandse industrie in de jaren dertig en tussen 1945 en 1950. De Arbeiderspers - Amsterdam.

Hendriks, F. (2001). 'The Netherlands: Reinventing tradition in local and regional democracy', p.143-172 in Loughlin, J. Subnational Democracy in the European Union. Challanges and opportunities. Oxfort University Press - Oxfort.

Hendriks, F. (2002). 'De provincie in het Nederlands openbaar bestuur: waartoe en waarheen?' pp.77-98 in Bestuurswetenschappen, No.2.

Herwijer, M. (1996). 'Interprovinciale samenwerking', pp.67-89 in Dam, M.J.E.M. van, J. Berveling, G.H.J.M. Neelen en A.C. Wille [ed.] Het Onzichtbare Bestuur: Over provincies, stadsprovincies en regionale vraagstukken. Eburon - Delft.

Herweijer, M. (1999). 'Over de regierol van het (samenwerkende) provinciebestuur', pp.947 in Raad voor het openbaar bestuur (Rob) De provincie in het vizier. Opstellen over het Nederlands middenbestuur. Rob - Den Haag.

Hesse, J.J. \& Kleinfeld, R.R. (1990). Die Provinzen im politischen System der Niederlande. Westdeutscher - Wiesbaden.

Heuvel, H. van den (2000). 'De politieke basis van de moderne provincie', pp.12-15 in Openbaar Bestuur, No.5.

Hood, C.C. (1983). The tools of government. The MacMillan Press - London.

Hoogenboezem, J. (2003). Implementation in the EU. An investigation into the implementation of utility reform directives in five European Union member states. University of Hull. Unpublished dissertation.

Hueting, E. (1989). De permanente herstructurering in het welzijnswerk. De Walburg Pers - Zutphen.

IPO / Commissie Regionaal Bestuur in Nederland ('Commissie Geelhoed') (2002). Op schaal gewogen. Regionaal bestuur in Nederland in de 21e eeuw. IPO - Den Haag.

Jacobs, D. (2009). Creatief innovatiebeleid? Rede uitgesproken bij de aanvaarding van het ambt van hoogleraar Industriële Ontwikkeling en Innovatiebeleid aan de Universiteit van 
Amsterdam op 19 maart 2009. Vossiuspers UvA - Amsterdam.

Jansen, J.C.G.M. (1997). 'Economische geschiedenis van Limburg 1800-1900', p15-89 in Jansen \& Rutten, Studies over de sociaal-economische geschiedenis van Limburg. XLII. Eisma - Leeuwarden/Maastricht.

Janssen, J. (2006). Vooruit denken en verwijlen. De (re)constructie van het plattelandschap in Zuidoost-Brabant, 1920-2000. Zuidelijk Historisch Contact - Tilburg.

Kingdon, J.W. (2003). Agendas, alternatives and public policies. Second edition. Longman - New York.

Kleinfeld, R. (1999). 'Een persoonlijke toekomstvisie van het Nederlandse binnenlands bestuur met bijzondere aandacht voor de rol van provincies', pp.131-158 in Raad voor het openbaar bestuur (Rob) De provincie in het vizier. Opstellen over het Nederlands middenbestuur. Rob - Den Haag.

Korsten, A. (1990). 'Ontzuiling in het maatschappelijk middenveld', pp.381-4 in Soeters, Spoormans \& Welten [ed.] Het Nieuwe Limburg. Herstructurering en ontwikkeling. Scriptum - Schiedam.

Kraaijestein, M. (1995). Gemeentelijk werkgelegenheidsbeleid en het Rijk: 1945-1990. Een beleidshistorische studie over decentralisatie en gemeentelijke beleidsvrijheid. Verloren Hilversum.

Kroeger, P.G. \& Stam, J. (1998). De rogge staat er dun bij. Macht en verval van het CDA 1974-1998. Balans - Amsterdam.

Laermans, R. (1999). Communicatie zonder mensen. Een systeemtheoretische inleiding in de sociologie. Boom - Amsterdam.

Landabaso, M. \& Reid, A. (2003). 'Developing regional innovation strategies: the European Commission as animateur', pp.19-39 in Morgan \& Nauwelaers [ed.] Regional Innovation Strategies. The Challenge for less-favoured regions. Routledge - London.

Lans, J. van der (2008). Ontregelen. De herovering van de werkvloer. Augustus - Amsterdam.

Leidelmeijer, K. \& Van Kamp, I. (2003). Kwaliteit van de leefomgeving en leefbaarheid. Naar een begrippenkader en conceptuele inkadering. RIGO/RIVM - Amsterdam/Bilthoven.

Lier, R. van (2007). De provinciale organisatie in continue staat van verandering. Waarom veranderen provincies van organisatiemodel? Erasmus Universiteit - Rotterdam. 
Lindblom, C. (1979). 'Still muddling, not yet through', in Public Administration Review, Vol. 39, pp. 517-526.

Lintsen, H. [ed.] (2000). Research tussen vetkool en zoetstof. Zestig jaar DSM Research 1940-2000. Walburg Pers - Zutphen.

Loughlin, J. (2001). Subnational democracy in the European Union. Challanges and Opportunities. Oxford University Press - Oxford.

Luhmann, N. (1981). Politische Theorie im Wohfarhtsstaat. Günther Olzog Verlag München.

Luhmann, N. (1997). Die Gesellschaft der Gesellschaft. Zweiter Teilband. Suhrkamp Verlag - Frankfurt am Main.

Luhmann, N. (2000a). Die Politik der Gesellschaft. Suhrkamp - Frankfurt am Main.

Luhmann, N. (2000b). Organisation und Entscheidung. Westdeutscher Verlag - Opladen/ Wiesbaden.

Luhmann, N. (2004). Ökologische Kommunikation. Kann die moderne Gesellschaft sich auf ökologische Gefährdungen einstellen? 4. Aufglage. VS Verlag für Sozialwissenschaften - Wiesbaden.

Lutters, A.H.A. (1976). Gedeputeerde staten, hun taken en bevoegdheden. Vuga - Den Haag.

March, J.G. \& Simon, H. (1993). Organizations. Second Edition. Blackwell Publishers Oxford.

Marks, G. \& Hooghe, L. (2005). 'Contrasting Visions of Multi-level Governance' pp.15-30 in Bache \& Flinders [ed.] Multi-level Governance. Oxford University Press - Oxford.

Mayntz, R. \& Scharpf, F.W. (1975). Policy-making in the German federal bureaucracy. Elsevier - Amsterdam.

Mayntz, R. (1997). 'The conditions of Effective Public Policy (1983)', pp.143-167 in Mayntz [ed.] Soziale Dynamik und politische Steuerung. Theoretische und methodologische Überlegungen. Campus Verlag - Frankfurt/New York.

Meijer, W. (1990). 'Internationalisering en de gevolgen daarvan voor de provincies', pp.24-29 in Bestuurswetenschappen, No.1. 
Merriënboer, J. van, Bootsma, P. \& Griensven, P. van (2008). Van Agt. Biografie. Tour de Force. Boom - Amsterdam.

Mertens, A.Th. (1963). Gouverneur van Limburg. 1947/1963. Herinneringen bij het afscheid van Dr. F.J.M.A.H. Houben als Commissaris der Koningin in Limburg. Leiter-Nypels Maastricht.

Messing, F.A.M. (1988). Geschiedenis van de mijnsluiting in Limburg. Noodzaak en lotgevallen van een regionale herstructurering 1955-1975. Martinus Nijhoff - Leiden.

Miedema, S. (1986). 'Doeleinden en instrumenten van het nationale regionale beleid', in Zoon [ed.] De Periferie Centraal. Opstellen ter gelegenheid van het veertigjarig bestaan van het Economisch-Technologisch Instituut voor Friesland en zijn integratie in het provinciaal apparaat. Friese Pers Boekerij - Drachten / Leeuwarden.

Mintzberg, H. \& Waters, J. (1985). 'Of strategies, deliberate and emergent' in Strategic Management Journal, Vol.6, p.257-272.

Modderkolk, A.J. (1990). 'De provincie: plaatsbepaling en koersaanduiding', pp.1-7 in Bestuurswetenschappen, No.1.

Mokken, R.J. \& Stokman, F.N. (1976). 'Power and influence as political phenomena' pp.33-54 in Barry [ed.] Power and political theory. John Wiley \& Sons - Londen.

Monchy, S.J.R. de (1976). Handboek voor het Nederlandse provincierecht. Bewerkt door Dr. A.H. Günther. Tsjeenk Willink - Zwolle.

Neelen, G.H.J.M. (1999). 'De zwakke legitimiteit van provincies: oorzaken en oplossingsrichtingen', pp.85-105 in Raad voor het openbaar bestuur (Rob) De provincie in het vizier. Opstellen over het Nederlands middenbestuur. Rob - Den Haag.

Neij, R. (1989). De organisatie van het Maatschappelijk Werk. De Walburg Pers - Zutphen.

Nieuwenhuijsen, P. (1999). 'Onpolitieke provincie, onzichtbare provincie', pp.24-30 in Binnenlands Bestuur, 17, 30 april 1999.

Nieuwenkamp, R. (2001). De prijs van het politiek primaat. Wederzijds vertrouwen en loyaliteit in de verhouding tussen bewindspersonen en ambtelijke top. Eburon - Delft.

Nijkamp, P., Bouman, H. \& Verhoef, A. (1986). 'De regionaal-economische ontwikkeling en het beleid in nationale context' pp.44-57 in Zoon [ed.] De Periferie Centraal. Opstellen ter gelegenheid van het veertigjarig bestaan van het Economisch-Technologisch Instituut 
voor Friesland en zijn integratie in het provinciaal apparaat. Friese Pers Boekerij - Drachten / Leeuwarden.

Nissen, P.J.A. (1990). 'Godsdienst en kerk in ontwikkeling' in Soeters, Spoormans \& Welten [ed], Het nieuwe Limburg. Herstructurering en ontwikkeling. Scriptum - Schiedam.

Peet, J. \& Rutten, W. (2009). Oranje-Nassau Mijnen. Een pionier in de Nederlandse steenkolenmijnbouw 1893-1974. Oranje-Nassau Groep / Waanders - Zwolle.

Pennen, A.W. van der [et.al.] (1995). Welzijnsbeleid in de lokale samenleving. Rapportage welzijnswerk 5. Sociaal Cultureel Planbureau - Rijswijk.

Pennings, P. (1992). 'Zuilen en lokale subsidies in 45 gemeenten, 1880-1930' in Blockmans \& Van der Valk [ed.] Van particuliere naar openbare zorg en terug? Sociale politiek in Nederland sinds 1880. Neha - Amsterdam.

Peper, B. (11976). Vorming van welzijnsbeleid. Evolutie en evaluatie van het opbouwwerk. Boom - Meppel.

Peters, B. Guy (2001). The politics of bureaucracy. Fifth edition. Routledge - Londen.

Peters, K. (2002). Verdeelde macht. Een onderzoek naar invloed op rijksbesluitvorming in Nederland. Boom - Amsterdam.

Peters, K. (2007). Het opgeblazen bestuur. Een kritische kijk op de provincie. Boom Amsterdam.

Pierre, J. \& Peters, B.G. (2000). Governance, politics and the state. MacMillan Press London.

Pijnenburg, P.D.M. (1956). Beschouwingen over het streekplan. Van Gorcum - Assen.

Porter, M.E. (2004). Competitive strategy. Techniques for analyzing industries and competitors. Free Press - New York.

Pressman, J. \& Wildavsky, A. (1984). Implementation. How great expectations in Washington are dashed in Oakland; or why it's amazing that federal programs work at all, this being a saga of the economic development administration as told by two sympathetic observers who seek to build morals on a foundation of ruined hopes. Third edition, expanded. University of California Press - Berkeley.

Putnam, R.D. (1993). Making democracy work. Civic traditions in Modern Italy. Princeton 
University Press - Princeton.

Raad voor het openbaar bestuur (Rob) (1999). De provincie in het vizier. Opstellen over het Nederlands middenbestuur. Rob - Den Haag.

Raad voor het Openbaar bestuur / Raad voor de financiële verhoudingen (2007). Brief aan de minister van BZK dhr. J. Remkes inzake 'Open huishouding provincie' van 21 februari 2007. Online beschikbaar [laatst geraadpleegd 30-3-2011]: www.ipo.nl/sites/default/files/ brief_rob_en_rfv_openhuishoudingvandeprovincie.pdf

Raspe, O. \& Oort, F. van (2007). Ruimtelijk economisch beleid in de kenniseconomie. Ruimtelijke Planbureau - Den Haag.

Reerink, J., Wetzels, P. \& Klijn, A. [ed.] (1989). Honderd jaar over de rooien. De sociaaldemocratie in Limburg van 1899 tot 1989. Gewest Limburg PvdA - Sittard.

Richelle, J.N.M. (1993). 'Lokaal welzijnsbeleid en de rol van WVC: een nieuwe bestuursfilosofie' pp.135-145 in Hortulanus, R.P. [ed.] Contouren van een nieuw lokaal welzijnsbeleid. Een discussie over vernieuwing. VUGA - Den Haag.

Ridder, J. de (1990). Toezicht in de ruimtelijke ordening. Een empirische studie naar intergouvermentele betrekkingen tussen provincie en gemeente in het kader van het planologisch toezicht. Kluwer - Deventer.

Rieken, J.G.P. \& Baaijens, J.M.J. [ed.] (1984). De provincie als bestuurlijk midden. Evenwicht tussen rijk, provincie en gemeente. Van Loghum Slaterus - Deventer.

Righart, H. (1986). De katholieke zuil in Europa. Een vergelijkend onderzoek naar het ontstaan van verzuiling onder katholieken in Oostenrijk, Zwitserland, België en Nederland. Boom - Meppel/Amsterdam.

Rijssenbeek, R.C.J.M. (1979). Wie is er baas in Limburg? Met medewerking van Jan Derix. Dagblad voor Noord-Limburg - Venlo.

Ringeling, A. (1987). 'Beleidstheorieën en theorieën over beleid' pp.41-53 in Lehning \& Simonis [ed.] Handboek beleidswetenschap. Boom - Meppel.

Roes, J. \& Schreurs, J. (2002). Midden in Limburg. Aspecten van een eeuw sociale werken door aalmoezeniers. Dienst Kerk en Samenleving / Bisdom Roermond - Roermond.

Rooy, P. de (2005). Republiek van rivaliteiten. Nederland sinds 1813. Mets \& Schilt Amsterdam. 
Rotmans, J. (1998). Geïntegreerd denken en handelen. Een noodzakelijk goed. Oratie uitgesproken bij de aanvaarding van het ambt van hoogleraar Integrated Assessment aan de Universiteit Maastricht op 18 september 1998.

Schaap, L. (1997). Op zoek naar prikkelende overheidssturing. Over autopoiese, zelfsturing en stadsprovincie. Eburon - Delft.

Schaap, L., Hupe, P.L., Ringeling, A.B. \& Vries, G.J.D. de (2000). 'Het geprangde middenbestuur vecht terug. Gebiedsgericht werken als vechtstrategie', pp.164-172 in Bestuurskunde, 9, No.4.

Schellen, M.A.C. \& Philipsen, P.G.J. (1990). 'Welzijnsbeleid in ontwikkeling' pp.256273 in Soeters, Spoormans \& Welten [ed.] Het Nieuwe Limburg. Herstructurering en ontwikkeling. Scriptum - Schiedam.

Schendelen, M.C.P.M. van (1987). 'Naar opheffing van de provincie', pp.256-261 in Namens, 2, No.5.

Schendelen, M.C.P.M. van (1990). 'Europese redding voor de vervallen provincie?', pp.2632 in Namens, 5, No.3.

Schuyt, T. (1980). 'Lokale welzijnsplanning: historie, achtergronden en stand van zaken' pp.35-51 in Van Harberden [ed.] Lokale welzijnsplanning. Over de maakbaarheid van het welzijn. VUGA - Den Haag.

Sharpe, L.J. (1993) [ed.]. The rise of meso government in Europe. SAGE Publications London.

Simon, H. (1997). Administrative behaviour. A study of decision-making processes in administrative organizations. Fourth Edition. The Free Press - New York.

Simonis, J. (1979). 'De Provincie' in Simonis, Jan \& Glasbergen, Pieter Ruimtelijk beleid in de verzorgingsstaat. Onderzoek naar en beschouwing over de (on)mogelijkheid van een nationaal ruimtelijk beleid in Nederland, p.98-146. Kobra - Amsterdam.

Simonis, J. \& Glasbergen, P. (1979). Ruimtelijk beleid in de verzorgingsstaat. Onderzoek naar en beschouwing over de (on)mogelijkheid van een nationaal ruimtelijk beleid in Nederland. Kobra - Amsterdam.

Siraa, H.T. (1989). Een miljoen nieuwe woningen. De rol van de rijksoverheid bij wederopbouw, volkshuisvesting, bouwnijverheid en ruimtelijke ordenining (1940-1963). SDU - Den Haag. 
Spoormans, H., Welten, R. \& Dittrich, K. (1990). 'Politiek: deining in de electorale stromen' pp.326-348 in Soeters, J., Spoormans, H. \& Welten, R. [ed.] Het nieuwe Limburg. Herstructurering en ontwikkeling. Scriptum - Schiedam.

Staatsen, A.A.M.F. (1984). 'De provincies: op een afstand maar niet te ver (hoofdstuk 15)', pp.175-185 in Rieken \& Baaijens De provincie als bestuurlijk midden. Evenwicht tussen rijk, provincie en gemeente. Van Lochum Slaterus - Deventer.

Tjeenk Willink, H.D. (1984). 'De weerbarstige centrale overheid? (hoofdstuk 4)', pp.41-51 in Rieken \& Baaijens De provincie als bestuurlijk midden. Evenwicht tussen rijk, provincie en gemeente. Van Lochum Slaterus - Deventer.

Toonen, Th.A.J. (1987). Denken over binnenlands bestuur. Theorieën van de gedecentraliseerde eenheidsstaat bestuurskundig beschouwd. VUGA - 's Gravenhage.

Toonen, Th.A.J. (1993). 'Dutch Provinces and the struggle for the meso' pp.117-153 in Sharpe [ed.] The rise of meso government in Europe. SAGE Publications - London.

Toonen, Th.A.J. (2005). Theorie van de Provincie. Bestuurlijk essay. IPO - Den Haag.

Torenvlied, R. (1996). Besluiten in uitvoering; theorieën over beleidsuitvoering modelmatig getoetst op sociale vernieuwing in drie gemeenten. Thesis Publishers - Amsterdam.

Ubachs, P.J.H. (2000). Handboek voor de geschiedenis van Limburg. Verloren - Hilversum.

Veen, R. van der (1999). 'De ontwikkeling en recente herziening van de Nederlandse verzorgingsstaat' pp.23-47 in Trommel \& Van der Veen [ed.] De herverdeelde samenleving. Ontwikkeling en herziening van de Nederlandse verzorgingsstaat. Amsterdam University Press - Amsterdam.

Vereniging van Nederlandse Gemeenten (VNG) (1982). Van verre vriend tot goede buur? Studie naar de veranderende positie van de provincie. VNG-studies nr.1. Uitgeverij VNG - Den Haag.

Vereniging van Nederlandse Gemeenten (VNG) (2006). Brief aan de leden (06/161) inzake 'Gesloten huishouding provincies' van 27 oktober 2006. Online beschikbaar [laatst geraadpleegd: 30-3-2011]:

www.vng.nl/Documenten/vngdocumenten/Ledenbrief_BB-U200601765.pdf

Versteden, C.J.N. (1990). 'Plaats en functie van de provincie, vanuit de optiek van differentiatie', pp.14-20 in Bestuurswetenschappen, No.1. 
Vijver, O. van de (1995). 'De wederopstanding van de provincie' pp.16-19 in Binnenlands Bestuur, No.8, 24 februari 1995.

Visser, R.K. (2008). In dienst van het algemeen belang. Ministeriële verantwoordelijkheid en parlementair vertrouwen. Boom - Amsterdam.

Vries, I. de \& Schippers, A. (2002). 'Afstemming tussen zorg en welzijn: een eis van deze tijd' pp.65-75 in Hortunanus, R.P. \& Machielse, J.E.M. [ed.] Ontmoeting, ontspanning en ontplooiing. Het Sociaal Debat. Deel 8. Elsevier Overheid - Den Haag.

Vries, M.S. de (2003). 'De teloorgang van de provincie', pp.113-130 in Bestuurswetenschappen, No.2.

Vries, M.S. de (2011). 'De provincies verdienen uw stem niet' in NRC Handelsblad, 24 februari 2011, p.11.

Wetenschappelijke Raad voor het Regeringsbeleid (2005a). Buurtinitiatieven en buurtbeleid in Nederland anno 2004. Analyse van een veldonderzoek van 28 casussen. Pallas Publications - Amsterdam.

Wetenschappelijke Raad voor het Regeringsbeleid (2005b). Vertrouwen in de buurt. Amsterdam University Press - Amsterdam.

Wijnen, J. \& Koopmanschap, T. (1981). Hoe katholiek is Limburg? De kerk en het bisdom Roermond. De Lijster - Maasbree.

Wildavsky, A. (2007). Speaking truth to power. The art and craft of policy analysis. Transaction Publishers - New Brunswick / London.

Wissink, B. (2000). Ontwerpen en ontstaan. Een praktijktheoretische analyse van het debat over het provinciale omgevingsbeleid. SDU - Den Haag.

Woud, A. van der (2004). Het lege land. De ruimtelijke orde van Nederland 1798-1848. Olympus - Amsterdam.

Zanden, J.L. \& Griffiths, R.T. (1989). Economische geschiedenis van Nederland in de 20 e eeuw. Aula/Het Spectrum - Utrecht.

Zanden, J.L. van (1997). Een klein land in de $20^{e}$ eeuw. Economische geschiedenis van Nederland 1914-1995. Het Spectrum, Utrecht. 


\section{Overzicht geïnterviewde personen (chronologisch)}

J.L.M. (Jan) Wijnhoven

K.A.M. (Karel) Farber

J.T.M. (Jan) Houwen

F.Q. (Frans) Hoebens

L.C. (Leo) Niesen

L.C.M. (Lou) Hermens

B. (Ben) Taken

A. (André) Peters

L.W. (Louis) Haas

J. (Jan) Ketelaars

H.M.J.M. (Harry) Tacken

Th.L.M. (Theo) Thomaes

G. (Gies) Dohmen

J.L. (Jo) Matti

J.M.A. (Jos) Benders

H.E.R.J. (Harry) Janssen

A.L.A. (Fons) Meijers

H.F. (Henk) Groen

E.H.M.T. (Lily) Rassin-Vijgen

J.B.J.M. (Jo) Stijnen

J.J. (Sjaak) Swartjes

J.H.M.A. (Joop) Kneepkens

A. (Cees) Grijsbach

M.A.C. (Martin) Schellen

A.J. (André) Plantinga

H.F.H. (Bart) Joosten

D.L.H.M. (Dominique) Ruijters

A. (Arthur) Jansen

G.H.G. (Gé) Waeijen

H.W.M. (Haro) Oppenhuis-De Jong

G.M.K. (Ger) Kockelkorn

P.L.G.C.M. (Peter) Parren

F.P.C. (Frans) van de Voort

B.J.M. (Ben) Gudde

L.P.J. (Leo) de Bruyn

P.M.J.A. (Piet) Tops

A.M.A.A. (Fons) de Baedts

M.C.E. (Rien) van Gendt
18 mei 2007 te Baarlo

4 juni 2007 te Maastricht

18 juni 2007 te Maastricht

10 juli 2007 te Tegelen

17 juli 2007 te Heerlen

18 juli 2007 te Maastricht

19 juli 2007 te Roermond

31 juli 2007 te Maastricht

13 september 2007 te Maastricht

13 september 2007 te Roermond

13 september 2007 te Herkenbosch

21 september 2007 te Maastricht

26 september 2007 te Panningen

26 september 2007 te Weert

27 september 2007 te Maastricht

4 oktober 2007 te Roermond

18 januari 2008 te Maastricht

28 januari 2008 te Maastricht

30 januari 2008 te Maastricht

7 februari 2008 te Maastricht

21 februari 2008 te Oisterwijk

28 februari 2008 te Maastricht

29 februari 2008 te Roermond

25 maart 2008 te Wijnandsrade

16 april 2008 te Leiderdorp

8 mei 2008 te Maastricht

8 mei 2008 te Maastricht

9 mei 2008 te Eijsden

20 mei 2008 te Maastricht

28 mei 2008 te Haarlem

17 juni 2008 te Meerssen

17 juni 2008 te Thorn

18 juni 2008 te Venlo

19 juni 2008 te Maastricht

25 juni 2008 te Maastricht

2 juli 2008 om te Sittard

3 juli 2008 te Maastricht

7 juli 2008 te Den Haag 
H.J. (Herman) Kaiser

P.G.G. (Piet) Hilhorst

L. (Lei) Stals

J.C.M (Jan) Dovermann

J.J.M. (Jan) Tindemans

J. (Sjeng) Kremers

J.H.M. (Jean) Bronckers

C.E.M. (Constant) de Waal

J.B.V.N. (Jef) Pleumeekers

M.C. (Riet) Greweldinger-Beudeker

B.J.M. (Berend-Jan) van Voorst tot Voorst

P.J.I.M. (Philip) Houben

J.J. (Jan) Schrijen

W.G.L. (Wien) Wijnen

G.J. (Gerard) Heiligers

T.J.P. (Pierre) Verhagen

F.R.B. (René) van den Bergh

J.B. (Jan) Haazen

F.H.J. (Frans) Koelman

H.W. (Henk) Riem

J.G.J. (Joep) Knapen

W.L.J. (Wim) Weijnen

M.T.P. (Margot) Hofman-Ruijters

H.F.M. (Henk) Evers

M.J.A. (Martin) Eurlings

H.J. (Hans) Brinkhof

M.J.H. (Mat) Vestjens

G.H.M. (Ger) Driessen

L.J.P.M. (Léon) Frissen

O.M.T. (Odile) Wolfs

H.M. (Bert) Kersten

H.T. J. (Herman) Vrehen

J.H.H. (Jan) Mans
8 juli 2008 te Doetinchem

11 juli 2008 te Sevenum

18 juli 2008 te Swartbroek

22 juli 2008 te Maastricht

23 juli 2008 te Beek (MAA)

13 januari 2009 te Bilthoven

14 januari 2009 te Maastricht

16 januari 2009 te Roermond

16 januari 2009 te Sittard

19 januari 2009 te Horst

21 januari 2009 te Maastricht

23 januari 2009 te Maastricht

27 januari 2009 te Sittard

5 februari 2009 te Eijsden

12 februari 2009 te Heerlen

12 februari 2009 te Maastricht

16 februari 2009 te Maastricht

16 februari 2009 te Beek

17 februari 2009 te Maastricht

18 februari 2009 te Maastricht

20 februari 2009 te Breda

27 februari 2009 te Maastricht

12 maart 2009 te Lemiers

16 maart 2009 te Nederweert

25 maart 2009 \& 6 april 2009 te Valkenburg

25 maart 2009 te Beek

1 april 2009 te Panningen

22 april 2009 te Maastricht

18 mei 2009 te Maastricht

31 maart 2010 te Maastricht

8 april 2010 te Maastricht

30 april 2010 te Roosteren

25 mei 2010 te Maastricht 


\section{Summary}

\section{Taking responsibility \\ Provincial politics in Limburg 1962-2007}

Political and public debate about the Dutch provinces frequently concerns two issues: why the provinces are in fact necessary (i.e. their legitimacy) and the scale that they ought to have. What a province actually does, how decisions are taken, and how those decisions take account of social trends are often ignored in the course of this debate. This book does not focus on what the provinces ought to do or ought to be, but with how a province functions. It takes a look behind the scenes at a particular province: the Province of Limburg.

The analysis of provincial politics in Limburg focuses on the actual practice of decision-making, i.e. the way in which decisions by the Province are prepared, taken, and implemented. Long-term patterns are identified from a historical perspective with an understanding of the circumstances under which they change.

Until the early 1960s, the Province concerned itself primarily with the regional infrastructure (motorways, railroads and canals) and supervision of the municipal finances. The Provincial Executive [College van Gedeputeerde Staten] that came into office in Limburg in 1962 changed course, and took the first steps towards economic policy, social welfare policy and spatial planning. From then on the government organisation that traditionally had a limited scope, and that responded mainly reactively to events within Limburg society, became an active political player and took initiatives on fields traditionally outside its sphere of interest.

The province from a different perspective: the practice of decision-making

Formally speaking, there has been little change in how decisions were taken by the Province in the period from 1962 to 2007 . From the constitutional point of view the Provincial Executive and the Provincial Council [Provinciale Staten] were - and still are the decision-making bodies for the Province of Limburg. There are significant changes in the actual practice of decision-making however, it seems that the formal competences and policy instruments of a province do in no way determine or limit the scope of decisionmaking. This book therefore concerns itself primarily with analysing decision-making processes. It attempts to explain how provincial decision-making operates, what longterm patterns can be distinguished in that process, and what circumstances lead to changes in those patterns.

For this analysis a political-sociological research framework was developed, concentrating on five particular aspects. Firstly, the use of competences and instruments by the Province is considered. The Dutch provinces operate within the context of the decentralised unitary state, which means that only the national government that can initiate legislation. Yet, the provinces (and the municipalities) have a certain degree of autonomy within their assigned competences. The provinces also have their own legal, financial, and organisational instruments available - bylaws [verordeningen], subsidies, 
manpower - that they can utilise in order to implement decisions.

Secondly, the practice of decision-making requires that the province takes into account the interests of various different persons, groups, and/or organisations. The Provincial Executive and Provincial Council do, ultimately, have the formal power to take a decision, but both internal and external actors influence the way that decision is arrived at. In other words, the second aspect of the research framework involves an analysis of influence and power.

A third element in the analysis of provincial decision-making is the use made of geographical divisions. In every political system geographical divisions are relevant in policy making. Governments may, for example, distinguish between policies for urban and rural areas but also between specific regions, or between depressed areas and areas with economic potential. Thus it can do justice to local and regional variations within its territory. It can also make comparisons with other provinces or sub-regions. Finally, a government can experiment with new policy for a particular defined area. The advantage of this is that if the experiment is a failure, it will not be the overall provincial policy that is called into question.

A fourth aspect involves the cooperation between politicians and the civil service. Relations between politicians and the civil service are relevant because civil servants play an important role in preparing decisions and formulating alternatives. The relationship between civil servants and politicians is not just a case of 'one-way traffic' but of constant interplay in which it is the politicians who are ultimately accountable for the decision taken. That interplay is important both when preparing and implementing decisions.

Finally, one can identify moments of new agenda-setting. At these turning points, there is a fundamental change in the strategic direction. The way decisions are prepared and taken changes, the role of the province changes, and new patterns of decision-making arise.

\section{Four periods, four strategies, four turning points}

This book analyses three areas of policy: spatial planning (Chapter 2), the regional economic policy (Chapter 3) and the social welfare policy (Chapter 4). These three fields are placed within a social, organisational, and political context; provincial policy is influenced by economic trends, changes in organisational structure or the appointment of persons, the composition of executive bodies, and relations with external contacts. The period from 1962 to 2007 can be subdivided into four sub-periods, each lasting between 12 to 16 years. The transitions between these sub-periods are moments of rapid changes, influencing fundamentally the overall provincial policy within just two or three years. At these turning points, a new strategy is created in the provincial politics of Limburg.

The first turning point in provincial policy was in the early 1960s. In 1962, it became apparent that the coalmining industry in Limburg was no longer profitable. This led to the announcement in 1965 by the Minister of Economic Affairs, J.M. den Uyl (Labour) of a phased closedown of the mines. In the same period, the Catholic Church gradually retreated from its active role in Limburg society. The disappearance of these two important 
social institutions - the mining industry and the Catholic church - presented not only an enormous economic challenge but also had major social and spatial consequences for the whole of Limburg. The Provincial Government could no longer stand aloof and - led by the new Provincial Governor Ch.J.M.A. van Rooy (Catholic People's Party) - worked closely with central government, the mining industry, and various Limburg organisations to give shape to a policy of restructuring, in particular for South Limburg. In doing so, the Province made use to a limited extent of the possibilities provided by new legislation in the field of spatial planning and social welfare.

In the period from 1962 to 1978, the Province of Limburg extended its role within the three policy fields. It investigated a new series of instruments for implementing policy intentions; it looked at how other provinces shaped comparable policy; and it commissioned studies to see which social-economic problems faced the Province. When it was announced that the mines were to close, the Province held central government responsible for the consequences this would have for Limburg. Numerous state subsidies became available, and the Province was given the task of distributing them within the region. It did so by setting up a large number of committees. In the course of the 1970s, the Provincial Government increasingly came to realise that it needed to shoulder greater responsibility regarding social-economic issues in the Province. However, the influence of a number of Limburg organisations such as the Agriculture and Horticulture Confederation, the regional economic research agency (Etil), and the Chambers of Commerce was still extremely dominant on important committees such as the Planning Committee, the Social Guidance Committee, and the Restructuring Committee. These organisations prevented new provincial policy initiatives by sticking to the status quo and thus consolidating their own position of power.

A second turning point came in the late 1970s. In 1978, unemployment in South Limburg had reached $10 \%$ and in the view of the new Governor J. Kremers (Christian Democrat) the then current system of administration via committees had not been effective. Kremers emphasized that the Province no longer should assign the responsibility for the economic situation in Limburg to the national government; rather, the Province needed to take the necessary new initiatives itself and not wait for proposals from the national government. The negotiations with the cabinet in early 1978 formed the basis for provincial policy that focused primarily on reducing unemployment in the Province. Governor Kremers and his right hand Executive Councillor K.W. Buck (Christian Democrat) set up an effective lobby towards the cabinet of prime-minister A.A.G. van Agt (also Christian Democrat). This also resulted in that Limburg was the sole province to be designated a pilot region for decentralised social welfare policy. This provides a second example of how the Province itself took the initiative to shape policy as it saw fit.

The period from 1978 to 1990 was unique in provincial history. In the course of the 1980s, the Provincial Executive - led by Governor Kremers and Executive Councillor Buck - negotiated successfully with central government. In the mid-1980s, the Province was given an important task in planning public housing, social welfare and health care policy, but the Provincial Executive gave priority to economic policy. Hundreds of 
projects were initiated and implemented by the Province in the context of this Perspectives Memorandum Policy [Perspectievennotabeleid], with most of them being financed by central government. The need for the Province to take an active role became even stronger from the mid-1980s given that central government increasingly relinquished control in favour of the provinces.

The Perspectives Memorandum Policy was terminated in December 1990, which once more brought about a change in the Province's decision-making. The administrative agreement ratifying the decentralisation of social welfare policy had already been completed one year previously. This put an end to years of collaboration with central government, but the basis had been laid for a province that took the initiative itself and made use of its competences to shape and implement policy. The Province was given full control of social welfare policy, which was transferred to it by central government. The national government also assigned new competences to the provinces in the field of spatial planning, environmental and water policy. The Provincial Executive that took office in 1991 was chaired by a temporarily appointed Queen's Commissioner, and two Executive Councillors already changed their jobs after only a year. These changes in personnel, new sectoral legislation, and different economic and political circumstances created another turning point.

The period from 1990 to 2003 saw an increase in the power of the civil service. Central government obliged the provinces to draw up policy in various fields. Particularly in the fields of the environment, nature and care, central government drew up new legislation that had to be elaborated at provincial level. At first - and in part inspired by the signing of the Maastricht Treaty in 1992 - the Province primarily sought to cooperate with the European Commission. In the second half of the 1990s, however, it was the intermediary organisations such as the Limburg Development Company (LIOF), the Syntens innovation platform, the Agriculture and Horticulture Confederation and the newly merged social welfare institution Symbiose that influenced provincial policy. Central government and the municipalities played only a subordinate role in this. Central government had relinquished control in favour of the provinces and was now focusing mainly on strengthening the position of the municipalities. In the 1990s, the political negotiations between the Province and the government were restricted to bilateral contacts between Executive Councillors and ministers or state secretaries. Whereas in the 1980s the overriding objective had been to combat unemployment, a variety of objectives were now formulated. There were, for example, provincial objectives in the area of technology policy, attempts to formulate quantifiable objectives in social welfare policy, and highly specific objectives in spatial planning policy. All these objectives were an expression of a more self-confident stance on the part of the Province. In order to actually achieve these objectives, expertise was required in the various policy fields, expertise that was to be found primarily within the civil service and that gave the latter a powerful position as regards the preparation of policy. It was primarily the intermediate organisations that influenced and implemented provincial policy.

That situation changed in 2003. The insolvency of a number of implementing 
organisations such as Symbiose and the Limburg Tourist Board and the wish of the new Provincial Executive for a more pronounced role for the Province, led to a change of course. No longer were the intermediary partners important. Now large corporations, industry, the knowledge institutions and major municipalities were involved in the preparation of policy. Clever use was made of the new national policies such as the community work approach, the new regional economic programme and the discussion of a new 'spatial development policy'. The draining away of industrial activity from Limburg to Asia, rising unemployment, and problems regarding the quality of life in certain urban areas and villages also contributed to this change of direction.

In the period from 2003 to 2007 the Provincial Executive gave shape to this new role of the Provincial Government. Various implementation problems in the preceding period and the economic downswing from 2004 onwards led to a new political profile. The Province collaborated with new actors such as the municipalities by drawing up joint agreement frameworks [Afsprakenkaders] and implementing 45 spatial planning projects. Business and industry, education institutions, and knowledge institutions worked with the Province on an economic Acceleration Agenda [Versnellingsagenda]. New instruments, new types of organisation, and different actors led to changes in provincial strategy. In all this, the Province of Limburg also keyed in actively to the priorities of national policy.

\section{New provincial agenda-setting: a Limburg story?}

The development of the Province features a growing awareness of the Province's own strength. Nevertheless, this development was not gradual but by fits and starts. At four points within the period from 1962 to 2007 , there was a fundamental shift - within a relatively short period of only two or three years - in the administrative role and strategic direction of the Province. At these four points, a new agenda was created within the provincial politics of Limburg, with three factors playing a role: pressing external circumstances, alliances between persons, and the scope offered to the Province by central government. It was the simultaneous combination of these factors that altered provincial strategy within spatial planning policy, economic policy and social welfare policy.

There is no empirical study of how any of the other provinces functioned over a lengthy period and, in this book, Limburg is the first province to be analysed and described in this way. A follow-up study will be necessary to determine whether the development outlined is unique to Limburg or whether similar patterns can be discovered in other provinces. 


\section{Over de auteur}

Hendrik Jan van Elmpt is geboren op 18 oktober 1978 te Geleen. Hij behaalde in 1997 zijn VWO diploma aan de Scholengemeenschap Groenewald te Stein. Hij studeerde Cultuuren Wetenschapsstudies aan de Faculteit der Cultuurwetenschappen van de Universiteit Maastricht in de periode 1997-2001. Hij behaalde zijn doctoraalexamen Cultuur- en Wetenschapsstudies met als specialisatie Politieke Cultuur. Zijn doctoraalscriptie was een literatuurstudie over de omgang en verwerking van het oorlogsverleden in Duitsland in vergelijking met de landen Japan en Zuid-Afrika. Na zijn afstuderen begon hij als onderzoeker bij de afdeling Onderzoek \& Ondersteuning van de Provincie Limburg. Hij werkt momenteel bij de concernafdeling Strategie \& Innovatie van de Provincie als senior strateeg. De interesse voor de wetenschap is nooit ver weg geweest als ambtenaar en het was juist zijn interesse voor de koppeling tussen theorie (wetenschap) en praktijk (provinciale politiek) die in 2006 uitmondde in de start van dit promotie-onderzoek. Het onderzoek is geschreven in opdracht van de Directie van de Provincie Limburg.

Hendrik Jan is getrouwd met Fleur Parabirsing. Ze hebben een dochter, Julia. 
Appendices 


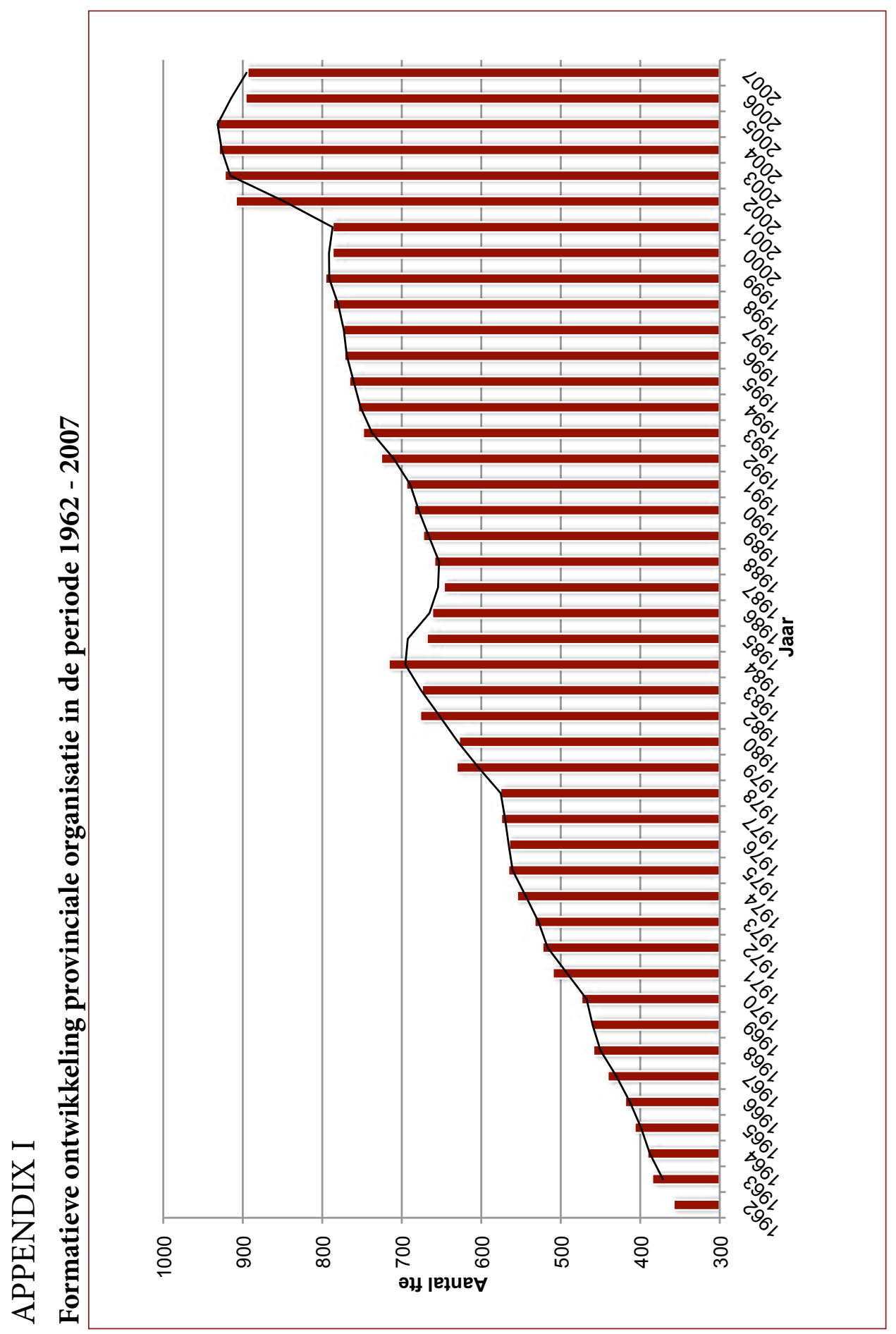




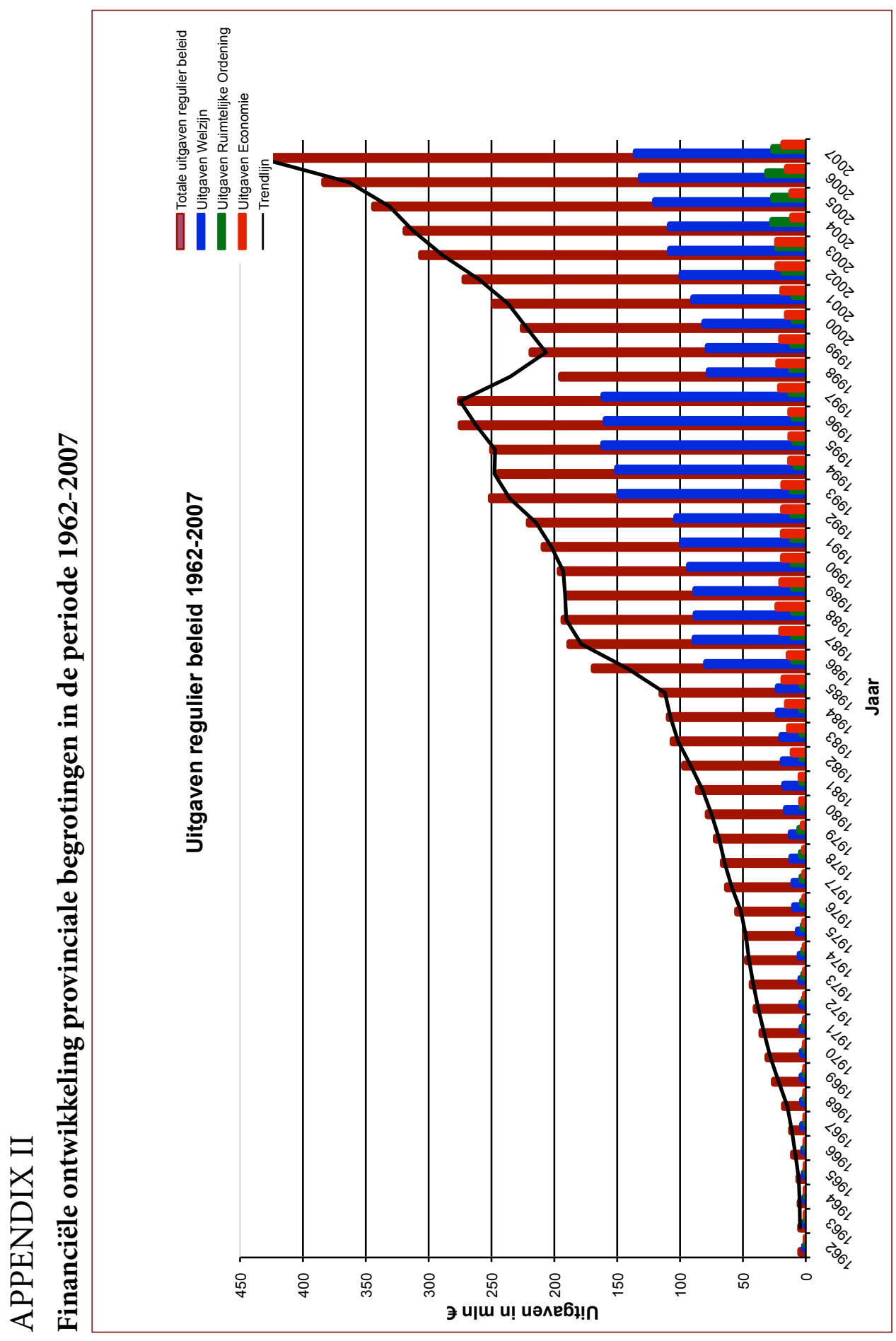




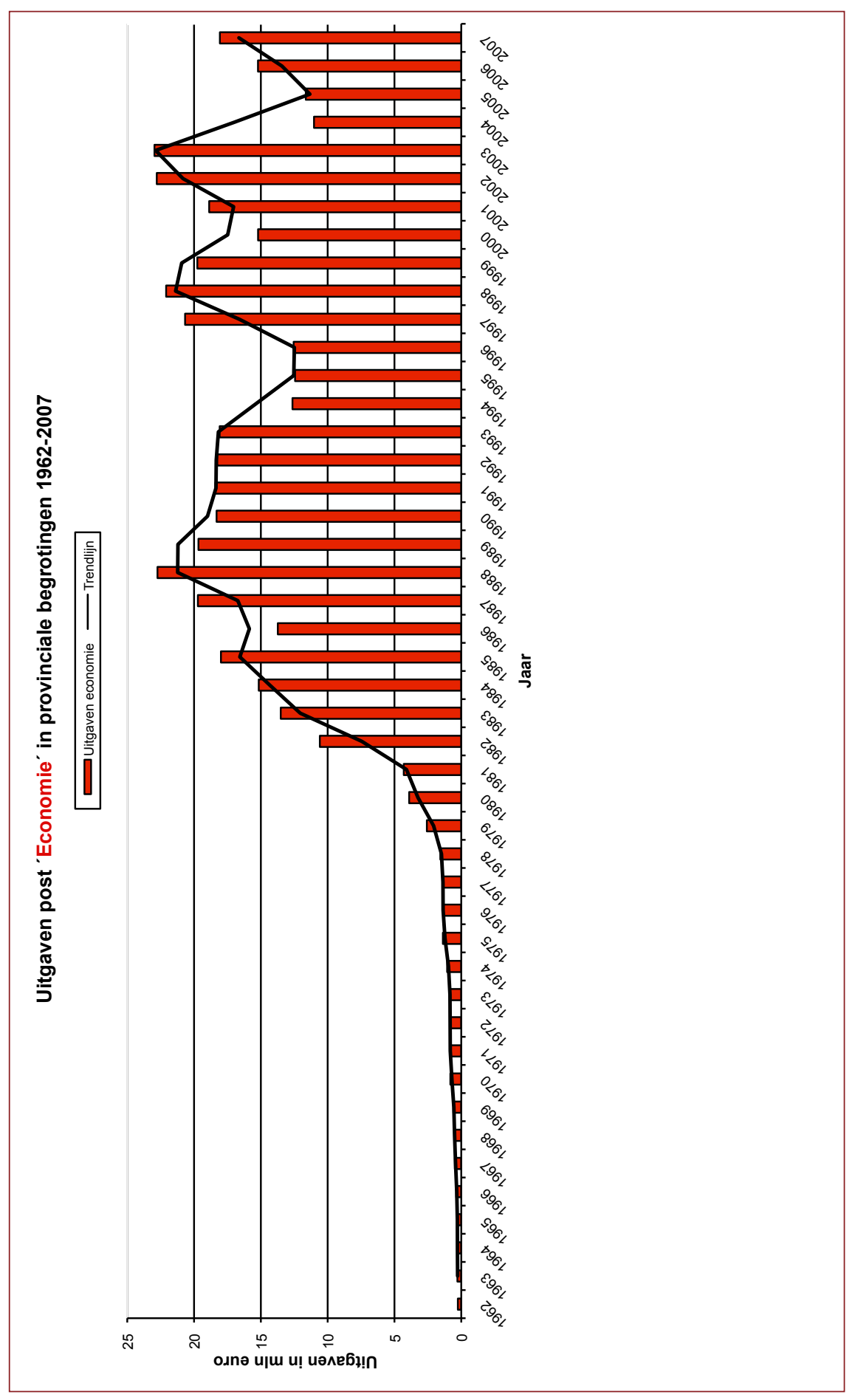




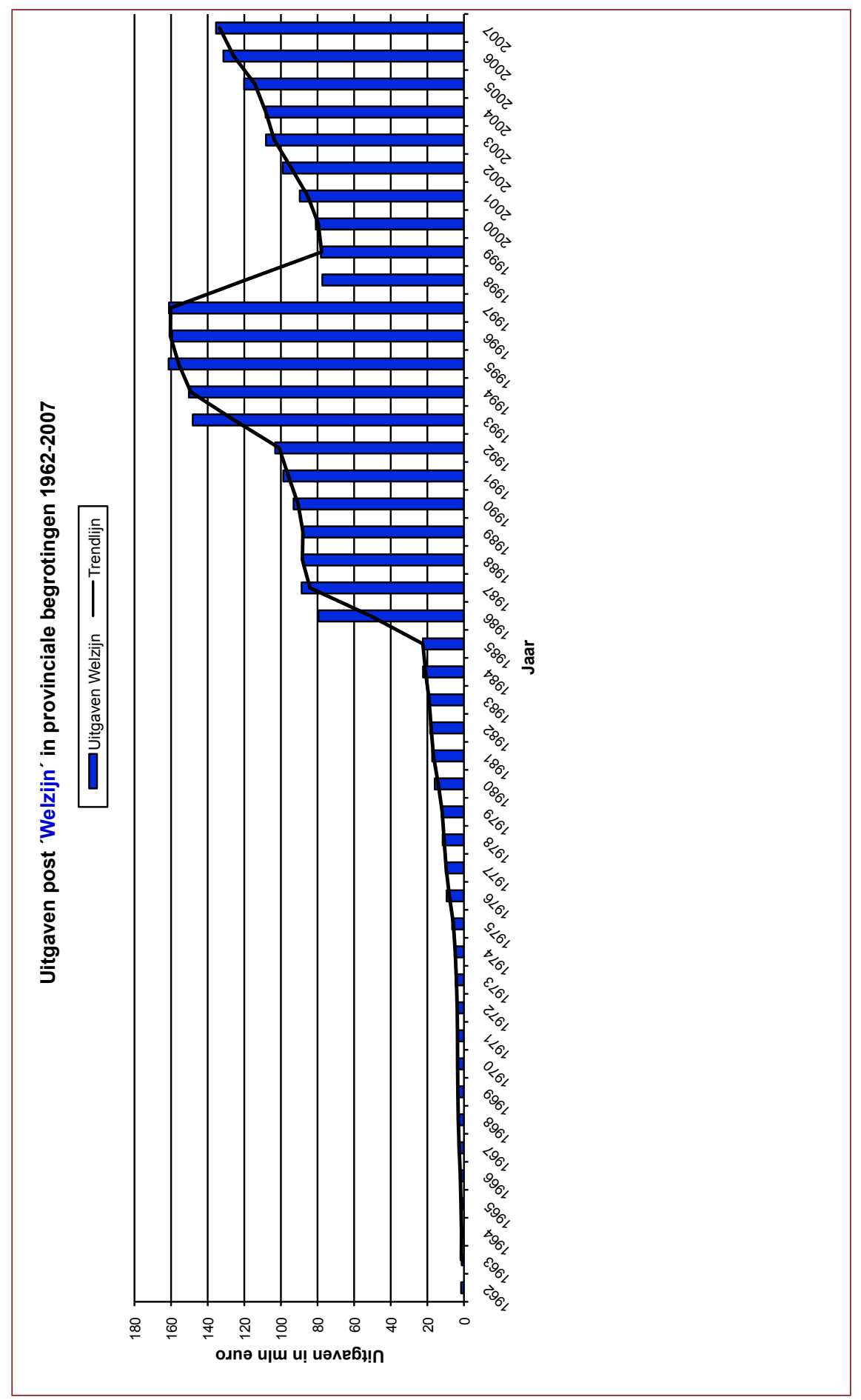




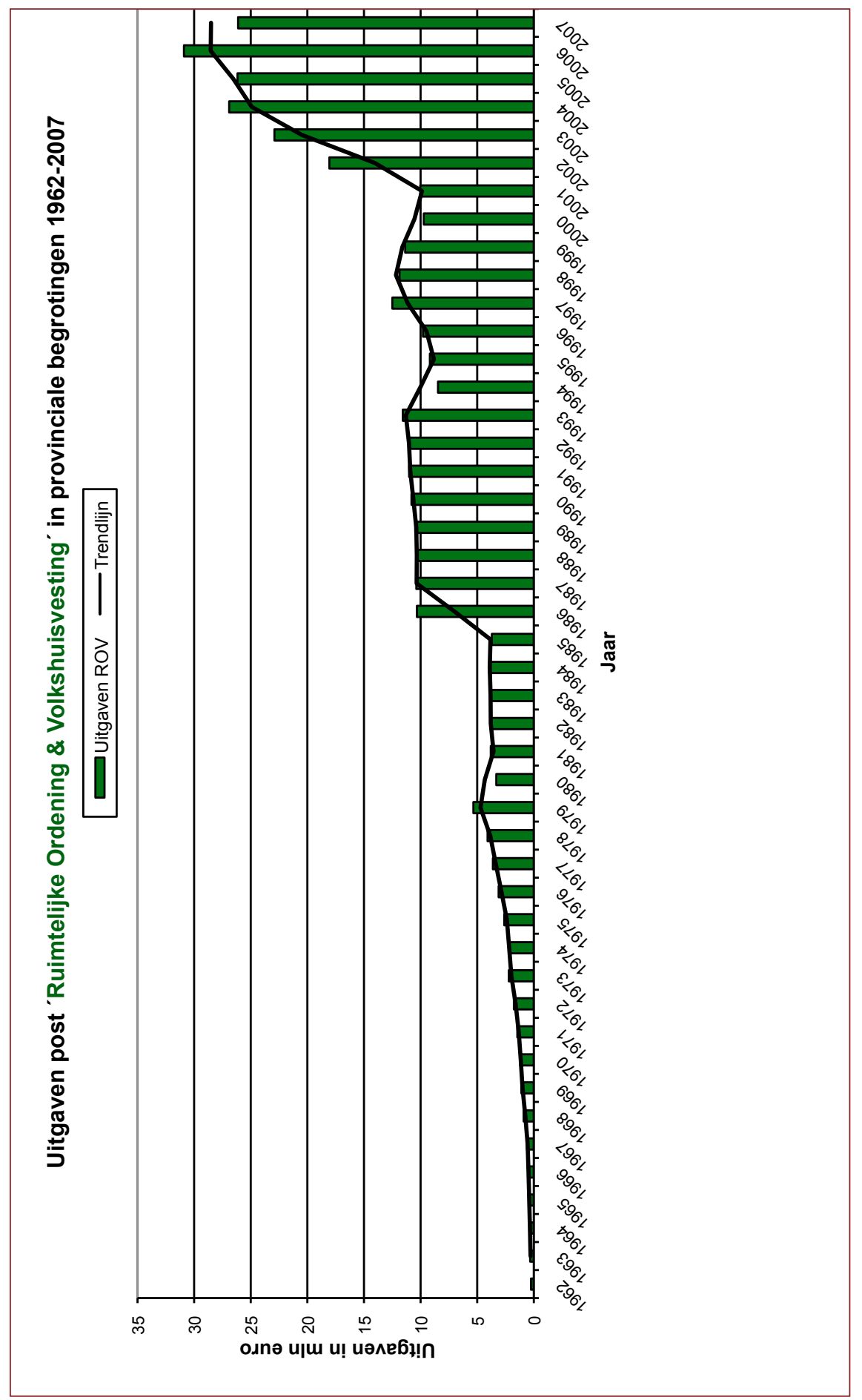




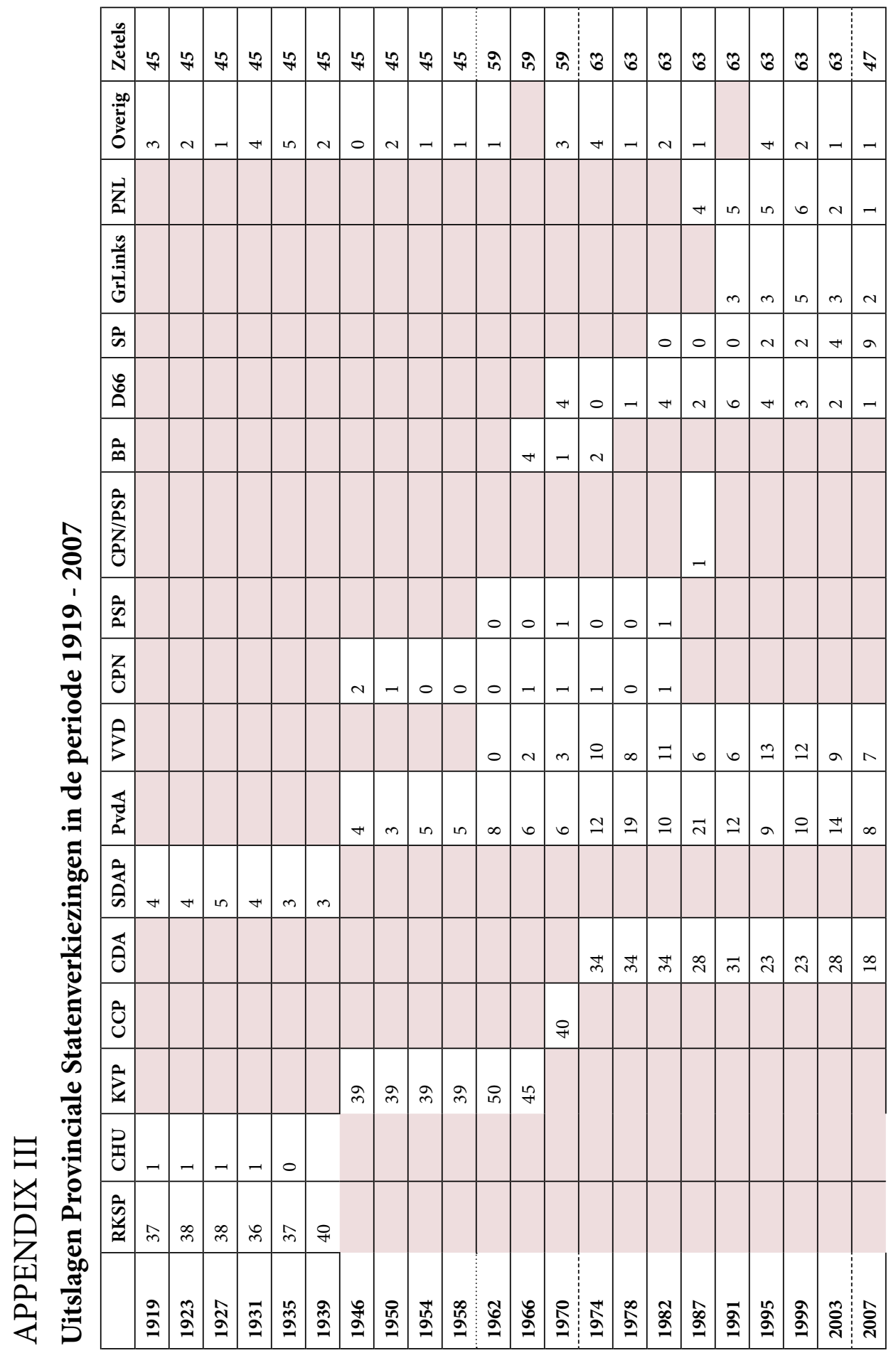




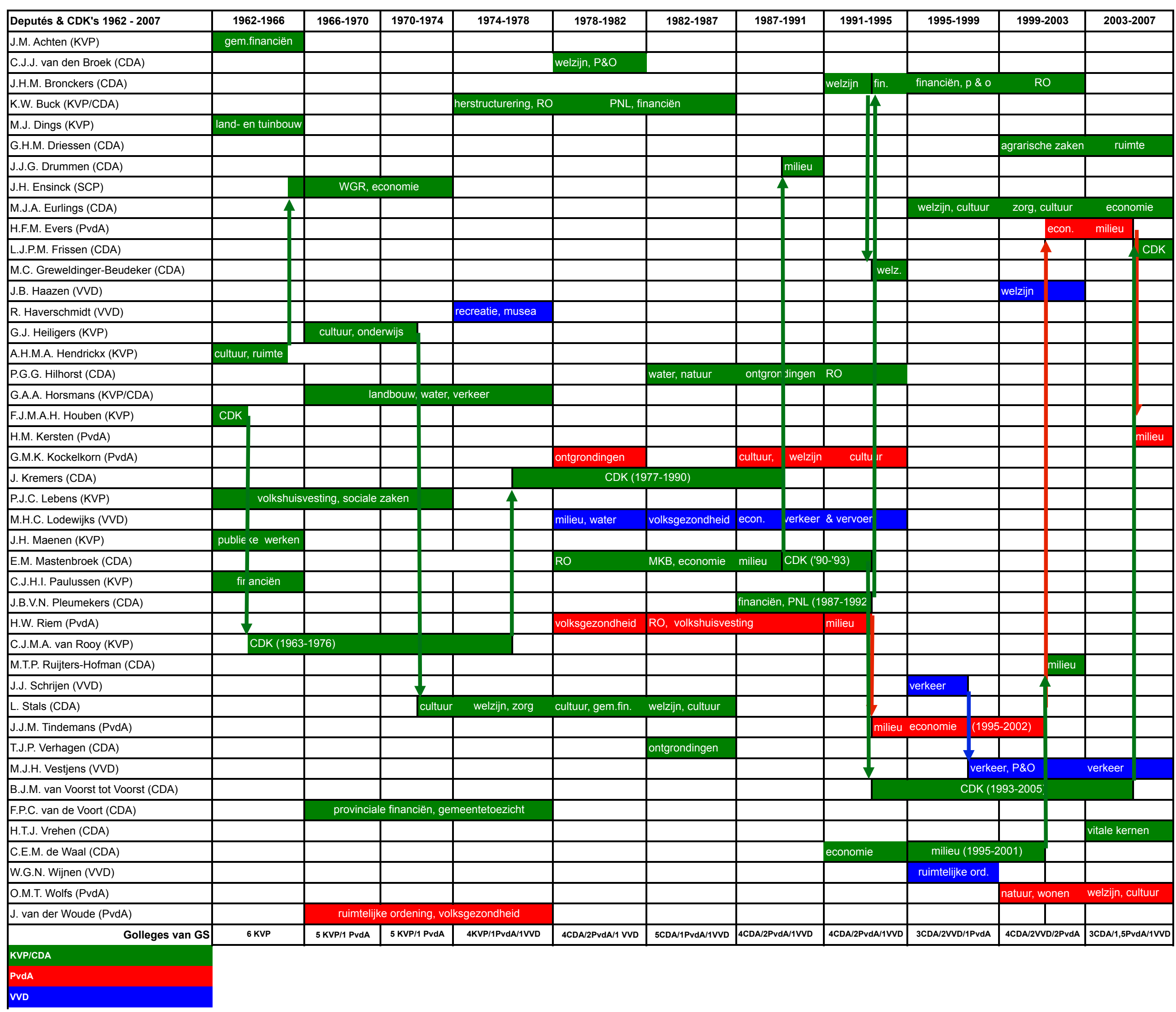




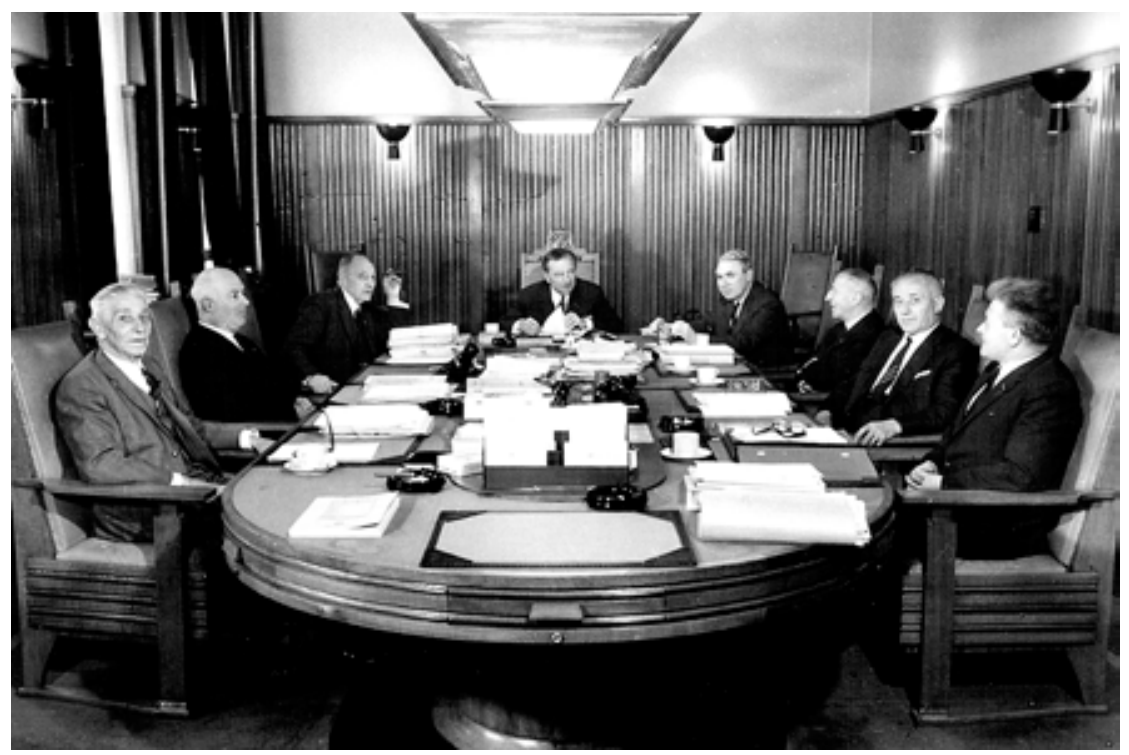

Het College van I 962- 1966 (anno 1965). Het college bestond geheel uit KVP-leden.Van links naar rechts: gedeputeerden M.J. Dings, P.J.C. Lebens en J.H. Maenen, gouverneur Ch.J.M.A. van Rooy, griffier E.P.A. Verhaegh, gedeputeerden C.J.H.I. Paulussen, J.M. Achten en J.H. Ensinck (vanaf 1965). Foto: Provincie Limburg.

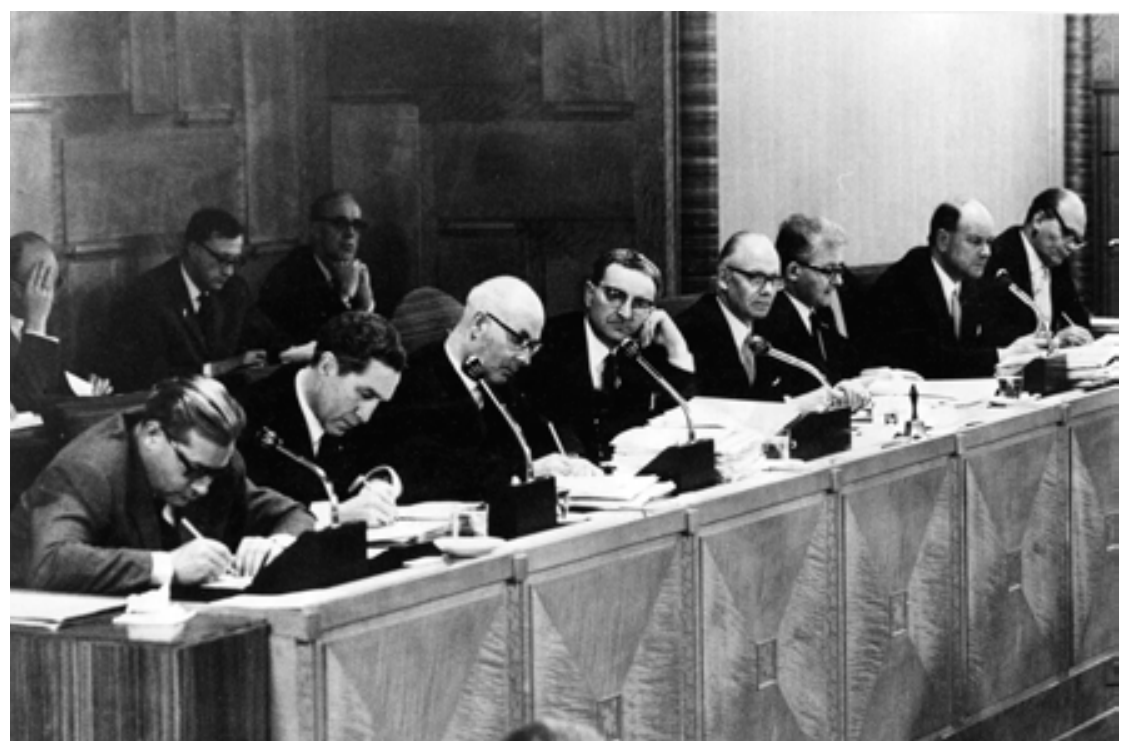

Het College van 1966- 1970 (anno 1966). Het College tijdens een vergadering van Provinciale Staten in december 1966. Vanaf 1966 nam J. van der Woude (rechtsboven) als enige gedeputeerde namens de PvdA deel aan het College.Van links naar rechts: gedeputeerden F.P.C. van de Voort (KVP), G.J. Heiligers (KVP) en P.J.C. Lebens (KVP), gouverneur Ch.J.M.A. van Rooy (KVP), griffier E.P.A. Verhaegh, gedeputeerden J.H. Ensinck (KVP), G.A.A. Horsmans (KVP) en J. van der Woude (PvdA). Foto: Fotodienst Limburgs Dagblad / Media Groep Limburg. 


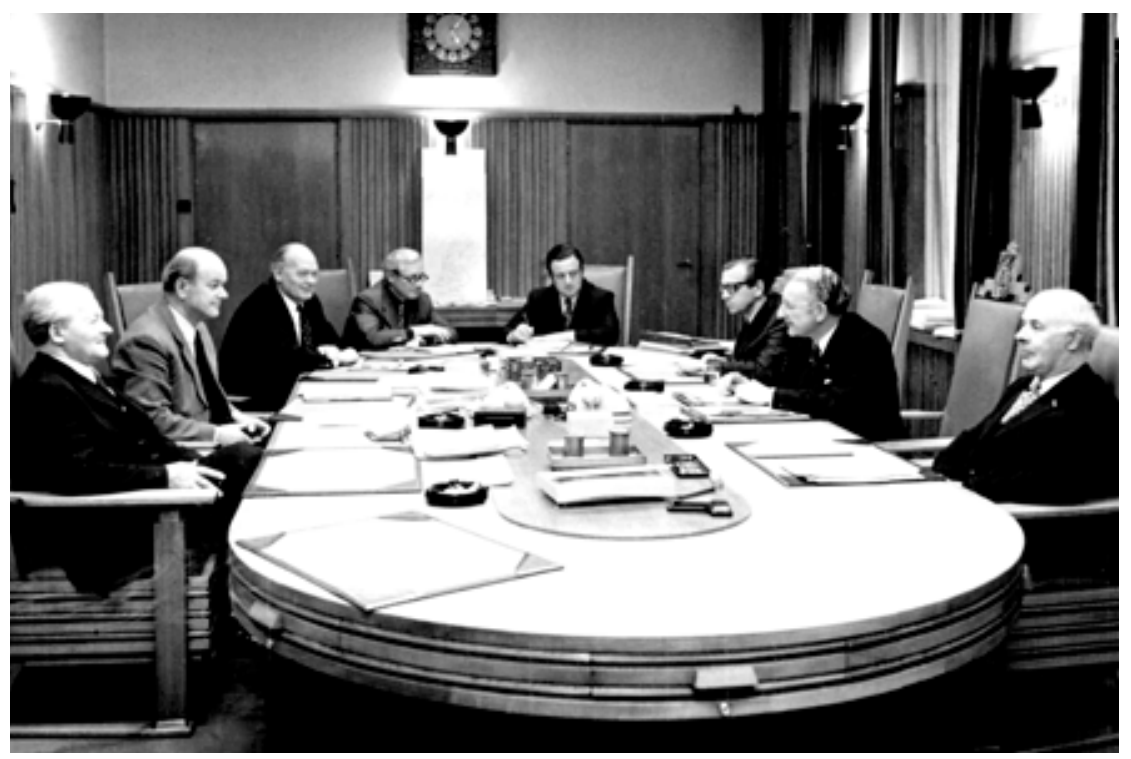

Het College van 1970-1974 (anno 1972). Van links naar rechts: gedeputeerden J.H. Ensinck (KVP), G.A.A. Horsmans (KVP), J. van der Woude (PvdA), F.P.C. van de Voort (KVP), L. Stals (KVP), griffier J.L. Matti, gouverneur Ch.J.M.A. van Rooy (KVP) en gedeputeerde P.J.C. Lebens (KVP). Foto: Provincie Limburg.

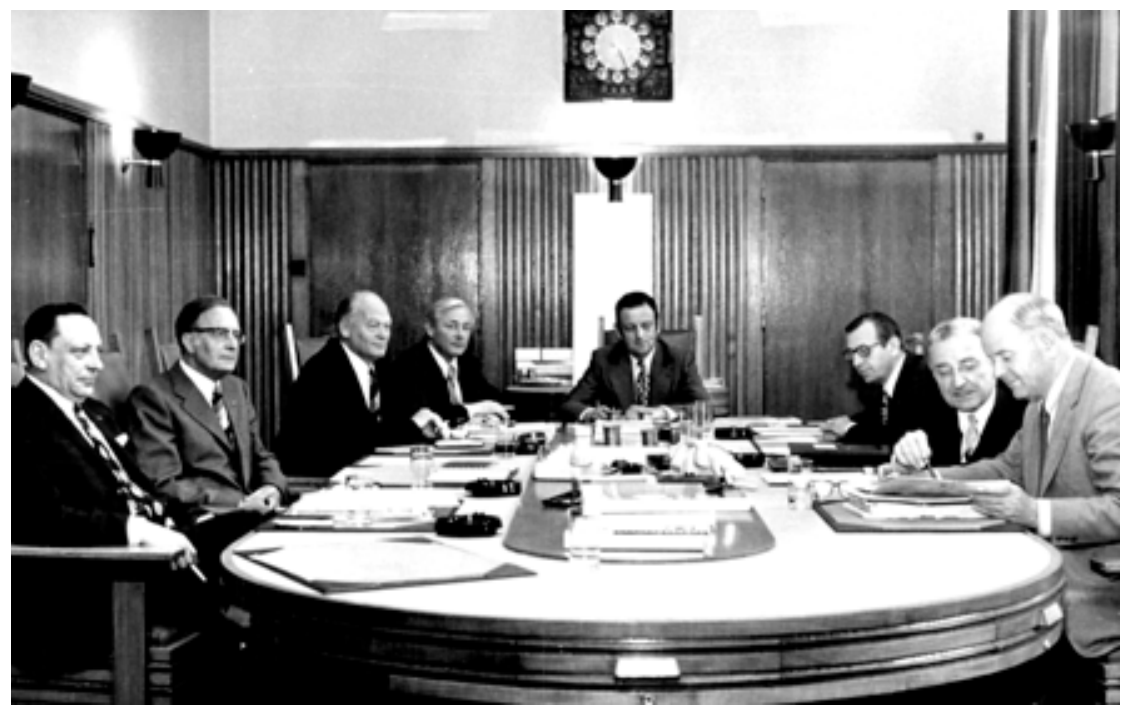

Het College van 1974-1978 (anno 1974). In 1974 was R. Haverschmidt de eerste VVDgedeputeerde in het College.Van links naar rechts: gedeputeerden K.W. Buck (KVP), R. Haverschmidt (VVD), J. van derWoude (PvdA), F.P.C. van deVoort (KVP), L. Stals (KVP), griffier J.L. Matti, gouverneur Ch.J.M.A. van Rooy (KVP) en gedeputeerde G.A.A. Horsmans (KVP). Foto: Provincie Limburg. 


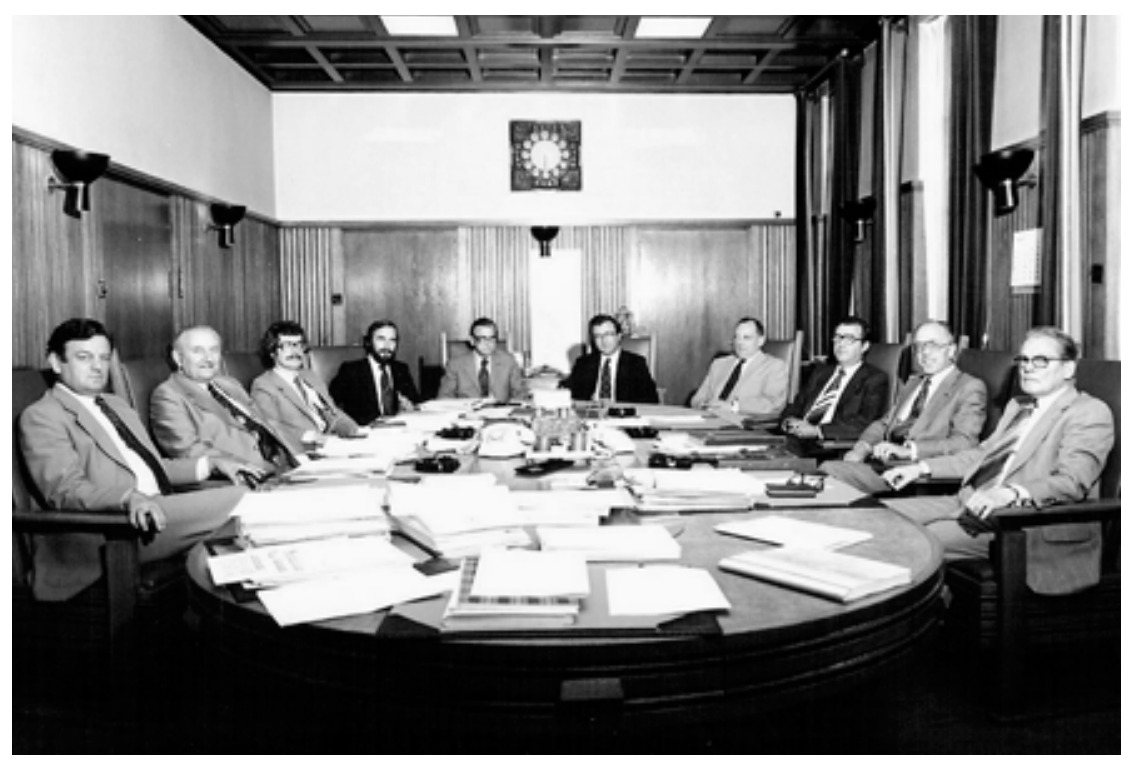

Het College van 1978-1982 (anno 1978). Na een forse verkiezingswinst in 1978 (I9 zetels) kon de PvdA twee gedeputeerden leveren. Van links naar rechts: gedeputeerden L. Stals (CDA), C.J.J. van den Broek (CDA), G.M.K. Kockelkorn (PvdA) en H.W. Riem (PvdA), griffier J.L. Matti, gouverneur J. Kremers (CDA), gedeputeerden K.W. Buck (CDA), M.H.C. Lodewijks (VVD) en E.M. Mastenbroek (CDA) en plv. griffier P. Houben. Foto: Provincie Limburg.

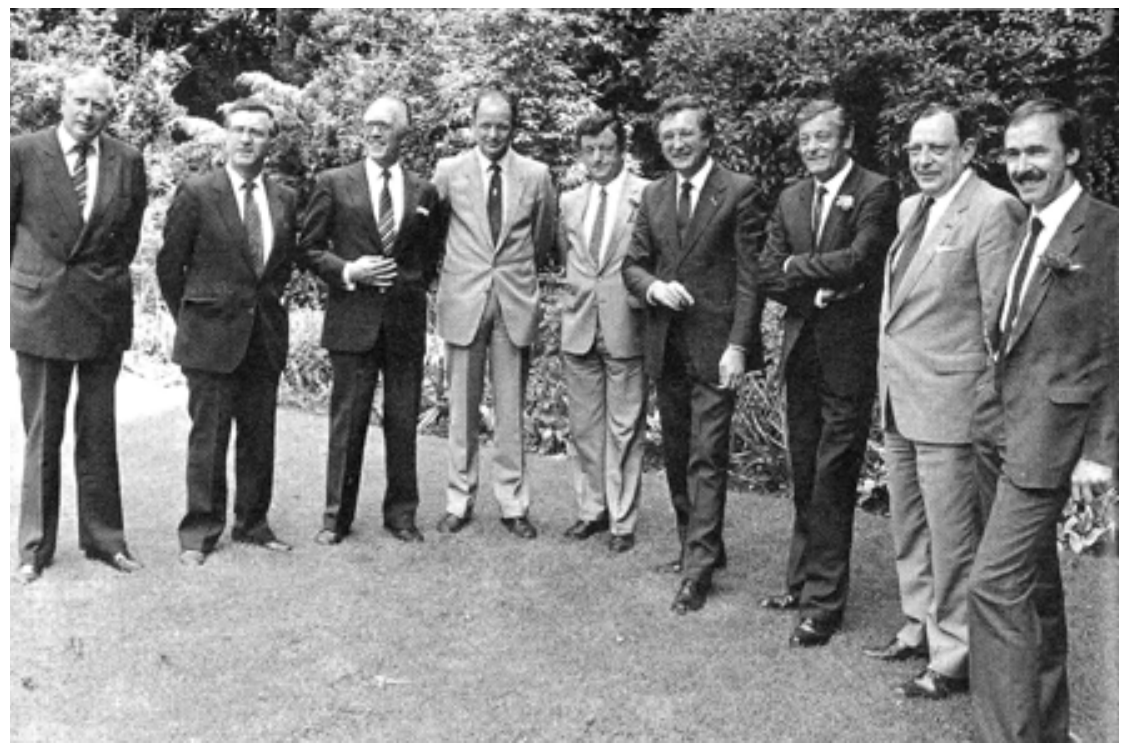

Het College van 1982- 1987 (anno 1982). Opnieuw 7 gedeputeerden, maar nu 5 van het CDA, I PvdA en I VVD. Van links naar rechts: griffier B.J.M. Gudde, gedeputeerden M.H.C. Lodewijks (VVD), E.M. Mastenbroek (CDA), P.G.G. Hilhorst (CDA), en L. Stals (CDA), gouverneur J. Kremers (CDA), gedeputeerden T.J.P.Verhagen (CDA), K.W. Buck (CDA) en H.W. Riem (PvdA). Foto: Provincie Limburg. 


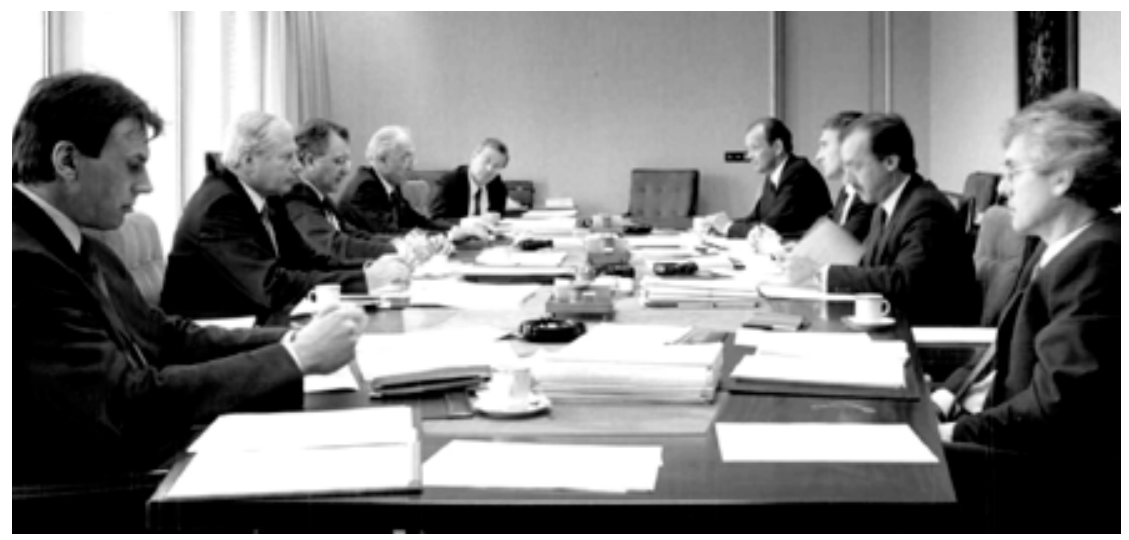

Het College van I987- 1991 (anno 1987). Het CDA verloor in 19876 zetels (28 zetels), PvdA behaalde een historische uitslag met $2 \mathrm{I}$ zetels. Van links naar rechts: adj. griffier H.W.M. Oppenhuis de Jong, griffier B.J.M. Gudde, gouverneur J. Kremers (CDA), gedeputeerden E.M. Mastenbroek (CDA), M.H.C. Lodewijks (VVD), P.G.G. Hilhorst (CDA), J.B.V.N. Pleumeekers (CDA), H.W. Riem $(\operatorname{PvdA})$ en G.M.K. Kockelkorn (PvdA). Foto: Provincie Limburg.

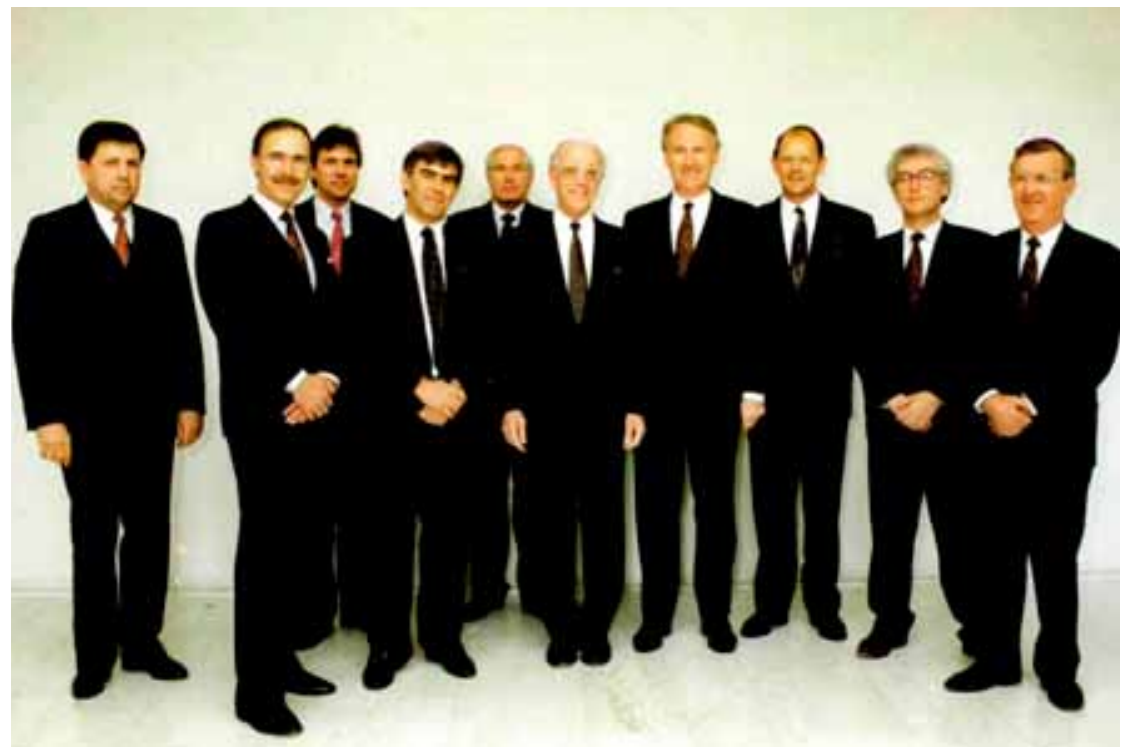

Het College van I99I-I995 (anno 199I). Het College van de portefeuillewisselingen. In I992 aanvaarden Pleumeekers en Riem beiden een burgemeestersfunctie en in 1993 volgde Van Voorst tot Voorst Mastenbroek op als gouverneur. Van links naar rechts: gedeputeerden J.H.M. Bronckers (CDA) en H.W. Riem (PvdA), adj. griffier H.W.M. Oppenhuis de Jong, gedeputeerde C.E.M. de Waal (CDA), griffier B.J.M. Gudde, gouverneur E.M. Mastenbroek (CDA), gedeputeerden J.B.V.N. Pleumeekers (CDA), P.G.G. Hilhorst (CDA), G.M.K. Kockelkorn (PvdA) en M.H.C. Lodewijks (VVD). Foto: Provincie Limburg. 


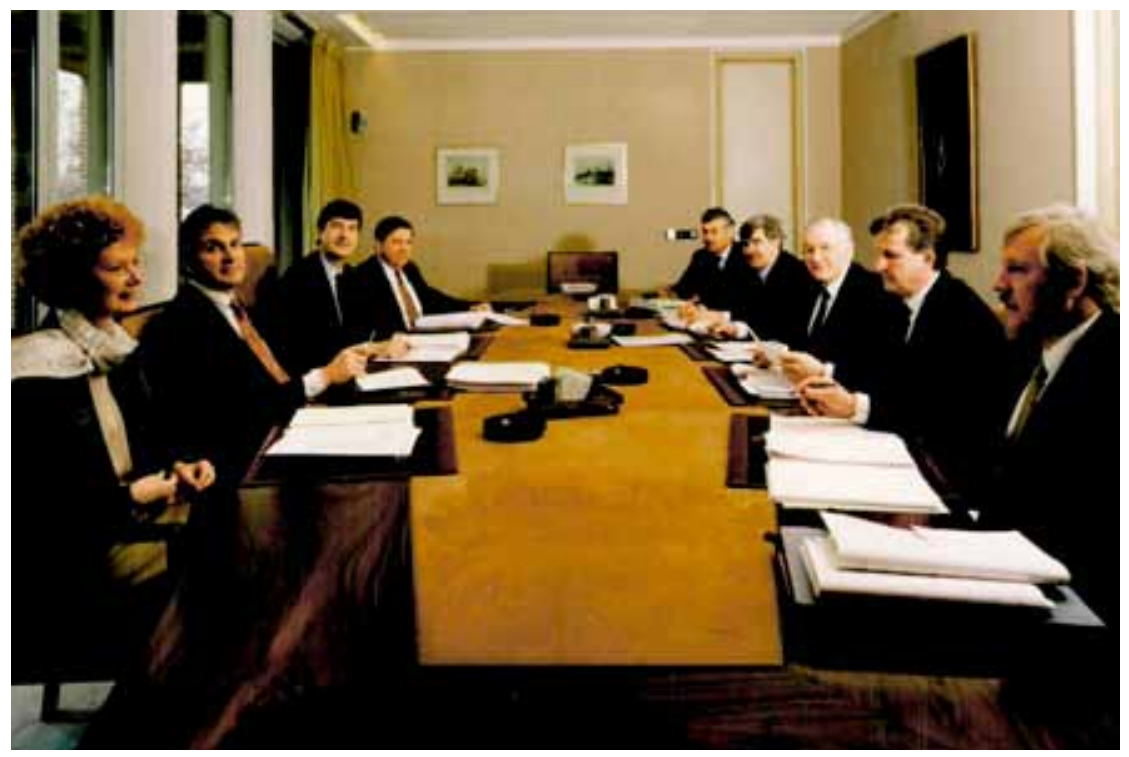

Het College van 1995- 1999 (anno 1998). De VVD profiteerde van het 'Bolkestein-effect' en mocht twee gedeputeerden leveren.Van links naar rechts: plv. griffier S. Groenewegen, griffier H.W.M. Oppenhuis de Jong, gouverneur B.J.M. van Voorst tot Voorst (CDA), gedeputeerden J.H.M. Bronckers (CDA), M.J.A. Eurlings (CDA), C.E.M. de Waal (CDA), W.G.N.Wijnen (VVD), M.J.H.Vestjens (VVD, vanaf 1998) en J.J.M.Tindemans (PvdA). Foto: Provincie Limburg.

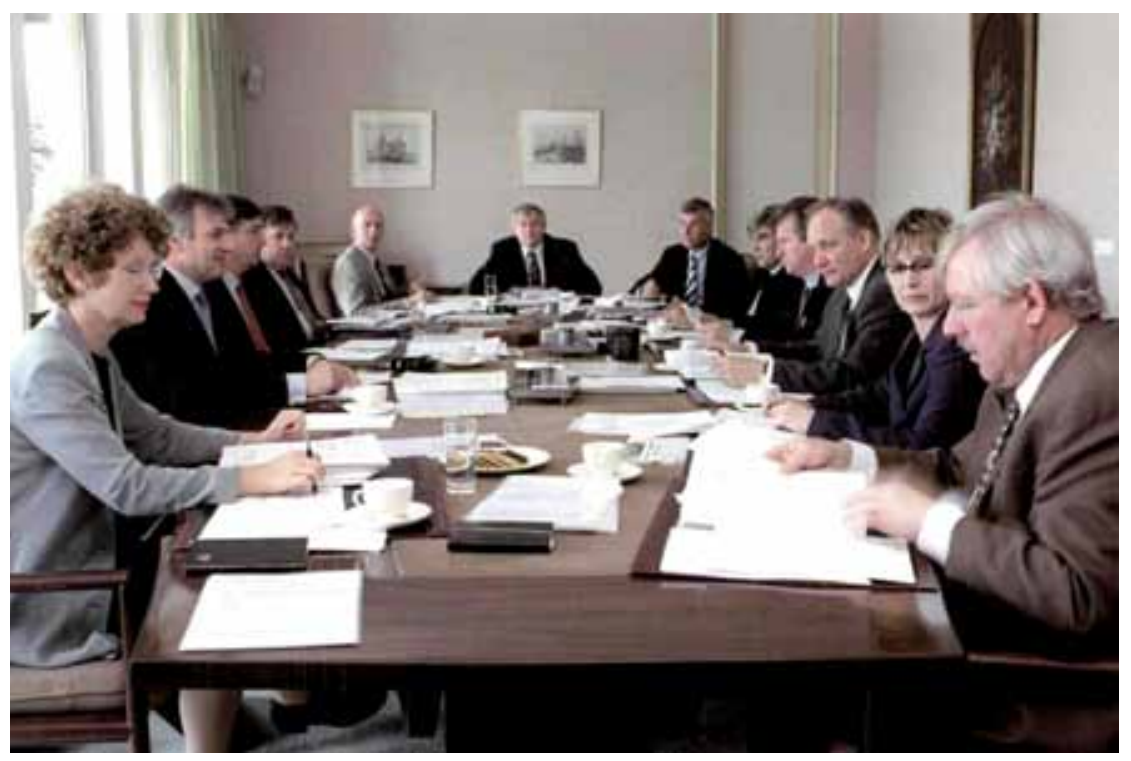

Het College van 1999-2003 (anno 1999). Een College van maar liefst 8 gedeputeerden. Gedeputeerden Wolfs, Driessen en Haazen werkten formeel gezien in deeltijd (0,6 fte). Van links naar rechts: plv. griffier S. Groenewegen, griffier H.W.M. Oppenhuis de Jong, gouverneur B.J.M. van Voorst tot Voorst (CDA), gedeputeerde J.H.M. Bronckers (CDA), hoofd voorlichting J.H.W. Albersen, gedeputeerden G.H.M. Driessen (CDA), M.J.A. Eurlings (CDA), C.E.M. de Waal (CDA), M.J.H. Vestjens (VVD), J.B. Haazen (VVD), O.M.T. Wolfs (PvdA) en J.J.M. Tindemans (PvdA). Foto: Provincie Limburg. 


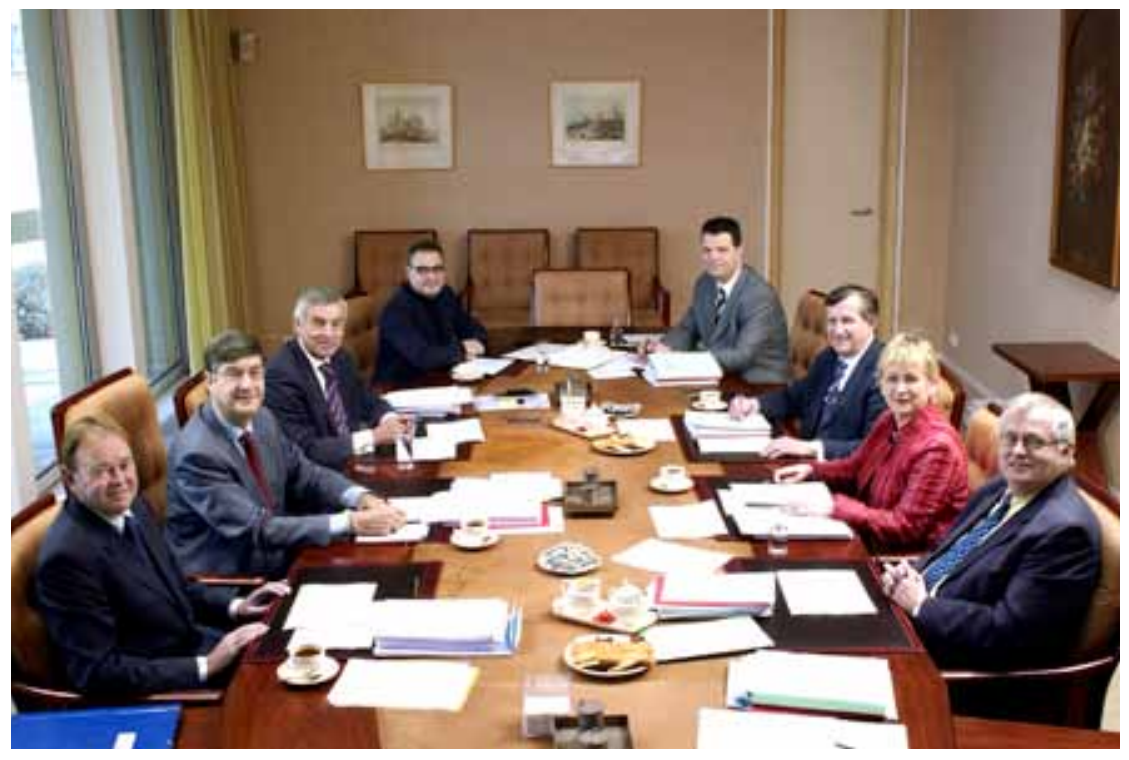

Het College van 2003-2007 (begin 2005). Het College dat een coalitieakkoord presenteerde waarin 5 thema's centraal stonden. Inzet was ook 5 gedeputeerden, het werden er uiteindelijk 6.Van links naar rechts: secretaris W.L.J.Weijnen, gouverneur Van Voorst tot Voorst (CDA), gedeputeerden M.J.A. Eurlings (CDA), H.M. Kersten (PvdA, vanaf oktober 2004), H.T.J.Vrehen (CDA), M.J.H.Vestjens (VVD), O.M.T.Wolfs (PrdA) en G.H.M. Driessen (CDA). Foto: Provincie Limburg. 
In dit boek wordt een blik in de keuken geworpen van de Limburgse provinciale politiek. Niet de vraag wat een provincie zou moeten zijn of zou moeten doen, maar de vraag hoe een provincie functioneert staat centraal. Hoe komt provinciale besluitvorming tot stand? Het jaar 1962 is het startpunt van deze analyse. In dat jaar werd de Provinciewet van kracht, bleek de Limburgse mijnindustrie niet langer rendabel en trok de katholieke kerk zich langzaam terug uit de Limburgse samenleving. Het Provinciaal Bestuur zag zich toen niet alleen geconfronteerd met een omvangrijke economische opgave, maar ook met een grote ruimtelijke en sociale problematiek.

Hendrik Jan van Elmpt beschrijft de patronen in besluitvorming voor een periode van 45 jaar en laat zien hoe meerjarige stabiele periodes van provinciaal beleid werden afgewisseld met korte maar fundamentele koerswijzigingen. Waar de Provincie Limburg zich tot begin jaren '60 afhankelijk opstelde en vooral passief reageerde op gebeurtenissen in de Limburgse samenleving, groeide zij in de daarop volgende decennia uit tot een initiatiefrijke politieke speler.

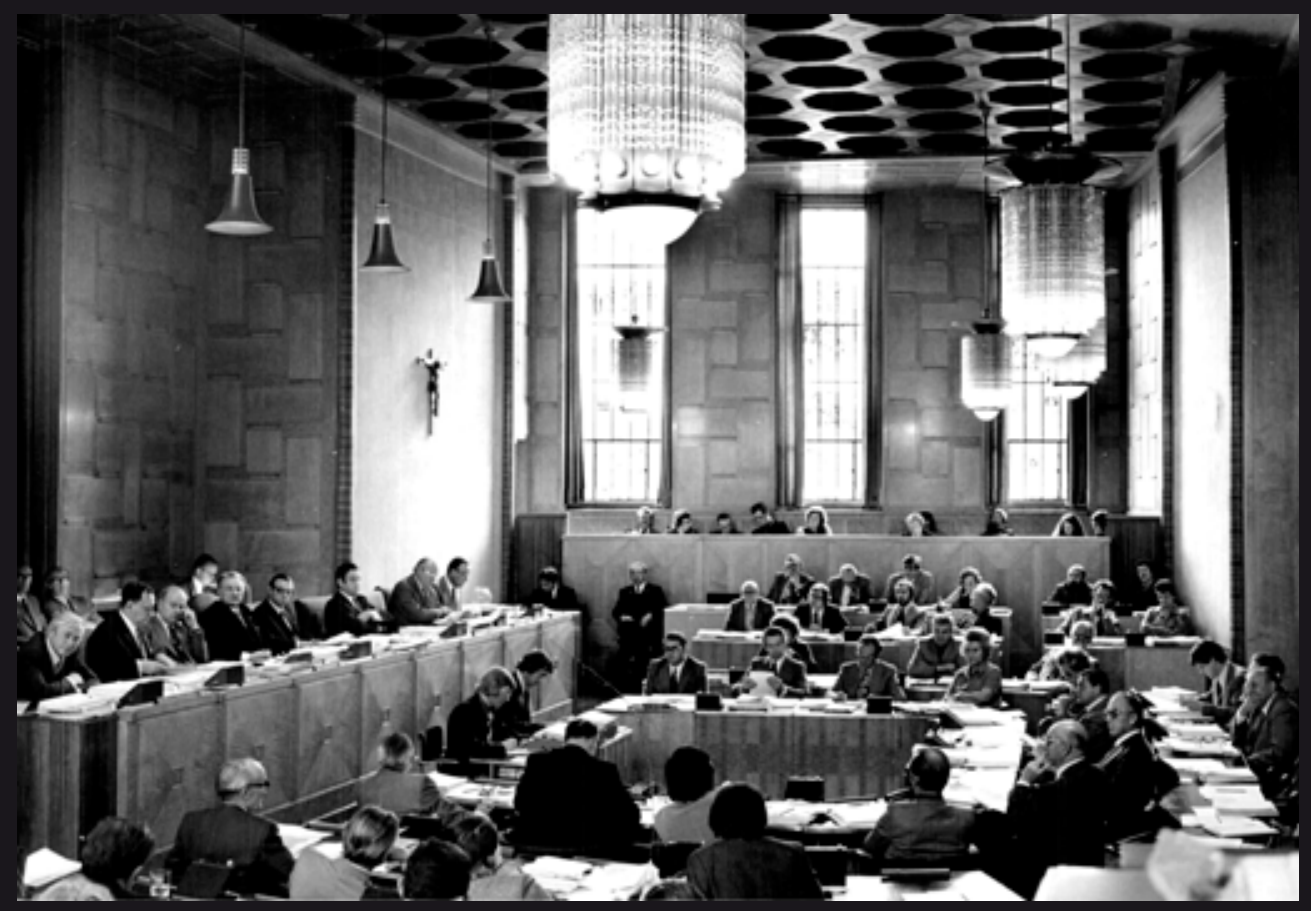

Een provinciale statenvergadering in de tweede helft van de jaren '70. Foto: Frits Widdershoven

Hendrik Jan van Elmpt (1978) studeerde Cultuur- en Wetenschapsstudies (Politieke Cultuur) aan de Universiteit Maastricht en is werkzaam bij de Provincie Limburg als senior strateeg bij de concernafdeling Strategie \& Innovatie. 